\title{
MOBILINEA
}

\section{DESIGN DE UM ESTILO DE VIDA (1959-1975)}

Dissertação apresentada à Faculdade de Arquitetura e Urbanismo da Universidade de São Paulo para obtenção do título de Mestre em Arquitetura e Urbanismo

Área de concentração História e Fundamentos da

Arquitetura e Urbanismo

Orientador

Prof. Dr. José Tavares Correia de Lira 
AUTORIZO A REPRODUÇÃO E DIVULGAÇÃO TOTAL OU PARCIAL DESTE TRABALHO, POR QUALQUER MEIO CONVENCIONAL OU ELETRÔNICO, PARA FINS DE ESTUDO E PESQUISA, DESDE QUE CITADA A FONTE.

E-MAIL DA AUTORA: minawh@gmail.com

Hugerth, Mina Warchavchik

H891m Mobilinea design de um estilo de vida (1959-1975) / Mina

Warchavchik Hugerth. --São Paulo, 2015.

281 p. : il.

Dissertação (Mestrado - Área de Concentração: História e

Fundamentos da Arquitetura e Urbanismo) - FAUUSP.

Orientador: José Tavares Correia de Lira

1.Design - Brasil 2.Mobiliário doméstico (História) 3.Mobilinea

4.Hauner, Ernesto, 1931-2002 5.Hauner, Georgia,1931- I.Título

CDU 7.05(81) 


\section{Mobilinea - Design de um Estilo de Vida (1959-1975)}

Mina Warchavchik Hugerth

Dissertação apresentada à Faculdade de Arquitetura e Urbanismo da Universidade de São Paulo para obtenção do título de Mestre em Arquitetura e Urbanismo

Banca Examinadora

Prof. Dr. Instituição:

Julgamento: Assinatura:

Prof. Dr. Instituição:

Julgamento: Assinatura:

Prof. Dr. Instituição: Assinatura: 

Para Georgia Hauner, que inspirou esta pesquisa. 

Para Natalia Kuschnaroff, minha querida amiga (in memoriam). 



\section{Agradecimentos}

À Georgia Hauner, por dispor sua casa, seus arquivos e sua história, me confiando uma responsabilidade que espero ter honrado. Esse agradecimento se estende a toda sua família;

Aos entrevistados Ada Hauner, Bibita Butcher, Jorge Kornbluh, Judit Magyary, Martin Wurzmann, Matias Eisler, Sergio Rodrigues e Yone Koseki, que me receberam e se dispuseram a compartilhar sua memória comigo;

A Adélia Pasta, Nelson Graubart, Cristiana Barreto, Célia e José Francisco Quirino, cujos móveis deram materialidade à pesquisa e a trouxeram à atualidade;

À FAPESP, pela bolsa de estudos, sem a qual não teria sido possível realizar esta pesquisa;

Ao professor José Lira, pela orientação e pela generosidade em dividir seu modo de ver a história, mobilizando ferramentas para gerar algumas respostas e tantas outras perguntas;

Aos professores Marcos Braga e Silvana Rubino pela contribuição na banca de qualificação e por diálogos que sempre me motivaram. Ao Marcos também por me receber como monitora na graduação;

Aos colegas da FAU, Beatriz Brandt, Diego BIS, Dora Dias, João Sodré, Juliana Braga, Luiz Florence, Milene Cara, Raíssa Oliveira, Raquel Schenkman, Samira Chahin e Victor Próspero, pela companhia e troca de ideias;

À Marina Botter pela ajuda na diagramação, e por estar sempre presente;

Aos leitores Kauê Lopes Santos, Luisa Hugerth, Tânia Helou e Vera Warchavchik pelo cuidado e dedicação;

Ao Fernando Spuri pelo apoio incondicional;

Aos amigos e familiares pelo interesse e paciência. 


\section{Mobilinea - design de um estilo de vida (1959 - 1975) \\ Resumo}

Esta dissertação visa recuperar e examinar criticamente a trajetória da empresa de móveis Mobilinea entre 1959 e 1975, considerando que foi uma das mais importantes do período no país, assumindo não apenas um papel de produtora de objetos, como também de promotora de certos estilos de vida. O primeiro capítulo pretende apresentar o contexto da produção moveleira no Brasil até a fundação da empresa, sua inserção no circuito de design brasileiro nos anos 1960 e 1970 e as histórias individuais de seus criadores e colaboradores. O segundo capítulo busca focalizar as principais características de seus produtos, assim como seus locais e formas de venda, evidenciando o modo como foram tratados enquanto parte de cenas domésticas completas. O terceiro capítulo exibe a presença da Mobilinea em publicações impressas durante o período estudado, analisando os diferentes discursos criados para cada público, elencando suas semelhanças e diferenças. Foi principalmente nestes espaços que a empresa divulgou seus valores, que incluíam formas de se ocupar e se comportar na casa, dando à mulher um papel de protagonismo na proposição e no consumo desses modos de morar.

Palavras chave:

Design brasileiro, história do mobiliário, domesticidade, Mobilinea, Ernesto Hauner, Georgia Hauner. 
Mobilinea - the design of a lifestyle (1959 - 1975)

Abstract

This dissertation aims to uncover and critically examine the evolution of Mobilinea, a Brazilian furniture design company. During the period from 1959 to 1975 it was one of the most prominent firms in the country, not only as a producer of goods but also in terms of promoting certain lifestyles. The first chapter of the study presents the context of furniture production in Brazil until the founding of the company, its insertion in the Brazilian design circuit of the 1960s and 1970s, and the individual stories of its creators and collaborators. The second chapter has a focus on the key attributes of the products, as well as the promotional environments and sales approaches, highlighting them as components of domestic environments. The third chapter reviews the presence of Mobilinea in publications during the studied period, analyzing the different messages created for the target audiences, through charting out the similarities and differences. It was mostly in this media that the company disseminated its values, which included ways of inhabiting and acting in the home, suggesting a leading role for women in developing and consuming these living styles.

Keywords:

Brazilian design, history of furniture, domesticity, Mobilinea, Ernesto Hauner, Georgia Hauner. 


\section{Lista de imagens}

Referência

1.1.01: Cadeira Thonet, século XIX. 36

1.1.02: Cama Patente fabricada pelas Indústrias Patente L. Liscio S.A. a partir de 1942. 37

1.1.03: Cadeira 1001, Móveis Cimo S.A.

36

1.1.04-1-1.05: Interiores da "Exposição de uma Casa Modernista", concebida e organizada por Gregori Warchavchik em 1930 em residência de sua autoria à Rua Itápolis.

1.1.06: Projetos de Bernard Rudofksy para o concurso Organic Design in Home Furnishings, 1941 40

1.1.07: Loja de Joaquim Tenreiro em São Paulo com móveis de sua autoria ambientados como em residências, década de 1950

1.1.08: Residência Milton Guper com móveis Branco \& Preto, 1951.

1.1.09: Poltronas do Studio Palma, c. 1949.

1.1.10: Inauguração da Móveis Artesanal Paranaense em 1953. À esquerda, de costas, o Conde Paolo Grasselli e à 48 direita da foto, de frente, Ernesto Hauner.

1.1.11: Vitrine da Galeria Artesanal com mesa fruteira, espreguiçadeira, cadeira de palha, churrasqueira e lâmpadas de chão.

1.1.12: Georgia e Ernesto Hauner

1.2.01: Propaganda Ernesto Hauner Decorações- Escrivaninhas.

1.2.02: Poltrona UnB e sofá Darcy no Prédio da Antiga Reitoria. 54

1.2.03: Cenário criado para propaganda Mobilinea com móveis laqueados em branco. 56

1.2.04: Ambientes de jantar na loja da Mobilinea no Shopping Iguatemi.

1.2.05: Cadeira em aço e fiberglass.

1.2.06: Carrinho de chá 61

1.2.07: Editorial apresentando a linha Prêt-à-Porter da Mobilinea - sala de estar. 64

1.2.08: Editorial apresentando a linha Prêt-à-Porter da Mobilinea - sala de jantar. 64

1.2.09: Editorial apresentando a linha Prêt-à-Porter da Mobilinea - quarto do casal. 65

1.2.10: Editorial apresentando a linha Prêt-à-Porter da Mobilinea - quarto de solteiro. 65

1.2.11: Ernesto e Georgia Hauner na Home Store.

1.3.01: Poltrona Mole- Sergio Rodrigues. 68 66

1.3.02: Propaganda Mobilinea e concorrentes. 70

1.3.03: Móveis de dormitório Arredamento. 70

1.3.04: Móveis de sala de estar Mobília Contemporânea. 71

1.3.05: Móveis de sala de jantar Hobjeto.

1.3.06: Propaganda Mobilinea - Poltrona Bienal 68. 76

2.1.01: Propaganda Ernesto Hauner Decorações - estantes E.H.D. 88

2.1.02: Propaganda Ernesto Hauner e Cia. Ltda. - estantes Mobilinea. 88 
2.1.04: Sala de aula UnB.

2.1.05: Propaganda Mobilinea - Carteiras Escolares.

2.1.06: Ambiente com móveis Mobilinea.

2.1.07: Propaganda Mobilinea - Patinhos.

2.1.08: Propaganda Mobilinea - Uma Estante num Instante.

2.1.09: Ambiente com móveis Mobilinea.

2.1.10: Banco Ripado.

2.1.11: Ambiente com móveis Mobilinea.

2.1.12: Ambiente de jantar Mobilinea com cadeiras Dinamarquesas.

2.1.13: Carta de Luiz Carta a Ernesto Hauner de 22 de janeiro de 1969.

2.1.14: Mobilinha. "Móveis Infantis" - embalagem e módulo de caixa como estante e cadeira.

2.1.15: Mobilinha. "Móveis Infantis" - berço, mesa e módulo de caixa como cadeira, bercinho e casinha de bonecas.

2.1.16: Mobilinha. "Móveis Infantis" -módulo de caixa como cadeira, mesinha, trem e carrinho.

2.1.17: Detalhe do sistema de molas de sofá Mobilinea de Adélia Pasta.

2.1.18: Móveis para sala de jantar (foto tirada na loja do Shopping Iguatemi).

2.1.19: Móveis para sala de estar (foto tirada na loja do Shopping Iguatemi).

2.1.20: Poltrona estofada.

2.1.21: Mesa de centro em aço e madeira com pintura em poliéster.

2.1.22: Detalhe do sistema de pino e tambor de estante modular Mobilinea de Adélia Pasta.

2.1.23: Detalhe do puxador de aparador modular Mobilinea de Nelson Graubart.

2.1.24: Páginas do catálogo "Mobilinea estante 1600".

2.1.25: Ambiente na loja da Mobilinea no Shopping Iguatemi.

2.1.26: Detalhes de ambientes com móveis da linha Prêt-à-Porter em Magnólia.

2.1.27: Linha completa de cadeiras em fiberglass empilháveis.

2.1.28: Ambiente na loja da Home Store com mesa-canteiro.

2.1.29: Mesa com pé tubular e cadeira em aço.

2.1.30: Páginas de catálogo da linha Mobilinea Escritórios.

2.1.31: Detalhe de reportagem sobre escritórios, mostrando linha Mobilinea laqueada.

2.1.32: Páginas de catálogo "Mobilinea apresenta a linha L. CD. de Alex Linder".

2.1.33: Gráfico das linhas produzidas e comercializadas pela Mobilinea entre 1960 e 1975, realizado a partir do levantamento de periódicos.

2.2.01-2.2.02: Fotografia das luminárias em papel feitas por Georgia Hauner, dobradas e montadas

2.2.03: Calendário das exposições realizadas na Galeria Mobilinea, realizado a partir do levantamento de periódicos.

2.2.04: Interior da loja da Mobilinea no Rio de Janeiro.

2.2.05: Detalhe de propaganda de divulgação do Shopping Iguatemi, mostrando sua construção.

2.2.06: Detalhe de propaganda de divulgação do Shopping Iguatemi, anunciando sua inauguração.

2.2.07: Parte da fachada da loja no Shopping Iguatemi, revelando alguns dos ambientes internos.

2.2.08: Vista interna da loja Mobilinea no Shopping Iguatemi com a vitrine redonda à direita, ambiente rebaixado ao centro e o palquinho à esquerda.

2.2.09: Vista interna da loja Mobilinea no Shopping Iguatemi a partir da vitrine, mostrando em primeiro plano o ambiente rebaixado e à frente o palquinho e a parede vazada à esquerda.

2.2.10: Ambiente de estar na loja Mobilinea no Shopping Iguatemi.

2.2.11: Ambientes de estar, jantar e dormitórios, separados por pisos elevados na loja Mobilinea no Shopping Iguatemi. 
2.2.13: Ambiente de estar em frente à abertura inferior da lareira, com escada caracol que dava acesso aos escritórios na loja Mobilinea no Shopping Iguatemi

2.2.14: Ambiente de escritórios com parede de ripas de Jacarandá da fachada na loja Mobilinea no Shopping Iguatemi.

2.2.15: Ambiente de dormitório com iluminação natural e poltrona Armando Cerello na loja Mobilinea no Shopping Iguatemi.

2.2.16: Ambiente de dormitório com janela interna ao Shopping Iguatemi.

2.2.17: Projeto para layout da loja Mobilinea no Shopping Iguatemi.

2.2.18: Foto do palquinho com vitrine "psicodélica" visto de outros ângulos, mostrando parte da loja Mobilinea no Shopping Iguatemi e os refletores da fotografia.

2.2.19: Ambiente de dormitório na vitrine da loja do Shopping Iguatemi, montado simultaneamente ao palquinho "psicodélico".

2.2.20: Pôster do filme "A Arte de Amar... Bem". 1970.

2.2.21: Catálogo para vendas KX Mobilinea.

2.2.22-2.2.23: Heliografias com layouts para a loja em Brasília.

2.2.24: Funcionamento das lojas e fábricas da Mobilinea entre 1960 e 1975, realizado a partir do levantamento de periódicos.

2.3.01: Propaganda Vidrobrás - O vidro existe para que V. possa aproveitar ao máximo o privilégio de viver na terra.

2.3.02: Propaganda Vidrobrás - Só o vidro traz para a sua vida a natureza como cenário e o céu como dimensão.

2.3.03: Mike Hauner em dormitório Mobilinea com equipamentos de som Gradiente.

2.3.04: Propaganda National -3 em 1.

2.3.05: Planta de apartamento decorado com móveis Mobilinea em brochura de apresentação para construtoras.

2.3.06: Propaganda de lançamento do Condomínio Edifício Juruá - Construhab.

2.3.07: Fachada do Edifício Cayowáa.

2.3.08: Folheto Mobilinea- Formaespaço.

2.3.09: Planta de situação da Home Store.

2.3.10: Fotos de maquete do projeto da Home Store.

2.3.11: Planta do térreo com indicação dos cortes. Projeto Home Store.

2.3.12: Corte A-A. Projeto Home Store.

2.3.13: Corte B-B. Projeto Home Store.

148-149

2.3.14: Corte C-C:. Projeto Home Store.

150-151

2.3.15: Corte D-D. Projeto Home Store. 150-151

2.3.16: Fachada da Home Store.

2.3.17: Passarela de entrada da Home Store com loja de lustres e galeria de arte.

2.3.18: Loja de joias na Home Store.

2.3.19: Ateliê do artesão na Home Store.

2.3.20: Banca de revistas na Home Store.

2.3.21: Ambiente de área externa com mesa-canteiro na Home Store.

2.3.22: Vista do poço com composição de quadros na Home Store.

2.3.23: Poço durante algum evento na loja. Sentado no chão à direita, Ernesto Hauner.

2.3.24: Ambiente de dormitório com móveis Mobilinea na Home Store.

2.3.25: Ambiente de estar com móveis Mobilinea e Probjeto na Home Store.

2.3.26: Cartela de móveis adesivos, com detalhe ampliado em que se vê a marca d'água Home Store.

2.3.27: Propaganda Home Store - Jovens Duros e Rebeldes.

3.1.01: Propaganda Mobilinea - espaço?. 


\begin{tabular}{|c|c|}
\hline 3.1.05: Propaganda Mobilinea - líder das classes produtoras vira a mesa. & 169 \\
\hline 3.1.06: Propaganda Mobilinea - empresário provoca revolução no gabinete. & 169 \\
\hline 3.1.07: Propaganda Mobilinea - conspiração de ante-sala atinge advogado. & 169 \\
\hline 3.1.08: Propaganda Mobilinea - homem de marketing finalmente levantou da cadeira. & 169 \\
\hline 3.1.09: Mosaico de imagens representando a Mobilinea. & 170 \\
\hline 3.1.10: Propaganda Mobilinea - balança de abacaxi. & 171 \\
\hline 3.1.11: Propaganda Mobilinea - Mobilinea convida você a sentar-se em seu mais novo design. & 172 \\
\hline 3.1.12: Propaganda Mobilinea - Você vai ver como é bom trabalhar com Mobilinea. & 173 \\
\hline 3.1.13: Capa de El Mueble com ambiente Mobilinea feito por Georgia Hauner para Claudia Decoração. & 178 \\
\hline 3.2.14: Propaganda Mobilinea - "Esta sala é de quem passou ontem pela Mobilinea". & 179 \\
\hline $\begin{array}{l}\text { 3.1.15: Gráfico das aparições da Mobilinea na mídia impressa por ano e título, realizado a partir do levantamento } \\
\text { de periódicos. }\end{array}$ & 181 \\
\hline 3.2.01: Ambiente de estar Mobilinea. & 183 \\
\hline 3.2.02: Proposta Mobilinea para divisores de ambientes. & 184 \\
\hline 3.2.03: Editorial feito por Georgia Hauner para Claudia Decoração misturando móveis de diversas empresas. & 185 \\
\hline 3.2.04: Planta vencedora do primeiro concurso "C. J. Visita" com Mobilinea. & 187 \\
\hline 3.2.05: Perspectiva da sala de estar do primeiro concurso "C. J. Visita” com Mobilinea. & 187 \\
\hline 3.2.06: Planta vencedora do segundo concurso “C. J. Visita” com Mobilinea. & 189 \\
\hline 3.2.07: Perspectiva da sala de estar do segundo concurso "C. J. Visita" com Mobilinea. & 189 \\
\hline 3.2.08: Vista externa da "Casa de Claudia” com explicações sobre a promoção. & 190 \\
\hline 3.2.09: Planta da "Casa de Claudia" feita por Georgia Hauner. & 190 \\
\hline 3.2.10: Sala de estar da "Casa de Claudia” com móveis de Mobília Contemporânea, Arredamento e Mobilinea. & 191 \\
\hline 3.2.11: Sala de jantar da "Casa de Claudia" com mesa Mobilinea e cadeiras Arredamento. & 191 \\
\hline 3.2.12: Quarto de bebê da "Casa de Claudia” com móveis Mobilinha. & 191 \\
\hline 3.2.13: Vista aérea do prédio em que o casal Hauner morava, no Itaim Bibi, com planta interna desenhada sobre a foto. & 194 \\
\hline 3.2.14: Sala de estar do apartamento do casal Hauner. & 194 \\
\hline 3.2.15: Terraço do apartamento do casal Hauner. & 194 \\
\hline 3.2.16: Planta do apartamento do casal Hauner no Edifico Sobre as Ondas, no Guarujá. & 195 \\
\hline 3.2.17: Sala de estar da casa de veraneio do casal Hauner com vista para a janela. & 196 \\
\hline 3.2.18: Sala de estar da casa de veraneio do casal Hauner com vista para a entrada. & 197 \\
\hline 3.2.19: Quarto conversível da casa de veraneio do casal Hauner. & 197 \\
\hline 3.3.01: Georgia Hauner fotografada na loja do Shopping Iguatemi. & 199 \\
\hline 3.3.02: Tutorial para fazer diversos objetos decorativos. & 202 \\
\hline 3.3.03: Molde para fabricação de almofadas. & 202 \\
\hline 3.3.04: Ambiente Mobilinea para quarto de adolescente. & 204 \\
\hline 3.3.05: Propaganda Mobilinea - “Entre na década de 70". & 206 \\
\hline 3.3.06: Quarto de casal Mobilinea (foto tirada na loja do Shopping Iguatemi). & 207 \\
\hline 3.3.07: Cadeira em aço e poliéster com modelo nua, foto produzida por Georgia Hauner. & 208 \\
\hline
\end{tabular}





\section{Sumário}

Introdução

1. Design e Designers 33

1.1. Rumos do móvel moderno no Brasil 36

1.2. A Mobilinea de Ernesto e Georgia Hauner 53

1.3. Circuitos e confluências nos anos 1960 e 70

2. Design à venda

2.1. O desenvolvimento dos móveis 88

2.2. As lojas e a comercialização de ideias 112

2.3. Das parcerias à Home Store 134

3. Design editado 163

3.1. O discurso na mídia impressa 167

3.2. Domesticidades modernas 182

3.3. A mulher Mobilinea 198

$\begin{array}{ll}\text { Considerações finais } & 213\end{array}$

$\begin{array}{ll}\text { Bibliografia } & 221\end{array}$

Fontes 229

$\begin{array}{ll}\text { Anexos } & 235\end{array}$ 

Introdução 

A empresa de móveis Mobilinea foi fundada pelo imigrante italiano Ernesto Hauner (1931-2002), que chegou ao Brasil em 1949 e logo começou a trabalhar com design de mobiliário ao lado de figuras como Lina Bo Bardi, Sérgio Rodrigues, Martin Eisler e Carlo Hauner, seu irmão. Iniciou o próprio negócio em 1959 com uma pequena fábrica em São Paulo, fazendo estantes modulares em madeira maciça, e abriu a primeira loja em 1962, concomitantemente à entrada do engenheiro inglês John Manoel de Souza (1930-) como sócio e responsável pela gestão administrativa da empresa. Os desenhos de Ernesto exploravam as possibilidades e usos de novos materiais que a indústria brasileira começava a produzir, adequando seus projetos para a fabricação em escala e desenvolvendo linhas de móveis completas para casa e escritório, sendo pioneiro no uso de pintura em cores fortes, além de criar peças em aço, fiberglass e acrílico, com projetos reconhecidos pelo Prêmio Roberto Simonsen e em todas as Bienais Internacionais de Design do Rio de Janeiro, firmando seu nome entre os designers mais importantes de sua geração no país.

Os móveis da Mobilinea, em especial os de uso doméstico, dirigiam-se às classes médias que ascendiam nos centros urbanos economicamente mais dinâmicos do Brasil, e a empresa guiava-se por uma perspectiva de atingir o maior público possível, como se verifica em suas propostas de peças componíveis, em vendas parceladas e mesmo na criação de um crediário próprio. Consideravam, entretanto, que não era suficiente que um móvel fosse acessível economicamente, mas que também pudesse ser compreendido e desejado e, nesse sentido, para além do design de móveis strictu sensu, Mobilinea investiria em elaborados espaços comerciais, propagandas, catálogos e editoriais, que visavam promover as peças em cenários que entendiam a casa moderna como um lugar descontraído e pessoal, onde objetos artesanais e peças de arte se complementavam e se contrapunham aos móveis industrialmente produzidos.

Georgia Hauner (1931-), imigrante croata e esposa de Ernesto, foi figura central neste âmbito da produção da Mobilinea: responsabilizou-se pelo planejamento e realização das lojas e fotografias de divulgação, desenvolvendo, curando e dispondo os artigos, revestimentos e acabamentos que compunham os ambientes propostos pela empresa, muitos dos quais pretendiam reagir às transformações nos estilos de vida, nas relações familiares e de gênero do período em uma escala mais ampliada. 
Em 1968, Georgia Hauner foi convidada pela Editora Abril para tornarse editora de decoração das revistas femininas Claudia, o que, além de um reconhecimento por seu trabalho na Mobilinea, representou a possibilidade de estabelecer-se como uma profissional independente, afirmando-se a partir de suas próprias criações e habilidades. Atuando na empresa e junto à editora, ela desenvolveu técnicas para expor e promover o design nacional elaborando imagens simultaneamente conceituais e comerciais, com apelo à informalidade do cotidiano, aos padrões de conforto das novas classes médias urbanas, ao universo lúdico, bem como ao papel das mulheres enquanto introdutoras do viver moderno no espaço doméstico, em seus objetos, atributos e comportamentos.

Em 1966, o primeiro shopping center de São Paulo era inaugurado à Rua Iguatemi, e Mobilinea foi escolhida para ser uma das lojas âncora do empreendimento, com um espaço próprio de $500 \mathrm{~m}^{2}$ distribuídos em três níveis e planejado de modo a que também pudesse ser usado como cenário para as campanhas promocionais da empresa. Prosseguindo um desejo de fornecer todos os objetos e complementos para a casa, em 1972 os sócios da Mobilinea decidiram criar a Home Store, unindo-se a 27 outras empresas em uma loja de $1800 \mathrm{~m}^{2}$ à Avenida Nove de Julho, onde era possível encontrar desde mobiliário para casa e jardim, a discos, flores e livros, sempre expostos em ambientações completas e seguindo os princípios dos outros espaços da Mobilinea, que tinha controle criativo do empreendimento.

Apesar do sucesso, por razões diversas o casal Hauner decidiu vender suas ações na Mobilinea em 1975 e deixou o país. Desde então, a empresa tomou outros rumos, paulatinamente mudando seu campo de atuação, abandonando a fabricação de móveis residenciais ou com desenhos próprios. Com a entrada do grupo canadense The Global Group na Mobilinea em 1998, ela passou a operar como Global Mobilinea, sendo uma das maiores produtoras de mobiliário corporativo no mundo atualmente ${ }^{1}$, mas afora o nome não guarda mais nenhuma semelhança com a experiência empreendida nas décadas anteriores $^{2}$. A importância desta primeira fase, contudo, sobreviveu a seu fim abrupto, deixando um legado que não pode deixar de ser discutido 3 .

Esta dissertação visa contribuir com os estudos sobre a história do mobiliário, dos arranjos domésticos e das formas de morar no Brasil, focando-se em examinar criticamente a trajetória da Mobilinea, de sua fundação em 1959, ao longo de seu desenvolvimento nos anos seguintes, até 1975, quando Ernesto 
e Georgia Hauner deixaram o país. Embora tenha sido uma das iniciativas mais bem sucedidas e longevas do período, chegando a estabelecer uma fabrica própria com mais de 280 operários $^{4}$ e uma rede de onze endereços de venda em oito estados brasileiros no fim da década de 1960, com indícios inclusive de expansão internacional, a experiência foi muito pouco documentada e vem sendo frequentemente subestimada pela historiografia do design.

Não se pode dizer, contudo, que seja uma ausência singular em um campo de outro modo estabelecido, pois a pesquisa em história do design no Brasil é quase em sua totalidade bastante recente. Afora textos críticos pontuais, consideramos que o primeiro trabalho de fôlego a pensar a produção nacional foi o de Maria Cecília Loschiavo dos Santos, "Móvel Moderno no Brasil"5, publicado em 1995 e baseado em sua pesquisa de mestrado da década anterior, na qual recupera o trabalho de arquitetos e designers que pensaram o móvel no país ao longo do século XX, privilegiando a produção ligada à arquitetura moderna. Desde então, outros estudos vêm sendo desenvolvidos em âmbito acadêmico e editorial com crescimento expressivo nos últimos anos, podendo ser identificadas algumas tendências: trabalhos voltados a outras áreas de conhecimento, como a antropologia, a história e a sociologia, que se apoiam no design para discutir suas problemáticas, dentre os quais reconhecemos em especial o trabalho de Marinês Ribeiro dos $\operatorname{Santos}^{6}$, que discute transformações nas relações de gênero e domesticidade no Brasil nos anos 1960 e 70 a partir da revista Casa \& Jardim, analisando, dentre outras, imagens produzidas pela Mobilinea, e a pesquisa de Vânia Carneiro de Carvalho ${ }^{7}$, que investiga mudanças nas relações de gênero na virada do século XX em São Paulo a partir da organização material da moradia; trabalhos focados na história da profissão, da difusão e do ensino de design no país, com destaque às pesquisas de Marcos da Costa Braga e Ethel Leon"; pesquisas sobre o campo gráfico"; e, finalmente, sobre design de produtos, dentre os quais o mobiliário é sem dúvida o mais popular, contando com estudos que apresentam o estado da arte em determinados locais e períodos, catalogando diferentes produções ${ }^{10}$, e com pesquisas específicas sobre designers e empresas, nas quais se enquadram os estudos de Marlene Acayaba sobre a móveis Branco \& Preto ${ }^{11}$, de Soraia Cals sobre Joaquim Tenreiro e Sergio Rodrigues ${ }^{12}$, de Mauro Claro sobre a Unilabor $^{13}$, de Maria Angélica Santi sobre a Móveis $\mathrm{Cimo}^{14}$, dentre outros ${ }^{15}$, trazendo luz a questões de extrema pertinência ao campo como um todo. 
Há preocupações recorrentes em boa parte desses trabalhos acerca do que seria o design verdadeiramente "moderno" ou verdadeiramente "brasileiro", que não nos furtamos de enfrentar, mas que não são efetivamente o nosso problema nesta pesquisa. Assumimos, assim, que a Mobilinea produziu design moderno brasileiro, não tanto por suas peças terem assumido tal ou qual proposta plástica, mas por terem sido pensadas frente às condições locais de produção e consumo, através de métodos racionais, econômicos e eficientes de projeto, fabricação e distribuição, visando atuar em um campo de aspirações associadas a processos de modernização técnica e social do país.

A empresa é mencionada em alguns desses estudos, mas via de regra em notas laterais com pequenas incorreções que por vezes repetem-se ou mesmo apresentam contradições entre si, de forma que, para traçar o desenvolvimento da Mobilinea, o levantamento e análise de fontes primárias foi essencial. Em setembro de 2012, realizei uma viagem a Vancouver, no Canadá, onde Georgia Hauner reside atualmente, para levantar o material que ela e Ernesto levaram da Mobilinea quando de sua mudança para aquele país em 1975, sobre o qual tínhamos poucas informações acerca da quantidade e natureza. Não foram encontrados projetos de mobiliário ou dados sobre o funcionamento da fábrica (pois o casal supôs em sua saída que as peças continuariam em produção), mas, por outro lado, havia um grande conjunto de fotografias das lojas e dos móveis, documentos originais datilografados por Georgia, Ernesto e John de Souza, catálogos, convites para exposições, correspondências e projetos para espaços comerciais, dentre os quais se sobressai um conjunto completo de desenhos para a Home Store ${ }^{16}$. Além disso, e o que se descobriu extremamente relevante, Georgia possui uma grande coleção de periódicos brasileiros que contavam com propagandas e reportagens sobre a Mobilinea ou realizadas por ela na Editora Abril, a partir dos quais começamos a entender seu impacto e o da empresa na mídia impressa.

Somando estes volumes ao levantamento feito na biblioteca da FAUUSP, na Editora Abril e nos acervos virtuais de A Folha de São Paulo e O Estado de São Paulo, localizamos aparições da Mobilinea nos dois jornais paulistas e em vinte e uma revistas nacionais e estrangeiras, voltadas a assuntos tão diversos quanto arquitetura, artes, política, economia, cultura, moda, decoração e temáticas direcionadas ao público feminino ${ }^{17}$. Com este material, foi possível criar um banco de dados usados não apenas como referência imagética ou para 
avaliar o impacto das propostas da empresa, mas também como parâmetro do funcionamento de pontos de venda, do lançamento e da repercussão de novos produtos, tendo em vista que muitos dos registros e catálogos próprios não são datados ${ }^{18}$.

Assim, a pesquisa tomou um rumo imprevisto em seu esboço inicial, deslizando do estudo do design e do processo de produção dos móveis da Mobilinea para o enfrentamento de suas relações com as propostas de revisão do ambiente doméstico, flagradas a partir das estratégias visuais e promocionais adotadas pela empresa em seus espaços comerciais e campanhas publicitárias. Esse foco no imaginário do morar e da vida privada promovido pela Mobilinea por um conjunto coerente de imagens associadas a seus móveis, bem como a seus usos, usuários e ambientes correspondentes, de fato conduziu a um interesse particular na atuação de Georgia Hauner, cuja figura permitiu que avançássemos em aspectos da história do móvel ligados a sua promoção publicitária e comercial, sua articulação com a história do gosto, dos estilos de vida e dos padrões de uso e conforto nos interiores domésticos, e do papel das revistas femininas e das mulheres - designers, editoras, leitoras, consumidoras - na afirmação do design e da ambientação modernos.

Seguimos o postulado de Beatriz Colomina de que a percepção de um espaço não é o que ele efetivamente é, mas apenas uma de suas representações e, neste sentido, o espaço construído não tem mais autoridade ou veracidade do que desenhos, fotografias ou descrições sobre ele ${ }^{19}$. Acreditamos que o mesmo se aplique não apenas para os espaços comerciais e imagens promocionais da Mobilinea, como para os móveis em si, e supomos que havia inclusive uma compreensão desta dimensão na Mobilinea, que assumidamente tornava o objeto indissociável de seu cenário e subsequente fotografia. Mais do que isso, consideramos que, através de periódicos, Mobilinea pode amplificar suas propostas para um público diverso e em escala nacional e, por tudo isso, focalizamos a presente pesquisa na imagem da empresa, buscando compreender seus mecanismos de promoção e suas relações com os estilos de vida propostos.

O material localizado na mídia impressa foi então confrontado a depoimentos de pessoas que atuaram ou estiveram próximas da Mobilinea, a começar pela própria Georgia Hauner, que me concedeu quatro entrevistas durante o período de pesquisa em Vancouver. Além dela, foram também 
ouvidas Ada Hauner (1924-), irmã de Ernesto e responsável pelas vendas da linha de móveis de escritório da Mobilinea desde meados dos anos 1960 até depois da saída do casal; Bibita (Maria Beatriz) Butcher (1944-), vendedora e gerente da loja do Shopping Iguatemi; Judit Magyary (1946-), inicialmente vendedora, atuou também assistindo clientes no planejamento de interiores, assim como na concepção da cenografia da Home Store; Yone Koseki Pierre (1940-), arquiteta que trabalhou na loja e também na fábrica como assistente de projetos de Ernesto; Jorge Kornbluh (1930-), engenheiro e primeiro sócio da empresa no início da década de 1960; Matias Eisler, filho de Martin Eisler, com quem Ernesto e Georgia trabalharam na Móveis Artesanal antes de fundarem a Mobilinea; Sergio Rodrigues (1927-2014), que os conheceu no mesmo período e foi amigo e colega de profissão desde então; e Martin Wurzmann, marchand igualmente ligado aos personagens da Móveis Artesanal.

As entrevistas foram planejadas e realizadas a partir da metodologia de história oral ${ }^{20}$, compreendendo que a maneira de preparar e conduzir estas conversas faz do pesquisador em si um produtor de fontes e, assim, sua responsabilidade neste processo não pode ser subestimada. Consideramos que a memória tem um caráter intrinsicamente impreciso, em que cada entrevistado ou entrevistada pode involuntariamente aumentar ou diminuir seu papel na história, bem como dos demais personagens citados, ou mesmo atribuir-lhes posições distintas em função de acontecimentos posteriores. Ainda assim, as informações transmitidas trouxeram uma série de dados importantes sobre o funcionamento da Mobilinea e seu posicionamento de mercado, além de contribuir sobremaneira na construção de uma sensibilidade sobre a experiência de trabalho na empresa. As perguntas centraram-se em informações gerais sobre a biografia de cada entrevistado ou entrevistada, sua experiência na Mobilinea e o que ele ou ela pudesse fornecer de descrições sobre os processos de projeto, fabricação e venda, sua relação com os demais funcionários, sua percepção da empresa frente às concorrentes e considerações sobre o design no período; foram gravadas, transcritas e revisadas por mim.

Havia um limite de indivíduos que seria possível entrevistar dentro do prazo de realização da pesquisa, de forma que muitos dos nomes citados não puderam ser buscados, e outros não foram encontrados ${ }^{21}$, mas consideramos que a seleção realizada foi capaz de promover uma complementação satisfatória às demais fontes. Ao longo do desenvolvimento da pesquisa, novos questionamentos 
surgiam e houve um diálogo constante com Georgia Hauner, que teve paciência e cuidado para elaborar pequenos textos respondendo aos nossos inquéritos, acrescentando outras informações que se lembrava a partir das conversas e até de alguma forma se reposicionando em função dessa troca, o que parece fazer parte também de um processo pessoal de recuperação de seu passado. Da mesma maneira, foi necessário prudência para não nos ampararmos demasiadamente em seu ponto de vista, uma vez que muitas informações sobre o funcionamento da empresa e sobre o pensamento por trás de suas ideias vieram através dela.

Além de todas estas interferências, entendemos que o trabalho de história, assim como o do arquiteto ou do designer em relação ao desenho, situa-se ele mesmo no tempo de sua escrita, "fala nele e dele se serve ainda quando se propõe a negá-lo, repensá-lo ou disseca-lo em suas diversas temporalidades"22 de modo que não temos ilusões de chegar a uma versão definitiva dos acontecimentos ou apresentar mais do que uma compreensão temporária sobre certos aspectos da trajetória da Mobilinea. Dentre estes caminhos possíveis, inspiramo-nos também na indicação metodológica de Manfredo Tafuri, quando propõe que "para desembaraçar uma meada de fios artificialmente emaranhados entre si, vamos ter de dispor paralelamente muitas histórias independentes para então verificar, onde existirem, suas interdependências mútuas"23 e apresentamos sequencialmente a trajetória da empresa sob diversos enfoques e trazendo contextos distintos do mesmo período, como se sucessivamente adicionássemos camadas a uma história em gestação, ou então a olhássemos em sua completude com lentes diferentes a cada instante.

O primeiro capítulo pretende situar qual era a a situação da produção moveleira no Brasil até a fundação da empresa, bem como nas histórias individuais de seus criadores, buscando elementos que viriam a operar em seu trabalho na Mobilinea. Na sequência, apresentamos a trajetória da empresa em seus principais marcos e com foco nas pessoas que lá atuaram, tentando mapear seus papeis e contribuições individuais. Depois, discutimos a inserção da Mobilinea no circuito de design brasileiro nos anos 1960 e 70, com ênfase nas relações com suas concorrentes e nas exposições e premiações que surgiam, parte de um movimento mais amplo de estabelecimento do campo profissional e cultural do design naquele momento.

Tendo exposto esse quadro, o segundo capítulo busca primeiramente apresentar os móveis projetados e fabricados na Mobilinea no período, 
investigando o raciocínio por trás do lançamento de novas linhase as tecnologias empregadas para estes fins. Em seguida, abordamos o crescimento da empresa em suas fábricas, lojas e demais pontos de venda, evidenciando as estratégias promocionais e especialmente as soluções cenográficas empregadas em seus espaços de exposição. Enfim, são abordadas as parcerias que a Mobilinea fez e que culminariam na Home Store, denotando simultaneamente outras formas de associar valores à marca e o desejo de promover um espaço doméstico em sua completude.

Com esse percurso detalhado, o terceiro capítulo apresenta a inserção midiática da Mobilinea no período estudado, analisando como cada tipo de veículo demandava um discurso diferente. Como foi principalmente em publicações impressas que a empresa promoveu seus ideais, montando cenários bastante complexos e chegando a construir casas inteiras para serem fotografadas em suas campanhas, ela ultrapassou em muito a preocupação em apenas promover suas peças para genuinamente orientar os leitores a planejar interiores domésticos, emulando certos modos de morar. Ademais, em grande medida graças ao trabalho de Georgia Hauner, Mobilinea delineou seu consumidor marcado em uma perspectiva de gênero, definindo quem desfrutaria daqueles espaços, ora associando-o à mulher que os editava, ora às modelos retratadas nas fotografias, ora às leitoras que os consumiam potencialmente, considerando-as como sujeitos cosmopolitas, urbanizados, informados, emancipados e antidogmáticos.

Finalmente, nas considerações finais, buscaremos ligar alguns pontos levantados nesse capítulo aos demais, fazendo um balanço da trajetória da Mobilinea, bem como assinalar algumas contribuições desta dissertação e indicar novas perspectivas de pesquisa que se abrem a partir desse estudo. 
Notas

1 Segundo informações de divulgação da empresa. Disponível em: http://www.mobilinea.com.br/aempresa. Acesso em 25/01/2015.

${ }^{2}$ Foram realizadas inúmeras tentativas de contato com a Global Mobilinea desde 2011, atendidas apenas em dezembro de 2014, quando descobrimos que a empresa efetivamente não possuía acervo anterior à década de 1980. Embora não tenha sido encontrado material aproveitável para esta pesquisa, agradeço ao Sr. Eduardo Stierbalov pela atenção dispensada. Georgia Hauner relatou que em passagem pelo Brasil no ano 2000, recebeu um conjunto de materiais da Global Mobilinea mas os considerou falsos e os jogou fora, o qual supomos que fossem originais. Georgia Hauner, Mobilinea - the good times, 2014, p. 13.

${ }^{3}$ Em 2010, Ernesto e Georgia Hauner foram selecionados para fazer parte da mostra "Os Modernos Brasileiros + 1" no Museu Oscar Niemeyer em Curitiba, com curadoria de Consuelo Cornelsen, como uma das atividades paralelas à Bienal Brasileira de Design, realizada naquele ano na capital paranaense. Isso motivou a vinda de Georgia Hauner ao Brasil com seu filho, Mike Hauner, e a partir daí estabeleceuse o contato que deu início à pesquisa. Além deles, a exposição expôs também o trabalho de Gregori Warchavchik, Lasar Segall, John Graz, Joaquim Tenreiro, Lina Bo Bardi, Vilanova Artigas, Zanine Caldas, Giuseppe Scapinelli, Flávio de Carvalho, Carlo Hauner, Sérgio Rodrigues, Geraldo de Barros, Jorge Zalszupin, Paulo Mendes da Rocha, Jean Gillon, Michel Arnoult, Oscar Niemeyer e Carlos Motta. Ficou em cartaz entre 23 de setembro e 28 de novembro daquele ano.

${ }^{4}$ Ernesto Hauner, Resumé, c. 1975, p. 2. Documento datilografado do acervo pessoal de Georgia Hauner. ${ }^{5}$ Maria Cecília Loschiavo dos Santos, Móvel Moderno no Brasil, 1995.

${ }^{6}$ Marinês Ribeiro dos Santos, O Design Pop no Brasil dos anos 1970: domesticidades e relações de gênero na revista Casa e Jardim, 2010.

7 Vânia Carneiro de Carvalho, Gênero e Artefato: o Sistema Doméstico na Perspectiva da Cultura Material - São Paulo, 1870-1920, 2008.

${ }^{8}$ Ethel Leon, IAC - Primeira Escola de Design do Brasil, 2014; Marcos da Costa Braga, ABDI e APDINS-RJ: História das Associações Pioneiras de Design do Brasil, 2011.

${ }^{9}$ Como os trabalhos de André Stolarski, Alexandre Wollner e a Formação do Design Moderno no Brasil: Depoimentos Sobre o Design Visual Brasileiro, 2005; Celso Longo, Design Total: Cauduro Martino, 19671977, 2007; Chico Homem de Melo, Linha do Tempo do Design Gráfico no Brasil, 2011; dentre outros.

${ }^{10}$ Dos quais destacamos o próprio livro de Maria Cecília Loschiavo dos Santos, bem como os de Alexandre Penedo Barbosa de Melo, Design do mobiliário moderno brasileiro: aspectos da forma e sua relação com a paisagem, 2008; Ethel Leon, Design brasileiro - Brazilian design: quem fez, quem faz - who did, who does, 2005; Gloria Bayeux, O Móvel da Casa Brasileira, 1997; Marcelo Vasconcellos e Maria Lucia Braga, Móvel Moderno Brasileiro, 2012; dentre outros.

${ }^{11}$ Marlene Milan Acayaba, Branco \& Preto: uma história do design brasileiro nos anos 50, 1994.

${ }_{12}$ Soraia Cals, Tenreiro, 1998; Soraia Cals, Sergio Rodrigues, 2000.

${ }^{13}$ Mauro Claro, Unilabor - desenho industrial, arte moderna e autogestão operária, 2004; Mauro Claro, Dissolução da Unilabor: crise e falência de uma autogestão operária - São Paulo, 1963-1967, 2012.

${ }^{14}$ Maria Angélica Santi, Mobiliário no Brasil: Origens da Produção e da Industrialização, 2013.

${ }^{15}$ Aline Sanches, O Studio de Arte Palma e a fábrica de móveis Pau Brasil: povo, clima, materiais nacionais e o desenho de mobiliário moderno no Brasil, 2004; Anna Maria Affonso dos Santos, John Graz: O Arquiteto de Interiores, 2008; Cristina Ortega, Lina Bo Bardi: móveis e interiores (1947-1968) - interlocuções entre moderno e local, 2008; Suely Ferreira da Silva, Zanine: sentir e fazer, 1995; Tania Galvão, Sergio Rodrigues: arquiteto e desenhista de móvel, 2001; dentre outros.

${ }^{16} \mathrm{~A}$ lista completa de todos os documentos localizados, fotografados e catalogados no acervo pessoal de Georgia Hauner encontra-se anexa a esta dissertação.

17 As revistas nas quais localizamos inserções da Mobilinea entre 1959 e 1975 foram: Arquiteto, Arquitetura, C. J. Arquitetura, Casa \& Jardim, Casa de Claudia, Claudia Noiva, Claudia, Ele \& Claudia, Desfile, Escritório Atual, Exame, GAM - Galeria de Arte Moderna, Indústria e Desenvolvimento, Jóia, Mais, Projeto e Construção, Realidade, Time Magazine - Latin American Edition, Veja e Visão. A lista com data e natureza de cada inserção encontra-se anexa a esta dissertação.

${ }^{18}$ Quando foram citados trechos de reportagens, entrevistas ou textos sobre a Mobilinea em periódicos, bem como no uso de documentos originais no acervo de Georgia Hauner, foi mantida à ortografia da época. ${ }^{19}$ Beatriz Colomina, Privacy and Publicity: Modern Architecture as Mass Media, 1994.

${ }^{20}$ Verena Alberti, História oral: a experiência do CPDOC, 1989.

${ }^{21}$ A ausência mais evidente dentre os entrevistados é a de John de Souza, que infelizmente encontra-se em um estado de saúde que não permitiu a realização de um encontro.

22 José Tavares Correia de Lira, "A História e o Fazer da Arquitetura" in: Desígnio, Dossiê: história, historiografias, historiadores, 2011, p. 16.

${ }^{23}$ Manfredo Tafuri, "Arquitetura e Historiografia. Uma proposta de método" in: Desígnio, Dossiê: história, historiografias, historiadores, 2011, p. 24. 

1. Design e Designers 

É importante situar o estado do design no Brasil antes da fundação da Mobilinea para se compreender sua trajetória, isto é, para se pensar o modo como ela se constituiu e se inseriu no mercado e no campo que ela partilhava e disputava com outras empresas. Serão discutidas neste capítulo primeiramente as iniciativas em desenho de móvel no país cuja atuação parece ter impactado mais diretamente a criação da empresa, seja por atuarem em um mesmo meio e contexto econômico e cultural, seja pelas rivalidades e parcerias que as aproximavam.

A partir disso, localizaremos a formação dos principais personagens a atuar na Mobilinea e como entraram em contato, principalmente a partir da Móveis Artesanal. Na sequência, a trajetória da empresa será apresentada em linhas gerais desde sua fundação, em 1959, ainda denominada Ernesto Hauner Decorações, até a saída de Ernesto e Georgia Hauner em 1975, com foco nos eventos que marcaram os rumos da empresa e na atuação dos diferentes profissionais que passaram por ela. Cada eixo de atuação da Mobilinea será analisado em maior detalhe nos capítulos seguintes, de forma que aqui buscase estruturar uma cronologia mais abrangente que auxilie a sua compreensão.

Esta trajetória será então reinserida em um panorama do móvel moderno no período, particularmente em São Paulo, de modo a entender como este campo de ofertas estéticas e comerciais se desenvolveu naquelas duas décadas. A existência de determinado número de empresas atuando de forma similar e mesmo concorrendo umas com as outras parece ter sido decisiva para que a própria ideia de móvel moderno se afirmasse cultural e economicamente, constituindo conjuntamente um público e um mercado. Ao mesmo tempo, com a institucionalização do design no país, eventos e premiações começaram a surgir, muitos dos quais contaram com a participação da Mobilinea e serão também apresentados aqui. 


\subsection{Rumos do móvel moderno no Brasil}

Ao longo do século XIX, com a expansão do comércio internacional e o fim do sistema escravista, muitas cidades brasileiras passaram por acelerados processos de mudança e crescimento, que tornaram dinâmicas urbanas e programas domésticos mais complexos, e trouxeram novos costumes e modismos. Já na virada para o século XX, começou a emergir no país um desejo de encontrar uma identidade própria para a produção moveleira, dando origem às primeiras iniciativas de interesse ao desenvolvimento do móvel moderno e que, grosso modo, podem ser divididas em duas vertentes: empreendimentos que investiram no aperfeiçoamento de seus desenhos tendo em vista a produção seriada, sem grandes questionamentos socioculturais; e iniciativas de artistas e arquitetos que, embora concebessem produtos para ambientes modernistas e em diálogo com a produção estrangeira, continuariam a fabricálos artesanalmente e em escala restrita.

Do primeiro grupo, há de se mencionar os móveis Thonet, criados na Áustria em meados do século XIX1 [1.1.01] e que começaram a ser produzidos no Brasil a partir de 1890 pela Companhia de Móveis Curvados no Rio de Janeiro. Em 1908, o empresário gaúcho João Gerdau instalou uma oficina de móveis vergados às margens do Rio Guaíba, em Porto Alegre, dando início à Gerdau², que passou a fabricá-las, e foi gradualmente aumentando sua produção para fazer as várias cadeiras e poltronas da linha com a mesma técnica3 [2.1.11].
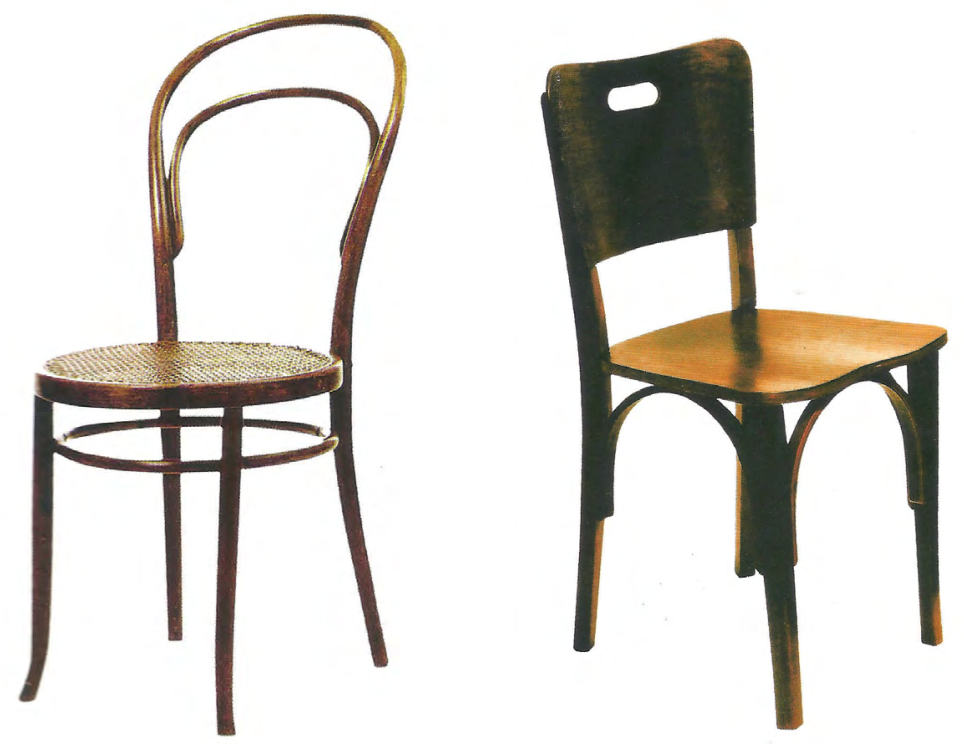

1.1.01: Cadeira Thonet, século XIX. Imagem publicada no livro Mobiliário no Brasil: Origens da Produção e da Industrialização, (Maria Angélica Santi, 2013), p. 141.

1.1.03: Cadeira 1001, Móveis
Cimo S.A. Imagem publicada
no livro Mobiliário no Brasil:
Origens da Produção e da
Industrialização, (Maria
Angélica Santi, 2013), p. 147. 
1.1.02: Cama Patente fabricada pelas Indústrias Patente L. Liscio S.A. a partir de 1942. Imagem publicada no livro Mobiliário no Brasil: Origens da Produção e da Industrialização, (Maria Angélica Santi, 2013), p. 144.

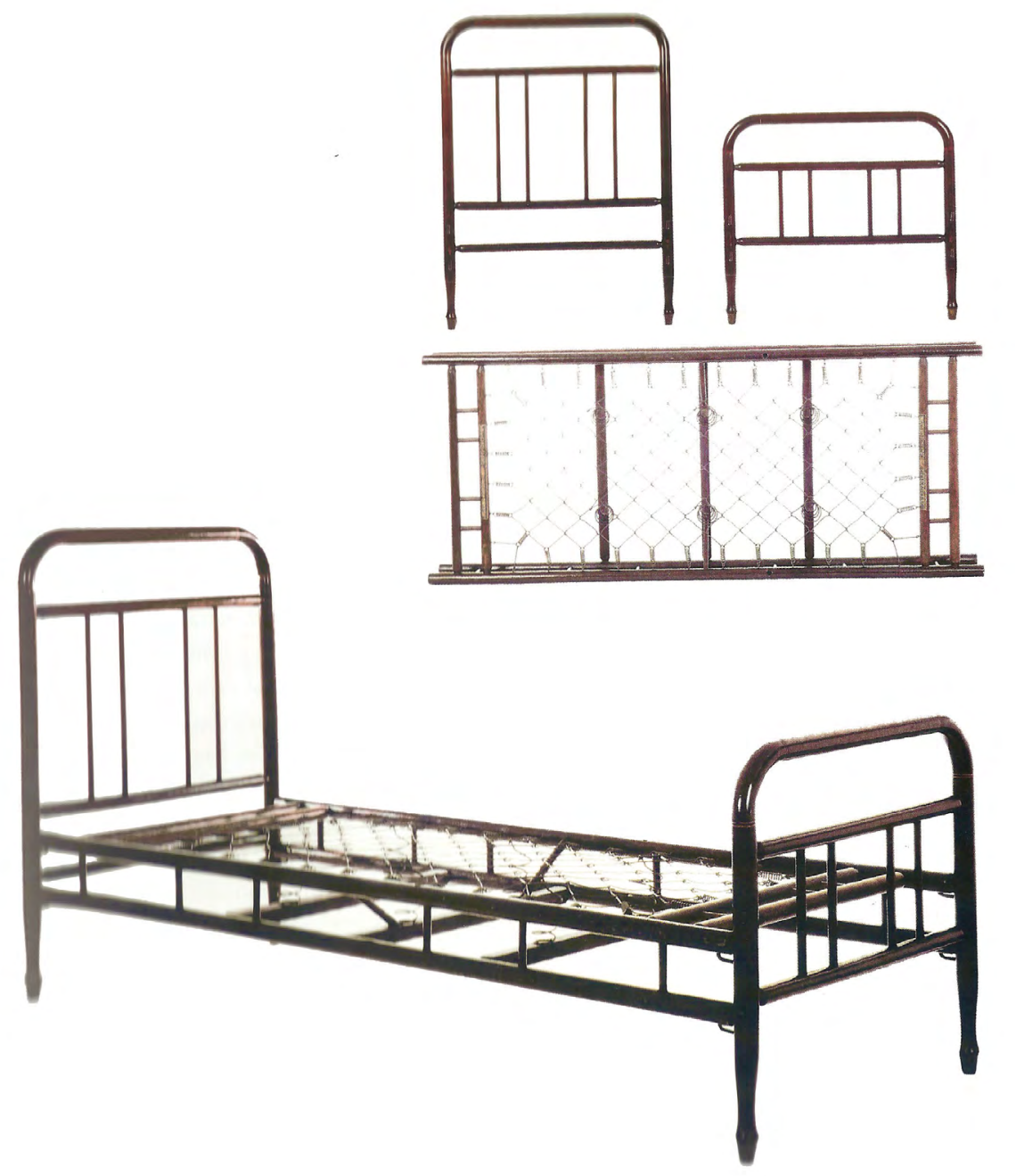

Com o eclodir da Primeira Guerra Mundial, a importação de uma série de produtos foi suspensa no Brasil, gerando oportunidades para o desenvolvimento da manufatura e da indústria no país, incluindo o setor moveleiro. Bons exemplos disso são a Cama Patente, de Celso Martinez Carrera, e a Indústria de Móveis Cimo. A primeira foi desenvolvida em Araraquara em 1914 para equipar uma clínica médica, já que camas inglesas de estrutura metálica estavam indisponíveis, e em 1915 Carrera finalizou seu desenho, considerando produção industrial a baixo custo com elementos em madeira torneada e encaixes metálicos ${ }^{4}$ [1.1.02]. A segunda, fundada em 1921, teve sua atuação mais marcante durante a década de 1930, com assentos em madeira vergada combinada a peças retas, desmontáveis para facilitar seu transporte, produzidas em série e feitas a partir de aparas de imbuia com encaixes quase todos feitos sem cola. A Cimo foi ainda pioneira no uso de madeira compensada laminada moldada, com a importação de maquinário apropriado para sua usinagem ${ }^{5}$ [1.1.03].

Nesses três casos, novas tecnologias foram desenvolvidas e o resultado formal das peças refletia uma capacidade de síntese que pode ser tomada como moderna, ainda que não viesse acompanhada de um discurso social reformador. 
Por uma via distinta, discussões acerca da arte e arquitetura moderna se desenvolviam nos círculos culturais das principais capitais do país a partir de meados dos anos 1920, e algumas experiências que visavam desenvolver a totalidade da habitação se debruçaram sobre qual seria o seu mobiliário. Dentre estas estava o trabalho do artista John Graz e sua esposa, Regina Gomide, que propunham a renovação dos interiores domésticos a partir de ambientações completas, com o planejamento dos cômodos, a produção de seu mobiliário e de elementos decorativos como quadros, tapeçarias, panneaux e almofadas ${ }^{6}$. Esses complementos eram feitos por Regina, que teve uma contribuição importante na exposição da casa modernista da Rua Itápolis, de Gregori Warchavchik. Este, ucraniano de nascimento e com formação em arquitetura na Itália, imigrou para o Brasil em 1923 e aqui tomou contato com os círculos modernistas, inaugurando em 1930 sua "Exposição de uma Casa Modernista”, que exibia uma casa com arquitetura e interiores desenvolvidos por ele e outros artistas modernistas, além de jardins criados por sua esposa, Mina Klabin Warchavchik ${ }^{7}$ [1.1.04-1.1.05].

Estes móveis eram feitos artesanalmente, muitas vezes com materiais novos - caros e importados -, que transmitiam o raciocínio de ambientações modernas no debate internacional. Nesse sentido, as peças foram raramente comercializadas desvinculadas de projetos de edificação, tanto em função da ausência de um mercado interessado, como de uma indústria de materiais de base e manufatura naquele estágio de desenvolvimento. Nas duas situações, vale enfatizar a parceria de casais e a divisão de tarefas entre eles, relegando aos homens um foco projetual mais técnico e às mulheres as artes consideradas menores, o que também viria a ocorrer na Mobilinea ${ }^{8}$.

Theodor Heuberger foi outro nome importante no ramo moveleiro entre as décadas de 1920 e 40, mas, ao contrário dos anteriores, não projetava. O marchand e animador cultural radicou-se no Brasil após emigrar da Alemanha e em 1926 abriu uma loja chamada Galeria Casa \& Jardim, no Rio de Janeiro. Sua ideia era integrar os espaços internos e externos da casa, unindo arquitetura, paisagismo, mobiliário e arte, com uma linha de móveis modernos e outra de clássicos, produzidos artesanalmente. Em 1938, abriu uma filial em São Paulo à Rua Barão de Itapetininga e, embora não haja informações sobre como era seu layout, pode-se supor que tenha sido um dos primeiros espaços no país a expor ambientes modernos de forma sistemática. Dentre outros, o arquiteto austríaco Bernard Rudosfky ${ }^{9}$ colaborou com projetos para os móveis lá comercializados, durante o período em que morou no Brasil (1939-1941).

Projetos de Rudofsky foram premiados no concurso de móveis e consequente exposição, Organic Design in Home Furnishings, organizados pelo 
1.1.04-1-1.05: Interiores da "Exposição de uma Casa Modernista", concebida e organizada por Gregori Warchavchik em 1930 em residência de sua autoria à Rua Itápolis. Acervo pessoal família Warchavchik.
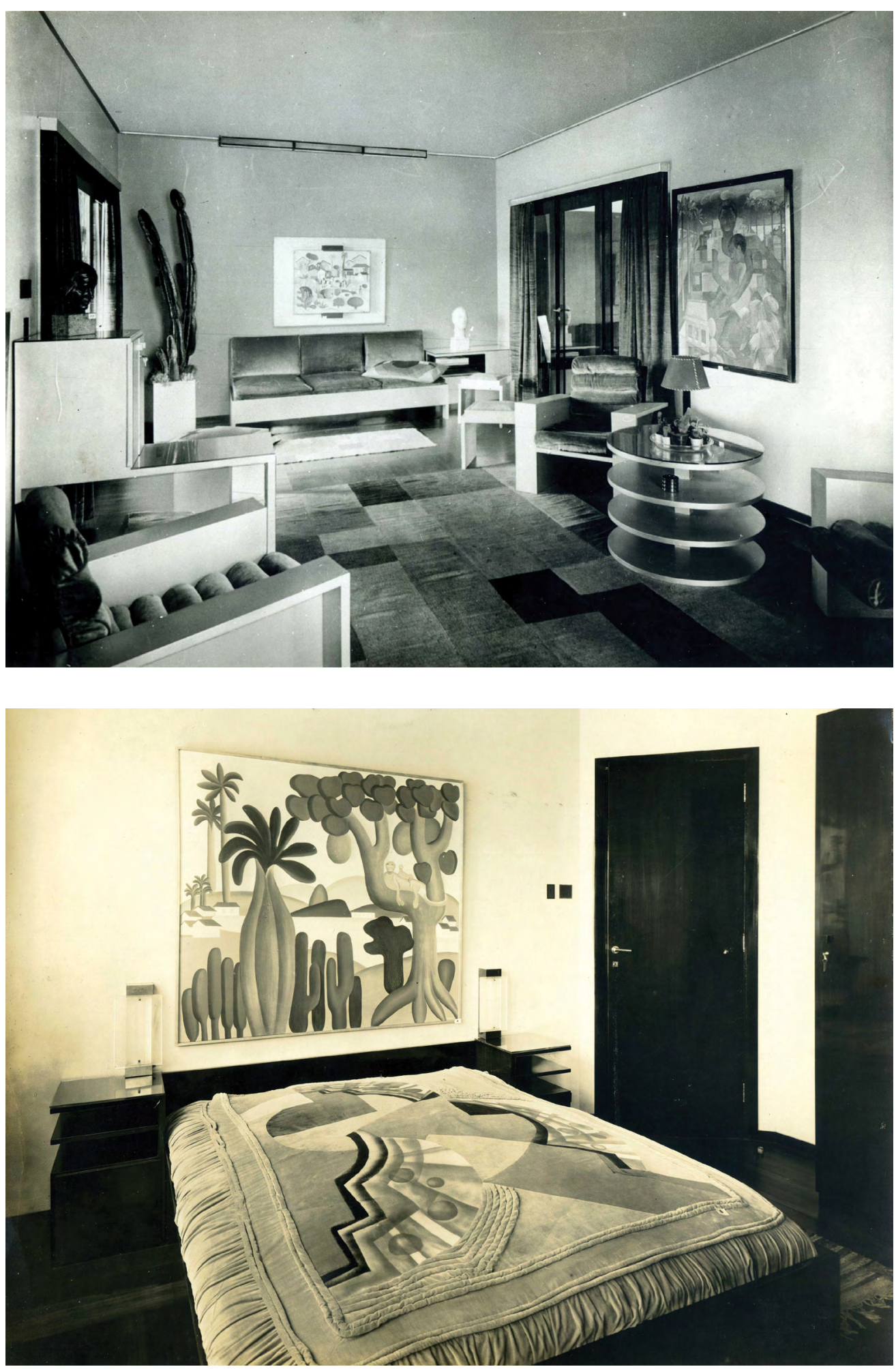

Museum of Modern Art (MoMA) de Nova York, em $1941^{10}$ com peças, como outras que desenvolvera na Itália, que continham elementos irreverentes mas também algo que remetia a uma linguagem europeia tradicional [1.1.06]. Neste caso, Rudofsky misturou materiais industriais como metais galvanizados e pintados a fibras naturais brasileiras, combinação que seria retomada alguns anos depois, no Studio de Arte Palma e na Móveis Artesanal, porém com outro resultado formal. 


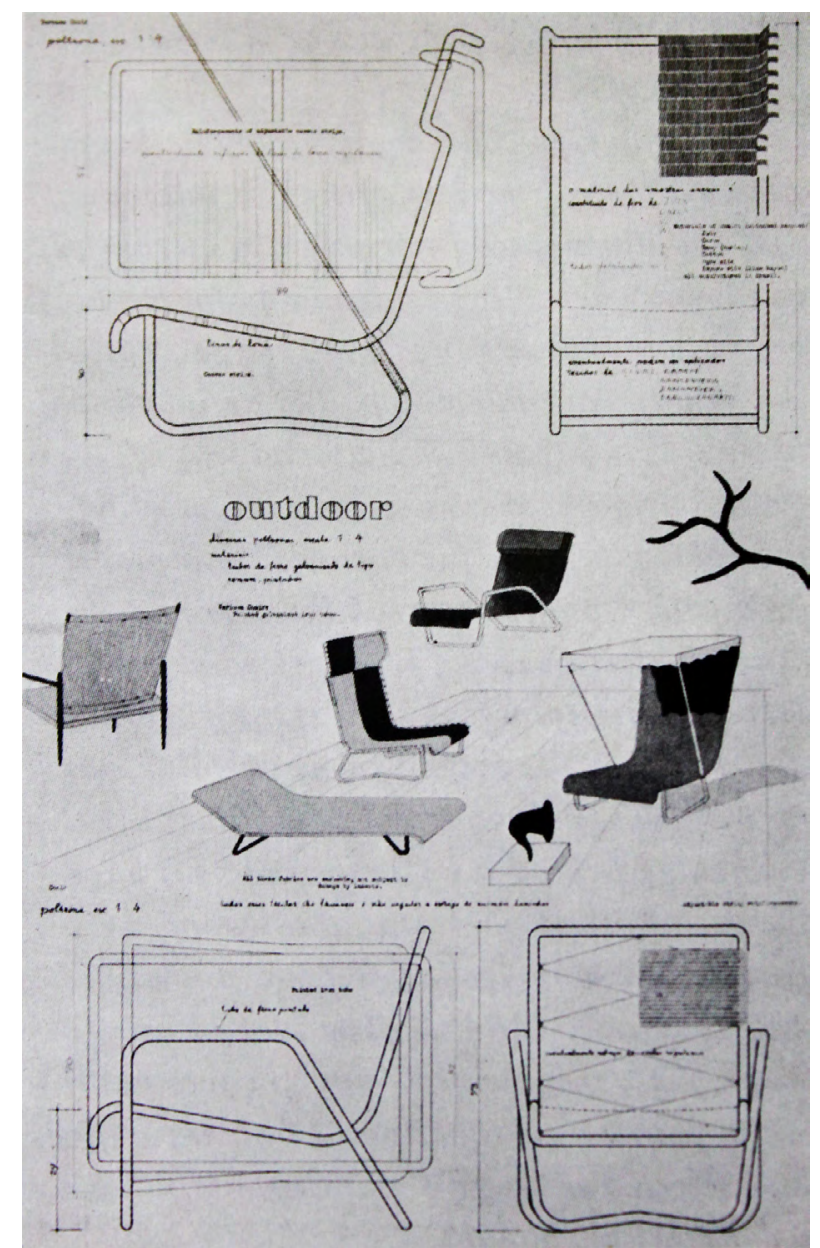

Apesar dessas experiências, boa parte dos móveis comercializados no país neste período reproduziam peças de estilo e, assim como a maioria dos bens manufaturados consumidos até a Segunda Guerra Mundial, continuavam a ser importados. Quando os conflitos tornaram Europa e Estados Unidos incapazes de suprir sua própria demanda de produtos industrializados, o Brasil pôde aumentar suas exportações e passou a produzir e consumir itens anteriormente importados, principalmente na região sudeste do país, que se tornou um polo de investimentos e empregos com a política de substituição de importações, a criação de indústrias de base e a instalação crescente de filiais de empresas multinacionais no país. Foi nesse contexto que teve início a produção de uma série de novos materiais como plástico, óleo diesel, detergente, asfalto, fibra sintética, alumínio, cimento e vidro, além da modernização de indústrias tradicionais dos setores têxtil, farmacêutico, de calçados e bebidas. Muitos destes materiais, por sua vez, possibilitaram a produção e o consumo no país de incontáveis equipamentos domésticos nos anos seguintes, como ferro elétrico, fogão à gás de botijão, panelas de pressão, frigideiras de alumínio, chuveiro elétrico, liquidificador, batedeira de bolo, geladeira, secador de cabelos, máquina de barbear, aspirador de pó, enceradeira, torradeira, máquina de lavar roupa, rádio de pilha, eletrola, vitrola hi-fi, aparelho de som, disco de
1.1.06: Projetos de Bernard Rudofksy para o concurso Organic Design in Home Furnishings, 1941. Imagem publicada no livro Bernard Rudofsky: a humane designer (Andrea Bocco Guarnieri, 2003), p. 283 
vinil, TV preto e branco e depois a cores, controle remoto, videocassete e arcondicionado ${ }^{11}$. Práticas sociais se transformaram com a disseminação destes novos produtos, mudando cotidianos, sobretudo entre as camadas médias e altas da população, cujos padrões de consumo e vida doméstica seriam fortemente afetados pelo acesso a esses bens modernos. Também no início dos anos 1950, foram fundadas a Duratex e a Eucatex, que passaram a fabricar madeira compensada em grande escala, usadas inicialmente na construção civil e depois na indústria moveleira. Visando este mesmo segmento, em 1954 Formiplac foi criada para produzir laminados para revestimento, e em 1966 a Placas do Paraná iniciou a fabricação de madeira aglomerada ${ }^{12}$.

Ainda neste período, trens foram substituídos por autoestradas, permitindo o espraiamento das manchas urbanas e a vinda de migrantes, e em um nível mais aproximado isso possibilitou também a dilatação da localização de pequenas e grandes fábricas. "Metropolização" parece ser o termo mais apropriado para entender este movimento, que alguns autores apontam como simplesmente a conurbação de diversas cidades, desprezando um contexto sociocultural mais complexo. Para Regina Meyer, contudo, metropolização é um processo de gerar novas formas "de construir, de comprar, de morar, de circular, de divertir-se, de usufruir e produzir objetos artísticos, de comunicarse e, sobretudo, de conviver de forma 'cosmopolita"'13. Neste processo, as diversas instâncias da vida urbana se voltam para as massas, para a produção em larga escala, especificamente no âmbito da indústria e da cultura, e esta produção prescinde, evidentemente, de um consumo em igual proporção. De acordo com João Manuel Cardoso de Mello e Fernando Novais, a sensação de grande parte dos brasileiros entre 1950 e o final dos anos 1970 era de que faltava dar poucos passos para o Brasil se tornar uma nação moderna, e o faria incorporando as conquistas materiais do capitalismo aos traços de caráter que nos singularizavam como povo: a cordialidade, a criatividade e a tolerância ${ }^{14}$.

Também devido à guerra, novas levas de imigrantes europeus chegaram ao Brasil, muitas das quais à São Paulo. Distinguindo-se de certo modo da grande imigração de algumas décadas antes, o fluxo deste período seria em grande medida formado por grupos profissionalizados, intelectualizados e urbanizados, que atuariam na mudança das relações sociais na capital e particularmente no campo da produção e do consumo cultural. Na década de 1950, um terço da população paulistana era deimigrantes oufilhos deimigrantes, e a população proveniente de migração interna era tampouco desprezível ${ }^{15}$. Essa efervescência levou à fundação de uma série de equipamentos culturais na cidade: em 1947, foi criado o Museu de Arte de São Paulo (MASP) por Pietro Maria Bardi e Assis Chateaubriand (o primeiro imigrante italiano e o segundo migrante da Paraíba) e quase ao mesmo tempo viabilizou-se o Museu de Arte 
Moderna de São Paulo (MAM), a partir da atuação de Ciccillo Matarazzo, inaugurado em 1948. O MAM foi também responsável pelas primeiras bienais de arte no país a partir de 1951, que contribuíram de maneira decisiva na divulgação da produção artística nacional e internacional, e contava ainda com seções de arquitetura, cinema e música.

Tomava corpo neste período o movimento do concretismo, que entendia que a arte deveria se libertar da banalidade e da representação não metafórica, assumindo um papel social ativo de transformação, desenvolvendo ideias de movimentos construtivistas europeus das décadas anteriores ${ }^{16}$. Esta espécie de "arte útil", lógica, que trabalhava formas seriadas, viria muito de encontro às discussões sobre desenho industrial que se davam tanto no campo gráfico como no de produtos. O MASP criou em 1951 o Instituto de Arte Contemporânea - IAC, uma escola de design que se baseava no método da Bauhaus e do Institute of Design de Chicago e, embora a dificuldade de inserção no mercado dos alunos egressos tenha levado o curso a fechar dois anos depois, esta experiência contribuiu para estruturar as bases da atividade de design no país ${ }^{17}$. Em 1947 foi criado o curso de arquitetura no Mackenzie e em 1948 na Faculdade de Arquitetura e Urbanismo na Universidade de São Paulo (FAUUSP), denotando clara ampliação do ensino superior, bem como do campo da arquitetura e do urbanismo.

Nesses anos, a arquitetura moderna brasileira se consolidava e era reconhecida internacionalmente, principalmente por seus edifícios monumentais, contemplados na exposição Brazil Builds, organizada pelo MoMA de Nova York em 1943, como resultado de uma viagem pelo país realizada por Philip Goodwin e G. E. Kidder Smith, sob supervisão de Lúcio Costa. Essa corrente da arquitetura moderna, também endossada pelo Estado, criava um elo com a produção colonial pela apropriação de elementos tradicionais filtrados pelos parâmetros do gosto modernista, e teve seu ápice com a construção de Brasília em $1960^{18}$. Parte da produção de móveis modernos neste momento respondia a esta produção, e parte trilhava caminhos independentes, mas pode-se dizer que ambas correntes buscavam conciliar uma produção ao mesmo tempo racional no sentido de desenho e fabricação, e popular no sentido de serem acessíveis e dialogarem com elementos locais. Apesar disso, essas iniciativas, em escalas variadas, encontraram impasses na fabricação e formação de público, levando a uma predominância de produções artesanais com preços ainda elevados.

Joaquim Tenreiro ${ }^{19}$ foi quem talvez tenha atuado mais proximamente ao grupo de arquitetos ligados a Lúcio Costa. Inicialmente, trabalhou como projetista de móveis de estilo, mas em 1942 abriu com o alemão Langenbach, ex-vendedor da empresa Laubisch \& Hirth, onde também ele trabalhara, uma loja de móveis chamada Langenbach \& Tenreiro, com uma linha tradicional 
e outra moderna, esta última sendo a única comercializada a partir de 1947. Tenreiro utilizou majoritariamente madeira maciça, em seções mínimas, encaixes delicados e revestimentos em couro e palhinha, consagrando uma nova estética para estes materiais; seus perfis mínimos estavam em diálogo com materiais coloniais e também com a produção moderna internacional de pés palitos metálicos, embora seus móveis fossem feitos de maneira estritamente artesanal e em poucas unidades ${ }^{20}$. Em 1953, abriu uma filial em São Paulo à Rua Marquês de Itu, que funcionou até 1961; a matriz carioca ficou aberta até 1968 com produtos expostos em ambientações completas [1.1.07].

\footnotetext{
1.1.07: Loja de Joaquim Tenreiro em São Paulo com móveis de sua autoria ambientados como em residências, década de 1950. Imagem publicada no livro Tenreiro (Soraia Cals, 1998), p. 48.
}

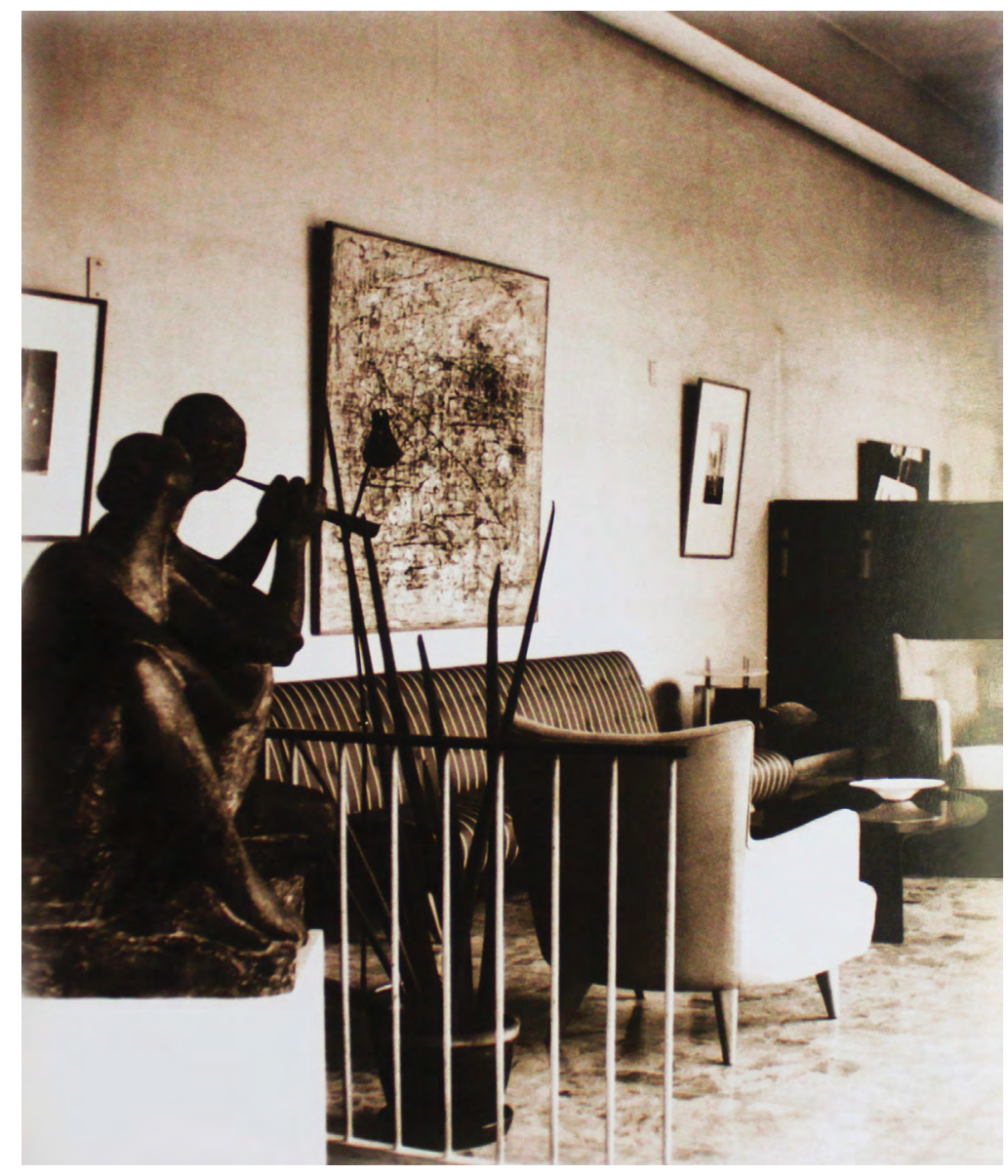

Também preocupada com a ambientação de suas peças, Branco \& Preto foi uma loja que tinha móveis expostos como em ambientes residenciais, amplos e integrados, com materiais sóbrios e poucos elementos decorativos, contando com profissionais à disposição para desenvolver o planejamento dos interiores. Fundada em 1952 pelos arquitetos Miguel Forte, Jacob Ructhi, Roberto Aflalo, Carlos Millan e Chen Y Hwa, a empresa nascera do desejo de realizar um projeto de arquitetura moderna do início ao fim, o que incluía seu mobiliário. O grupo seguia algumas premissas ligadas à produção arquitetônica norte-americana, especialmente para habitações unifamiliares, com ambientes integrados entre si e às áreas externas [1.1.08]. As peças da Branco \& Preto 
eram feitas artesanalmente em madeira maciça, com dimensões generosas, perfis delgados e linhas simples, dialogando com a produção de Tenreiro, influência inclusive reconhecida por eles. Os estofados eram de palhinha ou tecidos fabricados no Lanifício Fileppo com exclusividade para a loja, a partir de cores e padrões criados pelos arquitetos ${ }^{21}$.

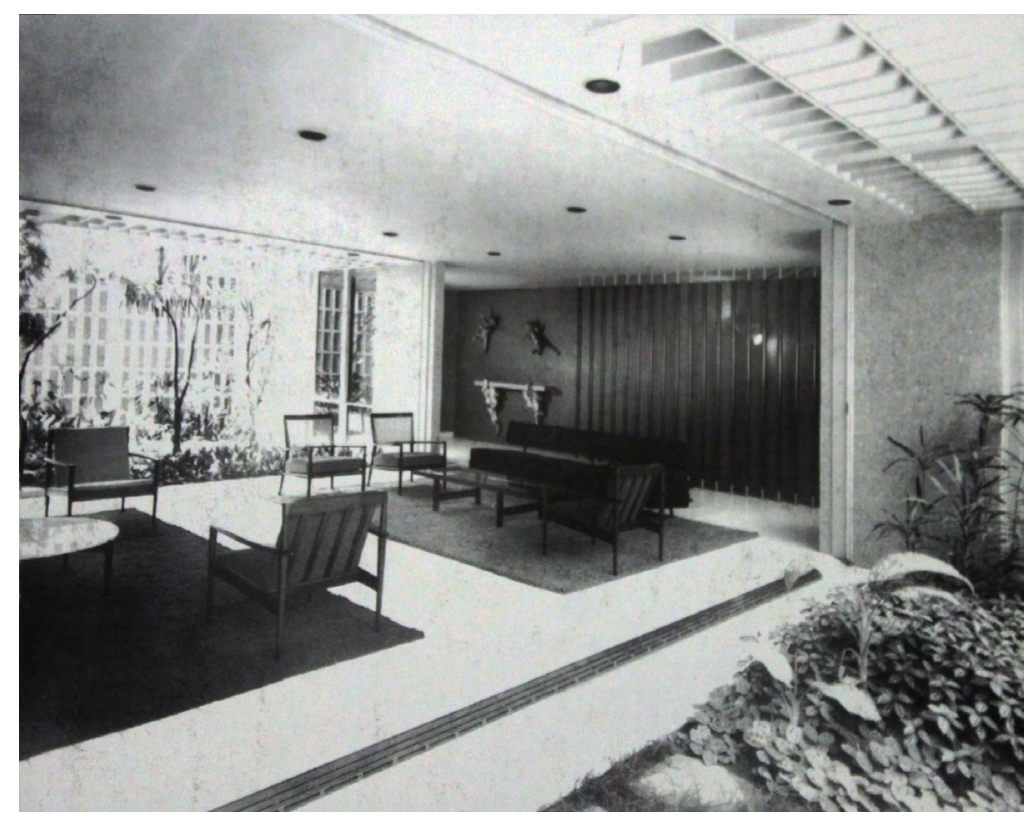

Também deve ser mencionada como relevante neste período a Ambiente, empresa fundada em 1950 pelo imigrante romeno Leo Seincman, que chamou diversos arquitetos para projetarem seus móveis, além de fabricar desenhos trazidos do exterior ${ }^{22}$, preocupando-se com questões de projeto e fabricação em escala industrial ${ }^{23}$. Além dos móveis, a Ambiente contava também com uma importante galeria de arte dirigida por Wanda Svevo, apresentando obras de artistas iniciantes e consagrados. Seincman permaneceu ligado à empresa até 1964, quando saiu para fundar a Probjeto, que viria a ter uma parceria com a Mobilinea e depois também participaria da Home Store.

Michel Arnoult, imigrante francês que formou-se arquiteto no Rio de Janeiro, criou no início dos anos 1950 uma pequena marcenaria em Curitiba com ex-funcionários da Móveis Cimo e o arquiteto inglês Norman Westwater. Em 1955, fundaram a firma Mobília Contemporânea em São Paulo, com uma loja à Rua Vieira de Carvalho e um novo sócio, o advogado Abel Barros de Lima. Os móveis eram pensados a partir de princípios de multifuncionalidade, modulação, multiuso, flexibilidade e desmontagem, e a usinagem era igual para todas as peças, o que tornava a execução simples, considerando sua industrialização ${ }^{24}$. Em 1959, construíram a própria fábrica, conquistando importante reconhecimento na década seguinte, sendo um dos principais concorrentes da Mobilinea e participando da Home Store.
1.1.08: Residência Milton Guper com móveis Branco \& Preto, 1951. Imagem publicada no livro Branco \& Preto: uma história do design brasileiro nos anos 50 (Marlene Acayaba, 1994), p. 111. 
Já a L'Atelier Móveis e Decorações foi fundada em 1955 pelos irmãos poloneses Leopoldo e Jorge Zalzupin, junto a três marceneiros. A produção começou artesanalmente, mas aos pouco adaptaram-se a uma lógica industrial a fim de ter maior produtividade, com desenhos de Jorge. A primeira loja foi aberta no Conjunto Nacional em São Paulo, com logo feito por Wesley Duke Lee, e nos anos seguintes cresceram significativamente, sendo pioneiros no uso de materiais plásticos e também disputando o mercado de móveis dos anos 1960²5. Outras empresas importantes no período, mas cujas trajetórias não se aproximaram tanto da Mobilinea são a Fábrica de Móveis $Z^{26}$, fundada por Zanine Caldas, que trabalhou com chapas de madeira compensada cortadas em perfil, e a Unilabor ${ }^{27}$, onde Geraldo de Barros começaria sua carreira como designer de móveis, que se consagraria na Hobjeto - esta sim concorrente direta da Mobilinea.

1.1.09: Poltronas do Studio Palma, c. 1949. Mobiliário Brasileiro: Premissas e Realidade. Museu de Arte de São Paulo. nov.-dez. 1971.
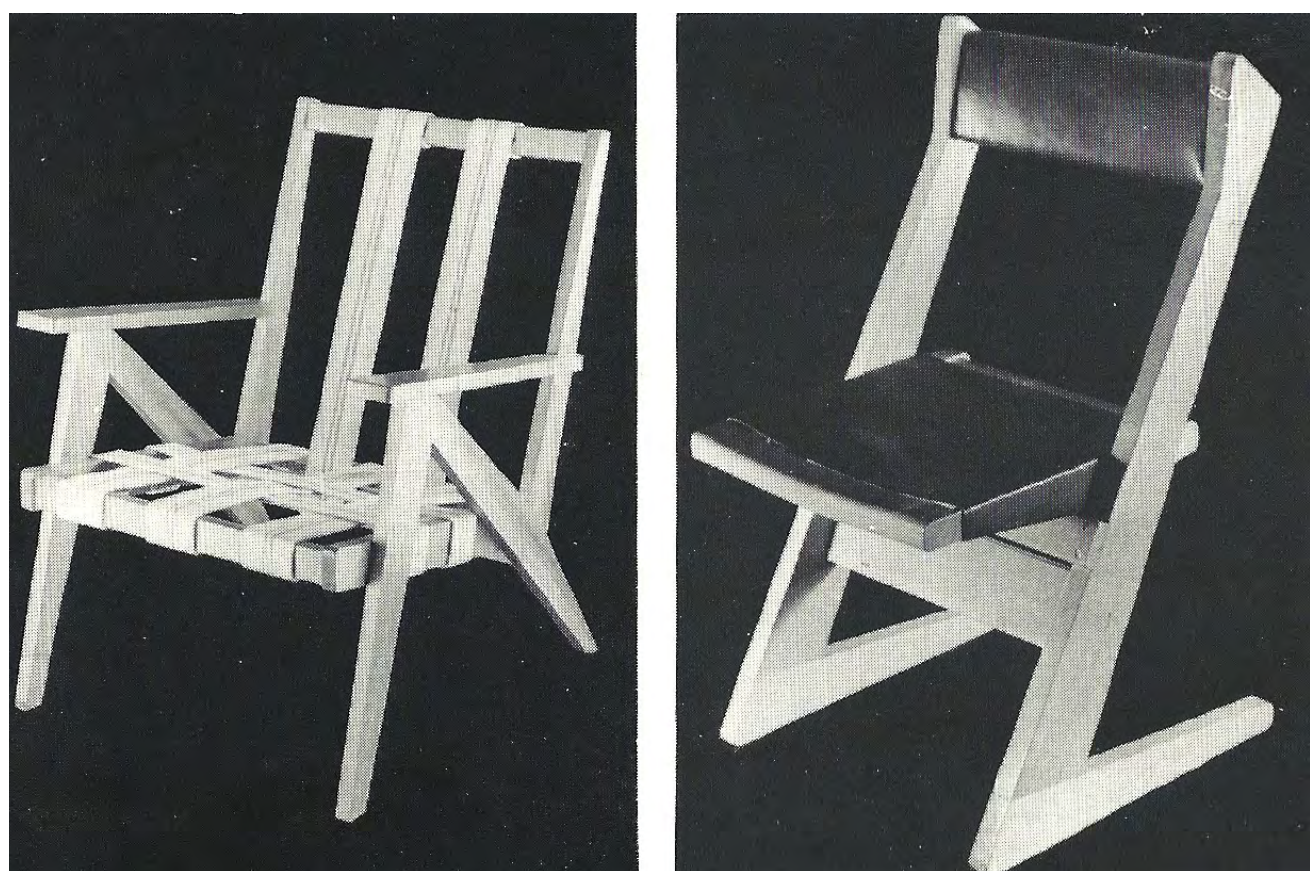

Lina $\mathrm{Bo}^{28}$ e Pietro Maria Bardi, que haviam imigrado para o Brasil em 1946 já tendo participado de maneira significativa das discussões acerca de arquitetura e design na Itália, tiveram dificuldades para produzir a cadeira que Lina desenhara para o auditório do MASP e, assim, decidiram fundar em 1948 uma empresa de fabricação e venda de móveis, batizada de Studio de Arte e Arquitetura Palma ${ }^{29}$, associando-se ao também arquiteto e imigrante italiano Giancarlo Palanti ${ }^{30}$. A empresa era composta por um antiquário, uma seção de exposição de arte antiga e contemporânea, um departamento para comercialização das obras, o estúdio de desenho de móveis chefiado por Lina e Palanti e uma fábrica para a produção das peças. Eles entendiam que não haveria mão-de-obra qualificada para fabricá-las, então trouxeram marceneiros de Lissoni, na Itália [1.1.09]. 
Em consonância com as demais iniciativas modernas, os móveis do Studio eram em sua maioria fabricados com madeiras maciças brasileiras, como Cabreúva e Jacarandá, por vezes contraplacadas em recortes retos da mesma maneira que a Móveis Cimo vinha fazendo desde a década anterior e que a Fábrica de Móveis $Z$ começava a experimentar, e de maneira distinta a produções europeias e norte-americanas como de Alvar Aalto ou Charles e Ray Eames, de madeira moldada. Assim, buscava-se uma produção seriada, embora durante toda a existência do Studio Palma a fabricação tenha permanecido artesanal. Os espaldares e assentos de poltronas e cadeiras eram de materiais nativos e populares, como tecidos naturais, fibras e couro, denotando preocupações em criar um móvel com identidade nacional e trazendo referências locais além do colonial. Ernesto Hauner, futuro fundador da Mobilinea, começou sua carreira profissional no Studio Palma, que viria a se transformar na Móveis Artesanal, onde Georgia também viria a trabalhar e onde se conheceriam.

Ernesto nasceu perto do Lago di Garda na província de Brescia, ao norte da Itália, em 1931, sendo o mais novo de quatro irmãos. Seu pai, Ferruccio Hauner, tocava violino na Orquestra Sinfônica de Brescia, dava aulas de música e produzia gravuras, mas, por causa de sua morte prematura, Ernesto foi criado pelos avós ${ }^{31}$. Sua irmã mais velha, Ada Hauner, nascera em 1924, formou-se no magistério e se casou com o artista e desenhista industrial Roberto Consolaro, sendo os primeiros na família a imigrar para o Brasil, instalando-se em São Paulo em janeiro de 1948. Em entrevista, Ada disse que não houve uma razão clara para a escolha pelo país, mas que foram assim orientados em Milão, e os motivos da partida eram as condições de vida na Itália após a Segunda Guerra Mundial $^{32}$. Aqui, Roberto foi inicialmente empregado por um empresário italiano e posteriormente o casal abriu galerias de arte em Belo Horizonte e no Rio de Janeiro ${ }^{33}$, porém depois se separaram e Ada retornou brevemente à Itália. Já nos anos 1960 ela voltaria a São Paulo e iria trabalhar na Mobilinea.

O segundo irmão de Ernesto, Carlo Hauner, nasceu em 1927 e formouse em desenho técnico na Academia de Brera, em Milão, mas seguiu carreira como pintor, chegando a participar da Bienal de Veneza de 1948. Pouco depois disso, imigrou para o Brasil e logo na sequência vieram Ernesto, que também estudara desenho técnico, com sua irmã Luciana e sua mãe, em 1949. Tudo indica que Carlo rapidamente se inseriu nos círculos artísticos de São Paulo por sua experiência na Itália, e pode-se supor que ele tenha se aproximado de marchands italianos como Pietro Maria Bardi. Ada contou que seu marido tinha um escritório no prédio dos Diários Associados, onde também ficava o MASP, e 
que ele fora responsável pelos cálculos estruturais da Casa de Vidro de Lina Bo Bardi, o que pode ter facilitado o acesso dos demais familiares ao casal Bardi ${ }^{34}$. De todo modo, foi Carlo quem apresentou Ernesto a eles ${ }^{35}$ e, em seu currículo, o caçula atesta que ainda em 1949 trabalhou no Studio de Arte Palma como desenhista, especializando-se em "desenho de móveis contemporâneos"36.37

O Studio, que abrira suas portas em 1948, fechou dois anos depois. Segundo P. M. Bardi, havia pouca aceitação por parte do público consumidor por móveis com aquela proposta estética e, ao mesmo tempo, as peças eram copiadas por outras empresas com resultados inferiores, estigmatizando negativamente seus produtos e tornando o negócio insustentável. Em entrevista a Maria Cecília Loschiavo dos Santos em 1980, Bardi declarou:

\begin{abstract}
As coisas não deram certo, a mentalidade era tão antimoderna! O que predominava eram os móveis da Paschoal Bianco e do pessoal do Brás. Começamos a perder dinheiro e então passamos a fábrica aos irmãos Hauner, que prosseguiram com o trabalho, mudando o nome da empresa para Móveis Artesanal. ${ }^{38}$
\end{abstract}

Através de depoimentos de Sergio Rodrigues e Georgia Hauner, foi possível apurar que a fábrica foi comprada apenas por Carlo Hauner, associado ao conde italiano Leoni Paolo Grasselli, que também havia imigrado para o Brasil após a guerra e atuava como marchand, tendo contato com Carlo desde a Itália ${ }^{39}$.

Os primeiros móveis divulgados - e possivelmente executados - pela Móveis Artesanal foram para o MASP, com desenhos assinados por Lina Bo Bardi $^{40}$. Os demais projetos fabricados na empresa eram de Carlo, que havia fundado em paralelo uma empresa de objetos decorativos em barro cozido desenhados por ele, em parceria com o médico Milton Guper ${ }^{41}$, chamada H. Cerâmica. Os móveis produzidos na Artesanal eram feitos em materiais e formas diversas, mas peças com estruturas metálicas, pés delgados e corpo estofado de maior massa predominavam nos anúncios. Além dos móveis de linha, faziam também projetos por encomenda.

Em 1953, Grasselli se desvinculou da empresa, concomitantemente à entrada de dois novos sócios: Martin Eisler $^{42}$ e Ernesto Wolf ${ }^{43}$. Eisler, que tomou conhecimento da empresa executando projetos sob medida lá, tornouse desenhista das peças de linha junto a Carlo, enquanto Wolf tinha uma função administrativa. Um ano antes, Ernesto Hauner havia fundado uma marcenaria em sociedade com Carlo e o arquiteto Herbert Duschenes, que empregava cerca de 20 funcionários e produzia peças provavelmente vendidas na Artesanal, da qual também tornou-se sócio em 1953, onde afirma ter atuado como diretor, consultor técnico e designer ${ }^{44}$.

Quando Carlo Hauner fez uma viagem à capital paranaense para apresentar os móveis da Artesanal para o novo Centro Cívico de Curitiba, foi Sergio Rodrigues, que então trabalhava no projeto, quem o atendeu ${ }^{45}$. A venda 
não se concretizou, mas a partir disso estabeleceu-se uma parceria entre eles e Rodrigues decidiu abrir uma filial da loja de São Paulo, batizada de Móveis Artesanal Paranaense, à qual Ernesto Hauner foi enviado para ajudar com a conceituação da exposição das peças [1.1.10]. O empreendimento foi, contudo, um fracasso, e fechou em seis meses: Rodrigues lembrou-se de que quem buscava aquela estética de móveis preferiam compra-las diretamente em São Paulo, enquanto a maior parte da população local ainda optava por peças com um desenho clássico. Depois que a loja encerrou suas atividades e a construção do Centro Cívico foi suspensa, Carlo aceitou empregar Sergio Rodrigues na filial de São Paulo e ele se mudou para lá ${ }^{46}$.

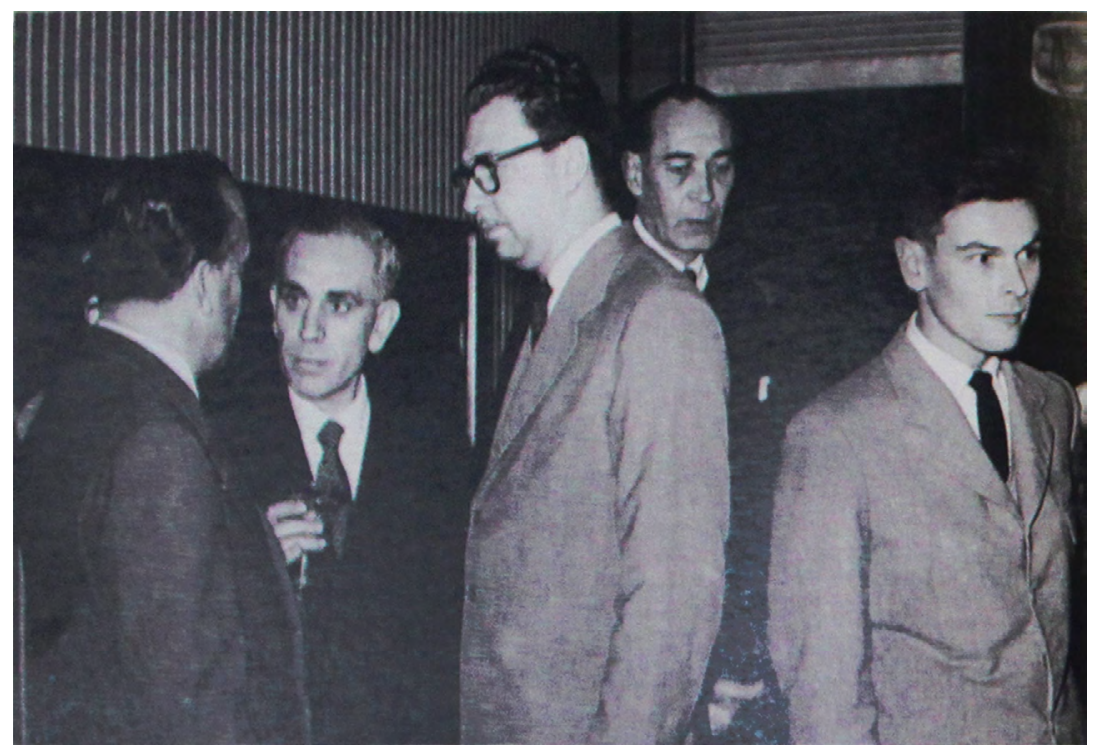

Em fins de 1953, foi inaugurada a Galeria Artesanal à Rua Barão de Itapetininga, uma das ruas comerciais mais importantes da cidade naquele momento. Com três pavimentos, a nova loja abrigava a venda de móveis da Artesanal e também uma galeria de arte gerida por Ernesto Wolf. Foi lá que Sergio Rodrigues começou a trabalhar, encarregado de fazer projetos de ambientação interna para clientes. Pouco depois, um desenhista decidiu sair da empresa e Carlo Hauner pediu que Rodrigues entrevistasse pessoas para o cargo. Colocaram um anúncio na porta e algumas pessoas apareceram, dentre as quais, Georgia Morpurgo.

Georgia nascera em Pozega, na Croácia, em 1931. Vittorio Morpurgo, seu pai, era judeu, ítalo-inglês, e enteado de Lionello Stock, fundador da empresa de bebidas Stock, na qual Vittorio trabalhava com a função de estabelecer novas fábricas. Uma destas foi em Pozega, onde conheceu Mara Vojnovic, cuja religião era cristã ortodoxa sérvia, e com quem se casou depois de se divorciar de uma primeira união. Georgia foi registrada com a nacionalidade inglesa do pai e a religião da mãe e, em 1933, a família mudou-se para Bielko, na Polônia, em função
1.1.10: Inauguração da Móveis Artesanal Paranaense em 1953. À esquerda, de costas, o Conde Paolo Grasselli e à direita da foto, de frente, Ernesto Hauner. Imagem publicada no livro Sérgio Rodrigues (Soraia Cals, 2000), p. 20. 
do trabalho de Vittorio, onde levaram uma vida confortável colecionando arte e antiguidades. Georgia relatou que seus pais eram reservados e cultos, e os costumes de sua infância demonstram que estavam atentos ao mundo das artes e da cultura: sua mãe fazia aulas de desenho de moda e era assistente de um professor de dança expressionista, com quem Georgia também tinha aulas, assim como de piano, além de frequentar uma escola católica com aulas em polonês.

Em 1939, o clima antissemita se intensificou na região e uma nova onda de pogroms emergiu. Como se sabe, logo eclodiu a Segunda Guerra Mundial e a Polônia foi invadida pelo exército de Hitler. Depois de duas semanas de bombardeios constantes, veio a notícia de que Bielko estava sob ocupação soviética e todos os pertences da família foram tomados, e nesse meio tempo perderam contato com Vittorio. Mara e a filha alugaram um pequeno quarto na cidade e ela voltou a frequentar a escola, aprendendo preceitos stalinistas em ucraniano e no alfabeto cirílico. A comida era esparsa e as condições de vida bastante duras, mas eventualmente conseguiram permissão para voltar à Croácia com a ajuda de um cônsul britânico e receberam a notícia de que Vittorio estaria vivo em um campo de concentração nazista em Nuremberg. Em 1941, tiveram que fugir novamente pela ascensão do nazismo na região dos Bálcãs e desta vez foram para Trieste, na Itália, onde residiam os avós paternos de Georgia e para onde seu pai iria após ser libertado por um arranjo da família com o governo alemão. Com o retorno e a recuperação de Vittorio, a família se mudou para uma villa de Lionello Stock em uma pequena cidade italiana, chamada Opicina, e mais uma vez Georgia começou uma escola em uma nova língua, tendo dificuldades para se adaptar à educação fascista. Pouco depois precisaram se mudar novamente, pois exércitos alemães continuavam próximos, e foram então para a região de Abruzi, mais ao Sul, onde não havia contato algum com o mundo exterior e precisavam ser absolutamente autossuficientes $^{47}$. De acordo com Georgia,

\footnotetext{
Durante a guerra na Europa, nós vivemos dois anos isolados de qualquer contato com a civilização. Quer dizer, nós estávamos lá nas colinas da Itália central e a gente tinha que fazer tudo em casa, porque não podíamos chegar a uma loja, nem sequer comprar uma agulha. Então aprendi a tecer, a fiar, eu fazia tudo o que os camponeses lá onde a gente morava faziam, e me interessava muito isso. Aprendi a fazer tricô, a fazer cestas, a fiar a lã, fazer sapatos... As coisas mais incríveis. Eu tinha de 11 a 13 anos quando tive essa experiência. Me interessava isso, eu gostava de fazer as coisas com as mãos. ${ }^{48}$
}

Ao fim da guerra, Georgia estava há dois anos sem escola, mas teve aulas particulares e conseguiu retornar ao colégio em Teramo, mudando-se um ano depois para Roma, onde começou o colegial no Liceo Artistico. Em 1946, entretanto, a família decidiu que Vittorio iria para São Paulo assumir uma fábrica Stock que ali existia. Georgia tinha então 15 anos, havia sobrevivido à 
Segunda Guerra Mundial, se deslocado entre países com ocupações nazistas, fascistas e stalinistas, tido aulas em quatro línguas e dois alfabetos, vivido entre a extrema pobreza e a alta cultura, e não há como ignorar o profundo impacto dessas experiências em sua formação e visão de mundo ${ }^{49}$.

Chegando ao Brasil, a família foi morar em Santo André, nos arredores de São Paulo, provavelmente em função da localização da fábrica administrada pelo pai. A essa altura, a situação econômica da família se estabilizava, e Georgia pode terminar o colegial na Graded School, na capital paulista, aprendendo inglês e português simultaneamente. Ao se formar, mudou-se para os Estados Unidos para cursar "Advertising \& Illustration" na Art Center School em Los Angeles ${ }^{50}$, onde morou em uma associação cristã de moças perto de Hollywood, na qual viviam atrizes aspirantes que a levavam para conhecer os estúdios das grandes companhias: “às vezes alguém me levava e eu ia ver esses cenários que preparavam para filmes, e me interessava muitíssimo. Foi isso uma das coisas que despertou meu interesse nas fotografias e na cenografia para interiores" 51 .

Nocurso de propaganda eilustraçãona Califórnia, Georgia diz ter aprendido novas técnicas de desenho e pintura e se interessado por arte moderna, mas precisou voltar ao Brasil para renovar seu visto e nesse meio tempo começou a trabalhar em uma agência de publicidade em São Paulo, de forma que não voltou aos Estados Unidos para terminar a faculdade. Segundo ela,

\begin{abstract}
Eu comecei a trabalhar em artes na agência como assistente do estúdio do diretor de arte, mas depois os sócios da agência descobriram que eu falava cinco línguas e me ofereceram um grande aumento para eu trabalhar de contato. Só que aí eu descobri que vender publicidade não era coisa que eu queria fazer, então saí. o que eu realmente queria fazer era trabalhar na Artesanal, que era o lugar que mais me atraía em São Paulo. Não havia nada que se comparasse com a Artesanal como imagem de móveis, de interiores, de design, que era o que me interessava na época. ${ }^{52}$
\end{abstract}

Quando viu a placa na frente da Artesanal procurando desenhistas, candidatou-se à vaga e Sergio Rodrigues a entrevistou, conforme ele se recordou:

\begin{abstract}
A Georgia veio com uma pasta grande trazendo desenhos e outras coisas ali dentro. E eu disse: "vamos ver o que você tem aí". Aí ela abriu as pastas e estava engraçado - quem estava vendo isso eram Martin Eisler e outros da diretoria - ela mostrou só desenhos de peixes, desenhos de campos, não coisas de arquitetura nem nada. Mas eu achei tão bem feito, com um acabamento tão bom, soube que ela esteve nos Estados Unidos e que fez cursos lá. E ela ficou encantada com o meu desenho, com a minha maneira de apresentar e, vamos dizer assim, defender os projetos. ${ }^{53}$
\end{abstract}

Georgia foi contratada e ajudava Sergio no atendimento aos clientes, fazendo plantas com a distribuição dos móveis nos ambientes. Um dia, Carlo lhe pediu que organizasse os móveis do primeiro andar e, como gostou do resultado, a encarregou de montar as vitrines e espaços internos da loja dali em diante [1.1.11]. 
Aos poucos, fui ficando mais arrojada. Eu queria atrair o público para a loja e comecei a fazer coisas mais fora do comum, por exemplo: me lembro de uma fruteira imensa de cobre, que era um móvel que estava na vitrine, e um dia eu falei que eu queria ir à feira para comprar frutas e verduras para enchê-la. Então um dos sócios ali me ofereceu um carro com motorista para ir à feira e eu comprei laranjas, berinjelas e coisas de cores muito vivas, enchi essa fruteira na vitrine, e começou a atrair gente! (...) todo mundo notou que havia um movimento novo lá dentro. ${ }^{54}$

1.1.11: Vitrine da Galeria Artesanal com mesa fruteira, espreguiçadeira, cadeira de palha, churrasqueira e lâmpadas de chão. "Móveis da Galeria Artesanal-S. Paulo". AD Arquitetura e Decoração. p. 24. dez-jan. 1954.
1.1.12: Georgia e Ernesto Hauner. Fotocópia de fotografia. 1955. Acervo pessoal de Georgia Hauner.

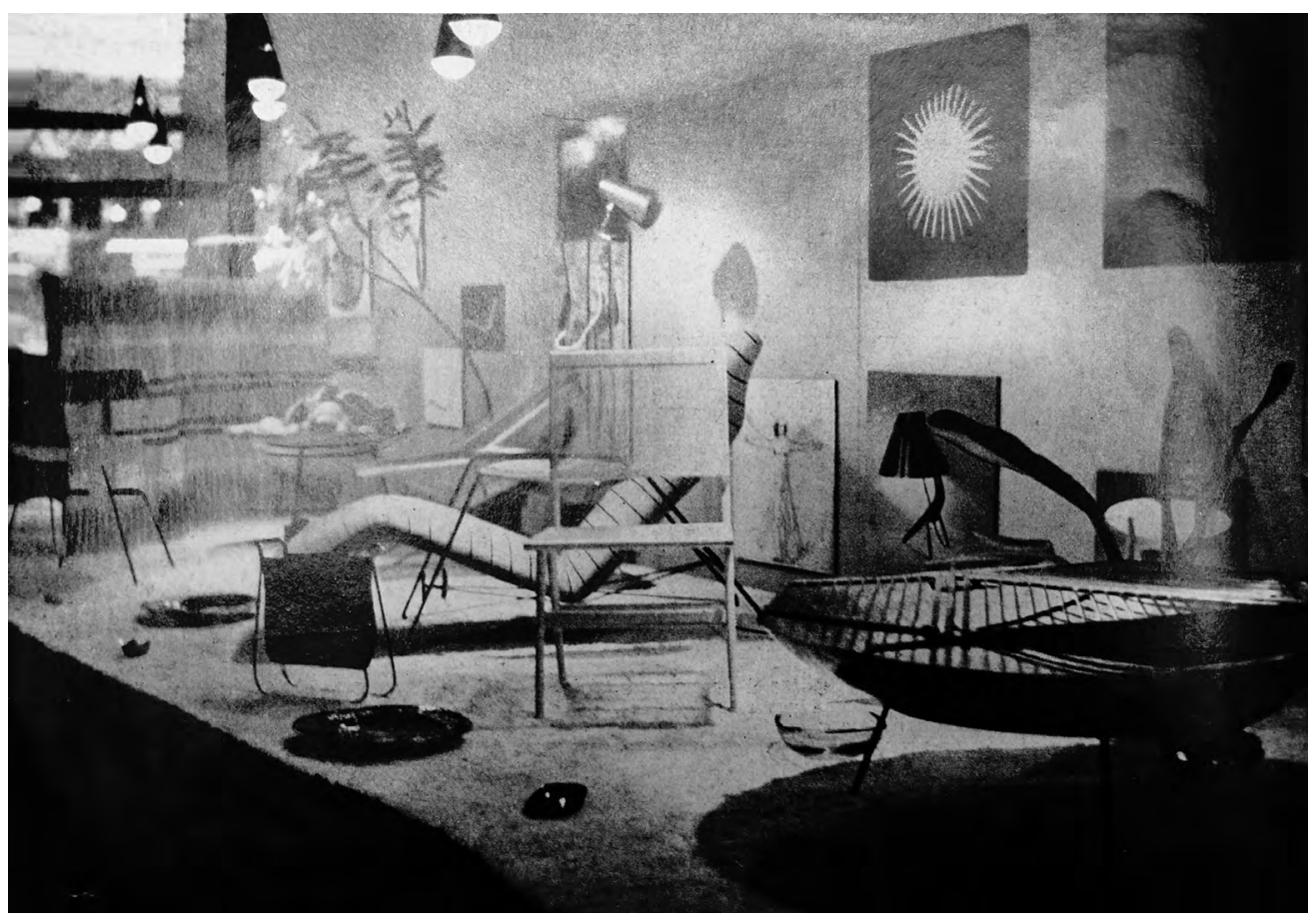

Ernesto Hauner então produzia móveis para a Artesanal em sua própria marcenaria, e abriu uma loja com Carlo para vender objetos de decoração na Rua Augusta, chamada Forma. Em 1955, ele se tornou sócio também da H. Cerâmica e no mesmo ano casou-se com Georgia Morpurgo, que havia conhecido na Artesanal um ano antes, tendo Sergio Rodrigues, Herbert Duschenes e suas respectivas esposas como seus padrinhos [1.1.12].

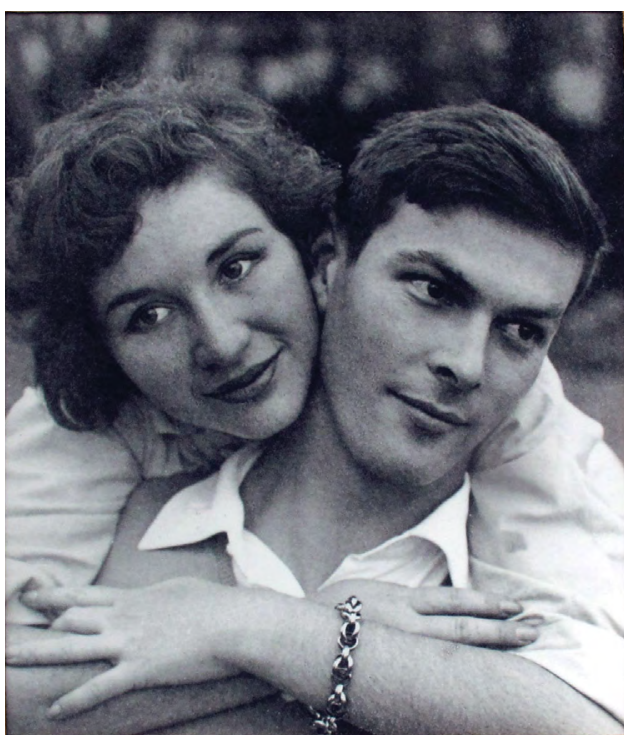


De maneira mais ou menos orgânica, Artesanal e Forma se fundiram em uma única empresa entre 1954 e 1955 e, por motivos distintos, Carlo Hauner e Sergio Rodrigues venderam suas ações no empreendimento, voltando o primeiro para a Itália e o segundo para o Rio de Janeiro. Ainda em 1955, Rodrigues fundou sua própria empresa, a Oca, que começou vendendo móveis da Ambiente e da Forma, mas logo desenvolveu os próprios desenhos e abriu uma pequena fábrica ${ }^{55}$.

Com as economias dele e de Georgia, Ernesto comprou as ações de Carlo e permaneceu na Forma, enquanto ela se afastou do trabalho, pois planejavam começar uma família e ela cuidaria do lar. Em 1957, entretanto, o casal decidiu também vender as ações da Forma e, com um filho recém-nascido e outro a caminho, voltaram à Itália em busca de mais formação ${ }^{56}$. Passaram um ano lá e não se adaptaram, mas neste meio tempo pesquisaram o mercado italiano de design em lojas, exposições e mercados. Georgia atestou que:

\footnotetext{
Roma era um lugar fascinante, então começamos a ver como se compunham as coisas nas vitrines modernas, mesmo de moda ou de móveis com peças antigas ou enfim... Foi uma experiência interessante. Quando voltamos ao Brasil eu já tinha mais ideias novas do que antes de ir para lá. ${ }^{57}$
}

Naquele período, a Itália começava a se firmar como um dos centros de vanguarda em design no cenário mundial, com nomes como Giò Ponti, Mario Asnago, Claudio Vender e Franco Albini, ainda ligados à primeira geração de arquitetos racionalistas no país, e figuras mais jovens que logo viriam a se destacar internacionalmente, como Vico Magistretti, Enzo Mari, Gae Aulenti, Marco Zanuso, entre outros. Desde então, consolidava-se lá a compreensão de que não era absolutamente necessário ser pró- ou anti- máquina, nem pró- ou anti- decoração e, de acordo com Lesley Jackson, essa produção italiana, assim como a escandinava, demonstrava justamente que o design poderia se exprimir por objetos feitos à mão e não apenas na produção em massa. Ainda segundo ela, a experiência da Guerra havia tornado mais essencial do que nunca que estes impulsos criativos pudessem novamente encontrar meios de expressão $0^{58}$.

Por sua origem e pelo retorno de seu irmão para a Itália, Ernesto frequentou o país com regularidade nos anos seguintes, permanecendo em contato com esta produção ${ }^{59}$. Os projetos que viria a desenvolver parecem ter se pautado solidamente nas condições locais para sua fabricação e com ambições a grande escala, mas há algo do caso italiano que ele e Georgia levaram consigo, que não considerava a industrialização como uma solução integral, e que também ecoava entre outros designers e arquitetos no Brasil em parte por limitações técnicas e em parte pela própria linguagem escolhida para seus projetos. 


\subsection{A Mobilinea de Ernesto e Georgia Hauner}

De volta a São Paulo em meados de 1958, Ernesto procurou alguns dos marceneiros ${ }^{60}$ que haviam trabalhado em sua antiga oficina e recomeçou o negócio, com o nome de Ernesto Hauner Decorações (E. H. D.) e início de atividades registrado na Junta Comercial do Estado de São Paulo em 17 de abril de $1959^{61}$. Segundo Ernesto, suas funções iniciais eram de presidente, tesoureiro, gerente de produção, designer e comprador de materiais ${ }^{62}$. Para os demais aspectos administrativos, contratou o amigo e engenheiro Jorge Kornbluh, que permaneceu um ano na empresa antes de dar prosseguimento aos seus estudos na França ${ }^{63}$.

Os primeiros móveis divulgados pela E. H. D. foram estantes em madeira maciça sem revestimentos, enfatizando que eram modulares, componíveis e multiuso. A preocupação com as vendas ficava evidenciada pela afirmação de que eram uma "solução econômica" e que havia "facilitação de pagamento". Não eram peças muito diferentes da produção geral do período, e Georgia preparava ambientações com os móveis no estúdio de um fotógrafo que morava na mesma rua em que eles ${ }^{64}$ para divulgação em periódicos. Os endereços para compra divulgados nestas primeiras propagandas são na Santa Cecília em São Paulo, onde era a fábrica, e em Copacabana no Rio de Janeiro, aproveitando o espaço da galeria carioca gerida por Ada Hauner e seu marido [1.2.01; 2.1.01-2.1.02].

Com a construção de Brasília, criou-se um furor em relação ao crescimento do país e à afirmação de uma identidade nacional via produção arquitetônica. Embora Ernesto e Georgia Hauner viessem trilhando um caminho diverso ao dos designers, arquitetos e empresas mais diretamente ligados à produção arquitetônica que se pretendia "brasileira", a Mobilinea também teve seu papel na construção da nova capital do país: à convite de Darcy Ribeiro, Sergio Rodrigues desenhou móveis institucionais e de habitação estudantil para a Universidade de Brasília (UnB), porém a Oca ainda não tinha capacidade de produção para atender aquele pedido, e então as peças foram produzidas na fábrica da E. H .D., o que pode ter gerado um volume inicial de produção importante $^{65}$ [1.2.02; 2.1.03-2.1.04].

Com a expansão do negócio, Ernesto precisou dedicar mais tempo desenvolvendo projetos e técnicas de fabricação, e por isso associou-se ao engenheiro John de Souza, que se focaria nos aspectos administrativos, 


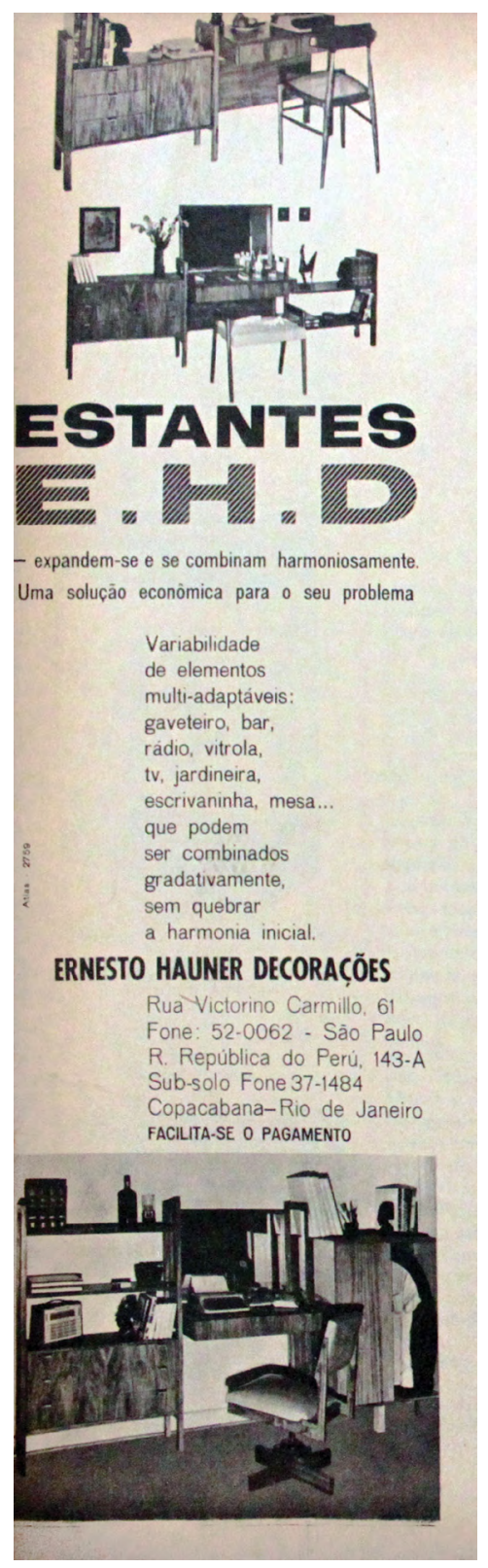

1.2.01: Propaganda Ernesto Hauner Decorações

- Escrivaninhas. Casa \&

Jardim. p. 8. mar. 1961.

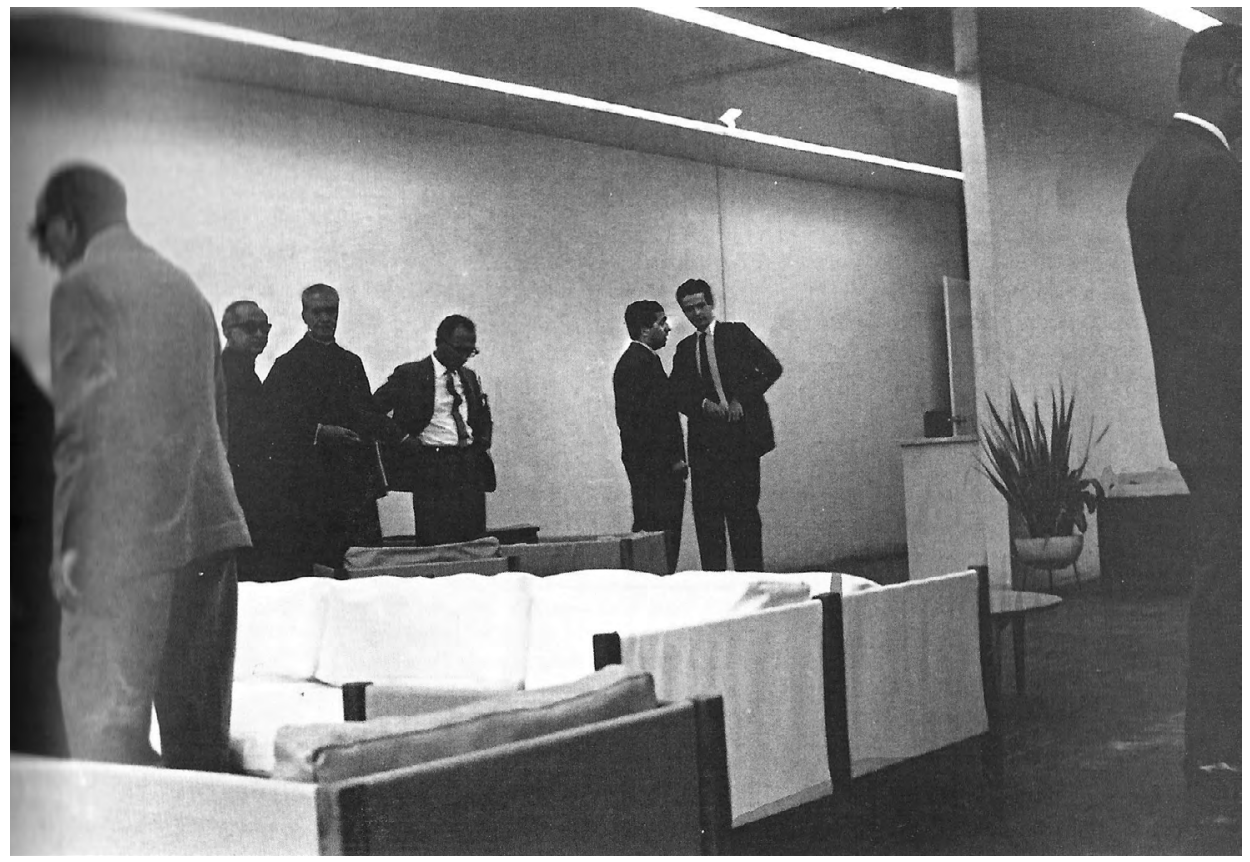

1.2.02: Poltrona UnB e sofá Darcy no Prédio da Antiga Reitoria. Imagem publicada no livro Mobiliário Moderno: das pequenas fábricas ao projeto da UnB (Alex Calheiros, Marcelo Mari, Priscila Rossinetti Rufinoni (org.), 2014), p. 109 
injetando novo capital na empresa ${ }^{66}$. Não foi possível obter muitas informações sobre a biografia de John, mas sabe-se que seu pai era ligado ao Moinho Santista e que ele tinha formação como engenheiro; à época da parceria, dava aulas na FAUUSP em disciplinas de tecnologia.

O primeiro showroom da empresa veio em 1962 à Rua Augusta, e neste mesmo ano mudaram de razão social: a data de início das atividades da Mobilinea na Junta Comercial do Estado de São Paulo é 14 de setembro de 1962, embora o nome só tenha sido registrado em 1964. Enquanto a Ernesto Hauner Decorações fora registrada como "fabricação de móveis de vime ou junco ou com sua predominância" (alguma questão legal deve ter sido facilitada com esta opção), a Mobilinea se enquadrou em "comércio varejista de móveis, objetos de arte, de decoração e de antiguidades" ${ }^{" 67}$ e passou a ser uma S. A., ou seja, uma sociedade de ações.

O nome Mobilinea vem das palavras italianas mobile e linea, que significam, respectivamente, móvel e linha. Georgia disse que a nomenclatura anterior era sabidamente provisória, e que ela e Ernesto pensaram em diversas alternativas até encontrar um que gostassem e então fizeram a mudança ${ }^{68}$. Ela foi também responsável por criar o logo da empresa, que é seu nome em caixa alta e em fonte com serifa ${ }^{69}$.

Ainda em 1962, a fábrica se mudou do primeiro endereço e estabeleceu-se em um galpão maior na Barra Funda, empregando cerca de 80 funcionários $^{70}$ que produziam móveis em Jacarandá e Amendoim maciços, modulares, ortogonais e utilitários, com produção seriada, mas semi-artesanal. Ernesto levava alguns protótipos dos novos móveis que desenhava para casa, para que Georgia desse sua opinião de "dona de casa": "minha função era verificar se as peças eram à prova de crianças, animais que se tem em casa e outros problemas domésticos" ${ }^{\prime 1}$. Para ter uma fonte de renda própria, ela decidiu fazer luminárias em papel dobrado e as colocou para venda nas lojas, de forma que foi progressivamente voltando ao mercado de trabalho, permanecendo responsável pela criação de imagens publicitárias e da cenografia das lojas da empresa $^{72}$ [2.2.01-2.2.02].

A primeira grande afirmação que a Mobilinea faria no campo do design nacional foi pintar suas peças em cores fortes, aproveitando os mesmos produtos que já eram comercializados em madeiras maciças sem revestimentos. Seu lançamento se deu em um anúncio publicado em 1965 em Casa \& Jardim ${ }^{73}$, na primeira aparição de móveis modernos coloridos na revista ${ }^{74}$. O que tornava a propaganda marcante, até mais do que a cadeira amarela, era seu assento revestido por um tecido estampado, bordado à mão, um vaso de flores silvestres e patinhos caminhando livremente sobre a mesa, que contribuíam para a composição de uma imagem bastante curiosa [2.1.07]. 
A partir de então, a empresa passou a comercializar principalmente móveis pintados, e relatos apontaram que outras marcas a seguiram, mas que a Mobilinea conseguira desenvolver técnicas de melhor acabamento, tornandose uma referência ${ }^{75}$ [1.2.03]. Nota-se que esta escolha assinala não apenas uma opção econômica e de nicho de mercado, mas a eleição de uma linguagem já efetivamente desvinculada de uma busca por algum tipo de identidade nacional exclusiva. Ainda assim, Georgia acredita que os móveis da empresa só poderiam ter sido desenvolvidos no Brasil, em parte pela população aberta e animada a aceitar novidades, de certa forma provindas do crescimento econômico do país naqueles anos, em parte pela diversidade cultural gerada pelos fluxos imigratórios, dos quais os fundadores da Mobilinea, como grande parte dos designers atuantes no país, eram parte:

Eu acho que o Ernesto sabia que a base das coisas era a simplicidade, e o bom design era internacionalmente aceito. Não havia nenhum motivo de orgulho nacional, patriotismo, brasileirismo ou italianismo nele. As ideias eram completamente para o bom produto, o uso universal daquilo que ele fazia. ${ }^{76}$

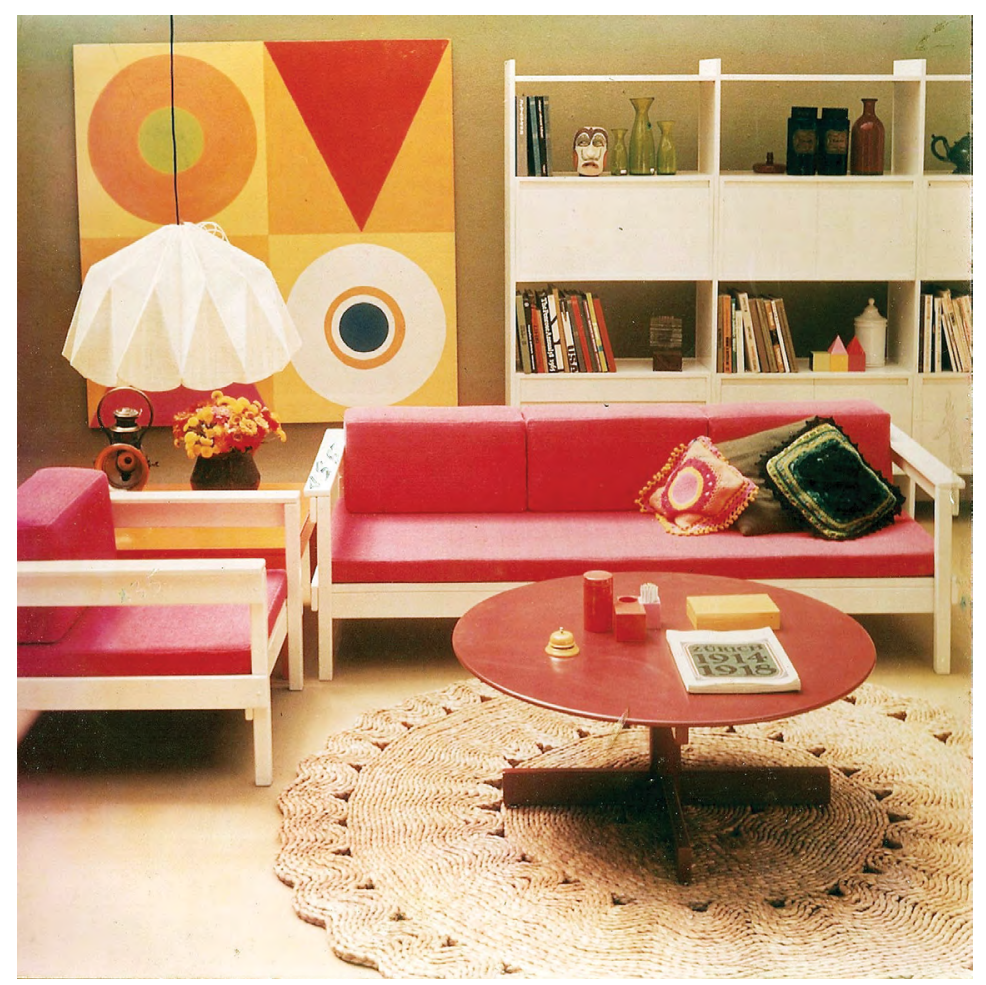

1.2.03: Cenário criado para propaganda Mobilinea com móveis laqueados em branco com luminária de papel feita por Georgia Hauner. Imagem de slide. Sem data. Acervo pessoal de Georgia Hauner.

De fato, todas as linhas lançadas pela Mobilinea partilhavam de preocupações como modulação, durabilidade e versatilidade do projeto da peça individualmente, em suas configurações possíveis e em diferentes espaços domésticos, ao mesmo tempo em que havia um cuidado para que esse pragmatismo não resultasse em austeridade em função de escolhas de acabamento. Paralelamente, linhas de móveis para escritório vinham sendo desenvolvidas por Ernesto desde as primeiras estantes com escrivaninhas e 
cadeiras, produzidas sob as mesmas premissas das peças residenciais, sem hierarquia no piso da fábrica.

Em 1965, Mobilinea já tinha duas lojas em São Paulo, uma no Rio de Janeiro e revendas em Belo Horizonte e Salvador. No ano seguinte, foram convidados a abrir uma loja no futuro Shopping Iguatemi em São Paulo, e o espaço interno e vitrines foram planejados por Georgia, pensados para serem usados em peça publicitárias, o que ocorreu com frequência maior a partir deste empreendimento, marcando a chegada da Mobilinea em um patamar de maior reconhecimento no mercado. Alguns objetos artesanais que Georgia vinha produzindo para as propagandas foram expostos e passaram a ser vendidos lá, além de uma série de pequenos objetos selecionados pela equipe de vendas ${ }^{77}$ $[1.2 .04 ; 2.2 .07-2.2 .16]$.

1.2.04: Ambientes de jantar na loja da Mobilinea no Shopping Iguatemi. Imagem de slide. Sem data. Acervo pessoal de Georgia Hauner.

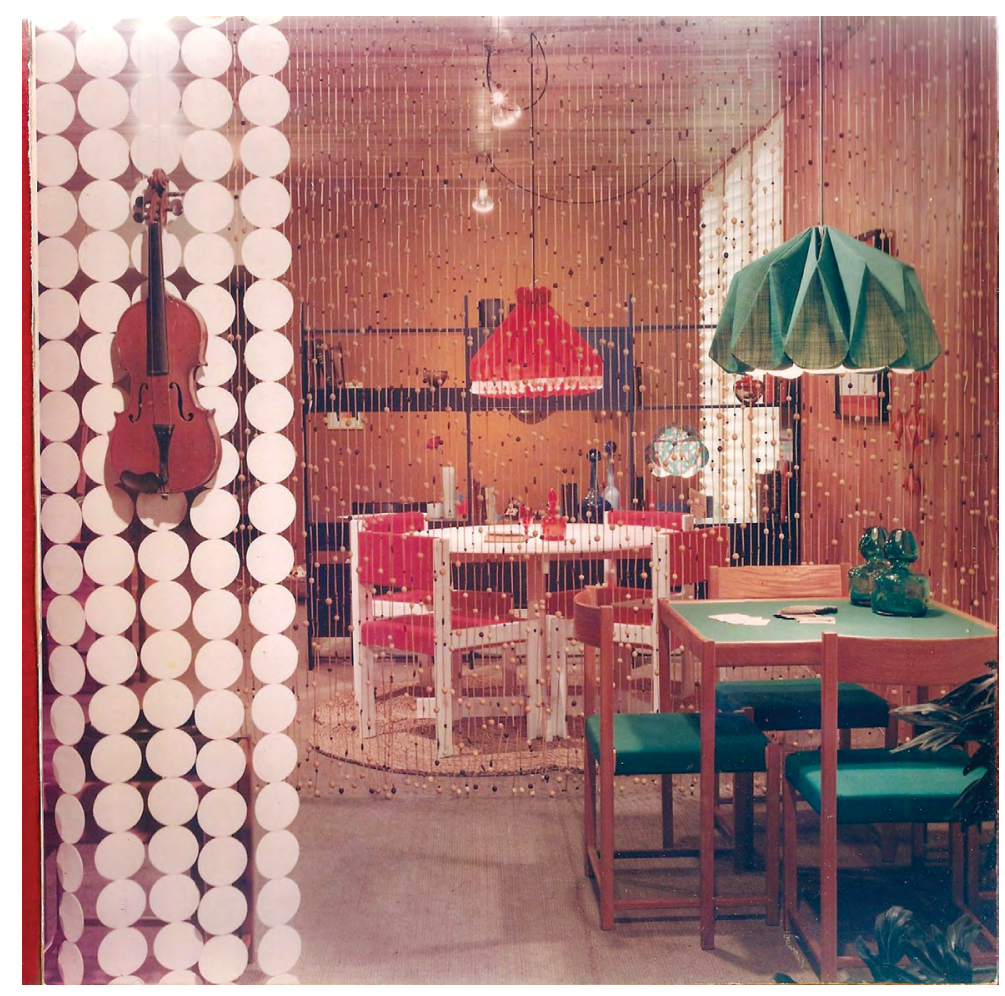

Fica evidente nos espaços expositivos e propagandas divulgadas neste momento, sempre dirigidas por Georgia Hauner, que a ideia de móveis industriais complementados e contrapostos a objetos artesanais, informais ou inusitados amadurecera desde as experiências na Artesanal, e a sensação de intimidade trazida pelos complementos decorativos, muitos dos quais concebidos especialmente para tal ou qual peça, vitrine ou fotografia, era impactante. Como ela declarou,

Os móveis da Mobilinea não podem ser separados da imagem total. O tecido do estofamento, o chão no qual foram colocados, os objetos em volta, as modelos nas fotografias, fazem parte do design. Os anúncios publicados nas revistas e as fotografias para promoções e catálogos, também participam no contexto da imagem Mobilinea. ${ }^{78}$ 
Como influências em seus trabalhos, Georgia citou os fotógrafos Otto Stupakoff e Yllen Kerr, os artistas Wesley Duke Lee e Paulo Becker e o arquiteto Sergio Rodrigues, muitos dos quais contribuíam com a revista Senhor e inseriam uma dose de humor no modo de apresentar o moderno, "zombavam da formalidade dos ambientes estabelecidos" 79 , fazendo parte do espírito da época e com caráter brasileiro. Georgia lembrou-se também de Waldemar Cordeiro, amigo com quem seu pai "tinha longas discussões sobre arte e filosofia" 80 e quem tinha a encorajado a buscar um emprego na Artesanal; e, finalmente, Suzana e Roberto Coelho Cardoso, paisagistas cuja residência mesclava ambientes interiores e exteriores com plantas diversas ${ }^{81}$. Eram influências de fora do mundo do design, mas que para ela representavam o que havia de mais atual nas maneiras de viver. Além disso, Georgia assinava os periódicos italianos Abitare, Domus e Oggi, o alemão Schôner Wolmen, o americano Ladies' Home Journal, e revistas de moda como Vogue e Marie Claire ${ }^{82}$, onde comparava a produção estrangeira de arquitetura, design, ambientes domésticos e comportamento.

Desde 1964, o país vivia em uma ditadura militar que vinha restringindo direitos civis, mas esse contexto não parece ter inicialmente produzido consequências diretas sobre o trabalho da Mobilinea. São Paulo era a maior cidade do país e todos os grandes municípios brasileiros cresciam em ritmo acelerado, o que implicou em mudanças na produção imobiliária e nas condições habitacionais. Consequentemente, o interior doméstico ${ }^{83}$, principalmente das novas classes médias urbanas, assumiu o papel de um lugar para se distanciar de condições adversas das grandes cidades, instituindo novos padrões de comodidade e privacidade guiados pela expansão do consumo. Ao longo da década, é visível em revistas como Casa \& Jardim que as habitações de classe média se tornavam menores, surgindo novas configurações familiares, e as empresas de móveis também tinham que responder a isso.

Ernesto viajava frequentemente para a Europa, bem como para os Estados Unidos e outros países da América Latina, e nessas viagens se atualizava da produção internacional para a criação de novos desenhos. Também foi bastante ao Norte do Brasil, onde pesquisava matérias primas, embora as madeiras fossem compradas em São Paulo, sob sua supervisão ${ }^{84}$. Georgia e Ernesto realizaram uma longa viagem juntos em 1967 para Nova York, Montreal, Londres, Oslo, Estocolmo, Helsinki, Copenhagen, Paris e Milão, para visitar lojas e fabricantes, e voltaram com novas inspirações. No Canadá, visitaram a 1967 International and Universal Exposition (Expo 67) em Montreal com o tema "Man and His World", que apresentava novidades de 62 países e os impressionou pelo uso de novas tecnologias e pesquisas sobre os modos de morar. A Finlândia também marcou Georgia: 
Helsinki me impressionou muito, porque já era novembro e tinha poucas horas de luz por dia, muita neblina, as ruas estavam escuras e parecia um clima um pouco deprimente. No entanto, as vitrines das lojas tinham uma vivacidade, um design maravilhoso, cores quentes e coisas que derretiam a alma. Então me animei muito com isso e me inspirei muito nas cores, combinações de cores, moda, não só os móveis. (...) Fiquei animada com aquilo pensando "bom, se aqui com esse clima, essa escuridão, essa neblina, eles conseguem fazer essa maravilha, imagina no Brasil!". 85

Após esta viagem, tanto o desenho dos móveis quanto suas ambientações mais do que nunca buscavam transmitir uma sintonia com as tendências estéticas do período, ecoando a emergência da cultura pop nacional e internacionalmente. Identificamos como influências na imagem da Mobilinea neste momento os movimentos musicais da Bossa Nova e da psicodelia inglesa e norte-americana; as roupas desenhadas pelo francês André Courréges, com seus ângulos geométricos, feitas em plástico e metal e exibindo os corpos femininos, ou da inglesa Mary Quant, que promoveram a cultura Mod e a minissaia; a estética da era espacial trazida pela viagem do homem à lua e o lançamento de novos materiais sintéticos com superfícies lisas e brancas; a criatividade artesanal escandinava, cuja maior representante era a empresa de tecidos finlandesa Marimekko; e a própria arte pop brasileira e estrangeira.

Em 1968, Tomaz Souto Corrêa, então editor de Claudia, convidou Georgia Hauner para ser a nova editora de decoração da revista e seus números especiais, com a função de promover a indústria nacional de design. Nas páginas das revistas, ela criou imagens inovadoras misturando produtos de várias empresas em um mesmo ambiente, apresentando possibilidades de incorporação de arte à decoração para várias faixas de renda e brincando com a maneira como as fotos eram feitas $[3.1 .24 ; 3.1 .26]$ e, nos poucos textos que escreveu para artigos, nota-se um desejo de incentivar as donas de casa a se apropriarem do espaço doméstico e a confiarem no próprio gosto ${ }^{86}$. Georgia trabalhou para Claudia até 1970 pois, além da demanda de trabalho gerada pela Mobilinea, seus depoimentos indicam que o volume de trabalho e os prazos da Abril eram extenuantes. Essa experiência em Claudia permitiu a ela testar novas formas de apresentar design que depois foram reaplicadas em fotos para a empresa, e foi através de anúncios e editoriais que foram divulgados não só o lançamento de suas novas linhas, mas a maneira como os móveis poderiam ser dispostos, os complementos para a casa e um tipo de vida desejável que se associava a isso.

É importante lembrar que uma fotografia para revista tem que ter uma composição equilibrada, como um quadro. Precisa ter um elemento que chame a atenção, e precisa contar uma história para prender a atenção de quem olha. Algum elemento de surpresa, também é importante. Uma reportagem de revista de uma página a cores, mais a produção com despesas de modelo, um bom fotografo com todo o equipamento, etc., tem um custo tão elevado, que não vale a pena fazer, a menos que a imagem transmita alguma emoção ao leitor. ${ }^{87}$ 
Quando Georgia precisava construir um cenário maior para a produção de fotos da Mobilinea e mesmo para Claudia, usava os espaços da fábrica e a mãode-obra de funcionários da Mobilinea, como o chefe de montagem Carmine e o encarregado de produção Colominas (imigrantes italiano e catalão, respectivamente), que a ajudavam na construção dos cenários; a chefe de tapeçaria Irene, que a auxiliava com estofamentos e acabamento de artesanatos; e Ernestinho, que fazia os moldes dos móveis em fiberglass, era responsável pela laqueação das peças em madeira e tinha habilidade para fazer grandes painéis decorativos (foi responsável pelos desenhos no "palco" do Shopping Iguatemi e da loja da São Luiz) ${ }^{88}$. Outros nomes mencionados em depoimentos como tendo uma atuação importante na fábrica foram Jazel, que inicialmente trabalhara na loja do Rio e depois passou a cuidar de assuntos contábeis, Plínio de Cerqueira Leite, que ajudava Ernesto com questões técnicas da produção, e Yone Koseki Pierre ${ }^{89}$.

Formada em arquitetura na FAUUSP em 1963, Yone começou a trabalhar na Mobilinea fazendo projetos de layout para clientes na loja da Rua Augusta, mas depois migrou para a fábrica e passou a trabalhar diretamente para Ernesto, principalmente em projetos para concorrências de mobiliário em grandes edifícios como hotéis e órgãos públicos. Ela contou que não eram desenhadas novas peças para estes fins, mas sim usadas as várias linhas da Mobilinea, eventualmente com alguma adaptação para o local específico. Yone não se lembra de terem ganhado muitas destas concorrências, mas foi a partir delas que começaram a fazer móveis para o Banco Itaú, que se desenvolveu em uma linha exclusiva ${ }^{90}$.

Ainda no período em que Yone estava na loja da Augusta, foi contratada como sua assistente Judit Magyary ${ }^{91}$, formada em um curso de decoração de interiores na Fundação Armando Alvares Penteado (FAAP) em São Paulo92. Até 1966, a gerente desta loja fora uma pessoa chamada Monica, mas com a inauguração da loja no Shopping Iguatemi, ela foi transferida para lá e entrou em seu lugar Bibita Butcher ${ }^{93}$ que, como Judit, havia passado por um curto período de treinamento com Ada Hauner no segundo endereço da empresa até então, à Avenida São Luiz, no centro da cidade ${ }^{94}$. O relato delas sobre o impacto inicial de trabalhar na Mobilinea foi de terem se sentido em um ambiente inovador e de se impressionarem com a pouca idade dos sócios.

A loja no Shopping Iguatemi logo se tornou a sede principal da Mobilinea e foi a que contou com o maior número de vendedoras, sendo lembrados em depoimentos os seguintes nomes, além dos acima mencionados: Balômia, Carmo, Gisela Haenel, Giselda Lenci Pistelli, Maria Eli Brunelli, Marily, Matô, Paula Giovana Lazzareschi e Roseli Bernardino. Pelo que se pode aferir, alem de 
mulheres, algumas delas tinham alguma formação em decoração de interiores e outras não. Também foi citado que a maioria delas trabalhou na loja por pouco tempo, normalmente saindo ao se casar ou engravidar. Salvo algumas exceções de mulheres na fábrica e do arquiteto Wilson Chica, que viria trabalhar nas lojas da Mobilinea alguns anos depois, a divisão de gênero entre a fábrica e as lojas era bastante evidente.

Ainda em 1968, a Mobilinea havia comprado um terreno de $21.200 \mathrm{~m}^{2}$ no Campo Limpo para construir uma nova fábrica, que se tornaria um edifício de $6.500 \mathrm{~m}^{295}$, inaugurado em 1973, e foi construído também um ambulatório com médico e dentista para atender aos funcionários, muitos dos quais vieram a construir suas casas no entorno do terreno. Embora não haja dados sobre o volume de produção, supõe-se que já fosse grande e que continuava em crescimento.

$\mathrm{Na}$ segunda metade da década de 1960, discussões acerca do design no país chegaram a um ponto de maturidade que, como veremos a seguir, levou às primeiras exposições e prêmios ligados ao campo, nos quais a Mobilinea foi regularmente reconhecida. Uma das linhas selecionadas para homenagens foi lançada em 1970 e era composta por peças em aço, fiberglass, poliéster e acrílico, todos materiais relativamente novos no mercado e inéditos na produção da empresa ${ }^{96}$ [1.2.05-1.2.06; 2.1.18-2.1.19].

1.2.05: Cadeira em aço e fiberglass. Mobiliário Brasileiro: Premissas e Realidade. Museu de Arte de São Paulo. nov.-dez. 1971.

1.2.06: Carrinho de chá. Mobiliário Brasileiro: Premissas e Realidade. Museu de Arte de São Paulo. nov.-dez. 1971.
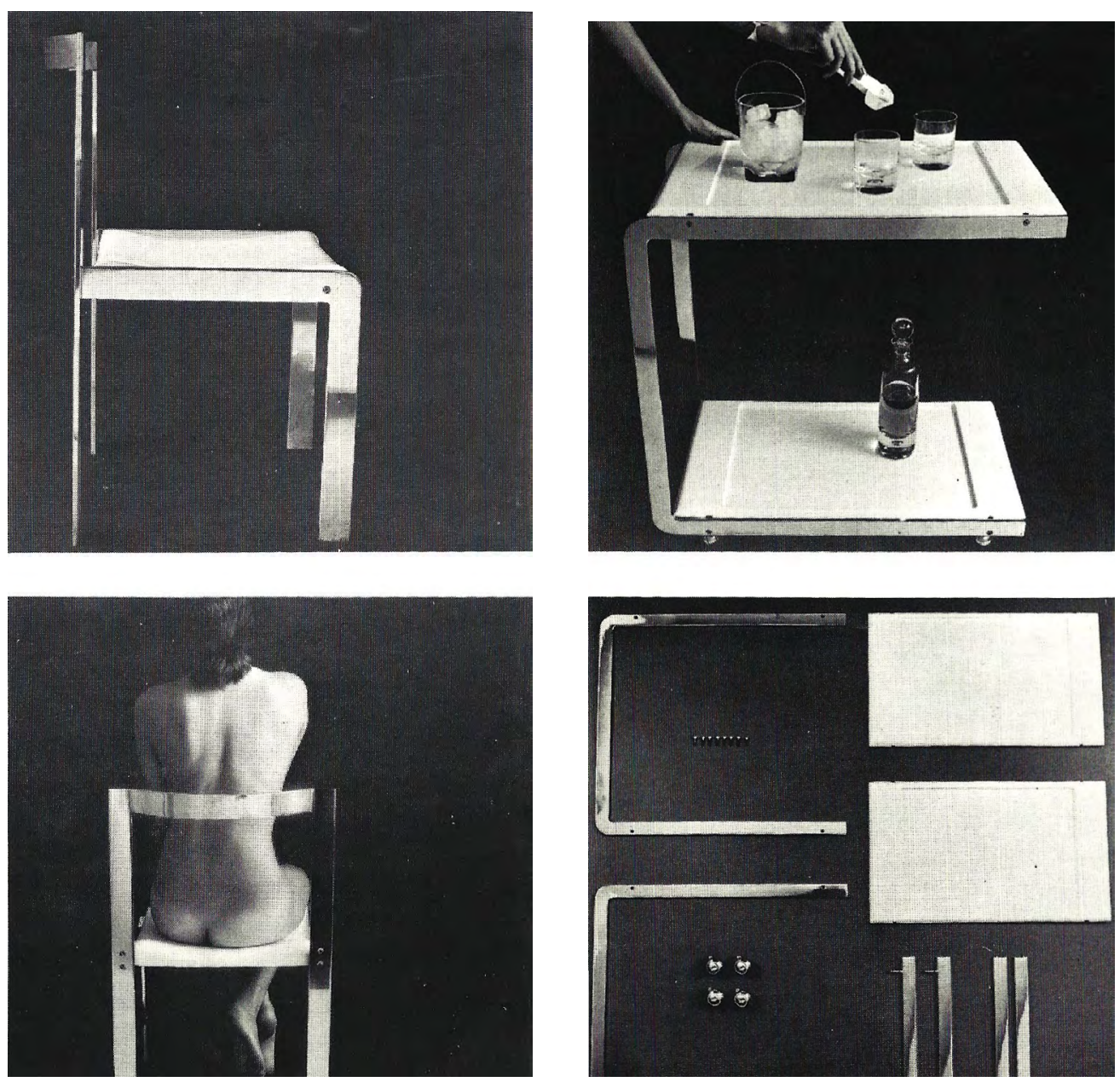
A militância para que se superasse o uso da madeira maciça como única matéria-prima era uma bandeira de Ernesto há alguns anos, assim como um desejo por mais avanço na industrialização nacional. Em 1971, ele declarou a revista Projeto e Construção: "hoje, o móvel, como os veículos, devem sair de uma linha de montagem, passando por tôdas as fases de contrôle, obedecendo os mesmos padrões de precisão. Não podemos nos referir à indústria de móveis em termos de marcenaria"97. Ainda assim, em 1971 outra grande linha foi lançada retornando à produção em chapas de madeira, porém com as vantagens de entrega em 24 horas e parcelamento da compra. Batizada de Prêt-à-Porter, termo emprestado do mundo da moda, as peças tinham um desenho similar ao que a Mobilinea já vinha realizando, mas davam um passo adiante no rigor produtivo.

Seu lançamento aconteceu em um editorial para a revista Casa \& Jardim, com os móveis arranjados livremente sobre arquibancadas, representando salas de estar, de jantar, quarto de casal e de solteiro. A rigidez da disposição era quebrada não só pelas cores - os degraus foram pintados em listras verdes e azuis, os móveis eram laqueados de branco e os estofados eram cor de laranja, mas porque cada ambiente vinha complementado por frutas dispostas entre as peças. As bananas em meio aos móveis de estar poderiam remeter a preços baixos, assim como as jacas junto às peças do quarto de solteiro denunciavam que Mobilinea era sem dúvida uma empresa brasileira [1.2.07-1.2.10].

Em entrevista concedida à revista Arquitetura em 1965, Ernesto dissera que para que fosse possível exportar móveis, era preciso haver incentivo a publicações, exposiçõesefeirasinternacionais, oqueatécertopontoaconteceria nos anos seguintes. Chegou a ser firmada uma parceria entre a Mobilinea e a empresa mexicana Lopez Morton, S.A., que iria fabricar e comercializar sua linha de escritórios no México sob o nome de KX Mobilinea ${ }^{98}$ [2.2.21]. Houve também uma tentativa de vender móveis no Panamá, que seriam exportados prontos do Brasil, e uma primeira leva chegou a ser enviada, provavelmente no fim da década de 1960. Em ambos os casos, entretanto, houve problemas de ordem administrativa e as parcerias foram descontinuadas, conforme Georgia relatou: "não lembro bem os motivos, mas acho que burocracia foi o obstáculo principal para impedir que os contatos iniciais levassem a bons resultados"99.

O contexto brasileiro naquele momento abarcava tanto o estímulo ao crescimento quanto tendências fortemente conservadoras e repressivas, fosse na política ou na cultura: John e sua esposa, Maria do Carmo Campello de Souza, a Carmute, foram presos em 1970 por supostas atividades subversivas. Segundo depoimentos, a polícia encontrou o fusca do irmão de Carmute (que era militante de grupos de esquerda) estacionado em frente ao prédio do casal no Sumaré, onde ele passara a noite anterior, então sua irmã e cunhado foram presos em seu lugar. Quando isso ocorreu, Ernesto estava na Itália e Georgia foi 
Nas páginas seguintes

1.2.07: Editorial apresentando a linha Prêt-à-Porter - sala de estar. "C.J. Visita... Mobilinea". Casa \& Jardim. pp. 42-43. Jul. 1971.

1.2.08: Editorial apresentando a linha Prêt-à-Porter - sala de jantar. "C.J. Visita... Mobilinea". Casa \& Jardim. pp. 44-45. Jul. 1971.

1.2.09: Editorial apresentando a linha Prêt-à-Porter - quarto do casal. "C.J. Visita... Mobilinea". Casa \& Jardim. pp. 46-47. Jul. 1971.

1.2.10: Editorial apresentando a linha Prêt-à-Porter - quarto de solteiro. "C.J. Visita... Mobilinea". Casa \& Jardim. pp. 48-49. Jul. 1971. instruída a não contar para ninguém o que estava acontecendo e não conversar com ele por telefone, pois suas ligações poderiam ser interceptadas. No dia em que Ernesto retornou, ela foi com o concunhado busca-lo no aeroporto, com a suspeita de que ele seria preso ao desembarcar ${ }^{100}$, mas nada aconteceu aos Hauner naquele momento, nem quando eles e outros funcionários tentaram ajudar John e Carmute por meio do consulado inglês ou contactando seus familiares, que também não tiveram sucesso em seus esforços.

Durante o período em que o casal esteve preso, a Mobilinea permaneceu funcionando normalmente, mas depoimentosindicam um clima deinsegurança, com telefones grampeados; além de Ernesto ficar sobrecarregado cobrindo as funções de John. Cerca de um ano depois, o casal foi libertado e a situação começou a se normalizar, embora seja difícil crer que algo mais profundo não tenha mudado em decorrência desta situação.

Em 1972, ainda em crescimento estável, os sócios decidiram abrir uma nova loja onde fosse possível comprar uma ampla gama de produtos domésticos em um único endereço, que seria o primeiro do tipo no país: Home Store. O showroom iria misturar os produtos das empresas participantes do mesmo modo que Georgia fizera nos editoriais para as revistas da Abril, experiência que contribuíra para um clima de confiança entre as concorrentes e, com efeito, aquelas promovidas em Claudia e as convidadas para a nova sociedade eram, em grande medida, as mesmas. Nesse sentido, a Home Store sintetizou muitos dos esforços anteriores da Mobilinea na promoção dos móveis modernos, unindo peças industriais diversas com objetos decorativos e artesanais, e criando ambientes ao mesmo tempo chocantes, vendáveis e habitáveis. Judit Magyary e Wilson Chica coordenavam o atendimento a clientes e Ada Hauner também passou a trabalhar de lá, administrando todas as vendas da linha de escritórios [1.2.11; 2.1.28; 2.3.16-2.3.25].

Para viabilizar o novo empreendimento, novos sócios entraram na empresa, dentre os quais foi citado o nome de Marcel Marmor, que havia trabalhado anteriormente na Hobjeto e é mencionado em alguns dos documentos que discutem a criação da loja ${ }^{101}$. Não é ainda possível precisar exatamente o porquê, mas parece que foi a partir da entrada destes novos sócios e da criação da Home Store, que poderia ser o grande ápice da Mobilinea, que começou também seu declínio nos moldes como havia sido concebida.

Yone Koseki Pierre saiu da empresa no início dos anos 1970, mesmo período em que Bibita Butcher foi demitida (após uma pausa, foi trabalhar na loja da Hobjeto à Rua Iguatemi); e Judit Magyary e Wilson Chica, àquela altura casados, também desligaram-se da empresa para passar um período na Europa. Alguns depoimentos indicaram que vinham surgindo divergências sobre os rumos da empresa entre os sócios e que haviam desvios de dinheiro internos à 


\begin{tabular}{|c|c|c|c|c|}
\hline $\begin{array}{l}\text { sua sala de estar chegou } \\
\text { no dia mareado! }\end{array}$ & 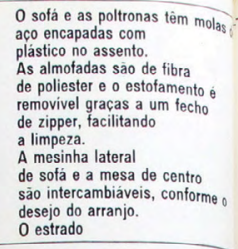 & 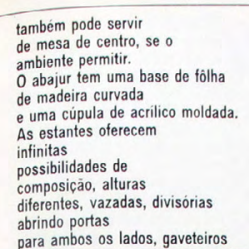 & 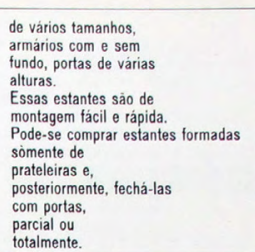 & 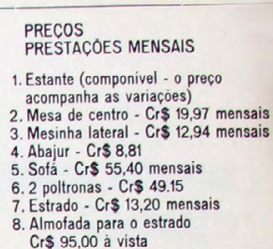 \\
\hline
\end{tabular}
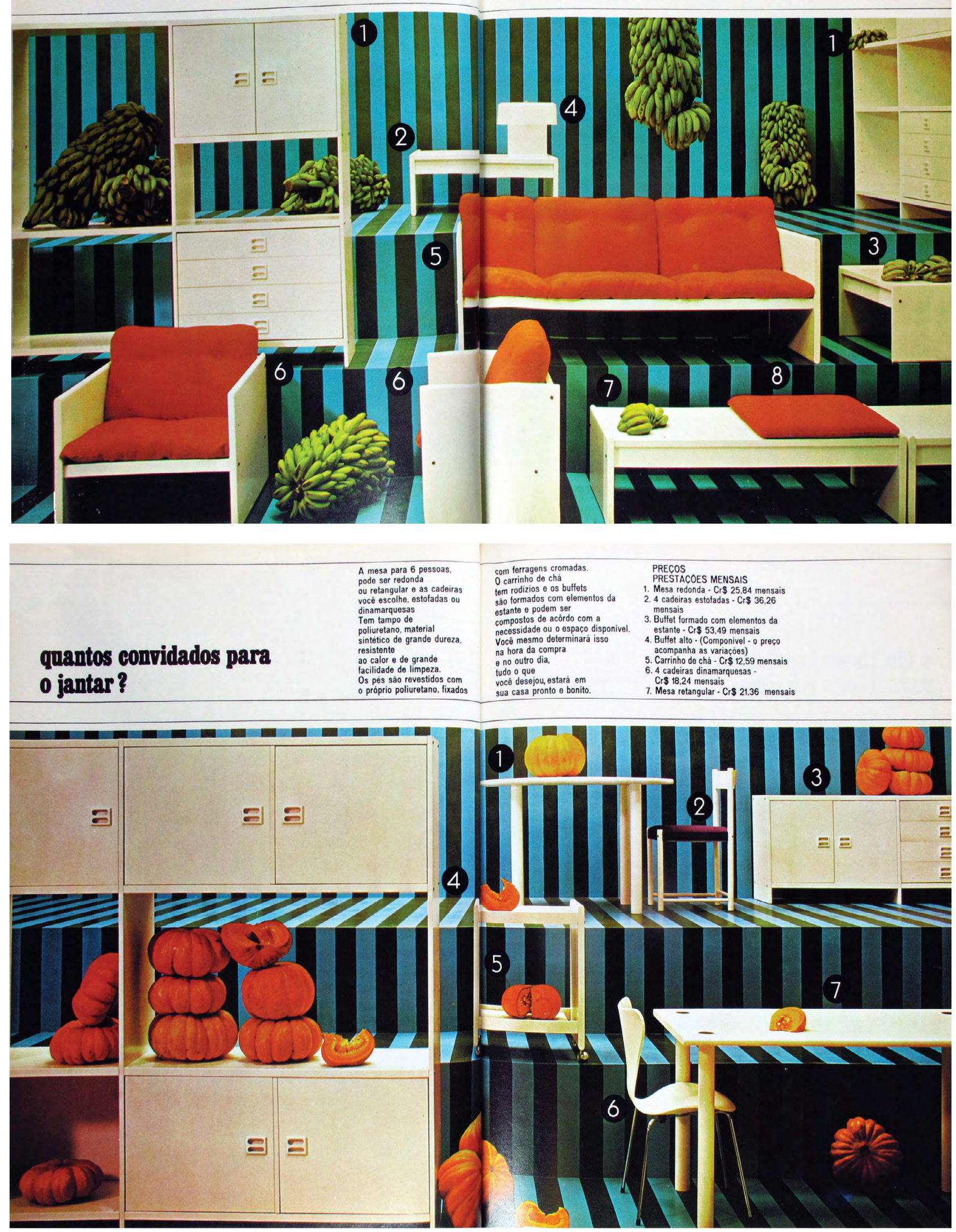

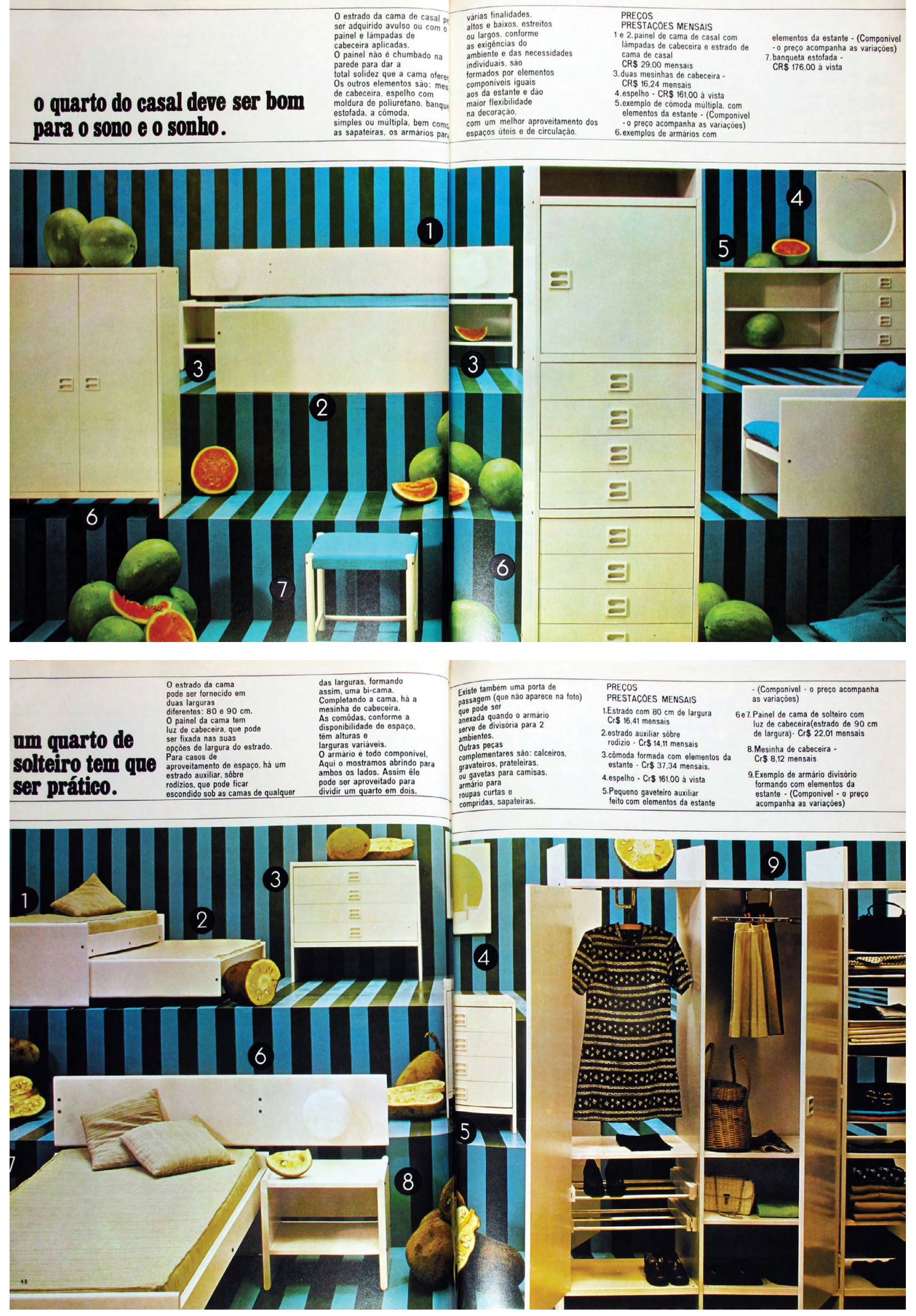
Mobilinea pois John e Ernesto tinham perdido o controle administrativo. Nesse sentido, a entrada de novos sócios pode ter sido, além de financeira, um esforço em criar uma gestão mais organizada e combater estas práticas, mas com isso ocorreu uma despersonalização da empresa também em um nível criativo.

Deste grupo de funcionários “originais", se é que se pode chamar assim, deve ser enfatizado um profundo respeito mútuo, com elogios muito generosos tendo sido tecidos durante os depoimentos, especialmente em relação aos Hauner. Segundo Georgia, os funcionários da fábrica apelidaram Ernesto de "pai" e ela era, consequentemente, a "mãe", o que dava a eles uma sensação de reconhecimento, mas também de uma responsabilidade muito grande ${ }^{102}$.

Todos estes fatores criaram um quadro complexo em que o casal era valorizado internamente e também no campo do design no país, ao mesmo tempo que sofriam pressões internas e uma sensação de que nunca se integrariam completamente no Brasil. Esta série de fatores levou o casal Hauner a questionar sua permanência no país, como Georgia explicou:

Nós sempre quisemos sair do Brasil. Nós achávamos muito difícil nos adaptar, a viver entre os grandes contrastes do Brasil e a ideia sempre foi de sair um dia. (...) Para a Europa nós não queríamos voltar porque já tínhamos falhado uma vez. Mas o Ernesto sempre dizia que ele queria viver num país onde ele pudesse trabalhar tranquilamente e pagar os impostos devidos, e não levar aquela vida de ânsia constante na corrupção, e tendo que pagar aqui e ali, de insegurança. (...) Também nos abalou bastante a situação do John e a gente não queria reviver mais os tempos do passado europeu. Os nossos filhos já estavam fora do Brasil, o Kim estava em Stanford, estudando em Palo Alto, na Califórnia, e o Mike nós tínhamos mandado acabar o high school na Suíça. (...) Daí nossos filhos nos escreviam falando "olha, vocês não estão ficando mais jovens, se vocês querem sair do Brasil, é melhor agora do que depois". Nós dois já estávamos com 45 anos, então resolvemos que se a gente ia começar a vida de novo em outro lugar, era agora ou nunca. ${ }^{103}$

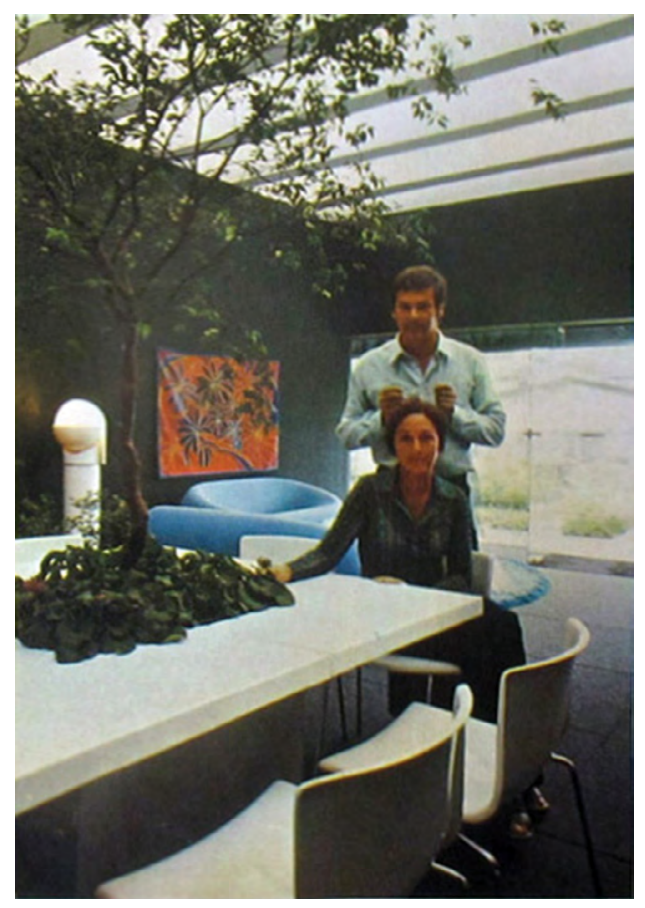

1.2.11: Ernesto e Georgia Hauner na Home Store. "Decoração? Não existe mais. É o que dizem os arquitetos de interiores". Mais. p. 45. abr. 1974 
Assim, em 1975, o casal anunciou que deixariam a empresa e o país, e pouco antes de saírem Ernesto vendeu suas ações a um empresário chamado Salvatore Ambrosino. Ada continuou trabalhando na Mobilinea até se aposentar e, quando questionada sobre mudanças em seu trabalho com a saída do irmão e da cunhada, disse:

Eu sempre procurei fazer um trabalho sério e positivo. Não houve diferença. Quer dizer, a coisa virou mais comercial, isso sim. Porque na época da Georgia e do Ernesto, era mais importante a parte intelectual de toda a organização do que a comercial. Eles indo embora, virou mais comercial. ${ }^{104}$

Judit Magyary, que após a temporada na Europa retornou à Mobilinea, tem opinião semelhante: "quando o Ernesto e Georgia existiam, tudo era diálogo, tudo era folia para a gente. Depois que eles foram embora, tudo virou burocracia"105. Evidentemente são opiniões de pessoas que viveram determinada experiência e em alguns aspectos discordam dos rumos que se seguiram, mas o que fica claro de todo modo é que houve mudanças drásticas na direção da Mobilinea, das quais a mais notável foi a gradual substituição dos produtos comercializados. Ernesto deixou todos seus projetos e respectivos direitos de produção na empresa, então a transformação que ela passou nos anos que se seguiram de fato se deu por uma opção em não dar continuidade à produção de peças com desenho próprio e com aquela linguagem.

Georgia e Ernesto tiveram mais uma breve passagem pela Itália e depois imigraram permanentemente para Vancouver, no Canadá. Lá, fundaram uma fábrica de produtos em vidro e cerâmica chamada Interstyle em 1977, que ainda está em atividade e é atualmente gerida por seus dois filhos. 


\subsection{Circuitos e confluências nos anos 1960 e 70}

Quando a Móveis Artesanal se relançou como Forma, inicialmente continuou vendendo os móveis desenhados por Martin Eisler e Carlo Hauner, mas em 1959 licenciou-se para produzir peças da Knoll International ${ }^{106}$, tornando-se sua representante oficial no Brasil. Embora eles também tenham aparecido em mais de uma ocasião em editoriais mistos com a Mobilinea, tinham uma estética mais luxuosa, eram mais caros e atendiam a uma demanda por peças assinadas e exclusivas.

Como dissemos, Sergio Rodrigues retornou ao Rio de Janeiro ao se desligar da Artesanal/Forma, inaugurando a Oca ainda em 1955, e em 1956 fundou uma fábrica para a produção de suas peças, batizada de Taba. Embora seus móveis, em sua vasta maioria feitos em madeiras maciças com estofados em couro ou palhinha, jamais terem sido produzidos em escala industrial, seu impacto cultural foi grande. Assim como no Studio Palma, na Artesanal, na Forma e na Mobilinea, a Oca expunha obras de arte e também funcionava como galeria. Em 1957, Rodrigues desenhou a Poltrona Mole para o amigo e fotógrafo Otto Stupakoff, em Jacarandá maciço, com perfis roliços e grandes almofadas de couro apoiadas em percintas. Essa poltrona concorreu, com pequenas modificações e sob o nome de Sheriff, no Concorso Internazionale del Mobile, em 1961, em Cantù, na Itália, onde obteve o primeiro prêmio. Ao contrário da estética delgada dos anos 1950, o móvel da Oca tinha perfis mais grossos e estofados volumosos, em consonância com posturas corporais descontraídas que marcariam a próxima década [1.3.01].

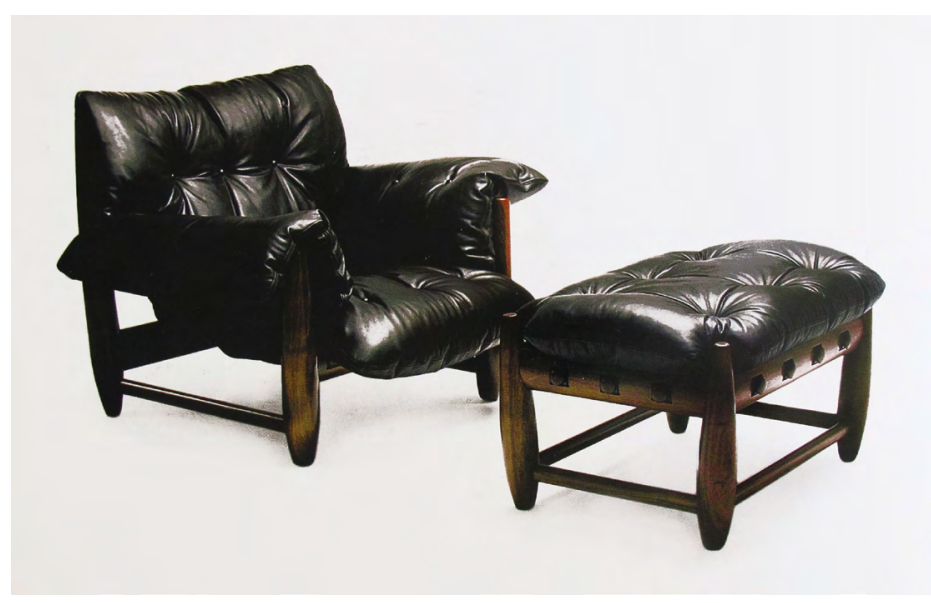

1.3.01: Poltrona Mole Sergio Rodrigues. Imagem publicada no livro Sérgio Rodrigues (Soraia Cals, 2000), p. 50. 
Em meados dos anos 1960, Rodrigues inaugurou a Meia-Pataca, loja irmã da Oca, que vendia móveis também desenhados por ele, porém de execução mais simples e, portanto, mais baratos, e foram comprados principalmente para mobiliar casas de veraneio ${ }^{107}$. Nenhuma de suas empresas competiu diretamente com a Mobilinea: na Oca, os móveis eram mais caros e funcionavam como elementos de destaque em um ambiente, quase como uma obra de arte; já a Meia-Pataca, embora com custos um pouco inferiores aos da Mobilinea, tinha uma proposta mais rústica. Apesar disso, a proximidade entre Sergio Rodrigues e os Hauner ultrapassou a parceria na Artesanal: em 1962, Sergio e Ernesto se associaram para fabricar na E. H. D os móveis que o primeiro projetara para a nova universidade federal em Brasília ${ }^{108}$; assim como os móveis da embaixada brasileira em Roma, encomendados a Sergio pela embaixador Hugo Gouthier, foram fabricados na Forma di Brescia, empresa que Carlo Hauner fundou naquela cidade após seu retorno à Itália.

Este tipo de parceria não era inusitada, assim como era habitualos designers se conhecerem e frequentarem os mesmos circuitos. Em sua diversidade, os móveis modernos compartilhavam uma estética despojada de ornamentos, despreocupada com uma concepção mais aristocrática de luxo e sem ligações diretas com o passado. Eram concebidas para contextos urbanos e imóveis recentemente construídos, especialmente considerando consumidores que, à semelhança da maioria de seus idealizadores, provinham de outras camadas sociais, tradições culturais ou lugares e estavam começando vida nova, com poucas heranças familiares ou nacionais a conservar.

À vista disso, se por um lado as empresas de design moderno do período tinham interesse em dizer que seus móveis eram acessíveis, por outro não queriam que fossem equiparados a algo de baixa qualidade ou que remetessem a um estilo de vida indesejável. Assim, estas empresas tinham que criar uma cultura de design para que seus produtos pudessem ser compreendidos e, neste sentido, elas dependiam da existência de concorrentes para que sua linguagem não estivesse totalmente alheia a qualquer referência conhecida. Não espanta, portanto, que em janeiro de 1966, Mobilinea, Oca, L'Atelier, Mobília Contemporânea, Ambiente, Forma e Arredamento tenham se unido para comprar espaços publicitários nos jornais paulistas Folha e Estado de São Paulo, visando promoverem-se conjuntamente ${ }^{109}$. Não havia nenhuma imagem na propaganda ali veiculada, apenas os logos de todas as empresas em uma lista contínua, e a aparente camaradagem era tanta que Arredamento, com espaço de divulgação maior, "pede licença aos seus principais concorrentes" para oferecer seus móveis em condições especiais [1.3.02].

Arredamento havia sido fundada em 1960, comercializando móveis desenhados por Ricardo Arrastia, arquiteto argentino formado em La Plata. 
Mobilinea

\section{Oca}

L'Atelier

IVOBILIA

CONTEMPORÃNEA

ambiente

lorrina

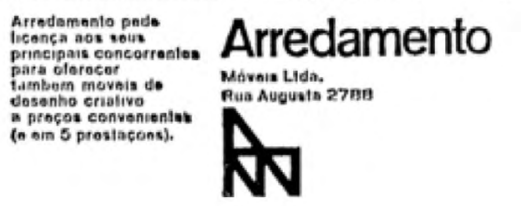

1.3.02: Propaganda

Mobilinea e concorrentes. A Folha de São Paulo. p. 9

Vida Social. 06 fev. 1966.

A empresa fazia peças em madeira maciça, modulares e com grande capacidade de composição a partir de dois grupos de elementos comuns (mesas, bancos e assentos, e estantes) e tinha preços próximos aos da Mobilinea [1.3.03]. A partir dos anos 1970, passaram a oferecer móveis laqueados e em 1972 lançaram uma linha em aço tubular ${ }^{110}$, além de uma linha de móveis infantis que seria comercializada na Home Store.

1.3.03: Móveis

Arredamento. "C. J. Visita... Arredamento". Casa \&

Jardim. pp. 40-41. out. 1970

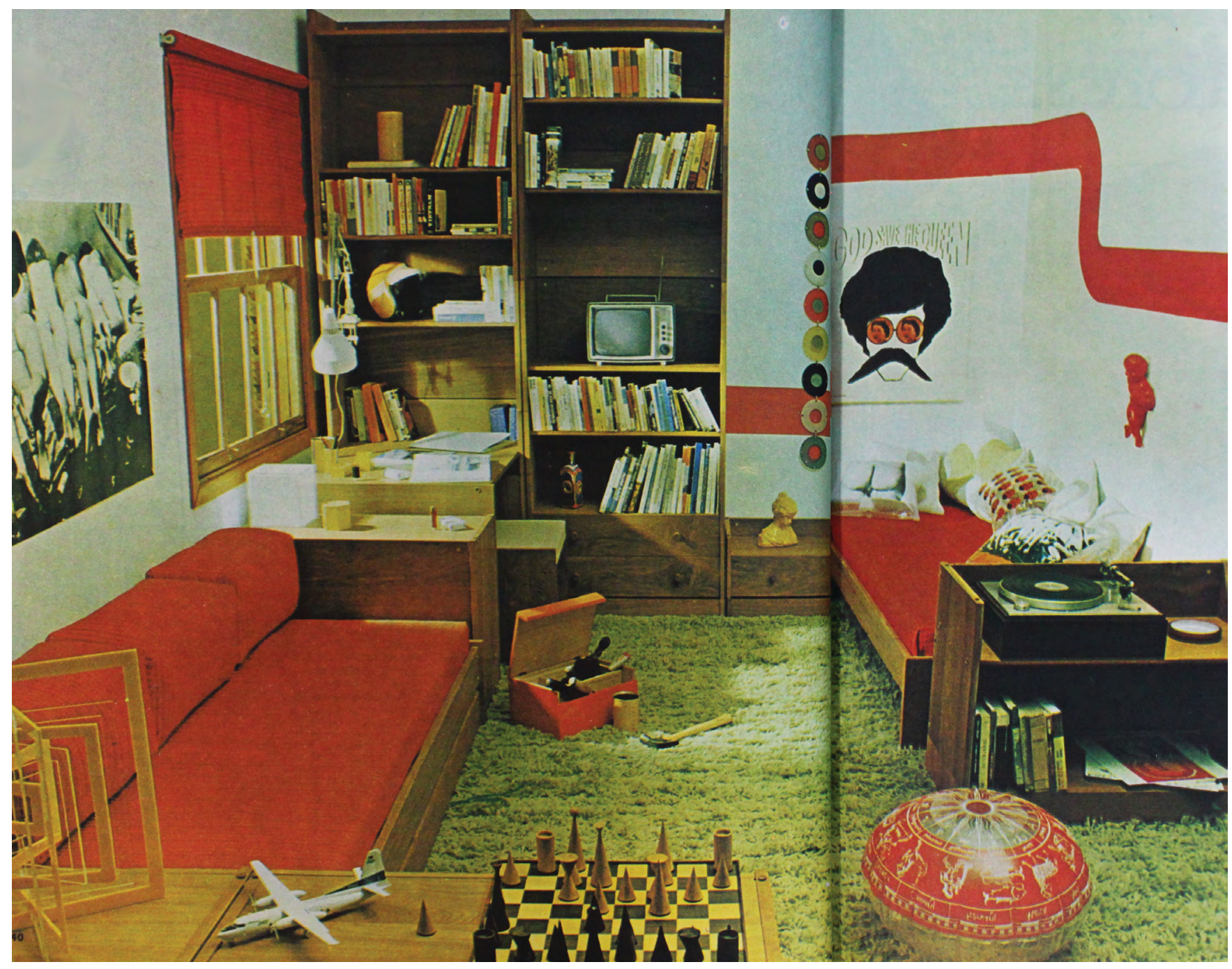


$\mathrm{Na}$ entrada dos anos 1960, L'Atelier começou a produzir móveis em poliuretano injetado e logo adquiriu os direitos de produção das cadeiras da empresa inglesa Hille, desenhadas por Robin Day. Em 1970, L'Atelier foi comprada pelo grupo empresarial Forsa, que contava com indústrias de diferentes materiais e permitiu aos designers utilizarem a tecnologia de todas elas ${ }^{111}$. As peças da empresa eram frequentemente escolhidas para aparecer em publicações impressas do período, mas aos poucos ela migrou para uma produção exclusiva de móveis de escritório.

Como vimos, a Ambiente fora criada por Leo Seincman, que em 1964 fundou também a Probjeto. Além de peças originais, a nova empresa tinha como foco a produção de desenhos estrangeiros de destaque, sendo a primeira licença comprada para a cadeira Series 7, de Arne Jacobsen, que passou a ser comercializada também na Mobilinea alguns anos depois [2.1.12]. Em 1972, adquiriram os direitos de produção e venda dos móveis da empresa italiana Cassina, que contava com os designers Mario Bellini, Carlo e Tobias Scarpa, entre outros, e que seriam um dos destaques da Home Store ${ }^{112}$.

A Mobília Contemporânea estava em atividade desde os anos 1950 e foi se readequando ao mercado conforme novas empresas surgiam e os modos de

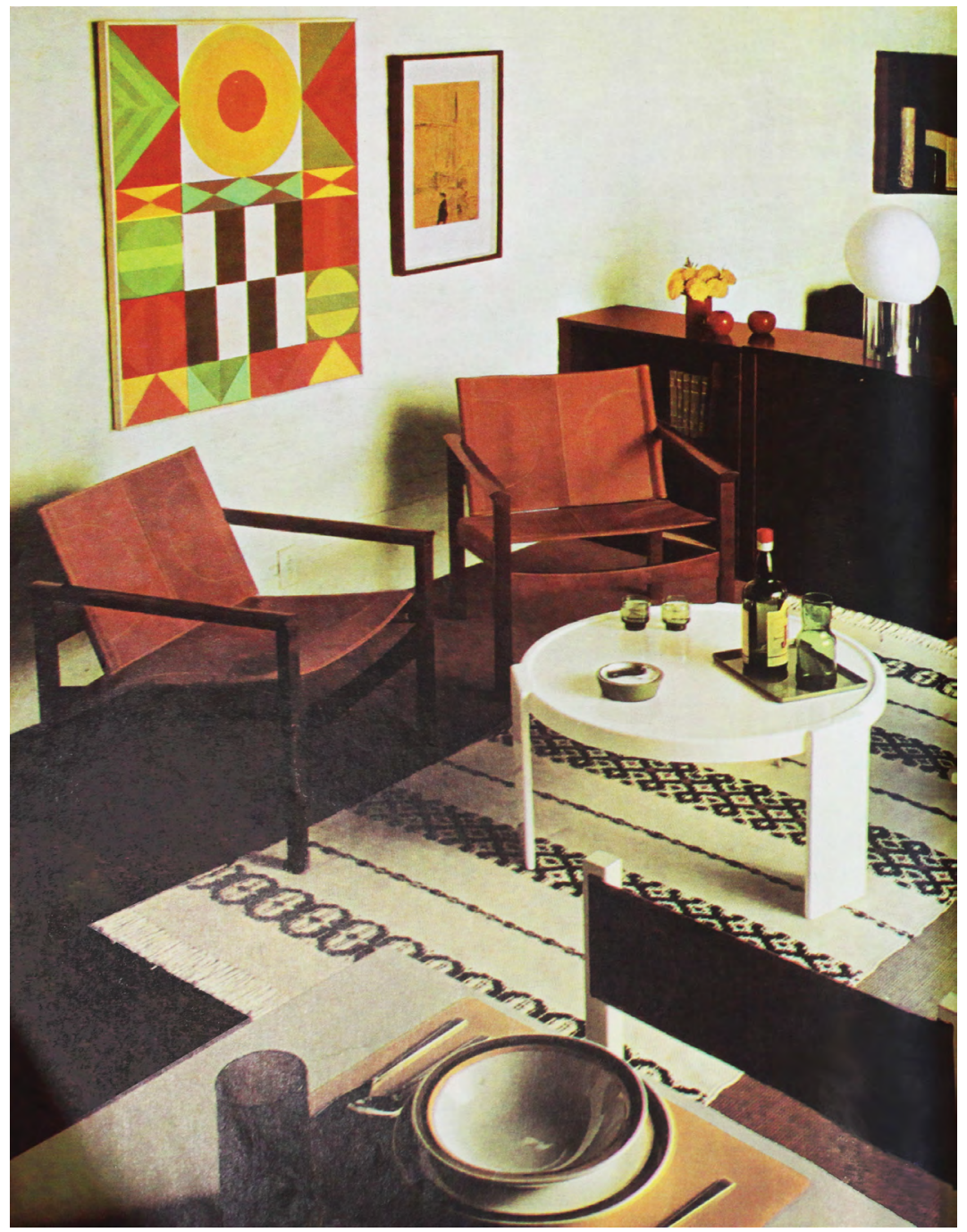


vida se modificavam, contando também com equipes nas lojas para ajudar no projeto de interiores de seus clientes. Em 1967, a empresa realizou uma pesquisa através da consultoria "Publicitestes, pesquisa, opinião pública e estudos econômicos" para analisar sua imagem entre seus consumidores, a partir da qual estabeleceram as seguintes informações: os clientes eram profissionais liberais, tinham entre 20 e 28 anos e em geral cursavam arquitetura ou engenharia ${ }^{113}$. Os estudos acerca de modulação e otimização dos processos de fabricação eram uma das preocupações centrais de Michel Arnoult, o que parece justificar seu público, e tiveram seu ápice com o desenvolvimento da linha Peg-Lev, vendida em caixas, deixando a montagem por conta dos clientes [1.3.04]. A ideia inicial era de que a linha fosse oferecida em supermercados, posicionando-se como um móvel despojado e democrático, mas em depoimento à Maria Cecília Loschiavo dos Santos em 1978, Arnoult declarou:

Primeiro, nós sentimos a concorrência da Hobjeto, da Mobilinea e de todo mundo; o mercado não era mais nosso, estava dividido. Diante disso, nós nos diferenciamos dos outros e, em 1970, pensamos em lançar móveis desmontáveis: o Peg-Lev, que, teoricamente, é uma ideia excelente, mas foi um erro comercial, porque o mercado era muito restrito para esse tipo de produto. ${ }^{114}$

A partir de 1970, a Mobília Contemporânea começou a fazer móveis laqueados, disputando diretamente mercado com a Mobilinea, mas as duas empresas tinham uma boa relação e Georgia usou muitos produtos da Mobília Contemporânea em seus editoriais para a revista Claudia, com destaque à sala de estar na casa modelo da "Casa de Claudia", empreendimento pré-fabricado que foi sorteado entre as leitoras inteiramente mobiliado em 1969 [3.2.083.2.12]. Segundo Georgia,

\begin{abstract}
A Mobília Contemporânea teve um lugar de honra porque eu fiz a sala com móveis de lá e o Michel gostou muito, teve sucesso. Eu soube que ele levou toda a turma de vendedores dele para mostrar essa exposição e para dizer a eles o que ele queria que fosse feito. Outra vez ali eu usei cores muito vivas, tecidos que a Mobília Contemporânea normalmente não fazia pra estofamentos e enfim, acho que mudei um pouquinho a maneira de eles se apresentarem. Era um pouco mais arrojado do que o normal da Mobília Contemporânea. ${ }^{115}$
\end{abstract}

A empresa chegou a comprar algumas fotos de editoriais de Claudia feitos por Georgia Hauner para usar posteriormente como propagandas próprias em revistas. Assim, em linhas gerais pode-se aventar que afora o uso de pintura, a Mobília Contemporânea se antecipou a alguns anseios da Mobilinea no que se refere a projeto e fabricação otimizados, enquanto a segunda tinha uma imagem e uma estrutura de vendas mais desenvolvida. Embora também tenham participado da Home Store, em entrevista a Aureliano Menezes em 1977, Arnoult afirmou que a Mobília Contemporânea fechou em 1973 porque não soube lidar com a concorrêncial116. 
A segunda grande concorrente da Mobilinea nas décadas de 1960 e 70 foi a Hobjeto. Geraldo de Barros, seu idealizador, trabalhara na Unilabor até 1964 e logo que se desligou associou-se aos marceneiros Antonio Bione (que também havia trabalhado no início da Unilabor) e Pascoal Onélio Moranti, fundando a empresa. A primeira loja própria da Hobjeto foi aberta em 1966 à Rua Iguatemi em São Paulo, a poucas quadras do futuro shopping center onde a Mobilinea vinha construindo seu novo showroom. No mesmo espaço foi instalada a galeria de arte Rex Gallery and Sons com Wesley Duke Lee, Nelson Leirner, Carlos Fajardo, José Rezende e Frederico Nasser. A galeria durou dois anos, mas foi bastante importante no cenário cultural paulistano, e encerrou suas atividades com um happening de Nelson Leirner. Além das exposições, havia também um jornal do grupo, escrito por Tomaz Souto Corrêa, futuro editor das revistas Claudia e quem contrataria Georgia Hauner para atuar como sua editora de decoração.

Em 1968, todas as peças da Hobjeto já eram produzidas em linha e começaram a fazer uso de madeira aglomerada; o início da produção de peças laqueadas foi anunciado em uma propaganda de abril de 1969 em Claudia Noiva ${ }^{117}$ e logo tornou-se padrão [1.3.05]. Hobjeto tinha preocupações similares às da Mobilinea em auxiliar os clientes a compreenderem como conceber um

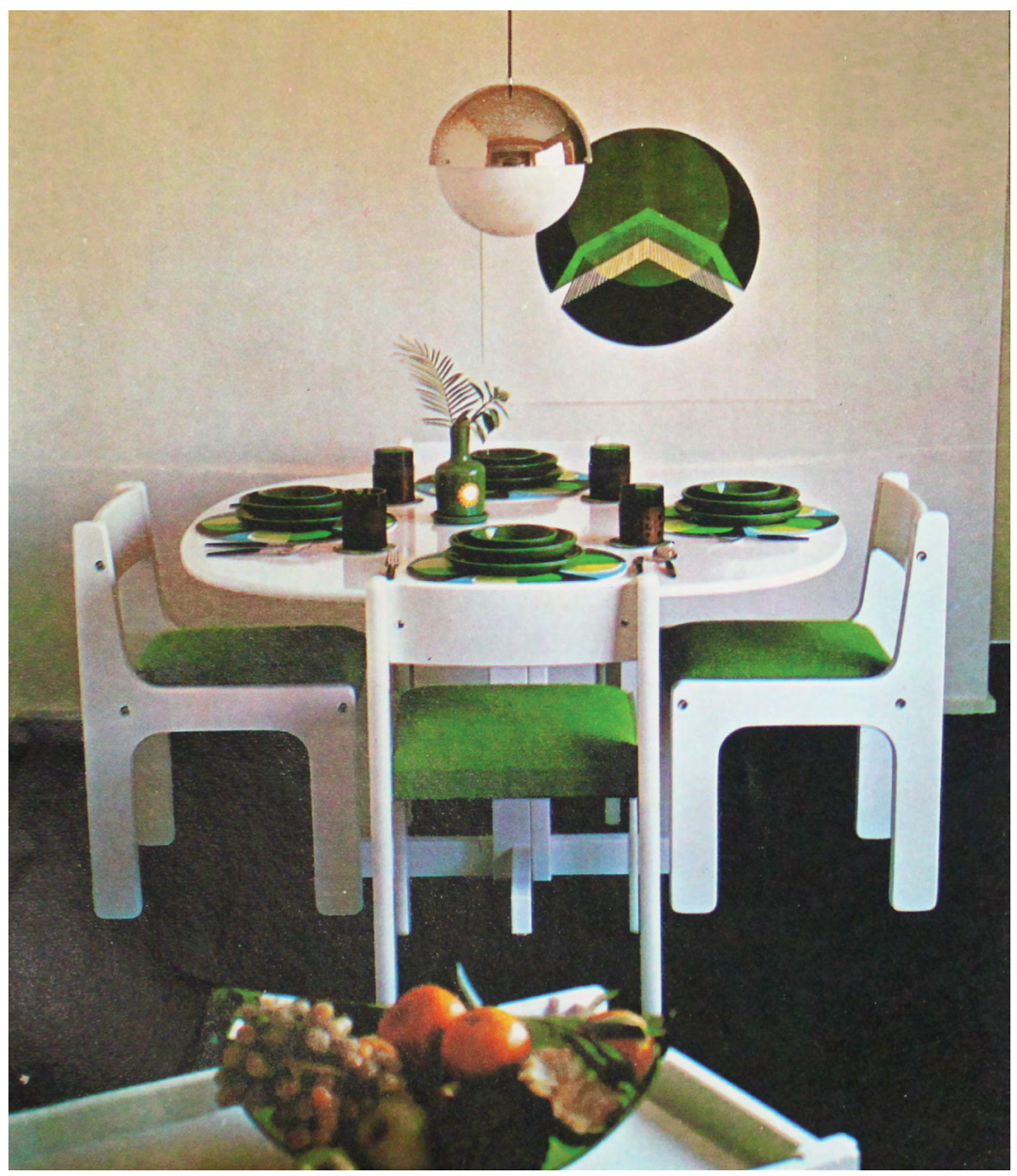


ambiente moderno em suas casas, e o fazia através de miniaturas de todos os seus móveis inseridos em plantas desenhadas em escala.

Tendo sido uma das empresas de maior sucesso no período, foi também uma das que tinha estratégias mais agressivas: muitas de suas propagandas em revistas parecem ser provocações diretas a outras empresas, e não hesitavam em produzir peças com desenho similar aos produtos de maior sucesso de suas concorrentes $^{118}$. A fabricação de móveis similares aos da Mobilinea na Hobjeto foi apontada em muitos depoimentos, mas vale enfatizar como principais diferenças entre elas que se o departamento de projeto da Hobjeto não tinha um comprometimento com a inovação formal, ela tinha uma estrutura administrativa e comercial mais desenvolvida. Bibita Butcher, que trabalhou na Mobilinea entre 1966 e 1971, e depois ficou na Hobjeto por quatro anos, declarou:

A Mobilinea era muito mais sofisticada, muito mais. Era assim, um luxo. Era maravilhosa. A Hobjeto era mais comercial mesmo. Tinha uma super estrutura para vender, todos os móveis tinham maquete 1:10 pra gente montar as maquetes em cima da mesa. Entrega era assim: "olha, vai ser entregue dia 5 de agosto", dia 5 de agosto ia. Na Mobilinea? Dia 10 de agosto, 15 de agosto... Eu ligava pro Ernesto e falava "Ernesto, pelo amor de deus...", "ah, não sei, está faltando tecido...", era enlouquecedor. ${ }^{119}$

Mobilinea, Hobjeto e Mobília Contemporânea também foram equiparadas pela Editora Abril, que selecionou as três para fazer parcerias de venda de móveis na revista Claudia. A primeira empresa chamada foi a Mobília Contemporânea, que criou pequenas estantes para enciclopédias vendidas em fascículos nas bancas; em 1968 foi a vez da Mobilinea, que desenvolveu uma linha de móveis infantis batizada de Mobilinha, também comercializada em suas lojas [2.1.14-2.1.16; 3.2.12]; e, finalmente, Hobjeto produziu módulos de apoio e armazenagem em parceria com a editora, em 1970.

Ao tempo em que lançou a Mobilinha e começou a construção de sua nova fábrica no Campo Limpo, em 1968, Mobilinea já tinha endereços próprios e revendas em seis cidades brasileiras, mantendo uma curva ascendente de crescimento $^{120}$. Não se pode deixar de notar que neste mesmo ano uma série de outras empresas de mobiliário fecharam suas portas, dentre as quais vale destacar Oca, Joaquim Tenreiro e Indústria Camas Patente, além de Unilabor em 1967. Evidentemente, há um conjunto de fatores particulares que levou ao fim de cada uma delas, mas uma perspectiva coletiva aponta um momento de ruptura no campo, talvez exigindo um nível de profissionalização maior.

Neste momento, discussões acerca do design no país chegaram a um nível em que se percebeu que os produtos deveriam ser divulgados de maneira mais significativa, além de criar postos de trabalho para os designers que começavam a se formar nos novos cursos criados e, assim, surgiram as primeiras exposições e prêmios ligados ao campo. A Associação Brasileira 
de Design Industrial (ABDI) havia sido criada em 1963, contando entre seus primeiros membros com docentes da Escola Superior de Desenho Industrial (ESDI) e da FAUUSP (cujo curso de design industrial havia sido criado em 1962, mesmo ano de fundação da ESDI), bem como por projetistas de mercado, artistas e industriais. De São Paulo, vale destacar os nomes de Lucio Grinover, João Carlos Cauduro, Abraão Sanovicz, Alexandre Wollner, Karl Bergmiller, Décio Pignatari, Willys de Castro e Leo Seincman. A associação não tinha fins lucrativos e era de caráter cultural: seu objetivo era reunir os interessados no desenvolvimento do desenho industrial no Brasil e divulgar suas atividades ${ }^{121}$.

A ABDI participava da organização de diversos prêmios e exposições, dentre os quais o Prêmio Roberto Simonsen para projetos e produtos de utilidades domésticas, que ocorreu anualmente entre 1963 e 1970 e era parte da Feira Nacional de Utilidades Domésticas - UD, criada em 1960 pela firma Alcântara Machado e patrocinada pela Federação das Indústrias do Estado de São Paulo (FIESP). Em 1964, uma poltrona desenhada por Michel Arnoult e Norman Westwater foi premiada na Feira UD, e as características da peça eram em grande medida similares ao modelo da Mobilinea que seria homenageado três anos depois: desmontável, com poucos elementos construtivos, fixação simples, sustentação do assento em fios de nylon e revestimento da espuma em plástico ${ }^{122}$. Em 1965, foi a vez da Hobjeto ficar em primeiro lugar no Prêmio com um beliche123. A vez da Mobilinea chegou em 1967, com uma poltrona desenhada por Ernesto Hauner, feita de ripas de madeira, desmontável, com estrado de percintas de borracha esticadas e almofadas soltas [1.3.06]. Nesta mesma edição, Mobilinea foi também responsável pela cenografia do estande da revista Casa \& Jardim, montado como um circo, com janelas redondas e motivos florais nas paredes e um toldo cônico por cima, e com móveis da empresa em madeira maciça organizando a ambientação ${ }^{124}$.

Já em um âmbito mais institucional, em 1968 ocorreu no Rio de Janeiro a primeira bienal de design no país, batizada de "Desenho Industrial 68 - Bienal Internacional do Rio de Janeiro", dedicada ao design de produto e comunicação visual. Montado pelo Instituto de Desenho Industrial do Museu de Arte Moderna do Rio (IDI-MAM), o evento contou com o apoio do Ministério das Relações Exteriores, ESDI, ABDI, Fundação Bienal de São Pauloe Confederação Nacional da Indústria $(\mathrm{CNI})^{125}$. A poltrona da Mobilinea premiada na UD foi exibida nesta primeira bienal, ao lado de peças de Michel Arnoult, Karl Heinz Bergmiller, Genaro Malzoni, Abrahão Sanovicz, Julio Katinsky, Sergio Rodrigues, entre outros. Dentre os premiados no campo gráfico, vale destacar os nomes de João Carlos Cauduro e Ludovico Martino, Alexandre Wollner, Fernando Lemos, Aloisio Magalhaes, Roberto Verschleisser e Leonardo Visconti Cavalleiro, Rogério Duarte, Rubem Martins e Antonio Maluf ${ }^{126}$. 

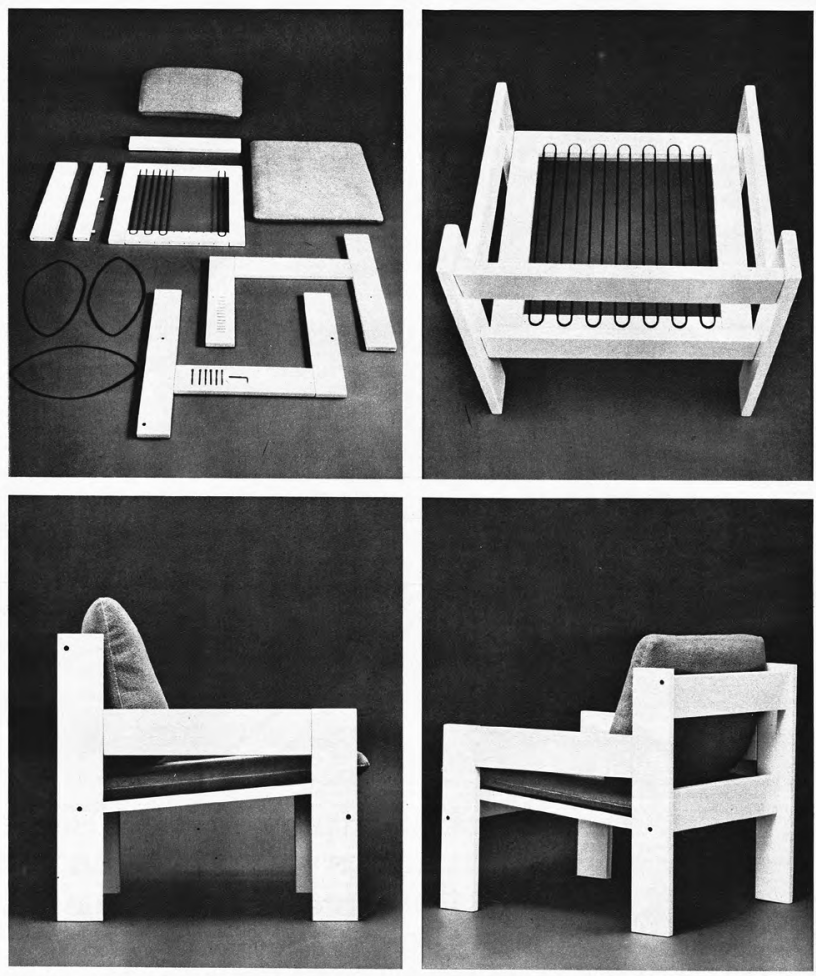

MOBILINE

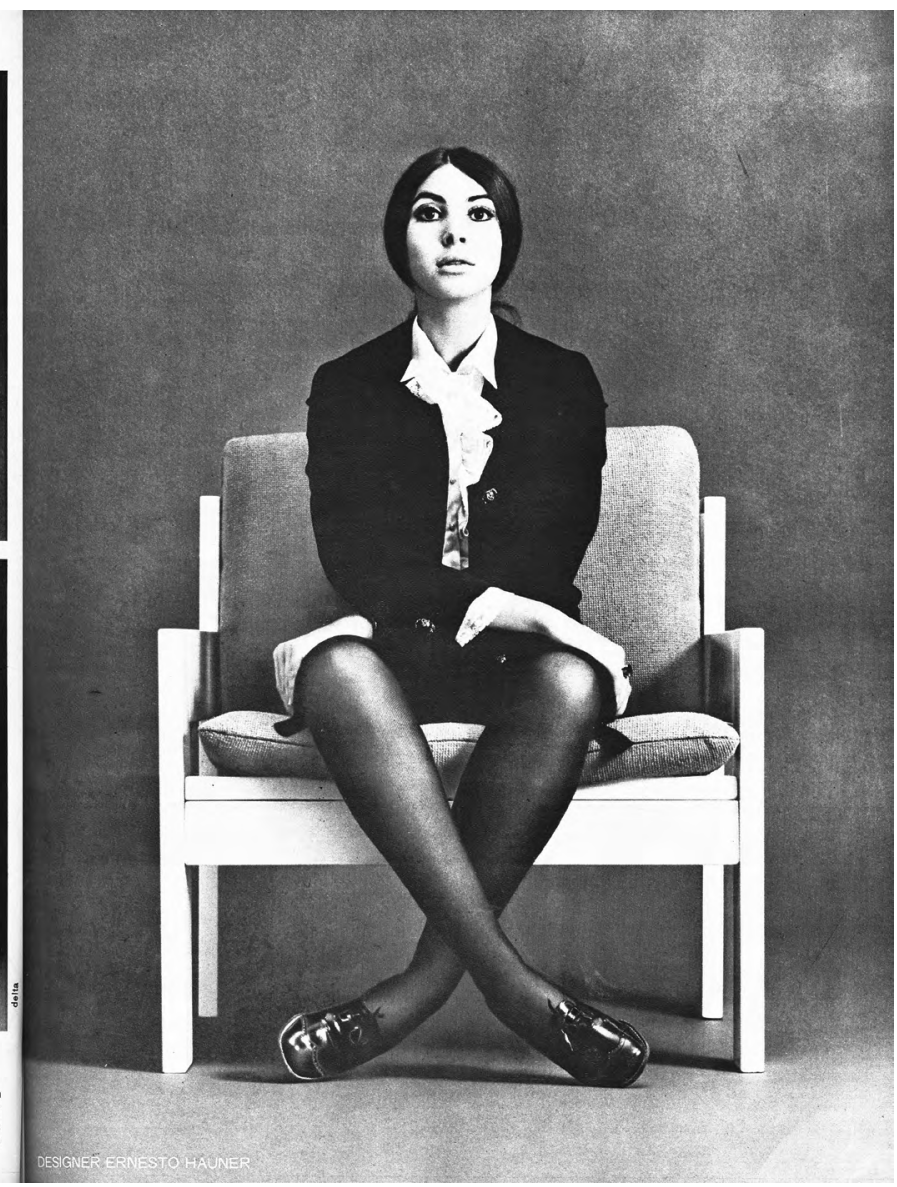

A Bienal teve duas edições seguintes, em 1970 e 1972, que obtiveram boa projeção internacional uma vez que, mesmo fora do país, exposições desse porte dedicadas exclusivamente ao design não eram comuns. A partir da "Desenho Industrial 70" foi organizado um concurso para profissionais brasileiros patrocinado pela CNI, no qual Ernesto ganhou o primeiro prêmio em 1970 com sua cadeira e carrinho de chá em aço e fiberglass, que também foram expostos no MASP na mostra "Mobiliário Brasileiro: premissas e realidade", de 1971, com curadoria de P. M. Bardi [1.2.04-1.2.05]. Autodeclarada a primeira exposição dedicada ao mobiliário brasileiro em termos museográficos ${ }^{127}$, esta contava também com peças de A \& O, Aki, Ambiente, Ao Gôsto, Arredamento, Bernardini, Dominici, Forma, Hobjeto, Inter/Design, L'Atelier, Lafer, Lustres Pelotas, Probjeto, Ruth Decorações e Tecnogeral. Na edição seguinte da Bienal em 1972, Ernesto Hauner foi novamente selecionado como um dos designers expostos, com uma cadeira de aço e fiberglass empilhável [2.1.27].

Em 1972, a ABDI organizou outra exposição de desenho industrial junto à empresa Eucatex chamada de Eucat Expo, que contou com projetos de Alessandro Ventura, Ludovico Martino, Ernesto Hauner, Livio Levi, Jorge Zalszupin, João Carlos Cauduro, Carlos Fongaro, Lucio Grinover, Roberto Verschleisser, Marilena Carvalho, David Pond e Karl Heinz Bergmiller, e tinha como objetivo "incentivar o desenvolvimento do desenhoindustrial no Brasil" 28.
1.3.06: Propaganda Mobilinea - Poltrona Bienal 68. Claudia Decoração. dez. 1968. 
No mesmo ano ocorreu a 8ª FUSE (Feira Internacional de Utensílio e Serviços de Escritório) no recém inaugurado pavilhão do Anhembi, e a revista Escritório Atual fez um número quase inteiramente dedicado a ela ${ }^{129}$, elencando, dentre outras, a participação das seguintes empresas: Probjeto, Escriba, Hobjeto, Teperman, Ambiente e Mobilinea que, além de estarem fisicamente próximas no pavilhão, eram aquelas que de alguma forma participavam das discussões do móvel moderno, muitas das quais atuavam no segmento corporativo tanto quanto residencial, como era o caso da própria Mobilinea.

Em julho do ano seguinte, Folha e Estado de São Paulo anunciaram a presença do Brasil, juntamente a França, Inglaterra, Bélgica, Espanha e Romênia na III Feira Internacional do Mobiliário - "Third International Home Furnishing Market" - que se realizaria em Nova York no "International Home Furnishing Market"130. As reportagens afirmavam que esta participação era um esforço do Ministério de Relações Exteriores, por intermédio da Divisão de Feiras e Turismo, para incrementar a exportação do móvel brasileiro, e que as empresas participantes eram: Arredamento, Engenhoca, Escriba, Italma, Mobília Contemporânea, Móveis Cimo, Mobilinea, Móveis Lafer e Ruth Decorações. Ao que parece, o país já havia participado da feira no ano anterior com resultados positivos, e para este ano estavam programados seminários, visita a lojas de departamentos e fábricas, entrevistas com especialistas e a exposição, para a qual haviam sido enviados 7.500 convites a lojistas e compradores norte-americanos.

Não foi possível averiguar qual o impacto desta participação no quadro geral das empresas participantes, mas pelo menos no caso da Mobilinea não foram localizadas consequências significativas do ponto de vista de sua produção ou internacionalização. Apesar disso, os esforços do governo em exportar o design brasileiro continuaram e, em junho de 1974, foi a vez da investirem no Canadá: de acordo com uma reportagem veiculada na Folha de São Paulo ${ }^{131}$, foi organizada uma "missão empresarial" para ir ao país averiguar as condições do mercado local e de exportação de produtos brasileiros para lá, na qual comprovou-se a aceitação de produtos de alimentação, confecções, calçados, artesanatos, autopeças, bicicletas e ferramentas. Estavam no grupo a Companhia Brasileira de Entreposto e Comércio (COBEC), Mobilinea, Polycouro, Badesp, FIESP, Trinea Máquinas e Artigos Plásticos, M. B. Indústria Metalúrgica, Têxtil Santa Ângela, Bicicletas Caloi e outras, sendo Mobilinea a única de mobiliário, campo em que aparentemente não houve um bom retorno.

Em seu currículo ${ }^{132}$, Ernesto Hauner afirmou ter sido convidado a participar da direção da ABDI em $1974^{133}$ e, embora tenha recusado o cargo, seu envolvimento com a Associação pode ser uma das explicações possíveis do porquê a Mobilinea se envolveu nesta atividade. Ter ido ao Canadá tão próximo de se desligarem da empresa também é relevante porque pode ter sido 
neste momento em que Ernesto Hauner escolheu seu próximo destino. De todo modo, é marcante como esforços pela consolidação do campo, enfatizando ora empresas, ora projetistas, ora a indústria, mesmo que em meio a uma série de dificuldades ${ }^{134}$, foram um projeto sério para um número grande de profissionais, órgãos culturais, institucionais e industriais, de forma que a Mobilinea que os Hauner deixaram em 1975 estava inserida em um meio muito diferente àquele que encontraram com a criação da Ernesto Hauner Decorações em 1959. 
${ }^{1}$ Os móveis Thonet estiveram entre os primeiros produzidos em escala industrial em todo o mundo, aliando funcionalismo à preocupação estética. Foram desenhados na Áustria pelo carpinteiro e empresário Michael Thonet, em 1841 e patenteados em 1849. São feitos a partir de uma técnica naval de envergar madeira em altas temperaturas e aparafusá-la, sem a necessidade de encaixes. Além disso, o armazenamento é feito com as peças desmontadas, o que poupa espaço.

2 Posteriormente, a produção das peças Thonet na Gerdau passaria à empresa Thonart, que produz as peças no Brasil até hoje.

${ }^{3} \mathrm{Em}$ 1967, a Gerdau firmaria uma parceria com a Mobilinea, que passaria a comercializar as peças da linha junto às suas próprias, incorporando seus processos de pintura e acabamento, como veremos na seção 2.1.

${ }^{4}$ Nascido na Espanha e filho de artesãos, Carrera imigrou para o Brasil em 1906 e em 1909 abriu a própria marcenaria com outros artesãos imigrantes e maquinário importado. Em 1919, o imigrante italiano Luís Liscio fundou a Indústria Camas Patente L. Liscio S. A., que registrou a marca em Araraquara e impediu que a Fábrica de Móveis Carrera continuasse a produzi-la, pois este não havia registrado seu desenho, ao contrário do segundo. Nos anos seguintes a nova fábrica expandiu e foram desenvolvidos métodos, máquinas e equipamentos próprios para sua fabricação, otimizando o uso do metal e da madeira. Por ser composta por peças, ela era desmontável e transportável. A Cama Patente foi comprada principalmente pelas classes médias, vendida em grandes magazines como Mappin Store, Casa Alemã, Mesbla e Cassio Muniz, além de por representantes de venda no interior do país. Foram produzidas até 1968. Ver a esse respeito: Maria Cecília Loschiavo dos Santos, Móvel Moderno no Brasil, 1995.

${ }^{5}$ Em 1921, os irmãos Martin e Jorge Zipperer instalaram uma fábrica de cadeiras na serraria e fábrica de caixas A. Ehrl \& Cia. em Rio Negrinho, nordeste de Santa Catarina. O nome CIMO veio apenas em 1954, sendo a razão social pelo qual esta produção é atualmente conhecida, ainda que sua atuação mais marcante tenha ocorrido entre 1925 e 1939. Ao longo dos anos, ampliaram a produção de cadeiras para poltronas de teatro e cinema, linhas institucionais completas para escritórios e escolas (amplamente utilizadas em órgãos governamentais) e alguns móveis residenciais, que foram comercializados em escala nacional. Havia preocupações com a racionalização da produção, mas sem um programa estético para os móveis, que foram adaptados e adornados para competir com peças de estilo ao longo da existência da empresa (especialmente a partir dos anos 1950), inclusive se aproximando dos móveis pintados da Mobilinea, antes de fechar as portas em 1982. Ver a esse respeito: Maria Angélica Santi, Mobiliário no Brasil: Origens da Produção e da Industrialização, 2013.

${ }^{6}$ John Graz nasceu na Suíça e imigrou para o Brasil quando se casou com a brasileira Regina Gomide, em 1920, após terem estudado juntos na Faculdade de Artes Decorativas de Genebra. Graz começou a desenhar móveis em 1923 com uma estética próxima ao art déco, empregando materiais como tubos metálicos e madeira laminada. O casal projetou os interiores de muitas residências da elite intelectual do período, e a produção dos móveis era feita em oficinas terceirizadas por encomenda, de forma artesanal e utilizando materiais importados. Ver a esse respeito: Anna Maria Affonso dos Santos, John Graz: O Arquiteto de Interiores, 2008

7 Gregori Warchavchik nasceu em Odessa em 1896, tendo iniciado sua formação em arquitetura na Escola de Arte local, e a concluiu em 1920 em Roma. Em 1923, imigrou para São Paulo para atuar na Companhia Construtora de Santos. Em 1927 casou-se com Mina Klabin, que era bastante engajada nos circuitos culturais da cidade e, no mesmo ano, construiu a residência do casal, à Rua Santa Cruz. Em 1930, organizou em São Paulo a "Exposição de uma Casa Modernista" em uma casa construída à Rua Itápolis, com a colaboração de vários arquitetos e artistas. A convite de Lúcio Costa, passou a integrar o corpo docente da Escola Nacional de Belas Artes no Rio de Janeiro; e entre 1931 e 32, no Rio, inaugurou duas outras obras de sua autoria com exposições de arquitetura. Ver a esse respeito: José Tavares Correia de Lira, Warchavchik: fraturas da vanguarda, 2011.

${ }^{8}$ Ver a esse respeito: Whitney Chadwick e Isabelle Courtviron, Significant Others: Creativity and Intimate Partnership, 1993; Tatiana Perecin, Mina Klabin Warchavchik: paisagismo e modernismo no Brasil, 2003; Ana Paula Cavalcanti Simioni, Profissão Artista: Pintoras e Escultoras Acadêmicas Brasileiras, 2008.

${ }^{9}$ Berard Rudofsky formou-se arquiteto e engenheiro em Viena em 1928 e trabalhou em diversos países europeus como arquiteto e artista antes de vir passar três anos no Brasil em 1938. Na Casa \& Jardim, Rudofsky foi nomeado diretor de arte da seção de decoração, desenhando móveis e prestando consultoria a clientes. O arquiteto também foi responsável pelo logotipo da empresa Fotoptica, em uso até meados dos anos 1970. Ver a esse respeito: Andrea Bocco Guarnieri, Bernard Rudofsky: a humane designer, 2003. ${ }^{10}$ A exposição Organic Design in Home Furnishings foi organizada no MoMA a partir de duas competições: uma delas com nove categorias e aberta a designers europeus e americanos, e outra sem categorias, para designers latino-americanos. Rudofsky foi um dos vencedores desta segunda e o único a submeter projetos do Brasil. Aos vencedores, era dada uma passagem para Nova York, para onde o arquiteto foi e não retornou mais ao Brasil. Ver a esse respeito: Andrea Bocco Guarnieri, op. cit.

${ }^{11}$ João Manuel Cardoso de Mello e Fernando Novais, Capitalismo Tardio e Sociabilidade Moderna, p. 564.

12 Maria Angélica Santi, op. cit, p. 271.

${ }^{13}$ Regina Meyer, Metrópole e Urbanismo: São Paulo anos 50, 1991, p. 10. 
${ }^{14}$ João Manuel Cardoso de Mello e Fernando Novais, op. cit., p. 560.

${ }^{15}$ Maria Arminda do Nascimento Arruda, Empreendedores culturais imigrantes em São Paulo, 2001.

${ }^{16}$ Ronaldo Brito, Neoconcretismo: vértice e ruptura do projeto construtivo brasileiro, 1999.

${ }^{17}$ A congregação do I.A.C. incluía Lasar Segall, Elisabeth Nobiling, Lina Bo Bardi, Giancarlo Palanti, Roberto Burle Marx, Thomas Farkas, Jacob Ruchti, Rino Levi, Flávio Motta, entre outros.

18 Hugo Segawa, Arquiteturas no Brasil: 1900-1990, 1998; Adrián Gorelik, Das Vanguardas à Brasília: cultura urbana e arquitetura na América Latina, 2005.

${ }_{19}$ Nascido em Portugal, Joaquim Tenreiro imigrou para o Brasil em 1928 e logo tomou contato com o meio artístico carioca. Entre 1931 e 1934, desenhou móveis em estilos diversos para a firma de móveis de origem alemã Laubisch \& Hirth que, embora contasse com cerca de 300 trabalhadores, tinha produção totalmente artesanal. Entre 1935 e 1938, trabalhou na empresa de origem portuguesa Leandro Martins, mas depois voltou para a Laubisch \& Hirth. Em 1941, Francisco Inácio Peixoto encomendou à empresa móveis para mobiliar sua casa em Cataguazes, projeto de Oscar Niemeyer, e não queria peças de estilo. Passaram o projeto a Tenreiro e ele fez o projeto completo, aprovado e comprado pelo cliente. Ver a esse respeito: Soraia Cals, Tenreiro, 1998.

${ }^{20}$ A Poltrona Leve, de 1942, é tida por muitos autores como o marco do início do design moderno em Tenreiro, tendo sido produzida em duas madeiras (pau-marfim e em imbuia lustrada em preto). Ela é estruturada em braços e pés torneados, com assento e encosto em espuma de borracha revestida em tecido. Seu projeto mais conhecido é a Cadeira de Três pés, de 1947, que podia ser feita com três a cinco madeiras diferentes e introduzia cor no móvel a partir do próprio material. Sua fábrica chegou a contar com cem artesãos fazendo móveis em madeira maciça e eventualmente em compensado e até metal.

${ }^{21}$ Os móveis da Branco \& Preto eram executados em pequena quantidade em marcenarias terceirizadas. As cortinas também eram desenhadas na empresa, estampadas em serigrafia por Paulo Becker. Pelo modo de produção, o móvel do Branco \& Preto era caro e um projeto secundário para alguns de seus fundadores, que logo se desvincularam. Os que permaneceram abriram uma filial à Rua Augusta, em São Paulo, com tecidos e objetos decorativos, que funcionou até 1970. Ver a esse respeito: Marlene Milan Acayaba, Branco \& Preto: uma história do design brasileiro nos anos 50, 1994.

${ }^{22}$ Segundo Marlene Acayaba, os móveis da Ambiente eram cópias de móveis estrangeiros americanos, em especial da Knoll. Roberto Aflalo, que depois fundaria a Branco \& Preto, começara sua carreira como desenhista de móveis lá, fiscalizando esta produção.

${ }^{23}$ Mais tarde, o arquiteto italiano Carlo Benvenuto Fongaro foi trabalhar na Ambiente e lá projetou linhas completas de móveis residenciais em madeira maciça e metal, além de propor ambientações para clientes. Outros nomes importantes que passaram pela empresa foram Karl Bergmiller e Eduardo Corona. Ver a esse respeito, Maria Cecília Loschiavo dos Santos, op. cit.

${ }^{24}$ Maria Cecília Loschiavo dos Santos, op. cit.

${ }^{25}$ Ver a esse respeito: Maria Cecília Loschiavo dos Santos, Jorge Zalszupin: Design Moderno no Brasil, 2014.

${ }^{26}$ Fundada pelo desenhista e maquetista José Zanine Caldas em parceria com Sebastião Pontes e Paulo Mello em 1948, em São José dos Campos, a Fábrica de Móveis Z, Zanine, Pontes e Cia. Ltda. propunha móveis baratos e industrializados com desenho moderno para as classes médias. Eram elaborados em madeira compensada recortada em formas sinuosas, porém com estudos de aproveitamento de chapa. As peças eram parafusadas, as forrações de lona ou tecido plástico eram pregadas com tachinhas e não havia costura (portanto não eram necessários tapeceiros) e o sistema de molas era simples. A produção era em série, sem mão-de-obra especializada e os móveis eram desmontáveis. A empresa fechou em 1961 quando a fábrica foi destruída por um incêndio, mas foram comercializados com êxito em grandes magazines. Ver a esse respeito: Marcelo Vasconcellos e Maria Lúcia Braga, Móvel Moderno Brasileiro, 2012. ${ }^{27}$ A comunidade de trabalho Unilabor, Indústria de Artefatos de Ferro, Metais e Madeira Ltda. foi fundada no bairro do Ipiranga em 1954, como uma cooperativa cristã coordenada pelo frei João Batista Pereira dos Santos, que reunia profissionais de vários meios, incluindo o artista plástico concretista Geraldo de Barros como desenhista das peças e da identidade visual da marca. Iniciaram a produção artesanalmente, mas logo desenvolveram linhas de móveis com elementos comuns fabricados em série; a maior preocupação no processo produtivo a partir desta transição foi não perder a participação dos trabalhadores no projeto e planejamento da fabricação de cada peça. Os móveis da Unilabor foram consumidos por classes médias que buscavam uma identificação com as vanguardas artísticas, eram modulares, feitos principalmente por estruturas verticais metálicas e caixas em madeira, permitindo que algumas peças básicas assumissem diferentes combinações e usos variados. Geraldo de Barros participou a Unilabor até 1964, quando teve desentendimentos com os sócios, e no mesmo ano viria a fundar a Hobjeto. Com crescentes dificuldades, a Unilabor permaneceu em atividades até 1967. Ver a esse respeito: Mauro Claro, Unilabor - desenho industrial, arte moderna e autogestão operária, 2004; Mauro Claro, Dissolução da Unilabor: crise e falência de uma autogestão operária - São Paulo, 1963-1967, 2012.

${ }^{28}$ Lina Bo Bardi nasceu em Roma em 1914 e formou-se arquiteta em 1939. Em 1940 inaugurou em Milão um escritório de arquitetura e design com o arquiteto Carlo Pagani e começou a colaborar com a revista Domus, da qual se tornou editora em 1943. Trabalhou também ao lado do arquiteto Giò Ponti e, assim, participou da organização das Trienais de Artes Decorativas. No ano de 1946, recém casada, embarcou para o Brasil em busca de novas oportunidades. Ver a esse respeito: Cristina Ortega, Lina Bo Bardi: móveis e interiores (1947-1968) - interlocuções entre moderno e local, 2008. 
${ }^{29}$ O Studio brasileiro foi batizado com o mesmo nome do Studio de Arte Palma de Roma, do qual Bardi fora proprietário e presidente.

${ }^{30}$ Giancarlo Palanti nasceu em Milão em 1906 e se formou arquiteto em 1929. Em 1930 apresentou móveis e objetos na IV Trienal de Monza e em 1931 abriu escritório de arquitetura e interiores com Franco Albini e Renato Camus, onde desenvolveu móveis modernos em materiais diversos. Contribuiu como redator nas revistas Domus e Casabella entre 1931 e 1946, ano em que também decidiu imigrar para o Brasil. Ver a esse respeito: Aline Sanches, A obra e a trajetória do arquiteto Giancarlo Palanti: Itália e Brasil, 2004.

${ }^{31}$ Georgia Hauner, Ernesto Hauner - brief resumé, 2011, p. 1.

${ }^{32}$ Entrevista concedida por Ada Hauner à autora em 29 de agosto de 2012.

${ }^{33}$ A galeria de Ada Hauner e Roberto Consolaro em Belo Horizonte funcionou de 1950 a 1955. Já a carioca chamava-se Penguin, por estar no subsolo da livraria Penguin, e funcionou entre 1959 e 1961.

${ }^{34}$ Entrevista concedida por Ada Hauner à autora em 29 de agosto de 2012.

${ }^{35}$ Georgia Hauner, Ernesto Hauner - brief resumé, 2011, p. 1.

${ }^{36}$ Ernesto Hauner, Resumé, c. 1975, p. 1. Documento datilografado do acervo pessoal de Georgia Hauner.

${ }^{37}$ Georgia mencionou que antes do trabalho no Studio Palma, Ernesto teve uma breve passagem como calculista nas Indústrias Pignatari. Georgia Hauner, Mobilinea (Updated march 2014), 2014, p. 2.

${ }^{38}$ Maria Cecília Loschiavo dos Santos, Móvel Moderno no Brasil, 1995, 98.

${ }^{39}$ Georgia Hauner, Mobilinea (Updated march 2014), 2014, p. 2.

${ }^{40}$ Conforme propaganda da empresa no primeiro número da revista Habitat, dirigida pelo casal Bardi. Propaganda Móveis Artesanal (Móveis em estilo moderno, decoração em geral). Habitat, p. 99. out.-nov.dez. 1950.

${ }^{41}$ A casa de Milton Guper foi projetada por Rino Levi em 1951 e, curiosamente, mobiliada com móveis Branco \& Preto. Marlene Milan Acayaba, op.cit, p. 111.

${ }^{42}$ Martin Eisler era austríaco, arquiteto de formação e tivera uma passagem pela Argentina antes de chegar em terras brasileiras. Era cunhado de Ernesto Wolf. Entrevista concedida por Matias Eisler à autora em 5 de fevereiro de 2013.

${ }^{43}$ Ernesto Wolf era alemão, também com uma passagem pela Argentina, depois da qual imigrou para o Brasil em 1947, tornando-se sócio da Algodoeira Paulista. Wolf era colecionador de artes e participou da organização da primeira Bienal de Arte de São Paulo, em 1951. Entrevista concedida por Martin Wurzmann à autora em 5 de fevereiro de 2013.

${ }^{44}$ Ernesto Hauner, op. cit., p. 1.

${ }^{45}$ Sergio Rodrigues havia se formado em arquitetura em 1951 e estava trabalhando em Curitiba no projeto do novo Centro Cívico, junto a David Xavier de Azambuja, Flávio Regis do Nascimento e Olavo Redig de Campos. Tinha alguma experiência com interiores e, por isso, foi o encarregado de tratar destes assuntos com Carlo Hauner.

${ }^{46}$ Entrevista concedida por Sergio Rodrigues à autora em 13 de novembro de 2012.

${ }^{47}$ Georgia Hauner, Memoir, 2010.

${ }^{48}$ Entrevista concedida por Georgia Hauner à autora em 11 de setembro de 2012.

${ }^{49}$ Georgia Hauner, op. cit.

${ }^{50}$ Georgia Hauner, Mobilinea, 2011.

${ }^{51}$ Entrevista concedida por Georgia Hauner à autora em 11 de setembro de 2012.

52 Entrevista concedida por Georgia Hauner à autora em 11 de setembro de 2012.

${ }^{53}$ Entrevista concedida por Sergio Rodrigues à autora em 13 de novembro de 2012.

${ }^{54}$ Entrevista concedida por Georgia Hauner à autora em 11 de setembro de 2012.

${ }^{55}$ Para mais detalhes sobre a trajetória e o fim da Artesanal, ver: Mina Warchavchik Hugerth, "Móveis Artesanal: prelúdio à Forma, Oca e Mobilinea" in: Marcos da Costa Braga; Dora Souza Dias (org.), Histórias do Design n Brasil II, 2014.

${ }^{56}$ Georgia Hauner, Segunda Parte de Respostas, 2012.

${ }^{57}$ Entrevista concedida por Georgia Hauner à autora em 11 de setembro de 2012.

58 Lesley Jackson, The Sixties - Decade of Design Revolution, 1996, pp. 14-15.

${ }^{59}$ Entrevista concedida por Georgia Hauner à autora em 12 de setembro de 2012.

${ }^{60}$ Dentre os marceneiros inicialmente contratados por Ernesto, Georgia lembrou-se do nome de Vicente Barbarullo. Georgia Hauner, Texto de Georgia Hauner, 2010.

${ }^{61}$ Ficha Cadastral Completa - Ernesto Hauner Decorações. Disponível em: <http://www.jucesp.fazenda. sp.gov.br/>. Acessado em 12/12/2012.

${ }^{62}$ Ernesto Hauner, op. cit., p. 1.

${ }^{63}$ Entrevista concedida por Jorge Kornbluh à autora em 12 de dezembro de 2013.

${ }^{64}$ Georgia Hauner, Segunda Parte de Respostas, 2012.

${ }^{65}$ Para mais detalhes sobre a participação da Mobilinea na produção de móveis para a UnB, ver: Mina Warchavchik Hugerth, "O caminho para a UnB: Sergio Rodrigues, Ernesto Hauner e o desenvolvimento do móvel moderno no Brasil” in: Alex Calheiros, Marcelo Mari, Priscila Rossinetti Rufinoni (org.), Mobiliário Moderno: das pequenas fábricas ao projeto da UnB, 2014.

${ }^{66}$ Ernesto Hauner, op. cit., p. 2.

${ }^{67}$ Ficha Cadastral Completa - Mobilinea. Disponível em: <http://www.jucesp.fazenda.sp.gov.br/>. Acessado em 12/12/2012. 
${ }^{68}$ Entrevista concedida por Georgia Hauner à autora em 14 de setembro de 2012.

${ }^{69}$ Georgia Hauner, Segunda Parte de Respostas, 2012.

${ }^{70}$ Ernesto Hauner, op. cit., p. 2.

${ }^{71}$ Decoração de JOIA (Caderno Especial). Joia. pp. 76. fev 1967.

72 Georgia Hauner, Mobilinea, 2011, p. 2.

${ }^{73}$ Propaganda Mobilinea- Patinhos. Casa \& Jardim. set 1965.

74 Evidentemente, pintar móveis não era uma prática inédita, tampouco exclusiva da Mobilinea. A novidade aqui era a combinação da linguagem das peças e cores utilizadas, que já se via em algumas revistas estrangeiras.

${ }^{75}$ Entrevista concedida por Judit Magyary à autora em 29 de julho de 2014.

${ }^{76}$ Entrevista concedida por Georgia Hauner à autora em 12 de setembro de 2012.

77 O tipo de objeto comercializado nas lojas da Mobilinea além de seus móveis próprios será discutido na seção 2.2 .

${ }^{78}$ Georgia Hauner, Carta para Mina, 2013, p. 1.

${ }^{79}$ Id. ibid.

${ }^{80}$ Georgia Hauner, Showrooms, Fotografia, Artesanato, 2011, p. 2.

${ }^{81}$ Georgia iria chamar Suzana Coelho Cardoso para trabalhar com ela em Claudia elaborando editoriais de paisagismo em 1969.

82 Georgia Hauner, Respostas sobre a Mobilinea, 2013, p. 1.

${ }^{83}$ Marinês Ribeiro dos Santos define o interior doméstico como o arranjo interno da moradia, definido tanto pelo espaço arquitetônico quanto "pela disposição dos móveis e demais artefatos de uso ou decorativos escolhidos para organizar funcional e simbolicamente a vida cotidiana". Ela entende que o resultado destes arranjos ocorre em diálogo entre o foro individual e o conjunto de valores em circulação no mundo social. Marinês Ribeiro dos Santos, O Design Pop no Brasil dos anos 1970: domesticidades e relações de gênero na revista Casa e Jardim, 2010, p. 26.

${ }^{84}$ Entrevista concedida por Georgia Hauner à autora em 14 de setembro de 2012.

${ }^{85}$ Entrevista concedida por Georgia Hauner à autora em 12 de setembro de 2012.

${ }^{86}$ A produção de imagens de Georgia Hauner em Claudia e especialmente seu discurso na revista serão discutidos ao longo do capítulo 3.

${ }^{87}$ Georgia Hauner, Segunda parte de respostas, 2012, p. 8.

${ }^{88}$ Georgia Hauner, Segunda parte de respostas, 2012.

${ }^{89}$ Yone Koseki nasceu em Pereira Barreto, interior do estado de São Paulo, de pai japonês e mãe descendente de imigrantes do mesmo país. Entrevista concedida por Yone Koseki Pierre à autora em 18 de julho de 2014

${ }^{90}$ Entrevista concedida por Yone Koseki Pierre à autora em 18 de julho de 2014.

${ }^{91}$ Judit Magyary nasceu em Budapeste, na Hungria. A família passou um curto período em um campo para refugiados de guerra na Itália, antes de virem para o Brasil em 1951. Seu pai era bancário mas tinha interesse em artes, e sua mãe era formada em desenho industrial com especialização em estamparia têxtil. Entrevista concedida por Judit Magyary à autora em 29 de julho de 2014.

${ }^{92}$ Dentre o corpo docente do curso de decoração que realizou na FAAP, Judit lembra-se dos professores Ideo Bava e Gontran Guanaes, e de que o ensino de alguma forma era uma dissidência do ladê, curso de decoração na capital paulista. Entrevista concedida por Judit Magyary à autora em 29 de julho de 2014.

${ }^{93}$ Nascida de pai inglês e mãe brasileira, Bibita Butcher conheceu a Mobilinea inicialmente porque sua mãe dava aulas de inglês para Ada Hauner. Entrevista concedida por Bibita (Maria Beatriz) Butcher à autora em 23 de julho de 2014.

${ }_{94}$ Entrevista concedida por Bibita (Maria Beatriz) Butcher à autora em 23 de julho de 2014; entrevista concedida por Judit Magyary à autora em 29 de julho de 2014.

${ }^{95}$ Ernesto Hauner, op. cit., p. 2.

${ }^{96}$ Uma análise mais aprofundada dos móveis produzidos pela Mobilinea será feita no item 2.1.

${ }^{97}$ Arquitetura de Interiores no Brasil. Projeto \& Construção. p. 42. jan. 1971.

${ }^{98}$ Catálogo para vendas KX Mobilinea. Sem data. Acervo pessoal de Georgia Hauner.

${ }^{99}$ Georgia Hauner, Respostas sobre a Mobilinea, 2013.

100 Georgia Hauner, Segunda parte de respostas, 2012, p. 7

${ }^{101}$ Localizados no acervo pessoal de Georgia Hauner.

102 Georgia Hauner, Mobilinea (Updated march 2014), 2014, p. 9.

${ }^{103}$ Entrevista concedida por Georgia Hauner à autora em 14 de setembro de 2012.

${ }^{104}$ Entrevista concedida por Ada Hauner à autora em 29 de agosto de 2012.

${ }^{105}$ Entrevista concedida por Judit Magyary à autora em 29 de julho de 2014.

${ }^{106}$ A Knoll foi fundada em Nova lorque em 1938 pelo imigrante alemão Hans G. Knoll, como uma fábrica e loja de móveis para ambientes modernos. A partir de 1946, sua esposa Florence Knoll e ele buscaram designers proeminentes no período para criar seus produtos, como Eero Saarinen, Harry Bertoia e Mies Van Der Rohe. O lema da empresa à época era "bom design é bom negócio". Ver a esse respeito: David Raizman, History of Modern Design, 2003.

${ }^{107}$ Entrevista concedida por Sergio Rodrigues à autora em 13 de novembro de 2012.

${ }^{108}$ Alex Calheiros, Marcelo Mari, Priscila Rossinetti Rufinoni (org.), op. cit. 
${ }^{109}$ A propaganda conjunta das várias empresas de móvel apareceu em Folha e Estado de São Paulo cinco vezes entre janeiro e março de 1966.

110 "C. J. Visita... Arredamento". Casa \& Jardim. set. 1972.

${ }^{111}$ Ethel Leon, Design brasileiro - Brazilian design: quem fez, quem faz - who did, who does, 2005, pp. 120-121.

${ }^{112}$ Encarte publicitário Home Store. A Casa Claudia. dez. 1973.

${ }^{113}$ Aureliano Menezes, op. cit., p. 18.

114 Maria Cecília Loschiavo dos Santos, op. cit., 142.

115 Entrevista concedida por Georgia Hauner à autora em 11 de setembro de 2012.

${ }^{116}$ Aureliano Menezes, op. cit.

${ }^{117}$ Propaganda Hobjeto - lançamento de móveis laqueados. Claudia Noiva. abr. 1969.

${ }^{118}$ Como visto nas reportagens "Sente-se. É um convite.". Casa \& Jardim. ago. 1970; “C. J. Visita... Hobjeto". Casa \& Jardim. out. 1971; entre outras.

${ }^{119}$ Entrevista concedida por Bibita (Maria Beatriz) Butcher à autora em 23 de julho de 2014.

$120 \mathrm{O}$ crescimento e distribuição das lojas da Mobilinea será analisado em maior profundidade na seção 2.2.

${ }^{121}$ Marcos Braga, ABDI: História concisa da primeira associação profissional de design do Brasil, 2007.

122 Maria Cecília Loschiavo dos Santos, op. cit.

${ }^{123}$ Fruto de desenhos que Geraldo de Barros começara a desenvolver ainda na Unilabor. Ver a esse respeito: Mauro Claro, Dissolução da Unilabor: crise e falência de uma autogestão operária-São Paulo, 1963-1967, 2012.

124 "UD - a feira que eu vi". Casa \& Jardim. maio 1967.

${ }^{125}$ Histórico das bienais de design. Disponível em: http://www.bienalbrasileiradedesign.com.br/historico. Acessado em 12/01/2015.

${ }^{126}$ Desenho Industrial 68. GAM - Galeria de Arte Moderna. n. 16, edição especial. pp. 38-50. 1968.

127 Pietro Maria Bardi, Mobiliário Brasileiro: premissas e realidade, 1971.

128 "A Arte Industrial". A Folha de São Paulo. p. 1, Ilustrada. 07 abr. 1972.

${ }^{129}$ Escritório Atual. abr. 1972.

130 "Feira". O Estado de São Paulo. p. 63, Caderno Geral. 24 jun. 1973.

131 "Canadá, um mercado a conquistar". A Folha de São Paulo. p. 4, Economia. 24 abr. 1974.

132 Ernesto Hauner, op. cit., p. 3.

${ }^{133}$ No mesmo ano, Ernesto foi também convidado a participar de uma exposição brasileira no Museu de Arte Moderna de Bruxelas e outra na Argentina, esta segunda também recusada por já estar com muitos compromissos. Georgia Hauner, Ernesto Hauner - brief resumé, 2011, p. 2.

${ }^{134}$ Organizações com a ABDI vinham tendo dificuldades em manter associados e seu corpo diretivo. Ver a esse respeito: Marcos Braga, op. cit. 
2. Design à venda 

O objetivo deste capítulo é, tendo apresentado a trajetória da Mobilinea e a maneira em que a empresa se inseriu no circuito de design, focalizar os aspectos referentes a seus produtos e a seus locais e formas de venda, a fim de somar novas camadas de interpretação ao quadro de sua trajetória geral.

A primeira aproximação nesse sentido se dará pela análise dos móveis projetados por Ernesto Hauner - sem a pretensão de apresenta-los em sua totalidade-, mas antes entendendo-os em sua dimensão material e delimitando o partido da Mobilinea frente ao design e às suas condições de produção. Se à primeira vista não parece haver tanta experimentação formal, há uma premissa de que os móveis sejam versáteis, customizáveis e produzidos de maneira racional, dando a ideia de serem peças acessíveis em todos os sentidos. Há também uma preocupação frente à concorrência e em participar das discussões no campo do design e dos avanços tecnológicos e produtivos, mais até em um nível comercial do que ideológico.

Nessa perspectiva, a aproximação seguinte discutirá o processo de venda na Mobilinea a partir de seus espaços comerciais, delineando seu funcionamento interno e expondo algumas das estratégias utilizadas para promover os ideais da empresa e visando criar um conceito de casa moderna que incluía componentes materiais e imateriais, contando com a colaboração de diversos funcionários. A partir do mapeamento dos endereços divulgados pela Mobilinea, foi possível acompanhar seu crescimento através da abertura de novas lojas e fábricas, fornecendo novos parâmetros para entender sua importância no período.

Houve experiências buscando expandir o público potencial da Mobilinea através de parcerias de diversas naturezas, a partir das quais pode-se entender outras maneiras de se posicionar no mercado e como a imagem da empresa se consolidou. Tanto nas lojas como nestas iniciativas, houve uma premissa de unir design, arte, artesanato e a ideia de uma vida culturalmente rica, assumindo um papel de protagonismo neste diálogo com a criação da Home Store em 1973. Lá, 27 empresas de design uniram-se a ela em um mesmo endereço, que de certa forma foi um grande laboratório de cenografia doméstica, exibindo móveis e complementos para toda a casa. A última aproximação proposta neste capítulo busca examinar essas empreitadas em maior profundidade. 


\subsection{O desenvolvimento dos móveis}

Em 1959, as experiências de Ernesto Hauner como designer compreendiam uma passagem pelo Studio de Arte Palma e uma participação secundária na Móveis Artesanal/Forma. Nesses anos, ele já vinha projetando peças próprias (embora não fossem aproveitadas pelas empresas) e teve uma breve passagem por Roma, onde atualizou seu repertório frente à produção italiana. Ao retornar e fundar a empresa Ernesto Hauner Decorações, começou a produzir estantes modulares em madeira maciça sem revestimentos, divulgadas em pequenas propagandas na revista Casa e Jardim e nos jornais O Estado de São Paulo e A Folha de São Paulo a partir de 1960. Pelo que se pode aferir, todas seguiam uma mesma lógica, tendo montantes com ferragens reguláveis para fixação de piso a teto, complementadas horizontalmente por módulos de prateleira, escrivaninha, gaveteiros e pequenos gabinetes. Todos os módulos tinham a mesma largura, e as alturas aparentam respeitar uma modulação rebatida na furação dos montantes [2.1.01].
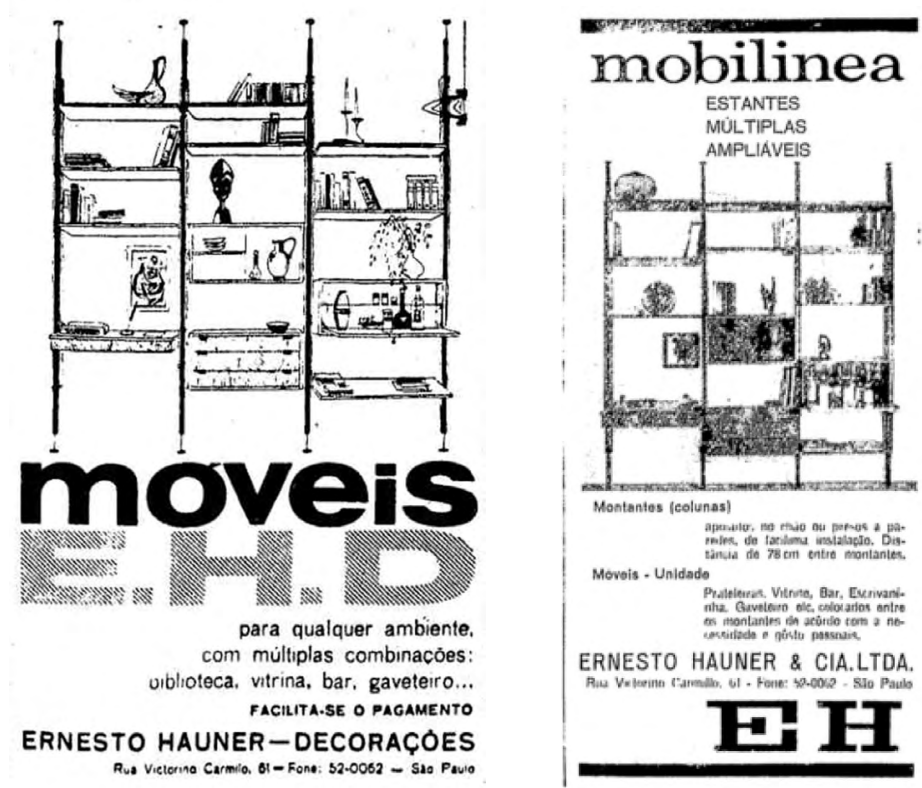

2.1.01: Propaganda Ernesto Hauner Decorações estantes E.H.D. O Estado de São Paulo. p. 132. 11 dez. 1960.

2.1.02: Propaganda Ernesto Hauner e Cia. Ltda. estantes Mobilinea. A Folha de São Paulo. p. 10, Caderno llustrada. 16 maio 1961.

Em 1961, esta linha passou a ser divulgada como "Mobilinea - estante de flexibilidade total" e os "móveis-unidade", como são descritos em suas propagandas, podiam ser comprados em diversas configurações, eram recomendados para casa e escritório e permitiam que a montagem ficasse a cargo 
2.1.03: Estante Mobilinea com montantes metálicos. "A Versatilidade das Estantes Modernas". Casa \& Jardim. p. 34. maio 1960. dos clientes. Certamente foi o sucesso dessa linha e deste nome que levaram a empresa a mudar sua razão social de Ernesto Hauner Decorações para assumir a identidade pela qual ficaria conhecida [2.1.02].

Outro sistema que aparece no mesmo período compreende montantes metálicos formando "escadinhas" que podem ser fixas na parede, complementadas por módulos em chapa de madeira maciça como os da linha "Mobilinea" [2.1.03]. Estantes como estas foram posteriormente produzidas na fábrica de Ernesto Hauner para os dormitórios do alojamento estudantil da Universidade de Brasília (UnB) sendo creditadas a Sergio Rodrigues, o que merece investigações futuras para estabelecer sua autoria ${ }^{1}$. A descrição de uma foto deste modelo, na reportagem sobre a "A Versatilidade das Estantes Modernas", publicada em Casa \& Jardim em maio de 1960², diz:

Estante composta de partes móveis e madeira e grades de ferro batido; é extraordinariamente prática e versátil, pois além de servir de suporte para livros, discos e diversos objetos de adorno, abriga um pequeno mas confortável bar, bastando aproximar-se uma cadeira da máquina de escrever para utilizá-la também como escrivaninha. (Modêlo: Ernesto Hauner) ${ }^{3}$

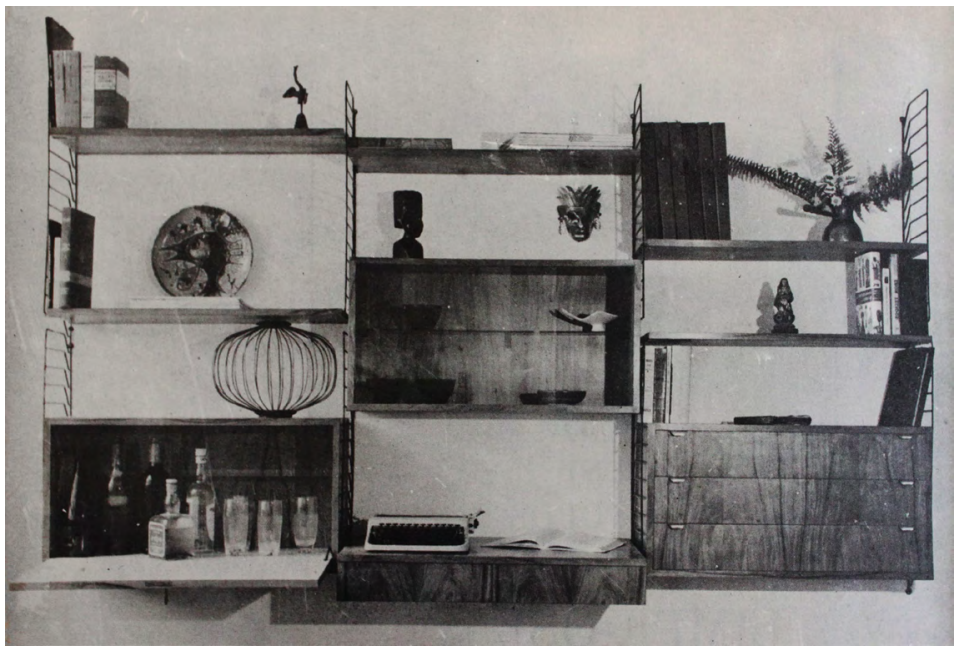

De fato, estantes modulares com diferentes soluções construtivas e formais foram sempre uma preocupação da empresa, mas nestes primeiros anos não parece ainda que tivessem rigidamente definido seu nicho de mercado e, dentre outras peças divulgadas em propagandas de jornais e revistas, a mais peculiar é indubitavelmente uma linha de carteiras escolares. Divulgada em alguns anúncios no Estado de São Paulo ao longo de 1962, a carteira é uma peça única estruturada em perfis metálicos tubulares que sustentam ao mesmo tempo cadeira e mesa, feitas em chapa de madeira. Uma alça da mesa encontra o encosto da cadeira, travando o conjunto, que é complementado ainda por apoio para pés, fechamento frontal e um compartimento para guardar materiais sob o assento. Descrita como simples e bela, o anúncio explica que são desmontáveis, resistentes e estão aguardando patente. Os motivos para 


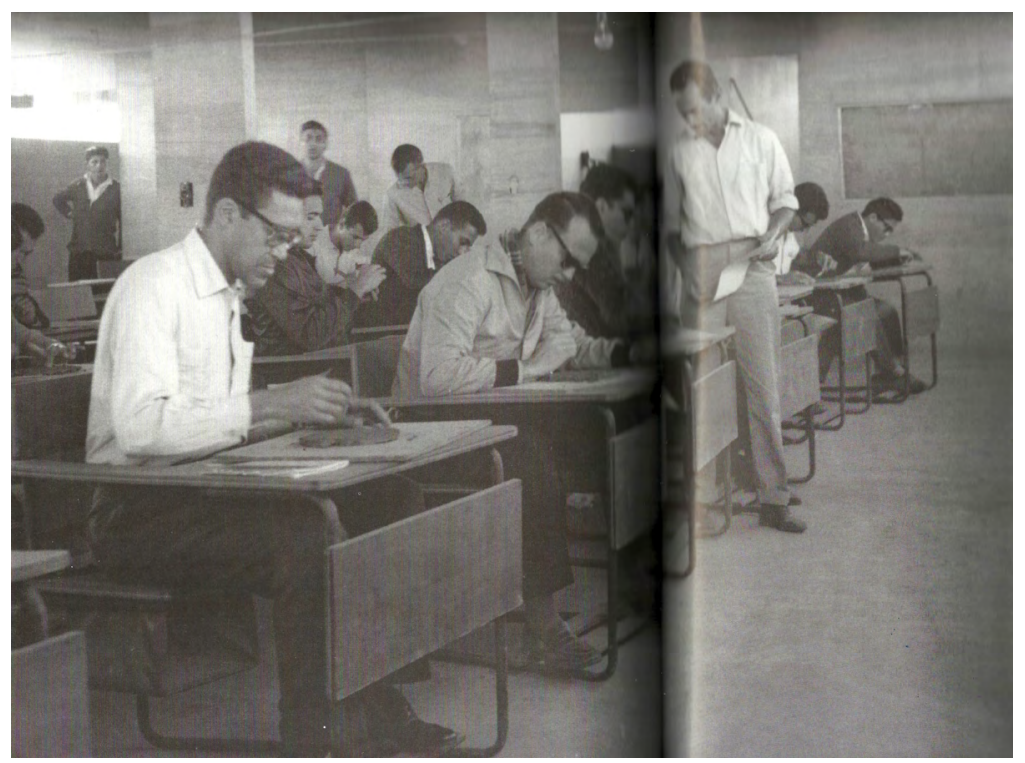

MOBILINEA CARTEIRAS ESCOLARES simplicidade

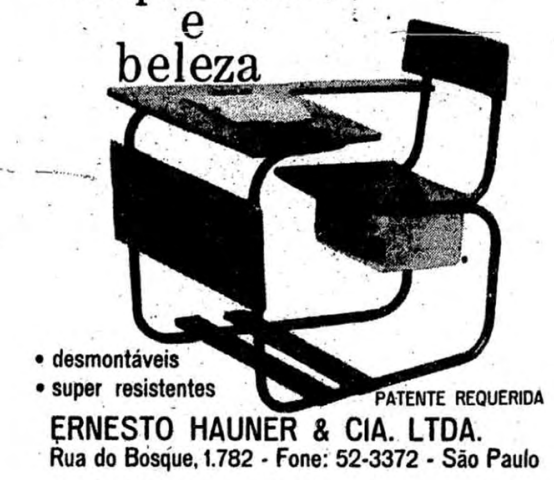

sua criação parecem ter sido efetivamente mobiliar as salas de aula da UnB, pois lá há registros de seu uso, e supomos que sua comercialização em São Paulo tenha ocorrido para acabar com estoque excedente [2.1.04-2.1.05].

Informações mais detalhadas sobre as matérias-primas dos móveis foram divulgadas pela primeira vez em uma reportagem da revista Casa \& Jardim de maio de $1964^{4}$ que apresenta um apartamento decorado pelo arquiteto Fabrício Fabriziani, no qual foram usados móveis da Mobilinea na sala de estar, em Jacarandá da Bahia com estofados em veludo cinza e azul forte, conforme descrição no texto. Embora o aspecto geral da sala seja convencional, há de se notar um desejo em utilizar móveis modernos, como os revisteiros e mesas laterais da linha Dominó, de Jorge Zalszupin [2.1.06].

No ano seguinte, Mobilinea lançou seus móveis pintados, em uma propaganda marcante pela intensidade das cores usadas ${ }^{5}$. Colorir móveis já era uma prática evidentemente conhecida, mas à época deste lançamento ainda não havia empresas produzindo peças para uso residencial com desenho moderno e nesta paleta [2.1.07]. A cadeira promovida no lançamento estava em produção ao menos desde $1963^{6}$ e fora batizada de 101 . Tem pés de madeira maciça de $2,7 \times 2,7 \mathrm{~cm}$ e travas inferiores em perfis de $1,8 \mathrm{xl}, 8 \mathrm{~cm}$; o encosto é uma barra de madeira maciça envergada e fixada diagonalmente nas travessas anteriores, o assento é de chapa de madeira recoberta com estofamento, não há encaixes aparentes e parecem não haver ferragens ${ }^{7}$. Vale notar que os demais assentos comercializados pela Mobilinea neste momento tinham estofados com revestimento em couro ou tecido e que a capa de flores bordadas vista nessa propaganda foi feita especialmente para a foto. Já a mesa que a acompanha é composta por uma cruz de perfis de madeira maciça sobre pezinhos metálicos, conectados a um pilar de madeira, que se liga a outra cruz e apoia o tampo, neste caso de mármore ou granito branco. Os perfis das cruzes de madeira

2.1.04: Sala de aula UnB. Imagem publicada no livro Mobiliário Moderno: das pequenas fábricas ao projeto da UnB (Alex Calheiros, Marcelo Mari, Priscila Rossinetti Rufinoni (org.), 2014), p. 169.

2.1.05: Propaganda Mobilinea - Carteiras Escolares. O Estado de São Paulo. p. 2. 26 abr. 1962. 
têm $3 \times 8 \mathrm{~cm}$, o tampo tem $1,8 \mathrm{~cm}$ de espessura e o perfil tubular é na verdade metálico, apenas revestido em folha de madeira ${ }^{8}$. Além da opção de tampo em pedra visto na imagem, foram também comercializadas versões em chapa de madeira compensada revestida em folha de madeira natural ou pintada, redonda ou quadrada. Complementava essa linha ainda um carrinho de chá fabricado com os mesmos perfis, e que em junho de 1968 foi divulgado em uma reportagem de Casa e Jardim ${ }^{9}$ que informava que as bandejas eram removíveis e fabricadas em Duraplac ${ }^{10}$.

O recurso a acabamentos como esses parece ter sido estimulado primeiramente por um interesse comercial em se distinguir do que outras empresas estivessem fabricando no período. Além disso, preocupações com a otimização de matérias-primas e a proteção das madeiras nobres brasileiras orientaram a opção por fabricar móveis laqueados, pois embora o uso de pintura nestes primeiros anos muitas vezes ainda fosse feito sobre peças em madeira maciça, não precisavam ser espécies tão nobres quanto as usadas nos móveis sem revestimentos ${ }^{11}$.

No mesmo ano deste lançamento, Ernesto concedeu uma entrevista à revista Arquitetura ${ }^{12}$ na qual manifestou preocupação frente à exportação desenfreada de madeiras eem não haver políticas de reflorestamento, apontando que o país deveria, ao contrário, exportar produtos acabados. Ao tratar da possibilidade de se produzir móveis de bom desenho, em larga escala e a baixo custo, respondeu que "de um modo geral é tão fácil produzir um móvel de bom desenho quanto um de mau desenho, pois o 'bom' desenho compreende, entre

2.1.06: Ambiente com móveis Mobilinea. “Um apartamento transformado pela decoração". Casa \& Jardim. p. 27. maio 1964.

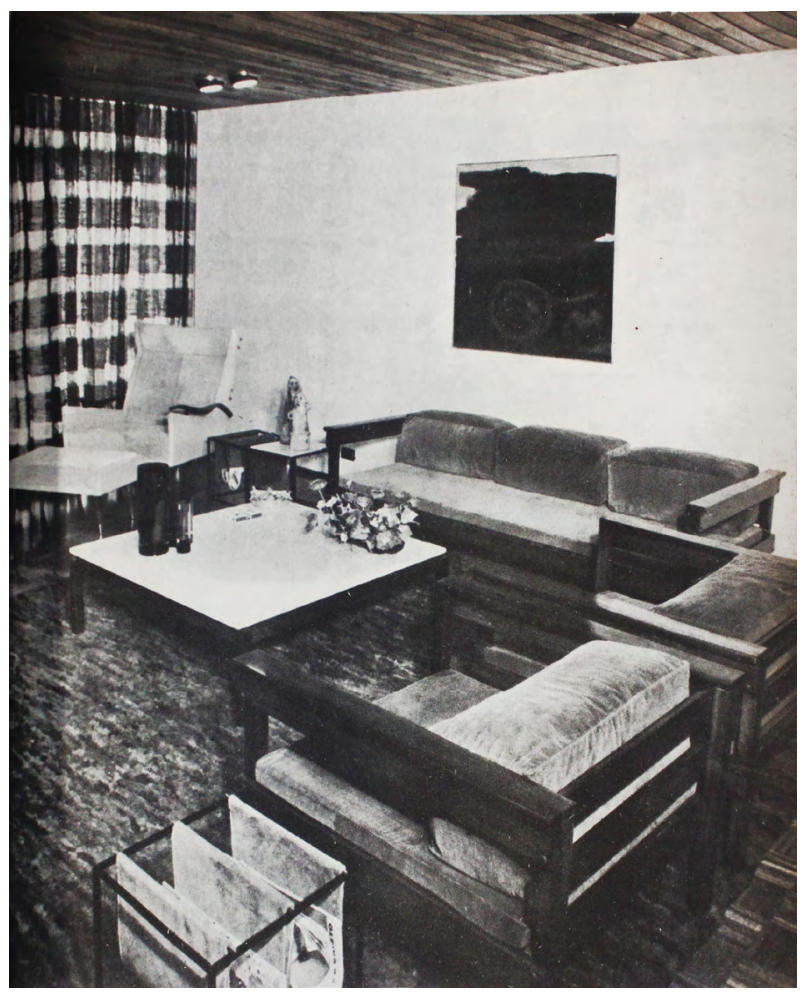




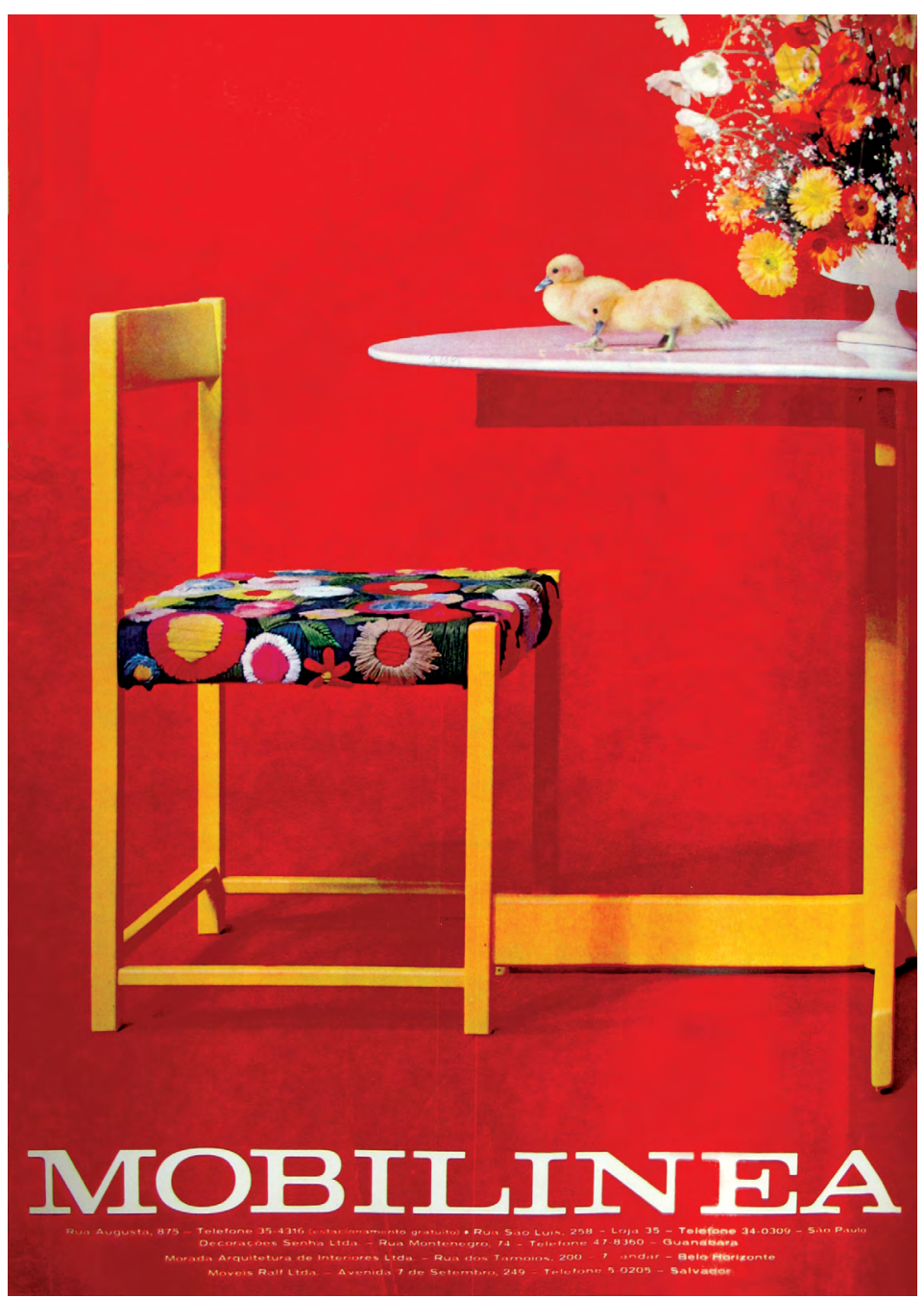

outras coisas, facilidade de produção"'3. Quanto à fabricação em si, chamou a atenção para a necessidade de garantia de demanda, de facilitação para construção ou importação de maquinário e da falta de promoção de concursos e prêmios; a questão que se impunha era justamente popularizar os processos e produtos do design:

Ainda sobre o desenho de móveis populares, vejo grandes possibilidades no fornecimento de móveis desmontados ou semi-acabados de preço reduzido, com a certeza de que o comprador que está acostumado a construir sua residência com as próprias mãos, não terá dificuldade em terminar o serviço em casa. ${ }^{14}$

Uma das estratégias da Mobilinea, ao que parece, realmente foi transferir a montagem de seus móveis aos compradores, embora a empresa tenha sempre mantido uma equipe de instalação à disposição, sendo pouco provável que os clientes fossem de uma faixa de renda que construiria a própria residência, como Ernesto declarou. Naquele momento, montar o próprio móvel parece ter sido aceito quase exclusivamente por uma pequena parcela da população, como a experiência da Mobília Contemporânea com o Peg-Lev sugere [1.3.04]. Da mesma maneira, a produção de móveis em madeiras maciças, inclusive 
em Jacarandá, não foi interrompida, mas a produção se expandiu, abrigando diversas linhas e matérias-primas.

Um novo sistema de estantes modulares foi lançado em 1966, aproximandose da aparência e montagem pela qual a produção moveleira da Mobilinea ficaria mais conhecida e se especializaria ${ }^{15}$, pois, agora, ao invés de montantes de uma altura fixa - piso a teto ou meia parede -, os próprios elementos verticais passavam a ser modulares e componíveis: através de chapas, era possível criar três alturas de móveis, compondo-os com caixas ou prateleiras e, nestas, outra novidade era poder encaixar uma chapa em suas faces posteriores, fechandoas. Como a estante era autoportante, ela poderia ficar solta no espaço e dividir ambientes, adaptando-se aos novos projetos de habitação que vinham sendo lançados, menores e com plantas livres. Aqui o desejo de que a montagem fosse feita pelos compradores é ilustrada de maneira que também apresenta a versatilidade da peça para diferentes configurações domésticas [2.1.08].

2.1.08: Propaganda Mobilinea - Uma Estante num Instante. Casa \& Jardim. jan. 1966.

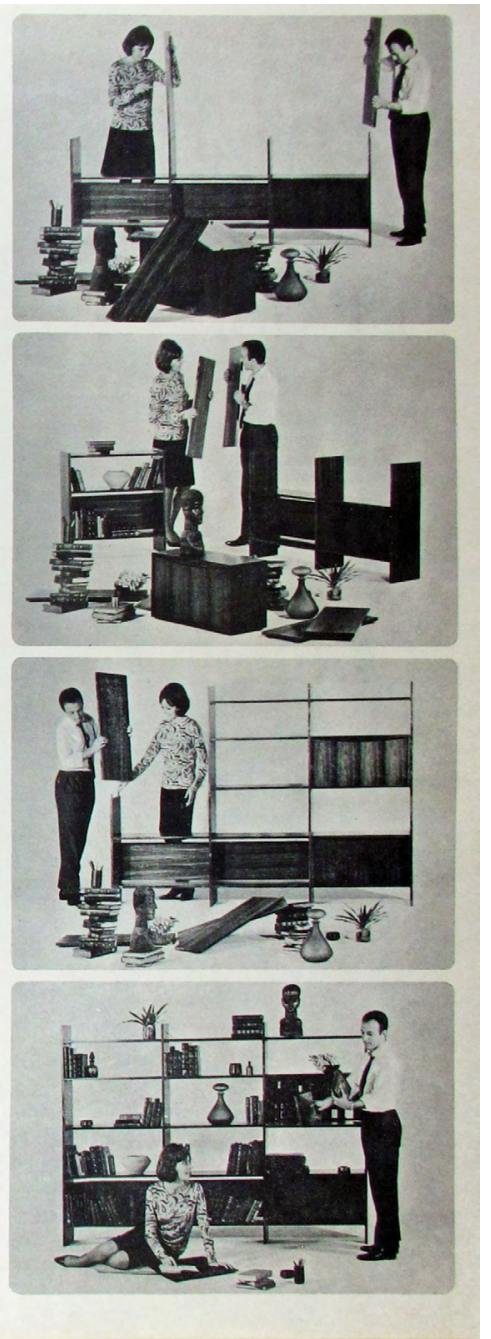

Georgia Hauner acredita que um dos grandes talentos de Ernesto tenha sido sua capacidade de desenvolver linhas completas de móveis partindo de peças únicas, e isso se manifestava em especial nas peças modulares e componíveis: 


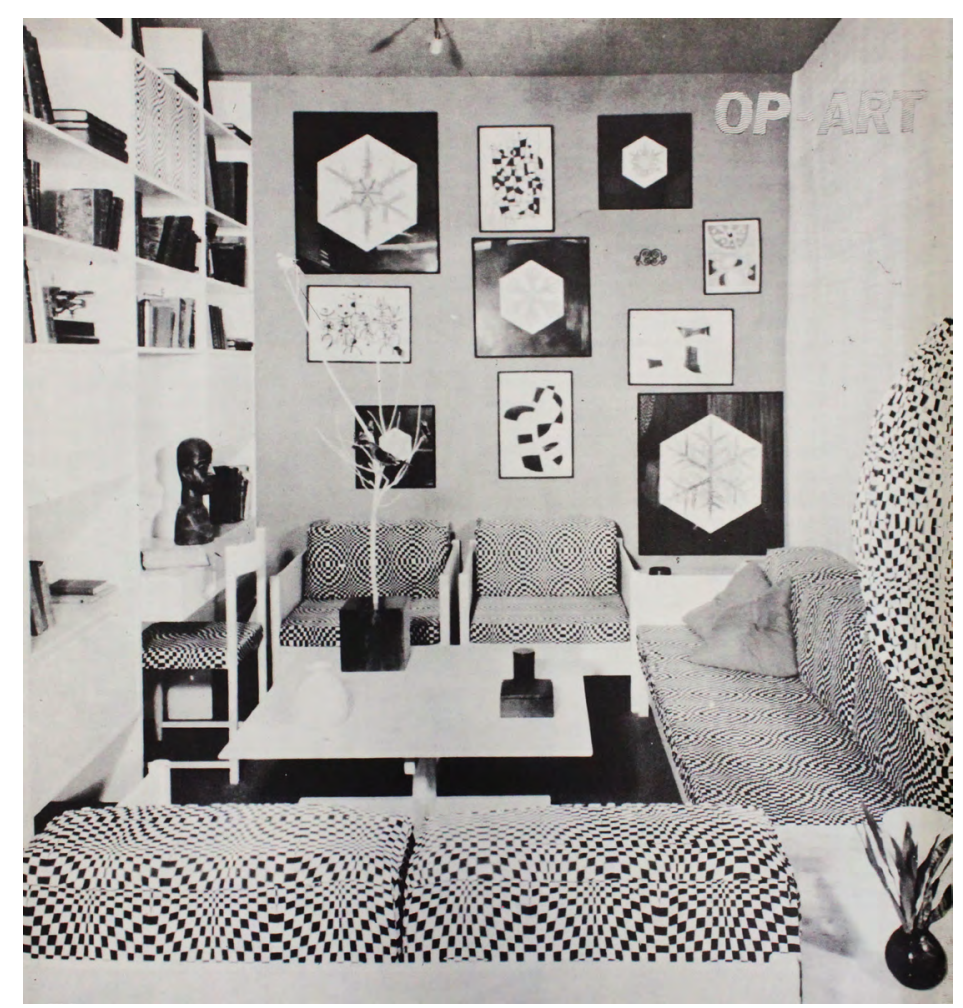

2.1.09: Ambiente com móveis Mobilinea. "Op Art". Casa \& Jardim. p. 34. jun. 1966.

Ernesto Hauner, meu marido, estabeleceu a MOBILINEA com o propósito de fabricar linhas de móveis modulados e desmontáveis, que podiam ser assemblados [sic] em conjuntos, para permitir o alongamento das peças e evitar a aparência fragmentada dos móveis avulsos, com brechas deselegantes entre um e outro. Um exemplo são as estantes moduladas. A repetição das peças básicas torna a produção em quantidade mais econômica, e conduz ao sistema de linhas de montagem industrial. Ernesto sempre acreditou na produção em grande escala, para reduzir os custos, sem precisar sacrificar o design, nem a qualidade. O sistema oferece muita flexibilidade para mobiliar interiores de vários tamanhos, e torna a necessidade para os móveis feitos sob medida obsoleta. ${ }^{16}$

Embora este novo sistema de estantes predomine nas propagandas da empresa do período, o sistema "Mobilinea" ainda é visto em editoriais, em cores variadas. Poltronas e sofás em ripas de madeira também continuavam em produção, acompanhados por outra linha feita em chapas de madeira que pode ser vista pela primeira vez em um editorial para Casa \& Jardim de junho de $1966^{17}$, na qual anunciavam que as capas dos estofados tinham zíperes e eram removíveis, podendo ser lavadas e trocadas. Na matéria, foi feita uma interpretação bastante reduzida do Op Art, mas que demonstrava um desejo de incluir arte e moda na decoração, com ferramentas para que as peças pudessem ser ao mesmo tempo transitórias e permanentes, driblando obsolescências [2.1.09].

Nos anos seguintes, foram desenvolvidas camas, criados, bancos, mesas e mesinhas seguindo as mesmas premissas de projeto e acabamento; havia peças em madeira maciça aparente, nas opções Jacarandá e Amendoim, além de opções de pintura em 15 cores $^{18}$. Um banco ripado que aparece em comprimentos diversos em diversas propagandas e editoriais parece fazer sucesso, provavelmente funcionando como outra opção de divisão de ambientes 
2.1.10: Banco Ripado. Imagem de slide. Sem data. Acervo pessoal de Georgia Hauner.
[2.1.10], função que também exerciam os carrinhos de chá, quando não usados como substitutos para buffets em ambientes de jantar. Para complementar os ambientes da Mobilinea em lojas e nas casas de clientes, eram fabricadas luminárias com base em madeira, espelhos e pequenos aparadores.

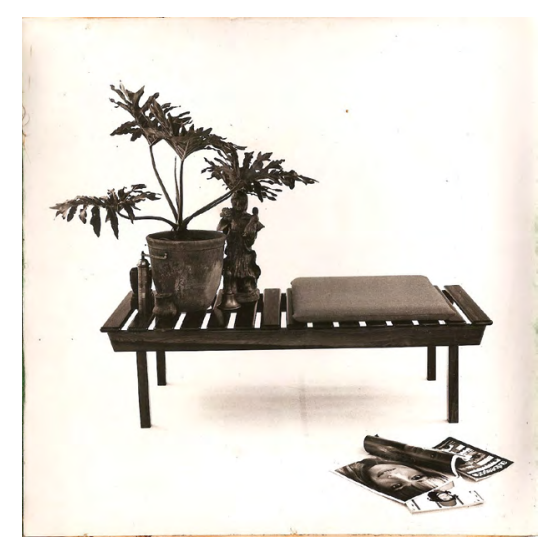

Na segunda metade da década de 1960, Mobilinea começou a realizar diversas parcerias, das quais algumas resultaram em móveis produzidos e comercializados na empresa. Em uma reportagem da revista Joia, de fevereiro de $1967^{19}$, e em uma grande quantidade de publicações subsequentes, aparecem móveis Thonet, então fabricados pelas indústrias Gerdau, pintados e vendidos como peças da Mobilinea [2.1.11]. Georgia Hauner afirmou que era sabido pelos clientes que os móveis não eram produzidos pela Mobilinea, mas que:

Sempre gostamos da Thonet, que começou da Áustria, e essa madeira curva tem uma graça e um espírito que se mistura muito bem com os móveis de linhas retas, móveis modernos. Então eram compradas as peças da Gerdau e eram coloridas junto com os móveis da Mobilinea e vendidos em conjunto. ${ }^{20}$

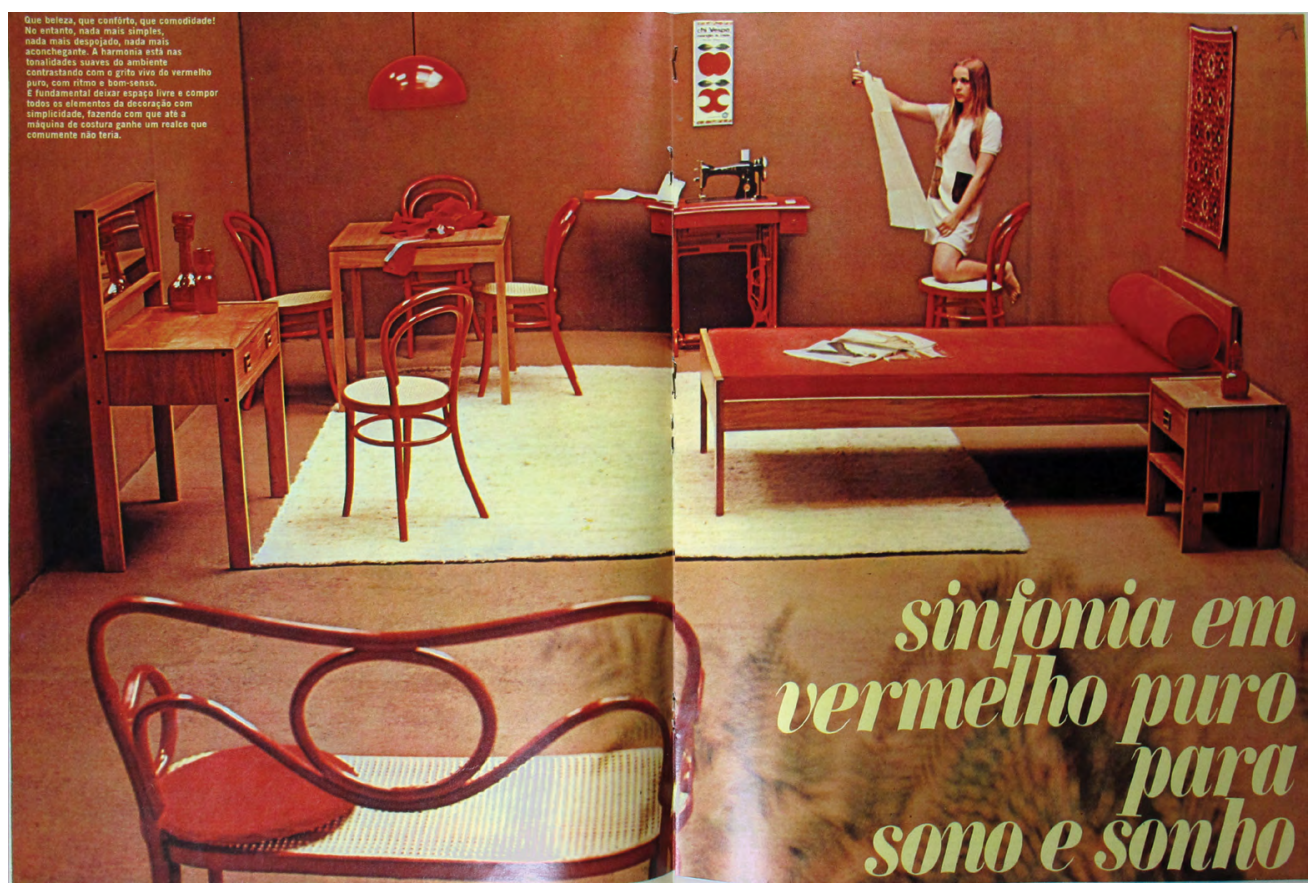

2.1.11: Ambiente com móveis Mobilinea. "Sinfonia em Vermelho". Joia. pp. 82-83. jul. 1969. 
A cadeira Series 7, de Arne Jacobsen, fabricada pela Probjeto e comercializada no Brasil com o nome de Dinamarquesa, também foi vendida na Mobilinea em diversas cores [2.1.12]. Com assento em madeira compensada e pés em estrutura tubular de aço, ela era pintada na Mobilinea e foi divulgada pela primeira vez em dezembro de 1968 em Claudia Decoração ${ }^{21}$, mas iria aparecer com mais frequência somente nos anos 1970, em especial nas propagandas das linhas de escritórios. No caso desta peça, a produção pela Probjeto era sempre anunciada, provavelmente como parte do acordo comercial entre as duas empresas.

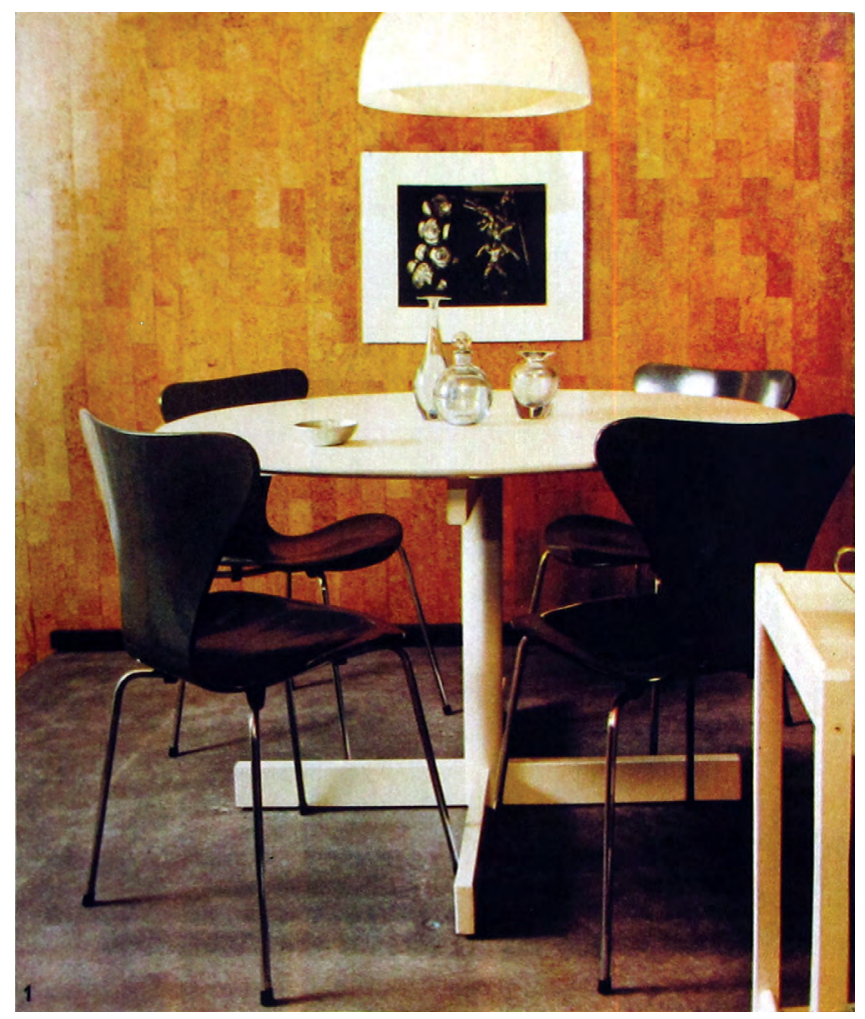

A Editora Abril também realizou algumas parcerias com empresas de design e, em setembro de $1969^{22}$, Claudia lançou uma linha de móveis infantis com a Mobilinea, batizada de Mobilinha Claudia, vendida nas lojas da empresa. Não foi possível esclarecer quais as condições para seu advento, salvo por uma carta assinada pelo então editor da Abril, Luiz Carta, para Ernesto Hauner, pedindo desculpas por desmarcar uma reunião, mas afirmando interesse na produção de "Móveis Infantis"23, o que sugere que foi Ernesto quem os procurou, provavelmente a partir dos contatos de Georgia como editora de decoração em Claudia [2.1.13]. Essa era uma área que a Mobilinea ainda não havia explorado e, como as revistas indicam, o quarto infantil vinha ganhando foco crescente na virada para os anos 1970, seja por mudanças culturais ou pelo próprio desenvolvimento do campo produtivo de móveis, que permitiu neste momento o surgimento de empresas especializadas no segmento.
2.1.12: Ambiente de jantar Mobilinea com cadeiras Dinamarquesa.

"As pequenas salas de jantar". Claudia Decoração. p. 14. jul. 1971. 
2.1.13: Carta de Luiz Carta a Ernesto Hauner de 22 de janeiro de 1969. Acervo pessoal de Georgia Hauner.

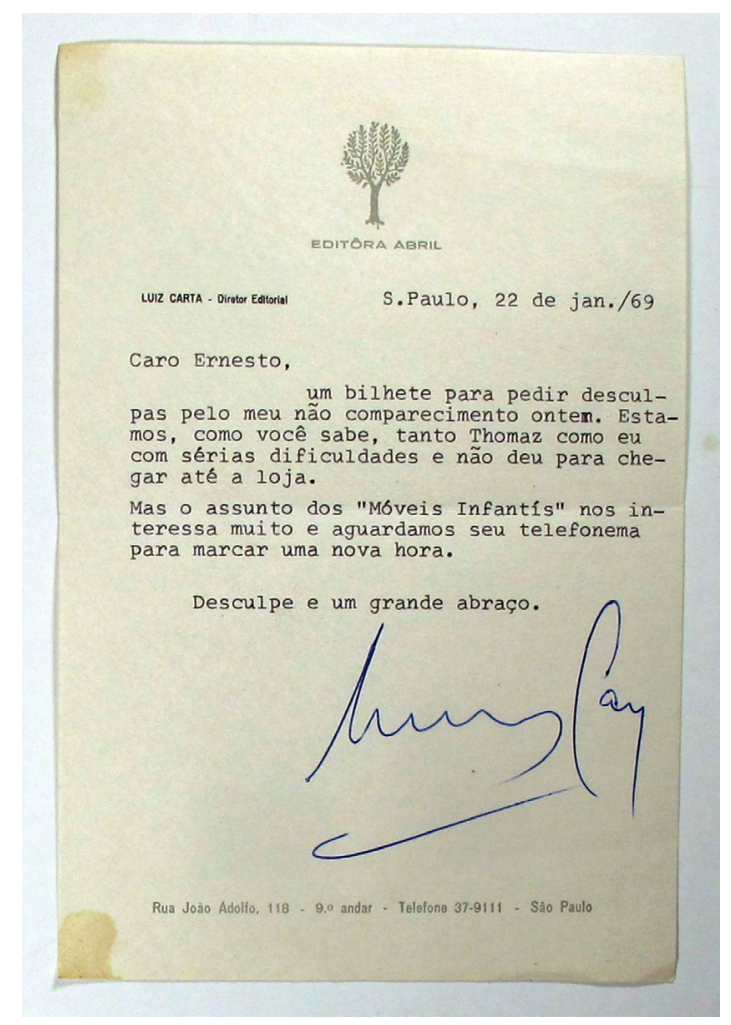

A ideia da Mobilinea com a Mobilinha era oferecer móveis baratos, alegres e versáteis também para o quarto infantil, que pudessem ser ao mesmo tempo funcionais e lúdicos, como é evidenciado em sua apresentação:

Na certa, você já andou pela cidade procurando um berço para seus filhos. Um berço que, quando êles crescessem, não ficasse jogado, ocupando um espaço inútil dentro de casa. Vai ver que você também procurou uma cadeirinha para êles. Onde êles se sentassem com toda a dignidade, com os pés no chão, feito gente grande. $\mathrm{Na}$ certa não encontrou nada que não fôsse convencional. Nada que resistisse a suas brincadeiras. Nada que fôsse assim como são os móveis do tempo em que êles estão sendo criados. Foi por isso que Ernesto Hauner criou para Claudia uma linha de móveis infantis. Móveis alegres, coloridos, sólidos. Os móveis infantis de Claudia são construídos em Duraplac, laqueados nas côres mais vivas. São ultra-resistentes e viram mil e uma coisas nas mãos das crianças. Os móveis vêm desmontados dentro de caixas de papelão, com porcas, arruelas e parafusos. Qualquer criança que saiba manejar uma chave de fenda poderá montar seus próprios móveis, empilhar cadeirinhas para formar estantes, caixas, formar o que quiser. Tôdas as peças já vêm preparadas com furos e pininhos que se encaixam para assegurar a mais perfeita estabilidade. A peça mais versátil é a cadeirinha: ela poderá transformar-se em mesinha, em banqueta, em estante, num vagão, num trem... ${ }^{24}$

As peças são apresentadas neste editorial e em propagandas subsequentes em configurações variadas, como o berço que vira sofá e o módulo que é uma cadeira, mas também mesa, estante e baú, além de parte de brincadeiras. A própria caixa na qual os móveis vinham (menos berço e mesinha redonda) era padronizada e tinha um desenho que podia ser recortado e virava um boneco, feito por Yone Koseki Pierre, que a esta altura trabalhava como projetista assistente de Ernesto Hauner. Complementos como rodízios e travas também eram vendidos separadamente. 
Os móveis eram inteiramente feitos em chapa de fibra de madeira Duraplac, o que devia baratear o custo de produção e exigia pintura para bom acabamento, anunciada em oito cores: branco, amarelo claro, amarelo ouro, vermelho, azul claro, azul escuro, verde limão e laranja [2.1.14-2-1-16].
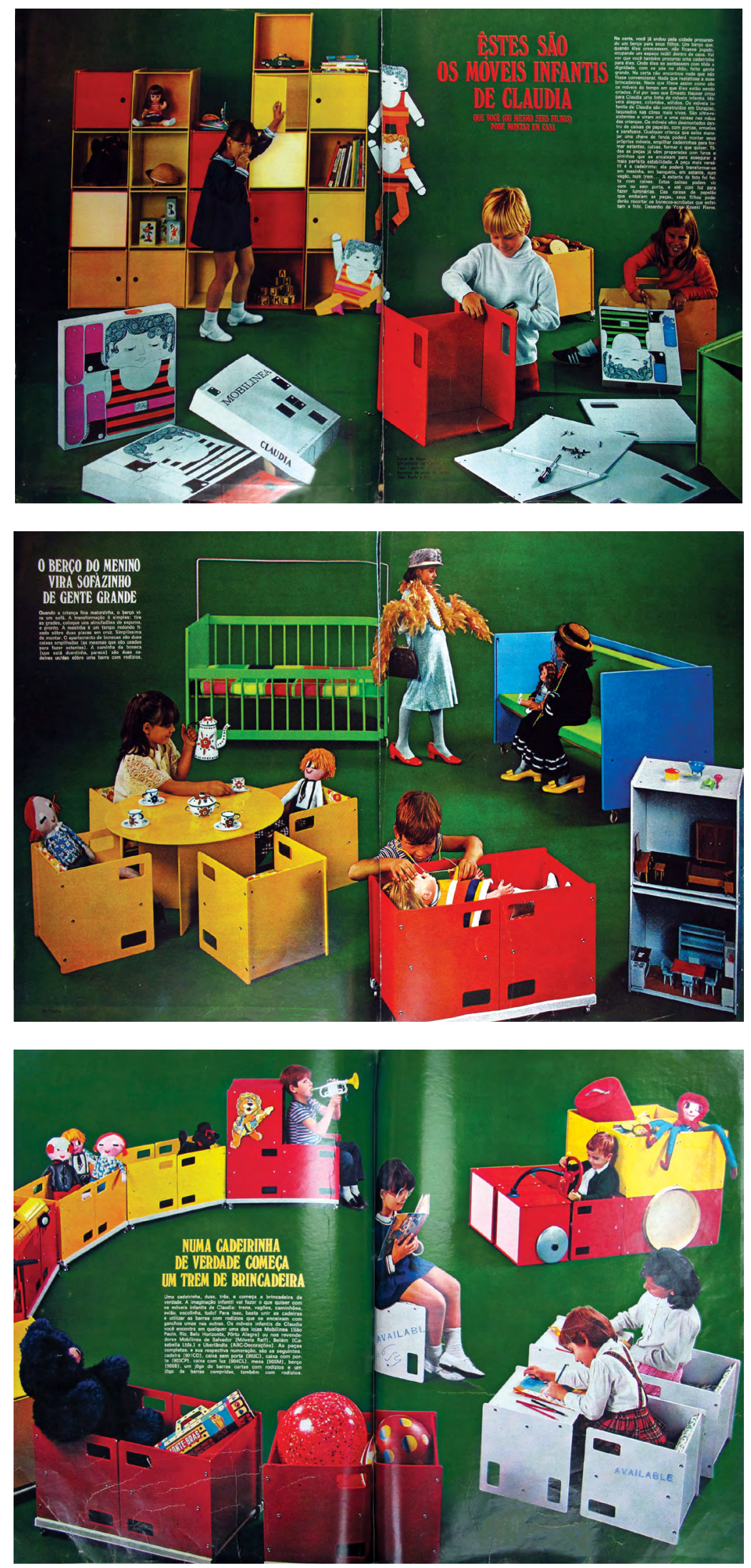

2.1.14: Mobilinha. "Móveis Infantis" - embalagem e módulo de caixa como estante e cadeira. Claudia pp. 144-145. set. 1969.

2.1.15: Mobilinha. "Móveis Infantis" - berço, mesa e módulo de caixa como cadeira, bercinho e casinha de bonecas. Claudia. pp. 146-147. set. 1969.

2.1.16: Mobilinha. "Móveis Infantis" - módulo de caixa como cadeira, mesinha, trem e carrinho. Claudia. pp. 148-149. set. 1969. 
Um ano antes, Ernesto Hauner desenvolvera a poltrona premiada na I Bienal Internacional de Desenho Industrial do Rio de Janeiro de 1968, recebedora do Certificado de Boa Forma do Prêmio Roberto Simonsen. É descrita pela revista GAM - Galeria de Arte Moderna, em edição especial para a bienal, da seguinte forma: "estrutura desmontável para armazenagem e transporte, dispensa mãode-obra especializada e pode ser entregue ao comprador em forma de kit. Almofadas de espuma com capas removíveis e assento sôbre molas"25 [1.3.06]. Estas molas são "tiras" recobertas por uma capa de plástico e ficam tensionadas paralelamente ao assento, e foram utilizadas também em sofás produzidos posteriormente pela empresa ${ }^{26}$ [2.1.17].

2.1.17: Detalhe do sistema de molas de sofá Mobilinea de Adélia Pasta (revestimento em plástico estourado em alguns pontos; peça produzida c. 1970). Fotografia de acervo pessoal, 2014.

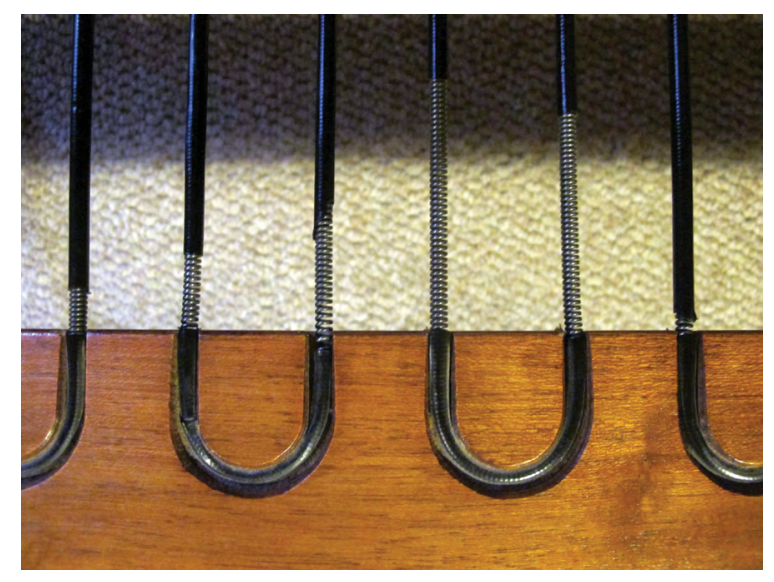

Em julho de 1970, Mobilinea lançou uma linha em aço cromado, fiberglass, acrílico e poliéster, que foi a mais distante de qualquer identidade regional vinculada à sua aparência, matérias-primas ou fabricação, e surgiu como outra alternativa às madeiras de Lei e em consonância com a produção estrangeira do período. A primeira vez que foi publicada em revistas inaugurou o projeto "C. J. Visita", de Casa e Jardim, em editorial exclusivo de dez páginas e capa ${ }^{27}$.

As peças apresentadas eram uma cadeira com pés tubulares em aço, assento e encosto em fiberglass com o mesmo desenho da cadeira em madeira; mesa composta por quatro perfis metálicos dobrados em $C$, cujas travessas horizontais apoiam tampo e encontram piso; carrinho de chá com dois perfis em $C$ cortados no sentido inverso aos da mesa, e travessas horizontais apoiando bandejas. Em todos os casos, as superfícies são em madeira aglomerada revestida com pintura em poliéster. Há também uma poltrona feita com perfis de aço e almofadas em espuma que se encaixam na estrutura, e grandes luminárias de piso com base em madeira laqueada e cúpulas de vidro [2.1.18-2.1.19].

Embora materiais como fiberglass impliquem em processos tecnologicamente mais complexos do que o corte e encaixe de chapas de madeira, Ernesto Hauner não mudou a linguagem de suas peças para estruturas polimórficas como outros designers vinham fazendo com o material (a exemplo 


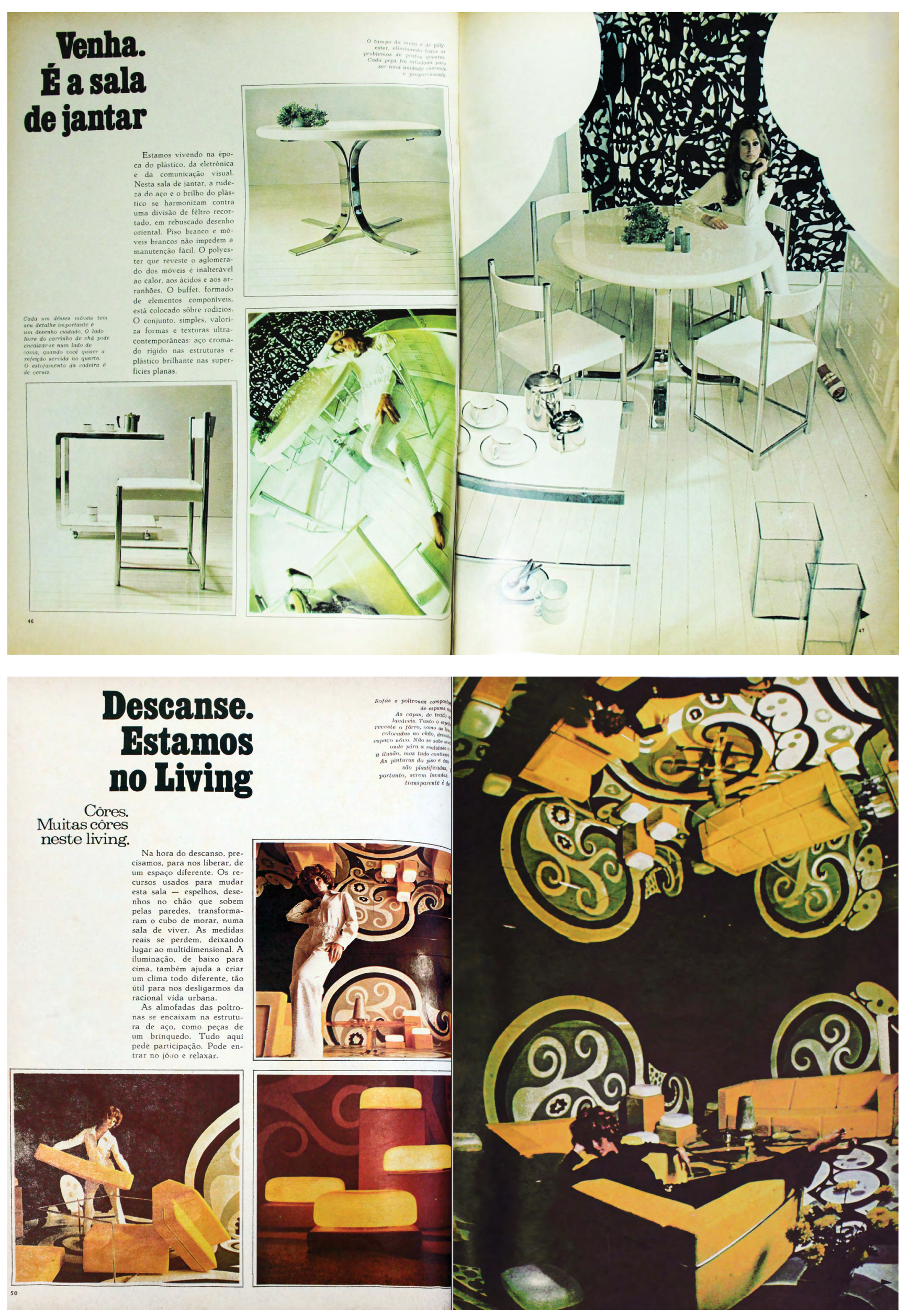


das cadeiras Tulipa, de 1958, ou Panton, de 1967, de Eero Saarinen e Verner Panton, respectivamente). Esta linha não parece assim ter sido uma ruptura em relação aos projetos anteriores, mas atesta um desejo de explorar novos materiais; surgem detalhes anatômicos nas peças graças às possibilidades de molde, porém permanece um diálogo claro com a estética das outras linhas.

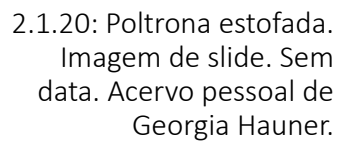

2.1.18: Móveis para sala de jantar (foto tirada na loja do Shopping Iguatemi). "C. J. Visita... Mobilinea". Casa \& Jardim. p. 47. jul. 1970.

2.1.19: Móveis para sala de estar (foto tirada na loja do Shopping Iguatemi). "C. J. Visita... Mobilinea". Casa \& Jardim. p. 51. jul. 1970.

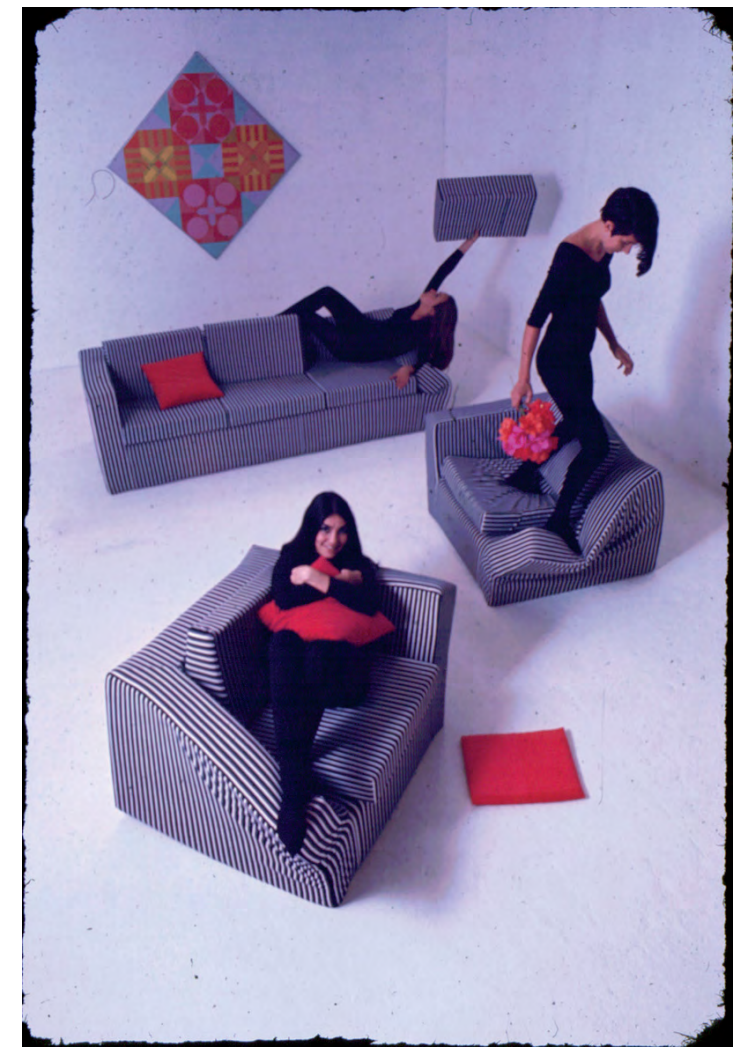

Experimentações e aprimoramentos nos móveis desenvolvidos pela Mobilinea podem ser identificados por lançamentos de peças similares em curtos intervalos de tempo: um ano antes deste editorial, uma poltrona estofada sem o chassi metálico havia sido divulgada e já deixara de aparecer ${ }^{28}$, percebendo que era preciso uma estrutura mais rígida para que o assento não se deformasse com o uso ${ }^{29}$ [2.1.20], corrigida no novo modelo [2.1.19].

A cadeira presente nesse "C. J. Visita" também foi reformulada e reapresentada alguns meses depois com barras de aço moldado, incorporando o encosto como parte da estrutura. Foi esta nova versão que participou da exposição no MASP “Mobiliário Brasileiro: premissas e realidade” em 1971 e ganhou o primeiro prêmio na II Bienal Internacional de Desenho Industrial do Rio de Janeiro ainda em 1970 [1.2.05]. Também desta linha, porém provavelmente desenvolvida posteriormente, é uma mesinha de centro quadrada com o pé centralizado aflorando no tampo [2.1.21].

Sobre a pesquisa e uso de novos materiais, Ernesto afirmou em uma entrevista concedida à revista Projeto e Construção em janeiro de $1971^{30}$, que o 


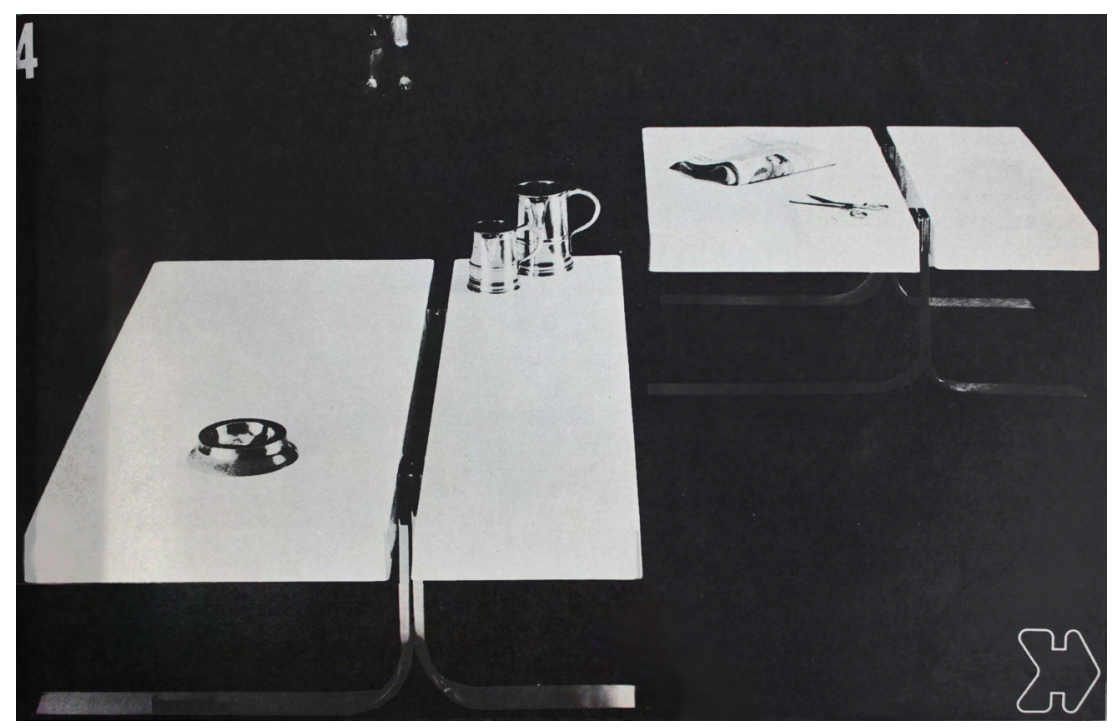

2.1.21: Mesa de centro em aço e madeira com pintura em poliéster. "Uma questão de bom design". Casa \& Jardim. p. 111. fev. 1973.

plástico era um material interessante para se trabalhar por oferecer "contrôle mais científico" dos processos, ainda que a madeira permanecesse vantajosa em termos econômicos, e declarou:

\begin{abstract}
Estamos atravessando uma fase difícil, porém fascinante, na pesquisa de novas matérias primas. O plástico, nas suas várias composições químicas, surge com qualidades de material digno de uma expressão própria, após ter sido desprestigiado e associado com limitações vulgares e de mau gôsto em geral. Até que enfim estamos livres de preconceitos e fórmulas rígidas que nos obrigavam a disfarçar encaixes e esconder parafusos. ${ }^{31}$
\end{abstract}

Novamente há de se pensar que a pesquisa para o lançamento de novos móveis e em novos materiais tinha uma dimensão comercial de criar diferenciais no mercado e, para Judit Magyary, o desejo de desenvolver estas peças não vinha precisamente de uma demanda local, mas do cenário do design em uma escala mais ampliada:

Era porque eles eram inovadores mesmo, porque eles eram criadores, tanto Georgia como Ernesto. Então a moda, a tendência mundial ia mudando, e a Mobilinea estava sempre à frente. Mesmo esse negócio de móvel pintado, no Brasil no começo foram só eles [...]. Aquelas mesas que tem aquela menina sentada, aquilo era aglomerado pintado com poliéster, mas eram várias demãos, era quase como uma laca chinesa o processo daquela pintura. Tinha câmara de pintura, com água no fundo e tudo, porque era um negócio muito sério. ${ }^{32}$

Não obstante, Bibita Butcher lembrou-se que durante sua experiência como gerente da loja da Mobilinea no Shopping Iguatemi, percebeu que o tampo riscava com facilidade, fazendo do móvel uma peça bonita, mas delicada ${ }^{33}$, denotando as dificuldades de experimentar tecnologias diferentes.

Em maio de 1971, Casa \& Jardim apresentou um perfil de Ernesto Hauner e da Mobilinea, que é interessante especialmente por trazer uma tabela com todos os materiais e acabamento que a empresa trabalhava naquele momento, além do aço e fiberglass ${ }^{34}$ : 
1) Materiais empregados na execução:

a) Aglomerado

b) Madeira maciça

c) Fôlhas (jacarandá e amendoim)

2) Acabamentos:

a) Pintura poliéster

b) Pintura poliuretano

c) Verniz sôbre as fôlhas

3) Peças da estante:

a) Montantes em várias alturas

b) Prateleiras de amarração

c) Fundos

d) Portas

e) Gavetas

f) Prateleiras

g) Acessórios

4) Características:

a) Montagem e desmontagem executáveis pelo cliente

b) Estante componível

c) Transporte facilitado pela não existência de grandes volumes.

d) Processo industrial na fabricação das peças, decorrendo disso maior precisão e menor custo.

e) Utilização múltipla, tanto em residências como em ambientes coletivos. ${ }^{35}$

Vemos o uso de chapa de madeira aglomerada tanto com revestimento em folha de madeira natural como pintada, além da permanência das madeiras maciças. É dado grande destaque aos sistemas de estantes modulares, reforçando serem componíveis, desmontáveis e adaptáveis para espaços residenciais ou corporativos.

Em julho deste mesmo ano, Mobilinea participou mais uma vez da seção “C. J. Visita” em Casa \& Jardim ${ }^{36}$, desta vez lançando a linha Prêt-à-Porter, desenvolvida por Ernesto Hauner com o auxílio de Yone Koseki Pierre, e retomando suas preocupações em produzir peças mais simples e acessíveis, em chapa de madeira recortada pintada ou folhada [1.2.07-1.2.10]. Já havia alguma divulgação da linha, mas aqui era oficializado que passavam a ser entregues de um dia pro outro, o que implicava em um rigor nas suas modulações, bem como no sistema de construção e encaixes. As ferragens tipo "pino e tambor"37 à mostra eram tomadas como um atrativo, tendo sido desenvolvidas na própria fábrica por Plínio de Cerqueira Leite e fabricadas em uma empresa terceirizada $^{38}$ [2.1.22]. A pintura era em poliuretano e as capas das almofadas eram de poliéster, sempre com zíperes. O puxador das portas de armários e gavetas fora desenvolvido por Ernesto e já vinha sendo divulgado havia pelo menos dois anos, mas se notabilizou nesta linha [2.1.23].

Nela, há estantes, armários, buffets, carrinho de chá, cadeiras, poltronas, sofás, mesas de jantar redonda e retangular, mesas laterais, bancos e banquetas, cama de casal, cama de solteiro simples e com bicama, espelho, cabeceira para casal e solteiro, criado-mudo e cômodas. A cadeira divulgada é bastante 

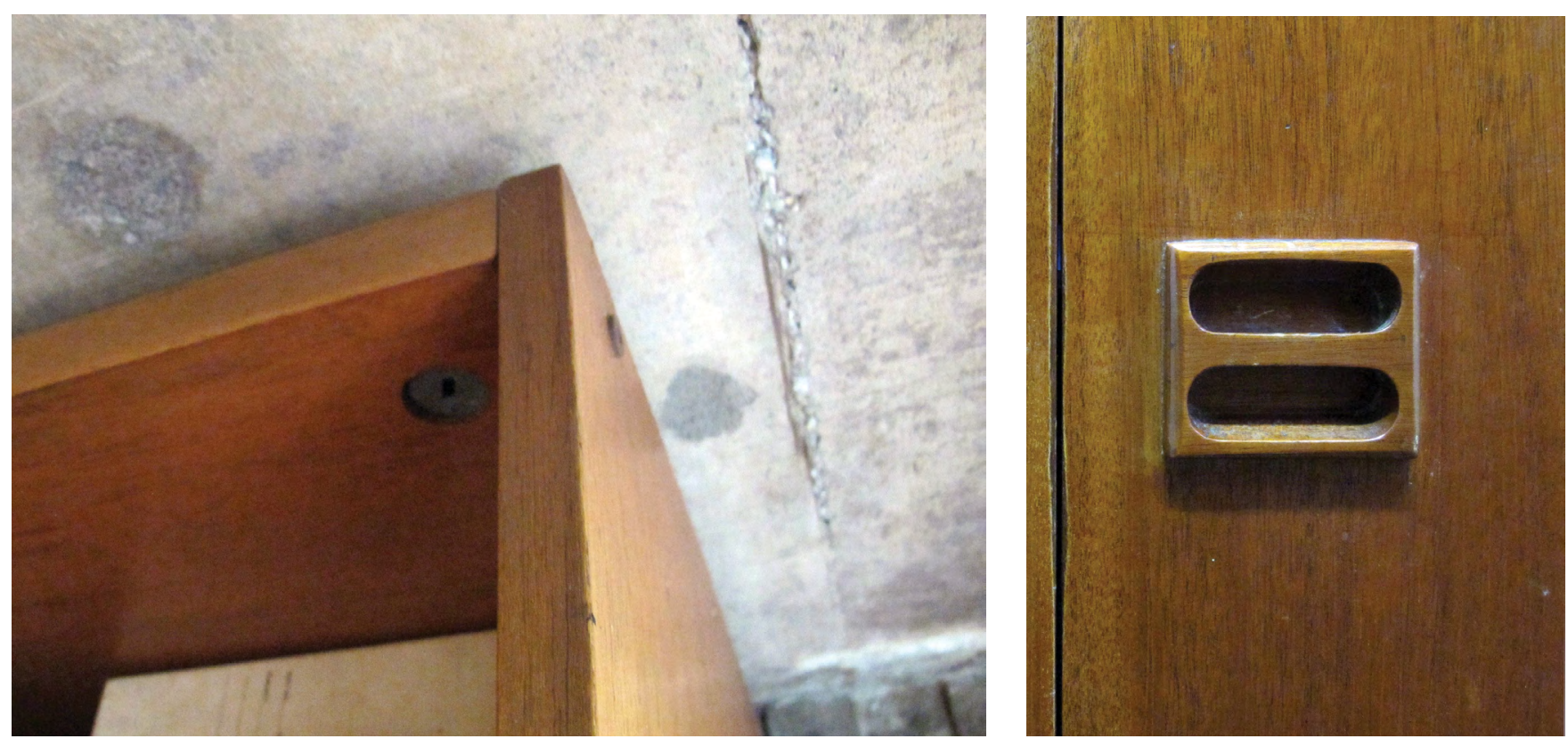

semelhante ao modelo 101, mas os perfis passaram a ser roliços e o encosto em madeira compensada moldada.

Em catálogo localizado no acervo pessoal de Georgia Hauner ${ }^{39}$ foram encontradas as dimensões do sistema de estantes: os montantes têm $18 \mathrm{~mm}$ de espessura e eram disponíveis em alturas subdivisíveis e modulares entre $63,2 \mathrm{~cm}$ e $268 \mathrm{~cm}$, sendo a altura mais comum, $216,8 \mathrm{~cm}$; em todos os casos, a profundidade dos móveis é de $43 \mathrm{~cm}$ e, dentre as estantes desta linha localizadas para levantamento, aferimos que a modulação da furação para encaixe dos módulos era de aproximadamente $12,5 \mathrm{~cm}$. Como complementos, eram oferecidas prateleiras e meias prateleiras, corrediças para pasta suspensa, gaveteiros, portas e fundos, cabideiros e sapateiras [2.1.24]. Na maioria das propagandas e editoriais que divulgam esta linha, os móveis estão laqueados em branco, mas há peças coloridas, inclusive com mais de uma cor no mesmo móvel [2.1.25].

Em janeiro de 1972, o jornal A Folha de São Paulo publicou uma matéria sobre uma mudança na legislação nacional que proibia a saída de madeiras maciças do Mato Grosso ${ }^{40}$ e, para avaliar o impacto da medida na indústria moveleira, conversou com um representante da Móveis Bergamo, um da Willo e Plínio de Cerqueira Leite, representando a Mobilinea. Este último disse que a empresa estava considerando comprar mogno da Amazônia, mas que usavam também madeira aglomerada laqueada com tinta poliuretano, além de folhas de madeira natural de Jacarandá, Amendoim e Mogno, compradas em São Paulo. Georgia Hauner lembrou-se de que Ernesto comprava madeiras em uma empresa chamada Masul ${ }^{41}$, em São Paulo, e que portanto eles não tinham acesso direto às madeireiras ${ }^{42}$, de forma que o impacto dessa situação teria sido sentido apenas enquanto reflexo na mudança de fornecedores terceirizados.
2.1.22: Detalhe do sistema de pino e tambor de estante modular Mobilinea de Adélia Pasta (c. 1970). Fotografia de acervo pessoal, 2014.

2.1.23: Detalhe do puxador de aparador modular Mobilinea de Nelson Graubart (c. 1971). Fotografia de acervo pessoal, 2014 

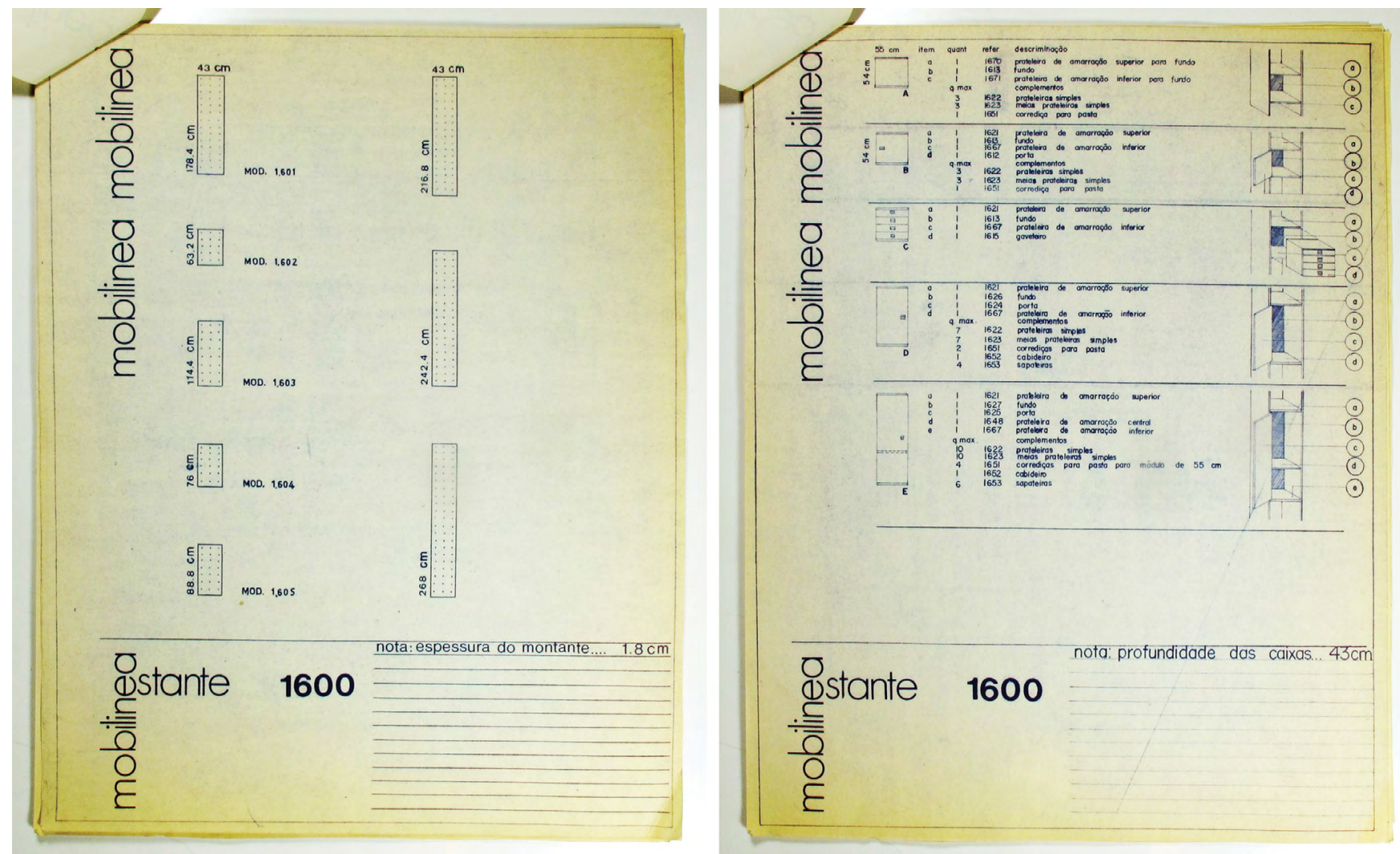

2.1.24: Páginas do catálogo "Mobilinea estante 1600". Sem data. Acervo pessoal de Georgia Hauner.
Já a referência feita por Cerqueira Leite ao Mogno não se reflete em nenhuma imagem ou descrição de peças da Mobilinea, de forma que pode-se supor que não se concretizou.

Por fim, foi lançada no início dos anos 1970 uma versão dos móveis da Mobilinea fabricados em uma madeira chamada "Magnólia". Sendo uma espécie pouco comum no Brasil e tradicionalmente não utilizada no setor moveleiro, esta nomenclatura devia dizer respeito somente à tonalidade do material, semelhante ao Pinho; conforme atestam as propagandas, ela podia ser tingida, criando peças coloridas, mas onde ainda se viam os veios da madeira. A Magnólia foi oferecida como opção na linha Prêt-à-Porter, mas em publicações foi localizada apenas na cor natural, como no apartamento de veraneio dos Hauner no Guarujá, publicado em A Casa Claudia de agosto de $1974^{43}[2.1 .26 ; 3.2 .17-3.2 .20]$.

A linha Prêt-à-Porter foi a mais divulgada nas propagandas da Mobilinea no início da década, mas móveis com outras linguagens também foram lançados. Dentre os que iriam explorar novos materiais estava uma cadeira para escritório e residência selecionada para a III Bienal Internacional de Desenho Industrial do Rio de Janeiro em 1972, com pés em aço nas versões fixa, sobre rodízios ${ }^{44}$ e com mesinha escolar. Os assentos tinham a cor incorporada à massa e foram moldados nas indústrias Aliberti ${ }^{45}$ [2.1.27].

Houve ainda duas mesas que quase não foram divulgadas em propagandas, mas apareceram com frequência em imagens da Home Store (portanto 


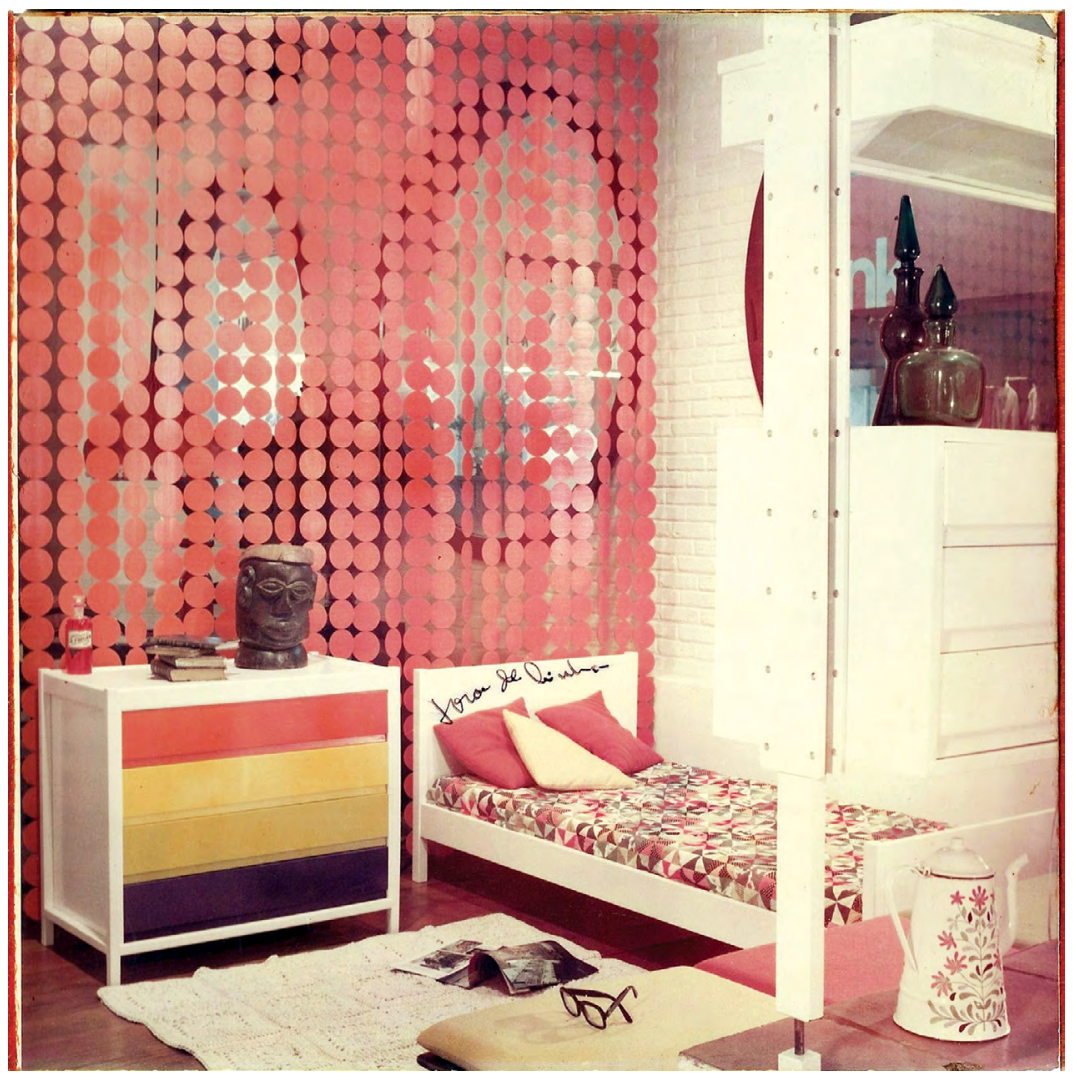

produzidas entre 1973 e 1975): a primeira era composta por quatro módulos, aparentemente com pés metálicos e tampos em fiberglass. O centro da mesa era vazado e nele se acomodava uma pequena árvore, podendo ser usada em áreas externas ou internas $[1.2 .11 ; 2.1 .28 ; 2.3 .21 ; 3.2 .15]$. A segunda mesa, mais simples, usava os mesmos materiais, mas com tampo redondo inteiriço e pé tubular em metal aparente [2.1.29]. Estas novas peças, especialmente por seus materiais, ficavam em uma zona híbrida entre as linhas residencial e corporativa.
2.1.25: Ambiente na loja da Mobilinea no Shopping Iguatemi. Imagem de slide. Sem data. Acervo pessoal de Georgia Hauner.
2.1.26: Detalhes de ambientes com móveis da linha Prêt-à-Porter em Magnólia. "Boa Ideia: Juntar dois Apartamentos Pequenos". Casa Claudia. p. 74. ago. 1974.
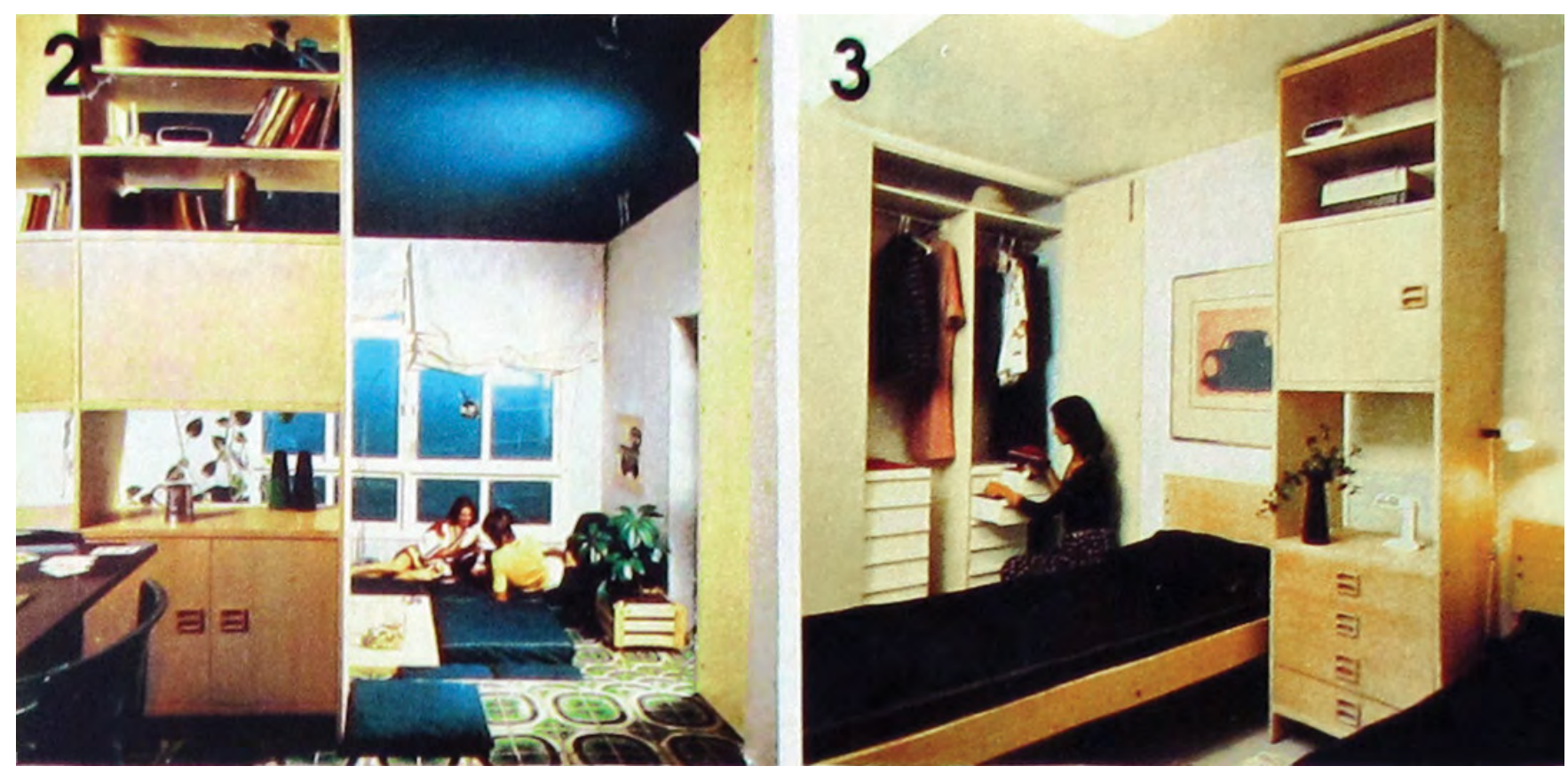

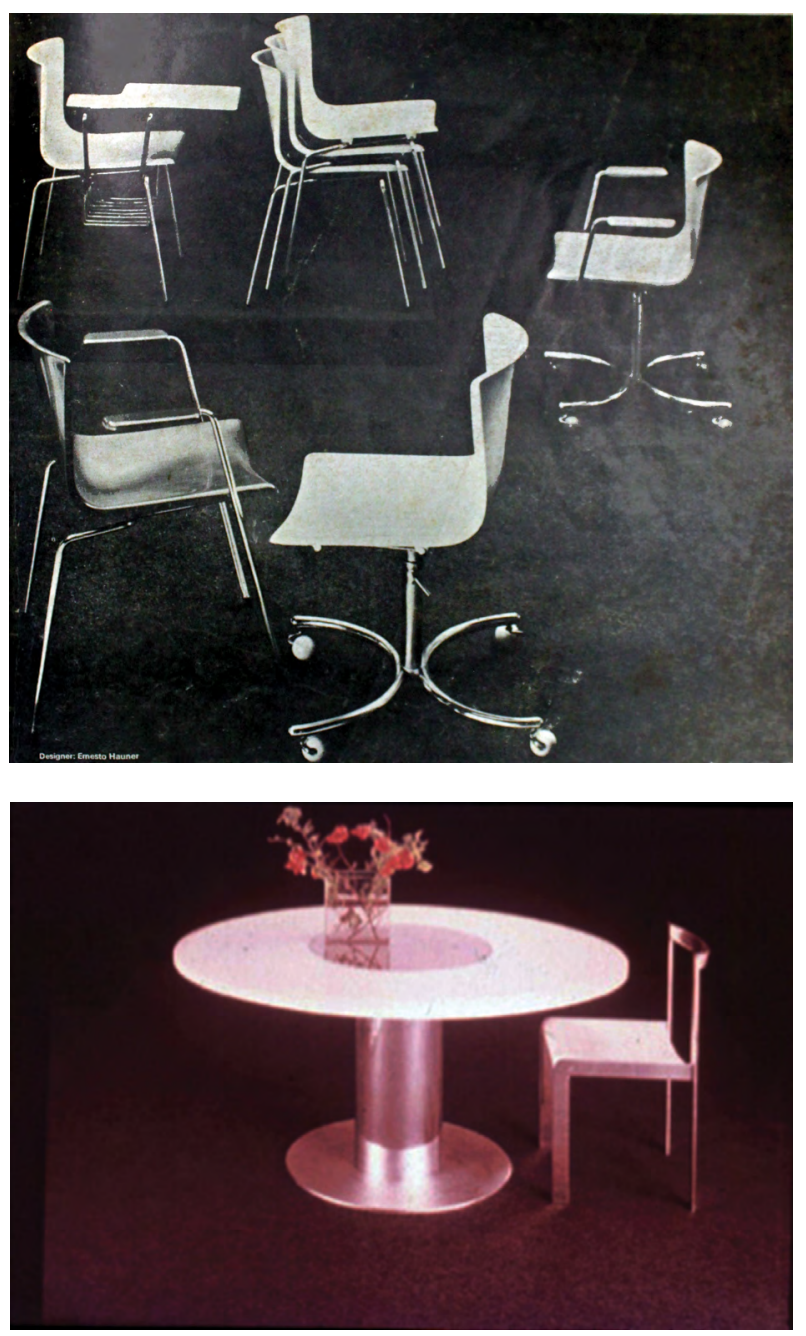

2.1.27: Linha completa de cadeiras em fiberglass empilháveis. "Móveis".

C. J. Arquitetura. p. 147. maio 1973.

2.1.28: Ambiente na loja da Home Store com mesacanteiro. Para viver melhor. Desfile - suplemento de decoração. jul. 1974.

2.1.29: Mesa com pé tubular e cadeira em acco. Imagem de slide. Sem data. Acervo pessoal de Georgia Hauner.

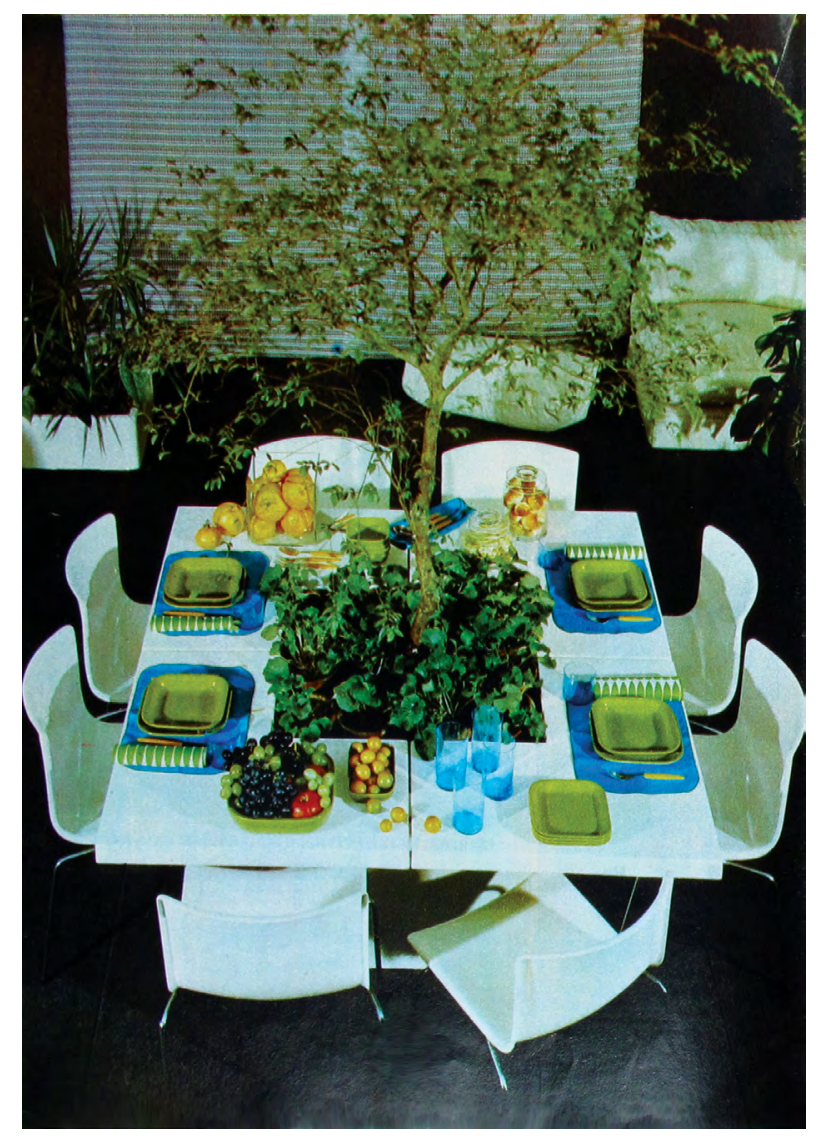




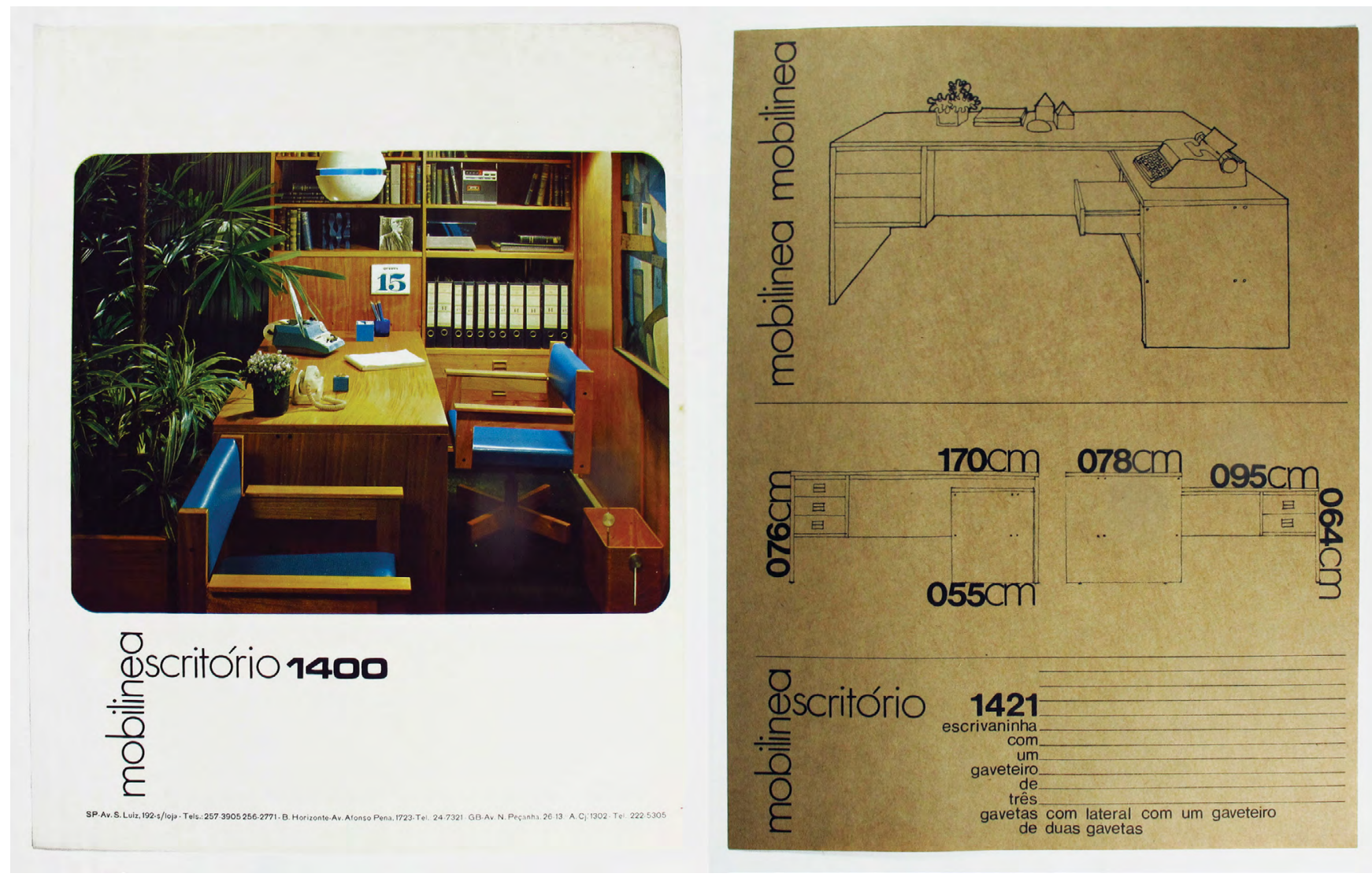

Ernesto havia projetado uma série de móveis para escritório quase simultaneamente às primeiras estantes modulares, e que vinham sendo desenvolvidos em paralelo às peças para uso residencial. É possível localizar em propagandas do fim da década de 1960 uma linha de móveis para escritório similar à Prèt-à-Porter, e que seguia a mesma modulação, sendo então intercambiáveis [2.1.30]. Em 1973, estas peças foram divulgadas em Claudia ${ }^{46}$ na versão pintada, o que é interessante para se pensar outra concepção de ambientes corporativos, mais descontraídos [2.1.31]. Havia também uma versão de mesas com pés metálicos, pintados ou aparentes, diversas cadeiras giratórias, poltronas, sofás e módulos de armazenamento.

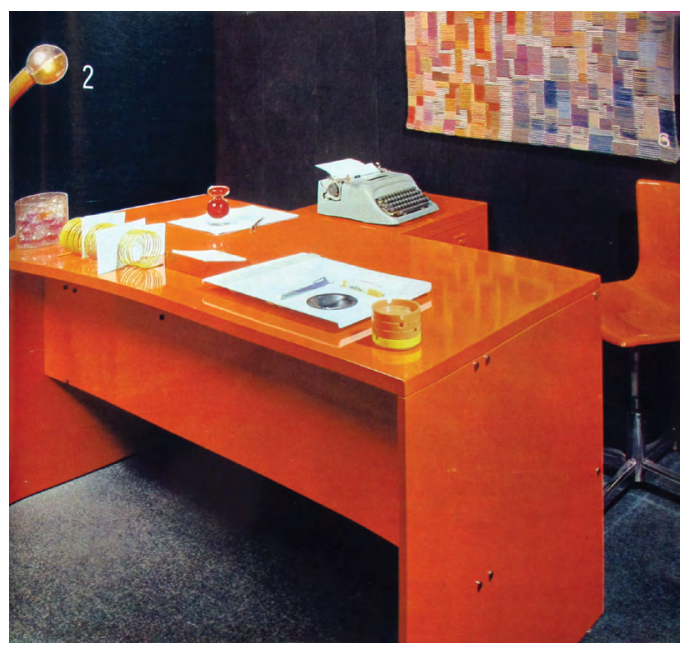

2.1.30: Páginas de catálogo da linha Mobilinea

Escritórios. Sem data. Acervo pessoal de Georgia Hauner.

2.1.31: Detalhe de reportagem sobre escritórios, mostrando linha Mobilinea laqueada. "Quatro Novas Maneiras de Decorar seu Escritório". Claudia. p. 120. mar. 1973. 
2.1.32: Páginas de catálogo "Mobilinea apresenta a linha

L. CD. de Alex Linder". Sem data. Acervo pessoal de Georgia Hauner.
Uma segunda linha de escritório desenvolvida neste período nunca foi comercializada para o público em geral pois era produzida exclusivamente para o Banco Itaú ${ }^{47}$, e infelizmente não foram encontradas imagens ou registros destes móveis.

Em 1974, Mobilinea comprou os direitos de produção da linha de móveis de escritório L.CD., da empresa alemã Alex Linder. Embora o desenho não tenha sido desenvolvido dentro da Mobilinea, descritivos dos materiais presentes em panfletos e catálogos de divulgação nos são úteis por listarem toda a tecnologia empregada em sua fabricação: nas mesas de trabalho, os pés eram compostos por perfil duplo de alumínio anodizado injetados lateralmente com poliuretano rígido; as cantoneiras eram em madeira maciça com acabamento em poliuretano; os tampos eram em chapa de aglomerado de madeira revestido com vinil ou em madeira maciça com verniz poliuretano; os gaveteiros, também de madeira aglomerada laqueada, tinham estrutura interna metálica e diversas combinações de gavetas. Todas as peças tinham acabamentos em preto, e haviam também mesas para reunião, bancadas de apoio, gabinetes, divisórias e armários [2.1.32]. Ada Hauner lembrou-se que esta linha foi comprada pela empresa Eternit ${ }^{48}$.

O que mais marcou o desenho e a fabricação dos móveis da Mobilinea durante estes dezesseis anos, acima de quaisquer diferenças formais, foi a

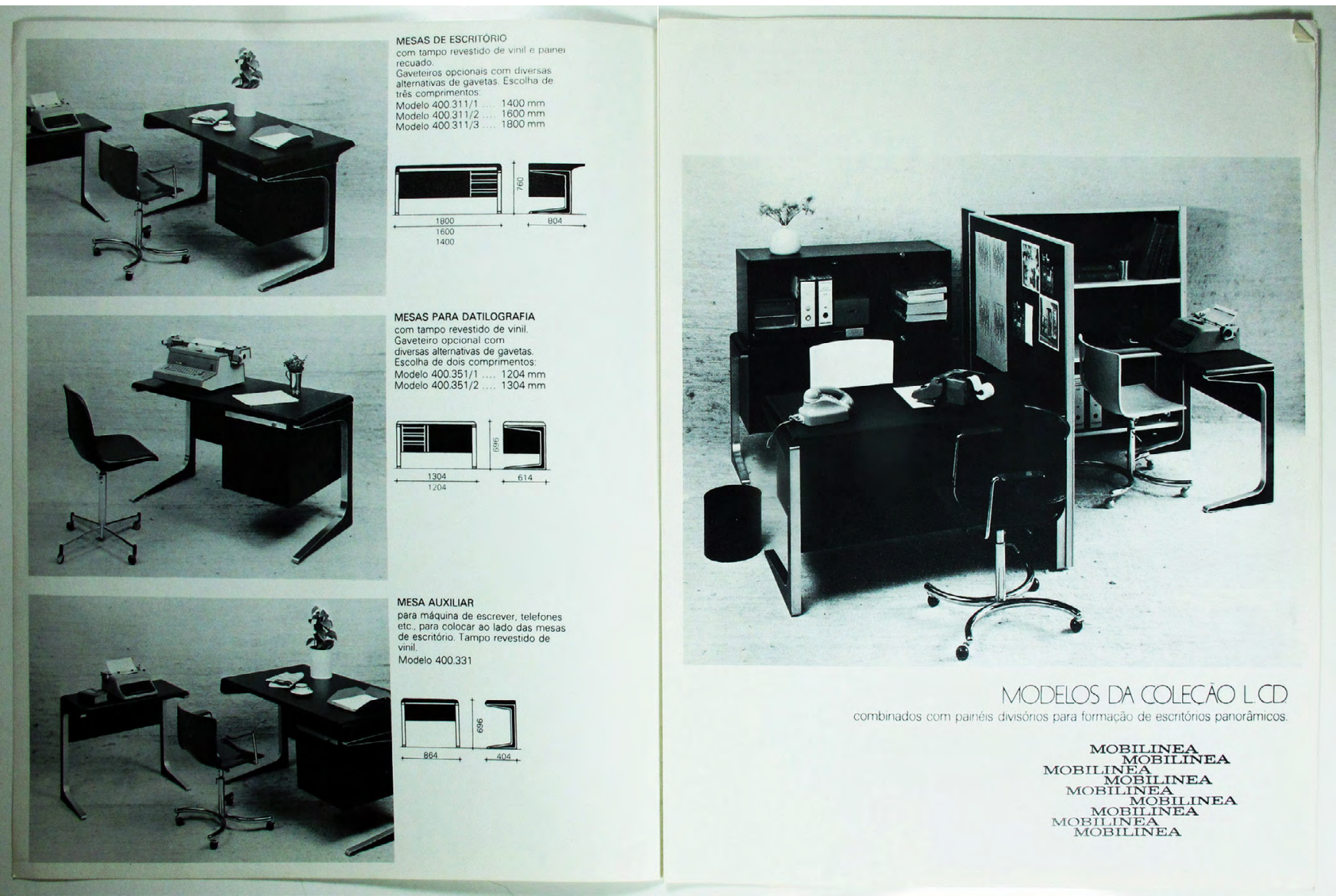


consistência na produção de linhas e não de móveis avulsos sob medida. Também é notável que para os ambientes de estar, jantar, dormitórios de casal e de solteiro, estas linhas eram completas a ponto de permitirem que cômodos inteiros pudessem ser mobiliados com peças da empresa. O partido dos móveis em módulos componíveis, embora rígido enquanto sistema, permitia uma elasticidade no sentido de adaptação a ambientes variados, compra em etapas e personalização dos espaços sem a necessidade de contratar um projeto especial, e a possibilidade de combinar móveis residenciais e corporativos também contribuía neste sentido.

Foram encontradas referências de móveis de madeira vendidos com pintura em branco, amarelo claro, amarelo ouro, vermelho, azul claro, azul escuro, verde limão, verde escuro, laranja e preto. Nos anos examinados, as únicas madeiras aparentes oferecidas em propagandas e editoriais foram Jacarandá, Amendoim e Magnólia. As peças em aço, fiberglass e acrílico funcionavam como um contraponto a estas peças mais básicas, e tinham também certa diversidade de cor nos acabamentos.

Os revestimentos de estofados para peças dos showrooms e propagandas eram escolhidos por Georgia Hauner ${ }^{49}$, mas, dentre os que eram oferecidos para venda, é possível localizar algumas características centrais: desde 1966 as capas tinham zíperes para que pudessem ser lavadas e trocadas, eram normalmente em algodão liso e em cores alegres, e o couro natural também era bastante utilizado. Em 1969 uma poltrona estofada foi anunciada com revestimento em tecido rosa choque de fibra acrílica lavável e que não desbotava de Elisabeth Wilheim ${ }^{50}$, feito exclusivamente para Mobilinea, podendo-se supor que esta parceria se estendia para outras cores, embora Bibita Butcher tenha se lembrado que também compravam muitos tecidos da Formatex ${ }^{51}$. A partir da criação da Home Store, ganharam destaque as almofadas em brim, material à época não utilizado na decoração e de certa forma ainda pouco comum mesmo no vestuário nacional.

Chama a atenção finalmente que, até a saída dos Hauner, as linhas entravam em produção e não eram interrompidas, indicando constante crescimento na capacidade produtiva da empresa [2.1.33], como também poderá ser observado pela expansão dos pontos de venda. 


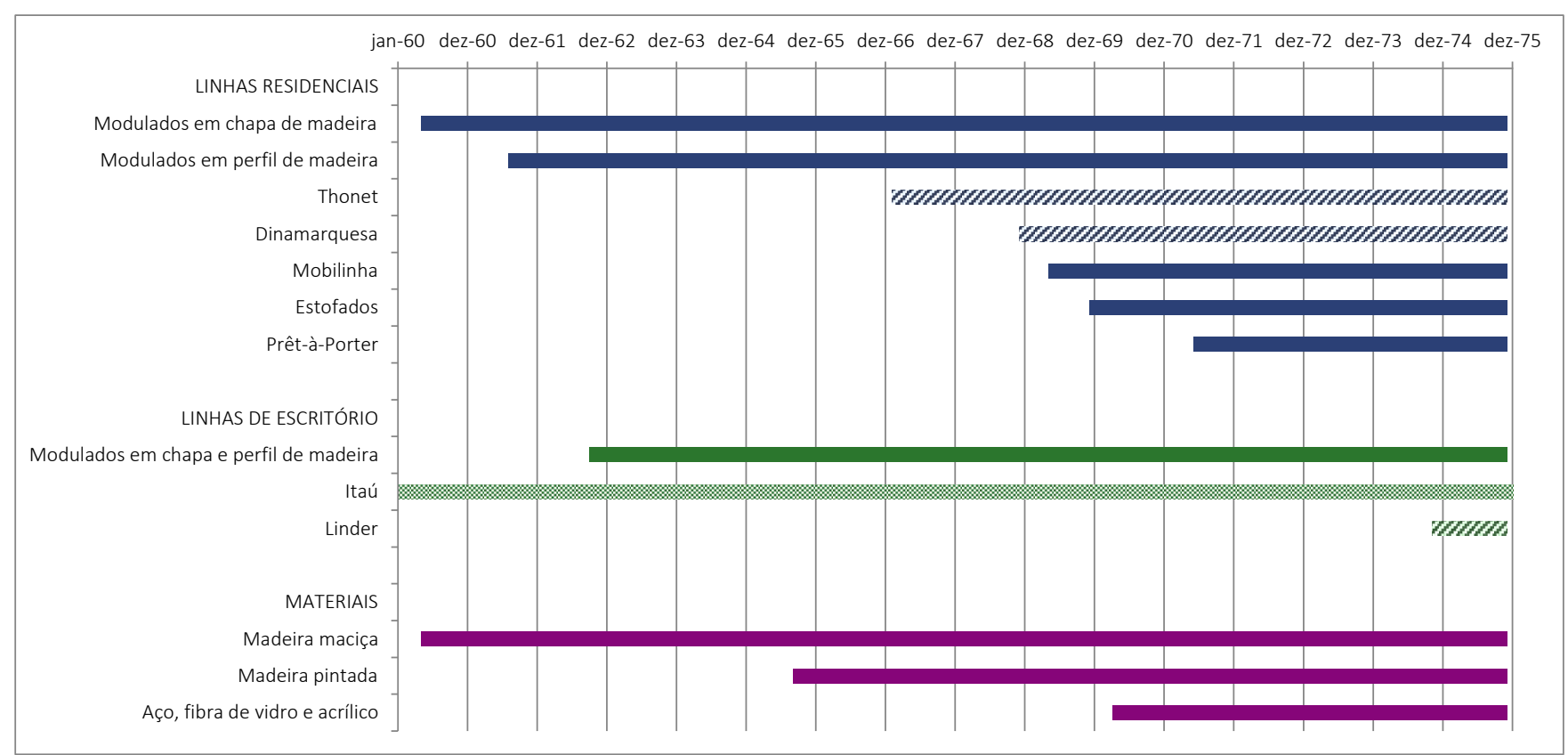

2.1.33: Gráfico das linhas produzidas e comercializadas pela Mobilinea entre 1960 e 1975 , realizado a partir do levantamento de periódicos.
* Linhas hachuradas correspondem a produtos comercializados porém não projetados ou fabricados inteiramente na Mobilinea.

** Não foi possível determinar quando a linha vendida ao Banco Itaú começou a ser fabricada. 


\subsection{As lojas e a comercialização de ideias}

O endereço inicial da Ernesto Hauner Decorações foi à Rua Vitorino Carmilo, 62, Barra Funda, em São Paulo. Lá ficava a fábrica, o escritório de projetos, a administração e também um pequeno showroom. Provavelmente a empresa se estabelecera ali desde 1959, mas o primeiro registro encontrado foi em uma propaganda de maio de 1960, e o último pouco mais de um ano depois, em outubro de 1961, ambos em propagandas publicadas em Casa \& Jardim. Segundo depoimento de Jorge Kornbluh, que auxiliou Ernesto na administração da empresa entre 1959 e 1960, não havia ali exatamente uma loja, apenas algumas peças montadas à frente da fábrica para mostrar aos compradores as opções de composição das estantes ${ }^{52}$. Embora já fossem modulares e componíveis, eram feitas apenas sob encomenda, e Jorge lembrou-se de serem caras, ficando restritas a um público de poder aquisitivo mais alto e círculo social reduzido.

Entre março e agosto de 1961, as propagandas da Ernesto Hauner Decorações divulgaram também um endereço de comercialização no Rio de Janeiro, mais especificamente à Avenida República do Peru, 143-A, subsolo, em Copacabana, que não por acaso era o mesmo endereço da Galeria Penguin $^{53}$, galeria de arte fundada por Ada Hauner e seu marido Roberto Consolaro no pavimento inferior da Livraria Penguin ${ }^{54}$. Por esta condição, este ponto parece ter sido mais uma conveniência do que uma ação planejada, uma vez que uma expansão organizada para outros estados viria a acontecer apenas alguns anos depois.

Em 196255, a fábrica da Mobilinea se mudou para a Rua do Bosque, 1782, também na Barra Funda, já desvinculada do espaço comercial. Nesse endereço permaneceram os departamentos de projeto e administração, sendo portanto local de trabalho de Ernesto e John de Souza, que neste momento se associava à empresa injetando-lhe novo capital, o que possibilitou esta expansão. Yone Koseki Pierre lembra que o escritório ficava lá, em um pequeno cômodo na parte da frente do galpão e o restante do espaço era aberto, onde iam-se acomodando as máquinas que eram adquiridas conforme as necessidades de fabricação ${ }^{56}$.

Concomitantemente à nova fábrica, foi inaugurada uma loja à Rua Augusta, $875^{57}$, na Consolação. Os clientes eram inicialmente atendidos por 
uma vendedora, mas caso quisessem um projeto de interiores completo, era chamada a decoradora de plantão, que discutia suas necessidades, fazia um levantamento dos espaços em sua casa e apresentava um projeto através de plantas e perspectivas feitas em papel vegetal à nanquim e canetas coloridas, colado em uma cartolina duplex branca ${ }^{58}$. O pagamento era feito com a gerente, responsável por negociar parcelas, prazos e descontos (salvo compras grandes, quando era consultada a fábrica). Ernesto passava todos os dias na loja para pegar os pedidos e deixar amostras de madeiras ou tecidos, e este hábito, conforme os depoimentos atestam, manteve-se até a Home Store e era a principal articulação entre fabricação e venda, pois era neste momento que as funcionárias das lojas podiam relatar a aceitação das peças e possíveis demandas de clientes, bem como o designer podia apresentar novos projetos e suas especificações técnicas para que elas pudessem explica-los no momento do atendimento.

Inicialmente, a loja da Augusta foi gerenciada por uma pessoa identificada nos depoimentos como Monica, cuja função era lidar com a entrada e saída de dinheiro e realizar a comunicação com a fábrica; e Yone Koseki Pierre, que atuava como decoradora, atendendo a clientes e fazendo projetos. Quando a loja do Shopping Iguatemi foi aberta em 1966, Monica foi transferida para lá e Bibita Butcher entrou em seu lugar na Augusta. Pouco depois, Judit Magyary foi contratada e trabalhou como vendedora inicialmente também na Augusta, função que ela descreveu como a de uma "tiradora de pedidos", pois consistia principalmente em definir a quantidade de montantes, prateleiras e caixas a serem solicitadas à fábrica ${ }^{59}$.

Georgia Hauner vinha organizando a imagem da empresa desde o pequeno showroom na Barra Funda, embora afastada de atividades profissionais regulares para cuidar dos filhos. Desejando ter uma fonte de renda própria, iniciou um pequeno negócio fabricando luminárias de papel inspiradas na empresa de design dinamarquesa Le Klint e, com o tempo, a complexidade dos projetos e as demandas de trabalho foram aumentando, de forma que ela contratou uma pequena equipe e se estabeleceram em um apartamento no mesmo prédio cujo térreo era ocupado pela loja da Mobilinea. Com dobras curvas, aplicação de tecido e passamanaria, estas luminárias foram pensadas para serem vendidas na própria empresa, preenchendo os espaços vazios entre os móveis e o teto da loja ${ }^{60}$ [1.2.04; 2.2.01-2.2.02; 2.2.08-2.2.16].

Judit Magyary descreveu a loja da Mobilinea na Augusta, como a conheceu em 1965, da seguinte maneira: a fachada era estreita e tinha um ambiente de vitrine, com a entrada por um corredor lateral; atravessando-o, havia um ambiente de estar e a mesa de vendas. Depois, passava-se por outro corredor cuja parede tinha montantes de madeira entre os quais foi fixado 
um revestimento em papel dobrado como as luminárias de Georgia, que era iluminado por trás de forma que imaginava-se estar atravessando uma área externa, embora houvesse apenas uma parede. Desse corredor, chegava-se enfim a um espaço maior onde havia mais ambientes montados e, ao fundo, ficava um pequeno depósito e o escritório ${ }^{61}$.
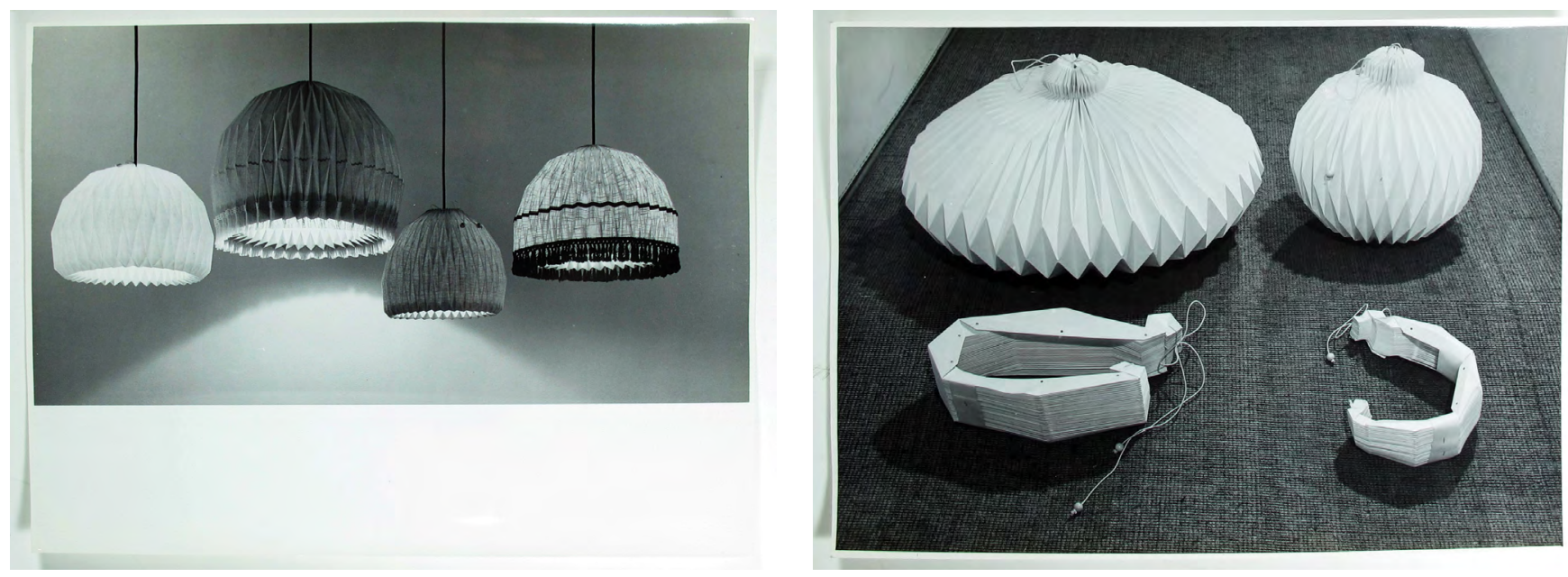

Quando Yone foi para a fábrica trabalhar com Ernesto, Judit, que atuava então como sua assistente, assumiu o cargo de decoradora na loja. Nesteínterim ela havia convivido bastante com Georgia e entendido a imagem da Mobilinea, de forma que se tornou responsável pelo desenvolvimento de alguns layouts da loja, incluindo nisso sua marca pessoal. Uma das vitrines que ela se lembra de ter feito foi com móveis laqueados em branco, iluminados por luz negra, à época uma grande novidade na cidade. Outra prática adotada pela Mobilinea foi incluir nos projetos apresentados alguns móveis de design europeu consagrado (ao que foi possível aferir, normalmente peças comercializadas pela Forma), a fim de mostrar como compor ambientes de forma mais integrada. Para Judit, essa estratégia inspirava confiança nos clientes, por estarem apresentando o que genuinamente ficaria melhor em sua casa e não os obrigando a obter todas as peças de uma única empresa ${ }^{62}$.

A partir deste tipo de tática, aliada às luminárias de papel, à customização de tecidos para estofamento das peças de showroom e à inserção de objetos artesanais acompanhando os móveis nos espaços expositivos, começou a se desenvolver na Mobilinea uma cultura de não apenas comercializar móveis, mas vender ambiências que representassem certo estilo de vida. A partir dessa chave entende-se porque foi aberta uma pequena galeria de arte dentro da loja da Rua Augusta e, embora não tenha havido muitas propagandas dos móveis da Mobilinea neste período, seu endereço estava constantemente na agenda cultural dos jornais A Folha de São Paulo e O Estado de São Paulo, dando alguma relevância à marca. A partir do levantamento nestes periódicos, foi possível

2.2.01-2.2.02: Fotografia das luminárias em papel feitas por Georgia Hauner, dobradas e montadas. Sem data. Acervo pessoal de Georgia Hauner. 
2.2.03: Calendário das exposições realizadas na Galeria Mobilinea, realizado a partir do levantamento de periódicos. localizar as principais exposições realizadas ali entre 1963 e 1966, quando deixaram de ocorrer provavelmente por causa da inauguração da loja da Mobilinea no Shopping Iguatemi [2.2.03].

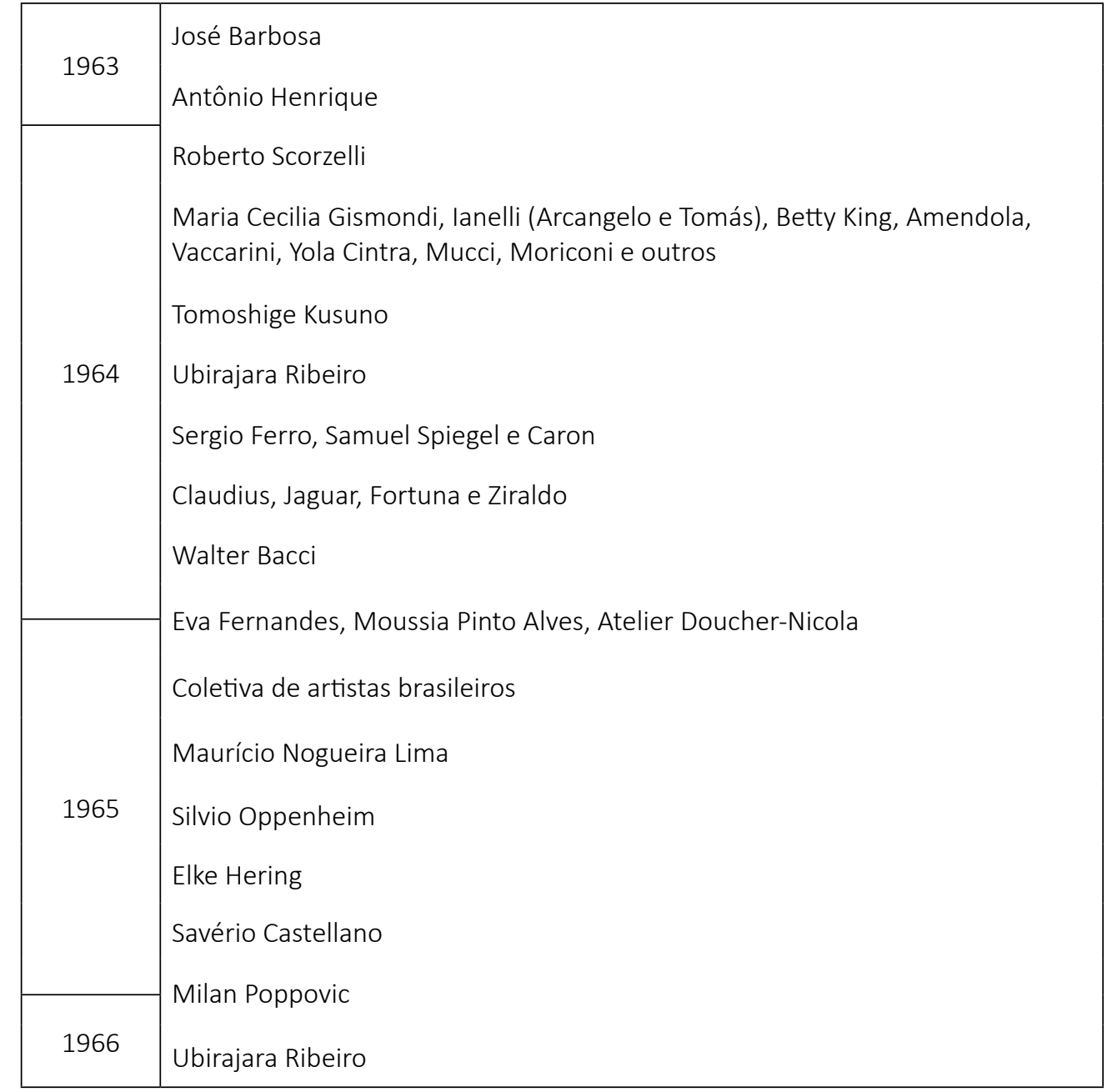

Grande parte dos artistas que expuseram na Mobilinea da Augusta eram arquitetos de formação e/ou imigrantes, o que pode ser entendido pelas próprias inserções sociais dos sócios e funcionários da empresa: John de Souza era professor na FAUUSP; Ernesto Hauner estava bem conectado ao círculo de imigrantes italianos; Georgia Hauner, por ter se formado na Graded School e pelos contatos de seus pais, também tinha um círculo de amigos imigrantes de alguma maneira envolvidos no campo da cultura; e, finalmente, de acordo com Judit Magyary, era Monica quem estava encarregada de encontrar os artistas e organizar estas exposições, provavelmente pertencendo então aos mesmos círculos que os demais.

Quando, em 1965, Mobilinea divulgou móveis laqueados em cores vibrantes na propaganda com patinhos [2.1.07], também anunciou uma série de novos endereços para a compra de suas peças em outros estados brasileiros, evidenciando que nestes primeiros anos de atuação haviam conseguido capital 
para se afirmarem no campo do design em uma escala mais ampliada. Foi reaberto um endereço no Rio de Janeiro, desta vez à Rua Montenegro ${ }^{63}$, 74, em Ipanema, loja que viria a ser gerenciada por uma pessoa identificada como Jazel (e que depois iria trabalhar na fábrica em São Paulo) [2.2.04]. Além disso, firmaram-se acordos de revenda com a loja Morada Arquitetura de Interiores, à Rua dos Tamoios, 200, $7^{0}$ andar, no centro de Belo Horizonte; e com a Móveis Ralf, à Avenida 7 de Setembro, 249, no centro de Salvador. No ano seguinte surgiu um terceiro endereço de revenda em Goiânia, na Taba Móveis e Decor, esquina das Ruas 23 e 4, no centro da cidade, mas que deixou de ser divulgado ainda em 1966. Como veremos, os pontos de venda no Rio, em Minas Gerais e na Bahia também passaram por transformações, mas ficaram ativos por mais tempo, e vale notar que esta expansão se dava não apenas por uma valorização e crescimento da marca Mobilinea, mas porque cidades em outros estados brasileiros também passavam por processos de urbanização e verticalização acelerada, abrindo assim novos mercados ${ }^{64}$.

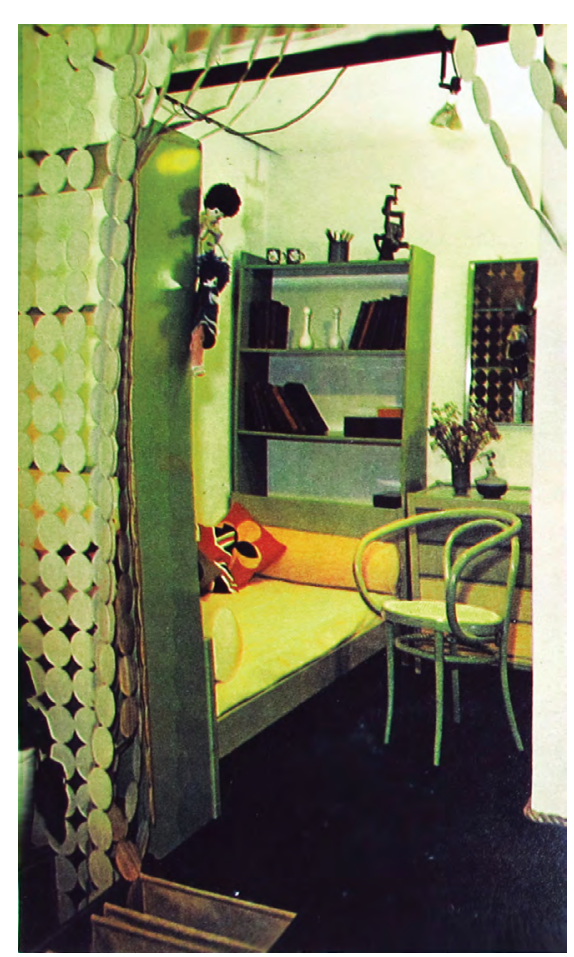

No anúncio dos patinhos, aparece também um novo endereço na cidade de São Paulo paralelo ao da Rua Augusta: nos conjuntos 34 e 36 da galeria do Edifício Zarvos, à Avenida São Luís, 258, no centro da cidade. Segundo Judit Magyary, essa loja tinha cinco ou seis ambientes de vitrine e, embora fosse pequena, era "toda cheia dos charminhos" funcionou como ponto de venda de todas as linhas da Mobilinea, mas aos poucos foi se organizando como um endereço apenas dos móveis de escritório, gerenciado por Ada Hauner.
2.2.04: Interior da loja da Mobilinea no Rio de Janeiro. Grandes Ideias para os Pequenos. Joí. p. 50. ago. 1968. 
No ano seguinte, o primeiro shopping center de São Paulo foi inaugurado, à Rua Iguatemi, $1191^{66}$, incorporado pela Construtora Alfredo Mathias, com projeto de $35.000 \mathrm{~m}^{2}$ desenvolvido pelo escritório Croce, Aflalo \& Gasperini em parceria com João Henrique da Rocha ${ }^{67}$ [2.2.05]. O Shopping Iguatemi anunciou amplamente sua chegada, principalmente nos jornais A Folha de São Paulo e O Estado de São Paulo e, como era um conceito bastante novo, muitas destas propagandas se dedicavam a efetivamente explicar como seria seu funcionamento. Em agosto de 1966, anunciaram em uma propaganda na Folha:

As mais famosas lojas de $\mathrm{S}$. Paulo - as mais populares, as de maior sortimento, as de melhores preços - estarão instaladas e funcionando no Shopping Center Iguatemi, a partir de novembro próximo. Não há mais uma só loja vazia. Iguatemi, assim, abrirá as suas portas com $100 \%$ da sua área de venda ocupada, vendendo 6 bilhões de cruzeiros por mês a mais de meio milhão de consumidores. ${ }^{68}$

2.2.05: Detalhe de propaganda de divulgação do Shopping Iguatemi, mostrando sua construção.

A Folha de São Paulo.

p. 5, Primeiro Caderno. 28 ago. 1966.

2.2.06: Detalhe de propaganda de divulgação do Shopping Iguatemi, anunciando sua inauguração. O Estado de São Paulo. p. 13, Caderno Geral. 27 nov. 1966.

\section{O PONTO OUE NASCE comecarā Com todas as suas lojas ocupadas.}

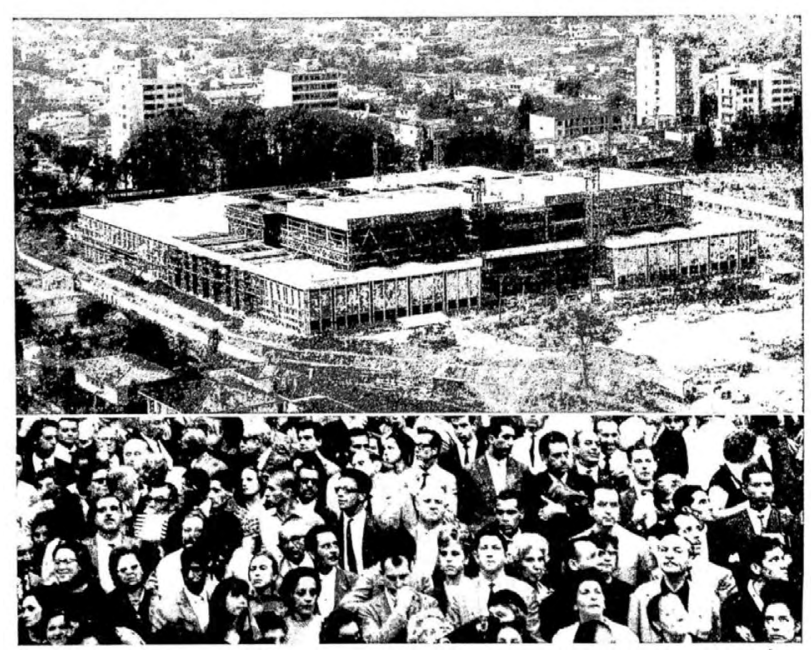

\section{inaugura-se hoje}

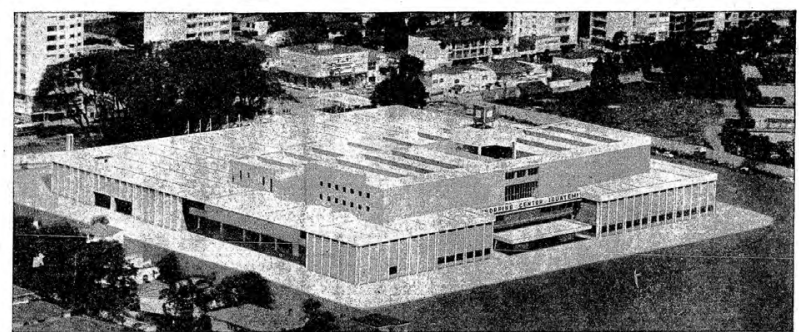

SHOPPING CENTER IGUATEMI 
A inauguração ocorreu em 27 de novembro de 1966, conforme anunciado em O Estado de São Paulo, com shows de Chico Buarque e Nara Leão, Chico Anízio, Eliana e Booker Pitmann e Caçulinha e seu Conjunto [2.2.06]. Nesse mesmo anúncio, foram listadas todas as lojas que faziam parte do empreendimento junto à Mobilinea:

\begin{tabular}{llll} 
A Baiuca & Colchões Durocrin & Grandela & \multicolumn{1}{c}{ Tecidos } \\
A Cegonha & Coliseu, Móveis e & Gonçalves e Irmão & Ofner Doceria \\
Acapulco & Interiores & Hi-Fi & Palácio dos Enfeites \\
Adriano & Colonial lguatemi & Indústria Young & Presentes Monita \\
Almeida e Irmão & Corrêa & Iris Auto Borrachas & Procópio Sports \\
Apar-Artesanato & Depósito Normal & Julie e Jim & Renata \\
Assumpção & Emprêsa & La Fatina & Roca \\
Armarinho & Cinematográfica & Lancellotti & Roupas A. B. \\
Arvi & Sul & Le Rideau & Ruletex, Tapetes e \\
Auto Serviço Rocar & Emprêsa Estadual & Lirs & Cortinas \\
Iguatemi & de Cinema & Livraria Francisco & Sears \\
Banco do & Escola Lanofiz & Alves & Sporting, Moda \\
Commércio e & Tricotex Ltda. & Lojas Americanas & Esportiva \\
Indústria de São & Farmácia e & Lojas Brasília & Sul Americana \\
Paulo S.A. & Drogaria Center & Lojas Cerello & Iguatemi \\
Café Brazão & Iguatemi & Lojas Clark & Superloja São Jorge \\
Cantinho da Moda & Florexótica & Malharia Palma & Supermercado Pão \\
Casa Buri & Foto Cine Color & Mobilinea & de Açúcar \\
Casa José Silva & Center & Modas Reveillon & Top's Comestiveis \\
Casa Kosmos & Fotoptica & Monk & Translor \\
Casa Salus Iguatemi & Giuliano, Jóias e & Móveis da Fazenda & T.V. Regência \\
Casa Sotero & Relógios & Multisport & Ultralar \\
Casa Valentim & Golden Dragon & Novidade Fabril & Welson's Boutique \\
& & & \\
& & &
\end{tabular}

Vale notar que havia uma quantidade razoável de lojas voltadas à venda de móveis e objetos decorativos: Coliseu Móveis e Interiores, Cerello, Mobilinea, Móveis da Fazenda, Sears e possivelmente Colonial Iguatemi e Depósito Normal. Além disso, há várias lojas de complementos para a casa, como Almeida e Irmão, Colchões Durocrin. Florexótica, Le Rideau, Novidade Fabril Tecidos e Ruletex Tapetes e Cortinas. Havia ainda uma livraria e uma loja de discos, tal como haveria na Home Store, que nessa perspectiva se colocaria quase como uma concorrente do Shopping.

Não foi possível compreender exatamente como se deu o convite ou solicitação para Mobilinea participar do empreendimento, mais ainda na posição de destaque que assumiu, sendo uma das lojas âncora e ocupando $500 m^{2}$ (localização T3-L3) com total liberdade para organizar seu espaço interior. O que se percebe é que este empreendimento foi um marco no crescimento da empresa, concomitante à abertura das revendas em Salvador e Goiânia, com impacto imediato no aumento da exposição da marca nos jornais paulistas e na revista Casa \& Jardim, e com reflexos a médio e longo prazo ainda mais significativos.

Yone Koseki Pierre, arquiteta da equipe, foi responsável pelo projeto executivo da loja e acompanhamento da obra, conceituado por Georgia 
Hauner e com contribuições de diversos funcionários da Mobilinea, inclusive da fábrica. Nestes anos começava a se tornar habitual construir desníveis nas casas para separar ambientes, e Yone trouxe a ideia para Georgia, que levou o conceito ao extremo criando novos pavimentos na loja ${ }^{70}$, conforme relata:

\begin{abstract}
Descobri que podíamos cavar o piso do andar térreo do shopping e projetei ali três níveis a vista das vitrines. A entrada permaneceu no mesmo nível, uma área em primeiro plano mais baixa de meio andar, e em segundo plano, um nível na altura dos olhos, para quem observava de fora. Isto separou as exposições sem vedar a vista geral do espaço. Aproveitei para a alvenaria nova criar degraus que formavam assentos, paredes baixas para encostar móveis e paredes divisórias rústicas, vazadas, com luz embutida para expor objetos. As estantes de linha do Ernesto eram desmontáveis e moduladas, auto-portantes e acabadas de todos os lados, portanto podiam ser colocadas para dividir os espaços de maneira diferente a cada mudança de exposição. Incluí no projeto alguns elementos fixos: uma lareira revestida de pedra sabão que dividia dois níveis de piso, e que permitia ver o fogo de ambos. Uma escadinha em caracol vazada, que separava ambientes e levava para os escritórios situados no mezanino. Os escritórios também eram abertos, separados somente pela altura e por algumas estantes desmontáveis. ${ }^{71}$
\end{abstract}

A fachada da loja era revestida com ripas de Jacarandá e janelas redondas, por onde se via o interior da loja [2.2.07]. Como o primeiro plano havia sido rebaixado, era possível vê-lo na parte inferior e, olhando em frente, via-se um segundo ambiente elevado atrás daquele, chamado de "palquinho" [2.2.082.2.09]. Além das estantes da Mobilinea, da parede vazada e da lareira em pedra sabão, também serviam como divisores de ambientes plantas e cortinas em materiais diversos, e caixas-piso modulares que criavam novos desníveis. A iluminação variava entre cênica e natural, de acordo com o espaço que exibiam, e não havia móveis soltos: estavam sempre compondo ambientes, fossem de estar, jantar, dormitórios ou escritórios [1.2.04; 2.2.10-2.2.16].

2.2.07: Parte da fachada da loja no Shopping Iguatemi, revelando alguns dos ambientes internos (por causa das letras impressas na parte superior da imagem, supõe-se ter sido usada na elaboração e algum tipo de divulgação). Imagem de slide. Sem data. Acervo pessoal de Georgia Hauner.

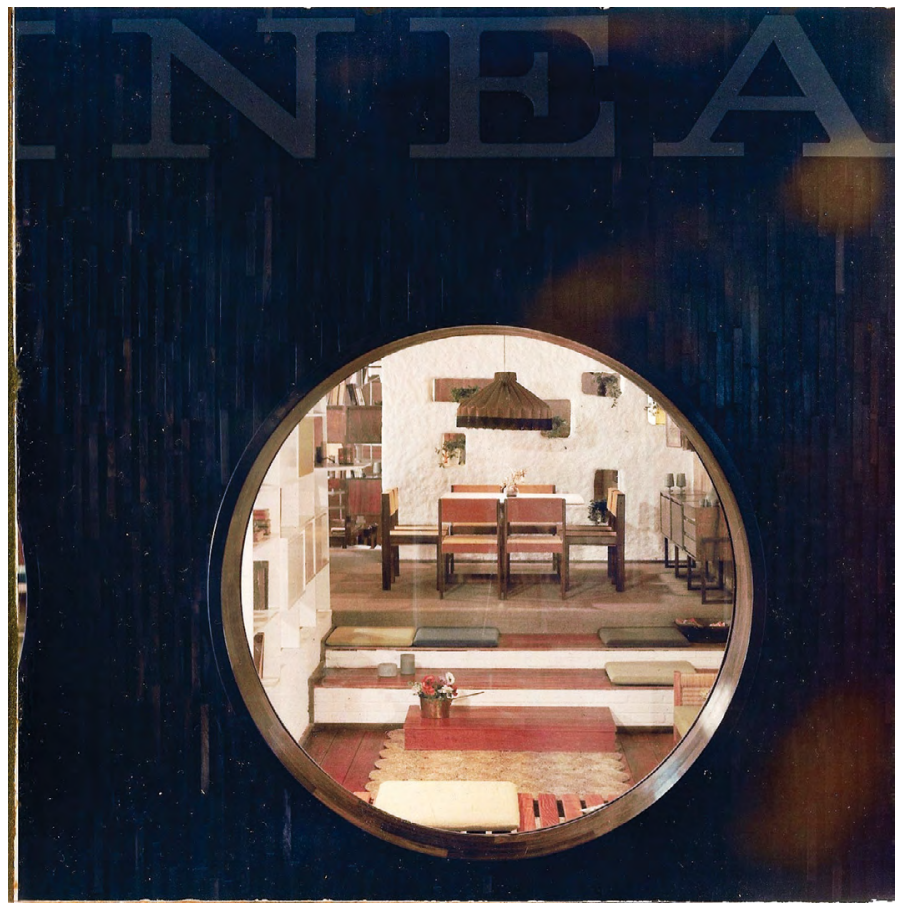




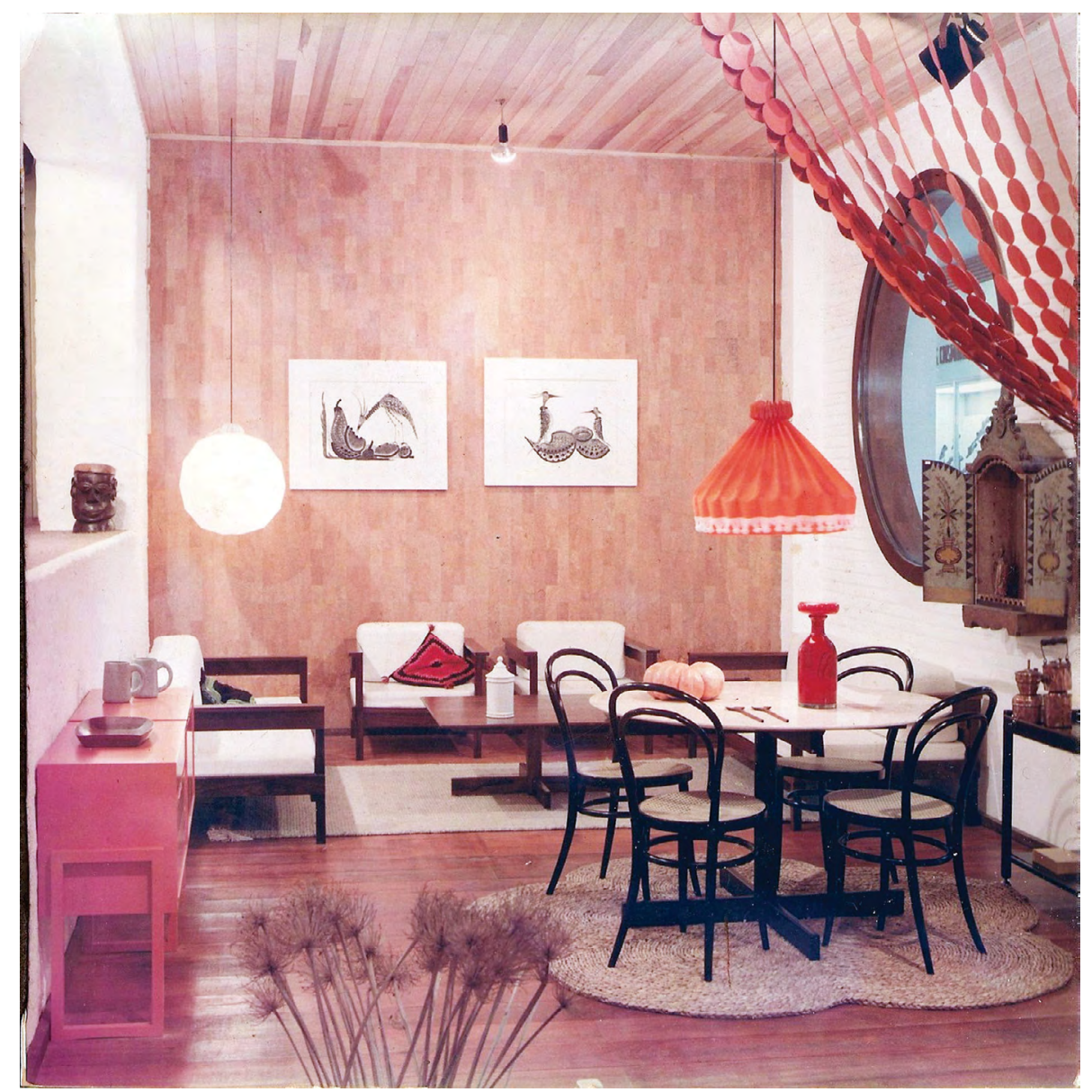

2.2.08: Vista interna da loja Mobilinea no Shopping Iguatemi com a vitrine redonda à direita, o ambiente rebaixado ao centro e o palquinho à esquerda. Imagem de slide. Sem data. Acervo pessoal de Georgia Hauner.

2.2.09: Vista interna da loja Mobilinea no Shopping Iguatemi a partir da vitrine, mostrando em primeiro plano o ambiente rebaixado e à frente o palquinho e a parede vazada à esquerda. Imagem de slide. Sem data. Acervo pessoal de Georgia Hauner. 
2.2.10: Ambiente de estar na loja Mobilinea no Shopping Iguatemi. Imagem de slide. Sem data. Acervo pessoal de Georgia Hauner.

2.2.11: Ambientes de estar, jantar e dormitórios, separados por pisos elevados

na loja Mobilinea no Shopping Iguatemi. Imagem de slide. Sem data. Acervo pessoal de Georgia Hauner.
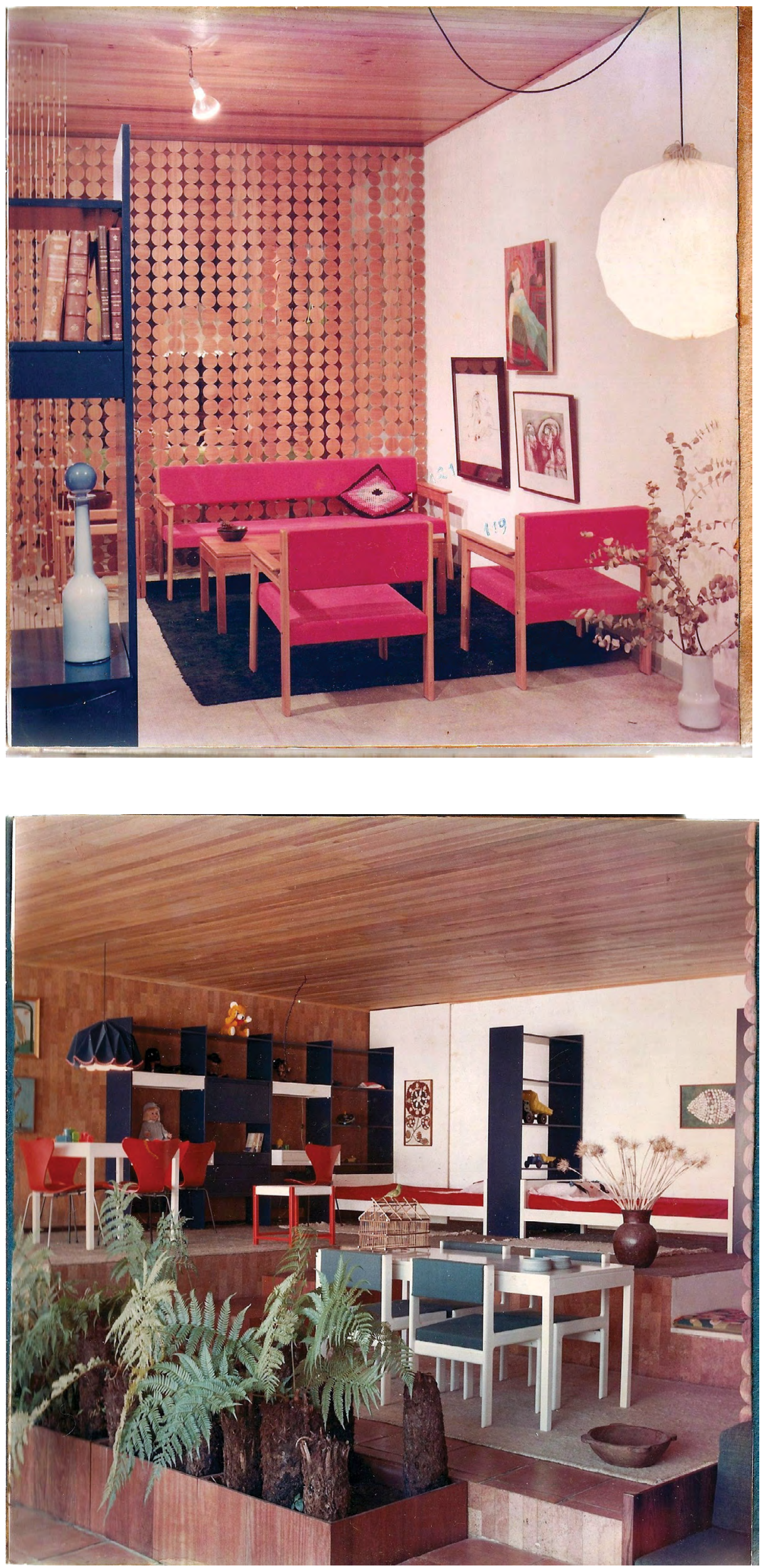


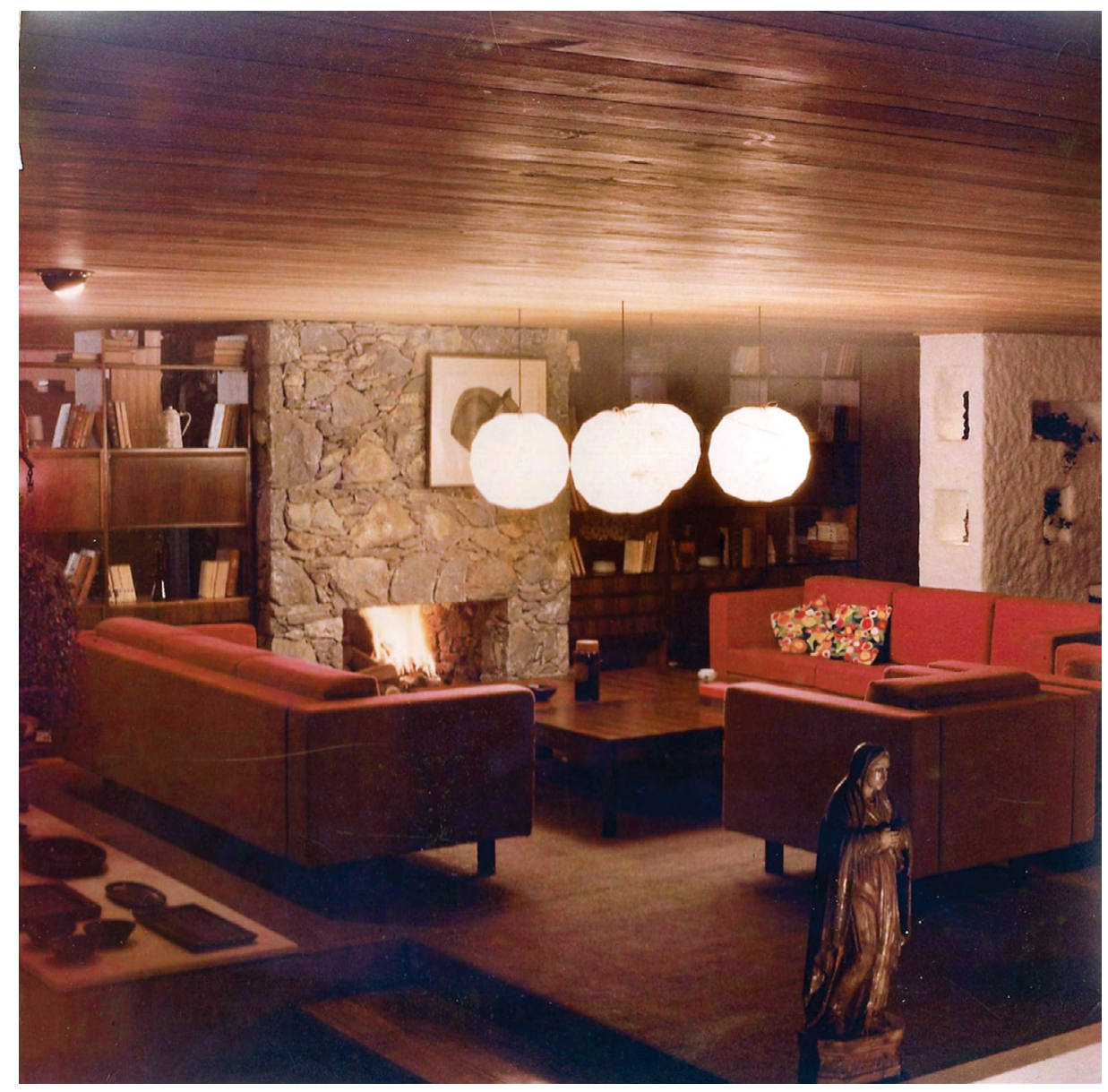

2.2.12: Ambiente de estar em frente à abertura superior da lareira na loja Mobilinea no Shopping Iguatemi. Imagem de slide. Sem data. Acervo pessoal de Georgia Hauner.

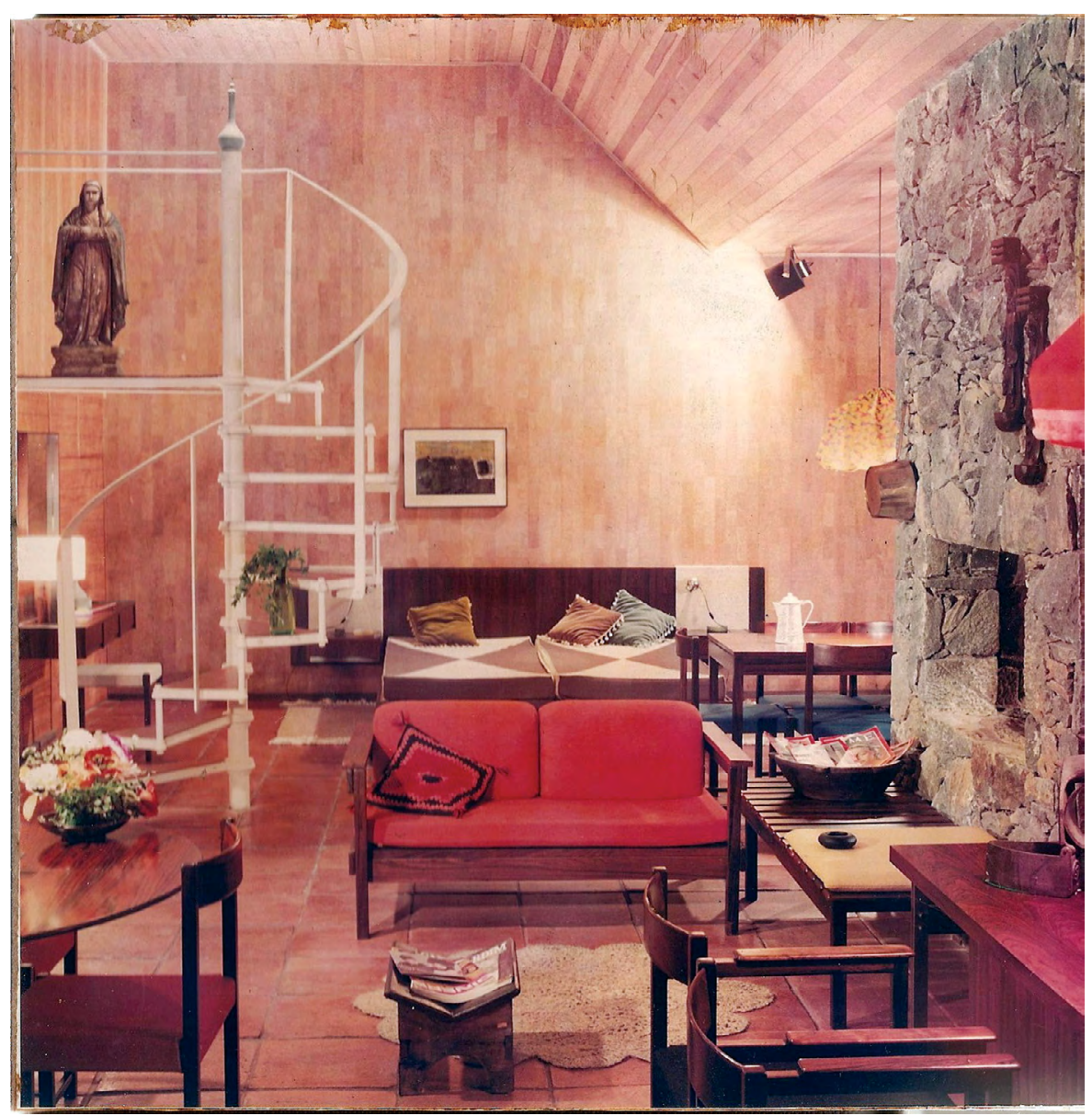

2.2.13: Ambiente de estar em frente à abertura inferior da lareira, com escada caracol que dava acesso aos escritórios na loja Mobilinea no Shopping Iguatemi. Imagem de slide. Sem data. Acervo pessoal de Georgia Hauner. 
2.2.14: Ambiente de escritórios com parede de ripas de Jacarandá da fachada ao fundo na loja Mobilinea no Shopping Iguatemi. Imagem de slide. Sem data. Acervo pessoal de Georgia Hauner.

2.2.15: Ambiente de dormitório com iluminação natural e poltrona Armando Cerello (não era vendida na Mobilinea; como a gaiola,

foi colocada apenas para completar a composição) na loja Mobilinea no Shopping Iguatemi. Imagem de slide. Sem data. Acervo pessoal de Georgia Hauner.
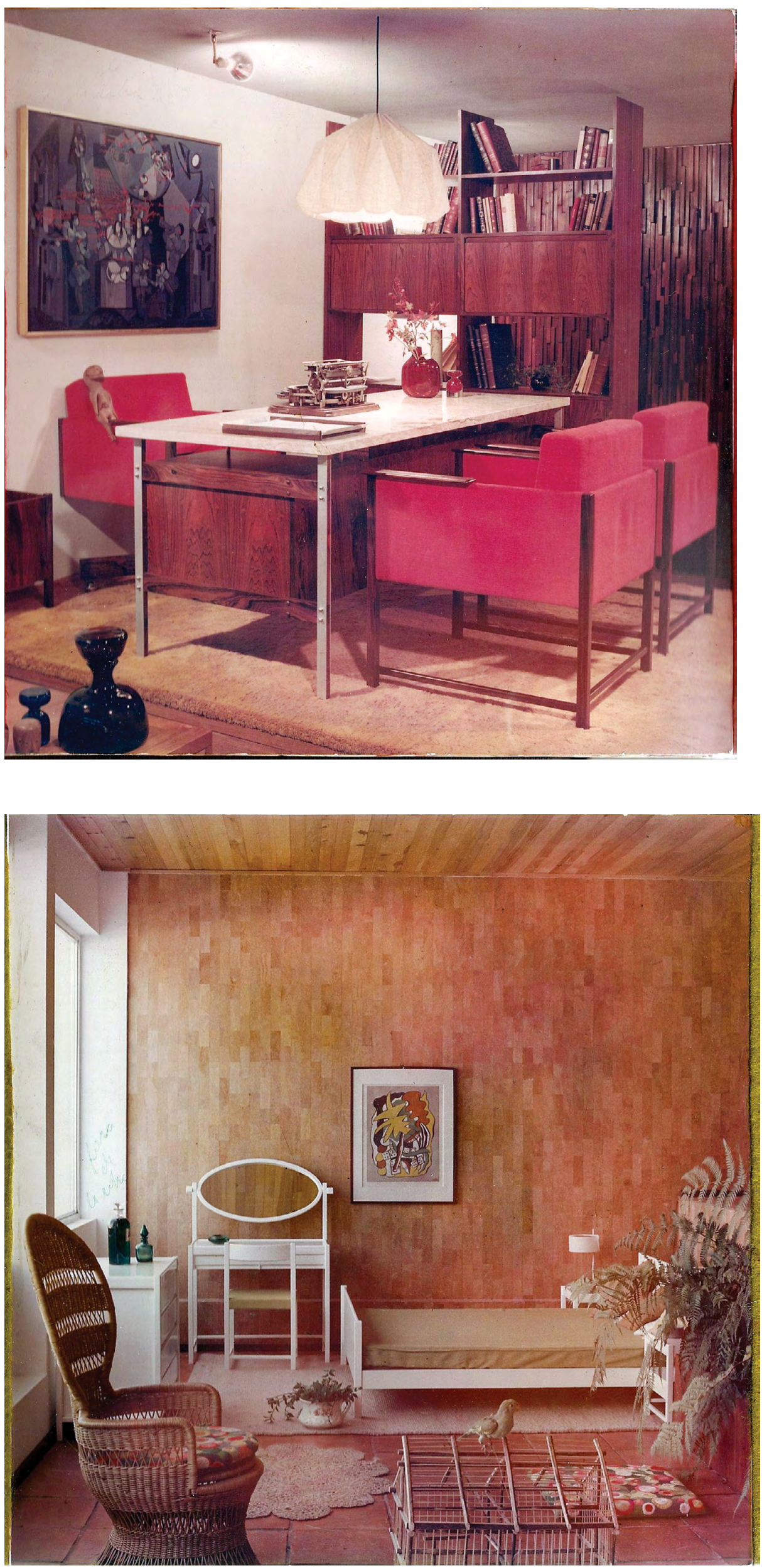


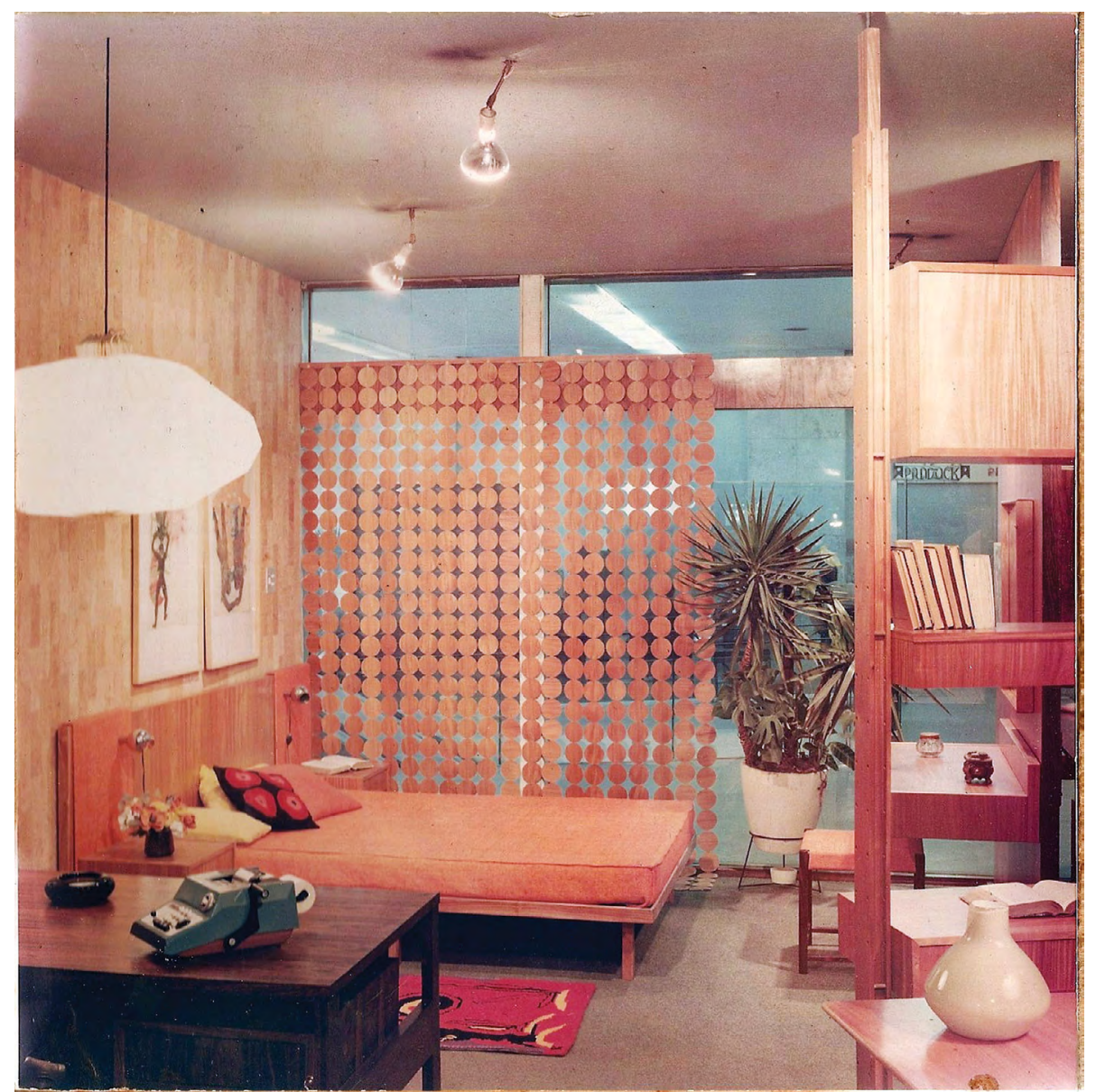

Nestas imagens, épossível ver uma série de elementos usados por Georgia na composição dos ambientes, como divisórias feitas a partir de cortinas de contas e discos de madeiras, quadros e gravuras, garrafas de vidro colorido, elementos artesanais como bordados, antiguidades como estátuas religiosas, funcionais como uma máquina de escrever, e inusitadas como um violino ou uma gaiola. Todos eles contribuíam trazendo novas cores, materiais e texturas às peças retas em madeira e davam caráter aos ambientes, tornando-os memoráveis.

Judit lembrou-se de uma vitrine que executou no palquinho para a primeira poltrona em blocos de poliéster [2.1.20]: foram compradas cortinas de plástico usadas para porta de açougue em tons de roxo, vinho, vermelho e rosa, fixadas por ela e Carmine, chefe de montagem na fábrica, de piso a teto em um desenho ondulado com várias camadas e misturando tons, formando o que ela descreveu como uma "aurora boreal de tiras de plástico", à frente da qual foram expostas as peças [2.2.17].

No lançamento da poltrona com chassi metálico alguns meses depois, foi montando no palquinho o ambiente para sala de estar com piso e paredes pintados com motivos "psicodélicos", com teto espelhado, publicado em Casa \& Jardim $[2.1 .19 ; 2.2 .18]$. O motivo da pintura foi escolhido por Georgia, responsável pela concepção desta vitrine, e foi executado por Ernestinho, pintor da fábrica.
2.2.16: Ambiente de dormitório com janela interna ao Shopping Iguatemi. Imagem de slide. Sem data. Acervo pessoal de Georgia Hauner. 
2.2.17: Projeto para layout da loja Mobilinea no Shopping Iguatemi. À esquerda vê-se a entrada da loja no mesmo nível do corredor. De lá, pode-se seguir reto para a exposição no interior da loja, descer meio nível à direita para ver o ambiente montado junto à fachada, ou subir meio nível para acessar o palquinho. Cópia de desenho original de Judit Magyary. c. 1969. Acervo pessoal de Georgia Hauner.
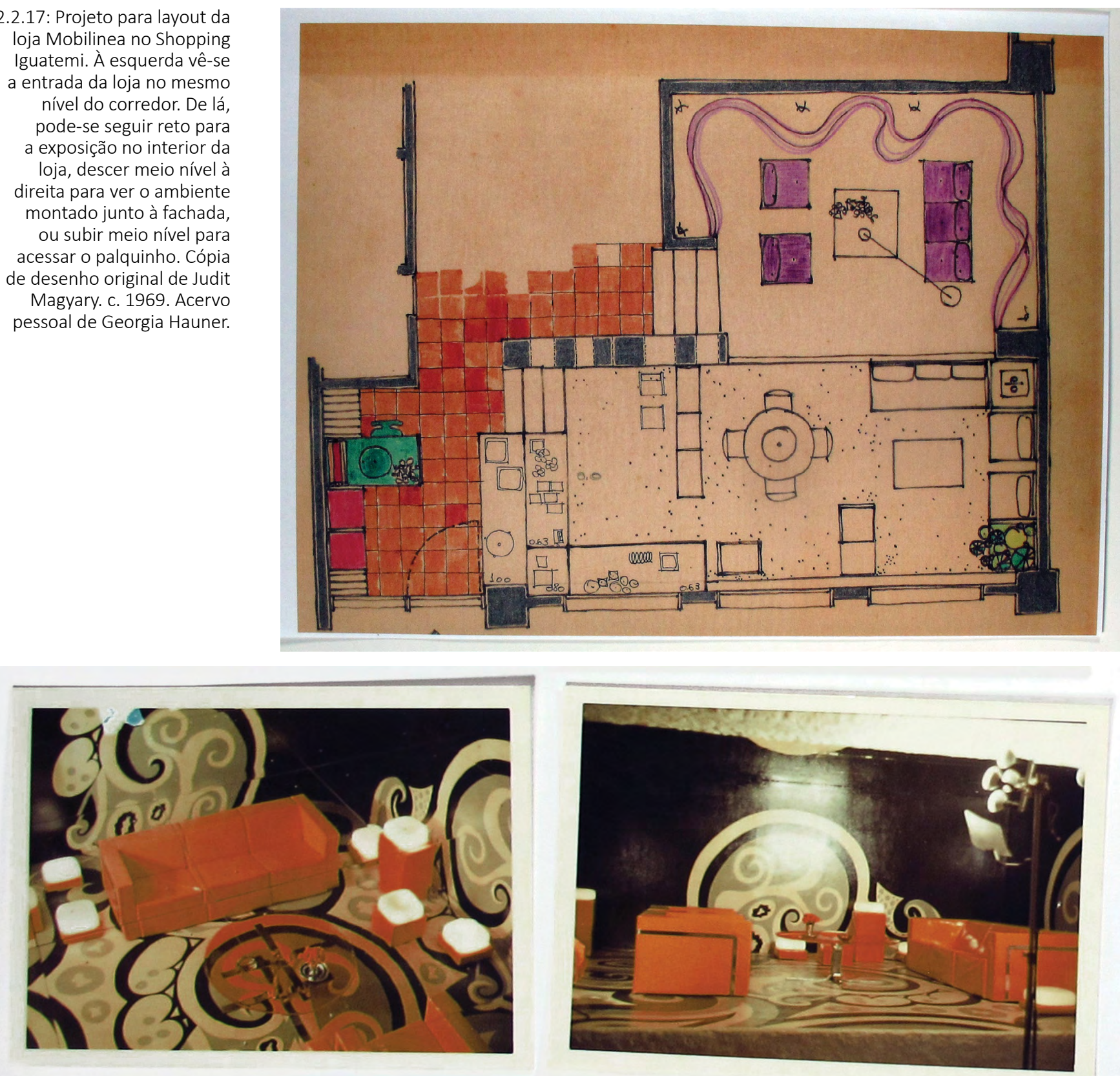

2.2.18: Foto do palquinho com vitrine "psicodélica" visto de outros ângulos, mostrando parte da loja Mobilinea no Shopping Iguatemi e os refletores da fotografia . 1970. Acervo pessoal de Georgia Hauner.
Os ambientes da loja, incluindo seus objetos decorativos, eram também pensados de forma a servirem para imagens publicitárias. Alguns dos acessórios desenvolvidos para a loja do Shopping Iguatemi passaram a ser comercializados regularmente, como tapetes, toalhas e almofadas. Em alguns casos, foram feitas adaptações para este comércio, como no caso das almofadas da "mulher deitada" ou a colcha Romeu e Julieta, ambas criadas por Georgia Hauner, inicialmente bordadas à mão e depois comercializadas com serigrafias [2.2.19; 3.3.01-3.3.02; 3.3.04].

Com o tempo, a importância da comercialização destes objetos decorativos tornou-se tal que todo o pavimento inferior da loja passou a ser exclusivo para sua exposição. Alguns eram fabricados na própria Mobilinea, outros eram deixados em consignação por artistas e arquitetos, e havia ainda peças garimpadas por 
Judit. Ela lembrou-se de caixinhas e pequenos objetos de madeira esculpidos, flores de arame com resina colorida feitos por Wilson Chica e um amigo artista plástico, grandes flores de papel crepom (baseadas em flores de papel típicas do México) feitas por uma mulher identificada como Kathy, objetos de pedra sabão trazidos de Minas Gerais, potes de barro do Alto São Francisco, vasos de vidro quadrados em diversos tamanhos, joias e louças. Judit afirmou que haviam pessoas que iam à Mobilinea no Iguatemi por vezes apenas para comprar estes objetos, pois havia poucas lojas do tipo em São Paulo ${ }^{72}$. A Galeria Mobilinea não teve continuidade no novo endereço, mas sempre houve telas expostas na loja, emprestadas dos sócios da Mobilinea ou pelos próprios artistas, como Paulo Becker, Ubirajara, Aldemir Martins ou Saragoza, que tiveram seus trabalhos divulgados em diversas propagandas da empresa.

Havia quatro vendedoras na loja, uma gerente e uma responsável por apresentar projetos de interiores. As funcionárias que trabalharam lá lembramse da loja estar sempre bastante vazia, pois o shopping à época era pouco visitado como um todo, mas falaram que tornavam o lugar aconchegante e convidativo, exemplificando que no inverno a lareira era acesa e serviam chá a quem entrasse na loja ${ }^{73}$. O público que comprava móveis continuava sendo de um nível social e intelectual mais elevado, e normalmente iam mulheres acompanhadas de arquitetos ${ }^{74}$, os maridos por vezes aparecendo no dia de pagar pela compra. Havia algum estoque das peças que compunham os móveis, mas os acabamentos eram dados conforme pedido, em qualquer combinação dentre as cores e madeiras oferecidas. Os móveis sem revestimento ainda eram bastante populares, mas a identificação com o móvel moderno era através da pintura branca; além disso, parecem ter havido "modas" de outras cores, a exemplo do vermelho ou do verde, por estarem na vitrine ou serem divulgados em algum editorial de revista.

Foram mencionadas ocasiões em que a Mobilinea recebeu clientes ilustres, quando as lojas eram fechadas para recebe-los com exclusividade. Em outras situações, aconteciam eventos que não interrompiam as atividades de venda e até se tornavam um atrativo, como Georgia explicou:

\footnotetext{
O showroom chamava a atenção e tínhamos constantes pedidos para permitir o uso dos nossos ambientes para eventos vários, tais como desfiles de moda, apresentações, reportagens, filmagens e fotografias. Era um lugar de encontro dos clientes com arquitetos e decoradores, artistas que organizavam mostras, John de Souza e Ernesto que encontravam com clientes e amigos. Eu aprontava montagens especiais para fotografias de promoção da MOBILINEA, para revistas de decoração, e de vez em quando para outros clientes. Notei que o público era prestativo, oferecendo-se para segurar um refletor, ou afastar fios de luz que invadiam a passagem de modelos. Havia um clima de colaboração e muito interesse no que estava se passando. Numa ocasião aprontei uma área para a filmagem de uma comedia intitulada: "A Garçonière de Meu Marido". A filmagem era feita durante a noite, mas os vários equipamentos ficavam a vista durante o dia e despertavam muita curiosidade por parte do público. ${ }^{75}$
} 
2.2.19: Ambiente de dormitório na vitrine da loja do Shopping Iguatemi, montado simultaneamente ao palquinho "psicodélico".

1970. Acervo pessoal de Georgia Hauner.
A maior parte destes eventos no shopping não tiveram registros, mas foram localizadas imagens no acervo pessoal de Georgia Hauner da montagem da fotografia do palquinho e do ambiente de quarto, que estava na vitrine rebaixada neste mesmo período [2.2.18-2.2.19].

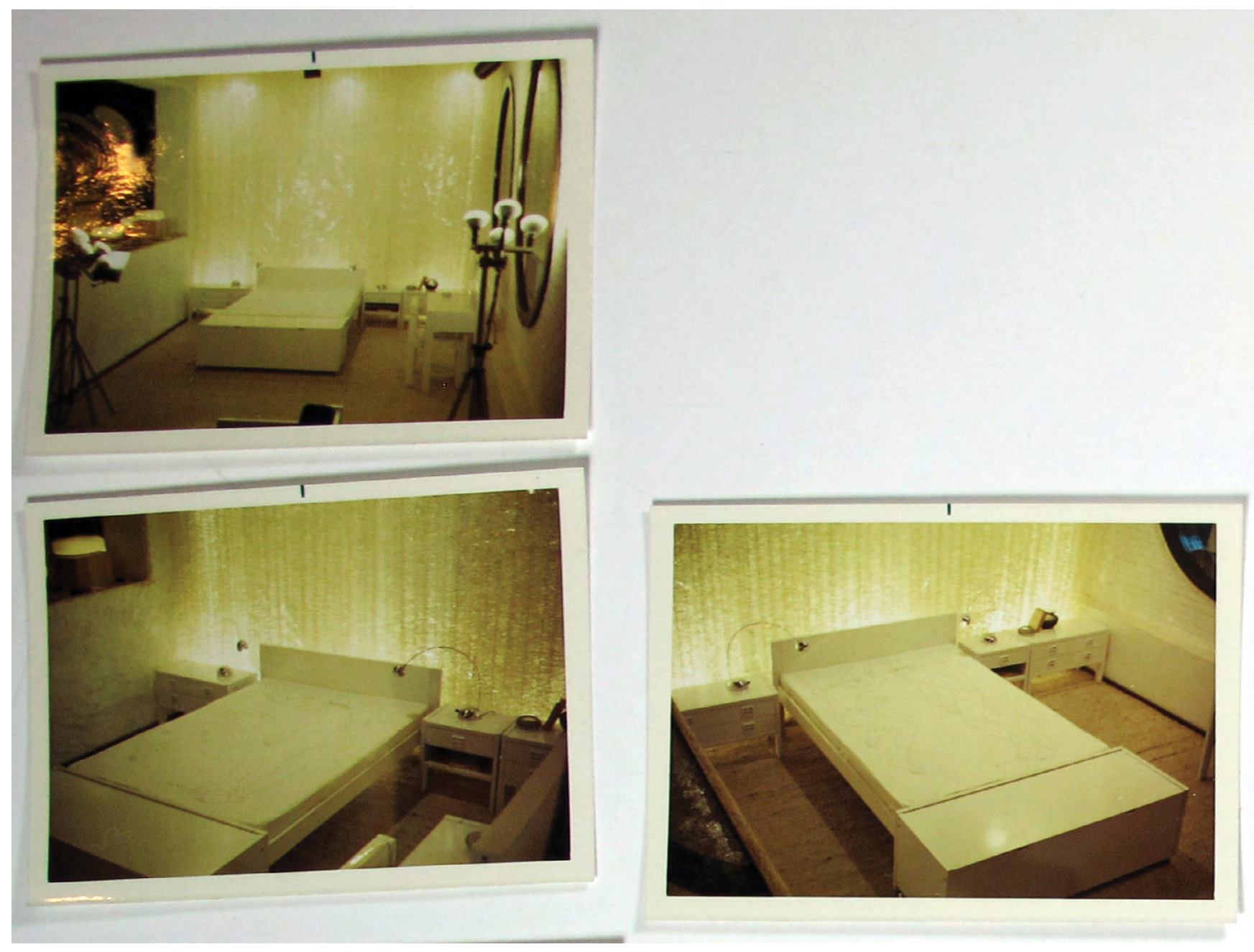

A filmagem a que Georgia Hauner se refere é um dos três episódios do filme "A Arte de Amar... Bem", dirigido por Fernando de Barros e lançado em 1970, intitulado “A Garçonière de meu Marido”. Nele,

Gardênia descobre que seu marido, o piloto de provas Iseu, tem uma garconière. Vai até lá com sua amiga Vivinha e fica admirada com o luxo do ambiente e resolve vestir um peignoir e se maquilar glamurosamente. Quando Iseu chega pensa que sua mulher é uma desconhecida e tenta conquistá-la. Gardênia faz um escândalo, mas termina cedendo à paixão de Iseu, um homem muito diferente daquele que conhece no lar. O casal resolve encontrar-se sempre na garçonière, para o desespero dos outros participantes e criando graves problemas para um teleator e sua mulher. ${ }^{76}$

A garçonière descrita nesta sinopse é caracterizada no filme pela personagem Gardênia como um lugar "tão diferente de casa... Tão bom, tão caro, tão chique!?77, e era a loja da Mobilinea. Como visto em um dos pôsteres 
de divulgação, o set foi montado no ambiente da lareira, com móveis laqueados em branco, capas de estofados turquesa e almofadas verdes [2.2.20]. A fala de Gardênia é muito significativa porque revela uma visão talvez comum de que um espaço como aquele tinha algo de novo e diferente, ao mesmo tempo que desejado, e neste desejo entravam ideias de que esta vida moderna estava aliada a um padrão de vida mais elevado.

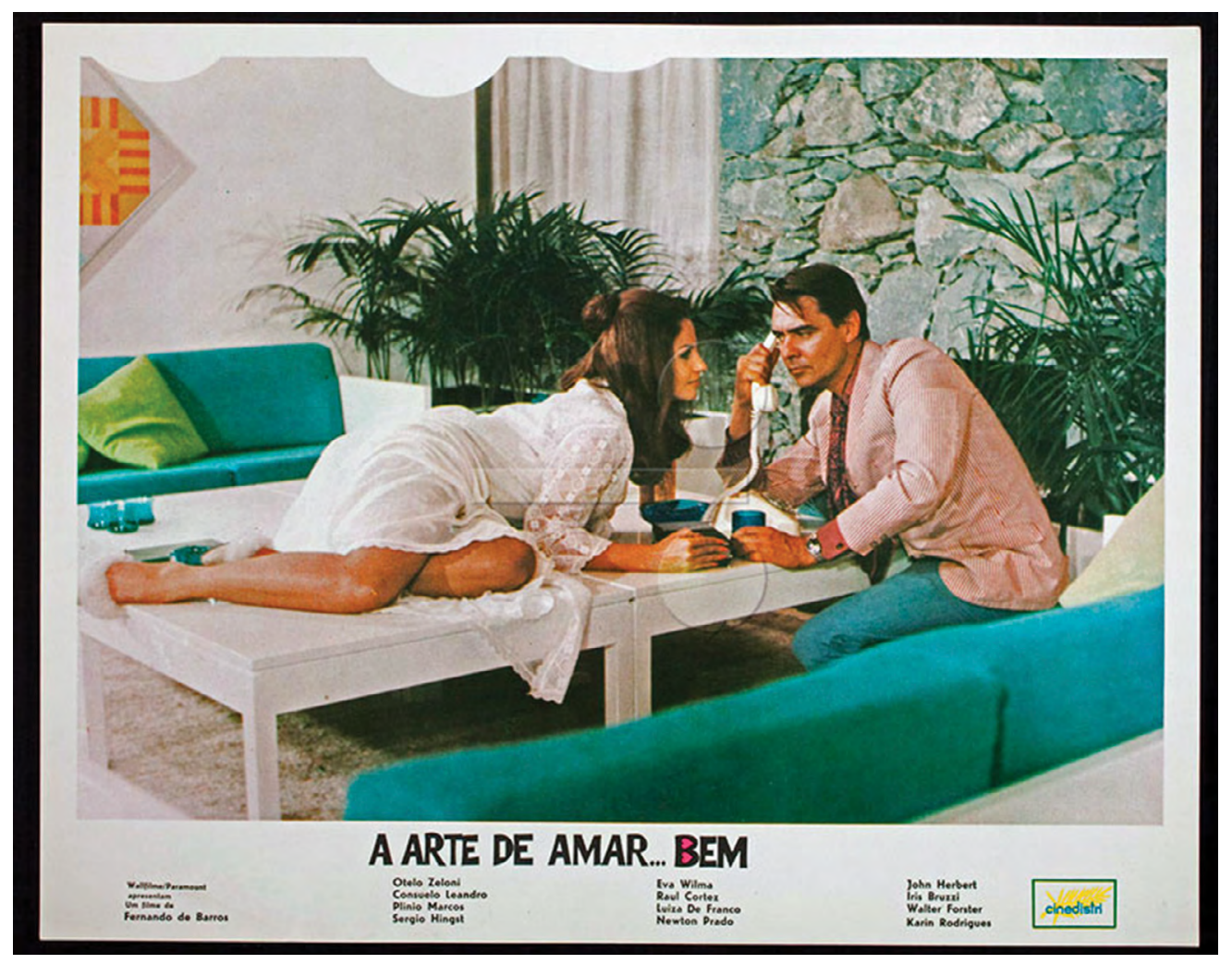

2.2.20: Pôster do filme "A Arte de Amar... Bem". 1970. Acervo digital da Cinemateca Brasileira.

De fato, mesmo sem ter móveis que chegassem a preços populares, Mobilinea continuava prosperando. Uma nova expansão dos pontos de venda fora divulgada em março de 1968 em Casa \& Jardim, citando, além dos quatro endereços em São Paulo (a fábrica na Rua do Bosque e as lojas na Rua Augusta, Zarvos e Shopping Iguatemi), da loja no Rio de Janeiro e das revendas em Belo Horizonte e Salvador ${ }^{78}$ : revenda em Belém na loja Casabella, à Avenida Governador José Malcher, 1693, no bairro de Nazaré; e na loja ARC Decorações, à Praça Tubal Vilela, 30, no centro de Uberlândia. No ano seguinte, se desvincularam da revenda em Belo Horizonte e abriram uma loja própria na capital mineira, à Rua Afonso Pena, 1723, também no centro da cidade e uma revenda no Recife à Rua do Hospício, 208, na Boa Vista, na loja L. C. Andrade. Houve ainda um endereço em Porto Alegre, que viria a se estabelecer mais solidamente apenas em 1971 na loja Sergio Mendes Ribeiro \& Cia. à Rua Professor Oscar Pereira, 209, Azenha, e um ponto de revenda em Manaus, à Rua Monsenhor Coutinho, 848, no centro, mas que foi divulgado apenas ao longo de 1968. 
2.2.21: Catálogo para vendas KX Mobilinea. À esquerda ao telefone de vestido preto, Bibita; ao seu lado direito, de rosa e acessando uma gaveta, Giselda; atrás delas, de vermelho, Jazel conversando com dois funcionários da fábrica; ao fundo no centro, de rosa, Judit; servindo café à direita, Maria, faxineira da loja do Shopping Iguatemi; à direita na frente, Gisela de laranja conversando com Colominas. Não foi possível identificar os demais personagens ${ }^{79}$. Sem data. Acervo pessoal de Georgia Hauner.
O certo é que uma década após sua fundação, Mobilinea chegou a ter suas peças comercializadas em onze endereços de oito estados brasileiros quase simultaneamente, com algumas tentativas de expansão internacional. Um panfleto da empresa mexicana Lopes Morton, que iria comercializar móveis de escritórios da Mobilinea sob o nome KX Mobilinea, é interessante não só por apresentar toda a linha, mas principalmente porque nela estão muitas das vendedoras da Mobilinea, que não raro eram chamadas para posarem como modelos nas fotos de divulgação. Judit ajudava Georgia nas produções e normalmente levava algum figurino especial, mas Bibita disse que ela e as outras vendedoras eram chamadas durante o expediente, de forma que eram retratadas com a roupa que estivessem usando para trabalhar. Assim, é seguro dizer que um cliente que entrasse na loja da Mobilinea seria atendido por mulheres jovens, de vestidos curtos em cores fortes, representando elas mesmas este ideal de modernidade que se buscava veicular com os ambientes das lojas [2.2.21].

Em São Paulo, a loja da Rua Augusta funcionou até o final de 1969 e, pelo que as entrevistas relatam, a decisão de desativá-la se deu porque a loja do Shopping Iguatemi havia se consolidado como o endereço sede dos móveis

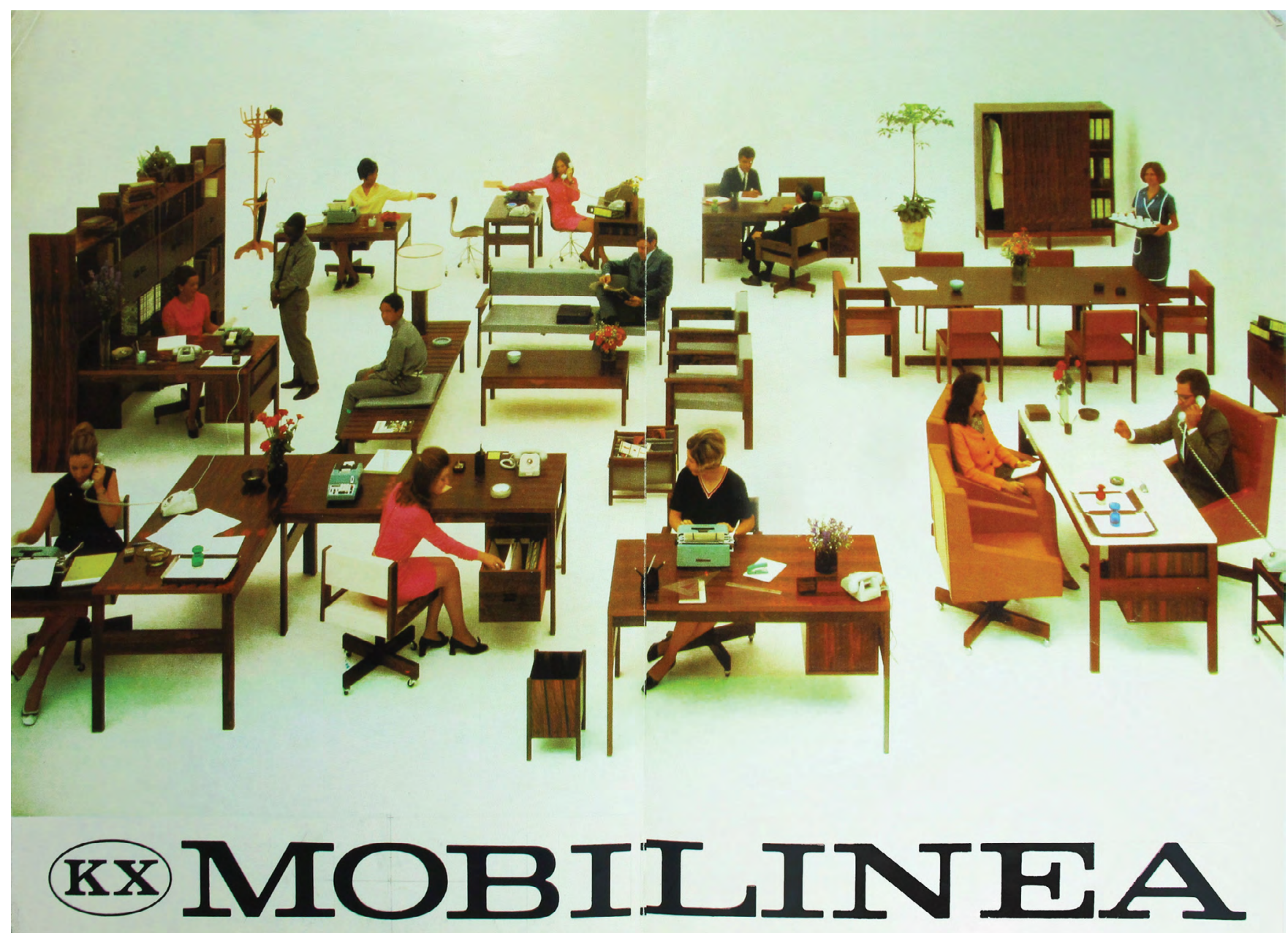


residenciais Mobilinea. Por outro lado, o ponto na Zarvos seguia estável e um novo endereço da linha de escritórios foi inaugurado na galeria do Edifício Louvre, à Avenida São Luís, no número 192, conjunto 27, em 1970. Segundo Georgia,

\begin{abstract}
Na Galeria Zarvos da Av. S. Luís, fiz exposições com grandes pinturas nas paredes e teto. Os escritórios se tornaram mais personalizados e menos austeros. Depois de alguns anos, o espaço da Zarvos ficou insuficiente para as nossas exposições e projetei uma loja maior, em outro prédio da Av. S. Luís. No projeto novo, fiz uma escada aberta, quadrada, que subia para um mezanino, também aberto. Para evitar a linha horizontal de um corrimão, fiz a proteção com fios de arame esticados entre teto e piso, parecendo cordas de harpa, ou violão. Ficou bonito, pois os fios refletiam a iluminação. Durante as obras descobri que atrás da parede de fundo existia um triangulo de espaço descoberto, entre o nosso e os prédios vizinhos. Uma investigação revelou que o espaço estava disponível. Então aproveitei para pôr caixas com plantas e trepadeiras para subir nas paredes de concreto e transformar aquilo num pequeno jardim, acessível da exposição. ${ }^{80}$
\end{abstract}

Em 1972, esta loja pegou fogo em um incêndio no Edifício Louvre, conforme divulgado em A Folha de São Paulo em 8 de dezembro:

\begin{abstract}
Pelo menos 25 lojas, das 48 instaladas na parte térrea e na sobre-lojas do Edifício Louvre, na avenida São Luís, 192, foram atingidas ontem por um incêndio que começou um pouco depois da zero hora, por causas que até agora não foram esclarecidas. Das 25 (a maioria firmas de investimentos e de turismo) seis foram totalmente destruídas: quatro pertencentes a Haspa, uma organização de crédito, financiamento e investimento, uma à Nacional Turismo e a outra a Mobilinea. ${ }^{81}$
\end{abstract}

Segundo Ada Hauner, o estrago na Mobilinea resumiu-se a tapetes e papeis molhados e, como a loja continuou sendo listada em endereços depois disso, supõe-se que foi possível recuperá-la. Já a fábrica passava por pequenas adaptações em função de novas peças ou demandas, mas o impacto maior foi com a introdução do sistema Prêt-à-Porter, que implicava não só na compra de maquinário novo, mas em uma nova gestão da produção, e o sistema de pronta entrega, pelos relatos, funcionou bem. A fábrica havia se mudado, ou expandido, da Rua do Bosque para a Avenida do Emissário ${ }^{82}$, 668, também Barra Funda, no final da década de 1960, e logo em seguida teve início a construção de uma nova fábrica no bairro do Campo Limpo, rua C, s/n ${ }^{83}$, que seria inaugurada em 1973.

Uma série de mudanças mais amplas estava tomando corpo na Mobilinea neste período com a entrada de novos sócios, dentre as quais a mais significativa foi a decisão de construir a Home Store, inaugurada também em 1973. Isso significou não só um investimento grande, como um reposicionamento da marca e, com ele, houve uma reestruturação de todos os pontos de venda da Mobilinea. Os endereços das lojas na Galeria Zarvos, em Belo Horizonte, Uberlândia, Belém, Porto Alegre e Recife foram divulgados pela última vez em junho de 1972 em Casa $\mho$ Jardim $^{84}$, fechando um ciclo importante na história da empresa. Intui-se que essa decisão tenha sido tomada para cortar gastos em função do novo empreendimento, mas parece ter sido uma escolha mais conceitual do que financeira. 
No ano seguinte, as publicações sobre a Mobilinea divulgaram quase exclusivamente o endereço da Home Store, à exceção de uma reportagem em Claudia Decoração de julho de 1973, onde todas as lojas em funcionamento foram listadas: em São Paulo permaneciam as lojas do Edifício Louvre e do Iguatemi; no Rio de Janeiro, a loja não só fora mantida, como ampliada, além de abrirem um segundo endereço à Avenida Nilo Peçanha, 23, 13ํandar, conjunto 1302. Além disso, reapareceram cidades em que a Mobilinea já havia atuado, mas em novos endereços, sempre em regiões centrais e valorizadas das cidades: em Salvador, à Rua Conselheiro Dantas, 3; em Belo Horizonte à Rua da Bahia, 1182/1196; e em Porto Alegre à Rua General Câmara, 156. Finalmente, inauguraram pontos de venda em duas novas cidades: Brasília, na CLS 302 Sul, Bloco D; e Curitiba, à Rua Emiliano Perneta, 476. Em nenhum destes endereços está indicado algum nome de revenda, podendo-se supor terem sido todas lojas próprias, ou em algum sistema de franquia.
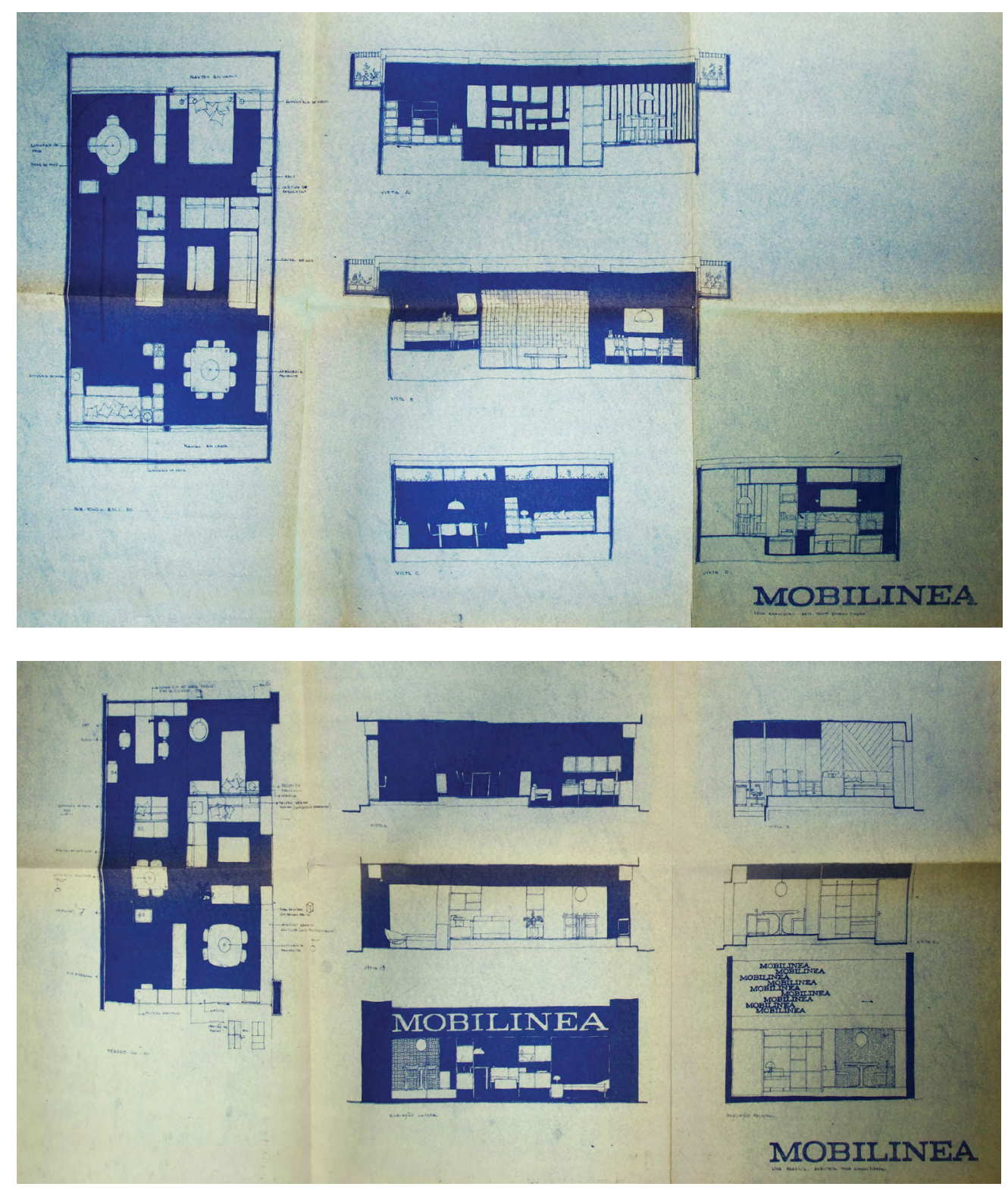
No caso de Brasília é possível comprovar a centralização na gestão pois foram encontrados projetos realizados por Georgia Hauner e Yone Koseki Pierre para sua fachada e ocupação interior. De forma simplificada, os layouts propostos refletem o mesmo raciocínio de ocupação vistos nas imagens do Iguatemi, como pisos elevados, revestimentos em algumas paredes de destaque, composições com quadros e uso de vegetação, além de uma disposição dos móveis sugerindo ambientes domésticos reais [2.2.22-2.2.23].

Depois de 1973, até a loja do Shopping Iguatemi deixou de ser mencionada em propagandas, restando apenas a Home Store e a loja do Edifício Louvre, mas não há por que imaginar que os espaços em outros estados tenham sido fechados. De todo modo, neste momento Ernesto e John estavam deslocados de um papel decisório nos rumos da empresa, e muitas das funcionárias que haviam tido uma participação ativa nas lojas ao longo dos últimos anos foram demitidas ou se afastaram, o que encerrava aquela maneira de construir e vender os ambientes da Mobilinea e aquela forma de expansão da empresa.

Apartirdolevantamentodeperiódicosfoipossívelmapearofuncionamento das lojas que vendiam móveis da Mobilinea nas diversas cidades brasileiras ao longo destes anos, incluindo uma curiosa aparição em um anúncio de maio de $1972^{85}$ do hipermercado da rede Pão de Açúcar, Jumbo Aeroporto, mas que não teve continuidade [2.2.24].
2.2.24: Funcionamento das lojas e fábricas da Mobilinea entre 1960 e 1975, realizado a partir do levantamento de periódicos. 


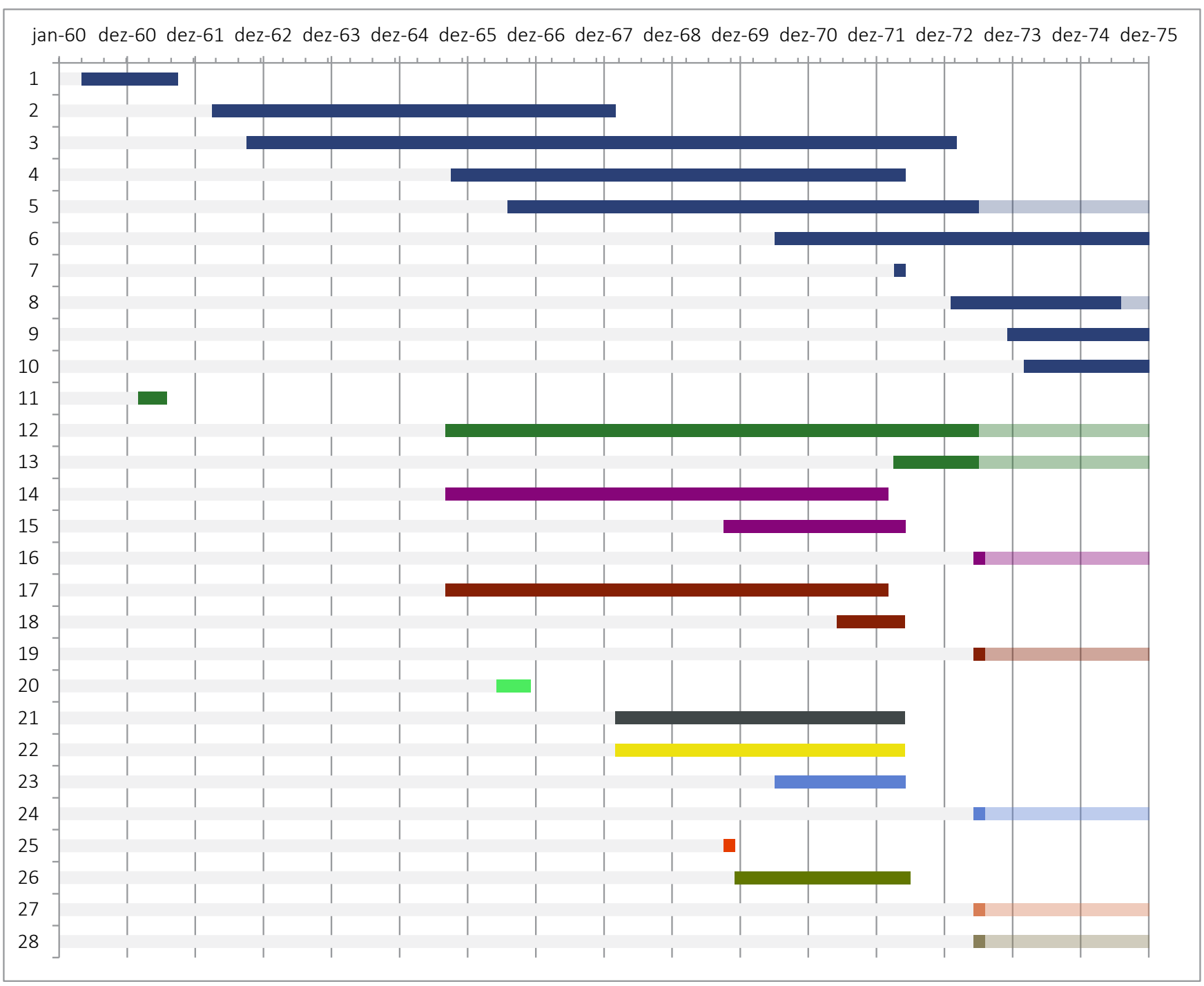

1. São Paulo (fábrica): Rua Vitorino Carmilo, 62, Barra Funda

2. São Paulo (fábrica): Rua do Bosque, 1782, Barra Funda

3. São Paulo (loja própria): Rua Augusta, 875 , Consolação

4. São Paulo (loja própria): Galeria do Conjunto Zarvos, Avenida São Luís, 258, conjuntos 34 e 36, Centro

5. São Paulo (loja própria): Shopping Iguatemi, Rua Iguatemi, 1191, loja T3-L3, Jardim Paulistano (atual Avenida Brigadeiro Faria Lima, 2232)

6. São Paulo (loja própria): Galeria do Edifício Louvre, Rua São Luís, 192, Centro

7. São Paulo (revenda): Jumbo Aeroporto, Avenida Washington Luís, 5859, Jardim Aeroporto

8. São Paulo (fábrica): Avenida do Emissário, 668, Barra Funda (provavelmente atual Avenida Antártica)

9. São Paulo (loja própria): Home Store, Avenida Nove de Julho, 5955, Jardim Paulista

10. São Paulo (fábrica): Rua C, s/n, Campo Limpo

11. Rio de Janeiro (revenda): Galeria Penguin, Rua República do Peru, 143-A, subsolo, Copacabana

12. Rio de Janeiro (loja própria): Rua Montenegro, 74, Ipanema (atual Rua Vinícius de Moraes)

13. Rio de Janeiro (loja própria): Avenida Nilo Peçanha, 23 13ㅇ andar, conjunto 1302, Centro

14. Belo Horizonte (revenda): Morada Arquitetura de Interiores, Rua dos Tamoios, 200, 70 andar, Centro
15. Belo Horizonte (loja própria): Rua Afonso Pena, 1723, Centro

16. Belo Horizonte (loja própria): Rua da Bahia, 1182/1196, Centro

17. Salvador (revenda): Móveis Ralf, Avenida 7 de Setembro, 249, 2 de Julho

18. Salvador (revenda): Iluminação de Ambientes, Avenida 7 de Setembro, 227, 2 de Julho

19. Salvador (loja própria): Rua Conselheiro Dantas, 3, Centro

20. Goiânia (revenda): Taba Móveis e Decor, esquina das Ruas 23 e 4, Centro

21. Belém (revenda): Casabella, Avenida Governador José Malcher, 1693, Nazaré

22. Uberlândia (revenda): ARC Decorações, Praça Tubal Vilela, 30, Centro

23. Porto Alegre (revenda): Sergio Mendes Ribeiro \& Cia., Rua Professor Oscar Pereira, 209, Azenha

24. Porto Alegre (loja própria): Rua General Câmara, 156, Centro

25. Manaus (revenda): Tapira Móveis, Rua Monsenhor Coutinho, 848, Centro

26. Recife (revenda): Detalhe/L. C. Andrade, Rua do Hospício, 208, Boa Vista

27. Brasília (loja própria): CLS 302 Sul, Bloco D

28. Curitiba (loja própria): Rua Emiliano Perneta, 476, Centro 


\subsection{Das parcerias à Home Store}

Ao longo de sua trajetória, Mobilinea buscou inserir seus móveis em um repertório mais amplo de revestimentos, objetos de design e arte, a exemplo da criação da Galeria Mobilinea ainda em 1963. Trouxe também móveis de outras empresas para suas lojas, como as cadeiras Thonet e Dinamarquesa, e mais tarde a linha de escritórios Linder, apropriando-se dos atributos de todas essas peças em seus ambientes.

No caso das cadeiras Thonet, em produção no Brasil naquele momento há pelo menos setenta anos, pode-se imaginar uma dupla significação, pois, se por um lado as peças torneadas poderiam remeter às casas em que os compradores da Mobilinea tivessem crescido, aludindo a algo conhecido e memórias afetivas; por outro, sua síntese projetual dialogava diretamente com o partido dos móveis desenhados por Ernesto Hauner [2.1.11]. A Dinamarquesa também se enquadrava nesta segunda interpretação, e sua origem escandinava era em si um atrativo para muitos dos compradores que acompanhavam as tendências da produção internacional [2.1.12]. A linha de escritórios Linder, por sua vez, tinha um aspecto futurista com o uso de materiais frios, lisos e plásticos, diferente da linha em chapa de madeira, mas coerente com as ideias da Mobilinea tendo em vista os móveis em aço e fiberglass, de forma que complementava bem sua cartela de produtos [2.1.32].

A partir deste mesmo raciocínio, outras marcas incorporaram peças da Mobilinea em suas promoções, dando boas indicações de como ela era percebida e quais os valores se buscava tomar emprestado. Vidrobrás, fabricante nacional de vidros, foi um destes casos: a empresa atingira alguma projeção na segunda metade de década de 1960, com participações na Feira UD e propagandas em Casa \& Jardim ao longo de 1969, em uma das quais encontramos banco e mesa de centro Mobilinea dispostos de maneira fiel à estética de suas lojas e propagandas, com objetos decorativos e frutas ${ }^{86}$ [2.3.01].

Não foi possível esclarecer se a direção de arte foi feita por funcionários da Mobilinea e não há nenhuma indicação da marca no anúncio, mas eram peças comumente divulgadas, tendo sido usada a mesma paleta de cores em um editorial feito pela Mobilinea para Casa $\mho$ Jardim em março de 1968, de forma que um leitor atento seria capaz de identificar sua autoria [3.3.04]. Nesta imagem, 
Vidrobrás introduziu seu produto em um cenário natural, mostrando a dimensão e a transparência de suas peças, mas trazendo a perspectiva doméstica pelo mobiliário, que, não obstante, dava a mesma sensação de avanços tecnológicos e modernidade do discurso sobre os vidros. Vale notar que em outra propaganda desta mesma campanha ${ }^{87}$, Vidrobrás fotografou seu produto em uma praia com uma modelo de biquíni e touca, olhando para cima como se estivesse contemplando o futuro, o que ajuda a embasar esta análise [2.3.02].

2.3.01: Propaganda Vidrobrás - O vidro existe para que $V$. possa aproveitar ao máximo o privilégio de viver na terra. Casa \& Jardim. p. 89. abr. 1969.

2.3.02: Propaganda Vidrobrás - Só o vidro traz para a sua vida a natureza como cenário e o céu como dimensão. Casa \& Jardim. p. 7. set. 1969.
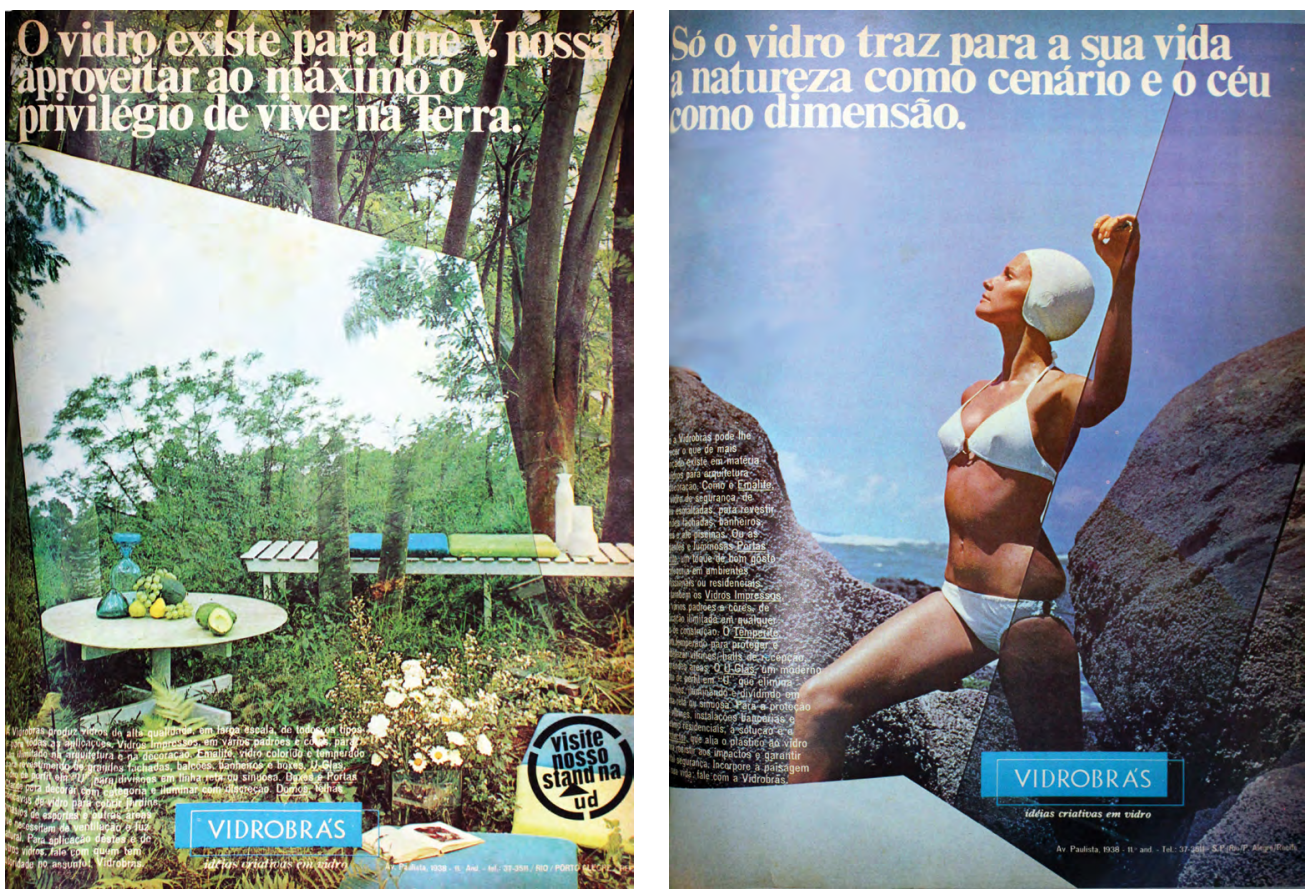

Outra parceria desta natureza se desenvolveu a partir de dezembro de 1969, quando Georgia Hauner fez um editorial em Claudia em que construiu a sala ideal para se ouvir música, com um sistema de som Gradiente desenvolvido especialmente para este projeto ${ }^{88}$. Com isso, estabeleceu-se um contato entre a empresa e a Mobilinea, que viria a culminar na associação na Home Store, mas também em um interessante editorial publicado em junho de 1972 em Casa \& Jardim. Nele, foram apresentados sistemas de som para o lar a partir de uma iniciativa conjunta das duas empresas, fotografada na loja do Shopping Iguatemi ${ }^{89}$. A primeira e a terceira foto retratam um casal em ambientes de estar e escritório com móveis Prêt-à-Porter em Amendoim, portando-se de maneira descontraída, enquanto os textos ressaltam as qualidades dos equipamentos Gradiente e dos móveis da Mobilinea, afirmando a afinidade entre as marcas. A segunda foto mostra um quarto de adolescente com móveis Prêt-à-Porter em branco e vermelho, um grande mural geométrico na parede, muitos discos e equipamentos de som nas estantes e, deitado sobre a cama, sem camisa ou sapatos, um jovem com fones de ouvido - que era Mike Hauner, filho de Georgia e Ernesto [2.3.03]. Diz o texto: 


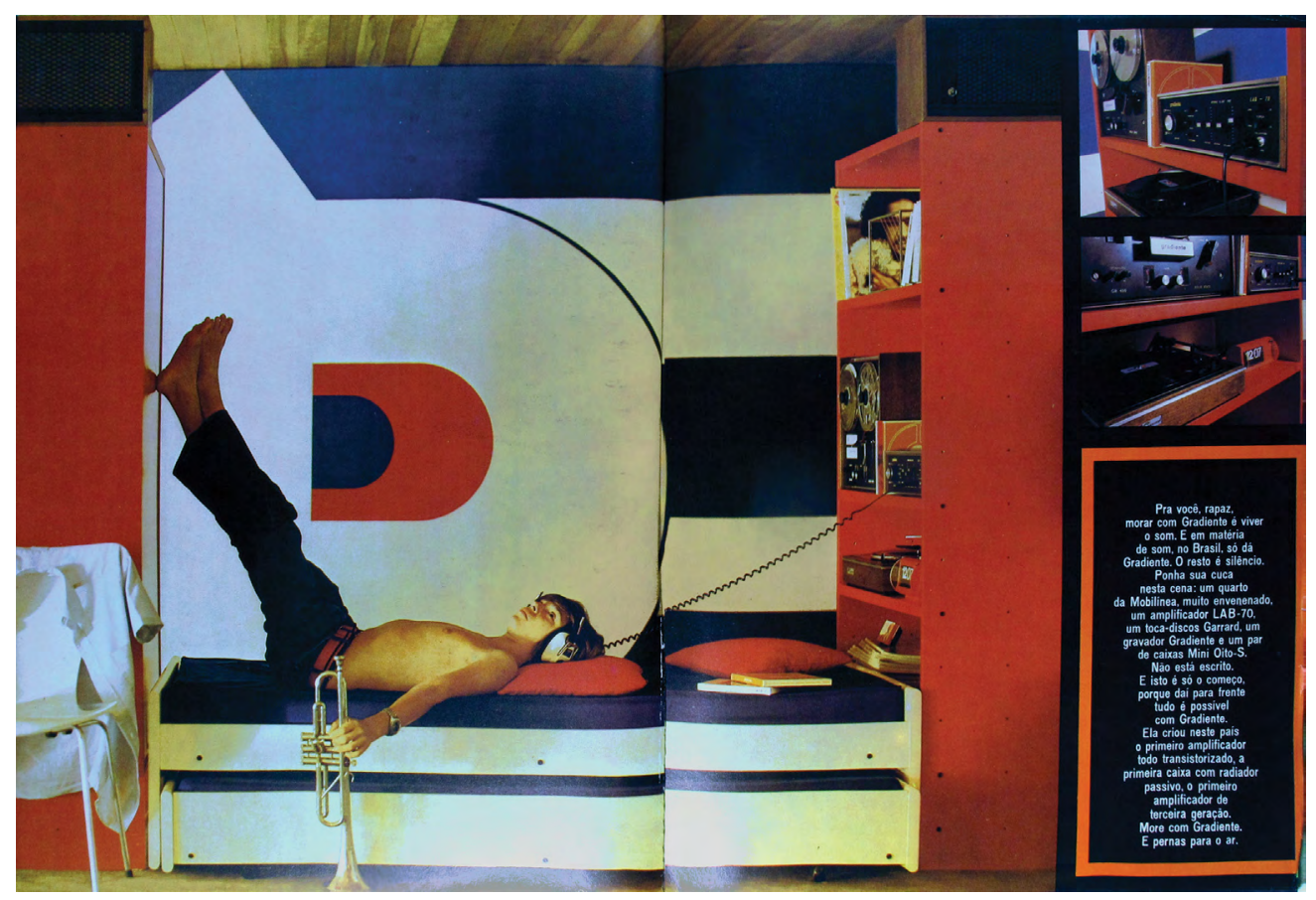

2.3.03: Mike Hauner em dormitório Mobilinea com equipamentos de som Gradiente. "O Som em Sua Casa". Casa \& Jardim. jun. 1972.

Pra você, rapaz, morar com Gradiente é viver o som. E em maneira de som, no Brasil, só dá Gradiente. O resto é silêncio. Ponha sua cuca nesta cena: um quarto da Mobilinea, muito envenenado, um amplificador LAB-70, um toca-discos Garrard, um gravador Gradiente e um par de caixas Mini Oito-S. Não está escrito. E isto é só o começo, porque daí para frente tudo é possível com Gradiente. Ela criou neste país o primeiro amplificador todo transistorizado, a primeira caixa com radiador passivo, o primeiro amplificador de terceira geração. More com Gradiente. E pernas para o ar. ${ }^{90}$

Considerações mais alongadas sobre a produção de imagens serão feitas no próximo capítulo; o que interessa aqui é pensar que um garoto moderno, um quarto "muito envenenado" e o que havia de mais novo tecnologicamente em matéria de som estavam associados em uma mesma cena, de forma que os valores individuais de cada um destes elementos assumia uma nova dimensão que incorporava os três conjuntamente.

A maior prova doimpacto que esta parceria teve pode ter sido outra empresa de aparelhos de som também promover seus produtos junto à Mobilinea, talvez buscando os mesmos resultados conseguidos pela concorrência. Em maio de 1973, a empresa Matsushita lançou, através de sua marca National ${ }^{91}$, o aparelho 3-em-1, que unia rádio, toca-discos e gravador de cassete em um anúncio de meia página em maio em A Folha de São Paulo ${ }^{92}$, no qual declaravam:

O rádio, o toca-discos e o gravador sempre estiveram muito perto um do outro. Nós apenas demos um empurrãozinho. Com esse empurrãozinho, nós juntamos num lugar só, todas as maneiras que existem para você ouvir música, longe de quem está fazendo música. E para que essa maravilhosa invenção não ficasse como privilégio de uma minoria, criamos uma linha inteira de aparelhos. A linha Nacional 3 em 1. Cada um deles tem uma missão a cumprir. La Grande, o SG-1050 A, vai ficar no alto de uma linda estante Mobilinea, animando reuniões de amigos no sábado à noite. (...) La Grande tem um sistema de desligamento automático que sabe o que fazer quando você está dormindo. É tão bonito quanto as estantes onde você vai colocá-lo. (...) A linha National 3 em 1 deve ser uma das coisas mais importantes 
2.3.04: Propaganda National -3 em 1. A Folha de São Paulo. p. 13, Primeiro Caderno. 31 maio 1973. que aconteceram com o rádio, o toca-discos e o gravador desde que inventaram os Beatles. O mundo é feito por empurrõezinhos. ${ }^{93}$

O mais curioso é que as imagens da propaganda não têm nenhuma indicação da Mobilinea [2.3.04], de forma que a mera sugestão de seu nome já teria valor, o que era, evidentemente, uma construção consciente.

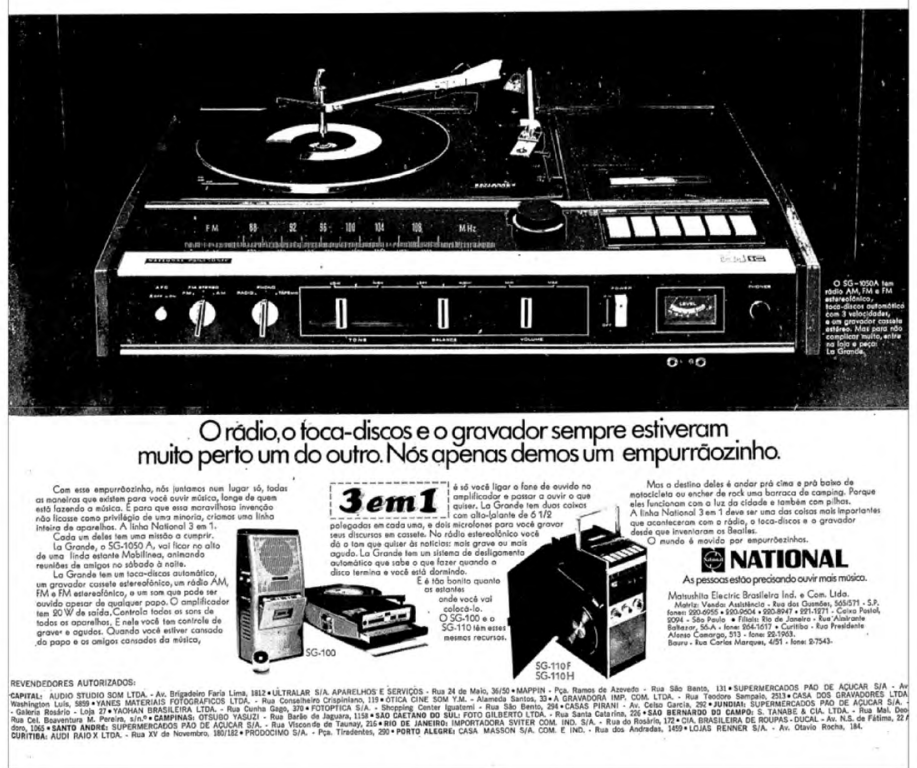

Assim, é interessante compreender como a empresa se apresentou para construtoras e incorporadoras de empreendimentos residenciais no início dos anos 1970, ao propor uma parceria elaborando apartamentos decorados:

\begin{abstract}
Por quê Mobilinea?
Para acompanhar o vasto campo criado pelas novas construções, Mobilinea está entrando agora em uma nova fase, com a instalação de uma fábrica moderníssima em Campo Limpo. Durante estes 10 anos de existência, sempre dando as melhores soluções para o aproveitamento de espaços, conseguimos uma posição profissional no mercado. Deixando de lado todo e qualquer amadorismo dedicamo-nos sériamente à pesquisa de produtos. Para um móvel ser Mobilinea, teve que passar antes, por um processo total de análise e estudos realmente sérios. Estuda-se o espaço que determinado móvel vai "criar", a "performance" que vai ter num ambiente, e sobretudo que influências vai exercer sôbre o indivíduo. E como traduzir tudo isso em benefícios para a construtora? Colocando Mobilinea, obtémse a atmosfera sob medida para o apartamento em exposição, não apenas uma simples "decoração." Pensando bem, quantas firmas têm capacidade de elaborar este tipo de trabalho? ${ }^{94}$
\end{abstract}

Precisamente neste momento, Mobilinea se lançava a um novo patamar no mercado através da construção da fábrica no Campo Limpo e do lançamento da linha Prêt-à-Porter, então parece fazer sentido que houvesse a possibilidade e talvez certa necessidade de expandir seu público. Associar-se a empresas de construção civil era uma opção interessante, pois reconhecia um potencial para aumentar as vendas de suas próprias peças, já que os compradores poderiam buscar soluções semelhantes às que viam nos estandes imobiliários. 
$\mathrm{Na}$ sequência do texto, Mobilinea se propunha a elaborar um projeto completo, que compreendia seus móveis de linha e "acessórios" - "objetos e móveis de terceiros, conforme o projeto apresentado" -, além da montagem e desmontagem dos ambientes no apartamento:

\begin{abstract}
O projeto apresentado pela Mobilinea, além de solucionar racional e originalmente o problema de espaço, será estudado a fim de sensibilizar psicológicamente a faixa de compradores indicada pela construtora. O apartamento será entregue decorado, com tudo colocado no lugar, inclusive sabonetes, toalhas, etc., para criar um clima mais pessoal e uma visão mais real do conjunto. ${ }^{95}$
\end{abstract}

A noção proposta pela Mobilinea de que seus ambientes tinham um impacto psicológico remete à ideia da divulgação de um estilo de vida desejável, não apenas pelo tipo de móvel escolhido ou objeto decorativo usado, mas na própria dinâmica familiar que se imaginaria ali. Neste mesmo material de divulgação, Mobilinea anexou a planta de um apartamento com três dormitórios, sala de estar, jantar e cozinha ocupados com peças da empresa, dando indicações de acabamento e decoração [2.3.05]. Ao final, havia ainda alguns cartões com fotos das peças usadas.
2.3.05: Planta de apartamento decorado com móveis Mobilinea em brochura de apresentação para construtoras. c. 1972. Acervo pessoal de Georgia Hauner.

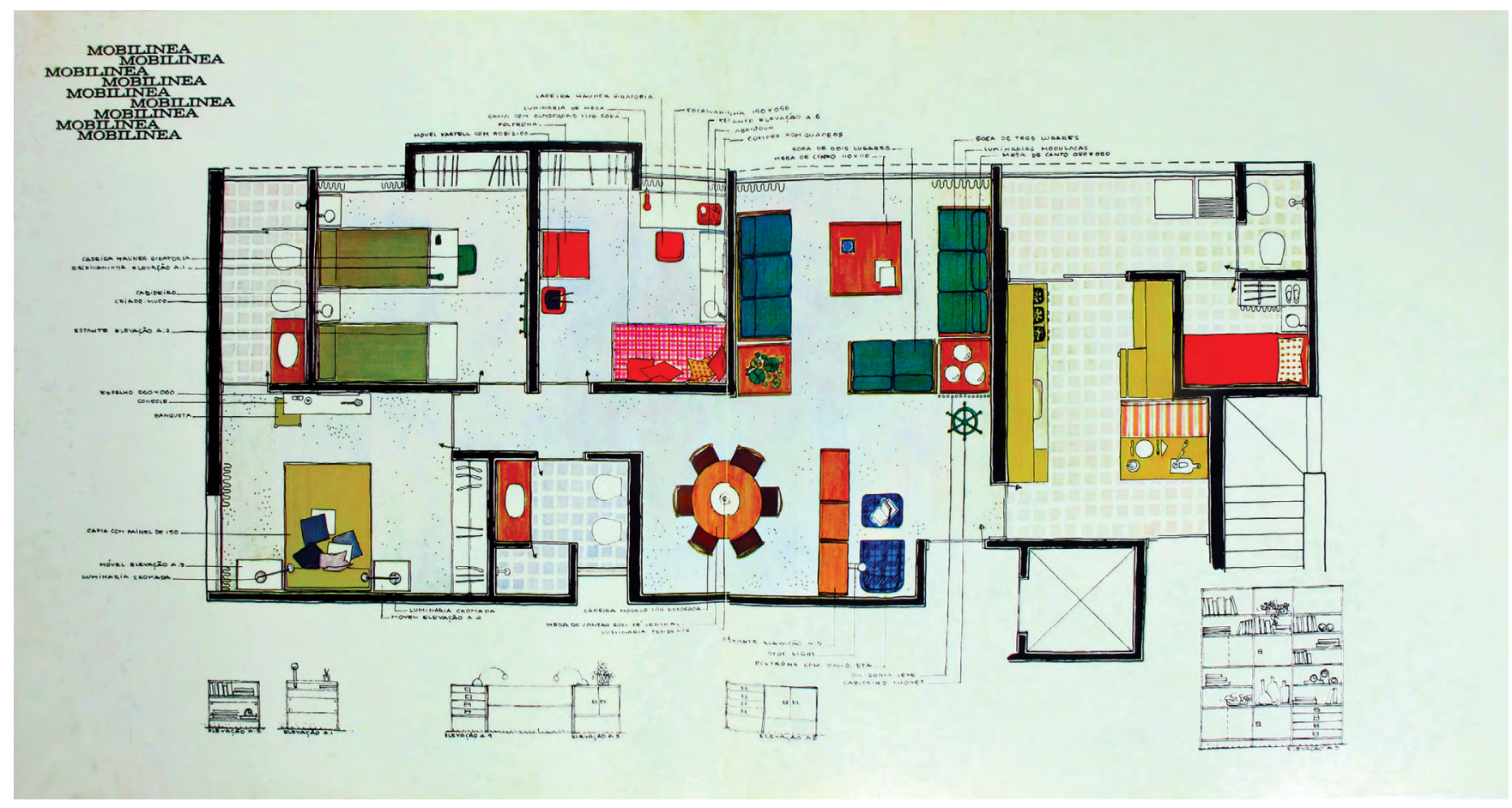

Embora com poucos dados, é possível aferir que foram realizados trabalhos deste tipo com ao menos duas construtoras paulistanas: Construhab e Formaespaço. Da primeira, dois lançamentos imobiliários com apartamentos decorados pela Mobilinea foram divulgados em diversas propagandas no jornal A Folha de São Paulo entre 1972 e $1973^{96}$, a começar pelo Condomínio Edifício Juruá, à Rua do Oratório, 522, na Mooca. A campanha foi elaborada para 
mostrar como este imóvel tinha características de empreendimentos similares nos bairros de Pinheiros ou Jardim Paulista, embora estivesse na Zona Leste. Os prédios da Construhab eram modernos, com estrutura modular e fachadas despidas de revestimentos, e este lançamento seguia este mesmo padrão. Havia três apartamentos decorados: um feito pela Mobilinea, um pela Mobília Contemporânea e um por Henri Matarasso, dentre os quais Mobilinea era a mais cara e com aspecto mais sofisticado, Mobília Contemporânea tinha móveis modernos mais simples, e Henri Matarasso produzia móveis em estilos históricos diversos, denotando a permanência de certos gostos e padrões e uma dissociação entre arquitetura e interiores, ao menos para este grupo social.

Já no lançamento do Condomínio Edifício Cayowáa, no número 2251 da rua homônima, em Perdizes, as empresas chamadas por Construhab para fazer apartamentos decorados foram Mobilinea, Forma, Oca, Mobília Contemporânea e Arredamento. Nesse grupo, Mobilinea está numa faixa média de preço, acima de Mobília Contemporânea, similar à Arredamento, e abaixo de Oca e Forma. O bairro, as empresas chamadas para fazer os decorados e o próprio programa do edifício tinham características distintas ao empreendimento da Mooca, com apartamentos maiores, incluindo eletrodomésticos e materiais de acabamento mais refinados.

2.3.06: Propaganda de lançamento do Condomínio Edifício Juruá - Construhab. A Folha de São Paulo. p. 5, Terceiro Caderno. 25 jan. 1973.

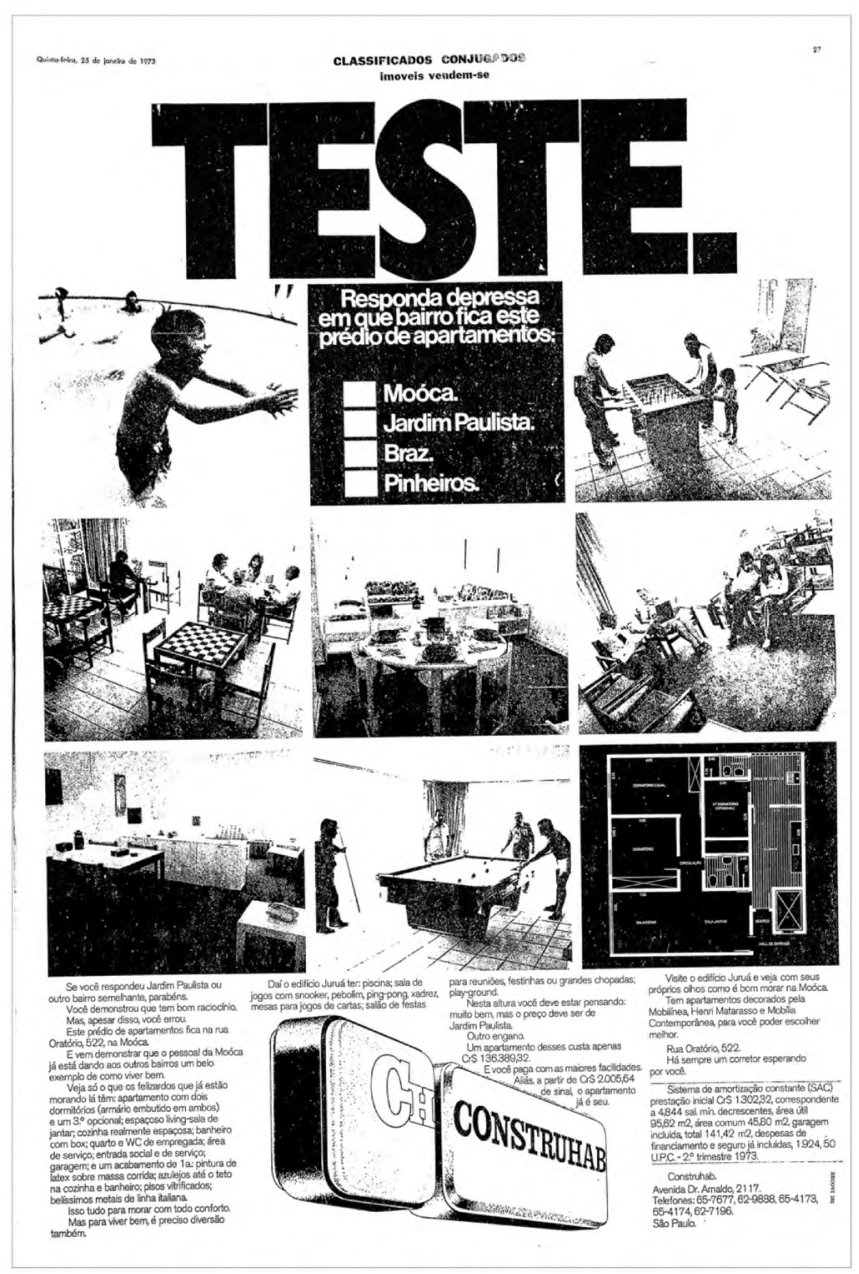


Embora almejando públicos diferentes, as duas campanhas da Construhab se focavam principalmente nos materiais construtivos, nas condições financiamento, na qualidade de vida conquistada e nas áreas de lazer do conjunto. No lançamento da Mooca aparecem uma planta e algumas imagens internas, mas sem características marcantes, enquanto a campanha de Perdizes foi feita somente com textos [2.3.06-2.3.07].

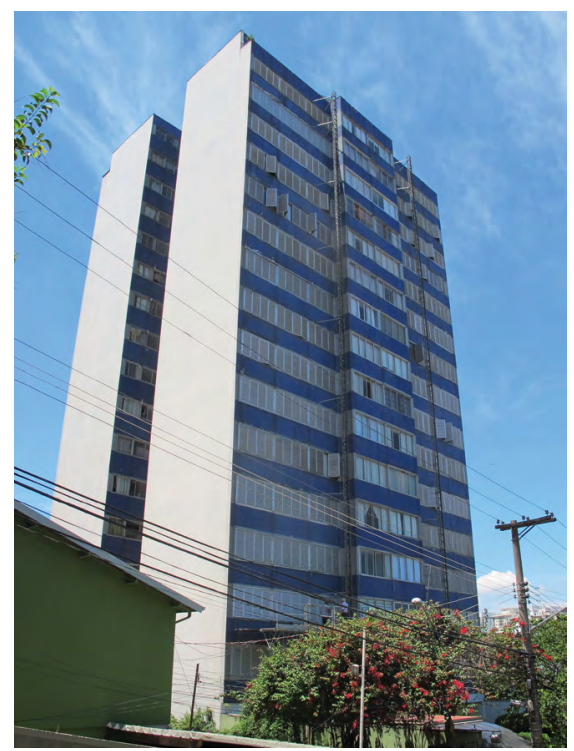

Formaespaço, por outro lado, se fez conhecida pela qualidade arquitetônica de seus empreendimentos, tendo se associado a arquitetos como Abrahão Sanovicz, Eduardo de Almeida, Ennes Silveira Mello, Fábio Penteado e Paulo Mendes da Rocha ${ }^{97}$. Foi localizado um impresso publicitário conjunto de Formaespaço e Mobilinea no acervo pessoal de Georgia Hauner, porém não ligado a um lançamento específico, o que indica que este material pode ter sido criado para uso em mais de uma ocasião. Nele, há desenhos de diversos móveis da Mobilinea em escala para serem recortados e utilizados no planejamento interno dos imóveis, cujas plantas eram provavelmente encartadas em folhas avulsas. Os móveis sugerem apartamentos de três dormitórios, com ambiente de salas de estar e jantar generosos [2.3.08]. Os edifícios da construtora foram em geral construídos nas Zonas Oeste e Sul, mirando um público de classes média e média alta, e apresentavam preocupações com racionalização da construção, que também se refletiam em edifícios modulares com a estrutura evidenciada.

É possível intuir o tipo de cliente que compraria imóveis construídos por Formaespaço ou Construhab a partir da tipologia do edifício e dos bairros em que eram implantados, e estas empresas parecem próximas não só em um espectro social, mas até em uma coerência entre os elementos construtivos aparentes nas fachadas dos prédios e os pinos de encaixe nos móveis Prêt-à-
2.3.07: Fachada do Edifício Cayowáa. Fotografia de acervo pessoal, 2015. 
Porter, de forma que a linguagem do edifício e sua ocupação dialogavam e se valorizavam mutuamente, tornando-se de certa forma um produto único para os clientes de ambas.

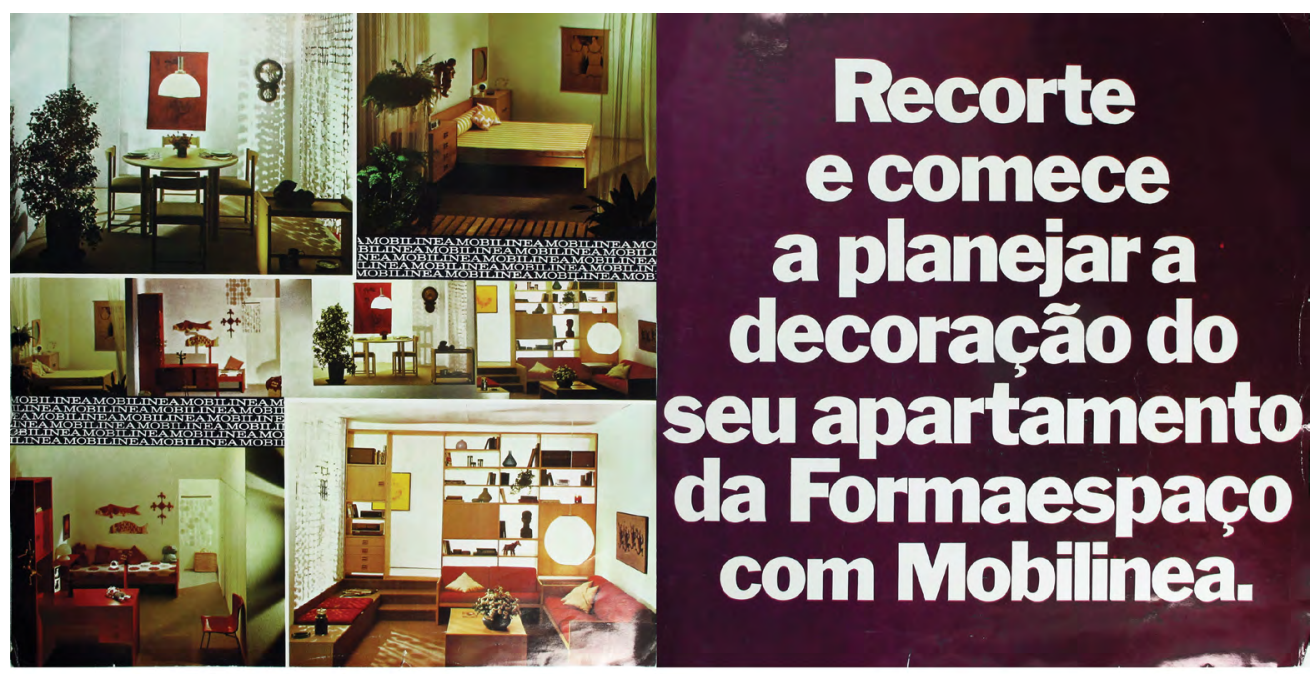

2.3.08: Folheto Mobilinea - Formaespaço. c. 1972. Acervo pessoal de Georgia Hauner.

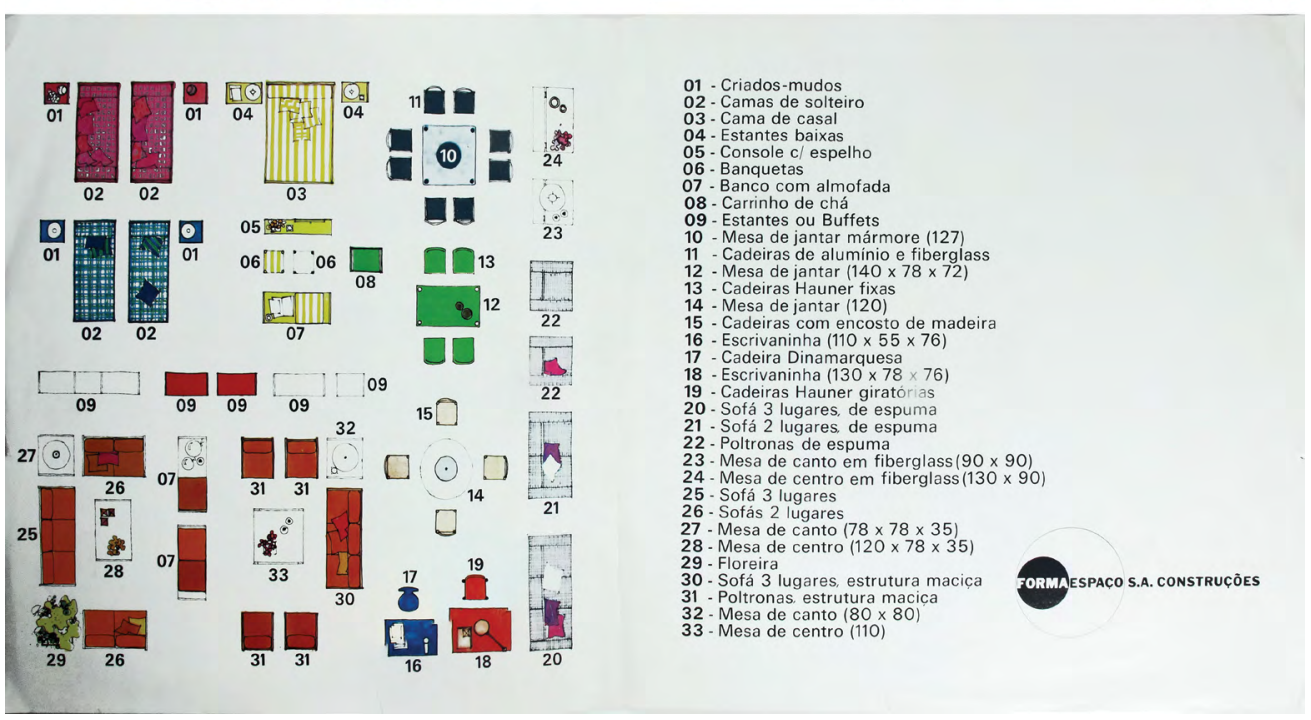

Há de se considerar que morar em apartamentos neste momento implicava em novidades na mais variadas esferas: o isolamento em relação à cidade, como também à natureza, que se dava pela mediação de portaria e elevador; a experiência do condomínio e as regras de convívio que conferiam uma nova dimensão a ideias de privacidade; e, o que nos interessa mais aqui, a impossibilidade de expansão através da construção de anexos, que implicava em organizar a moradia em suas diversas configurações naquela área delimitada, exigindo uma lógica mais racional de uso, que tanto os exemplos de ocupação quanto o uso de móveis componíveis vinham a responder.

Em vista destes episódios, a decisão de abrir uma grande loja em São Paulo onde seria possível encontrar tudo para o lar parece ter surgido de uma série de fatores e condicionantes da situação da Mobilinea na virada para a década de 1970, sendo central o desejo de pensar a ocupação da casa toda, visível 
desde as lojas até os projetos para decorados, compreendendo que apenas a empresa não supriria todos os elementos que criam um ambiente doméstico. A experiência de se aliar a outras marcas também vinha se desenvolvendo desde as propagandas conjuntas, no trabalho de Georgia Hauner em Claudia e até na venda de produtos de outros fabricantes e a inserção em campanhas externas. Mais do que isso, o que pode ter sido decisivo, neste momento a marca havia estabelecido uma imagem que tornava a proposição de uma parceria atraente, isto é, as empresas que se aliassem à Mobilinea ganhariam, além de exposição comercial, todos os valores aos quais ela era associada (que também vinham sendo fortemente desenvolvidos por sua inserção editorial). Assim, na mesma medida, havia abertura para convidarem as marcas que em sua avaliação contribuiriam com o estilo de vida que estavam propondo.

Ernesto Hauner e John de Souza encontraram o lote que abrigaria a Home Store em 1971 [2.3.09-2.3.10], e Georgia foi levada para conhece-lo:

\begin{abstract}
Um dia Ernesto me levou para ver um espaço que ele tinha descoberto por acaso, situado no andar térreo de um prédio em construção, numa localização fabulosa, na 9 de Julho, com acesso de mais três ruas. Ele achava que se houvesse a possibilidade de incorporar umas áreas cobertas com outras descobertas, e ligar tudo com uma praça ajardinada e mais um estacionamento na frente, daria para fazer um showroom espetacular. "Acredito que você seria capaz de fazer um projeto com estas áreas", falou. "Que tal?", "Vou pensar nisto", respondi. O lugar era enorme. Ernesto achava que seria possível reunir uma boa parte de firmas de bom design para fazer uma exposição em conjunto. Isto ainda não existia em São Paulo. ${ }^{98}$
\end{abstract}

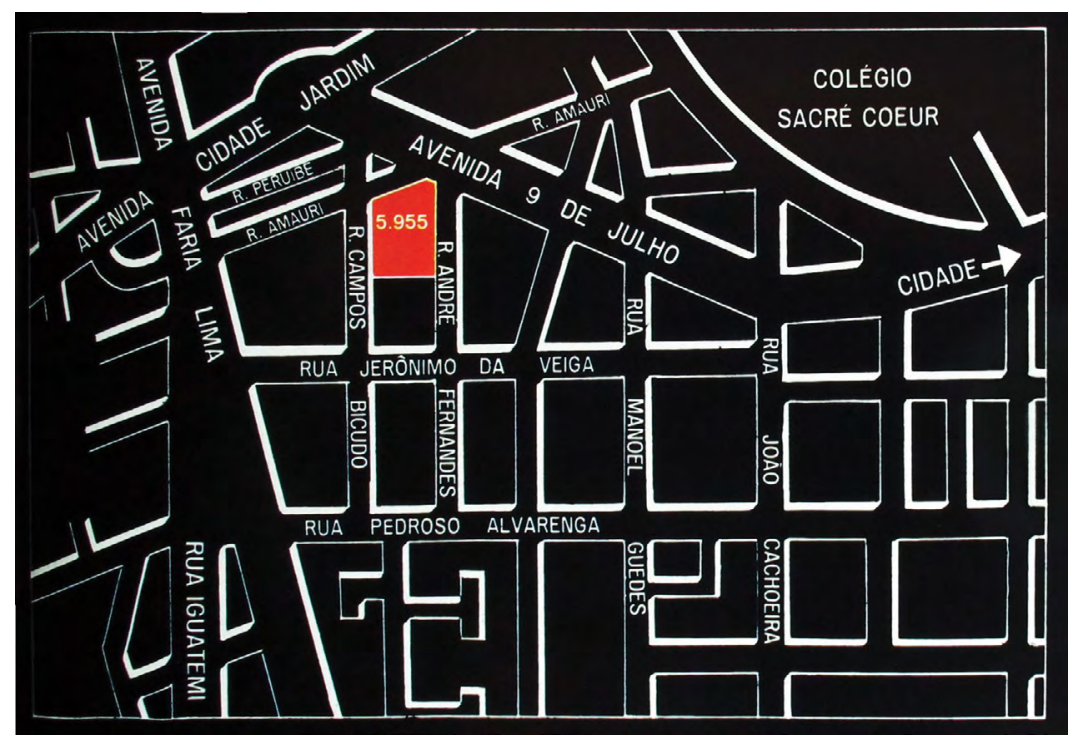

Foram localizados no acervo pessoal de Georgia Hauner documentos datilografados por ela e John elaborando a conceituação do empreendimento, o planejamento do espaço e o andamento da obra, bem como o projeto completo em cópias heliográficas e um número razoável de fotografias. Para os fins aqui propostos, eles serão apresentados de maneira a nos aprofundarmos mais nos aspectos próximos à Mobilinea.
2.3.09: Planta de situação da Home Store. Encarte publicitário Home Store. A Casa Claudia. dez. 1973. 
2.3.10: Fotos de maquete do projeto da Home Store. Sem data. Acervo pessoal de Georgia Hauner.

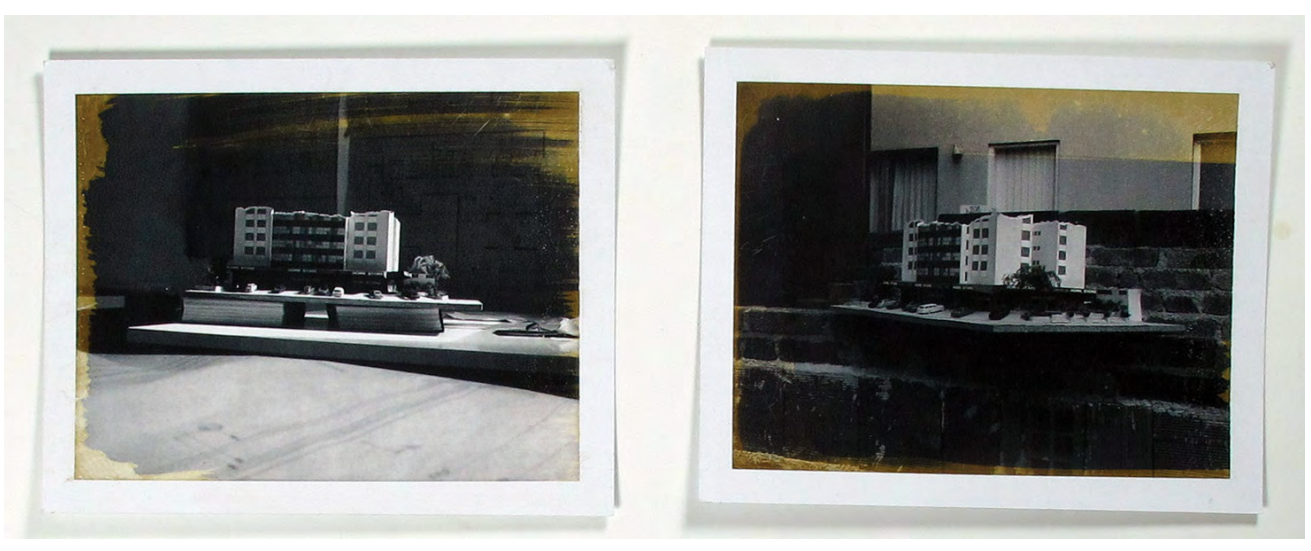

John de Souza elaborou a proposta para apresentar às empresas que poderiam querer participar do empreendimento em meados de 1972, expondo as dificuldades de cada fábrica gerir sua própria loja do ponto de vista comercial, da manutenção de um espaço de vendas, dos custos de operação e da manutenção de linhas pouco lucrativas. Argumentava que os clientes dos diversos negócios também iriam preferir o novo formato de venda pelas facilidades de encontrar produtos para diversos ambientes e com faixas de preço distintas num mesmo lugar, podendo realizar um único financiamento, e enfatizou ainda que este seria o primeiro empreendimento do tipo no Brasil e que havia planos de expansão para outras cidades e estados.99

Os produtos, segundo Georgia, deviam "comunicar o BEM ESTAR e AS COISAS BOAS DA VIDA" ${ }^{\text {1100 }}$. Na sequência deste texto assinado e datado em 7 de agosto de 1972, ela explicava o que esperava de cada uma das categorias de produtos vendidos e qual seria o seu diferencial: a floricultura deveria vender flores "do mato", como eram os arranjos da Mobilinea; a bombonière poderia embalar seus chocolates em objetos de design de outras empresas, os livros da livraria complementariam ambientes de estar, e assim por diante. Para Georgia, a ideia de criar um estilo de vida total em que tudo seria desejado, e mais do que isso, percebido como uma imagem, era clara:

Imagino que um agrupamento de mercadorias bem sucedido deveria levar o cliente
a comprar um maço de camélias junto com o bule no qual foram colocadas, a mesa
que os sustenta, o toldo que os protege, o piso, a poltrona e tudo mais que compõe
determinada imagem. Acredito que todas as pessoas sonham com lugares e coisas
que as apresentam em forma de "cartão postal" na própria mente. Fabricando
imagens pitorescas, frequentemente tocamos a sensibilidade do indivíduo, que
identifica a imagem apresentada com um de seus "cartões postais". ${ }^{101}$

Neste mesmo documento, ela fez uma longa defesa da autonomia do gosto dos clientes, argumentando que o serviço prestado pelos profissionais na nova loja deveria ser de planejamento e não decoração, que impunha padrões para os clientes desconsiderando suas opiniões, e era uma prática comum em revistas e outras empresas. 
Os clientes deverão ser preparados aos poucos para aceitarem a nova terminologia em matéria de assistência e encoragiados [sic] a expressar os próprios gostos quanto a decoração, atravez [sic] dos exemplos expostos. Devemos lembrar que existe um movimento contra esquemas rígidos no mundo inteiro e em vários setores. Um exemplo típico é a moda feminina que está em franca revolução. As mulheres não se sujeitam mais à ditadura dos grandes costureiros e moda hoje em dia é ser original e muito individual. É inevitável que o mesmo espírito haverá de prevalecer no campo da decoração, portanto seria perfeitamente inútil basear um empreendimento novo em ideias já superadas. ${ }^{102}$

Não obstante, havia limites. Em outro documento de 28 de novembro de 1972, que tratava da sistematização de algumas decisões acerca de público e funcionamento, Georgia declarou:

É imprescindível que haja um rigoroso controle sôbre todos os departamentos para evitar a vulgaridade. Não devemos jamais permitir que interesses comerciais sobrepujem este controle, pois correríamos o risco de nos tornarnos outra Sears, ou Jumbo, possivelmente chegando a oprimir o nosso sensato público com monstruosos anjos de isopor (como os exemplares que zelam pelos bons negócios no Shopping Center neste fim de ano). De qualquer forma, possíveis interesses de um ou outro departamento para se vulgarizar, teriam na mais otimista das hipóteses um efeito a curto prazo, com o público que visamos alcançar. ${ }^{103}$

Como exemplo, diz que teriam cadeiras caras como as da Mobilinea e de preço médio como da Probjeto ou da Mobilinea Contemporânea, mas nunca cadeiras de mau desenho e má qualidade. Também em relação à Mobilinea, Georgia afirmara que haveria uma redução na própria linha para aliviar a produção e também porque com móveis de outras empresas não haveria mais necessidade de criar ambientes feitos apenas com peças de um único fabricante, ideia que "se enquadra perfeitamente com o conceito do novo individualismo"104.

As alternativas para objetos acessíveis não deveriam ser dadas por peças inferiores imitando algo de valor, mas por exemplo com belas gravuras ao invés de quadros assinados, o que distanciaria a Home Store de outras lojas de departamento ou do Shopping Iguatemi. A questão da acessibilidade da loja (torna-la menos "hermética") aparece nestes vários documentos, até considerando se deveriam operar com portas abertas ou fechadas, usando ventilação natural ou ar-condicionado, e em mais de uma ocasião Georgia indicou a própria cenografia como solução:

[...] uma linda sala de jantar, atrás de Blindex, não anima ninguém com trinta cruzeiros no bolso a entrar. Porem uma revista, 100 gramas de balas, ou um disco, incutem confiança. Uma vez que o sujeito entrou, descobre o crediário, fica sabendo que a sala que admirou não é tão inacessível assim, o cafezinho é gratuito e nenhum vampiro se esconde atrás das folhagens. ${ }^{105}$

O projeto da Home Store foi feito por Georgia Hauner com o auxílio de Yone Koseki Pierre. Esta, sendo a única arquiteta na Mobilinea, recorda-se de ter se encarregado da reforma com certa apreensão porque era uma obra complexa, que incluía a remoção de pilares do térreo dos edifícios existentes e a criação de mezaninos que muitas vezes deveriam ser sustentados nessa mesma 
estrutura, mas alguns engenheiros a ajudaram informalmente e, no geral, as questões foram resolvidas in loco ${ }^{106}$. A ideia de Georgia era criar um percurso para que o cliente percorresse a loja passando por ambientes variados, mantendo generosas áreas de vitrine. A entrada se dava por uma lateral mais estreita, à esquerda da qual ficava a "Casa da Vera", uma área de aproximadamente $30 \mathrm{~m}^{2}$ onde periodicamente se montavam pequenos apartamentos completos com móveis e objetos simples e baratos, porém de bom gosto. Seguindo à direita, para acessar a loja, atravessava-se uma passarela de serviços:

\begin{abstract}
Neste projeto introduzi mais cenografia do que nos showrooms anteriores. Na parte da frente tinha uma espécie de passarela para o público, simulando uma passagem de rua, com alguns degraus descendo, ou subindo, de ambos os lados, levando para centros de venda de artesanato, discos, galeria de arte, objetos, livros, plantas, cafezinho, etc. Havia um "CINEMA" (projeção de slides dos produtos à venda). "A CASA DA VERA" (um pequeno apartamento com arrumação de baixo custo). "BOMBEIROS" (uma porta com um sino de bronze, escondendo o equipamento existente). A "GALERIA DE ARTE" (uma sacada, com um manequim de barba, sentado atrás de um cavalete, tendo de fundo uma parede cheia de quadros a venda). Havia ainda um pequeno edifício circular que disfarçava colunas de concreto, chamado "BANCO" aonde se pagava pelas compras, e se apanhavam os embrulhos. ${ }^{107}$
\end{abstract}

Além disso, havia artesãos trabalhando ao vivo, uma banca de revistas especializada em arquitetura, jardinagem e decoração, lojas de discos e de joias, livraria, bombonière e floricultura ${ }^{108}$ [2.3.17-2.3.20]. Daí, chegava-se aos espaços expositivos propriamente ditos, que contavam com áreas internas e externas de dimensões e pés direitos variados por causa da união dos vários lotes. Também por isso, os mezaninos precisaram de escadas independentes para acesso [2.3.21-2.3.25]. Muitas das ideias das outras lojas foram usadas na Home Store, a exemplo dos desníveis no piso:

\begin{abstract}
Nesta exposição projetei desníveis criados por caixas acarpetadas e moduladas, que podiam ser levadas para outros lugares, quando se mudavam as exposições. As caixas formavam pisos elevados e quando ficavam excluídas de determinada área, formavam uma depressão no chão. Esta área afundada de uns $30 \mathrm{~cm}$, era guarnecida com almofadas revestidas de algodão rústico e apelidada "poço". Os clientes tiravam os sapatos para descer e experimentar o conforto do poço. Ficavam esparralhados [sic] lá dentro, sem vontade de sair, e conversando uns com os outros. ${ }^{109}$
\end{abstract}

Nas páginas seguintes 2.3.11: Planta do térreo com indicação dos cortes. Projeto Home Store. 1972. Acervo pessoal de Georgia Hauner.
As instalações da loja incluíam ainda um setor comercial com três departamentos: um entregue a terceiros para arrendamento (como a banca de revistas e a loja de discos), um para compra e venda de produtos (como pequenos objetos, louças e tecidos) e um para venda por representação (móveis de diversas procedências - inclusive a Mobilinea, lustres, tapetes e afins) $)^{110}$. Finalmente, havia vestiários, lanchonete, cozinha, área de serviço, sanitários, depósitos e salas de reuniões, desenho e compras ${ }^{111}$. A área total do andar térreo era de $1.191,57 \mathrm{~m}^{2}$ e nos mezaninos, 565,79m²; destas, $1.278,04 \mathrm{~m}^{2}$ eram para exposição e 476,32 $\mathrm{m}^{2}$ eram de apoio, totalizando $1.754,36 \mathrm{~m}^{2112}$ [2.3.11-2.3.15]. 


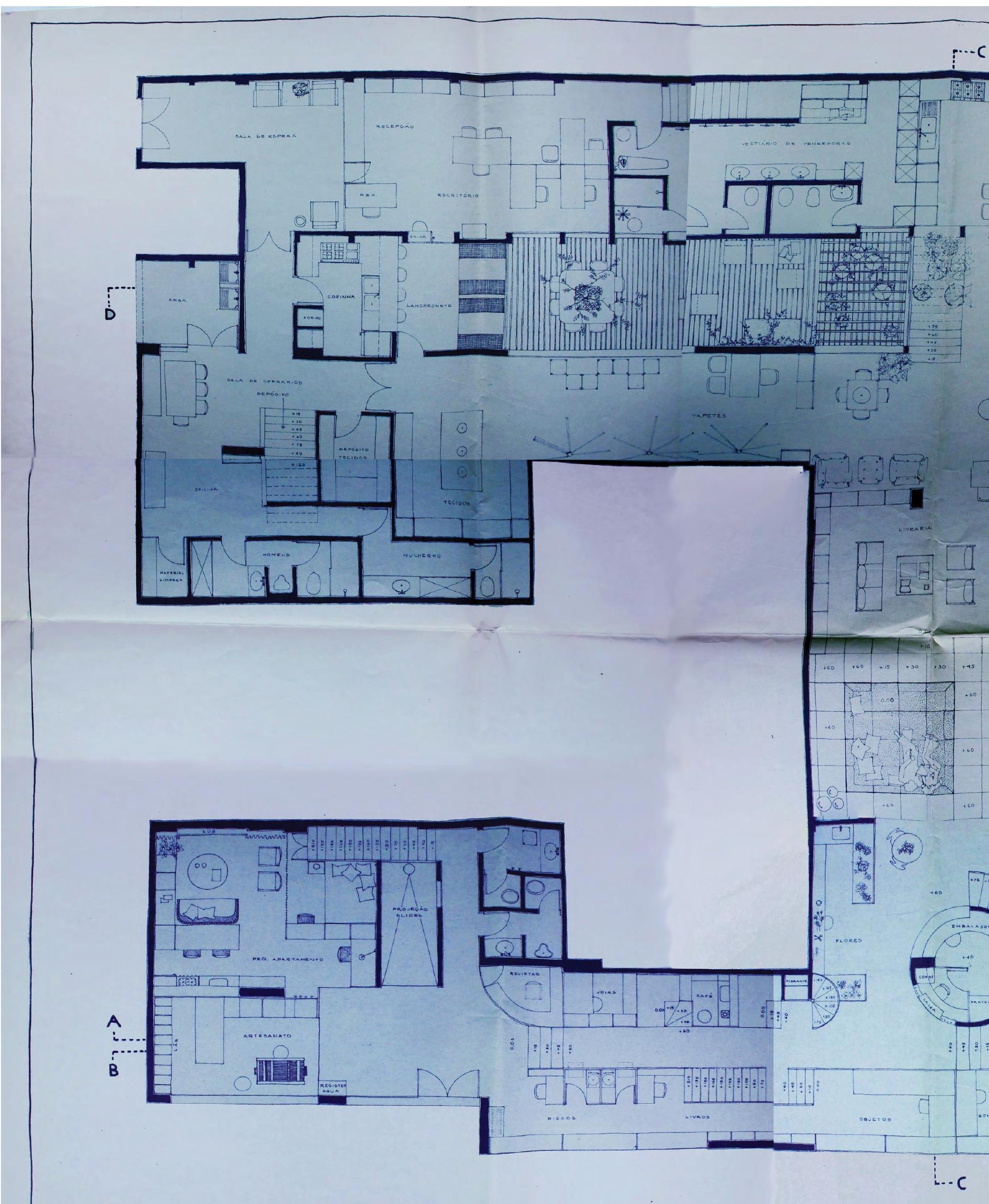




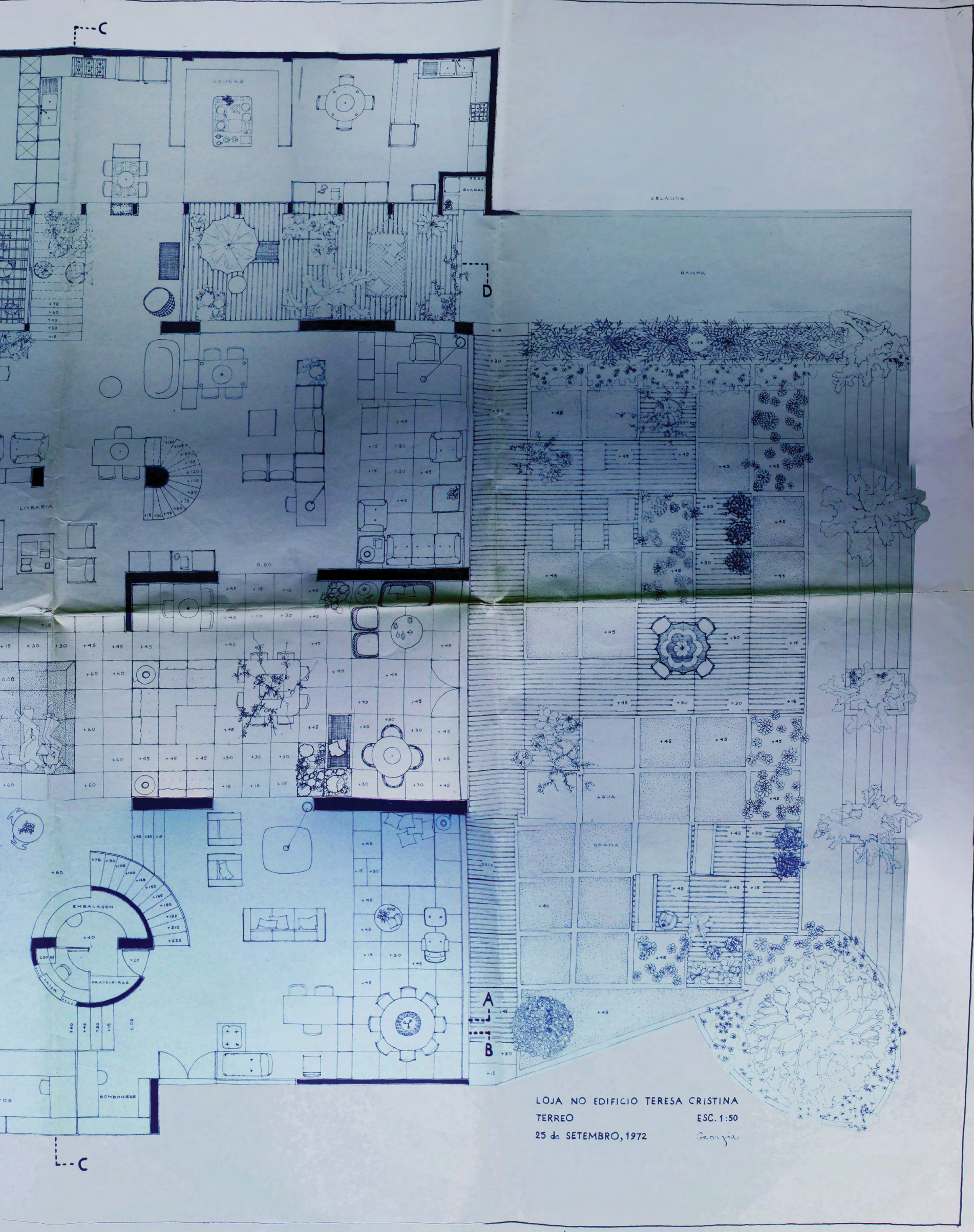



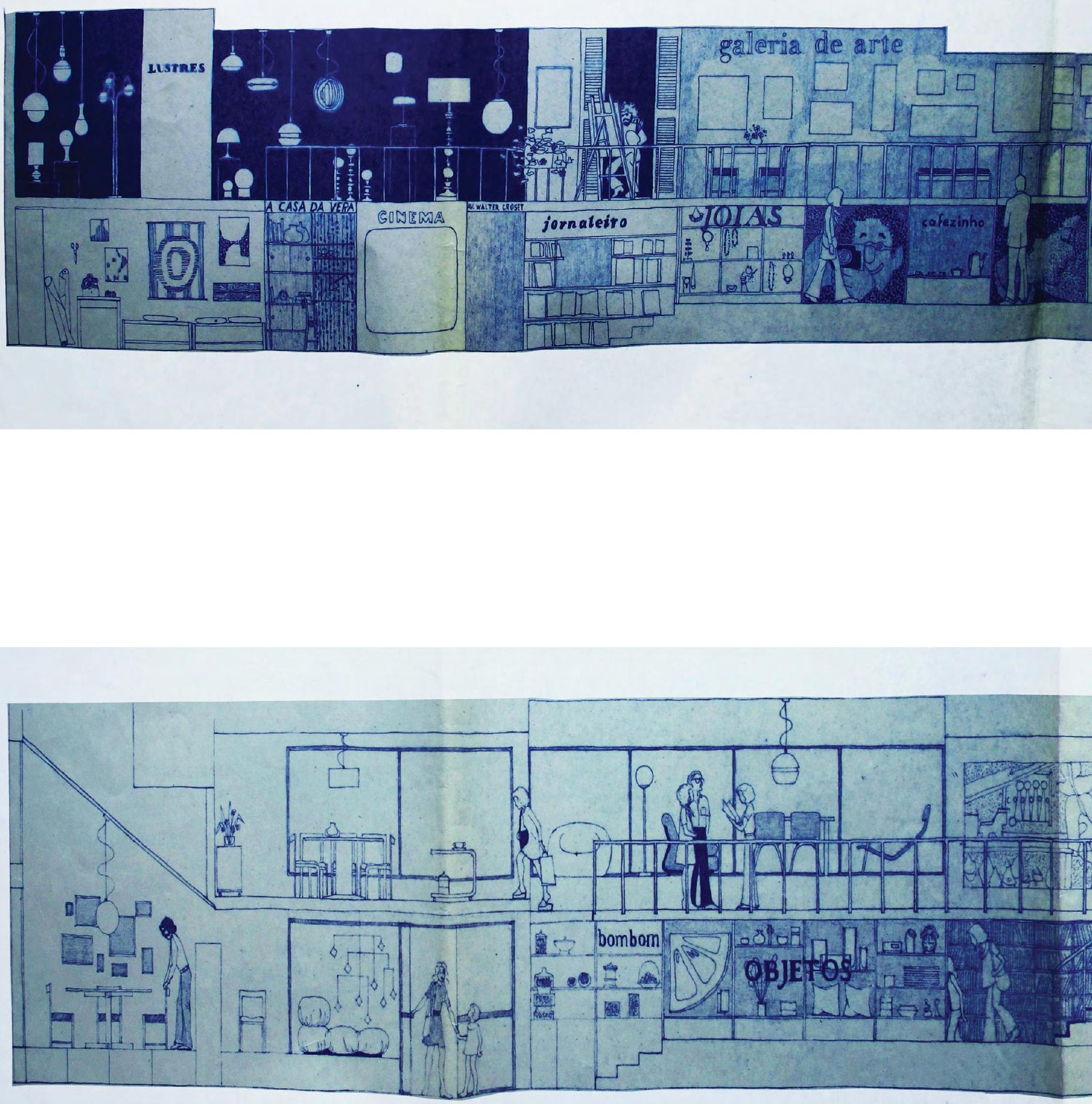


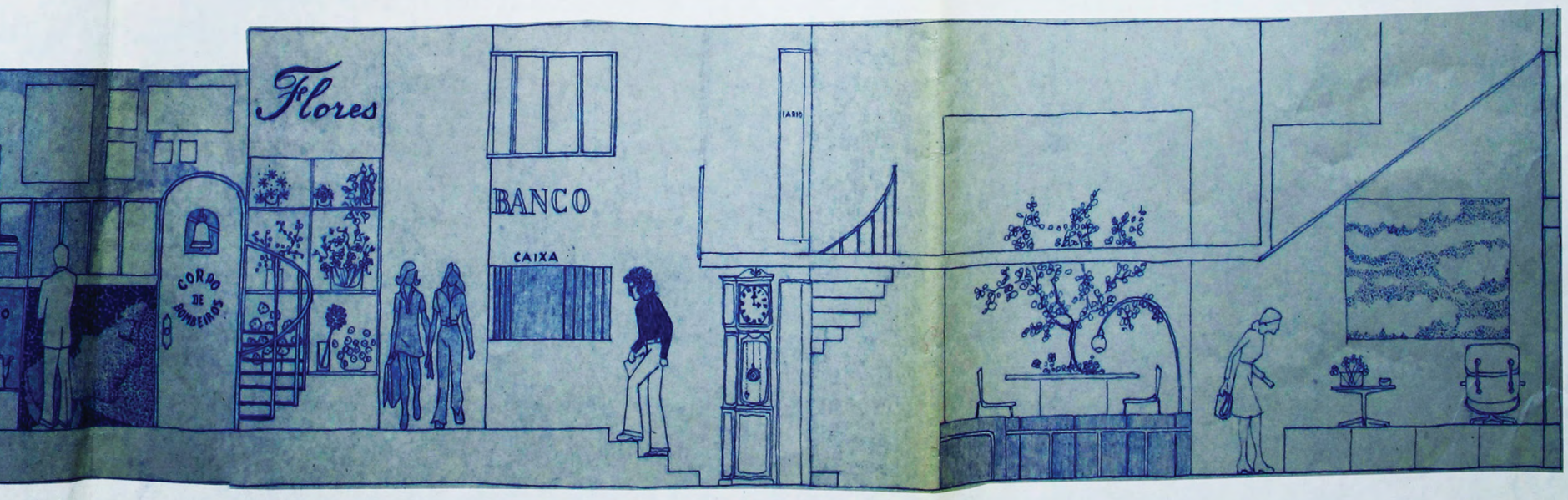

2.3.12: Corte A-A: vista transversal da passarela de entrada olhando para dentro da loja. À esquerda vê-se a Casa da Vera, seguida da rua interna de serviços e à direita a entrada para os ambientes residenciais, passando pelo Banco. Projeto Home Store. 1972. Acervo pessoal de Georgia Hauner.

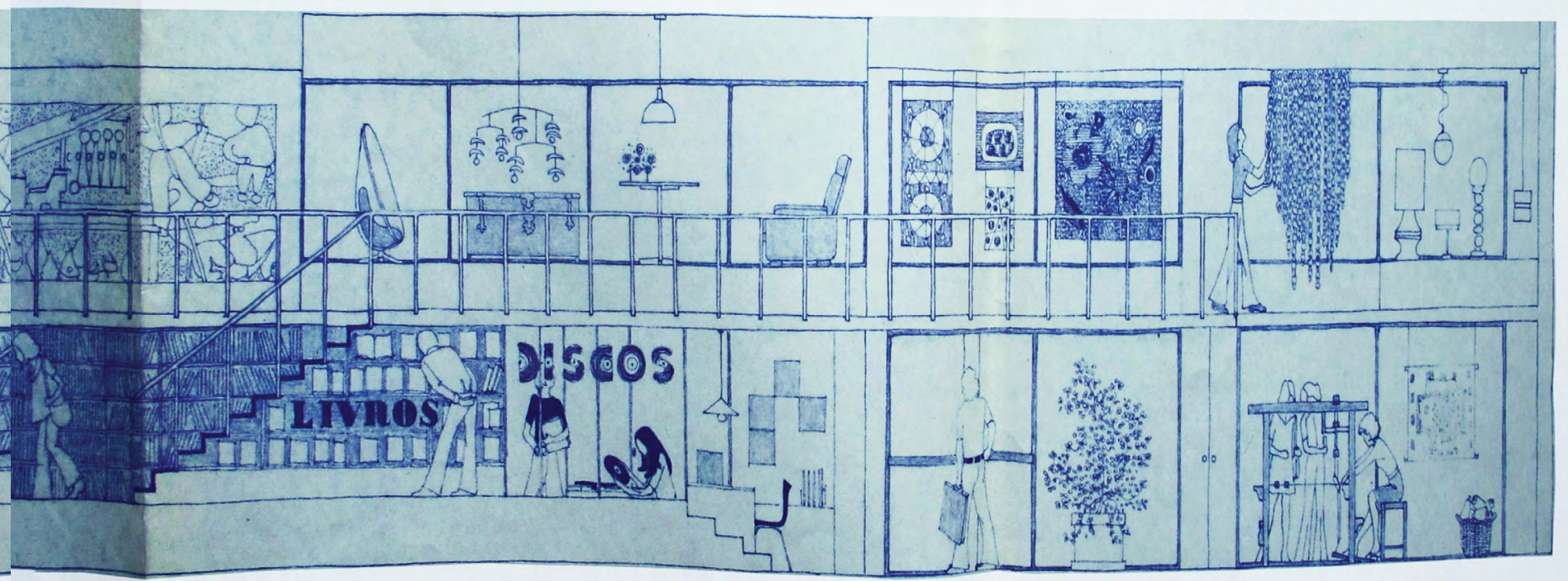

2.3.13: Corte B-B: vista transversal da passarela de entrada oposta ao corte A-A. A Casa de Vera fica à direita, onde também há um artesão trabalhando, seguida da rua interna de serviços e à esquerda um pequeno ambiente de jantar. Projeto Home Store. 1972. Acervo pessoal de Georgia Hauner. 

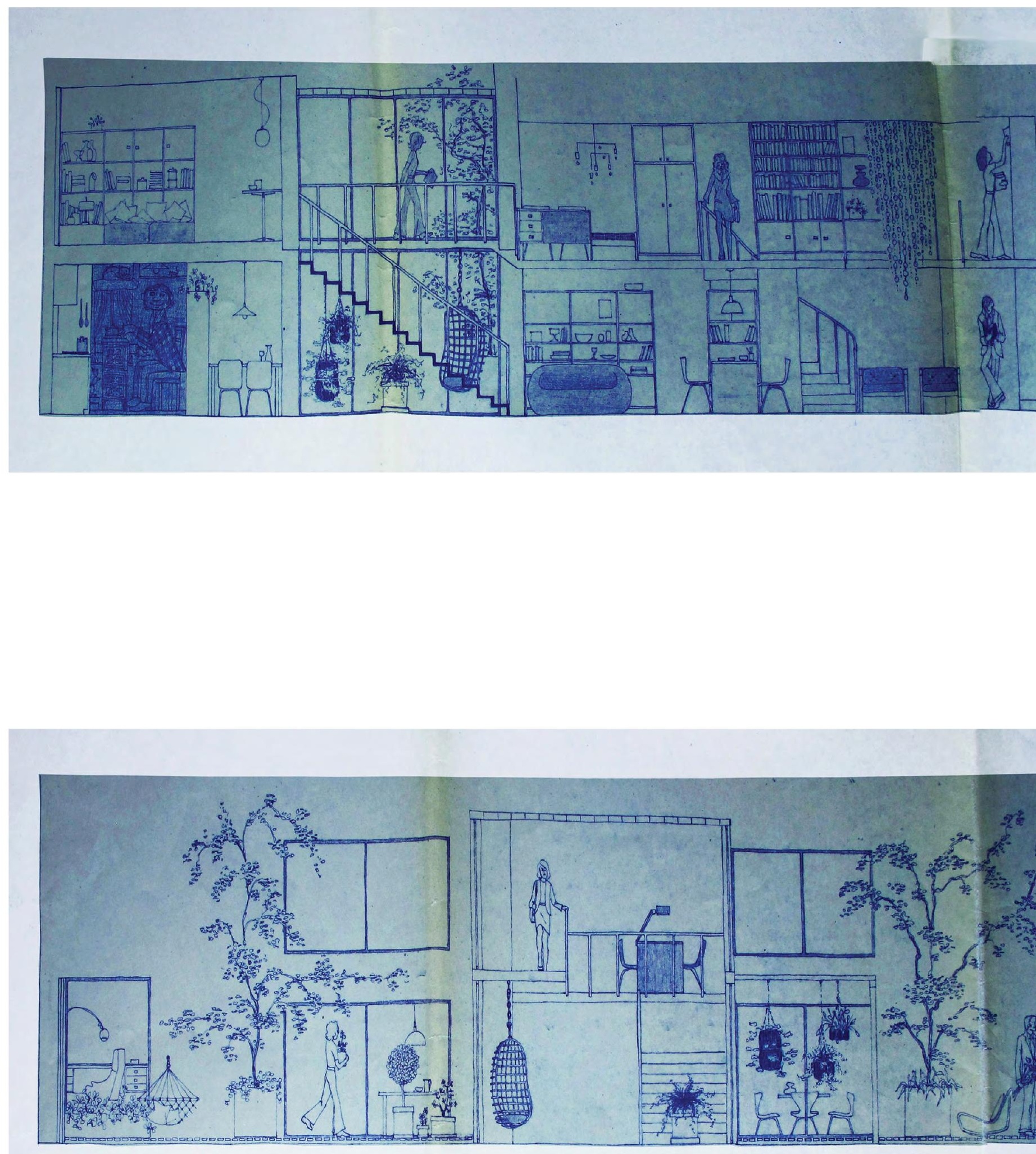


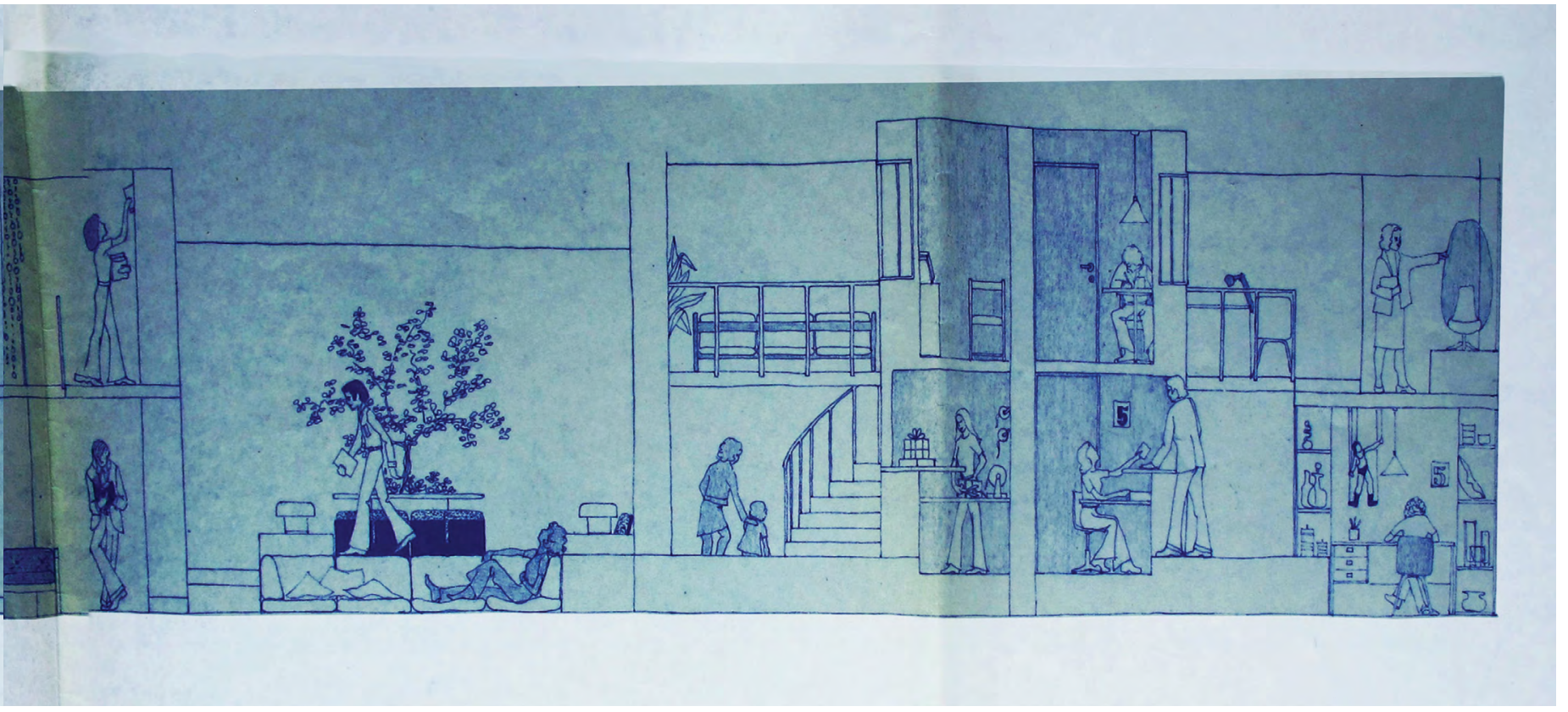

2.3.14: Corte C-C: vista longitudinal da loja olhando para seu interior. À direita vê-se o volume do Banco, na sequência o Poço e os ambientes de showroom. Projeto Home Store. 1972. Acervo pessoal de Georgia Hauner.

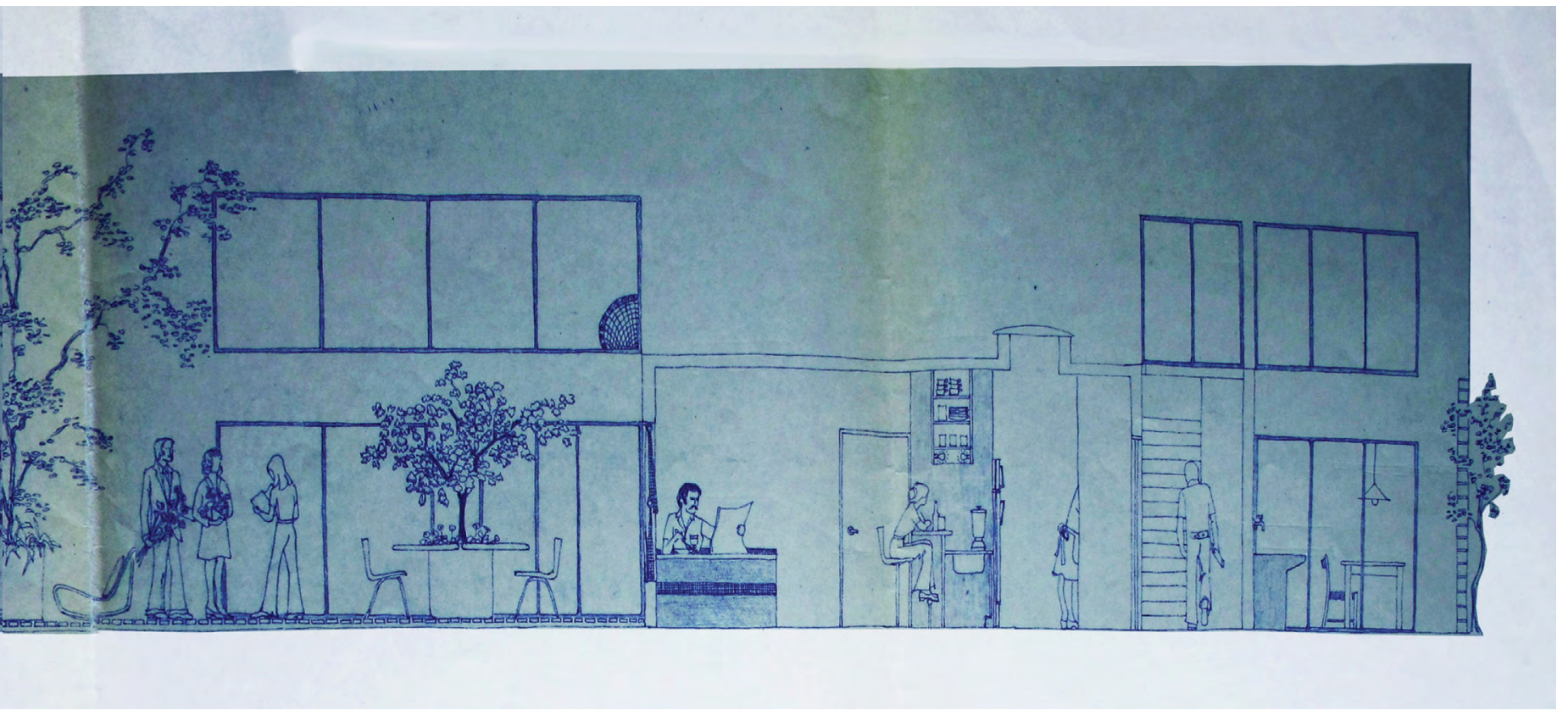

2.3.15: Corte D-D: vista transversal das áreas externas feitas nos recuos dos vários edifícios, e setor de serviços e descanso dos funcionários. Projeto Home Store. 1972. Acervo pessoal de Georgia Hauner. 
Foi John quem batizou a Home Store, e também quem organizou quais as empresas convidadas para participar do empreendimento dentro das diferentes formas de associação. Mobilinea ficou com 60\% das ações da Home Store, cuja lista final de colaboradores foi:

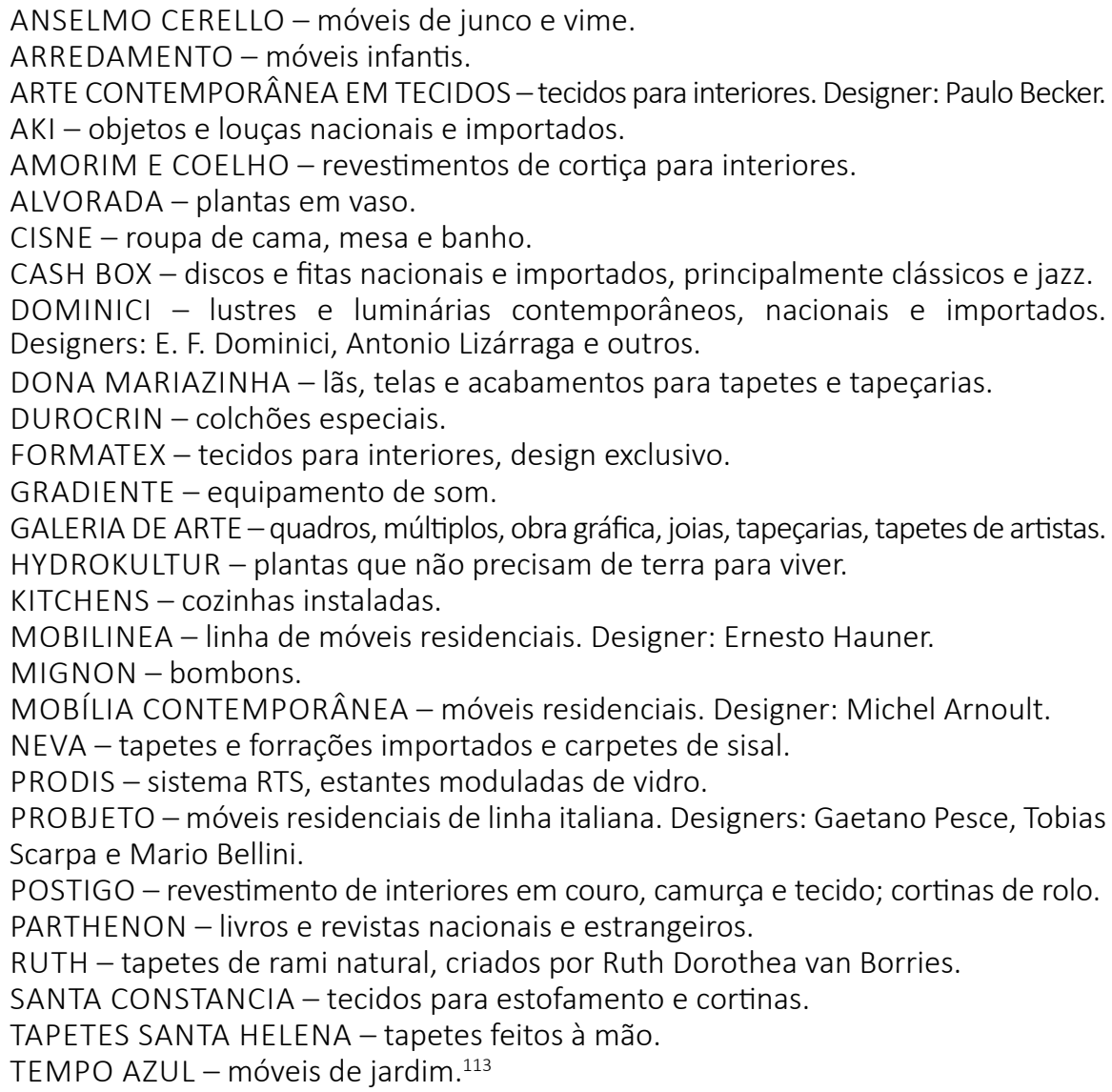

Almofadas e tapetes desenhados por Georgia Hauner e Judit Magyary foram produzidos em parceria com outras empresas ou na própria Mobilinea para serem comercializados lá, mas já com processos de seriação, pois meios de fabricação artesanais não se adequavam à nova escala de vendas. Judit foi também encarregada de criar todas as ambientações internas da loja, bem como a reposição de peças vendidas e a programação de lançamentos.

Para as vitrines, ela recortou figuras humanas estilizadas em chapa de madeira, e as revestiu com um filme espelhado da $3 \mathrm{M}$ chamado Scotchtint ${ }^{114}$. Assim, ao invés de passar uma fita ao longo do vidro para evitar choques, ela criou elementos lúdicos que levavam os transeuntes para dentro dos ambientes pela sua transposição no reflexo, contribuindo para desmontar a ideia de ser uma loja intimidante ou arrogante na qual um público comum não se adequaria. O logo da Home Store foi desenvolvido pelo escritório Cauduro Martino $^{115}$ a partir de um triângulo que talvez simulasse o telhado de uma casa arquetípica, e era usado tanto na assinatura da empresa, como em um painel que se repetia em relevo ao longo de toda a fachada da loja, dando unidade aos térreos dos vários prédios incorporados [2.3.16]. 

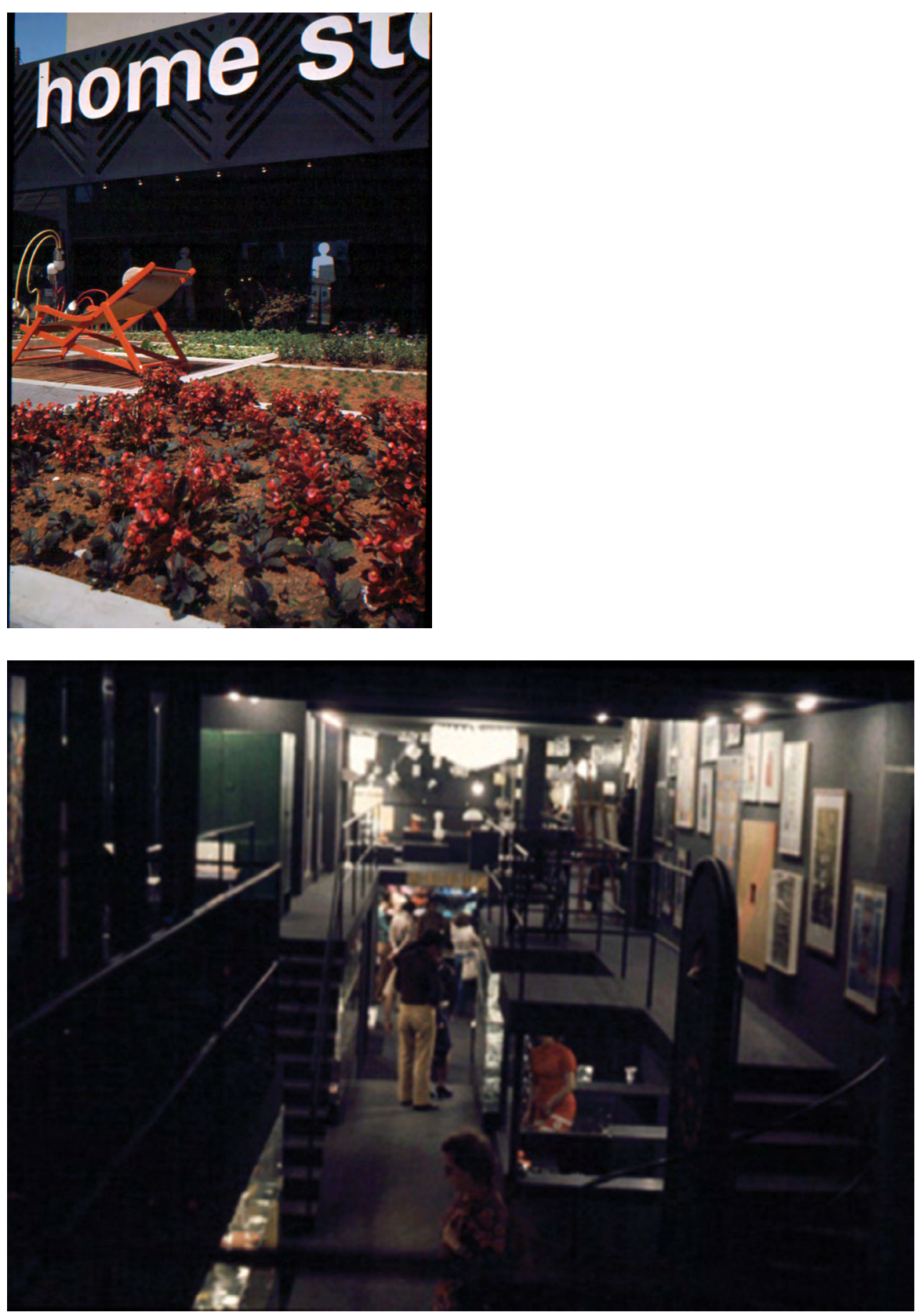

2.3.16: Fachada da Home Store. Imagem de slide. Sem data. Acervo pessoal de Georgia Hauner.

2.3.17: Passarela de entrada da Home Store com loja de lustres e galeria de arte. Imagem de slide. Sem data. Acervo pessoal de Georgia Hauner.

2.3.18: Loja de joias na Home Store. Imagem de slide. Sem data. Acervo pessoal de Georgia Hauner.

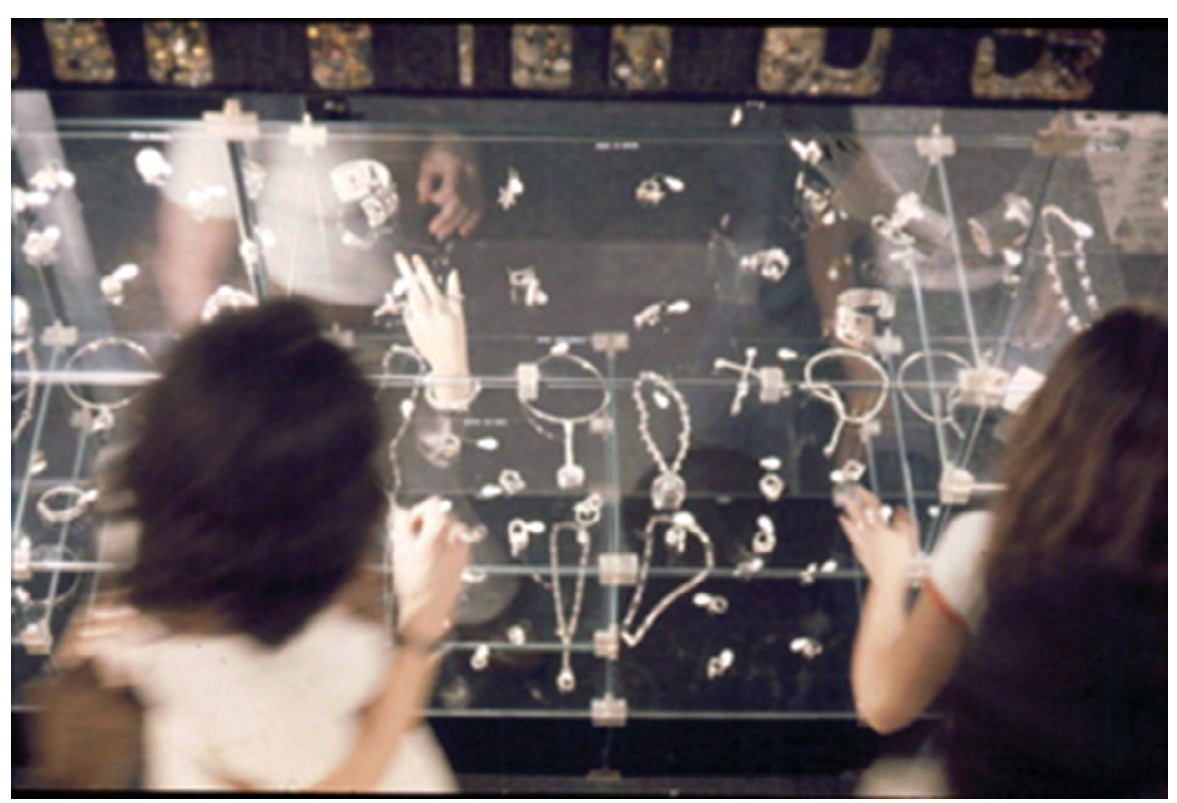




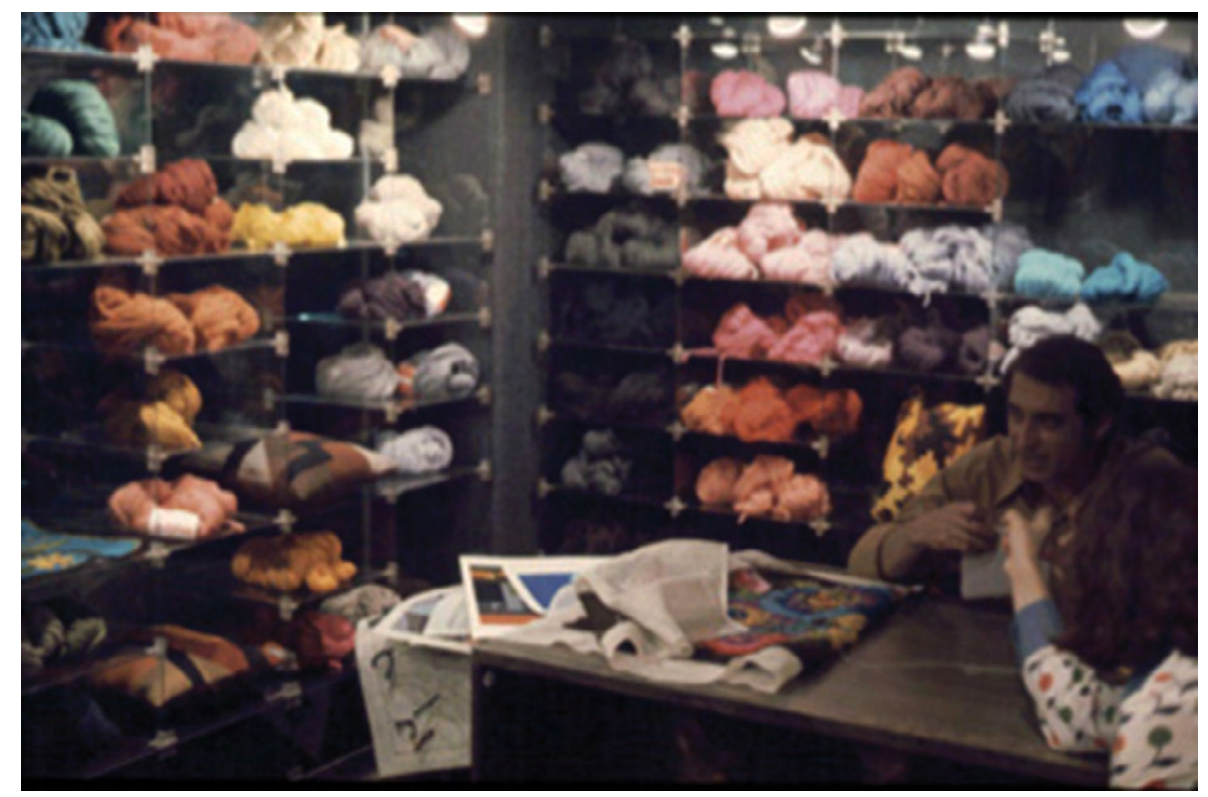

2.3.19: Ateliê do artesão na Home Store. Imagem de slide. Sem data. Acervo pessoal de Georgia Hauner.

2.3.20: Banca de revistas na Home Store. Imagem de slide. Sem data. Acervo pessoal de Georgia Hauner.

2.3.21: Ambiente de área externa com mesa-canteiro na Home Store. Imagem de slide. Sem data. Acervo pessoal de Georgia Hauner
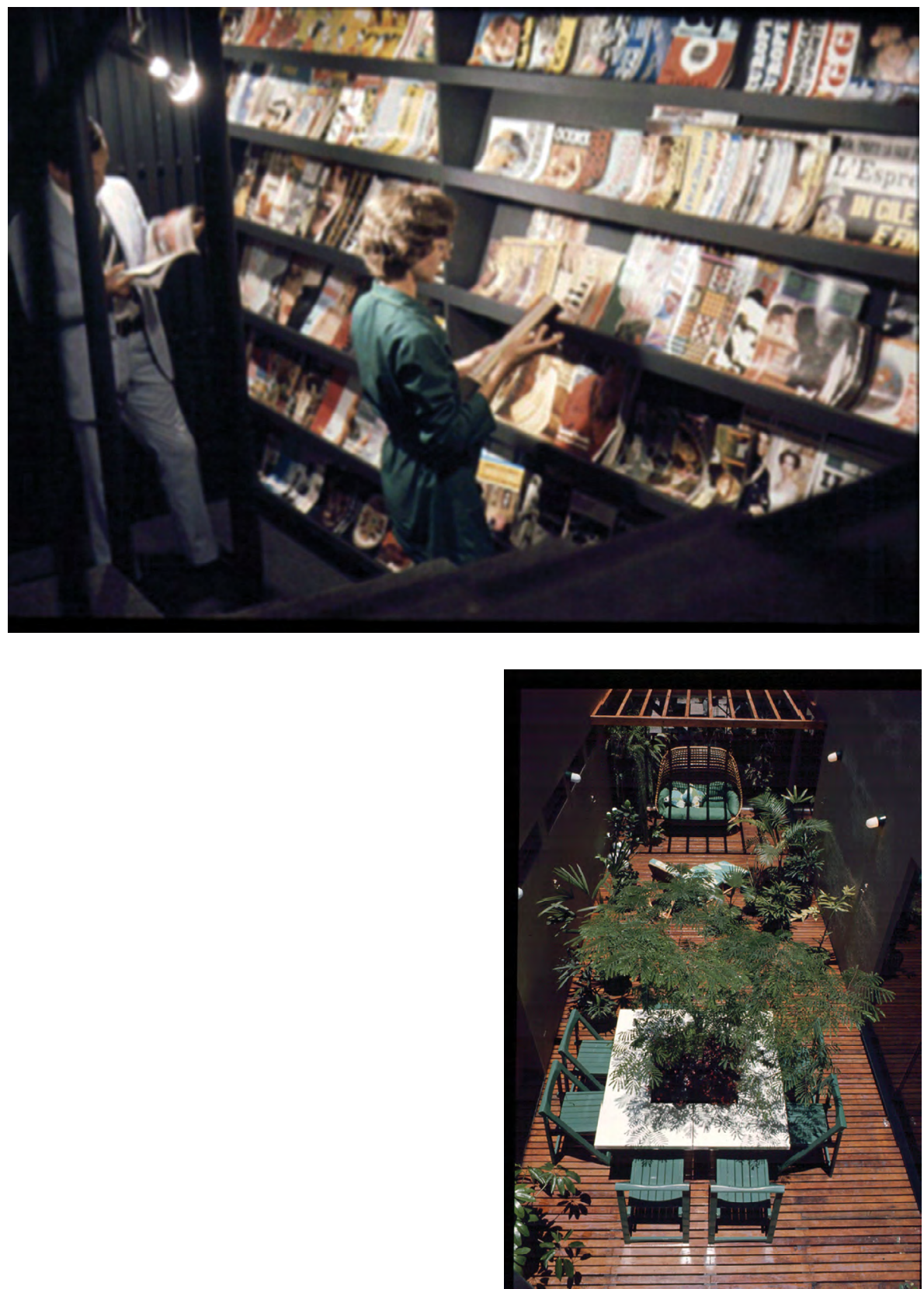
2.3.22: Vista do poço com composição de quadros na Home Store. Sala de estar comer e viver bem. Desfile

- suplemento de decoração. pp. 14-15. nov. 1974

2.3.23: Poço durante algum evento na loja. Sentado no chão à direita, Ernesto Hauner. Sem data. Acervo pessoal de Georgia Hauner.

2.3.24: Ambiente de dormitório com móveis Mobilinea na Home Store.

Imagem de slide. Sem data. Acervo pessoal de Georgia Hauner.
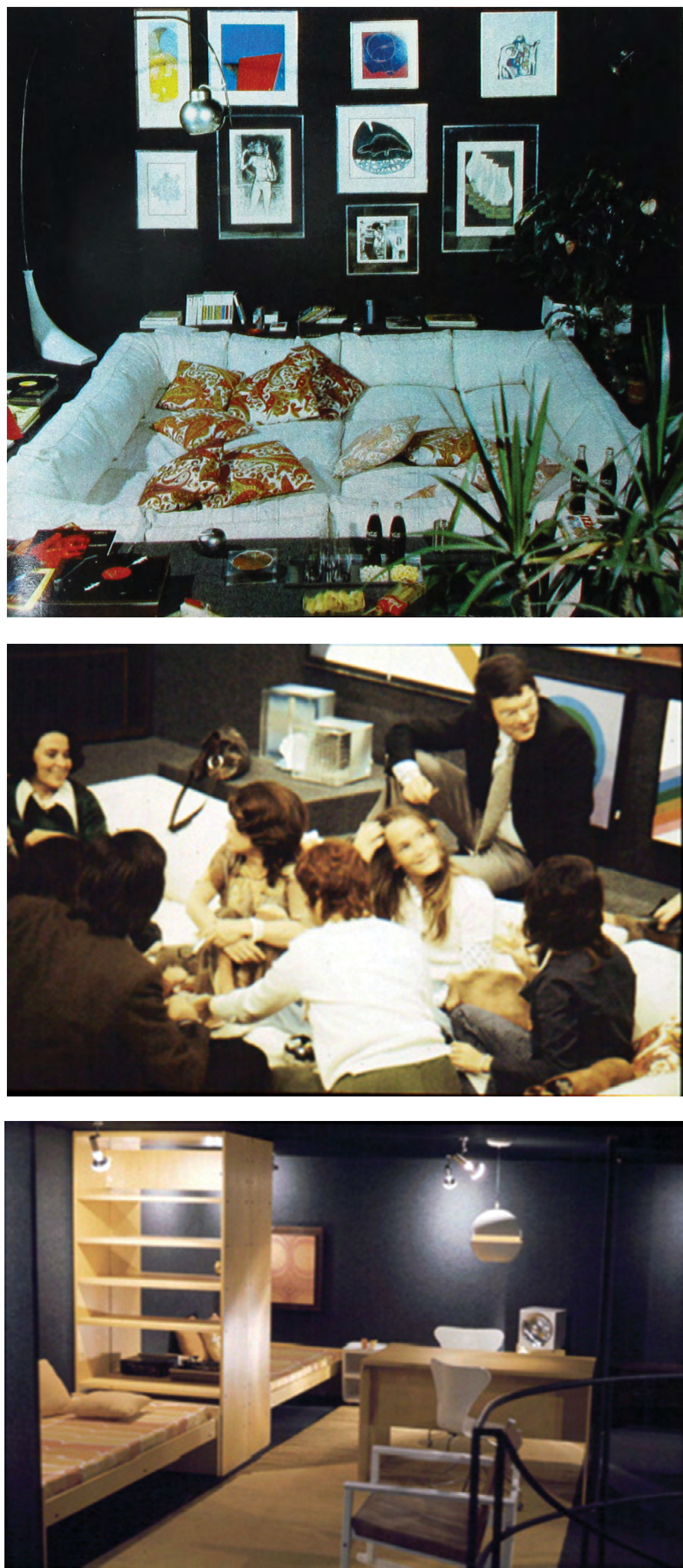


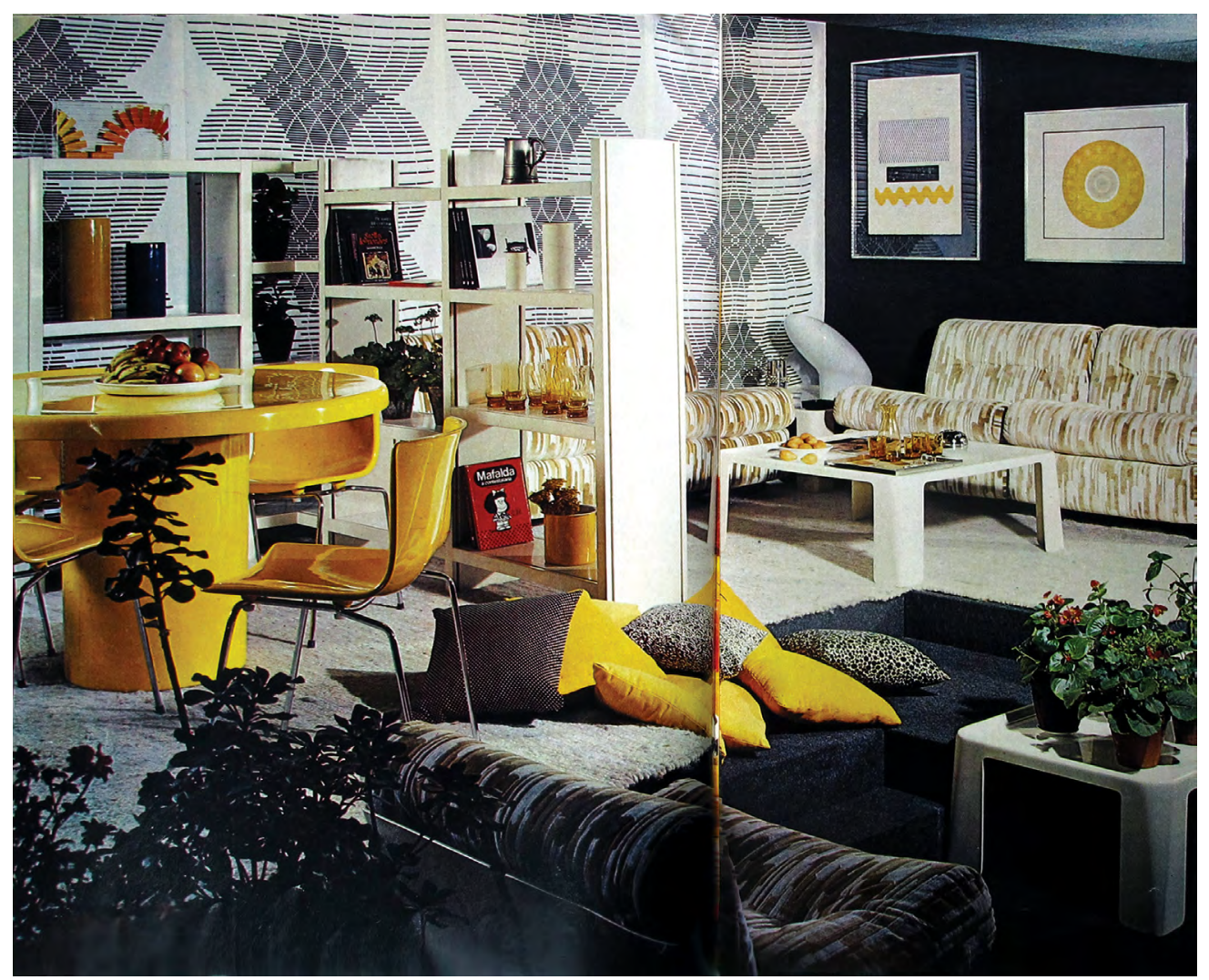

É evidente que a loja criou ambientes com diferenças significativas em relação a layouts para casas reais, até porque paredes e piso eram pretos para destacar as peças expostas, criando um ambiente nitidamente teatral, como uma "caixa preta". Ainda assim, há uma completude dos elementos em cada pequeno cenário que proporciona a ideia de "cartão postal" concebida por Georgia, em que se compreende a totalidade dos elementos, gerando um desejo por todo o estilo de vida sugerido.

A maioria das vendedoras da loja do Shopping Iguatemi foi trabalhar na Home Store, assim como Ada Hauner, que passou a chefiar o departamento de vendas de móveis de escritório. Alguns entraves em relação ao alcance de público parecem ficar latentes a partir deste momento, e em encarte promocional inserido em Claudia em dezembro de 1973, mais uma vez houve um esforço em explicar os diferenciais da empresa e atrair possíveis clientes:
2.3.25: Ambiente de estar com móveis Mobilinea e Probjeto (linha Amanta, de Mario Bellini, produzidas sob licença) na Home Store. "Para viver melhor". Desfile - suplemento de decoração. jul. 1974.

Ajudado por uma equipe de decoradores, você pode ver na hora como as cadeiras de determinado fabricante podem combinar com a mesa de outro, qual a cortina que fica bem com aquele sofá, como um equipamento de som cabe em determinada prateleira, enfim, há plena liberdade de escolha, sem qualquer preconceito de marcas ou estilos [...]. Com tanta variedade de artigos e de preços, o Home Store não pode ser situado como deste ou daquele padrão de poder aquisitivo. Ele é dirigido, sobretudo, a um público de bom nível cultural, identificado com um dos pensamentos básicos do empreendimento: "o lugar mais importante do mundo é onde a gente mora, ele é uma extensão da pessoa que vive nele". Portanto não é o preço de um produto o que mais importa, mas o bom "design" feito até com materiais mais em conta, capaz de expressar com simplicidade a individualidade que todos desejam para sua casa. ${ }^{116}$ 
2.3.26: Cartela de móveis adesivos, com detalhe ampliado em que se vê a marca d'água Home Store. Sem data. Acervo pessoal de Georgia Hauner.
O crediário para financiamento direto no local também buscava relativizar o custo integral das peças e garantia um fluxo de caixa contínuo. No atendimento, além da combinação física dos móveis das várias empresas, foram impressas cartelas adesivas com os móveis à venda, para que a planta dos clientes pudesse ser proposta na hora [2.3.26].

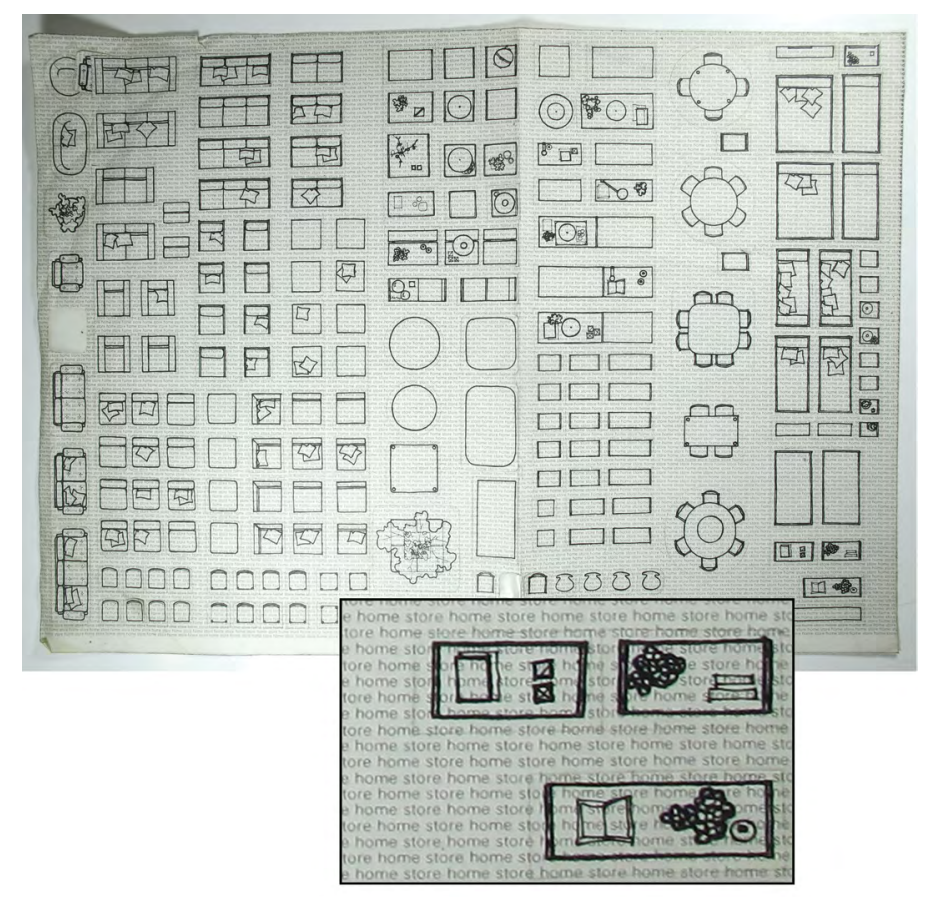

O impacto da Home Store na imprensa não foi muito significativo, ao menos nos dois anos que seguiram sua inauguração. Alguns móveis e objetos foram anunciados em editoriais temáticos (agrupados por função, matériasprimas ou cômodos da casa) e em propagandas em revistas e jornais, não raro privilegiando a Mobilinea, mas quase sempre contando com as próprias revistas para produzirem as fotos. Isso pode ter acontecido por alguns motivos: a loja era em São Paulo enquanto as revistas tinham tiragem nacional, e a Home Store já se beneficiava das propagandas das empresas participantes por seus anúncios individuais; ou então, estabelecendo-se como um ponto de referência na cidade, ela talvez não requeresse mais investimentos desta natureza; ainda, e o que parece mais provável, os novos sócios não tinham este tipo de preocupação como prioridade.

Uma propaganda lançada em agosto de 1975 em C. J. Arquitetura e depois em outros títulos, decerto após a saída dos Hauner, mostra uma clara diferença de linguagem em relação ao material anterior. Ao invés de explorar ambientes onde se aspirasse estar, eram retratados casais, ainda que com alguma diversidade, muito tradicionais. O discurso se pautava pouco na questão do design e era muito mais voltado à venda, já que não havia nenhuma referência a marcas ou designers [2.3.27]. 
Jovens duros e rebeldes. senhoraienhores, casais milionários e priblico de bom gosto em geral: vejam o quinte Store anda comprando para vocês.

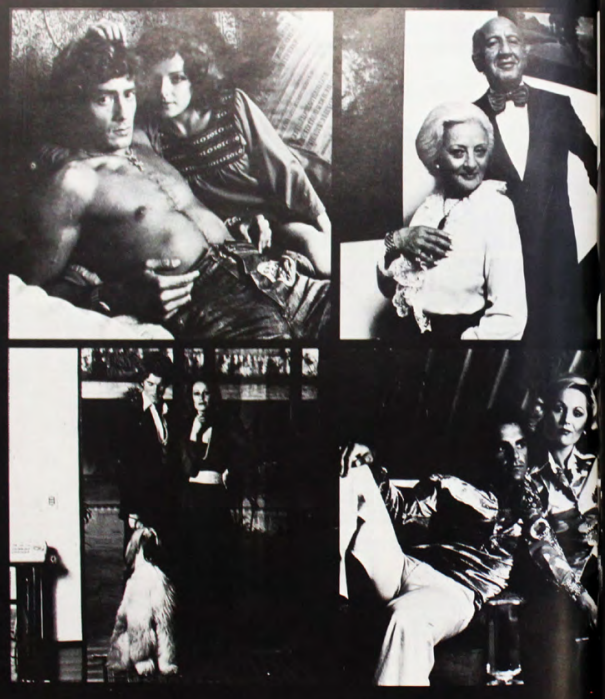

O único compromisso do

HOME STORE é escolher o bom design, entre

os milhares de produtos que se fabricam

para casa. Separar o joio do trigo e comprar so

o que é fino e atual. Para você poder escolher entre

uma cadeira de um designer famoso e outra

de palha feita por um caiçara de muito talento.

Preço para nós não define nada.

Se uma mesa de 10 milhões fica bem com cadeiras

de 100 cruzeiros, porque não? Nós juntamos

as duas para você colocar na sua casa e

assumir a sua personalidade. No HOME STORE

é assim. Caro ou barato, o produto de

bom design está lá. Mau gosto, nem de graça.

Venha conhecer as últimas compras

mesas, cadeiras, estantes, gravuras, tapetes,

objetos, faqueiros, copos, roupa de banho, mesa,

tapeçarias, puffs, plantas, tecidos e

penduricalhos que compramos para você.

Um show

aprovados pelo

HOME STORE

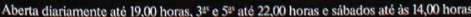

de coisas e produtos
2.3.27: Propaganda Home Store - Jovens Duros e Rebeldes. C. J. Arquitetura. pp. 68-69. ago. 1975.

De todo modo, dentre as parcerias realizadas enquanto Ernesto e Georgia Hauner estavam no Brasil, vimos que a complementação de produtos para a criação de uma imagem de estilo de vida, dos aparelhos de som ao apartamento que os móveis ocupariam, era um ponto central na promoção da empresa. Essas preocupações se transmitiam igualmente para a divulgação em mídia empresa, com investimentos ainda maiores para inserções exclusivas da Mobilinea, como veremos a seguir. 
Notas

${ }^{1}$ Ver imagens do projeto de Sergio Rodrigues em: Alex Calheiros, Marcelo Mari, Priscila Rossinetti Rufinoni (org.), Mobiliário Moderno: das pequenas fábricas ao projeto da UnB, 2014, p. 219. Em 1961, Mobília Contemporânea lançou um sistema bastante similar, indicando ao mesmo tempo o tipo de desenho que alcançava sucesso comercial e que todos esses designers estavam próximos em suas pesquisas projetuais.

2 "A Versatilidade das Estantes Modernas". Casa \& Jardim. pp. 33-35. maio 1960.

${ }^{3}$ Idem, p. 34.

4 "Um apartamento transformado pela decoração". Casa \& Jardim. pp. 26-28. maio 1964.

${ }^{5}$ Visto pela primeira vez em propaganda Mobilinea- Patinhos. Casa \& Jardim. set 1965.

${ }^{6}$ Localizada pela primeira vez em propaganda Mobilinea - móveis de linha. O Estado de São Paulo. p. 7. 14 out. 1962.

${ }^{7}$ Conforme levantamento realizado pela autora em cadeira Mobilinea (c. 1965) de Célia e José Francisco Quirino em 18 de junho de 2014

${ }^{8}$ Conforme levantamento realizado pela autora em mesa Mobilinea (c. 1971) de Nelson Graubart em 16 de junho de 2014. Em entrevista, Yone Koseki Pierre também atestou a existência do miolo metálico no pé da mesa. Entrevista concedida por Yone Koseki Pierre à autora em 18 de julho de 2014.

9 "Cada Carrinho no Seu Canto". Casa \& Jardim. pp. 68-71. jun. 1968.

${ }^{10}$ Chapa de fibra de madeira produzida pela empresa Duratex.

${ }^{11} \mathrm{Em}$ entrevista, Yone afirmou que não era possível pintar móveis feitos em Jacarandá por causa da resina da madeira, que manchava a peça. Assim, supõe-se que, neste momento, todos os móveis pintados eram feitos em Amendoim ou chapa de madeira aglomerada. Entrevista concedida por Yone Koseki Pierre à autora em 18 de julho de 2014.

12 "O Móvel Brasileiro - Inquérito". Arquitetura. pp. 17-24. jan. 1965.

${ }^{13}$ Idem, p. 24.

14 Id. Ibid.

${ }^{15}$ Localizada pela primeira vez na propaganda Mobilinea - Uma Estante num Instante. Casa \& Jardim. jan. 1966.

${ }^{16}$ Georgia Hauner, Showrooms, Fotografia, Artesanato, 2011, p. 1.

17 "Op Art". Casa \& Jardim. pp. 33-34. jun. 1966.

${ }^{18}$ Conforme anunciado no jornal O Estado de São Paulo em 14 de maio de 1970, p. 88.

19 "Decoração de JOIA" (Caderno Especial). Joia. pp. 55-77. fev. 1967. Vale notar que a madeira em que os móveis estão expostos e como a foto foi tirada indicam que provavelmente a direção de arte deste ambiente não foi feita por Georgia Hauner.

${ }^{20}$ Entrevista concedida por Georgia Hauner à autora em 12 de setembro de 2012.

21 "As pequenas salas de jantar". Claudia Decoração. 14. jul. 1971.

22 "Móveis Infantis". Claudia. pp. 144-149. set. 1969.

${ }^{23}$ Carta de Luiz Carta a Ernesto Hauner de 22 de janeiro de 1969. Acervo pessoal de Georgia Hauner.

24 "Móveis Infantis". op. cit., p. 144.

25 "Desenho Industrial 68". GAM - Galeria de Arte Moderna. n. 16, edição especial. p. 47. 1968.

${ }^{26}$ Conforme levantamento realizado pela autora em sofá Mobilinea (c. 1970) de Adélia Pasta em 07 de julho de 2014.

27 “C. J. Visita...". Casa \& Jardim. pp. 45-57. jul. 1970.

28 "O tecido na Moda da Decoração". Claudia Decoração. pp. 22-25. dez. 1969.

${ }^{29}$ Conforme atestado por Judit Magyary em entrevista concedida à autora em 29 de julho de 2014.

30 "Arquitetura de Interiores no Brasil". Projeto \& Construção. n. 2. pp. 41-44. jan. 1971.

${ }^{31}$ Idem. pp. 41-42.

${ }^{32}$ Entrevista concedida por Judit Magyary à autora em 29 de julho de 2014.

${ }^{33}$ Entrevista concedida por Bibita (Maria Beatriz) Butcher à autora em 23 de julho de 2014.

34 "O Móvel de Hoje". Casa \& Jardim. pp. 20-23. maio 1971.

${ }^{35}$ Idem. p. 20.

36 "C. J. Visita...". Casa \& Jardim. pp. 41-53. jul. 1971.

${ }^{37}$ Neste tipo de sistema de fixação, uma caixa conectora (tambor) é instalada na lateral do móvel e um parafuso (pino) atravessa o montante perpendicular a ele, de forma que sua cabeça é introduzida no centro do tambor, sendo apertado firmemente. Desta maneira, o metal não desgasta a madeira a cada montagem, aumentando a vida útil do móvel e facilitando os processos de montagem na fábrica e na casa dos clientes.

${ }^{38}$ De acordo com entrevista concedida por Yone Koseki Pierre à autora em 18 de julho de 2014.

${ }^{39}$ Catálogo "Mobilinea estante 1600". Sem data. Acervo pessoal de Georgia Hauner.

40 "Indústrias de Móveis serão Pouco Afetadas". A Folha de São Paulo. p. 16, Primeiro Caderno. 13 jan. 1972.

${ }^{41}$ A razão social da empresa Masul S.A. Madeiras Sul-Americanas ainda existe e tem sua sede no bairro do Jabaquara, em São Paulo.

${ }^{42}$ Entrevista concedida por Georgia Hauner à autora em 14 de setembro de 2012.

43 "Boa Ideia: Juntar dois Apartamentos Pequenos". Casa Claudia. pp. 74-77. ago. 1974.

${ }^{44}$ Georgia Hauner lembrou-se de que os rodízios eram feitos a partir de bolas de bilhar coloridas, adaptadas para este uso. Entrevista concedida por Georgia Hauner à autora em 12 de setembro de 2012. 
${ }^{45}$ Conforme descrito na reportagem "Assim foi a UD". Casa e Jardim. p. 36. jun. 1972.

46 "Quatro Novas Maneiras de Decorar seu Escritório". Claudia. p. 119-126. mar. 1973.

${ }^{47}$ Conforme aferido em entrevista concedida por Ada Hauner à autora em 29 de agosto de 2012.

${ }^{48}$ Entrevista concedida por Ada Hauner à autora em 29 de agosto de 2012.

${ }^{49}$ Georgia Hauner, Segunda parte de respostas, 2012.

${ }^{50}$ À época, Elisabeth Wilheim era uma importante fabricante de tecidos.

${ }^{51}$ Entrevista concedida por Bibita (Maria Beatriz) Butcher à autora em 23 de julho de 2014.

${ }^{52}$ Entrevista concedida por Jorge Kornbluh à autora em 12 de dezembro de 2013.

53 O nome da Galeria Penguin é citado em propaganda da Ernesto Hauner Decorações - Mobilinea. A

Folha de São Paulo. p. 10, Caderno llustrada. 10 jun. 1961.

${ }^{54}$ De acordo com entrevista concedida por Ada Hauner à autora em 29 de agosto de 2012.

${ }^{55}$ Conforme informado na propaganda Mobilinea - Carteiras Escolares. O Estado de São Paulo. p. 2,

Caderno Geral. 26 abr. 1962.

${ }^{56}$ Entrevista concedida por Yone Koseki Pierre à autora em 18 de julho de 2014.

${ }^{57} \mathrm{~A}$ primeira referência à loja foi encontrada na propaganda Mobilinea - Catálogo. O Estado de São Paulo. p. 7, Caderno Geral. 14 out. 1962.

${ }^{58}$ De acordo com entrevista concedida por Bibita (Maria Beatriz) Butcher à autora em 23 de julho de 2014.

${ }^{59}$ Entrevista concedida por Judit Magyary à autora em 29 de julho de 2014.

${ }^{60}$ Georgia Hauner, Segunda parte de respostas, 2012.

${ }^{61}$ Entrevista concedida por Judit Magyary à autora em 29 de julho de 2014.

62 Entrevista concedida por Judit Magyary à autora em 29 de julho de 2014.

${ }^{63}$ Atual Rua Vinícius de Moraes.

${ }^{64}$ Sobre a Móveis Ralf (revenda da Mobilinea entre 1965 e 1971) e o mercado de decoração soteropolitano, ver: Yumara Pessôa, Decoração Soteropolitana na Década de 70: cores, formas e representações, 2007.

${ }^{65}$ Entrevista concedida por Judit Magyary à autora em 29 de julho de 2014.

${ }^{66}$ Atual Avenida Brigadeiro Faria Lima, 2232.

${ }^{67}$ Ver a esse respeito: Demósthenes Santos, A História da Construtora Alfredo Mathias 1960-1985, 2013.

${ }^{68}$ Propaganda Shopping Iguatemi - O Ponto que Nasce Feito. A Folha de São Paulo. p. 5, Primeiro Caderno. 28 ago. 1966.

${ }^{69}$ Propaganda Shopping Iguatemi - Lançamento. O Estado de São Paulo. pp. 11-13, Caderno Geral. 27 nov. 1966. Grifo nosso.

${ }^{70}$ Entrevista concedida por Yone Koseki Pierre à autora em 18 de julho de 2014.

${ }^{71}$ Georgia Hauner, Showrooms, Fotografias, Artesanato, p. 3.

72 Entrevista concedida por Judit Magyary à autora em 29 de julho de 2014.

${ }^{73}$ Entrevista concedida por Judit Magyary à autora em 29 de julho de 2014.

${ }^{74}$ Nas entrevistas, foi dito que iam muitos arquitetos de origem judaica e/ou árabe, mas não se sabia exatamente por quê.

${ }^{75}$ Georgia Hauner, Showrooms, Fotografias, Artesanato, p. 3.

${ }^{76}$ Ficha do filme no banco de dados da Cinemateca Brasileira. Disponível em: http://www.cinemateca. gov.br/cgi-bin/wxis.exe/iah/. Acesso em 16/07/2014.

77 Excerto do filme disponibilizado online. Disponível em:

https://www.youtube.com/watch?feature=player_embedded\&v=JhPNZN2dPVI. Acesso em 21/08/2014.

${ }^{78} \mathrm{Em}$ 1971, a revenda na capital baiana mudou da Ralf Decorações para a lluminação de Ambientes, no número 227 da mesma Rua Sete de Setembro. Conforme visto em propaganda Mobilinea - Esta é a sala de quem passou ontem Pela Mobilinea. Casa \& Jardim. jun. 1971.

${ }^{79}$ Identificação feita com o auxílio de Judit Magyary.

${ }^{80}$ Georgia Hauner, Showrooms, Fotografias, Artesanato, p. 3.

81 "O Incêndio e o Pânico no Edifício Louvre". A Folha de São Paulo. p. 12, Primeiro Caderno. 08 dez. 1972.

${ }^{82}$ Ao que tudo indica, atual Avenida Antártica.

${ }^{83}$ Ao que tudo indica, atual Rua Diogo Martins, 650.

${ }^{84}$ Propaganda Mobilinea - Esta é a sala de quem passou ontem pela Mobilinea. Casa \& Jardim. jun. 1972.

${ }^{85}$ Propaganda Jumbo - Os mais avançados móveis brasileiros estão reunidos no Jumbo Aeroporto. $A$ Folha de São Paulo. p. 30, Primeiro Caderno. 19 maio 1972.

${ }^{86}$ Propaganda Vidrobrás - O vidro existe para que V. possa aproveitar ao máximo o privilégio de viver na terra. Casa \& Jardim. p. 89. abr. 1969.

${ }^{87}$ Propaganda Vidrobrás - Só o vidro traz para a sua vida a natureza como cenário e o céu como dimensão. Casa \& Jardim. p. 7. set. 1969.

88 "Sonhe com Claudia: essa é uma sala louca por música". Claudia Decoração. pp. 52.55. dez. 1969.

89 "O Som em Sua Casa". Casa \& Jardim. jun. 1972.

${ }^{90}$ Id. Ibid.

${ }^{91}$ Atualmente a empresa apresenta-se como Panasonic, conforme anunciado em: http://panasonic.com. br/about/news/detail.aspx?id=30020. Acesso em 02/10/2014.

92 Propaganda National - 3 em 1. A Folha de São Paulo. p. 13, Primeiro Caderno. 31 maio 1973.

${ }_{93}$ Idem, grifo nosso.

${ }^{94}$ Brochura Mobilinea de apresentação para construtoras. c. 1972. Acervo pessoal Georgia Hauner. Grifo no original. 
95 Idem.

${ }^{96}$ A primeira propaganda de lançamentos da Construhab em parceria com a Mobilinea foi publicada em 8 de fevereiro de 1972 e a última em maio de 1973.

97 Ver a esse respeito: Maria Imbronito, Três Edifícios de Habitação para a Formaespaço: Modulares, Gemini e Protótipo, 2003.

98 Georgia Hauner, Segunda parte de respostas, 2012, p. 6.

99 John de Souza, Nova Firma de Móveis e Complementos para o Lar, sem data, p. 1. Documento datilografado do acervo pessoal de Georgia Hauner.

100 Georgia Hauner, Sugestões para o Novo Centro Comercial na 9 de Julho, 7 ago. 1972. Documento datilografado do acervo pessoal de Georgia Hauner.

101 Idem, p. 3.

102 Georgia Hauner, Sugestões para o Novo Centro Comercial na 9 de Julho, 7 ago. 1972, p. 4. Documento datilografado do acervo pessoal de Georgia Hauner. Grifo no original.

103 Georgia Hauner, Esclarecimentos sobre o projeto da Loja na Av. 9 de Julho, 28 nov. 1972, p. 1. Documento datilografado do acervo pessoal de Georgia Hauner. Grifo no original.

${ }^{104}$ Georgia Hauner, Sugestões para o Novo Centro Comercial na 9 de Julho, 7 ago. 1972, p. 4. Documento datilografado do acervo pessoal de Georgia Hauner.

105 Georgia Hauner, Esclarecimentos sobre o projeto da Loja na Av. 9 de Julho, 28 nov. 1972, p. 2. Documento datilografado do acervo pessoal de Georgia Hauner.

${ }^{106}$ Entrevista concedida por Yone Koseki Pierre à autora em 18 de julho de 2014

107 Georgia Hauner, Showrooms, Fotografia, Artesanato, 2011, p. 4.

108 Georgia Hauner, Esclarecimentos sobre o projeto da Loja na Av. 9 de Julho, 28 nov. 1972. Documento datilografado do acervo pessoal de Georgia Hauner.

${ }^{109}$ Georgia Hauner, Showrooms, Fotografia, Artesanato, 2011, p. 4.

110 John de Souza, Loja 9 de Julho, p. 1. Documento datilografado do acervo pessoal de Georgia Hauner.

${ }^{111}$ Georgia Hauner, Esclarecimentos sobre o projeto da Loja na Av. 9 de Julho, 28 nov. 1972. Documento datilografado do acervo pessoal de Georgia Hauner.

112 Georgia Hauner, Distribuição de espaço na Loja 9 de Julho, 7 dez. 1972, p. 3. Documento datilografado do acervo pessoal de Georgia Hauner.

113 Encarte publicitário Home Store. A Casa Claudia. dez. 1973.

114 "Uma finíssima camada de poliéster" usada para espelhar janelas em edifícios. "Aplicação Inusitada do Scotchtint". Jornal 3M. n. 1. 1974.

115 O logo pode ser visto em: João Carlos Cauduro, Marcas CM Cauduro Martino Arquitetos Associados / João Carlos Cauduro, Ludovico Martino, 2005

${ }^{116}$ Catálogo Home Store encartado em A Casa Claudia. dez. 1973. 



\section{Design editado}



As inserções da Mobilinea na mídia impressa, assim como seus móveis e suas lojas, dão parâmetros para compreendermos a história da empresa, evidenciando a importância da comunicação no design e a elaboração de diferentes discursos para diferentes públicos. Em meio a eles, sua identidade visual se consolidava através de elementos comuns presentes em editoriais, catálogos e propagandas, nos quais a marca promovia não apenas seus produtos, mas determinado estilo de vida com a atitude que os clientes da Mobilinea teriam ou almejariam ter, por meio de ambientações completas que muitas vezes incluíam seus ocupantes.

Nestecapítulo, buscaremosprimeiramentesituarquaiseram aspublicações em que a Mobilinea esteve presente: entre 1959 e 1975, localizamos inserções em dezenove revistas brasileiras, duas estrangeiras e nos dois principais jornais paulistas, apresentados aqui na medida em que dialogam com a trajetória da

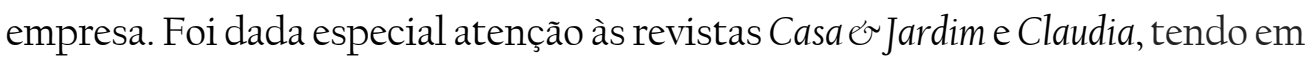
vista que a primeira é seguramente a mais importante do período no âmbito especializado, e a segunda, através de suas edições temáticas especiais, a que promoveu matérias mais inovadoras, contando com a própria Georgia Hauner como editora de decoração entre 1968 e 1970.

Em muitas destas promoções, foram simulados ambientes com móveis da Mobilineajunto aos diversos componentes necessários para compor uma situação doméstica, tal qual nas lojas, frequentemente incorporando elementos inusitados para chamar a atenção dos leitores e distinguir a empresa de outros anunciantes. Ocasionalmente estas imagens revelavam os cenários construídos para sua produção, novamente buscando um impacto visual, mas também denotando uma preocupação em traduzir estas cenas para espaços reais. Em outros momentos, projetos para casas e apartamentos foram publicados discutindo efetivamente o que se entendia como domesticidade na Mobilinea e, por duas vezes, casas dos Hauner chegaram a ser publicadas em periódicos, fazendo de seu estilo de vida pessoal um modelo a ser reproduzido e atestando uma coerência em sua estética na vida privada e em suas proposições profissionais.

Nesse sentido, é preciso pensar nestas imagens em função de quem as produziu e a quem visavam. Como veremos, os periódicos em que a empresa teve mais espaço e se colocou de maneira mais significativa eram voltados a mulheres, de forma que elas eram as maiores interlocutoras da Mobilinea. 
O discurso de Georgia Hauner era em muitos aspectos indissociável ao da empresa, mas ainda deve ser examinado em seus próprios méritos, considerando que tipo de ferramentas ela julgava interessante fornecer às leitoras para que criassem sua própria linguagem de interiores. Muitas das imagens produzidas contavam ainda com representações femininas, de alguma forma encarnando os valores aos quais essas leitoras deveriam se identificar. 


\subsection{O discurso na mídia impressa}

Em linhas gerais, foi possível distinguir quatro tipos de publicações impressas nas quais Mobilinea apareceu: jornais, revistas de assuntos gerais, revistas especializadas e revistas de estilo de vida. Em cada uma dessas, as formas de inserção se diferenciavam de acordo com os assuntos tratados, o público e a linguagem do periódico, de modo que serão apresentadas a seguir a partir destes temas.

Dentre os jornais, foram investigadas aparições da Mobilinea em A Folha de São Paulo e O Estado de São Paulo, títulos que na década de 1960 já tinham escala e legitimidade considerável. Como vimos, muitos dos primeiros lançamentos da empresa quando ainda se chamava Ernesto Hauner Decorações foram anunciados em jornais, exibindo móveis em vistas simples com fundo infinito ${ }^{1}$ [2.1.01-2.1.02]. Quando John de Souza entrou como sócio na empresa e ela passou a se chamar Mobilinea, os jornais foram os únicos veículos em que se manteve uma presença constante da marca através destes pequenos anúncios, mas, com a inauguração da loja da Augusta, isso se inverteu: entre 1963 e 1966, Mobilinea só apareceu em Folha e Estado nas listagens semanais de exposições de arte, sob o nome de "Galeria Mobilinea", incluindo algumas reportagens específicas sobre os artistas expostos [2.2.03]. No início de 1966, a campanha conjunta entre as diversas empresas de móveis foi lançada [1.3.05] e logo em seguida vieram os anúncios da inauguração do Shopping Iguatemi [2.2.052.2.06]. Ao longo de 1967, uma nova campanha foi publicada em O Estado de São Paulo emulando a identidade visual dos jornais com vistas dos móveis alinhados quase como em uma sequência textual, com peças para uso residencial ou corporativo [3.1.01-3.1.03].

Depois disso, Mobilinea ainda apareceu esporadicamente nos jornais, mas não de maneira que tenha lhe dado muito destaque. Dentre as poucas propagandas da empresa em jornais no período, em outubro de 1971 está o lançamento da linha Prêt-à-Porter na Folha ${ }^{2}$ com um desenho feito por Judit Magyary, que mostrava uma mulher metaforicamente levando uma nova sala de estar, dentro de um balão, para sua casa ${ }^{3}$ [3.1.04]. Este anúncio estava mais alinhado às demais campanhas da Mobilinea em outros veículos por mostrar ambientes completos em fotografia e dirigir-se a um público feminino, mas se mostrou uma exceção em relação às demais inserções da empresa nos jornais. 


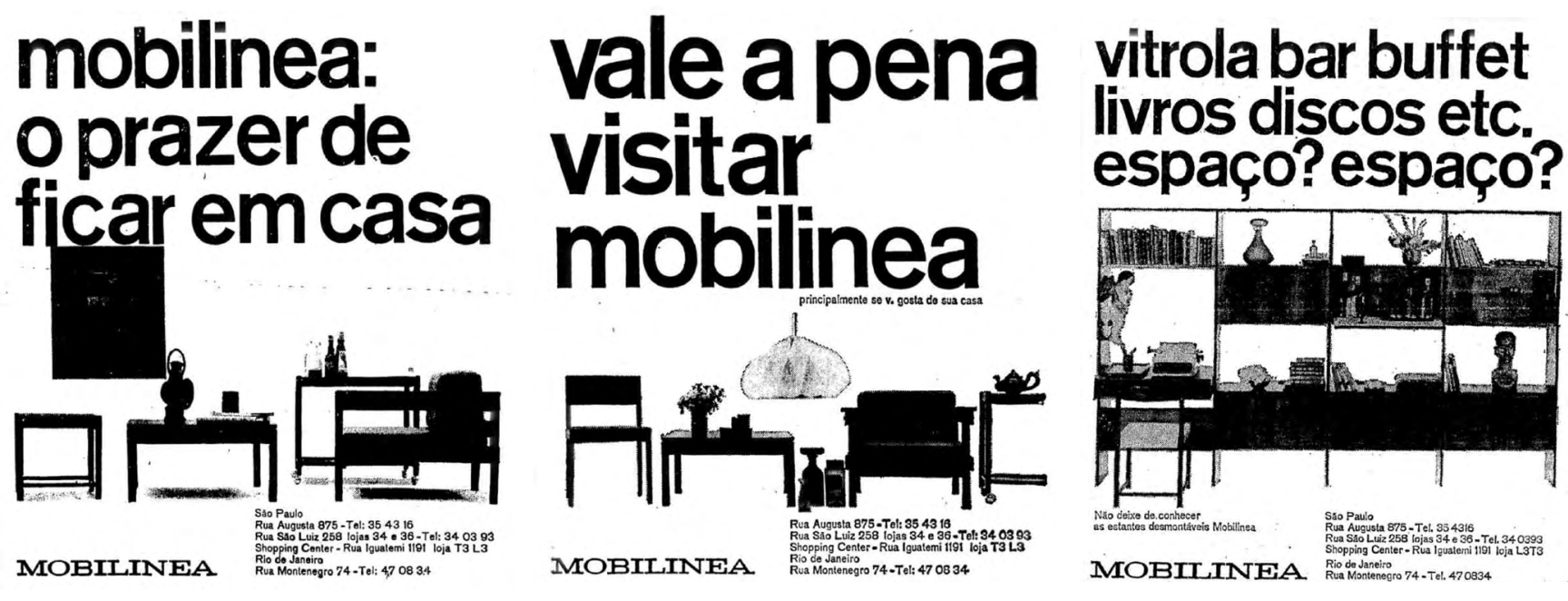

Em 1973, outra propaganda apresentou as cadeiras em fiberglass moldado e pés tubulares, com pequenos textos descrevendo suas qualidades técnicas considerando seu uso em ambientes corporativos. No ano seguinte este direcionamento foi levado ao extremo em uma campanha sem nenhuma imagem ou referência aos móveis: na íntegra da página os anúncios se mesclavam a reportagens reais, com uma grande "manchete" que anunciava um acontecimento drástico em uma empresa fictícia, e na sequência uma "notícia" explicando que o ocorrido se dera por causa da inauguração da nova fábrica da Mobilinea, e que estavam produzindo móveis de escritório com entrega em um dia [3.1.05-3.1.08]. A ideia destes anúncios parece ter sido misturar informação e humor, visando um público masculino em cargos de chefia nas empresas que poderiam vir a trocar seus atuais móveis pelos da Mobilinea:

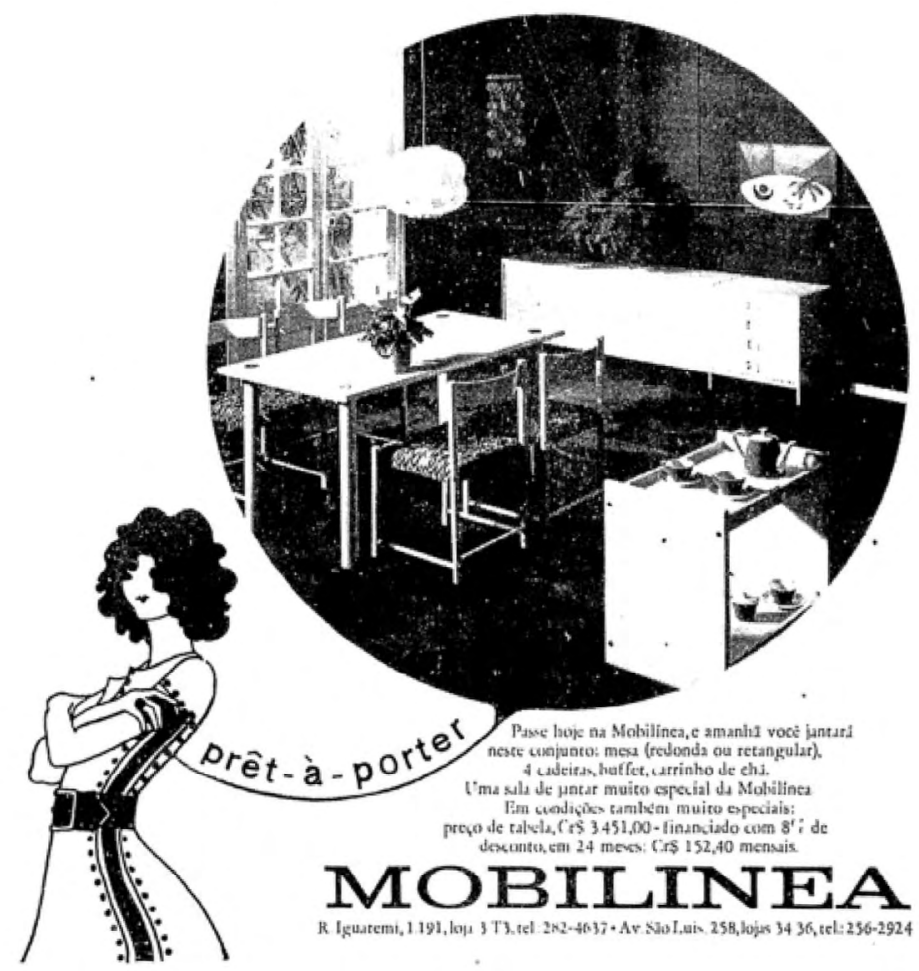

3.1.01: Propaganda Mobilinea - espaço?. $O$ Estado de São Paulo. p. 8, Caderno Geral. 13 abr. 1967.

3.1.02: Propaganda Mobilinea - vale a pena visitar. O Estado de São Paulo. p. 12, Caderno Geral. 04 maio 1967.

3.1.03: Propaganda Mobilinea - o prazer de ficar em casa. O Estado de São Paulo. p. 10, Caderno Geral. 20 jun. 1967.

3.1.04: Propaganda Mobilinea - Prêt-à-Porter, mulher. A Folha de São Paulo. p. 14, Caderno de Domingo. 24 out. 1971. 

escritório da noite para o dia. E comprou uma cadeira muito mais confortável. E um aconchegante sofá. ${ }^{4}$

3.1.05: Propaganda Mobilinea - empresário provoca revolução no gabinete. O Estado de São Paulo. p. 6, Caderno Geral. 06 nov. 1974.

3.1.06: Propaganda Mobilinea - homem de marketing finalmente levantou da cadeira. $O$ Estado de São Paulo. p. 22, Caderno Geral. 26 nov. 1974.

3.1.07: Propaganda Mobilinea - líder das classes produtoras vira a mesa. $O$ Estado de São Paulo. p. 27, Caderno Geral. 05 nov. 1974.

3.1.08: Propaganda Mobilinea - conspiração de ante-sala atinge advogado. O Estado de São Paulo. p. 4 Caderno Geral. 08 nov. 1974.

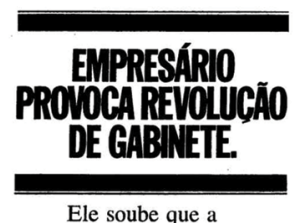

Ele soube que a
Mobilínea ampliou a fábrica e agora pode fornecer móveis para escritório da noite para o dia. E de acordo com as atuais técnicas de administração da F.G.V., revoluciono seu gabinete, instalando móveis cinematográficos.

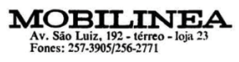

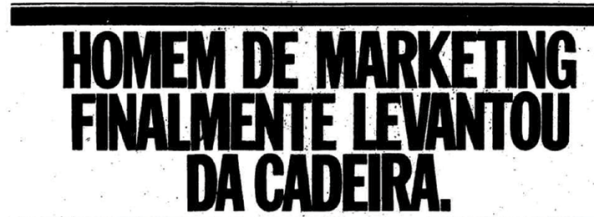

Ele soube que a Mobilínea ampliou a fábrica e agora pode fornecer móveis para escritório da noite para o dia. Ecomprou uma cadeira muito mais confortável. E um aconchegante sofá.

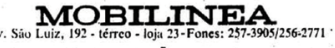

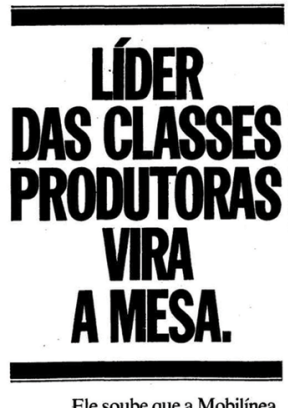

Ele soube que a Mobilínea ampliou a fábrica e agora pode fornecer móveis para

Sua mesa de reuniōes que já se tornara pequena, virou que mesa enorme.

mesa enorme. nir com todo conforto para votar os novos preços.

\section{MOBHILINNEA}

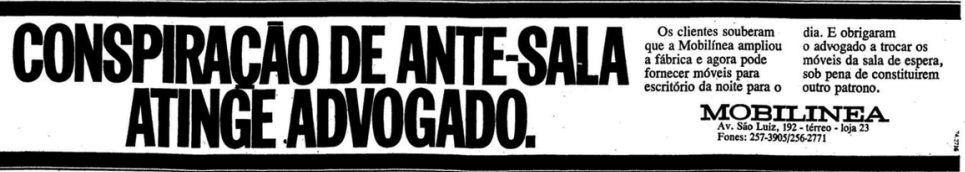

O partido adotado no conjunto das inserções de jornal, em suas variações, apresentou duas características principais: a apresentação direta das peças e uma predileção por comunicação textual. Supomos que tenha sido contratada uma agência publicitária para comprar estes espaços nas páginas dos jornais e produzir os anúncios, mas não foram localizadas informações a este respeito. De todo modo, fica uma sensação de que as diretrizes vinham mais de setores administrativos e financeiros da Mobilinea do que da equipe das lojas.

Dentre as revistas que consideramos como "especializadas", o público alvo também parece ser masculino, o que talvez seja o maior elo de contato entre os títulos do grupo. Estão nele: revistas de arquitetura e design (Arquitetura, Arquiteto, C. J. Arquitetura e Projeto e Construção), de arte (GAM - Galeria de Arte Moderna) e corporativas (Indústria e Desenvolvimento e Escritório Atual), que entre si também tinham suas especificidades.

Arquitetura e Arquiteto foram revistas organizadas pelo Instituto de Arquitetos do Brasil do Rio de Janeiro e de São Paulo, respectivamente, e tinham sua distribuição voltada para profissionais. C. J. Arquitetura, embora derivada de Casa \& Jardim, visava o mesmo público destas outras, como explicado em seu primeiro número, de janeiro de 1973:

Será uma revista trimestral destinada a veicular as conquistas profissionais dos arquitetos brasileiros pela publicação de suas ideias, opiniões e projetos, e ainda, servirá de órgão de divulgação dos comunicados e matérias do I.A.B. e seus Departamentos. (...) A revista terá circulação dirigida, sendo enviada a arquitetos, engenheiros, escolas de arquitetura, firmas de construção e consultoria, Ministério das Relações Exteriores, e a um público flutuante formado por instituições e empresas ligadas ao tópico tratado na matéria central. ${ }^{5}$ 
Em Arquitetura, Mobilinea foi uma das empresas consultadas para a elaboração de um grande dossiê sobre a situação do móvel brasileiro em janeiro de 1965\%; em Arquiteto, divulgou uma propaganda da cadeira de escritórios em fiberglass moldado em 19727; e em C. J. Arquitetura, a mesma cadeira e outros móveis em aço e fiberglass foram publicados em propagandas e reportagens, privilegiando peças corporativas através de imagens simples e sem cenários [2.1.27].

Projeto e Construção também tinha arquitetura como seu tema central, porém se voltava a um público leigo. Em 1971, Mobilinea foi uma das empresas chamadas para opinar sobre a situação do design e dos interiores no Brasil, e nessa ocasião Ernesto e Georgia foram convidados a depor juntos ${ }^{8}$. Enquanto ela direcionou seu discurso ao planejamento dos interiores e à necessidade de um entrosamento entre os móveis e a arquitetura, ele mais uma vez discutiu fabricação e comércio, reproduzindo a maneira como haviam dividido suas competências e trabalho na Mobilinea. No mosaico de imagens representando a empresa feito pela revista, vemos estampas artesanais de Georgia, o logo da Mobilinea, perspectivas da linha Prêt-à-Porter e uma foto do casal. A maneira como a imagem foi tratada fez com que Georgia e Ernesto parecessem estar usando uma espécie de jaleco, dando um ar científico às opiniões por eles formuladas. Possivelmente também para legitimar sua seleção, ambos foram apresentados pela revista como arquitetos, o que efetivamente não eram [3.1.09].

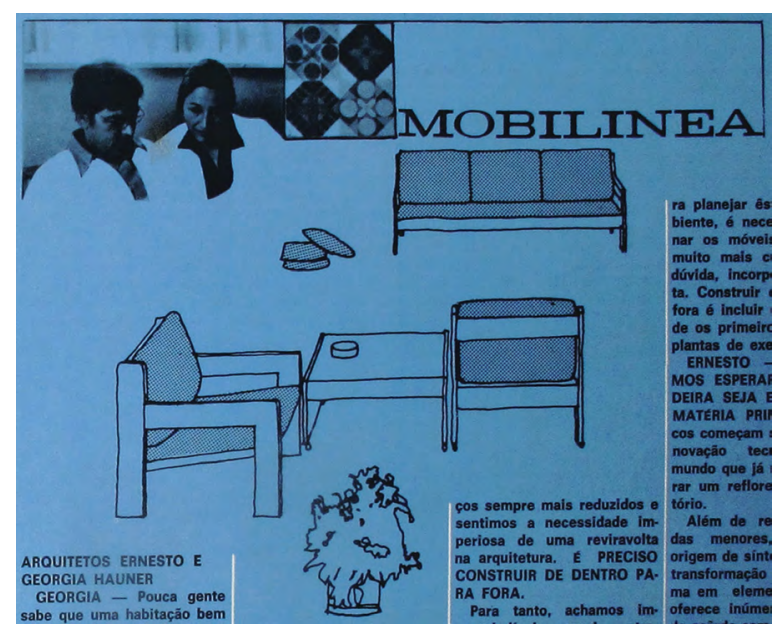

Em Indústria e Desenvolvimento, a participação da Mobilinea também se deu em um dossiê sobre a situação do design no Brasil, publicado em setembro de 1974 e intitulado "Forma estética e bom gosto ajudam a vender produtos", com fotos na Home Store. De modo geral, em publicações desta natureza, o foco dos debates era a situação do design no período e no pensamento por trás dos projetos, se pautando por vezes mais até no discurso da empresa e seus promotores do que nos objetos em si, e menos ainda em seus consumidores.
3.1.09: Mosaico de imagens representando a Mobilinea. "Arquitetura de Interiores no Brasil". Projeto e Construção. p. 41. jan. 1971. 
3.1.10: Propaganda Mobilinea - balança de abacaxi. GAM - Galeria de Arte Moderna. Edição Especial. 1968.
Já a presença da Mobilinea em uma revista de arte como GAM se justificou porque em virtude da I Bienal Internacional de Design do Rio de Janeiro em 1968, lançaram um número especial sobre ela com caráter catalográfico. A poltrona da Mobilinea na listagem de premiados não se fez com uma imagem que apresente elementos de interesse, mas uma propaganda na mesma revista exibia a cadeira 101, com braços, em vários ângulos, complementada por passarinhos, frutas, um busto em madeira e uma balança ${ }^{10}$. A letra $\mathrm{O}$ do nome Mobilinea está levemente deslocada para baixo, dando a sensação, junto aos objetos, de que apesar do aparente equilíbrio, algo ficava fora da ordem [3.1.10].

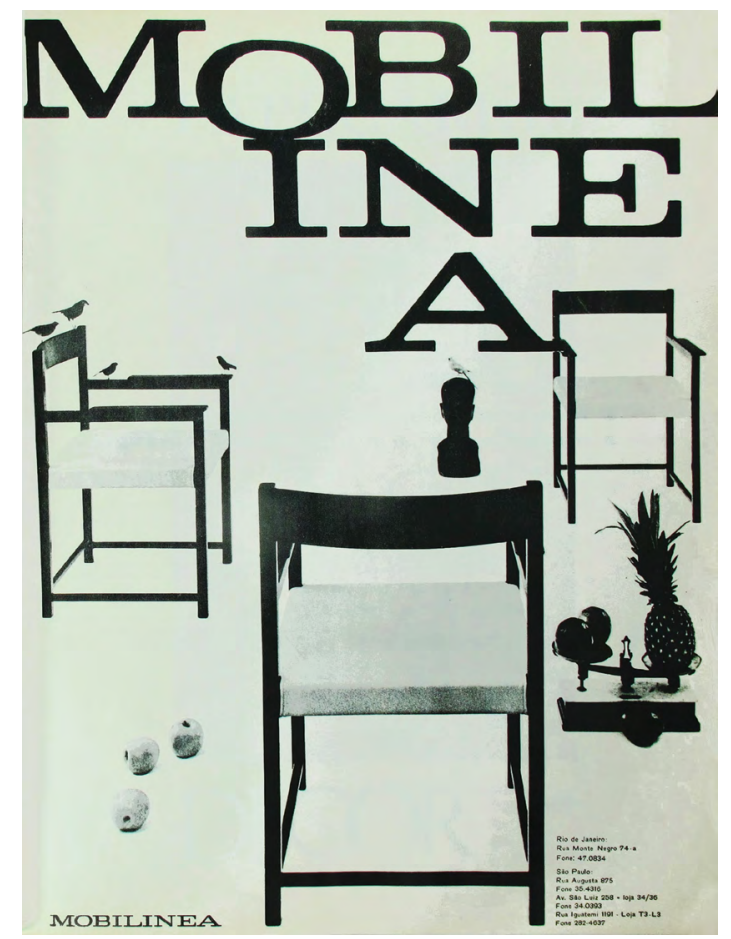

Finalmente, em Escritório Atual, Mobilinea apareceu como uma das

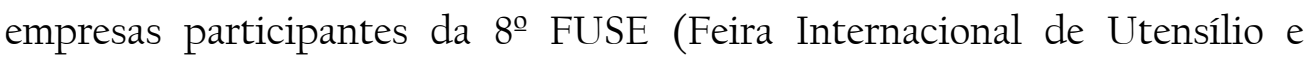
Serviços de Escritório), com duas pequenas fotos do showroom. Além disso, a cadeira de escritório em fiberglass foi mais uma vez promovida em publicações dessa natureza, em uma propaganda colorida mostrando as diversas cores do assento ${ }^{11}$ [3.1.11]. Se ainda eram exibidas sem cenário, nessa imagem as peças foram complementadas por gatinhos que as percorriam livremente, em contraste com seu aspecto industrial e da mesma maneira que ocorrera com a inserção dos abacaxis ou patinhos [2.1.07; 3.1.10].

Essa mesma propaganda apareceu em Exame, uma revista que classificamos como de assuntos gerais, embora também focasse um púbico primordialmente masculino e corporativo ${ }^{12}$. Neste mesmo grupo estão Veja, Realidade, Visão e Time - Latin American Edition. Realidade, Exame e Veja (lançadas em 1966, 1967 e 1968, respectivamente) são títulos da Editora Abril, com alguma diferença em 
seu foco e público alvo: a primeira se destacava por grandes reportagens de caráter investigativo, com design gráfico elaborado; a segunda era mais voltada à economia e negócios; e a terceira transitava entre política, economia, cultura e ciência. Visão foi uma publicação fundada pelo grupo norte-americano Vision, Inc. em 1952, inicialmente produzida no Rio de Janeiro e, a partir de 1957, em São Paulo, com um foco similar ao de Veja. Finalmente, Time foi fundada nos Estados Unidos em 1923, e durante a década de 1960 teve uma versão especial circulando na América Latina, com reportagens em inglês que debatiam temáticas similares às de Visão e Veja, mas de um ponto de vista internacional.

Uma propaganda da Mobilinea com móveis de escritório foi publicada em Visão em fevereiro de 1969, contando com as vendedoras das lojas como modelos. As peças são de Jacarandá e estão dispostas em três planos em relação à câmera, com elementos "emoldurando" a cena para que não houvessem vazios na imagem, além de contar com pequenos objetos cênicos por toda a composição - todas essas estratégias recorrentes na produção de imagens por Georgia Hauner [3.1.12]. Os móveis são práticos e multifuncionais, mas o que os torna memoráveis é a legenda, que visa transmitir a seriedade da Mobilinea e de seus clientes, assim como das mulheres retratadas em uma situação de trabalho:

Êles entregam os pedidos absolutamente dentro do prazo. Prestam total assistência a partir do momento em que $\mathrm{V}$. faz o pedido. E... muito importante... Mobilinea dá um nôvo aspecto ao seu escritório. É bom trabalhar com gente séria. ${ }^{13}$

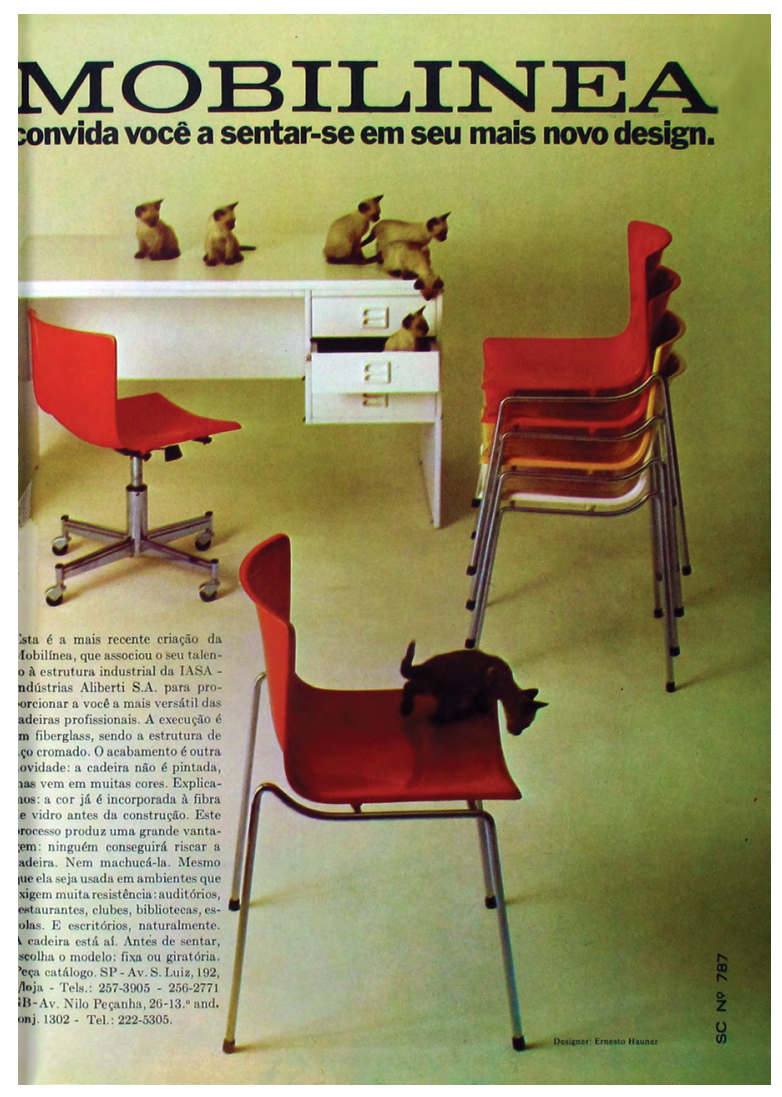

3.1.11: Propaganda Mobilinea - Mobilinea convida você a sentar-se em seu mais novo design. Escritório Atual. abr. 1972. 
3.1.12: Propaganda Mobilinea - Você vai ver como é bom trabalhar com Mobilinea. Em primeiro plano, Bibita Butcher, no meio Judit Magyary e ao fundo uma funcionária não identificada ${ }^{14}$. Visão. fev. 1969.

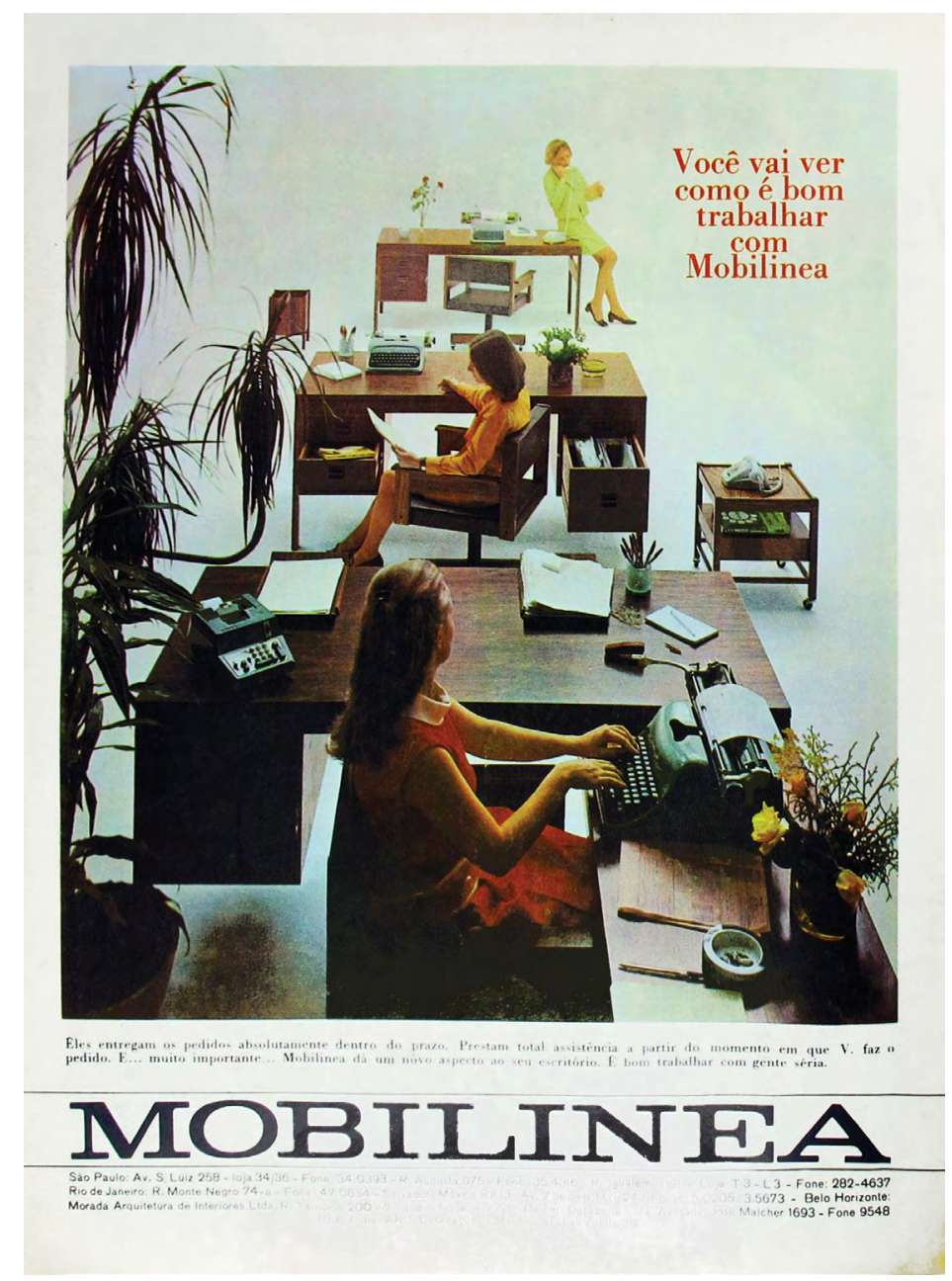

Em Time - Latin American Edition, foram localizadas duas propagandas de 1968: uma que repete a imagem do catálogo para vendas dos móveis de escritório no México, que também contava com as vendedoras da Mobilinea como modelos [2.2.21]; e outra que se apropriava de uma imagem produzida por Georgia para a revista Claudia [3.2.04], e que se repetiu em Veja no mesmo ano, com móveis residenciais. Nestas revistas, portanto, há uma abordagem híbrida, em que ainda há uma preferência pela divulgação de móveis corporativos, mas aparecem também promoções de ambientes domésticos com uso maior de cenografia e modelos. Enfim, em Realidade, Mobilinea foi coadjuvante em uma reportagem sobre a casa dos Hauner, que incluía alguns dos móveis da empresa, mas focava-se principalmente na arquitetura [2.1.26; 3.2.18-3.2.20].

Finalmente, chegamos às revistas classificadas como "mídias de estilo de vida”. Marinês Ribeiro dos Santos define este tipo de publicação discutindo seu impacto cultural ao produzir, divulgar e legitimar valores e comportamentos individuais e coletivos, funcionando como:

Guias que ajudam a definir o que e como escolher dentro de um vasto rol de possibilidades que incluem produtos, serviços e também experiências. Elas oferecem oportunidades para a atualização pessoal, por meio de sugestões acerca de como as pessoas podem aprimorar suas vidas, tanto moral quanto esteticamente. ${ }^{15}$ 
Encontramos inserções da Mobilinea nos seguintes títulos que se encaixam sob esta definição: Casa \& Jardim, Claudia e seus números especiais (Claudia Noiva, Claudia Decoração, Casa de Claudia, Claudia Cozinha e Ele e Claudia), Joia, Mais e Desfile, todos com público predominantemente feminino.

Fundada pela Editora Monumento em 1952, Casa \& Jardim buscava apresentar soluções que conciliassem a preservação de valores familiares tradicionais com a modernização do espaço doméstico ${ }^{16}$. Tinha distribuição nacional, abordando principalmente decoração e jardinagem, com tutoriais para costurar roupas, fazer receitas, arranjos florais ou pequenos artesanatos, além de incluir reportagens sobre arquitetura e construção civil, solicitando assim que suas leitoras tivessem habilidades tão variadas quanto compreender desenhos técnicos a fazer ikebanas.

A presença de Mobilinea em Casa e Jardim foi constante e variada ao longo dos 16 anos pesquisados, começando por algumas propagandas da Ernesto Hauner Decorações entre 1960 e 1961, ainda com uma estética similar à dos jornais [1.2.01]. Em Casa $\mho$ Jardim, houve uma clara ruptura durante a transição da empresa de Ernesto Hauner Decorações para Mobilinea, não havendo inserções na revista entre maio de 1961 e outubro de 1964; nessa data, a empresa foi selecionada para participar da seção "Um Móvel por Vez", na qual Casa $\sim$ Jardim escolhia uma peça para expor suas qualidades técnicas e plásticas [2.1.03]. Ainda assim, ao longo do ano seguinte, Mobilinea esteve presente na revista somente na seção de eventos culturais, como Galeria Mobilinea.

Em maio de 1965, Casa e Jardim passou a ser publicada pela Editora Monumento, com novo formato, mais fotos e projeto gráfico sofisticado. Mobilinea voltou às suas páginas em setembro daquele ano com a propaganda de lançamento dos móveis laqueados feita em fundo infinito vermelho [2.1.07]. A partir daí, e principalmente após a inauguração do Shopping Iguatemi, a presença da empresa tornou-se constante em propagandas e editoriais temáticos.

A família retratada pela revista até meados dos anos 1960 era bastante tradicional: heterossexual, branca, de classe média e nuclear, na qual a mãe deveria dedicar-se a cuidar da casa e dos filhos. Conforme a década avançou, essa situação começou a mudar, se tornando mais comum e eventualmente padrão que ela tivesse um emprego formal e que o marido ajudasse nas tarefas domésticas; sugestões para casais sem filhos ou para pessoas morando sozinhas também começaram a aparecer.

Ao longo dos anos, Casa \& Jardim demonstrou interesse crescente em promover a indústria nacional de design, organizando seu projeto mais ambicioso em 1970: “C. J. Visita”. Nele, empresas de design eram mensalmente selecionadas pela revista para produzir um editorial exclusivo, responsabilizando-se pela 
produção das imagens - o que permitia que a iniciativa tivesse um custo baixo para a revista, mas ainda interessasse às empresas pela escala da promoção. Além disso, os leitores eram convidados a enviar a planta de sua moradia à empresa divulgada, e a situação mais interessante ganharia um projeto de interiores com grandes descontos na posterior aquisição dos móveis, com publicação da solução na revista [3.2.04-3.2.07]. Mobilinea foi escolhida para inaugurar este projeto em julho de 1970 com um editorial de doze páginas fotografado na loja do Shopping Iguatemi, dirigido por Georgia Hauner. Apresentando a linha de aço e fiberglass, os ambientes mostravam as peças da empresa em ambientes completos, contando com representações femininas em várias das fotos [2.1.182.1.19; 3.3.05]. Nos meses seguintes, as empresas que apresentaram editoriais em Casa \& Jardim dentro de "C. J. Visita" foram: Mobília Contemporânea, Celina Decorações, Arredamento, Forma e Lafer.

Houve uma interrupção do projeto entre janeiro e junho de 1971, quando foi retomado com um novo editorial produzido pela Mobilinea, e continuou até outubro de 1975. Todas as empresas do primeiro ciclo salvo a Forma também estiveram neste segundo, além de Hobjeto, Guelman, Móveis Práticos, Velha Bahia, Cimo, Gerdau, entre outras. Em sua segunda participação, Mobilinea optou por uma abordagem diferente, não reproduzindo ambientes domésticos, mas criando um cenário abstrato com móveis da linha Prêt-à-Porter distribuídos sobre arquibancadas, entre frutas tropicais [1.2.07-1.2.10]. Esse tipo de desconstrução espacial foi usada em algumas propagandas da Mobilinea no período, e o uso de comida ou animais, como vimos, tornava as imagens marcantes e quebrava a rigidez das linhas industriais dos móveis.

No mesmo sentido de promover a indústria nacional de design como fazia em "C. J. Visita", Casa e Jardim criou na virada para a década de 1970 uma seção em que entrevistava designers proeminentes no Brasil (muitas vezes os mesmos cujas empresas eram escolhidas para os editoriais, mas em números distintos) e Ernesto foi o selecionado em maio de 1971, respondendo a perguntas de natureza similar às das revistas especializadas ${ }^{17}$.

Com o surgimento da Home Store, Mobilinea diminuiu seu investimento na mídia impressa para focar no novo empreendimento, e há poucas participações relevantes em Casa Jardim. Em linhas gerais, algumas características puderam ser identificadas na revista no decorrer dos anos 1970: por um lado, aumentaram as reportagens sobre arquitetura e interiores reais, bem como propagandas de materiais de construção e revestimentos; ao mesmo tempo, surgiram matérias sobre outros ramos da decoração além de mobiliário, como tecidos e louças, o que parece um sinal de maior variedade e especialização do mercado.

O segundo título mais importante para Mobilinea dentre as revistas de estilo de vida foi Claudia, que ultrapassava preocupações referentes aos 
cuidados com o lar, buscando tratar de todas as questões do universo feminino. Segundo Jaqueline Rios dos Santos, "a proposta editorial de Claudia, na época do lançamento, foi digerir e traduzir em linguagem corriqueira as mudanças e revoluções da sociedade brasileira" ${ }^{18}$. Para Luís Carta, primeiro editor da revista, ela foi o "abrasileiramento de uma fórmula de revista feminina mensal que já vinha sendo aplicada, fazia vários anos, nos EUA (Mc Call's e Ladies Home Journal) e na Europa (Marie Claire, Arianna)"19. Claudia foi lançada pela Editora Abril em 1961, com tiragem nacional, concebida e dirigida inicialmente por Sylvana Civita - esposa de Victor Civita - e Micheline Gaggio Frank, que viera em 1953 da Editorial Abril da Argentina para atuar em Capricho, Ilusão e outros títulos femininos da empresa brasileira ${ }^{20}$. Luís Carta foi o diretor de redação até o fim de 1965, quando entrou em seu lugar Thomaz Souto Corrêa, que permaneceu até 1972. Depois dele, ocupou o cargo Carlos Alberto Fernandes até 197821.

A mulher com quem Claudia conversavae personificava tinha características similares às da mulher retratada em Casa \& Jardim, mas aqui investia-se na cumplicidade com as leitoras e mesmo na ideia de confidência entre amigas, o que deixava a revista bastante persuasiva ${ }^{22}$. Os artigos de comportamento eram maioria, mas seções temáticas foram aos poucos se consolidando e tornaramse publicações independentes, lançadas em intervalos variados. Claudia Noiva e Claudia Cozinha surgiram em abril de 1964, Claudia Decoração em abril de 1967, A Casa de Claudia começou em agosto de 1969 (em abril de 1974 passou a se chamar Casa Claudia), Ele e Claudia apareceu em outubro de 1971, Claudia Moda em abril de 1971, Claudia Beleza em junho de 1971 e Claudia Moda e Beleza em junho de $1973^{23}$.

As fotos de interiores domésticos em Claudia até a segunda metade da década de 1960 eram compradas de publicações estrangeiras ou feitas na casa de personalidades brasileiras, sem instruções sobre como adquirir as peças exibidas. Aos poucos, a produção nacional começou a ser mais valorizada e, no início de 1968, Tomaz Souto Corrêa convidou Georgia Hauner para fazer um editorial em Claudia Noiva que sairia em março daquele ano, tendo como tema a casa de recém-casados ${ }^{24}$. Esse contato pode ser entendido como um reconhecimento pelo trabalho que ela vinha realizando nas lojas e propagandas da Mobilinea, e seu editorial foi bem recebido na Abril, de forma que foi chamada para ser a nova editora de decoração de Claudia e seus números especiais. As solicitações da revista para cada edição eram bastante livres e Georgia teve liberdade para expor seus pontos de vista: ela era incumbida de produzir um determinado número de páginas ${ }^{25}$ e tinha um prazo para entrega-las, podendo escolher quais empresas promover, com um carro da Abril à disposição para buscar e devolver os móveis selecionados. Os cenários eram construídos em estúdios fotográficos ou na fábrica da Mobilinea, muitas vezes mobilizando 
operários da fábrica para este fim. De acordo com Georgia, a Abril não interferia muito em seu trabalho por considera-la uma especialista:

\begin{abstract}
Os editores olhavam, às vezes criticavam nas minhas fotos uma coisa ou outra, às vezes elogiavam. E também no planejamento das revistas eles me deixavam mais ou menos livre. Nunca me deram temas para desenvolver, a não ser o de promover a indústria brasileira. Essa era a única direção que me deram para as revistas que eu fazia para eles. ${ }^{26 v}$
\end{abstract}

Por iniciativa própria, Georgia estabeleceu uma parceria com o Museu de Arte de São Paulo (MASP), diretamente com Pietro Maria Bardi, que a apoiou e passou a emprestar quadros e esculturas para os cenários por ela construídos, entendendo que mais gente teria acesso àquelas obras nas páginas da revista do que no próprio museu. Via Bardi, Georgia entrou também em contato com a Divisão de Parques e Jardins da Prefeitura de São Paulo para pedir sua colaboração, a partir da qual foi possível incorporar uma boa variedade de plantas nos ambientes ${ }^{27}$. Ela diz sempre ter tomado cuidado em não privilegiar a Mobilinea em detrimento de outras empresas de design que julgasse relevantes ${ }^{28}$ mas, ainda assim, móveis da empresa apareceram em quase todos os editoriais feitos por ela, o que aumentou consideravelmente a exposição da marca na mídia durante este período.

Em 1969, a Editora Abril criou uma promoção para os leitores de Claudia sorteando duas casas pré-fabricadas de $120 \mathrm{~m}^{2}$ produzidas por Bel Recanto, que poderiam ser montadas em qualquer lugar do Brasil. A promoção da "Casa de Claudia" foi anunciada pela primeira vez em março, e no mês seguinte foi publicado um novo anúncio informando que houvera uma grande mobilização de empresas de construção e decoração interessadas em contribuir com a promoção, de modo que definiu-se que a casa seria sorteada completa, com todos os móveis, aparelhos, tintas e acabamentos. Uma casa modelo foi construída no bairro do Morumbi com projeto interno feito por Georgia Hauner e aberta para visitação, incluindo peças de Ajardinamentos Alvorada, Anselmo Cerello, Arredamento, Cerâmica Sanitária Porcelite, C.I.A.C.I. Cortinas, Corticeira Paulista, Decorações Ruth, Dominici, Galeria das Lonas, General Motors do Brasil, Frigidaire, Honey's, Trorion, Mobília Contemporânea, Mobilinea, Probjeto e Tintas Coral [3.2.08-3.2.12].

No mesmo ano, houve a experiência da Mobilinha Claudia, parceria entre a Mobilinea e a Editora Abril para a produção de uma linha de móveis infantis, que se refletiu em um editorial e em propagandas subsequentes também feitos por Georgia [2.1.14-2.1.16]. Esta colaboração se inseria em uma política mais ampla da Editora em fomentar o design nacional por ações diretas, e com este mesmo fim foram localizadas parcerias entre Abril e Mobília Contemporânea em janeiro de 1968, e com Hobjeto em setembro de 1970. 
Georgia trabalhou para Claudia até 1970. Além da demanda de trabalho que mantinha na Mobilinea, seus depoimentos indicam que o volume de trabalho e prazos de entrega impostos pela Abril eram extenuantes. As imagens que produziu enquanto estava contratada, entretanto, permaneceram como propriedade da editora, que tinha liberdade para usá-las da maneira que quisesse. Isso explica como uma foto produzida por Georgia Hauner publicada em dezembro de 1968 em Claudia Decoração apareceu na capa da revista espanhola El Mueble em $1975^{29}$.

Na reportagem original, "Você nem percebe, mas está cercada de arte por todos os lados"30, a proposta era mostrar como incluir arte na decoração da casa independentemente do nível de renda de seus moradores e, na imagem representando o quarto de casal, todos os móveis eram da Mobilinea e estavam laqueados em amarelo. Sobre a cama, haviam sido fixadas algumas páginas dos fascículos "Gênios da Pintura", coleção resultante de uma parceria entre a Editora Abril e o MASP, e na parede à esquerda da imagem, via-se um quadro pintado por Georgia de seus dois filhos ${ }^{31}$ [3.1.13].

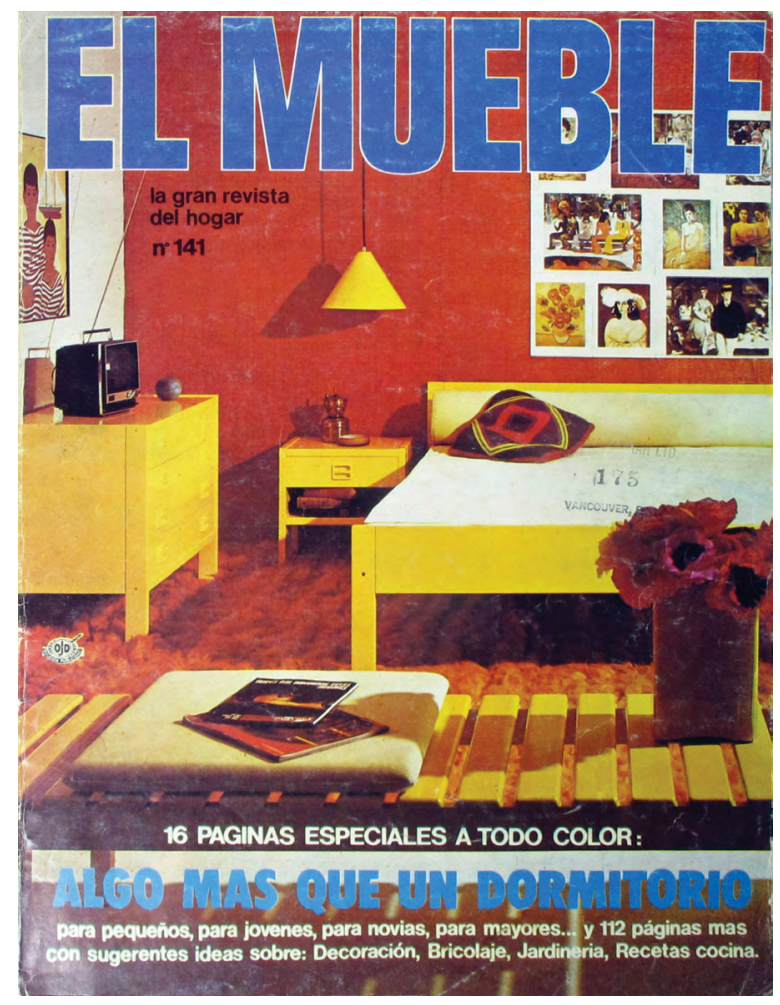

Com isso, vemos que a circulação de imagens acontecia em diversos sentidos, podendo-se imaginar que da mesma forma que fotos de ambientes identificados como alemães, franceses ou americanos apareciam em Claudia, esta enviava suas imagens a editoras destes países, divulgando e compartilhando certa estética doméstica. Não é exibida mais nenhuma foto da Abril no interior deste número de El Mueble mas, ainda assim, esta escolha de capa desvinculada
3.1.13: Capa de El Mueble com ambiente Mobilinea feito por Georgia Hauner para Claudia Decoração. El Mueble. Capa. 1975. 
de qualquer intenção comercial reafirma a ideia de que a Mobilinea, a partir dos ambientes criados por Georgia Hauner, havia estabelecido uma linguagem que representava um estilo de vida desejável e que ultrapassara a própria marca e mesmo o país.

Ainda assim, a empresa continuava se promovendo individualmente e, entre julho de 1971 e novembro de 1972, promoveu uma elaborada campanha para divulgar a linha Prêt-à-Porter, na qual todas as propagandas tinham a mesma diagramação, com uma imagem e um pequeno texto que ressaltava as qualidades dos móveis e da empresa, e que foi divulgada em Casa e Jardim, Claudia Decoração e Casa Claudia. Ao todo, foram produzidas seis fotografias, que apresentavam salas de jantar e de estar, dois dormitórios de casal e um de solteiro, e um depoimento de Marcelino de Carvalho atestando a qualidade dos móveis da empresa ${ }^{32}$. A primeira propaganda dessa série foi localizada em julho de $1971^{33}$, exibindo um ambiente de jantar: na imagem, vemos uma mesa e quatro cadeiras, um carrinho de chá e dois buffets ladeando uma janela central, todos laqueados de branco; o piso está coberto por um tapete azul escuro, a estampa

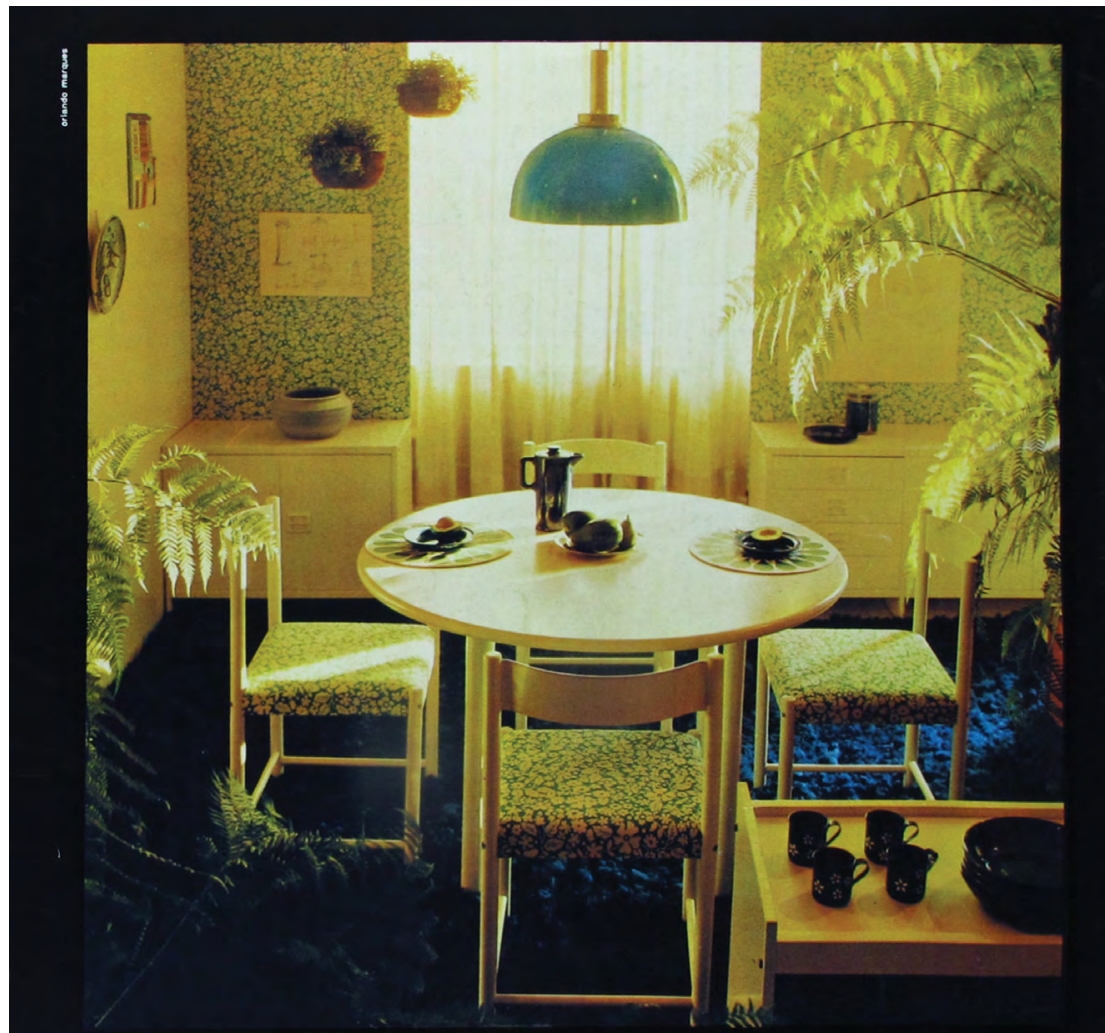

Esta sala é de quem passou ontem pela Mobilinea.

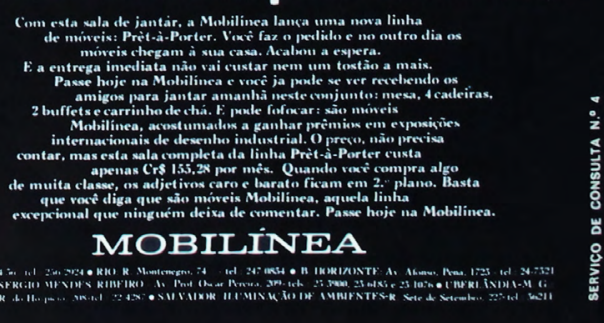


do estofado das cadeiras e da parede ao fundo é azul com flores brancas, uma luminária azul pende sobre a mesa e objetos diversos decoram as paredes. Todo o ambiente está banhado por uma luz que vem da janela e de uma fonte à direita do quadro, quentes e claras como um pôr do sol. Folhas de samambaia emolduram a imagem, ao mesmo tempo em que criam uma situação voyeurística, colocando o leitor em uma posição de olhar interessando, como se estivesse observando de outro cômodo ou até outra janela, vislumbrando como seria sua vida com Mobilinea, estratégia que se repetiu ao longo da campanha [3.1.14].

Nas demais revistas de estilo de vida, Mobilinea apareceu principalmente após a inauguração da loja no Shopping Iguatemi, quando atingiu uma posição mais consolidada no mercado: Joia, revista feminina da Editora Bloch que concorria com Claudia, criou editoriais temáticos entre 1967 e 1969 com ambientes da Mobilinea [2.1.11; 2.2.04]; já Desfile, publicação de moda também da Editora Bloch, lançou alguns números especiais sobre decoração entre 1972 e 1974, que contaram com fotos produzidas na Home Store exibindo móveis da Mobilinea e de outras empresas [2.1.28]. Finalmente, Mais, revista feminina da Editora Três, incluiu a empresa em uma reportagem de 1974 que buscava entender qual era o papel da decoração naquele momento, perguntando aos profissionais que "de uma forma ou de outra, ditam as regras do jogo. Para concluirmos que poucos são os que seguem estas regras"34; Ernesto Hauner foi entrevistado como designer da Mobilinea, e Georgia Hauner como responsável pela Home Store, onde foram mais uma vez fotografados juntos [1.2.11]. Em linhas gerais, a presença da Mobilinea nas revistas de estilo de vida foi marcada por liberdade para expor seus pontos de vista e um investimento grande na produção de imagens, transmitindo novas maneiras de agenciar o morar e se portar no espaço doméstico, como veremos a seguir.

Foi possível enxergar um padrão de representação nas diversas formas de inserção da empresa na mídia impressa, que ia desde uma preocupação em atestar a acessibilidade de seus móveis por prazos de entrega ou formas de pagamento até, e o que parece mais importante, por certa irreverência que marcava tanto os textos como as imagens da empresa: o "homem de marketing que finalmente se levantou da cadeira", os ambientes ocupados por frutas, animais e objetos descabidos, ou as funcionárias trabalhando de mini saia, todos buscavam se destacar nas páginas dos periódicos e transmitir uma sensação de atualidade e ousadia.

Afim de tornarmais clara a dimensão da empresa na mídia impressa, criamos um gráfico com as aparições da Mobilinea por título e ano. Nele, nota-se uma constância da empresa em Casa \& Jardim e o aumento da exposição da marca com a entrada de Georgia Hauner na Editora Abril, aliada a uma pluralização do tipo de revista que contava com a presença da empresa em suas páginas, 
3.1.15: Gráfico das aparições da Mobilinea na mídia impressa por ano e título, realizado a partir do levantamento de periódicos. que pode ser creditado também a um reconhecimento dos projetos de Ernesto Hauner no campo do design. Como vimos, a partir da inauguração da Home Store, que se valeu não apenas das estratégias desenvolvidas para as demais lojas da Mobilinea como também destas experiências editoriais, os investimentos da Mobilinea na mídia impressa diminuíram consideravelmente, mas suas peças ainda eram escolhidas para participar de reportagens temáticas, mesmo que fossem apresentadas em vistas simples ou em fotos produzidas pelas revistas, por isso não se evidencia um declínio imediato. No caso dos jornais, optamos por uma representação separada porque, com suas tiragens diárias, não se pode atribuir o mesmo peso a inserções neles e em revistas [3.1.15].

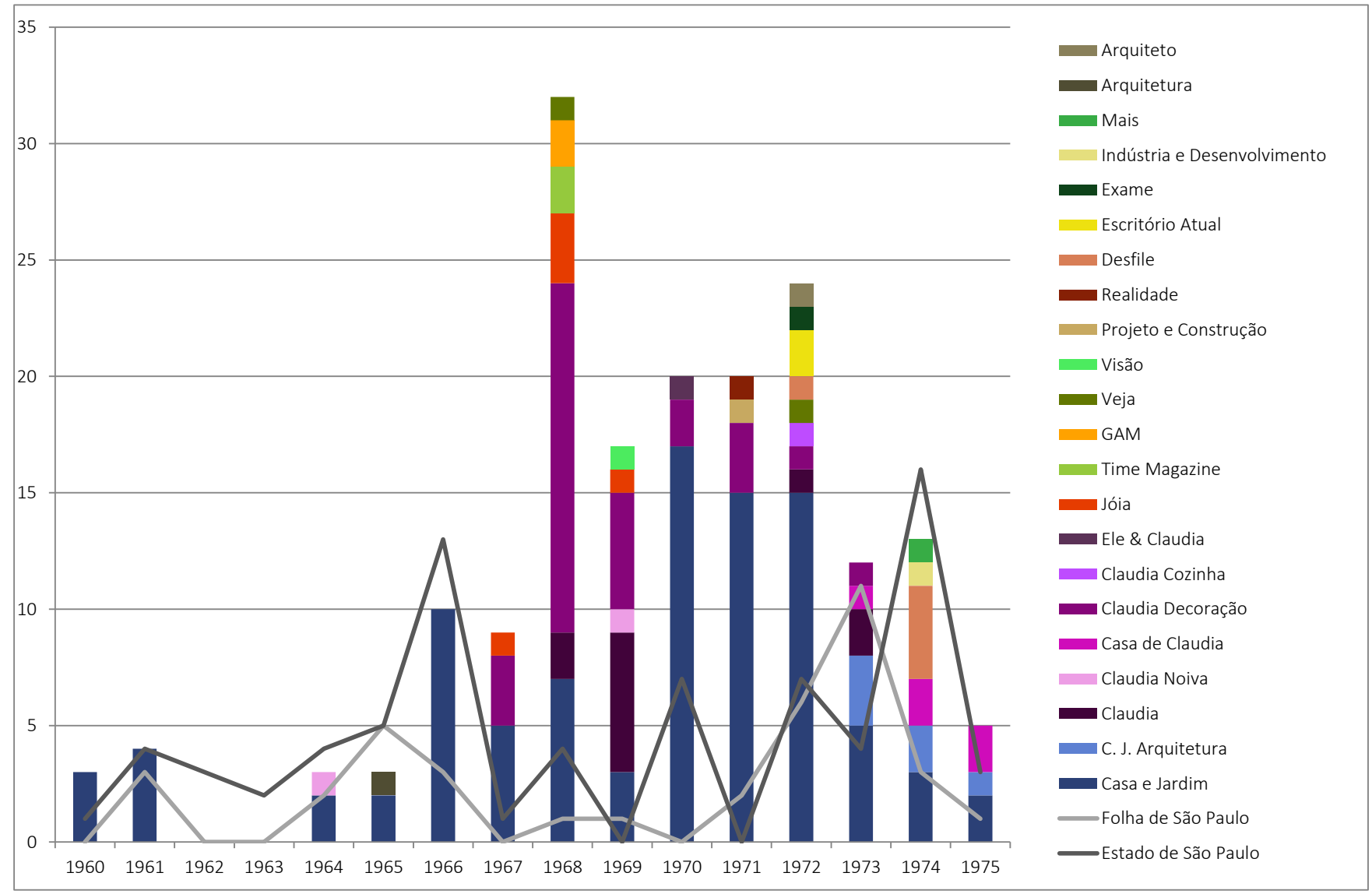




\subsection{Domesticidades modernas}

Em fotos como as da campanha para divulgar os móveis Prêt-à-Porter ou produzidas para editoriais (muitas das quais circularam posteriormente como propagandas), bem como na disposição das lojas que também emprestavam seus espaços para estes fins, evidencia-se na Mobilinea uma coerência na forma de se ocupar ambientes e um cuidado em transmitir que aqueles móveis tinham uma neutralidade sobre a qual poder-se-ia imprimir a personalidade de seus ocupantes. Móveis em madeiras maciças aparentes eram populares na Mobilinea, mas a escolha pelo branco ao longo dos anúncios e reportagens dava um status de novidade ao mesmo tempo em que não limitava as opções de composição, e eram dispostos de maneira que suas qualidades materiais fossem valorizadas, mas também com uma intenção de suscitar nos leitores um desejo de que suas vidas insinuassem uma narrativa atraente como as propostas nas imagens, muitas vezes fora de padrões tradicionais.

Em abril de 1968, Casa $\approx$ Jardim fez uma reportagem sobre quartos e salas de estar com sugestões para diversos tamanhos de casa, na qual ponderavam que comprar móveis deveria ser um investimento e portanto eles deveriam durar - tanto física como esteticamente, e convidaram algumas empresas para apresentarem suas propostas ${ }^{35}$. A sala criada por Mobilinea foi dividida em dois níveis: no primeiro plano, vemos um conjunto de sofás, poltronas e mesa de centro; atrás deste ambiente, elevado cerca de meio metro em relação ao primeiro, foi montada uma área de jantar com mesa, poltronas Thonet, carrinho de chá e estantes modulares. Mais uma vez os móveis foram laqueados em branco, com estofados e lustre de papel em tons de laranja, complementados ainda por flores, um pote de laranjas, abóboras espalhadas pelo piso, mais alguns objetos decorativos e muitas plantas. O texto de apresentação fala que seria uma decoração para "apartamento ou residência com três cômodos para recém-casados que desejam utilizar um dos quartos como escritório ou ambiente de leitura" ${ }^{36}$, e descreve os ambientes com algumas características materiais, reforçando que seriam moradores jovens e alegres [3.2.01].

Esta sala apareceu no mês seguinte em uma propaganda da revista Time Latin American Edition com diferenças mínimas em relação à imagem do editorial de Casa $\mho$ Jardim $^{37}$, e também em uma propaganda de página simples divulgada 
3.2.01: Ambiente de estar Mobilinea. "Sala e quartos". Casa \& Jardim. pp. 80-81. abr.1968.

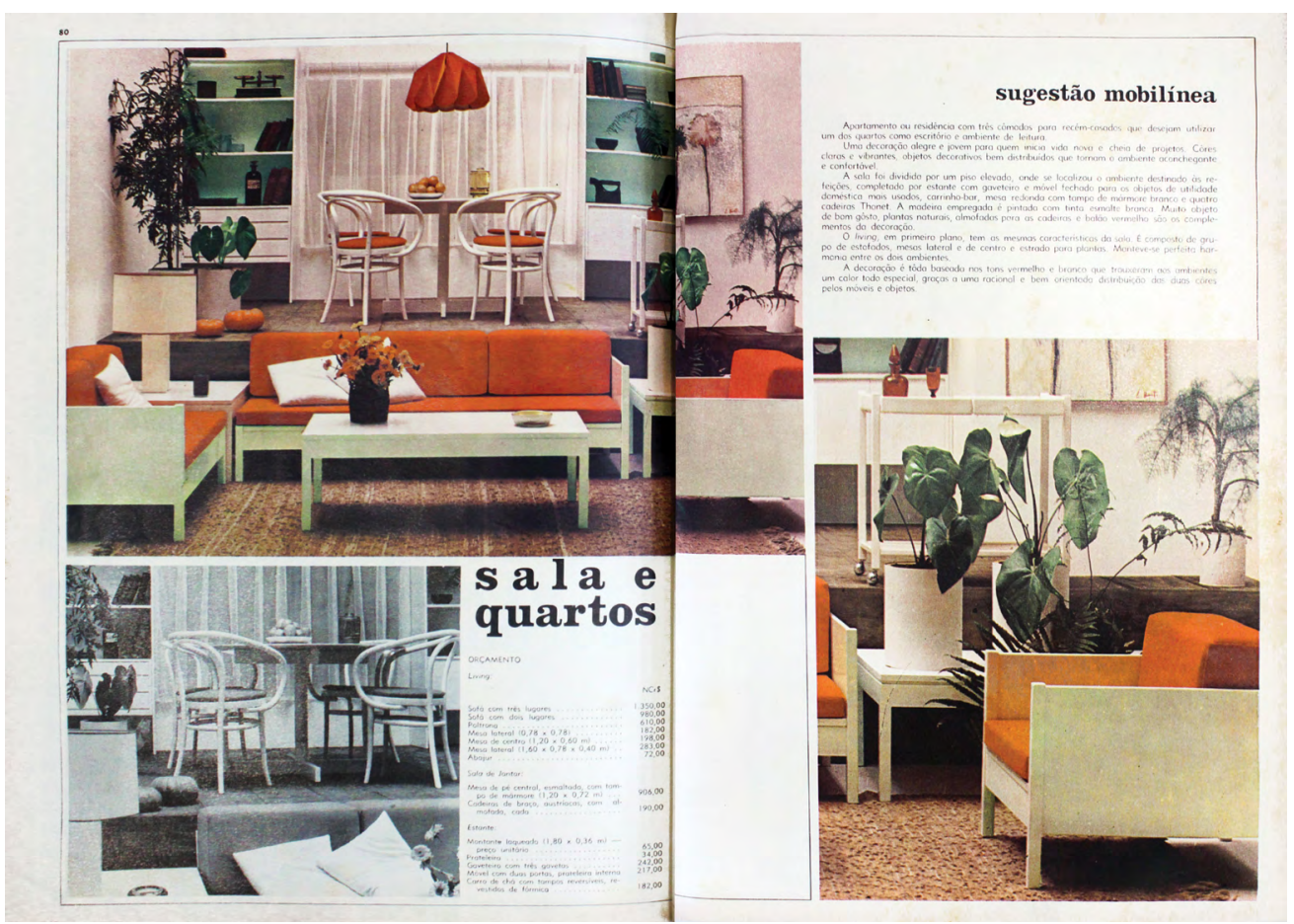

nas edições de Claudia e Claudia Noiva em março de $1969^{38}$. Nelas, foi incluído um pequeno texto que reforçava a ideia de que este ambiente estaria voltado a um casal jovem começando a vida juntos: "Mobilinea compreende os problemas de quem inicia a vida agora. Converse com eles. Temos a certeza que você irá encontrar um planinho racional de decoração (e de pagamentos também)"39. Se esse "casal" já teria um nível financeiro que permitisse a compra de um apartamento de tamanho razoável, a possibilidade de financiar seus móveis permitia dissolver gastos.

Como vimos, ambientes integrados estavam em voga porque a arquitetura residencial caminhava para espaços menores e por isso menos compartimentados, mas que ainda exigiam algum tipo de organização. A fim de criar repertório acerca dessas questões, revistas publicavam editoriais didáticos, e em algumas destas ocasiões Mobilinea teve a oportunidade de não apenas apresentar suas peças, mas com efeito mostrar o passo a passo para a construção de seus ambientes, como no caso da reportagem "Divisores de Ambientes" de maio de $1968^{40}$, em que Casa $\sim$ Jardim pedira a Celina Decorações, Companhia Produtora de Vidro (Providro) e Mobilinea que organizassem ambientes grandes ou pequenos a partir de divisórias, aparentemente sem restrições quanto à apresentação de suas propostas ${ }^{41}$. Mobilinea, além de desenvolver uma planta, construiu um apartamento cenográfico inteiro para mostrar como resolver um imóvel de dimensões reduzidas perdendo o mínimo possível de área, o que significou remover todas as paredes além do banheiro e criar divisórias com estantes próprias e também a partir de armários embutidos e cortinas. Além de fotos com vistas parciais dos cômodos, o mais impactante 
neste editorial foi uma fotografia tirada por cima do cenário, mostrando todos os ambientes do apartamento construído como em uma planta perspectivada, recurso que não foi visto em revistas antes deste momento, e que Georgia viria a usar nos editoriais para Claudia. Como em outras inserções, os móveis utilizados tinham pintura branca, deixando as cores para revestimentos e objetos decorativos [3.2.02].

Aqui, não restam dúvidas de que a proposta da empresa ultrapassava a necessidade de promover apenas seus produtos, preocupando-se com o projeto do ambiente doméstico em uma escala total. A revelação do estúdio fotográfico foi igualmente marcante em um editorial desenvolvido por Georgia Hauner já em Claudia Decoração em agosto de $1968^{42}$, no qual mostrava novamente como usar desníveis para dividir ambientes em casas ou apartamentos, e mais uma vez construindo uma sala de estar com móveis da Mobilinea em primeiro plano, à frente de uma sala de jantar com piso elevado, mas deixando-se ver também o chão, os refletores e demais equipamentos do estúdio fotográfico [3.2.03] $]^{43}$.
Aqui eu fiz questão de mostrar que era montagem fotográfica porque o público sempre achava que a gente ia na casa de alguém e tirava foto. O público nunca se deu conta que não dava para tirar foto assim numa casa de alguém porque tinha que recuar com a máquina fotográfica, então... Essas montagens chocaram mais gente, "nunca se fez isso em revista" porque revista fazia de conta que era coisa que existia. ${ }^{44}$
3.2.02: Proposta Mobilinea para divisores de ambientes. "Divisores de Ambientes". Casa \& Jardim. pp. 52-53. maio 1968.

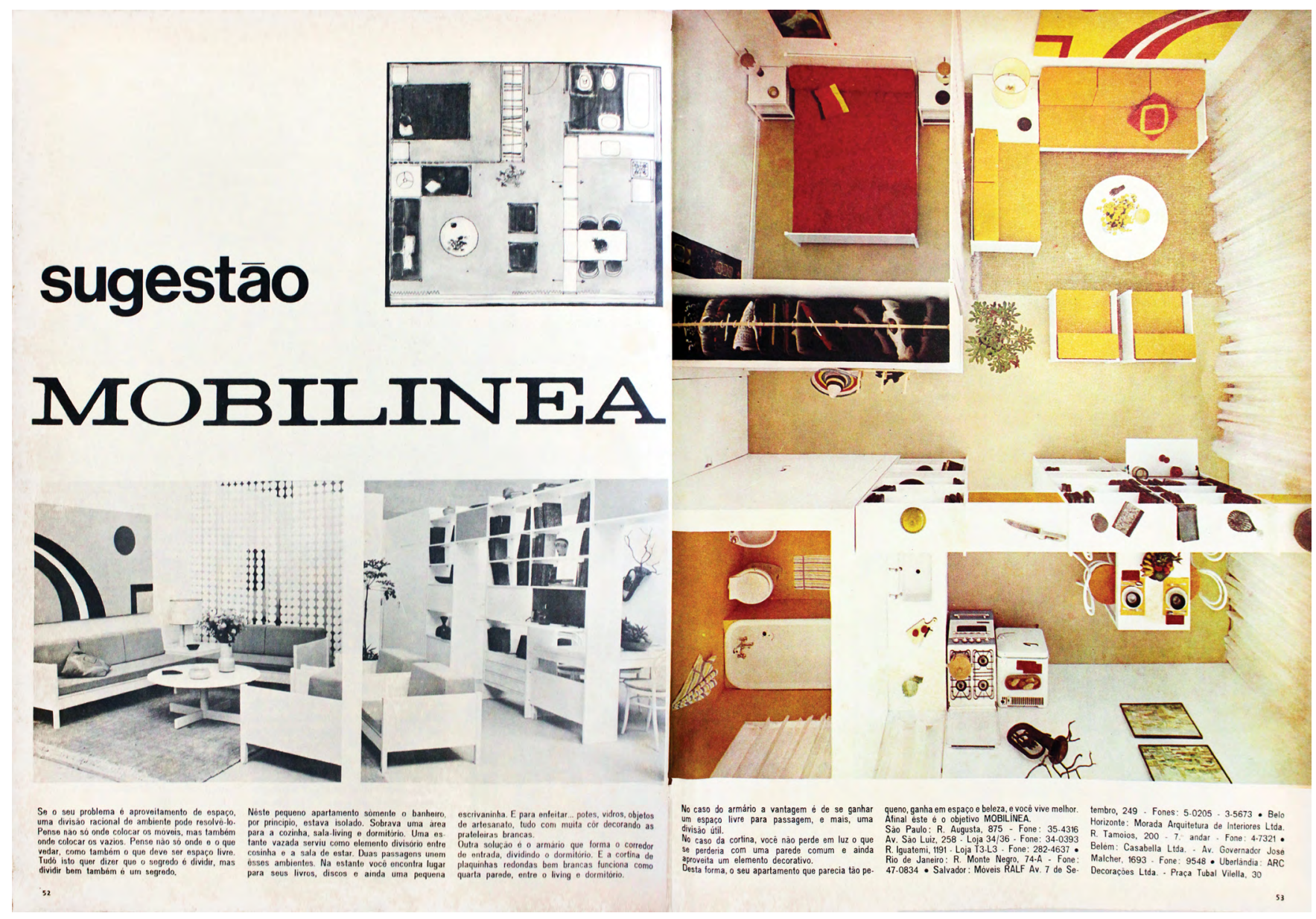


3.2.03: Editorial feito por Georgia Hauner para Claudia Decoração misturando móveis de diversas empresas: sala de estar com móveis Mobilinea e Cerello; quarto com móveis Mobília Contemporânea e Probjeto.

"Degraus formam bancos e mesinhas". Claudia Decoração. pp. 56-57. ago. 1968.
Nos dois casos, a preocupação era criar ambientes que pudessem ser organizados de maneiras outras que não com paredes separando cômodos, gerando espaços maiores e com alguma permeabilidade em seus usos. Tanto os desníveis como os "móveis-divisória" exercem papel similar em definir e organizar espacialmente a casa, e neste sentido as estantes da Mobilinea assumem um caráter diverso aos seus móveis "avulsos" que ocupavam o centro dos cômodos, evidenciando a complementação das linhas. A proposição de imagens em que o cenário e o trabalho de quem os criou ficava exposto, de alguma forma desmontando a ilusão da revista, também tornava seu resultado mais visível, mais apropriável - se é possível fazer isto em um estúdio, há de ser possível fazer na casa do leitor.

Na promoção organizada por Casa e Jardim através de "C. J. Visita" para sortear um projeto de interiores entre os leitores, a maneira de ensinar como ocupar uma casa se deu a partir da elaboração de um projeto personalizado, com instruções para que todos os artifícios propostos pudessem ser construídos. Nesses editoriais, depois das fotos dos produtos, a revista incluía páginas quadriculadas nas quais os leitores deveriam reproduzir a planta de suas casas em escala 1:100, incluindo os móveis próprios que quisessem manter, e enviar para a empresa promovida naquele mês. A empresa e a revista
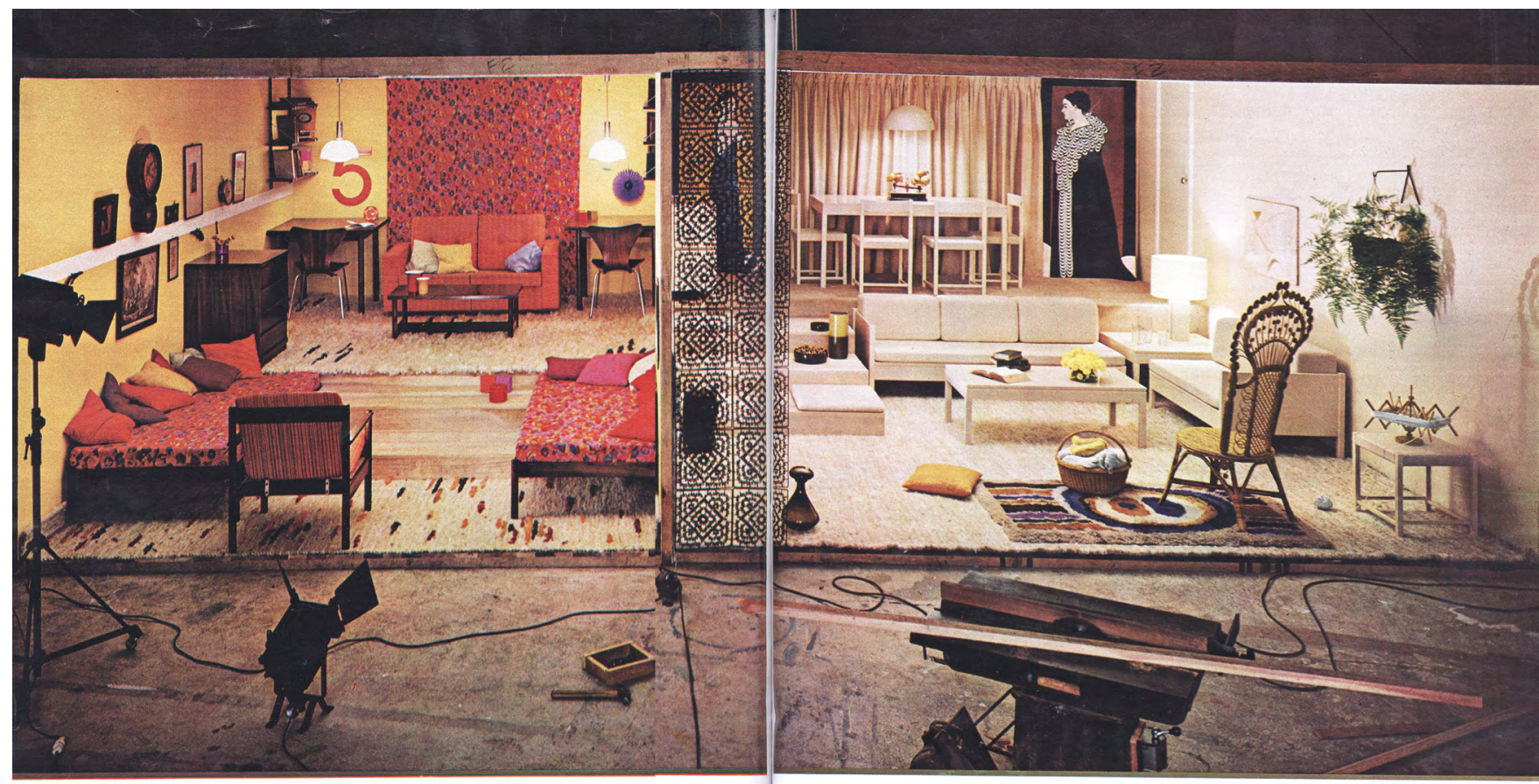

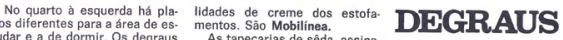

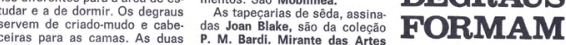

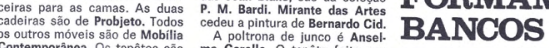

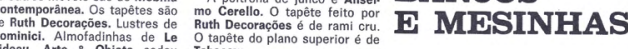

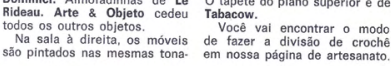


escolheriam então o caso mais "difícil”, para o qual seria desenvolvido um projeto gratuitamente, e o vencedor ganharia ainda um desconto de 50\% nas suas compras; inicialmente, o limite de valor era de $\mathrm{Cr} \$ 8.000,00$ a ser pagos por Casa \& Jardim (para projetos orçados em Cr\$16.000,00 ou mais) ${ }^{45}$.

Como foi Mobilinea quem estreou “C. J. Visita” em julho de 1970, não havia ainda um parâmetro de como este projeto deveria ser feito. O vencedor foi anunciado em novembro ${ }^{46}$ em uma reportagem que começava explicando como funcionou a promoção e depois anunciando que o vencedor fora o Sr. Kanitar Aymoré Sabóia Cordeiro, economista e professor de Curitiba, casado com três filhos. Sua casa fora escolhida, segundo o texto, por ser “absolutamente normal, sem nenhum característica específica, onde a decoração criaria os ambientes"47; era térrea, com $312 \mathrm{~m}^{2}$ e construída recentemente. Além da disposição dos móveis, o projeto criava desníveis no piso com especificação de materiais para cada um deles, assim como para as paredes, portas e janelas. A matéria explicava ambiente a ambiente em detalhes:

No hall de entrada, na área de circulação e sala de jantar: piso de lajotas de cerâmica, para o escritório, a sala de visita e a parte dos quartos: carpete. A sala de estar íntima se diferencia por um piso elevado de tábuas largas.

A sala de visita, separada do resto da casa, foi resolvida em vários tons de cinza. As poltronas são de aço inox, com estofamento em tecido acrílico. No centro, uma mesa redonda de acrílico fumé com estrutura de aço. No canto, três luminárias brancas, com revestimento de poliéster. Para completar o ambiente, na parede, um painel pintado, formando ondas desde o preto até o branco.

[...]

Para o escritório, onde o proprietário pode receber clientes, foi escolhido o amendoim, tanto para a estante como para os acessórios. A parede em frente à janela é revestida de cortiça, com composição de quadros.

$[\ldots]$

No meio da sala íntima, uma estante divide o espaço em duas áreas, deixando uma passagem para dar acesso aos quartos. Esta estante, de um lado, tem lugar para a vitrola, televisão, etc, e do outro lado tem uma mesa embutida para estudos das crianças. Na salinha íntima, um tapetão claro, móveis coloridos e uma grande mesa central de mármore formam o ambiente da lareira. De cada lado do fogo, foram colocados bancos de ripas com almofadas. Os sofás são montados sôbre rodízios, para facilitar a manutenção.

$[\ldots]$

No quarto da menina, uma estante formada de módulos da linha infantil: caixas, com e sem portas, bem coloridas. A parede, até um metro de altura, seria revestida de tecido, da mesma cor que a colcha. Para a menina brincar, uma mesa pintada e três cadeirinhas em escala infantil.

No quarto do casal, cama com colcha de veludo listrado e criados-mudos modulados, pintados de branco. Perto da janela, um console com espelho serve de penteadeira. ${ }^{4}$

Todas as linhas lançadas pela Mobilinea até então foram ali usadas: móveis em madeira maciça natural e pintada, em acrílico e aço, Thonet e Mobilinha [3.2.04-3.2.05]. Há alguma proximidade entre este projeto e a planta do apartamento tipo enviado às construtoras [2.3.05] na maneira como os quartos são arranjados e, mesmo com um cliente específico, houve liberdade na ocupação e tratamento dos espaços. O orçamento superava em muito o limite 
3.2.04: Planta vencedora do primeiro concurso " $\mathrm{C}$. J. Visita" com Mobilinea. "Casa \& Jardim e Mobilinea escolhem o projeto vencedor". Casa \& Jardim. pp. 52-53. nov. 1970.

3.2.05: Perspectiva da sala de estar do primeiro concurso "C. J. Visita" com Mobilinea. "Casa \& Jardim e Mobilinea escolhem o projeto vencedor". Casa \& Jardim. p. 52. nov. 1970.
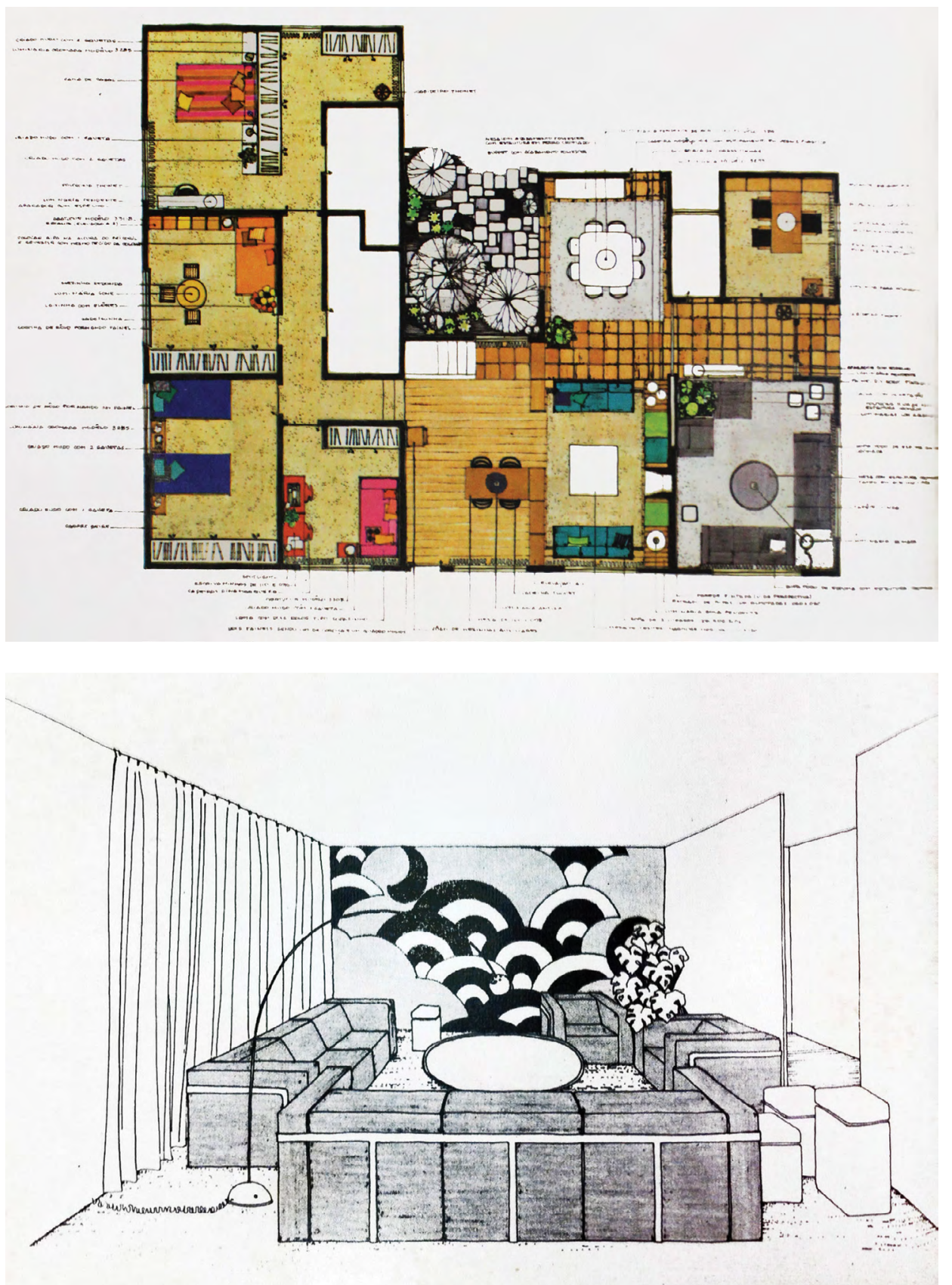

máximo dos Cr\$ 8.000,00 que seriam pagos por Casa \& Jardim, de forma que caso os móveis tenham todos sido comprados, ficou ao vencedor da promoção um investimento de Cr\$39.731,00, fora os gastos de obra.

\begin{tabular}{ll} 
Orçamento: & \\
Sala de visita & $\mathrm{Cr} \$ 12.890$ \\
Escritório & $\mathrm{Cr} \$ 1.487$ \\
Estante do escritório & $\mathrm{Cr} \$ 3.458$ \\
Sala de jantar & $\mathrm{Cr} \$ 6.897$ \\
Estante divisória & $\mathrm{Cr} \$ 5.401$ \\
Sala íntima & $\mathrm{Cr} \$ 7.427$ \\
Quarto de hóspedes & $\mathrm{Cr} \$ 2.639$ \\
Quarto dos meninos & $\mathrm{Cr} \$ 1.501$ \\
Quarto de menina & $\mathrm{Cr} \$ 2.044$ \\
Quarto de casal & $\mathrm{Cr} \$ 3.897$ \\
\cline { 2 - 2 } TOTAL & $\mathrm{Cr} \$ 47.731^{49}$
\end{tabular}


Mobilinea participou pela segunda vez de "C. J. Visita" em julho de 1971, anunciando o vencedor em fevereiro do ano seguinte ${ }^{50}$. Dessa vez, a empresa mudou o perfil do imóvel e escolheu um pequeno apartamento do leitor Flavio Cancieiro Pinheiro, à Av. Ataulfo de Paiva, 620, no Leblon, Rio de Janeiro. Tratava-se de uma cobertura para um único morador com sala, cozinha, banheiro, área de serviço e terraço, e para a qual foi desenvolvido um projeto também com especificação de pisos, iluminação, divisórias e móveis da Mobilinea e de outras empresas. É curioso que nas duas ocasiões em que a empresa participou da promoção, homens foram premiados, implicando que havia também um público masculino atento às iniciativas da revista.

A descrição do projeto começava pelo terraço, onde seriam criados três espaços separados por desníveis no piso e um forro na zona central; na sequência, a disposição dos móveis era apresentada, mas de forma breve. Observando os desenhos, a característica mais interessante do projeto era a criação de um pequeno hall com uma estante divisória para a sala e acesso à cozinha [3.2.063.2.07]. Nesta fase, Casa \& Jardim dava até Cr\$10.000,00 para o vencedor (para projetos de Cr\$20.000,00 em diante), e o orçamento total da Mobilinea ficou em Cr\$21.498,00. Também neste caso não há como confirmar se o vencedor comprou os móveis e executou o projeto, mas há algo nesta proposta que parece mais factível, talvez por uma descrição e representação menos minuciosa de cada ambiente, permitindo mais liberdade na interpretação do projeto.

As características vistas nas propostas da Mobilinea em propagandas e editoriais se repetem em "C. J. Visita" no tipo de acabamento e disposição dos móveis, bem como na organização do espaço com diferentes materiais e alturas de piso, e novamente são elaboradas duas funções para os móveis de ocupação e de definição dos ambientes. Na proposta para o apartamento carioca aparecem móveis de alvenaria (obviamente não produzidos pela Mobilinea), trazendo a esfera construtiva também para a decoração.

Os interiores da "Casa de Claudia", promoção da Editora Abril que sortearia duas casas entre seus leitores, também foram planejados por Georgia Hauner e tratavam da construção de um ambiente doméstico integral, então ainda que não tenha sido uma promoção de ambientes exclusiva da Mobilinea, exibia algumas estratégias recorrentes no trabalho da empresa que devem ser examinadas. Com ambientes de estar, jantar e cozinha integrados, três quartos, um banheiro e dois terraços, uma casa igual às que seriam sorteadas foi construída para visitação no Morumbi, em São Paulo, ocupada com móveis e acabamentos das diversas empresas participantes a partir do projeto de Georgia. A revista dizia que estas casas poderiam ser construídas em qualquer lugar do Brasil, mas seu aspecto interior e exterior em madeira aparente (Canela e Peroba, principalmente) e telhados em duas águas sugeriam mais 


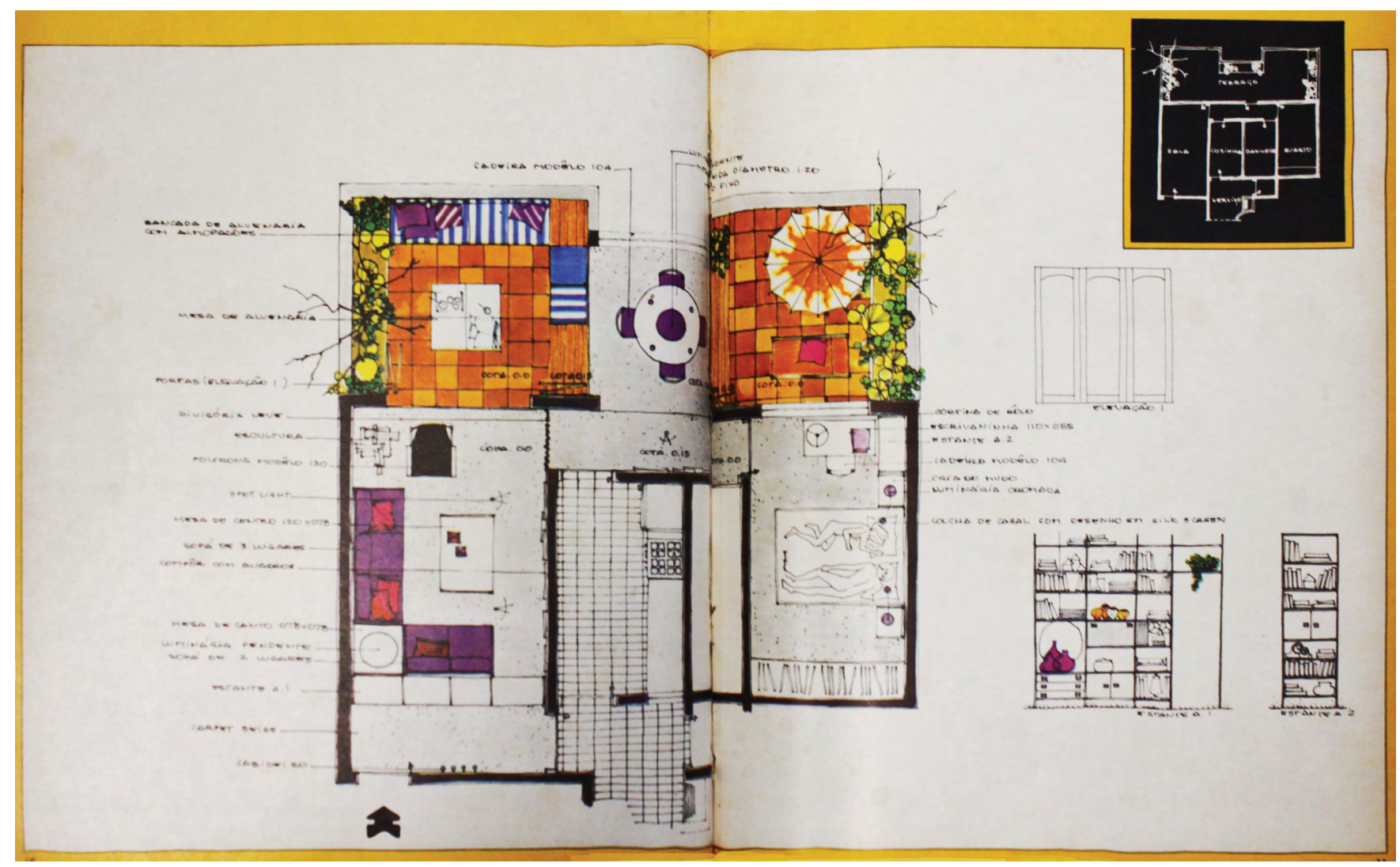

3.2.06: Planta vencedora do segundo concurso " $\mathrm{C}$. J. Visita" com Mobilinea. "Casa \& Jardim e Mobilinea escolhem o projeto vencedor". Casa \& Jardim. pp. 10-11. fev. 1972.

3.2.07: Perspectiva da sala de estar do segundo concurso "C. J. Visita" com Mobilinea. "Casa \& Jardim e Mobilinea escolhem o projeto vencedor". Casa \& Jardim. p. 12. fev. 1972.

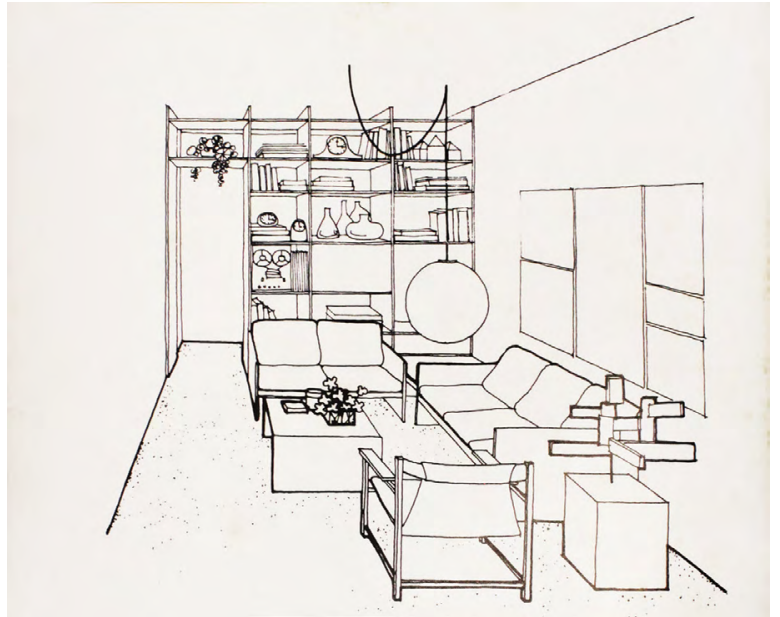

uma locação suburbana ou de veraneio do que na cidade, o que era permitido pela promoção [3.2.08].

$\mathrm{Na}$ revista Claudia de junho de $1969^{51}$, três meses depois do início da promoção, foi publicada uma planta em perspectiva mostrando a casa com todos os móveis e acabamentos selecionados. Nela, vemos que a cozinha é aberta para a sala, separada por estantes e bancadas, e por isso na prática não há corredores. O piso é único, mas tapetes marcam os vários ambientes [3.2.09].

Os móveis escolhidos para a sala de estar eram da Mobília Contemporânea, laqueados em branco, com mesa de centro em Jacarandá de Arredamento. Havia também uma poltrona de balanço Thonet laqueada em vermelho da Mobilinea e objetos de Ruth Decorações, Dominici, Baú, Arte \& Objeto e uma 

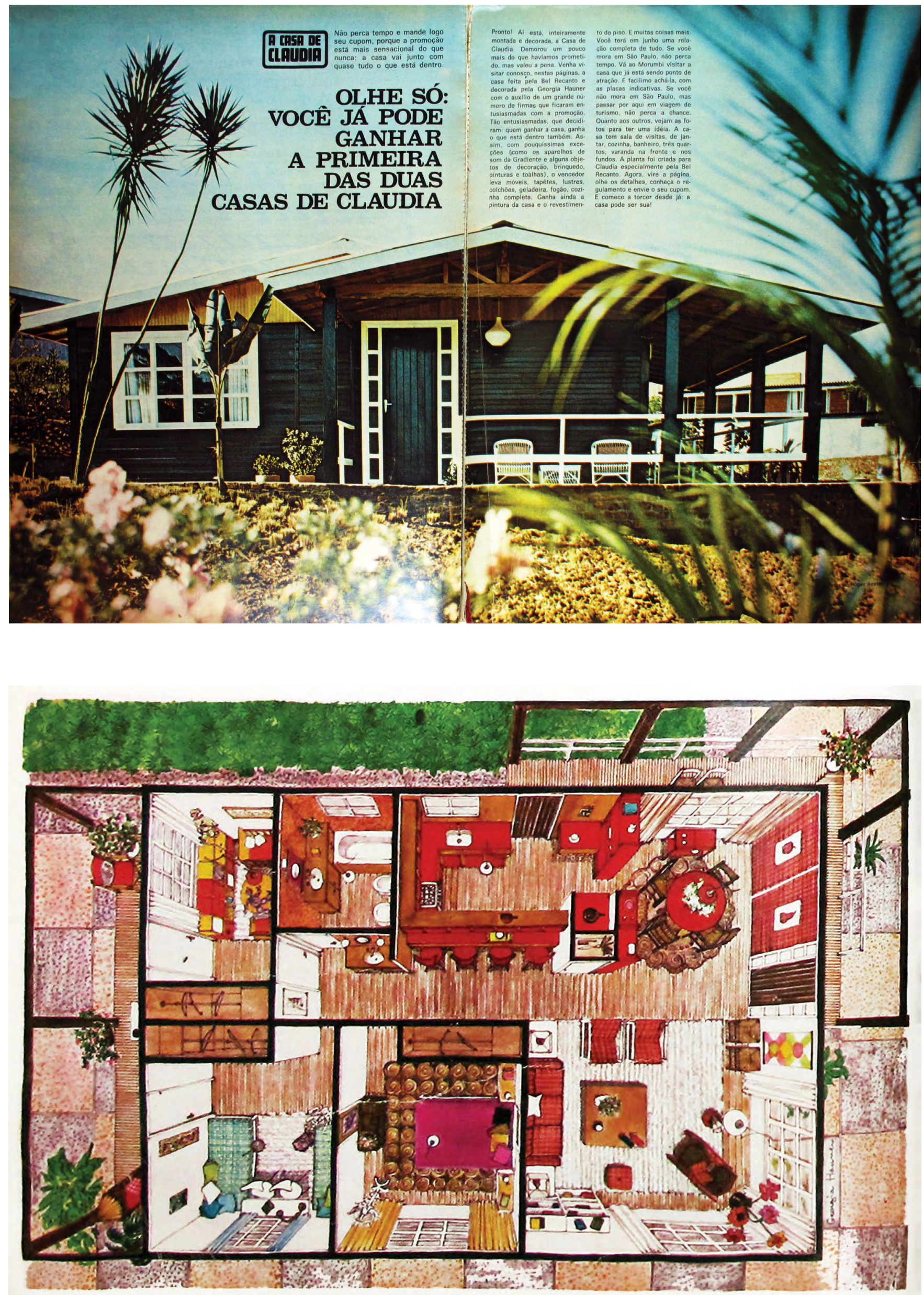
3.2.08: Vista externa da "Casa de Claudia" com explicações sobre a promoção. "Olhe só: você já pode ganhar a primeira das duas Casas de Claudia". Claudia. pp. 76-77. maio 1969.

3.2.09: Planta da "Casa de Claudia" feita por Georgia Hauner. "Êste mês a Casa de Claudia poderá ser sua". Claudia. p. 54. jun. 1969.

3.2.10: Sala de estar da "Casa de Claudia" com móveis de Mobília Contemporânea, Arredamento e Mobilinea.

"Olhe só: você já pode ganhar a primeira das duas Casas de Claudia". Claudia. pp. 76-77. maio 1969.

3.2.11: Sala de jantar da "Casa de Claudia" com mesa Mobilinea e cadeiras Arredamento. "Olhe só: você já pode ganhar a primeira das duas Casas de Claudia". Claudia. pp. 76-77. maio 1969.

3.2.12: Quarto de bebê da "Casa de Claudia" com móveis Mobilinha. "Olhe só: você já pode ganhar a primeira das duas Casas de Claudia". Claudia. pp. 76-77. maio 1969.
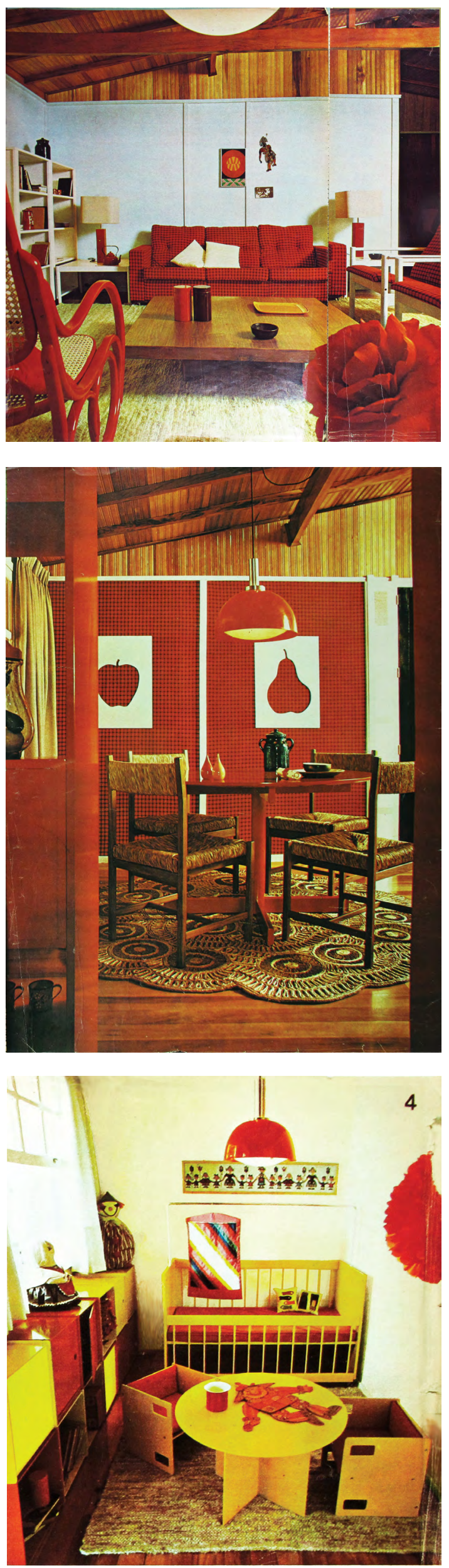
pintura de Paulo Becker que aparecera anteriormente em propagandas da Mobilinea [3.2.10]. A sala de jantar separava-se deste primeiro ambiente por tapetes e tinha uma mesa redonda da Mobilinea laqueada em vermelho com quatro cadeiras de palhinha Arredamento. O mesmo tecido vermelho xadrez utilizado para revestir os assentos dos sofás e poltronas na sala foi colocado em paineis na parede da copa, sob lambris e chapas de madeira com recortes de frutas, pintadas de branco [3.2.11]. Duas estantes modulares vermelhas da Mobilinea configuravam a entrada para a cozinha fabricada pela Honey's, revestida em fórmica vermelha e amadeirada, com cadeiras dinamarquesas vermelhas da Probjeto/Mobilinea.

No quarto do casal e no infantil, camas e mesas de cabeceira eram da Mobília Contemporânea, cercados por objetos e acessórios das outras empresas participantes e mais um quadro de Paulo Becker. No primeiro quarto, as cores principais escolhidas por Georgia foram rosa, mostarda e castanho, enquanto o segundo foi todo ocupado em branco e azul claro. Finalmente, no quarto do bebê, todos os móveis eram da linha Mobilinha da Mobilinea, laqueados em amarelo e vermelho [3.2.12].

A escolha dos tecidos e revestimentos é menos impactante do que nos editoriais e propagandas feitos por Georgia para a Mobilinea por não terem padronagens ou cores contrastantes, mas talvez suas possibilidades estivessem restritas à oferta dos demais participantes, ou ela tenha procurado se adequar a um gosto mais sóbrio. Além disso, pelos próprios limites físicos dos ambientes, a iluminação e o enquadramento das fotos não se destacaram da mesma maneira que na produção de imagens feitas nas lojas ou em estúdios.

Apesar da "Casa de Claudia” contemplar um espaço que seriagenuinamente vivido, ela ainda não contava com moradores e não tinha um lugar social ou geográfico definido, o que de certa forma a deixava tão subjetiva quanto as propostas de "C. J. Visita", já que nenhuma delas foi exibida após essas formas de ocupação terem sido vivenciadas. Houve duas ocasiões, contudo, em que as revistas examinadas efetivamente apresentaram os móveis da Mobilinea em ambientes reais e habitados, e não por acaso foram residências do casal Hauner: em março de 1971 na revista Realidade e em agosto de 1974 em Casa de Claudia. Nessas reportagens, o interesse era exibir o ambiente doméstico como um todo e discutir os recursos arquitetônicos empregados para cria-lo.

Evidentemente, Georgia e Ernesto não podem ser tomados como consumidores típicos da Mobilinea, mas em nenhum dos casos foram promovidos como "personalidades", então para as revistas eram casas de um casal moderno, mas não excepcional. Não é explicitado por que ou como foram escolhidos, mas considerando a informalidade dos circuitos profissionais, é provável que tenham sido indicações de amigos do casal envolvidos na editora (ambas publicações eram da Editora Abril, onde Georgia deixara de trabalhar em 1970). 
Em março de 1971, a revista Realidade publicou uma reportagem intitulada "Reforme sua Casa"52, na qual apresentava dicas para reformar casas e apartamentos a partir da residência dos Hauner no bairro Itaim Bibi, em São Paulo. O texto começava afirmando que a "decoradora paulista Georgia Hauner comprou um apartamento de cobertura e resolveu transformá-lo inteiramente. Ela fêz da cobertura - que no projeto original se resumia a um salão de festas e piscina - um outro apartamento." ${ }^{\text {53 }}$. Georgia disse recentemente que a adaptação na planta fora feita desde o início da construção do prédio, que durou quatro $\operatorname{anos}^{54}$. A reportagem comentava então as dificuldades de se fazer uma reforma, afirmando que tudo fora planejado antecipadamente, desde os custos de material até a colocação de mobiliário: "eu, simplesmente, transferi minha casa térrea para o 16. andar de um edifício do bairro Itaim, em São Paulo. Assim, juntei o confôrto de uma casa às vantagens de um apartamento" ${ }^{55}$. A matéria seguia explicando particularidades de obras em prédios de apartamentos do ponto de vista estrutural e condominial e depois dava dicas para reformas de casas, sem fotografias.

Para mostrar a reforma e o edifício, Georgia e a revista colaboraram na produção de uma planta perspectivada desenhada sobre uma foto aérea do edifício (tirada de um helicóptero contratado pela Abril ${ }^{56}$ ). Nela, vemos que dois jardins externos foram incorporados ao imóvel, incluindo a piscina que provavelmente havia sido pensada para uso coletivo. O apartamento em si tinha dois quartos, uma sala-escritório, uma sala de estar, sala de refeições e serviços; embora uma integração total não tenha sido possível porque ele era cortado ao meio pela prumada de circulação vertical do edifício, as duas salas reuniam mais de uma função, separando os ambientes com mobiliário e desníveis. Todos os móveis principais eram da Mobilinea e em cada lado do imóvel utilizava-se uma madeira - provavelmente Jacarandá na sala principal e Amendoim na sala íntima; o quarto de casal tinha móveis brancos. É curioso notar como Georgia obliterou a cozinha na planta, o que dificulta um pouco a leitura de como era o funcionamento geral da casa [3.2.13].

Nas fotos dos ambientes, vemos a sala de estar com uma estante-divisória ao lado de uma parede de tijolos aparentes com lareira, lembrando o projeto da loja do Shopping Iguatemi. Em outra foto é possível ver um jardim de inverno onde está a mesa com canteiro central, rodeada por cadeiras em plástico moldado e uma Bertoya, além de vasos de planta e xaxins arranjados em diversas alturas [3.2.14-3.2.15].

Três anos depois, na edição de Casa de Claudia de agosto de 19747, um projeto de natureza similar foi apresentado: a casa de veraneio dos Hauner no Guarujá no Edifício Sobre as Ondas, também reformado por Georgia, desta vez a partir da união de duas unidades de um dormitório ${ }^{58}$. O novo imóvel ficou com $104 \mathrm{~m}^{2}$ e o apartamento da frente passou a concentrar as áreas sociais de estar 

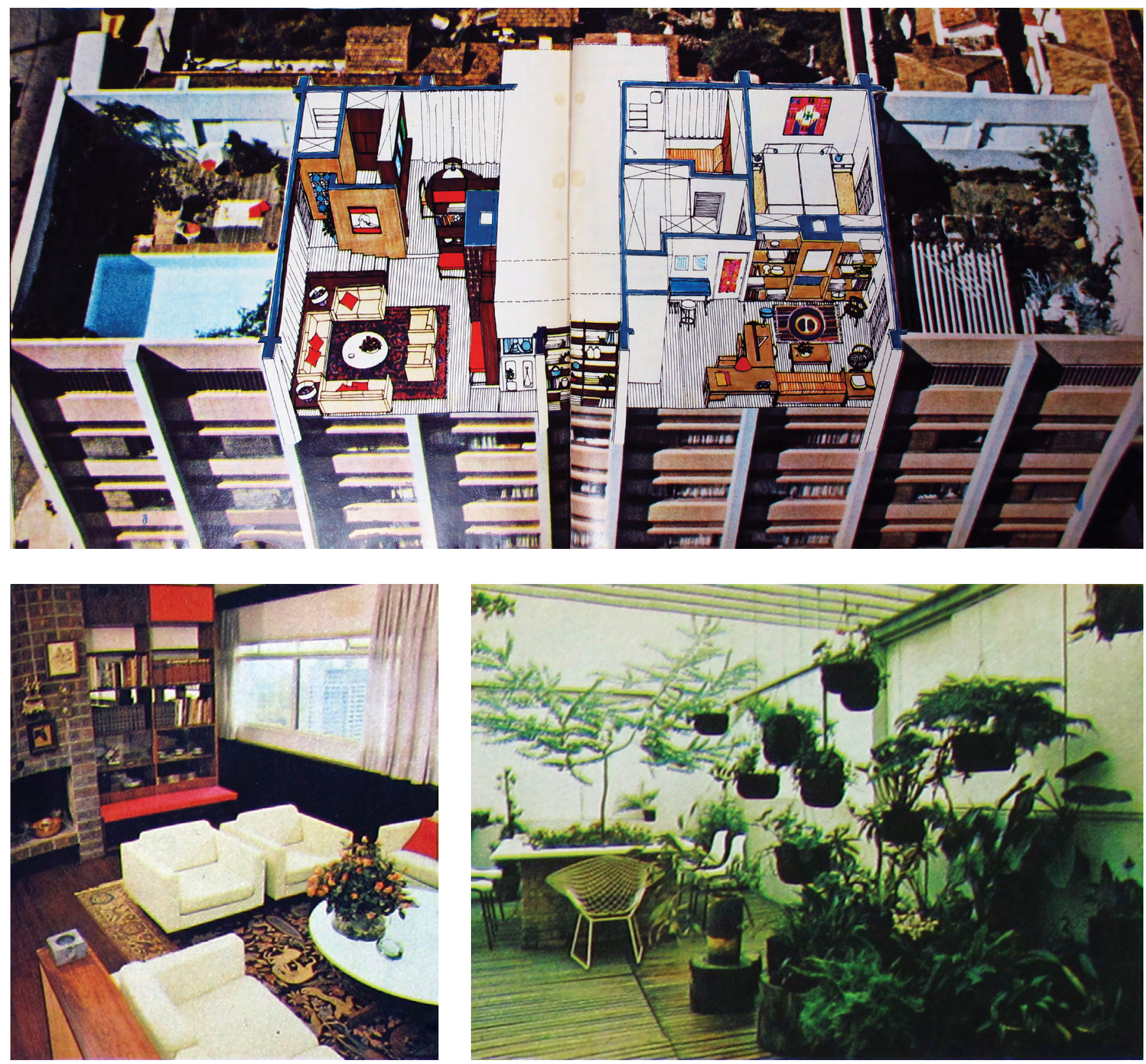

e jantar, além de um quarto conversível, cozinha, lavabo, banheiro e quarto de empregada ${ }^{59}$. O apartamento de trás (um pouco maior pela arquitetura curva do edifício) acomodou três quartos e dois banheiros. O primeiro parágrafo da reportagem anunciava que a reforma fora feita por Georgia Hauner e que o novo imóvel era todo decorado com peças da Home Store, de forma que neste caso pode ter havido um interesse mais direto na promoção dos móveis [3.2.16].

$\mathrm{O}$ piso nas áreas sociais era de cerâmica verde e azul de H. Cerâmica ${ }^{60}$ que funcionava como elemento de comunicação entre os espaços, enquanto a sala separava-se da entrada do apartamento por uma estante modular e degraus que serviam de arquibancada ${ }^{61}$. Os módulos de assento neste ambiente sugeriam posturas informais aos seus usuários, que poderiam sentar-se como em sofás ou deitarem-se neles abertos como espreguiçadeiras, além de também ser possível ocupar o chão, contando com almofadas [2.1.26; 3.2.17-3.2.18].
3.2.13: Vista aérea do prédio em que o casal Hauner morava, no Itaim Bibi, com planta interna desenhada sobre a foto. "Primeiro problema: o apartamento". Realidade. pp. 142-143. maio 1971.

3.2.14: Sala de estar do apartamento do casal Hauner. "Primeiro problema: o apartamento". Realidade. p. 143. maio 1971.

3.2.15: Terraço do apartamento do casal Hauner. "Primeiro problema: o apartamento". Realidade. p. 143. maio 1971. 
3.2.16: Planta do apartamento do casal Hauner no Edifico Sobre as Ondas, no Guarujá. A imagem de cima mostra o andar original com dois apartamentos, e a de baixo, a união dos dois com o projeto de interiores feito por Georgia Hauner. "Boa idéia: juntar dois apartamentos pequenos". Casa de Claudia. p. 77. ago. 1974.
A sala lateral foi pensada para funcionar tanto como sala de jantar quanto como um quarto extra: este primeiro arranjo era feito com mesinhas modulares Probjeto e cadeiras em fiberglass Mobilinea azul marinho, que podiam formar mesas maiores ou ser dispostas individualmente, dependendo do número de convidados que se tivesse, e se gostariam de ficar todos juntos ou em pequenos grupos. Fechando a parede divisória entre ambientes, surgia uma cama pivotante de casal, que aberta criava um novo quarto mantendo os mesmos acabamentos da sala, de forma que não havia uma hierarquia material entre os usos da casa [3.2.19].

Vê-se desse modo uma coesão entre os ambientes em que os Hauner viviam e os que eram apresentados em nome da Mobilinea e, neste sentido, sua conceituação sobre o que entendiam por uma residência moderna e o que era divulgado pela empresa não podem ser separados. As características comuns entre eles, em toda sua variação de propostas, eram de descontração, misturando peças artesanais e industriais, objetos decorativos inusitados e de arte em sua concepção mais tradicional, plantas tropicais e silvestres;

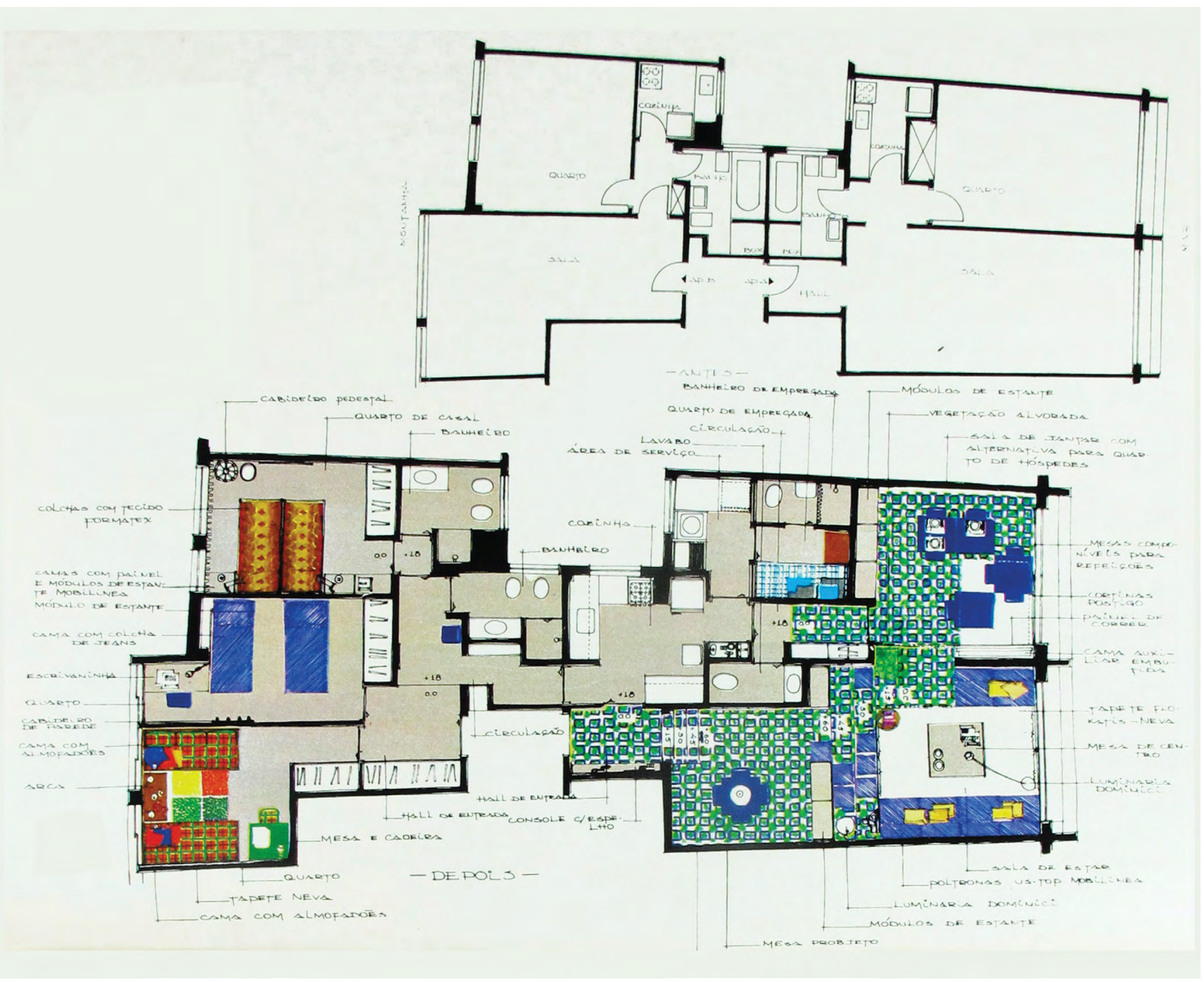


a remoção de paredes, delimitando ambientes de estar, jantar ou repousar através de desníveis ou divisórias que serviam também outras funções; a separação, nesse sentido, de móveis de organização e de ocupação do espaço; o uso frequente de cores, estampas e texturas como recursos para renovar acabamentos mantendo a estrutura básica desses móveis; e uma "harmonia" nos espaços em todos os seus elementos - não há nada que não combine -, indicando um projeto integral, e que supõe ocupantes que também estejam em conformidade com ele.

Assim, a domesticidade proposta pela Mobilinea dizia respeito também à sua ideia de moral e padrões de relacionamento dos habitantes de uma mesma casa, propondo comportamentos distintos aos da geração anterior em que móveis e objetos domésticos não eram pensados e dispostos para serem usados, mas vistos como composições estáticas. Enquanto as imagens da Mobilinea publicadas em periódicos eram extremamente visuais, inspiravam igualmente o toque e o consumo, sugerindo com isso que a própria leitora das revistas assumisse um papel em que não se inserisse mais no ambiente doméstico para adornar a casa como esposa ou para garantir sua manutenção como dona-decasa, mas para desfrutar e ter prazer em estar lá.

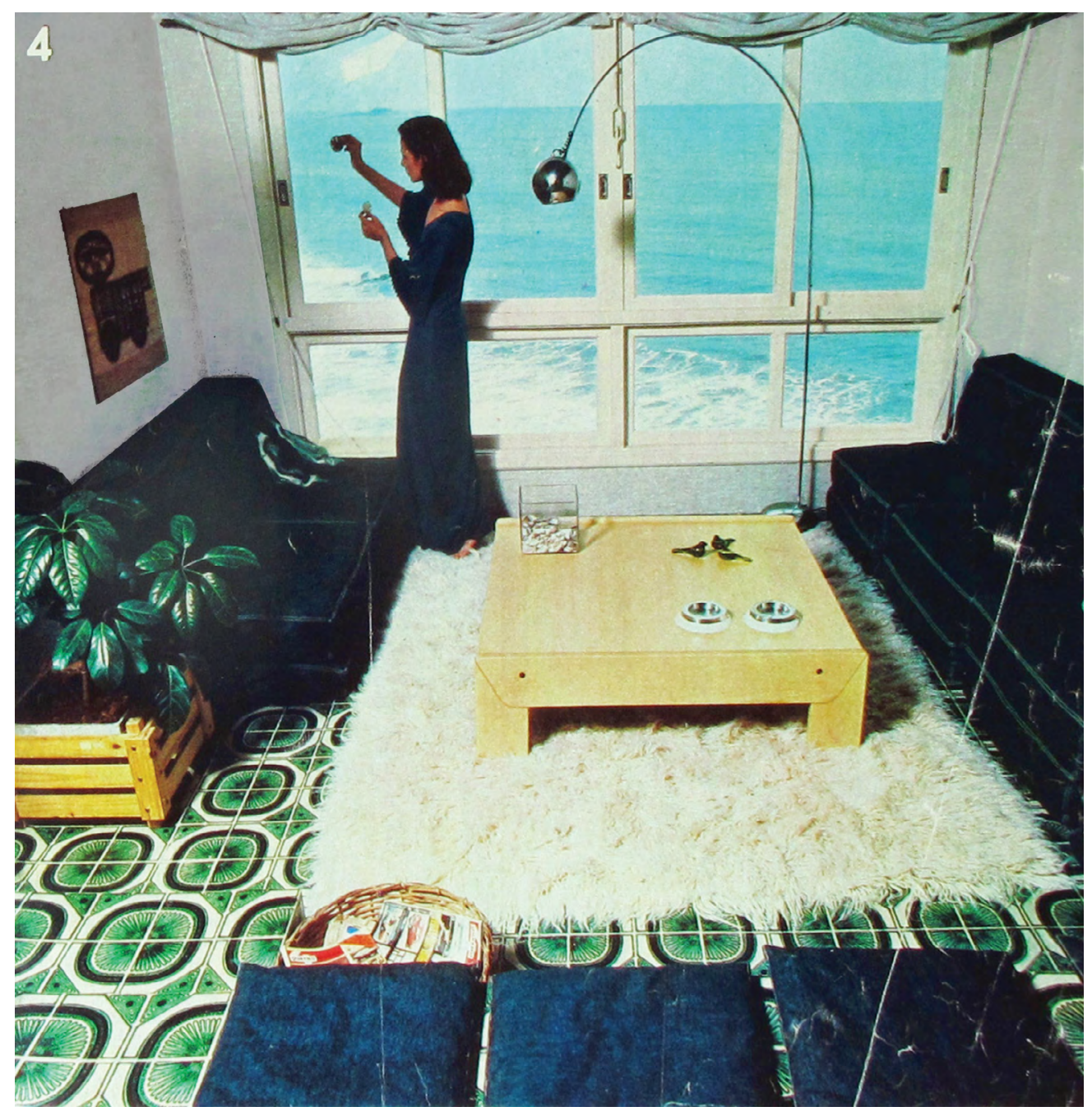

3.17: Sala de estar da casa de veraneio do casal Hauner com vista para a janela. "Boa idéia: juntar dois apartamentos pequenos". Casa de Claudia. p. 75. ago. 1974. 

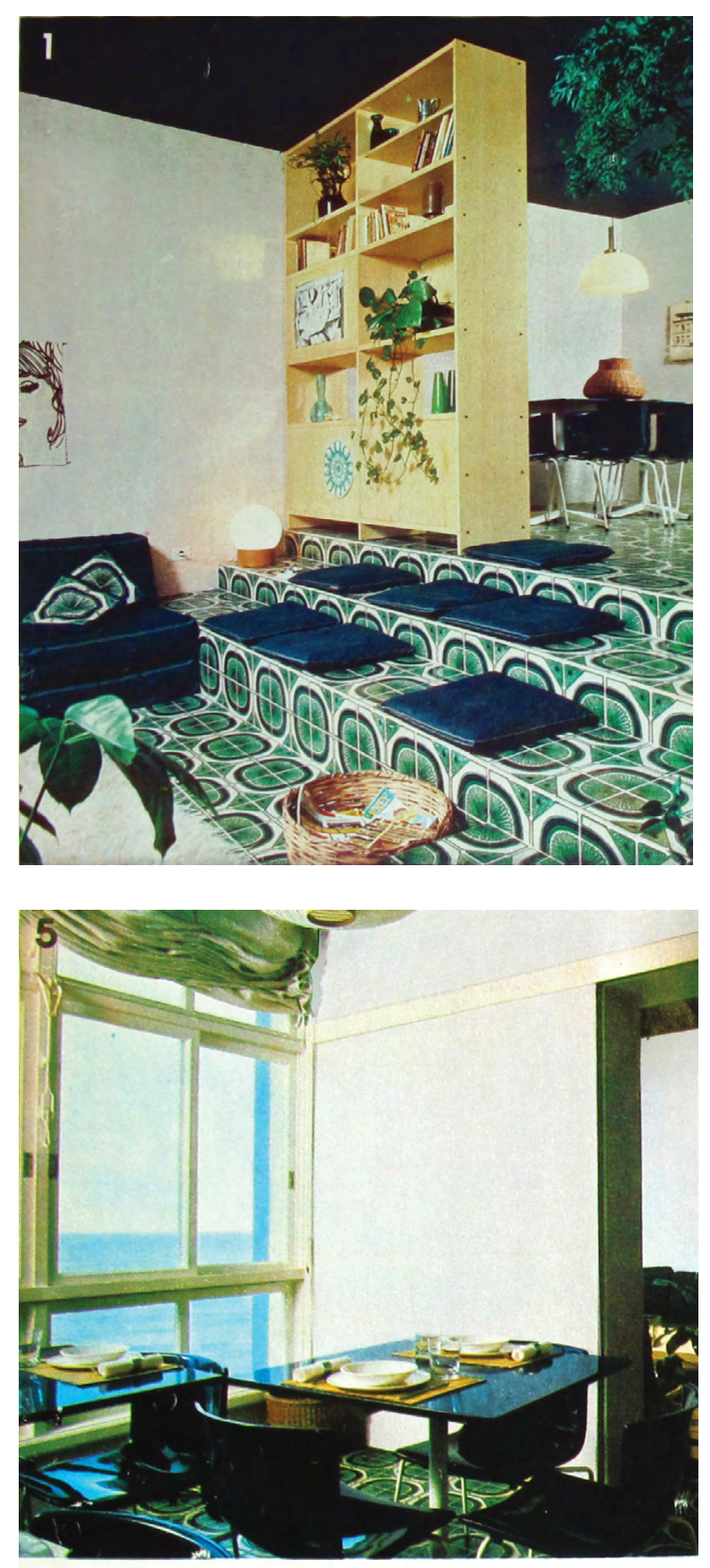

3.2.18: Sala de estar da casa de veraneio do casal Hauner com vista para a entrada. "Boa idéia: juntar dois apartamentos pequenos". Casa de Claudia. p. 74. ago. 1974.

3.2.19: Quarto conversível da casa de veraneio do casal Hauner. Acima, como sala de refeições conjugada à sala. Abaixo, com porta de correr fechada, cama pivotante aberta e cortinas abaixadas.

"Boa idéia: juntar dois apartamentos pequenos". Casa de Claudia. p. 76. ago. 1974.

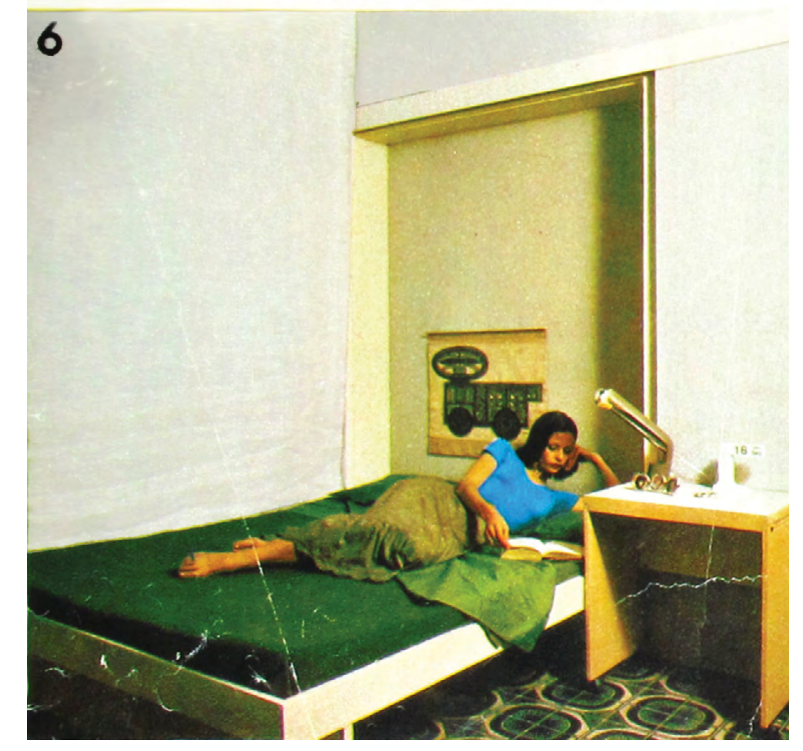




\title{
3.3. A mulher Mobilinea
}

A maneira de Georgia Hauner pensar interiores domésticos era indissociável dos cenários e ambientes que criou na Mobilinea e para si própria, mas, ao mesmo tempo, com o convite para trabalhar como editora de decoração para Claudia em 1968, ela pode estabelecer seu nome e seu trabalho de maneira independente e também com maior projeção. Para Marinês Ribeiro dos Santos,

\begin{abstract}
A intermediação cultural desempenhada pelas/os realizadoras/os das mídias de estilo de vida assume um caráter de voz de autoridade capaz de interpretar e de traduzir, para parcelas particulares da população, conhecimentos e padrões de gosto relacionados a práticas cotidianas. ${ }^{62}$
\end{abstract}

Enquanto estava nesta posição, escreveu o texto "Cursinho Rápido de Decoração", em Claudia Decoração ${ }^{63}$ de agosto de 1968, que talvez tenha sido o mais relevante que publicou ao longo do período estudado, no qual abria com a seguinte afirmação:

\begin{abstract}
Você sabe fazer decoração. Tôda mulher sabe. É como dar um jeito no cabelo, arrumar um prato de servir no jantar, colocar flôres num vaso. Decorar uma casa ou um apartamento, você sabe, também. Você nasceu sabendo. Esta sua habilidade é que transforma em lar a casa que você escolheu para morar. Nenhum decorador profissional pode substituir você nessa função, exclusivamente sua, que é aprontar o "ninho". Um bom profissional poderá ajudar no planejamento. Mas não corra o risco de permitir que essa orientação penetre na sua vida íntima, a ponto de colocar arranjos de flôres artificiais, bibelôs em cima das mesas, livros em suas estantes, e outras arbitrariedades. (...) Deixe que todo o mundo saiba quem você é, quais livros gosta de ler, os discos que gosta de ouvir, os quadros que a fazem vibrar, as côres que a deixam feliz. Muita gente não vai gostar. E daí? O mais interessante, o que mais caracteriza a personalidade de cada pessoa, são justamente essas pequenas diferenças que fazem umas se distinguirem das outras. ${ }^{64}$
\end{abstract}

Aqui, ela implicava as leitoras em responsabilizarem-se pela decoração de suas casas, afirmando que esta era uma habilidade natural que todas teriam e para a qual não existia um fórmula correta, mas um desejo e necessidade de expressarem-se individualmente. Na sequência, Georgia explicava o que entendia por planejamento: "não confunda planejamento com decoração. Planejamento é a distribuição funcional e agradável dos móveis dentro do ambiente"65; e como ler uma planta: "quando você olhar uma planta, imagine que está olhando o apartamento de cima, sem teto, e que está vendo o chão de todos os cômodos, os corredores, tudo"66, como mostrava também nos cenários 
3.3.01: Georgia Hauner fotografada na loja do Shopping Iguatemi. "Conheça a opinião destes sete decoradores". Casa de Claudia. pp. 26-32. jul. 1971. fotografados de cima. Recomendava às leitoras que estudassem a planta do imóvel que estivessem pensando em comprar antes de decidirem-se e, para tal, ensinava como desenhar em escala e distribuir móveis e pontos de interesse. Em relação aos acabamentos, aconselhava uma paleta de cores neutra, relegando tons fortes ou da moda aos elementos que pudessem ser mais facilmente substituídos, e encerrava declarando que a leitora estava "diplomada" com essas dicas e seu bom senso, e poderia então decorar sua própria casa.

Em julho de 1970, pouco antes de Georgia sair da Editora Abril, foi selecionada como uma das vozes da decoração brasileira, na reportagem "Conheça a Opinião Destes Sete Decoradores", em Casa Claudia ${ }^{67}$ [3.3.01]. Além dela, foram ouvidos Terry Della Stuffa (decorador independente), Alceu (da equipe de decoração das lojas Sears), Norma (da equipe de decoração da Henri Matarasso), Jean-Claude Bailly (decorador da Jansen), Joaquim Tenreiro e Sergio Rodrigues.

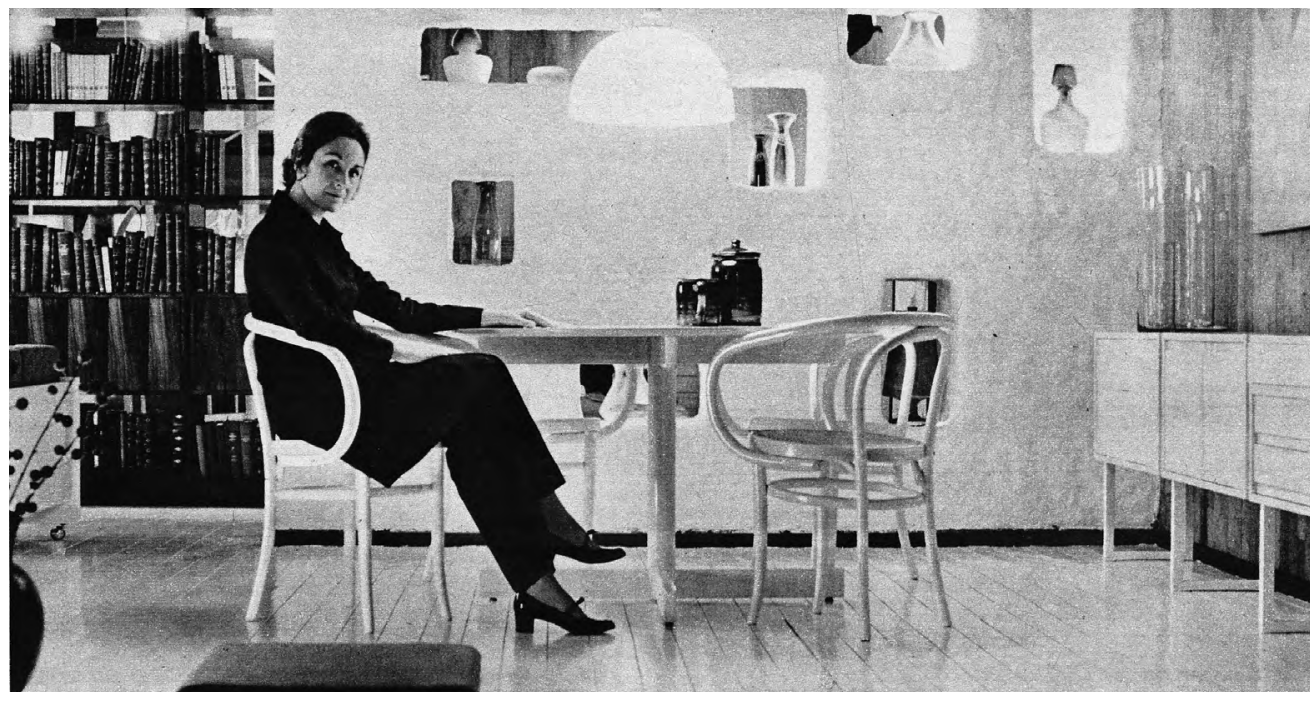

Em seu depoimento, Georgia reforçou algumas das ideias que expusera no "Cursinho de Decoração" em relação à moda e gosto pessoal, além de se contrapor à segmentação dos espaços domésticos, em acordo com os ambientes integrados que vinha propondo nas lojas, propagandas e editoriais:

\begin{abstract}
O importante na decoração é que as paredes deixem de funcionar como simples divisões de ambiente. Elas devem participar da decoração, formando saliências e reentrâncias, transformando-se em móveis, tornando-se recantos, fazendo parte da mobília. O que não é fácil: na maioria das vêzes, as casas e os apartamentos são entregues com as paredes formando um monte de "caixinhas". Numa caixinha dormimos, numa caixa maior recebemos os amigos, em uma outra cozinhamos. ${ }^{68}$
\end{abstract}

Reafirmava então a importância de que cada leitora confiasse em seu próprio gosto para ocupar a casa, pensasse esta ocupação junto à construção do imóvel e não se prendesse a estilos. Enfim, retomava a diferenciação que 
fazia entre decoração e planejamento (que ela levaria mais tarde à conceituação da Home Store):

\begin{abstract}
Meu trabalho é êsse. Criar ambientes gostosos onde as pessoas possam se encontrar a si mesmas. Onde procuro dar um entrosamento entre a mobília e a construção. É um trabalho que não considero 'decoração'. Acho que o têrmo 'planejamento' é mais próprio. Decoração é um estado de espírito, uma questão de humor. Arranjar flôres num vaso, pôr uma toalha de mesa com guardanapos contrastantes, levar para casa um galho seco encontrado no campo, fazer uma almofadinha de crochê, tudo isso é decoração. E isso é uma coisa muito pessoal que tôda pessoa deve fazer para si mesma. ${ }^{69}$
\end{abstract}

Assim, ao mesmo tempo em que buscava capacitar as leitoras, Georgia também se diferenciava delas colocando-se como uma profissional qualificada, inclusive ultrapassando um cargo como de cenógrafa ou diretora de arte, para uma posição "entre a mobília e a construção". Em janeiro de 1971, ela levou seu posicionamento ao campo da construção civil de fato, em uma entrevista na revista Projeto e Construção ${ }^{70}$, na qual afirmou:

\begin{abstract}
Pouca gente sabe que uma habitação bem resolvida não é resultado da construção que depois de pronta, é "decorada". A PALAVRA PLANEJAMENTO APARECE RARAMENTE EM RELAÇÃO A INTERIORES. Planejamento deveria ser uma fusão de arquitetura de interiores e colocação de mobiliário. (...) Planejamento é lógica aplicada às atividades cotidianas do ser humano. Dedicamo-nos com entusiasmo à busca de soluções para preservar a dignidade individual em espaços sempre mais reduzidos e sentimos a necessidade imperiosa de uma reviravolta na arquitetura. É PRECISO CONSTRUIR DE DENTRO PARA FORA. (...) OS INTERIORES DO MUNDO INTEIRO ESTÃO SE MODIFICANDO, HÁ MAIS ALVENARIA e menos móveis avulsos, em casas e apartamentos de qualquer tamanho. Para planejar êste tipo de ambiente, é necessário selecionar os móveis avulsos com muito mais cuidado e, sem dúvida, incorporá-los à planta. Construir de dentro para fora é incluir os móveis desde os primeiros esbôços das plantas de execução da obra. ${ }^{71}$
\end{abstract}

Nessa ocasião, muitas das questões que vimos como posturas da empresa frente à domesticidade se evidenciavam, ficando clara a diferenciação que Georgia Hauner fazia entre planejamento e decoração e os graus de responsabilidade que conferia a cada ator neste processo. Nos textos de circulação interna sobre a conceituação da Home Store, em que não precisava medir suas palavras, ela chegou a dizer sobre "projetos de decoração" que "este tipo de violação da intimidade do lar é um esporte praticado por milhares de incompetentes sem escrúpulos, e se tornou uma verdadeira praga com o passar

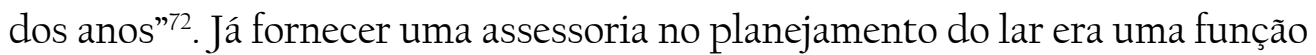
necessária e aceitável, a qual as funcionárias da Mobilinea, como ela, estariam qualificadas a realizar.

Via de regra, as leitoras das revistas e clientes da Mobilinea eram descritas por Georgia como mulheres, donas-de-casa e também como consumidoras de arquiteturae design; em seustextos eimagens, ela apontava parauma estetização do viver doméstico e para um domínio destas mulheres frente às possibilidades 
de ocupação do lar. De fato, a maioria dos periódicos examinados eram voltados ao público feminino, e relatos das vendedoras da Mobilinea indicam que eram elas que iam às lojas escolher os móveis para a casa da família ${ }^{73}$. Assim, o papel que este grupo desempenhou neste momento, definindo como seriam os ambientes domésticos através da escolha do mobiliário, do planejamento junto a profissionais, da busca de referências em periódicos e da produção de complementos decorativos não pode ser menosprezado.

Seguindo o raciocínio de Georgia Hauner, a decoração feita pelas próprias moradoras, que supomos serem de classes médias e médias altas, deixava de ter um caráter pejorativo ou artificial e tornava-se uma ferramenta para a modernização e individualização de suas casas. Em cidades cada vez mais impessoais, com habitações massificadas, nas quais o próprio mobiliário oferecido pela Mobilinea também era padronizado - ainda que configurável em arranjos diversos -, seriam estes complementos que deixariam a nova domesticidade ao mesmo tempo mais palatável e única. Ambientes promovidos pela Mobilinea traziam ideias que podiam ser copiadas pelas leitoras, e em muitas páginas produzidas para a Abril, Georgia ensinou como fazer objetos decorativos e funcionais, trazendo novo repertório a uma prática tradicional das revistas e mesmo das leitoras.

Na reportagem "Acredite: você pode fazer tudo isso sozinha", da mesma Claudia Decoração de agosto de $1968^{74}$ que trazia o "cursinho de decoração", Georgia apresentou uma série de objetos decorativos que havia produzido recentemente para a Mobilinea e especialmente para a ocasião, explicando como faze-los. Eram eles: "uma colagem de flôres e fôlhas sêcas", "uma borboleta 'pintada' com a máquina de costura", "uma tapeçaria" "uma colcha de retalhos", "uma divisão de crochê", "um tapete finlandês", "uma almofadinha tricotada", "uma figura bordada (e deitada) em três almofadas"75 e "uma cortina de contas de madeira e canudinhos de palha" [3.3.02].

As imagens apresentavam uma versão dos resultados, mas as instruções não davam limitações como cores, acabamentos ou o arranjo de cada peça, o que era incomum neste tipo de seção. Na colagem de flores, por exemplo, o texto dizia: "para o fundo, use um pedaço de compensado forrado com um tecido que the agrade. Se a madeira fôr muito bonita, deixe-a à vista. Você também pode cobrir o fundo com um papel colorido"76. No caso da divisória em crochê, "se você sabe fazer crochê, poderá facilmente copiar o ponto que está na foto. Poderá também fazê-lo parecido, ou ainda mais bonito que o nosso"77; já no tapete, "por favor, faça o seu desenho você mesma. Nada de copiar dos outros: para fazer um desenho simples como êste, não precisa ser nenhuma grande artista"78, e assim por diante. Apenas para a figura bordada em três almofadas foi disponibilizado um molde ao final da revista, mas sem especificação de cores e sugerindo que se 


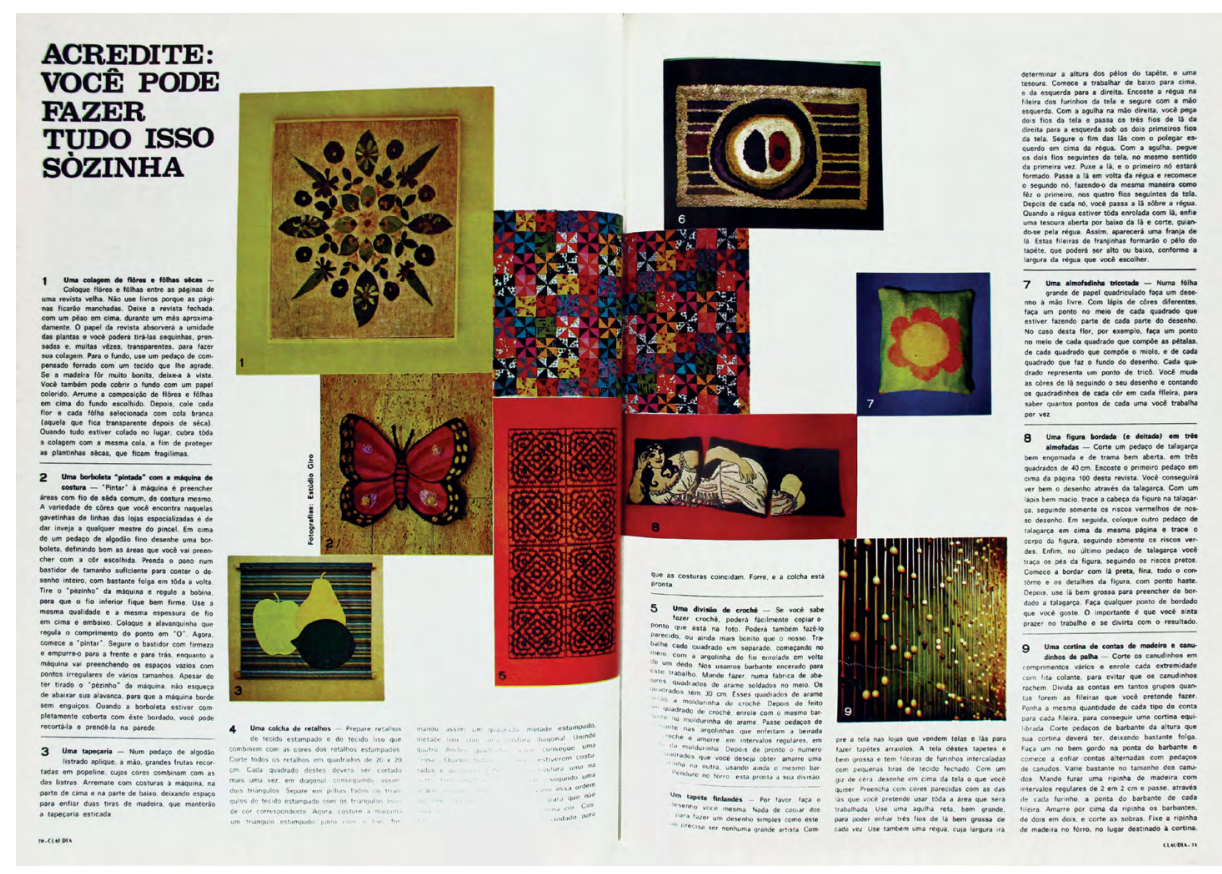

3.3.02: Tutorial para fazer diversos objetos decorativos. "Acredite: você pode fazer tudo isso sozinha". Claudia Decoração. pp. 70-71. ago. 1968.

\subsubsection{3: Molde para}

fabricação de almofadas. "Aqui está o molde para você bordar a almofada da mulher deitada". Claudia Decoração. pp. 100-101. ago. 1968.

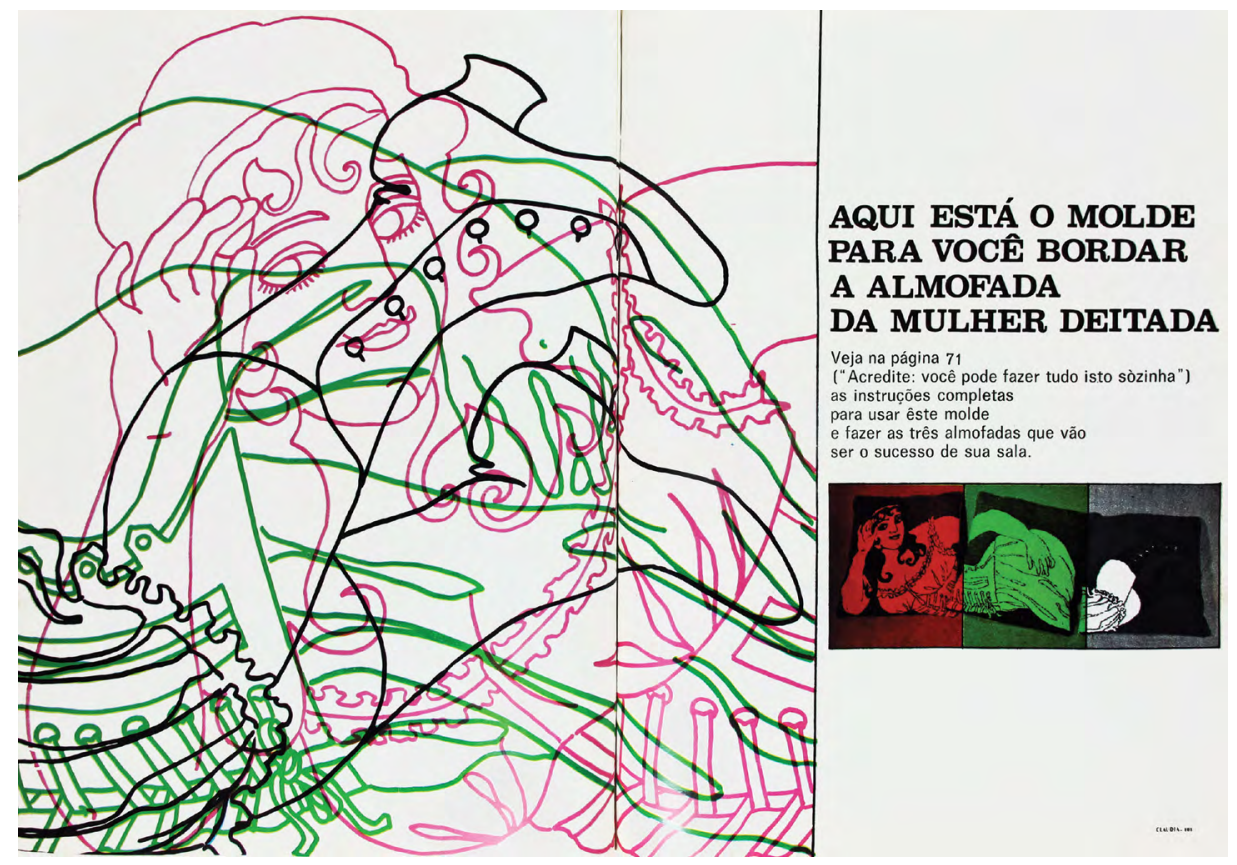

"faça qualquer ponto de bordado que você goste. O importante é que você sinta prazer no trabalho e se divirta com o resultado"79 [3.3.03]. Os conhecimentos específicos exigidos para a produção de cada peça variavam entre nenhum, costura à máquina, crochê e tricô.

Ao mesmo tempo em que se supõe que as leitoras a quem Georgia se dirigia teriam tempo e habilidade de realizar estes e outros projetos artesanais e decorativos, havia um reconhecimento de que novos cotidianos e dinâmicas domésticas não suportavam mais uma mulher que vivesse em função de uma casa de difícil manutenção. Era também neste sentido que Mobilinea propunha móveis com estofados revestidos em tecidos sintéticos e com capas removíveis e laváveis, e mesmo móveis com acabamentos simples. 
Essa praticidade nas peças e em seu arranjo também parece vir da compreensão sobre as novas tipologias dos apartamentos que surgiam: Georgia repetidamente apresentou soluções para o pequeno - ou "mini" apartamento enquanto editora de decoração de Claudia, raramente usando móveis de empresas de design e preferindo criar peças com materiais baratos ou técnicas caseiras. Essa preocupação se aproximou mais diretamente da Mobilinea na Home Store, com a "Casa da Vera", que visava mostrar aos clientes como resolver um espaço mínimo com poucos gastos, e justificava-se frente às demais peças oferecidas como uma solução inicial e provisória, ainda que de funcionalidade e bom gosto equivalentes.

Essa casa moderna nas imagens produzidas por Georgia se delineava no equilíbrio entre peças estandardizadas e detalhes pessoais, planejada de forma racional frente aos modos de vida e o espaço disponível, muitas vezes indicando um ocupante pela presença de pequenos objetos pessoais, e se completava quando modelos estavam efetivamente nos ambientes, portandose modernamente ${ }^{80}$. A primeira propaganda da Mobilinea com a presença de figuras humanas foi em "Uma Estante num Instante" de janeiro de $1966^{81}$ [2.1.08], na qual um casal era visto montando uma estante em uma posição de igualdade tanto na fixação dos elementos, como no posterior arranjo dos objetos decorativos. Depois disso essas presenças foram se tornando mais frequentes, retratando quase exclusivamente mulheres.

Em março de 1968, Casa ఓ Jardim ${ }^{82}$ propôs a Mobilinea, Celina Decorações e Arredamento ${ }^{83}$ que desenvolvessem um quarto para uma "menina-moça" para um editorial com este tema. O quarto Mobilinea foi construído em um cenário montado na fábrica da empresa ${ }^{84}$ despido de referências femininas óbvias como cor de rosa, bonecas ou objetos delicados, e mobiliado com cama, cômoda, luminária, dois bancos ripados e um conjunto de penteadeira e poltrona Thonet. Os bancos e a luminária foram laqueados em verde e os demais móveis em branco, as paredes e o piso também eram brancos, a colcha e os estofados eram de veludo verde e azul, e o quarto foi decorado com flores de papel nestes três tons, posicionadas ao longo das paredes e às margens do enquadramento da foto; há ainda discos de vinil sobre os bancos, no chão e na cama, onde uma garota de mini saia está deitada ouvindo música [3.3.04].

O texto parece ter sido escrito pela redação de Casa e Jardim, pois há alguma unidade nas descrições dos ambientes das três empresas, talvez tendo se baseado em memoriais enviados por cada uma delas. Sobre o quarto da Mobilinea, único ocupado, era enfatizada a versatilidade dos móveis e o estilo de vida da adolescente que o habitaria, uma garota independente com gostos atuais e que recebia amigos em seu quarto ${ }^{85}$. 


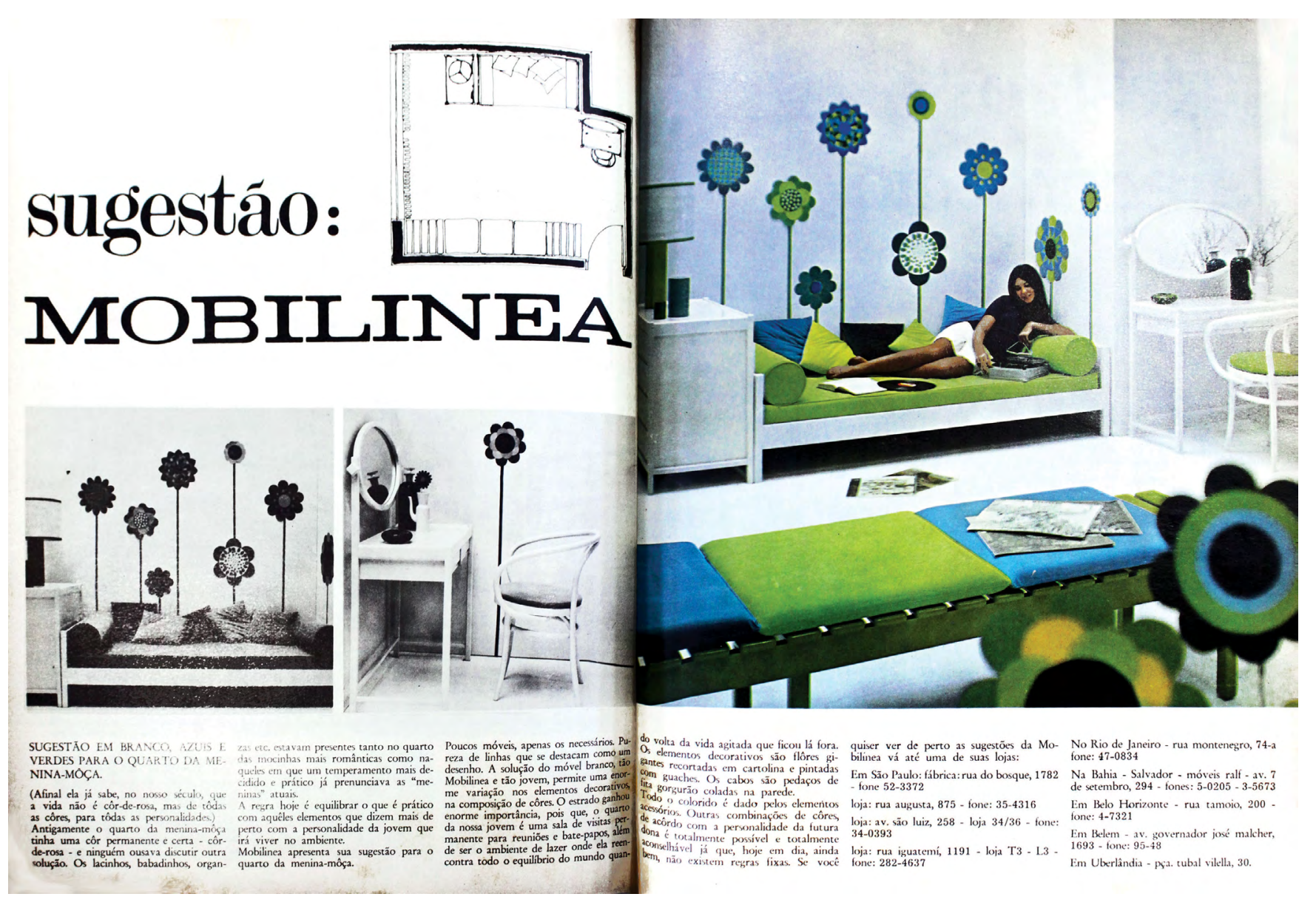

SUGESTÃO EM BRANCOS, AZUIS E VERDES PARA O QUARTO DA MENINA-MÔÇA. (Afinal ela já sabe, no nosso século, que a vida não é côr-de-rosa, mas de tôdas as cores, para tôdas as personalidades.) A regra hoje é equilibrar o que é prático com aquêles elementos que dizem mais de perto com a personalidade da jovem que irá viver no ambiente. Poucos móveis, apenas os necessários. Pureza de linhas que se destacam como um desenho. A solução do móvel branco, tão Mobilinea e tão jovem, permite uma enorme variação nos elementos decorativos e na composição de côres. O estrado ganhou enorme importância, pois que, o quarto da nossa jovem é a sala de visitas permanente para reuniões e bate-papos, além de ser o ambiente de lazer onde ela reencontra todo o equilíbrio de volta da vida agitada que ficou lá fora. ${ }^{86}$

Evidenciava-se novamente que os móveis deveriam ser uma base sobre a qual seriam colocados os elementos que "dizem mais de perto" com a personalidade da ocupante, com o branco sendo associado igualmente à Mobilinea e à juventude, e o ambiente como um espaço para distanciar-se da vida urbana e aproximar-se dos amigos. A maneira como a menina está esparramada pela cama era parte importante da idealização desta personagem, e diversas outras imagens da empresa contavam com mulheres repetindo esse tipo de comportamento, dentre as quais vale recuperar a foto de catálogo em que garotas quase desmontavam as peças da Mobilinea sentando, deitando e caminhando sobre elas ${ }^{87}$ [2.1.20] e que contava com Silvia Duschenes em primeiro plano. Filha do casal Herbert e Maria Duschenes ${ }^{88}$, que haviam sido padrinhos de casamento dos Hauner, Silvia era bonita e tinha feições marcantes,
3.3.04: Ambiente Mobilinea para quarto de adolescente. "O quarto da menina-môça". Casa \& Jardim. pp. 52-53. mar. 1968. 
além de, na proximidade dos circuitos sociais, ser alguém a quem Georgia tinha acesso. Ela foi sem dúvida a modelo mais frequentemente chamada para participar de editoriais feitos por Georgia para a Mobilinea e em Claudia, sempre nas imagens produzidas com móveis da empresa. Foi também Silvia quem apareceu como a "cara" da Mobilinea no lançamento da poltrona que participou da Bienal de Design de $1968^{89}$ sentada com braços e pernas cruzadas e entreabertas, encarando a câmera com uma expressão enigmática [1.3.06].

No primeiro editorial de “C. J. Visita” em $1970^{90}$, várias imagens contavam com mulheres nas fotos, usando roupas leves e em poses que denotavam liberdade e descontração, com os pés para o alto ou escorregando dos assentos [2.1.18-2.1.19]. Dessa produção, surgiu também uma propaganda realizada no ambiente de jantar, publicada pela primeira vez na mesma Casa e Jardim de julho de $1970^{91}$, que contava com uma imagem análoga a do editorial e que fazia referência a tendências da estética espacial como do filme "2001: Uma Odisseia no Espaço" 92 ou quem sabe à personagem de Jane Fonda em "Barbarella", ambos de 1968. Tratava-se de uma foto em grande angular de uma sala de jantar com móveis em aço e poliéster, materiais frios, que tornavam-se mais convidativos pela presença de plantas, uma divisória de feltro e uma modelo toda vestida de branco sentada de maneira deslocada sobre a cadeira, descalça e encarando a câmera [3.3.05].

Toda a encenação sugeria um estilo de vida descontraído mas com refinamento estético, e o texto que acompanhava a imagem posicionava explicitamente quem seria a mulher moderna que consumiria os produtos da Mobilinea:

\begin{abstract}
Você que acredita que a terra é redonda, que a casinha no fundo do quintal não é a última palavra em higiene, que eletricidade não é bruxaria, que a máquina voadora é uma realidade, você que deixou de usar espartilho e ceroulas, que não acha imoral mulher sair sozinha na rua, que não faz questão de usar chapéu, que sabe que a dignidade do móvel não está na pata do leão, que maillot sem saiote não é indecente, que arte não precisa ser acadêmica, que o phonographo está superado, que Cadillac "rabo de peixe" não representa o máximo em elegância, que decoração não se faz com aparador "pé de palito", que abandonou o sapato pontudo de saltinho fino, entre na década de 70 com móveis de aço cromado e poliester da MOBILINEA ${ }^{93}$
\end{abstract}

Mesclando constatações óbvias como a terra ser redonda a um posicionamento sobre o papel da mulher ("[você] que não acha imoral mulher sair sozinha na rua") e design ("que decoração não se faz com aparador 'pé de palito"'), este texto condensava um conjunto de valores sobre o que havia de mais contemporâneo, por uma lente ao mesmo tempo cômica e enfática, afirmando que Mobilinea seria sua síntese. Para Marinês Ribeiro dos Santos, o 'você' utilizado nesta mensagem oscila entre a imagem da moça e a pessoa que lê, de maneira que "o discurso evoca a cumplicidade do público com a posição 
de sujeito construída para as mulheres no anúncio, a saber, ousada, livre e informal"94. Embora saibamos que o texto tenha sido escrito por Georgia ${ }^{95}$, nos questionamos se ele fala de um ponto de vista masculino ou feminino e a qual gênero se dirigia, podendo funcionar como um discurso ao qual mulheres se identificariam e se equiparariam, como a homens que estivessem investidos nessa visão de mundo e se atrairiam pela mulher retratada. Nos dois casos, incluíam-se nessas qualidades um elemento de sedução.

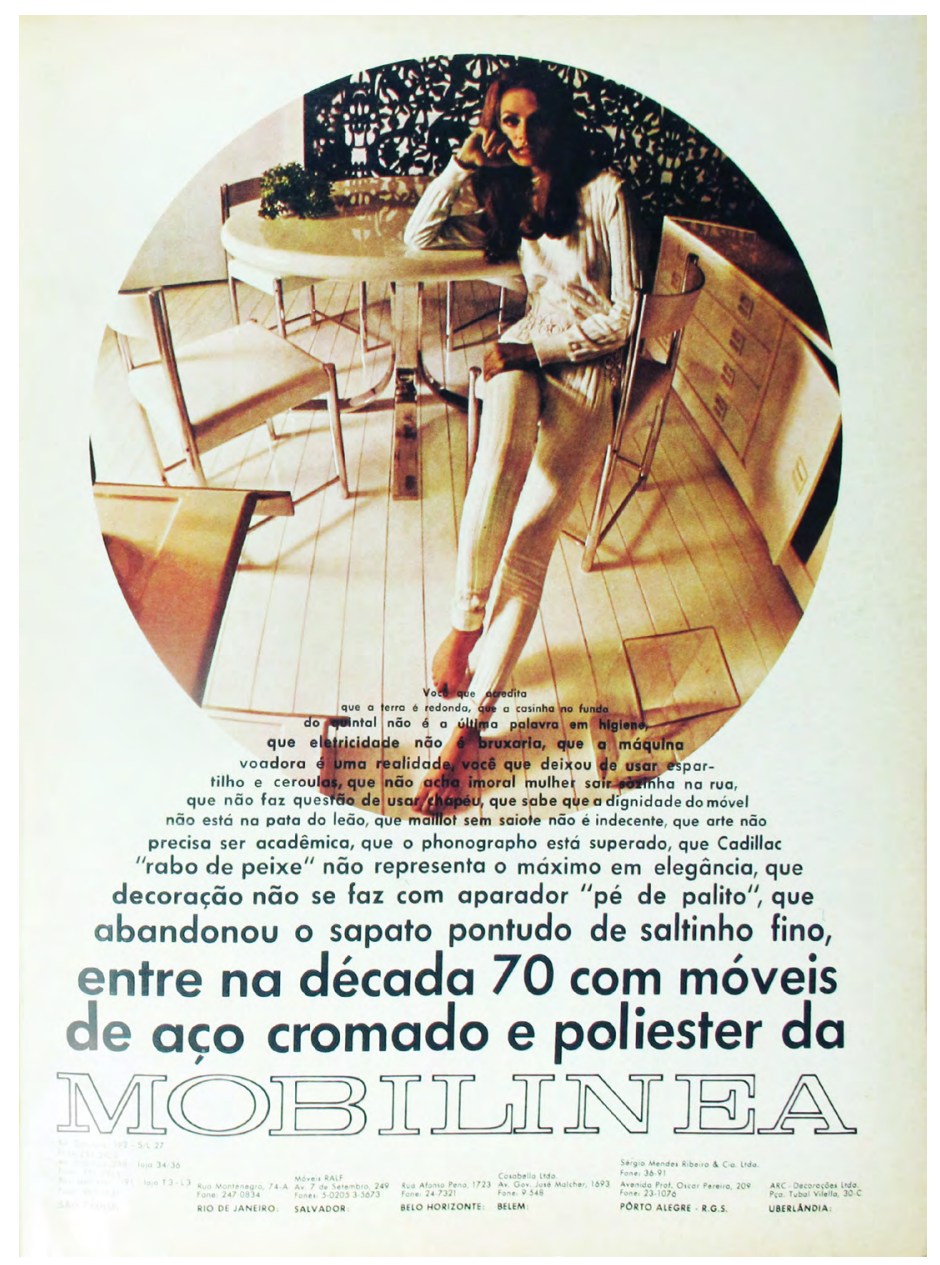

Em duas outras ocasiões, editoriais da Mobilinea que contavam com figuras femininas correram o risco de ser barradas pela censura ${ }^{96}$. A primeira vez foi com o ambiente de quarto de casal em "C. J. Visita" ${ }^{97}$ que, embora não retratasse pessoas, apresentava uma colcha bordada com o desenho de um casal nu, tranquilamente adormecidos [3.3.06]. Feita a partir de um desenho que "compilava" partes dos corpos de vários membros de sua família, Georgia havia bordado as imagens em linha preta sobre uma colcha de piquê branca ${ }^{98}$ e, com seu sucesso, reproduções passaram a ser fabricadas em serigrafia, tanto em modelos para cama de casal como de solteiro, e vendidas na Mobilinea. $\mathrm{O}$ que pode haver de ousado em relação a esta colcha, mais do que o desenho em si, é a ideia de uma representação de nudez no espaço doméstico e em um
3.3.05: Propaganda Mobilinea - "Entre na década de 70". Casa \& Jardim. jul. 1970. 
3.3.06: Quarto de casal Mobilinea (foto tirada na loja do Shopping Iguatemi). "C. J. Visita". Casa \& Jardim. pp. 48-49. jul. 1970. dos móveis mais íntimos da casa, a cama, dando a ela uma conotação mais abertamente sexual. O quarto em si é mobiliado a partir das premissas de ocupação do espaço habituais da Mobilinea, e se torna singelo especialmente por uma cortina-divisória feita com canudos e iluminada por trás.

A segunda vez em que Georgia relatou preocupações dos editores com uma possível censura foi quando Mobilinea decidiu publicar uma das fotos produzidas para a exposição "Mobiliário Brasileiro: premissas e realidade" de 1971 no MASP [1.2.05-1.2.06] na entrevista de Ernesto Hauner a Casa e $\operatorname{Jardim}^{99}$, que contava com uma modelo nua sentada em uma cadeira, vista de costas [3.3.07]. A frieza do aço e do fiberglass era mais uma vez contraposta à suavidade do corpo humano, que trazia elementos simultaneamente sedutores e francos. Evidentemente, nos dois casos a publicação foi permitida.

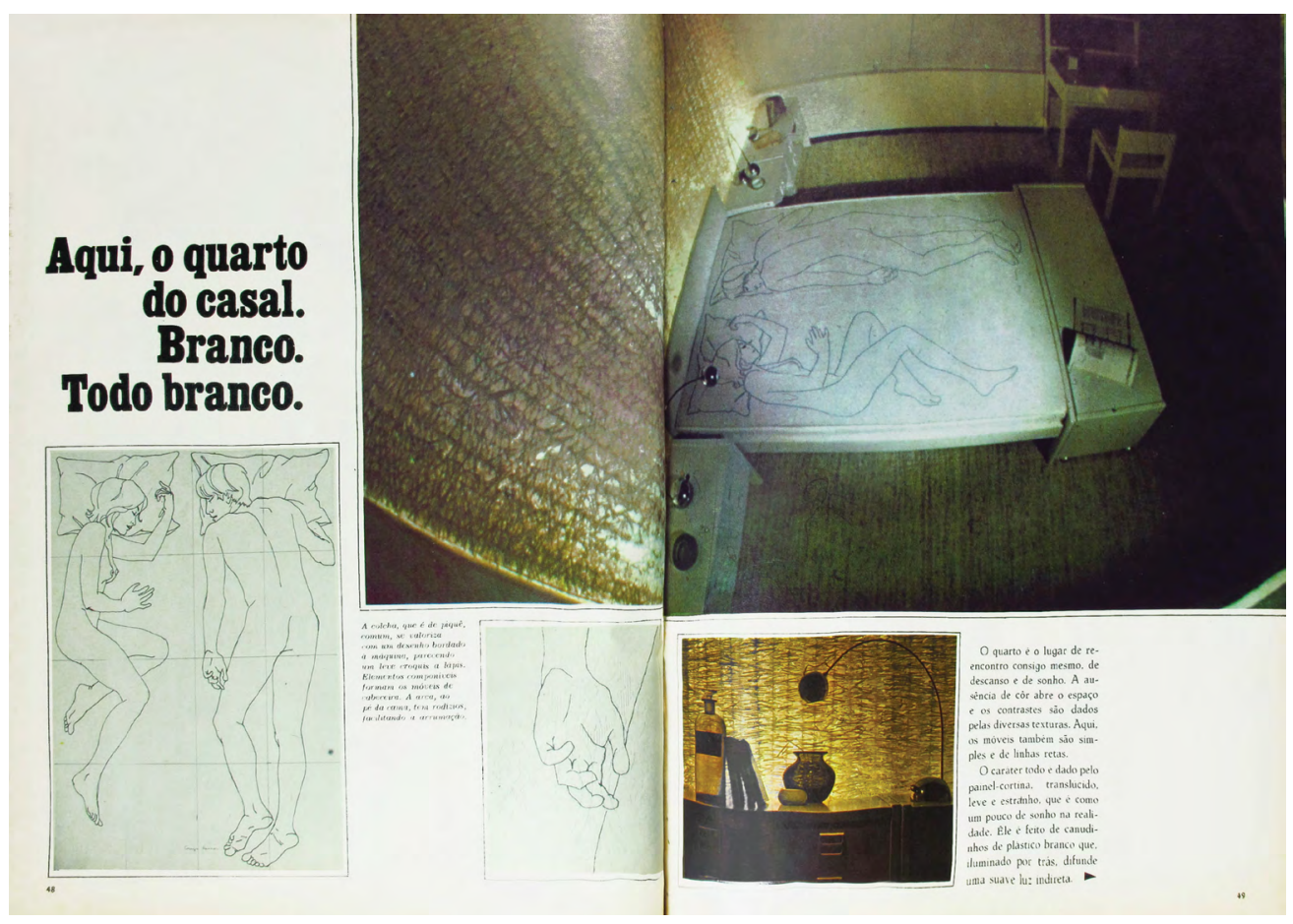

As funcionárias da Mobilinea, como vimos, também se deixaram retratar [2.2.21; 3.1.12] e transmitiam as mesmas ideias de modernidade que as modelos através de seus trajes e comportamentos, embora em um contexto corporativo - tanto nas propagandas como, supomos, no atendimento a clientes.

O trabalho feminino foi extremamente importante na Mobilinea, especialmente nas lojas, onde elas se responsabilizavam pelo planejamento das casas dos clientes e pela produção de cenários e objetos decorativos. Através das entrevistas, foi possível identificar dois tipos de funcionárias: as que fizeram carreira, dentro ou fora da empresa, e as que trabalharam lá apenas até se casarem e depois tornaram-se donas-de-casa, como parece ter sido o caso da maioria. A própria Georgia Hauner tinha assumido inicialmente um papel 


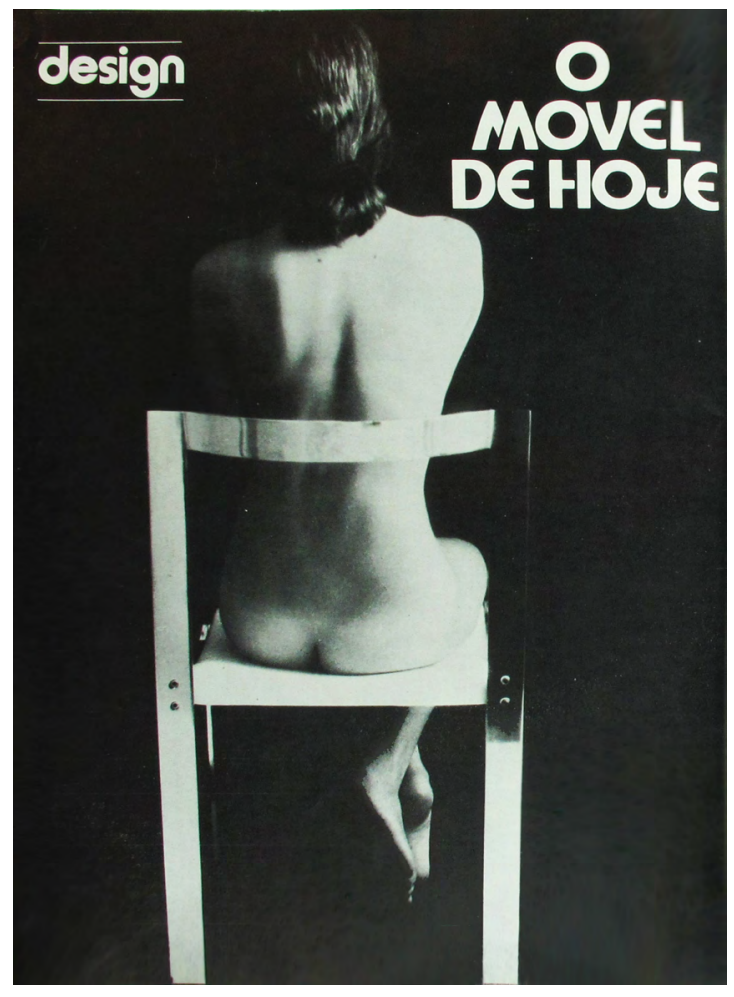

3.3.07: Cadeira em aço e poliéster com modelo nua, foto produzida por Georgia Hauner. "O Móvel de Hoje". Casa \& Jardim. p. 20. maio 1971.

mais tradicional como mãe e esposa, e foi aos poucos voltando ao mercado de trabalho a partir das luminárias e desenvolvendo seu trabalho até conquistar independência total em Claudia. Ada Hauner também havia se afastado do trabalho quando os filhos eram pequenos, mas entrou na Mobilinea após se separar do marido e permaneceu lá mesmo depois da saída do irmão. Yone Koseki Pierre, a única dentre os funcionários localizados com formação em arquitetura, começou como atendente nas lojas, mas posteriormente migrou para a fábrica para trabalhar ao lado de Ernesto; lá também estavam Jazel, na contabilidade, e Irene, na tapeçaria ${ }^{100}$.

O que entendemos como a "mulher" Mobilinea é então a somatória de todas estas figuras - Georgia Hauner, as vendedoras e funcionárias da empresa, as modelos posando nas fotos e as leitoras de revista e clientes Mobilinea. Elas representavam diversas facetas de um tipo de mulher que se estabelecia socialmente naquele período, e que se propunha a consumir um produto feito em escala industrial e se identificava com uma vida urbana e de trabalho. As roupas curtas e leves, a desenvoltura nas poses e atitudes buscavam comprovar sua emancipação de um papel subalterno anteriormente ocupado; e a maleabilidade em aceitar esta estética e funcionalidade modernas unida a objetos artesanais e decorativos vinha igualmente de um desejo de acrescentar algo pessoal nessa domesticidade de outra maneira bastante nova, mas também de uma leveza em não assumir bandeiras tão rígidas frente aos estilos de vida e formas de morar, que vinha de discussões da vanguarda da produção arquitetônica e de design no período. 
Notas

${ }^{1}$ Essas propagandas apareceram inicialmente entre os classificados, mas aos poucos foram migrando para páginas de reportagens.

2 Propaganda Mobilinea - Prêt-à-Porter, mulher. A Folha de São Paulo. p. 14, Caderno de Domingo. 24 out. 1971.

${ }^{3}$ Entrevista concedida por Judit Magyary à autora em 29 de julho de 2014.

${ }^{4}$ Propaganda Mobilinea - homem de marketing finalmente levantou da cadeira. O Estado de São Paulo. p. 22, Caderno Geral. 26 nov. 1974.

${ }^{5}$ Apresentação da Revista. C. J. Arquitetura. p. 3. jan. 1973.

6 "O Móvel Brasileiro". Arquitetura. pp. 17-24. jan. 1965. As outras empresas consultadas foram L’Atelier, Brafor, Oca, Mobília Contemporânea, Ambiente-Spazio e Tenreiro Móveis e Decorações.

7 Propaganda Mobilinea - Você vai ver como é bom trabalhar com Mobilinea. Arquiteto. mar. 1973.

8 "Arquitetura de interiores no Brasil". Projeto e Construção. pp.41-44. jan. 1971. Os outros entrevistados foram: Knoll (Martin Eisler e Petco Gueorguiev), Mobília Contemporânea (Michel Arnoult e Abel de Barros Lima).

9 "Forma estética e bom gosto ajudam a vender produtos". Indústria e Desenvolvimento. pp. 42-43. set. 1974. Além da Mobilinea, são exibidos produtos de Equipesca e outros não identificados; Alexandre Wollner é citado como um dos entrevistados.

${ }^{10}$ Propaganda Mobilinea - balança de abacaxi. GAM - Galeria de Arte Moderna. Edição Especial. 1968.

${ }^{11}$ Propaganda Mobilinea - Mobilinea convida você a sentar-se em seu mais novo design. Escritório Atual. abr. 1972.

${ }^{12}$ Propaganda Mobilinea - Mobilinea convida você a sentar-se em seu mais novo design. Exame. abr. 1972.

${ }^{13}$ Propaganda Mobilinea - Você vai ver como é bom trabalhar com Mobilinea. Visão. fev. 1969.

${ }^{14}$ Identificação feita com o auxílio de Judit Magyary.

${ }_{15}$ Marinês Ribeiro dos Santos, O Design Pop no Brasil dos anos 1970: domesticidades e relações de gênero na revista Casa e Jardim, 2010, p. 63.

${ }^{16}$ Id. Ibid.

${ }^{17}$ O Móvel de Hoje. Casa \& Jardim. pp. 20-23. maio 1971

18 Jaqueline R. Santos, Minha amiga Claudia (História, gêneros jornalísticos e produção de uma revista feminina), 1996.

${ }^{19}$ Depoimento de Luís Carta em Claudia, p. 29, out. 1981.

${ }^{20}$ Maria Celeste Mira, O Leitor e a Banca de Revistas - A Segmentação da Cultura no Século XX, 2001. p. 51.

${ }^{21}$ Jaqueline R. Santos, op. cit.

${ }^{22}$ Carla Pinksy, Mulheres dos Anos Dourados, 2014.

${ }^{23}$ Jaqueline R. Santos, op. cit.

24 "Muito amor e poucos Móveis". Claudia Noiva. pp. 42-49. mar. 1968.

${ }^{25}$ Ao todo foram localizadas 163 páginas produzidas por Georgia Hauner enquanto editora de decoração em Claudia, sendo 18 páginas em Claudia, 15 páginas em Claudia Noiva e 130 páginas em Claudia Decoração. Estes números descontam propagandas da empresa e inserções da Mobilinea realizadas independentemente de seu cargo na Abril.

${ }^{26}$ Entrevista concedida por Georgia Hauner à autora em 14 de setembro de 2012.

${ }^{27}$ Georgia Hauner, Segunda parte de respostas, 2012.

${ }^{28} \mathrm{Id}$, Mobilinea (Updated march 2014), 2014, p. 6.

${ }^{29}$ El Mueble. Capa. 1975.

30 "Você nem percebe, mas está cercada de arte por todos os lados". Claudia Decoração. dez. 1968.

${ }^{31}$ Este quadro sempre esteve em sua posse. Entrevista concedida por Georgia Hauner à autora em 16 de setembro de 2012.

32 Marcelino de Carvalho era conhecido à época como professor e autor de livros sobre etiqueta e gastronomia, redator de colunais sociais e apresentador de um programa de TV sobre estes temas. Ver a este respeito: Renira Appa, Transgredir, Jamais! Interação e cortesia linguísticas nos manuais de etiqueta, 2012.

${ }^{33}$ Propaganda Mobilinea - Esta sala é de quem passou ontem pela Mobilinea. Casa \& Jardim. jul. 1971; Claudia Decoração. jul. 1971

34 "Decoração? Não existe mais. É o que dizem os arquitetos de interiores". Mais. p. 40. abr. 1974.

${ }^{35}$ As empresas chamadas para participar desta matéria foram Mobilinea, Hobjeto, Montmartre Jorge, Novo Rumo, Celina Decorações, Paschoal Bianco e Arredamento. "Sala e quartos". Casa \& Jardim. abr. 1968. ${ }^{36}$ Id. Ibid.

${ }^{37}$ A nova foto deste cenário foi tirada de uma altura superior e o enquadramento foi melhor trabalhado com a inserção de uma tapeçaria na parede esquerda e mais plantas à direita. Propaganda Mobilinea ...This is Mobilinea. Time - Latin American Edition. p. XX. maio 1968.

${ }^{38}$ Propaganda Mobilinea - Os problemas de quem inicia a vida agora. Claudia. mar. 1969.

${ }^{39}$ Id. Ibid.

40 "Divisores de Ambientes". Casa \& Jardim. pp. 49-55. maio 1968. 
${ }^{41}$ Celina mostrou uma planta residencial e fotos em estúdio de uma estante em madeira maciça de piso a teto com duas faces, separando salas de estar e jantar, e Providro apresentou vidros recém-lançados no mercado nacional, através de fotos de projetos já executados para espaços corporativos. "Divisores de Ambientes". Casa \& Jardim. pp. 49-55. maio 1968.

42 "Degraus formam bancos e mesinhas". Claudia Decoração. pp. 56-57. ago. 1968.

${ }^{43}$ Este ambiente da Mobilinea era mais refinado do que os anteriores pela escolha de móveis e estofados monocromáticos (novamente em branco) e pelos objetos e quadros usados, cedidos pela galeria Mirante das Artes e da coleção particular de Bardi. Quando uma propaganda da Mobilinea utilizou apenas esta imagem no cenário, retornou uma sensação de que este era um ambiente real, em versão divulgada em setembro de 1968 em Veja e na Edição do Ano de Casa \& Jardim de 1969. Propaganda Mobilinea- ...Isto é Mobilinea, tapeçaria. Veja. set. 1968., Propaganda Mobilinea - MOBILINEA. Casa \& Jardim. E.A. 1969. ${ }^{44}$ Entrevista concedida por Georgia Hauner à autora em 16 de setembro de 2012.

45 "C. J. Visita... Mobilinea". Casa \& Jardim. p. 55. jul. 1970.

46 "Casa \& Jardim e Mobilinea escolhem o projeto vencedor". Casa \& Jardim. pp. 52-54. nov. 1970.

${ }^{47}$ Id. p. 53.

${ }^{48}$ Id. pp. 53-54.

${ }^{49}$ Id. p. 54.

50 "Casa \& Jardim e Mobilinea escolhem o projeto vencedor". Casa \& Jardim. pp. 10-12. fev. 1972.

51 "Êste mês a Casa de Claudia poderá ser sua". Claudia. pp. 54-57. jun. 1969.

52 "Primeiro problema: o apartamento". Realidade. pp. 142-145. maio 1971.

${ }^{53}$ Id. p. 142.

${ }^{54}$ Georgia Hauner, Mobilinea (Updated March 2014), 2014, p. 7

55 "Primeiro problema: o apartamento". Realidade. p. 142. maio 1971. O casal morava anteriormente em um casa no bairro do Sumaré, em São Paulo.

${ }^{56}$ Georgia Hauner, Mobilinea (Updated March 2014), 2014, p. 7.

57 "Boa idéia: juntar dois apartamentos pequenos". Casa de Claudia. pp. 74-77. ago. 1974.

${ }^{58}$ Vale lembrar que a estratégia de unir imóveis diferentes para que se adequassem aos objetivos imaginados pelos Hauner fora utilizada tanto na residência do casal no Itaim Bibi, como no projeto da Home Store.

${ }^{59}$ A mulher nas fotos deste editorial foi uma modelo contratada pela Editora Abril, pois Georgia diz não ter tido interesse em participar. Entrevista concedida por Georgia Hauner à autora em 16 de setembro de 2012

${ }^{60}$ Georgia Hauner, Mobilinea (Updated March 2014), 2014, p. 7.

${ }^{61}$ Sobre a arquibancada foram distribuídas pequenas almofadas que faziam um contraponto às almofadas no sofá - estas identificadas por Georgia como se fossem "cerâmica mole", por repetirem o padrão do piso. Entrevista concedida por Georgia Hauner à autora em 16 de setembro de 2012.

62 Marinês Ribeiro dos Santos, op. cit., p. 62.

${ }^{63}$ Georgia Hauner, "Cursinho Rápido de Decoração", Claudia Decoração. pp. 6-10. ago. 1968.

${ }^{64}$ Id. p. 6. Itálico no original.

65 Id. ibid.

${ }^{66}$ Id. p. 8.

67 "Conheça a opinião destes sete decoradores". Casa de Claudia. pp. 26-32. jul. 1971.

${ }^{68}$ Id. p. 26.

${ }^{69}$ Id. ibid.

70 "Arquitetura de interiores no Brasil". Projeto e Construção. pp.41-44. jan. 1971.

71 Id. p. 41.

72 Georgia Hauner, Sugestões para o Novo Centro Comercial na 9 de Julho, 7 ago. 1972. Documento datilografado do acervo pessoal de Georgia Hauner.

73 Entrevista concedida por Bibita (Maria Beatriz) Butcher à autora em 23 de julho de 2014; entrevista concedida por Judit Magyary à autora em 29 de julho de 2014.

74 "Acredite: você pode fazer tudo isso sozinha". Claudia Decoração. pp. 70-71. ago. 1968.

75 Para a produção desta almofada, Georgia atestou ter contado com a ajuda de sua mãe, que também produzia outros artesanatos para as lojas e havia ajudado na fabricação de luminárias desenvolvidas por Georgia no início dos anos 1960. Georgia Hauner, Segunda parte de respostas, 2012.

76 "Acredite: você pode fazer tudo isso sozinha". p. 70.

77 Id. p. 71.

78 Id. ibid.

${ }^{79}$ Id. ibid.

${ }^{80}$ Para uma análise mais aprofundada sobre o papel da mulher nos ambientes domésticos propostos nos periódicos brasileiros durante este período, ver Marinês Ribeiro dos Santos, op. cit.

81 Propaganda Mobilinea - "Uma Estante num Instante”. Casa \& Jardim. jan. 1966.

82 "O quarto da Menina-Moça". Casa \& Jardim. mar. 1968.

${ }^{83}$ Nesta reportagem, Celina apresentou um quarto com uma bicama e móveis modulares em Jacarandá e palhinha, "tipo moderno, mas sem exageros", e Arredamento também fez um quarto com móveis modulares em madeira aparente, com estofados vermelhos e azuis, e pôsteres psicodélicos nas paredes. "O quarto da Menina-Moça". Casa \& Jardim. mar. 1968. 
${ }^{84}$ Georgia Hauner, Segunda parte de respostas, 2012.

85 Esta cena reapareceu transformada em propaganda na revista Claudia em maio do mesmo ano, e mais uma vez em setembro, o que leva a crer que a imagem teve um retorno positivo não apenas dentro da própria empresa, mas também pelo público. Propaganda Mobilinea - ...Isto é Mobilinea, quarto verde. Claudia. maio 1968.

86 "O quarto da Menina-Moça". Casa \& Jardim. mar. 1968.

87 Poltrona estofada. Imagem de slide. Sem data. Acervo pessoal de Georgia Hauner.

88 Ronaldo Duschenes era arquiteto e sua esposa, Maria, bailarina.

89 Propaganda Mobilinea - Poltrona participante da Bienal 68. Claudia Decoração. dez 1968.

90 “C. J. Visita... Mobilinea". Casa \& Jardim. pp. 45-57. jul. 1970.

91 Propaganda Mobilinea - “Entre na década de 70”. Casa \& Jardim. jul. 1970.

92 Georgia Hauner, Segunda parte de respostas, 2012.

93 Propaganda Mobilinea - "Entre na década de 70".

94 Marinês Ribeiro dos Santos, op. cit., p. 222.

95 Georgia Hauner, Segunda parte de respostas, 2012, p. 2.

${ }^{96}$ Entrevista concedida por Georgia Hauner à autora em 16 de setembro de 2012.

97 “C. J. Visita... Mobilinea”. Casa \& Jardim. pp. 48-49. jul. 1970.

98 Georgia Hauner, Segunda parte de respostas, 2012.

99 O Móvel de Hoje. Casa \& Jardim. pp. 20-23. maio 1971

100 Os demais funcionários de administração e da fábrica, até onde se tem notícia, eram homens. A situação inversa também acontecia nas vendas, sendo Wilson Chica o único nome masculino dentre todos os vendedores das lojas. 



\section{Considerações finais}

cos

(2n) 

Ao longo desta dissertação, buscamos recuperar a trajetória da empresa Mobilinea sob diversos enfoques, prioritariamente com vistas a preencher uma lacuna historiográfica no panorama da produção de móveis no Brasil nas décadas de 1960 e 70. Nesse sentido, buscamos situar a empresa ao longo de uma história mais ampliada, levantando experiências que moldaram o cenário no qual ela viria a se inserir, mas também preocupando-nos em posicionar a Mobilinea em relação às suas concorrentes e parceiras (muitas das quais ainda carecem de estudos específicos), compreendendo que uma história descolada de sua inserção no campo torna-se extremamente empobrecida.

Pensamos odesign comoumfenômenoculturale esperamos ter evidenciado a vitalidade da produção no período, apontando que houve iniciativas que conseguiram unir seu raciocínio construtivo a suas formas de fabricação, venda e promoção, isto é, foram capazes de levar a cabo um projeto de móvel moderno com impactos socioculturais relevantes. O circuito profissional do período enlaçava os escritórios de projeto, suas fabricas e lojas, tanto ao meio artístico de vanguarda quanto a um público mais amplo, equilibrando-se entre a busca por reconhecimento no circuito institucional através de prêmios e exposições, e o universo corporativo e da cultura de massas, representada pela imprensa, as propagandas e as feiras.

O móvel da Mobilinea partia de uma preocupação inicial em otimizar matérias-primas e processos de fabricação, o que em muitos sentidos moldou sua estética. Em relação aos acabamentos, o uso de cor permitiu criar um diferencial no mercado, além da possibilidade de personalização de componentes padronizados, o que ia muito de encontro ao modo como os móveis eram promovidos. Havia móveis que organizavam ou definiam espaços, dentre os quais as estantes modulares são o maior exemplo; e os que ocupavam efetivamente o recinto, como mesas, cadeiras, bancos, entre outros. Os móveis em aço e fiberglass se encaixavam nesta segunda categoria, e parecem ter tido uma vocação de destaque no ambiente, complementados por móveis mais básicos sobre os quais se imprimiria a personalidade do usuário através de elementos decorativos e pessoais, não raro elaborados artesanalmente. Estas peças eram dispostas em espaços que simulavam ambientes domésticos integrados, organizados por desníveis ou acabamentos de piso diferentes, com frequente aplicação de texturas como tijolos e cortiça nas paredes, tendo em vista também serem aproveitados na produção de fotografias publicitárias. 
Para estes fins, houve um trabalho frequente em misturar materiais naturais e sintéticos, cores neutras nas peças permanentes com outras fortes, lisas ou em estampas, nos revestimentos e complementos decorativos, que eram muitas vezes objetos efêmeros, lúdicos ou nonsense, que muitas vezes denotavam algum significado cultural, e ainda flores, frutas, animais e folhagens.

Assim, Mobilinea visava não somente vender seus produtos, mas contribuir para a modelagem de um público, compondo aquilo que Georgia Hauner descreveu como "cartões postais"l de um estilo de vida que se desejaria consumir. Estes ambientes encenados se propunham como espaços contemporâneos e descontraídos, supostamente capazes de responder aos anseios de uma classe média urbana em formação através do modo como definiam e vivenciavam suas residências, cuja arquitetura em grande medida também era diversa das com que vinham convivendo até então. Os consumidores desses móveis, moradores desses lares reais e imaginados pela empresa, deveriam então refletir a informalidade dos ambientes propostos, apoiando-se sobre os móveis ou no chão, recebendo também de modo informal amigos e visitantes, ou simplesmente desfrutando da casa como um espaço de lazer. Os habitantes em vista podiam ser uma família nos moldes tradicionais, mas também organizarem-se em outras configurações, tendo em vista a multifuncionalidade dos móveis e as possibilidades de decoração que ofereciam. Como vimos, neste ambiente as mulheres deixavam de ser elas mesmas um objeto decorativo para se tornarem um personagem ativo, que não só usufruía a casa, interagindo com seus novos atributos, como eram em grande medida seu canal de modernização. Manifestando claramente um novo perfil feminino que transparecia independência, individualidade e autoconfiança, as mulheres retratadas nas campanhas da empresa diziam respeito a estas ambições de colocação social de suas consumidoras, e é neste sentido que parece ter havido um interesse em remeter-se a elas para promover os produtos da Mobilinea.

Havia dentro da própria empresa uma clara divisão de gênero que, com suas nuances e exceções, criou uma situação em que projeto e fabricação eram predominantemente masculinos e, venda e consumo, femininos. Quem dava o tom de como cada uma destas instâncias se caracterizava e complementava, sem dúvida, eram Ernesto e Georgia Hauner, cuja parceria igualmente se dividia entre dois polos: ele da racionalidade, economia e padronização; ela da espontaneidade, charme e individualidade. De fato, parece que o estilo de vida 
proposto pela Mobilinea só funciona na somatória destes pontos de vista, e que parece ter acontecido de forma natural, até despretensiosa. Para Georgia,

\begin{abstract}
A Mobilinea não foi a conceituação de um projeto, mas sim a expressão logica de uma habilidade aprendida, de uma experiência, de uma filosofia de vida. O dialogo subentendido com o público sempre foi: acredito que o que é bom para mim, provavelmente é bom para você também. ${ }^{2}$
\end{abstract}

Pode ter sido esta perspectiva que efetivamente diferenciou Mobilinea de seus concorrentes e explicaria a sua longevidade em relação a tantos deles, e também o motivo pelo qual ela mudou tão drasticamente com a saída do casal. Mais do que isso, se o projeto proposto pela Mobilinea se dava na somatória dos papéis exercidos por Ernesto e Georgia Hauner, sua parceria fala também sobre uma divisão sexual do trabalho no campo, bem como de uma ocupação em permanente crise, a decoração. Na arquitetura, assim como o paisagismo, a decoração era muitas vezes tratada como um campo secundário, de frágil profissionalização, que caberia a diletantes. Mesmo em seu discurso, Georgia buscou desvincular-se deste papel, propondo uma diferenciação entre decoração e planejamento de interiores, este último representando a superação do trabalho de dona de casa, passando por uma vocação artesanal e, finalmente, pelo estabelecimento do setor no universo das profissões liberais. Enquanto tal, o planejamento de interiores ocuparia uma posição intermediária "entre a mobília e a construção"”, isto é, entre o design de móveis e a execução de projetos arquitetônicos, expressando um tensionamento desses campos que realmente se dava não apenas nas propostas da Mobilinea, mas que foi visto nos periódicos examinados como um movimento mais geral no design de interiores, ao mesmo tempo em que se flexibilizavam algumas doutrinas da arquitetura e do design do entre guerras que não favoreciam o tipo de ambiência criada na Mobilinea, passando a dar espaço para este tipo de concepção.

A realização de um estudo de design à luz de sua relação com a promoção comercial permite este tipo de observação e revela circunstâncias de criação, propagação e estabelecimento de diferentes tendências. Foi especialmente marcante o comprometimento de alguns veículos, em especial Casa \& Jardim e Claudia, em apoiar a indústria nacional de design, ao proporem-se como guias aos leitores para ensinar as formas de usar estes móveis e compor ambientes modernos, investindo em uma espécie de curadoria das empresas que julgavam ter boas propostas e cedendo seu espaço editorial a elas. O diálogo da Mobilinea 
com seus/suas consumidores/as só era possível, em grande medida, através destes canais, quando um ambiente de loja ou estúdio deixava de ter um limite físico e geográfico pontual e se projetava enquanto uma referência amplamente difundida e acessível.

Como esta é a primeira pesquisa acadêmica a respeito da empresa e seus personagens, não houve nenhuma ambição em esgotar temas, e de maneira alguma subestimamos a necessidade de examinar outros aspectos, que tanto quanto possível foram apresentados em linhas gerais. Sistematizar, analisar e disponibilizar os dados levantados tomou uma dimensão central no percurso do mestrado, na esperança de instigar outros pesquisadores a abordar questões que este primeiro esforço não alcance. Nos parece que, para aprofundar os debates sobre a trajetória da empresa, seria muito proveitoso buscar informações sobre o chão de fábrica e entender a dinâmica de criação de novos móveis, dando voz a outros personagens ainda não localizados. Também parece instigante realizar uma pesquisa mais extensa sobre o trabalho de Georgia Hauner para além da Mobilinea, na Editora Abril, incluindo aí a história da revista Claudia e seus demais colaboradores, muitos dos quais também femininos, o que por sua vez desdobra-se em um estudo sobre o tipo de espaço doméstico promovido neste tipo de mídia no período, seus demais promotores e consumidores. Finalmente, a continuação da história da empresa e seu arranjo após a saída de Ernesto e Georgia Hauner certamente contribuiria para apresentar continuidades ainda não visíveis neste momento de aparente ruptura, assim como linhas de fuga na produção de móveis no Brasil desde então.

De todo modo, acreditamos que recuperar a história da Mobilinea como foi possível aqui já tem sua relevância, não só para colocá-la em seu devido protagonismo no cenário do design em determinado momento, modificando também como as outras empresas a atuar no período devem ser então percebidas em função do reestabelecimento destes diálogos, como pelos reflexos que podem ser vistos a partir de suas propostas na produção de design e editorial à época e desde então. Neste sentido, acreditamos que a pesquisa presta-se ainda a reapresentar ideias outrora esquecidas que podem agora encontrar nova continuidade, adequando-se à realidade presente. 


\section{Notas}

${ }^{1}$ Georgia Hauner, Sugestões para o Novo Centro Comercial na 9 de Julho, 7 ago. 1972. Documento datilografado do acervo pessoal de Georgia Hauner, p. 3.

${ }^{2}$ Georgia Hauner, Segunda parte de respostas, 2012.

3 "Conheça a opinião destes sete decoradores". Casa de Claudia. p. 26. jul. 1971. 

Bibliografia 

Acayaba, Marlene M. Branco e Preto. Uma história do design Brasileiro nos anos 50. São Paulo: Instituto Lina Bo e P.M. Bardi, 1994.

Alberti, Verena. História oral: a experiência do CPDOC. Rio de Janeiro: Centro de Pesquisa e Documentação Histórica Contemporânea do Brasil, 1989.

Appa. Renira. C. Transgredir, Jamais! Interação e cortesia linguísticas nos manuais de etiqueta. Tese (Doutorado em Filologia e Língua Portuguesa), Faculdade de Filosofia, Letras e Ciências Humanas, Universidade de São Paulo, São Paulo, 2012.

Argan, Giulio C. História da Arte como História da Cidade. São Paulo: Martins Fontes, 2005.

Arruda, Maria Arminda N. Metrópole e Cultura: São Paulo no meio do século XX. Bauru: Edusc, 2001.

. "Empreendedores culturais imigrantes em São Paulo". Tempo Social, revista de sociologia da USP, v.17, n.1, pp. 135-58, 2005.

Atique, Fernando. Memória de um projeto moderno: a idealização e a trajetória do Edifício Esther. Dissertação (Mestrado em Tecnologia do Ambiente Construído), Escola de Engenharia de São Carlos, Universidade de São Paulo, São Carlos, 2002.

Ballent, Anahi. "Tres veces Claudia: renovación de la prensa, las imágenes de la mujer y el habitar doméstico, 1957-1975”. In: Primera Reunón de Trabajo, Los 60' de otra manera: vida cotidiana, género y sexualidades em la Argentina. Buenos Aires, 2008.

Apartment buildings for the middle-class: cultural transformation of domestic life and urban densification. Buenos Aires, 1960-1975. IPHS, São Paulo, 2012.

BARdi, Pietro Maria. Catálogo. Mobiliário Brasileiro: premissas e realidade. São Paulo: MASP, 1971.

Bayeux, Glória. OMóvel da Casa Brasileira. São Paulo: Museu da Casa Brasileira, 1997.

BIENAL BRAsileIRA DE DESIGN 2010. Bienal Brasileira de Design 2010 Curitiba vol.1 e 2. Curitiba: Centro de Design Paraná, 2010.

Borges, Adélia. Sergio Rodrigues. Rio de Janeiro: Viana \& Mosley Editora, 2005. Braga, Marcos C. "ABDI: História concisa da primeira associação profissional de design do Brasil". Revista Da.: design, educação, sociedade e sustentabilidade. v. 1, pp. 13-32. Porto Alegre: UniRitter, 2007.

. ABDI e APDINS-RJ: História das Associações Pioneiras de Design do Brasil. São Paulo: Blucher, 2011.

; Dias Dora S. (org.). Histórias do Designn Brasil II. São Paulo: Annablume, 2014.

BRITO, Ronaldo. Neoconcretismo: vértice e ruptura do projeto construtivo brasileiro. São Paulo: Cosac Naify, 1999.

Bruand, Yves. Arquitetura Contemporânea no Brasil. São Paulo: Editora Perspectiva, 1981. 
Buitoni, Dulcília H. S. Mulher de papel: a representação da mulher pela imprensa feminina brasileira. São Paulo: Loyola, 1981.

Calheiros, Alex; Mari, Marcelo; Rufinoni, Priscila Rossinetti (org.). Mobiliário Moderno: das pequenas fábricas ao projeto da UnB. Brasília: Editora Universidade de Brasília, 2014.

Cals, Soraia (org.). Tenreiro. Rio de Janeiro: Bolsa de Arte do Rio de Janeiro, 1998. (org.). Sergio Rodrigues. Rio de Janeiro: S. Cals, 2000.

CARÁ, Milene S. Do desenho industrial ao designn no Brasil: uma bibliografia crítica para a disciplina. Dissertação (Mestrado em Arquitetura e Urbanismo), Faculdade de Arquitetura e Urbanismo, Universidade de São Paulo, São Paulo, 2008.

Carvalho, Vânia C. Gênero e Artefato: o Sistema Doméstico na Perspectiva da Cultura Material - São Paulo, 1870-1920. São Paulo: EDUSP, 2008.

Cauduro, João C. Marcas CM Cauduro Martino Arquitetos Associados / João Carlos Cauduro, Ludovico Martino. São Paulo: Imprensa Oficial, 2005.

Chadwick, Whitney; Courtviron, Isabelle. Significant Others - Creativity and Intimate Partnership. New York: Thames and Hudson, 1993.

Claro, Mauro. Unilabor - Desenho Industrial, Arte Moderna e Autogestão Operária. São Paulo: SENAC, 2004.

. Dissolução da Unilabor: crise e falência de uma autogestão operária - São Paulo, 1963-1967. Tese (doutorado em Arquitetura e Urbanismo), Faculdade de Arquitetura e Urbanismo da Universidade de São Paulo, São Paulo, 2012.

Colomina, Beatriz. "The Split Wall: Domestic Voyeurism” In: Colomina, Beatriz (org.). Sexuality and Space. Princeton: Princeton Architectural Press, 1992.

. Privacy and Publicity: modern architecture as mass media. Cambridge: MIT Press, 1994.

Curtis, William J. R. Arquitetura moderna desde 1900. Porto Alegre: Bookman, 2008.

Desígnio. Dossiê: história, historiografias, historiadores. Edição temática, São Paulo: n. 11-12, mar. 2011.

ForTy, Adrian. Objeto de Desejo - design e sociedade desde 1750. Cosac Naify. São Paulo. 2007.

GaLvão Tânia N. Sergio Rodrigues: arquiteto e desenhista de móvel. Dissertação (Mestrado em Arquitetura e Urbanismo), Faculdade de Arquitetura e Urbanismo, Universidade de São Paulo, São Paulo, 2001.

GARnER, Philippe. Sixties Design. Köln: Taschen, 2003.

GORELIK, Adrián. Das vanguardas à Brasília: cultura urbana e arquitetura na América Latina. Belo Horizonte: Editora UFMG, 2005.

GuARNIERI, Andrea B. Bernard Rudofksy: a humane designer. New York: SpringerWien, 2003.

Guerra, Abílio (org.). Textos fundamentais sobre história da arquitetura moderna brasileira, 2 vols., São Paulo: Romano-Guerra, 2010. 
Imbronito, Maria I. Três Edifícios de habitação para a Formaespaço: Modulares, Gemini eProtótipo. Dissertação (Mestrado em Arquitetura e Urbanismo), Faculdade de Arquitetura e Urbanismo da Universidade de São Paulo, São Paulo, 2003.

Jackson, Lesley. The Sixties - Decade of Design Revolution. London: Phaidon Press Limited, 1996.

Katinsky, Júlio R. "O Concretismo e o Desenho Industrial". In: Amaral, Aracy. Projeto Construtivo Brasileiro na Arte. São Paulo, Pinacoteca do Estado de São Paulo/Rio de Janeiro: Museu de Arte Moderna do Rio de Janeiro/ Funarte, 1977.

. Desenho Industrial. In ZaninI, Walter. História Geral da Arte no Brasil, v. 2. São Paulo: Instituto Moreira Salles, 1983.

Kugelmas, Eduardo. “Maria do Carmo Campello de Souza (1936-2006)”. Revista de Ciências Sociais. v. 49, n. 1, pp. 5-10, 2005.

LeON, Ethel. Design brasileiro - Brazilian design: quem fez quem faz-who did, who does. Rio de Janeiro: SENAC Rio/Viana \& Mosley, 2005.

LirA, José T. C. Warchavchik: fraturas da vanguarda. São Paulo: Cosac Naify, 2011. "Arquitetos Estrangeiros, a arquitetura no estrangeiro e a história". In:

Lanna, A. L. D. et al. São Paulo, os estrangeiros e a construção das cidades. São Paulo: Alameda, 2011.

Lutz, Brian. Knoll: A Modernist Universe. New York: Rizolli, 2009.

MaChado, Paula M. Casa Jardim: a revista e a divulgação do ideário moderno na década de 1950. Dissertação (mestrado em Arquitetura e Urbanismo), Faculdade de Arquitetura e Urbanismo da Universidade Federal do Rio de Janeiro, Rio de Janeiro, 2007.

Menezes, Aureliano. A Situação do Móvel no Brasil: Do projeto à Implantação Industrial - Depoimentos. Trabalho de Graduação Interdepartamental (Graduação em Arquitetura e Urbanismo). Faculdade de Arquitetura e Urbanismo, Universidade de São Paulo, São Paulo, 1977.

MeYer, Regina. Metrópole e urbanismo: São Paulo anos 50. Tese (doutorado em Arquitetura e Urbanismo), Faculdade de Arquitetura e Urbanismo da Universidade de São Paulo, São Paulo, 1991.

Miller, David. Material culture and mass consumption. New York: Basil Blackwell, 1999.

Mira, Maria Celeste. O Leitor e a Banca de Revistas - A Segmentação da Cultura no Século XX. São Paulo: Olho d'Água/FAPESP, 2001.

Nobre, Ana Luíza. Fios cortantes: projeto e produto, arquitetura e design no Rio de Janeiro (1950-70). Tese (Doutorado em História Social da Cultura), Pontifícia Universidade Católica do Rio de Janeiro, Rio de Janeiro, 2008.

Mello, João Manuel Cardoso; Novais, Fernando. "Capitalismo Tardio e Sociabilidade Moderna". In: Schwarcz, Lilia Moritz (org.). História da 
Vida Privada no Brasil 4: Contrastes da Intimidade Contemporânea. São Paulo: Companhia das Letras, 1998, pp. 559-658.

Ortega, Cristina. Lina Bo Bardi: móveis e interiores (1947-1968) - interlocuções entre moderno e local. Tese (Doutorado em Arquitetura e Urbanismo), Faculdade de Arquitetura e Urbanismo da Universidade de São Paulo, São Paulo, 2008.

Pedro, Joana. Traduzindo o debate: o uso da categoria gênero na pesquisa histórica. História, São Paulo, v. 24, n. 1, pp. 77-98. 2005.

Pedrosa, Mario. Dos Murais de Portinari aos espaços de Brasília. São Paulo, Ed. Perspectiva, 1981.

PessôA, Yumara S. Decoração Soteropolitana na Década de 70: cores, formas e representações. Dissertação (Mestrado em Artes Visuais), Escola de Belas Artes da Universidade Federal da Bahia, Salvador, 2007.

Pinsky, Carla B. Mulheres dos Anos Dourados. São Paulo: Contexto, 2014.

Queluz, Marilda L. P. (org.). Design e Cultura. Curitiba: Editora Peregrina, 2005. (org.). Design e Identidade. Curitiba: Editora Peregrina, 2008.

Raizman, David. History of Modern Design. New Jersey: Prentice Hall Art, 2003.

ReED, Paula. 50 ícones que inspiraram a moda: 1960. São Paulo: Design Museum/ Publifolha, 2013.

. 50 ícones que inspiraram a moda: 1970. São Paulo: Design Museum/ Publifolha, 2013.

RIvisTa dell'Arredamento (Ed.). Living the Modern Way - form and color in modern interiors. Studio Books: London, 1964.

(Ed.). Modern interiors. Milan: Gorlich Editore S.p.A., 1969.

Rubino, Silvana. "Corpos, cadeiras, colares: Charlotte Perriand e Lina Bo Bardi”. Cadernos Pagu. n. 34, pp. 331-362. jan./jun. 2010.

SAnches Aline C. "O Studio de Arte Palma e a fábrica de móveis Pau Brasil: povo, clima, materiais nacionais e o desenho de mobiliário moderno no Brasil". Revista Risco. São Carlos: Universidade de São Paulo, 2004.

. A obra e a trajetória do arquiteto Giancarlo Palanti: Itália e Brasil. Dissertação (Mestrado em Arquitetura e Urbanismo), Escola de Engenharia de São Carlos, Universidade de São Paulo, São Carlos, 2004.

SANTI, Maria Angélica. Mobiliário no Brasil: origens da produção e da industrialização. São Paulo: Editora Senac, 2013.

Santos, Demósthenes M. A História da Construtora Alfredo Mathias 1960-1985. Dissertação (Mestrado em Arquitetura e Urbanismo), Faculdade de Arquitetura e Urbanismo, Universidade de São Paulo, São Paulo, 2013.

SANTos, Jacqueline R. Minha amiga Claudia (História, gêneros jornalísticos e produção de uma revista feminina). Dissertação (mestrado em comunicação social). Instituto Metodista de Ensino Superior. São Bernardo do Campo, 1996.

Santos, Maria Cecília Loschiavo dos. Móvel Moderno no Brasil. São Paulo: Nobel/ FAPESP/Edusp, 1995. 
Jorge Zalzupin: Design Moderno no Brasil. São Paulo: Editora Olhares, 2014.

Santos, Marinês R. O Design Pop no Brasil dos anos 1970: domesticidades e relações de gênero na revista Casa e Jardim. Tese (Doutorado em Ciências Humanas), Universidade Federal da Santa Catarina, Florianópolis, 2010.

. Domesticidade e identidades de gênero na revista Casa e Jardim (anos 1950 e

60). Cadernos Pagu (36). Disponível em: 〈www.scielo.br〉, acessado em 11/06/2013.

, PEDRO, Joana. M., RIAL, Carmen. Novas práticas corporais no espaço doméstico: a domesticidade pop na revista Casa \& Jardim durante os anos 1970. Cadernos Pagu (36), 2012. Disponível em: 〈www.ieg.ufsc.br〉, acessado em 26/06/2013.

Scotr, Joan. "Gender: a useful category of historical analyses" In: Scotr, Joan, Gender and the politics of history. New York: Columbia University Press, 1989.

Segawa, Hugo. Arquiteturas no Brasil: 1900-1990. São Paulo: EDUSP, 1998.

SiLva, Suely F. (org.). Zanine, sentir e fazer. Rio de Janeiro: Agir, 1991.

StRAuss, Jack. História da Indústria e Comércio do Mobiliário no Brasil - Os Pioneiros. São Paulo: Editora Moveleiro, 1990.

Touceda, Adriana M. I. Da Califórnia a São Paulo. Referências norte-americanas na casa moderna paulista 1945-1960. Tese (Doutorado em Arquitetura e Urbanismo), Faculdade de Arquitetura e Urbanismo da Universidade de São Paulo, São Paulo, 2005.

Vasconcellos, Marcelo; Braga, Maria Lúcia (org.). Móvel Moderno Brasileiro. Rio de Janeiro: Aeroplano, 2012.

Wright, Gwendolyn. Building the dream: a history of social housing in America. Cambridge: MIT Press, 1983, 2001.

. Women in Modernism. Disponível em: 〈http://bwaf.org/wp-content/ uploads/2011/01/WRIGHT-WomenInModernism.pdf>, acessado em 02/02/2014. 

Fontes

(2. 



\section{Acervos}

Acervo pessoal de Georgia Hauner; Arquivos Editora Abril; Arquivos online da Junta Comercial de São Paulo; Biblioteca FAU-USP; Biblioteca ECA-USP; Biblioteca FFLCH-USP; Biblioteca Poli-USP.

\section{Periódicos}

A Folha de São Paulo (busca no arquivo online a partir das palavras chave: Mobilinea, Hauner e Home Store entre 1950 e 1975).

AD Arquitetura e Decoração (todos os volumes entre 1953 e 1955).

Arquiteto (março/1972).

Arquitetura (janeiro/1965).

C. J. Arquitetura (todos os volumes entre 1973 e 1975).

Casa \& Jardim (todos os volumes entre 1959 e 1975, salvo dezembro/1975).

Claudia (Claudia Noiva de abril/1964 + todos os volumes regulares e especiais entre dezembro/1967 e dezembro/1975, menos julho a setembro/1972), compreendendo os seguintes títulos: Claudia, Claudia Noiva, Casa de Claudia, Claudia Decoração, Claudia Cozinha, Ele e Claudia, Beleza Claudia, Moda Claudia, Claudia Moda e Beleza.

Desfile (maio/1970, novembro/1972) e Desfile - suplemento de decoração (julho/1974, outubro/1974).

El Mueble (n. 141/c. 1986).

Escritório Atual (abril/1972).

Exame (abril/1972).

GAM - Galeria de Arte Moderna (edição especial 1968).

Habitat (todos os volumes entre 1950 e 1955).

Indústria e Desenvolvimento (setembro/1974).

Joia (janeiro/1966, fevereiro/1967, abril/1968, agosto/1968, julho/1969).

Mais (abril/1974).

Nova (fevereiro/1974).

O Estado de São Paulo (busca no arquivo online a partir das palavras chave:

Mobilinea, Hauner e Home Store entre 1950 e 1975).

Projeto e Construção (janeiro/1971).

Realidade (maio/1971).

Senhor (setembro a dezembro/1962, junho e julho/1963, maio/1971).

Time - Latin America Edition (31/05/1968, 27/12/1968).

Veja (18/09/1968, 05/04/1972).

Visão (28/02/1969). 


\section{Entrevistas}

\section{Ada Hauner}

Teleconferência São Paulo/Cunha, 29 de agosto de 2012. Gravação digital (58 min.).

Bibita (Maria Beatriz) Butcher

Carapicuíba, 23 de julho de 2014. Gravação digital (92 min.).

\section{Georgia Hauner}

Vancouver, 11 de setembro de 2012. Gravação digital (45 min.).

Vancouver, 12 de setembro de 2012. Gravação digital (59 min.).

Vancouver, 14 de setembro de 2012. Gravação digital (51 min.).

Vancouver, 16 de setembro de 2012. Gravação digital (126 min.).

Jorge Kornbluh

São Paulo, 12 de dezembro de 2013. Gravação digital (40 min.).

Judit Magyary

São Paulo, 28 de julho de 2014. Gravação digital (15l min.).

Martin Wurzmann

São Paulo, 05 de fevereiro de 2012. Gravação digital (72 min).

\section{Matias Eisler}

São Paulo, 05 de fevereiro de 2013. Correio eletrônico.

\section{Sérgio Rodrigues}

Rio de Janeiro, 13 de novembro de 2012. Gravação digital (143 min.).

Yone Koseki Pierre

São Paulo, 18 de julho de 2014. Gravação digital (73 min.).

\section{Textos de Georgia Hauner}

Hauner, Georgia. [texto não publicado] Memoir. Vancouver, 2010.

Texto de dezoito páginas escrito previamente a contatos de pesquisadores, em que Georgia iniciava suas memórias. Aborda sua infância até a emigração da família em 1946.

. [texto não publicado] Texto de Georgia Hauner. Vancouver, 2010.

Texto de duas páginas que trata de sua formação, o trabalho na Artesanal, o fim da empresa e o início da Mobilinea.

. [texto não publicado] Artesanato. Vancouver, 2011.

Texto de uma página, escrito em resposta à pesquisadora Dra. Marinês dos Santos, em que fala sobre os objetos artesanais que fez para as fotos de revistas e espaços comerciais. Anexo a este texto, enviou fotos da revista Claudia de agosto/1968.

. [texto não publicado] Ernesto Hauner - brief resumé. Vancouver, 2011.

Texto de duas páginas com o currículo de Ernesto Hauner, escrito a partir de texto elaborado pelo próprio em 1975, posteriormente localizado no acervo pessoal da família Hauner. 
[texto não publicado] Mizu. Vancouver, 2011.

Carta de cinco páginas para uma pessoa identificada como Mizu. Nele, trata de forma resumida de toda a sua trajetória profissional, mas com foco na Interstyle, empresa de revestimentos que fundaram após imigrar para Vancouver.

[texto não publicado] Mobilinea. Vancouver, 2011.

Texto de quatro páginas sobre a história da Mobilinea escrito a partir de texto produzido para a exposição "Os Modernos Brasileiros + l".

[texto não publicado] Revistas. Vancouver, 2011.

Texto de duas páginas escrito para a pesquisadora Dra. Marinês dos Santos com comentários sobre alguns trabalhos realizados para a Editora Abril, considerados os mais importantes por Georgia.

[texto não publicado] Showrooms, fotografias, artesanato. Vancouver, 2011. Texto de quatro páginas sobre o trabalho de Georgia nas lojas, citando influências, o processo de criação da loja do Iguatemi, da Galeria Zarvos e Home Store.

[texto não publicado] Segunda parte de respostas. Vancouver, 2012.

Texto de onze páginas escrito para a pesquisadora Dra. Marinês dos Santos, que apresenta uma linha do tempo de seu trabalho no Brasil, falando sobre o trabalho na Mobilinea e principalmente na Editora Abril. É feita uma explicação específica de algumas propagandas e editoriais.

[texto não publicado] Carta para Mina. Vancouver, 2013.

Texto de uma página que fala das influências internacionais no trabalho de Georgia e a imagem criada pela Mobilinea como um projeto total.

[texto não publicado] Respostas sobre a Mobilinea. Vancouver, 2013.

Texto de três páginas que responde a alguns questionamentos feitos acerca de suas influências, as linhas e lojas da Mobilinea, informações sobre as tentativas de exportação, a decisão de sair do Brasil e a prisão de John de Souza.

[texto não publicado] Mobilinea (Updated March 2014). Vancouver, 2014.

Texto de onze páginas produzido como resposta ao artigo "Mobilinea and the Promotion of

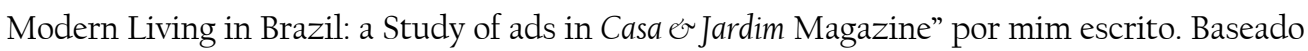
em seu outro texto "Mobilinea" de 2011.

[texto não publicado] Recordações. Vancouver, 2014.

Texto de duas páginas com informações sobre as técnicas de representação e desenho de projetos de ambientes da Artesanal à Home Store.

[texto não publicado] Mobilinea - the good times. Vancouver, 2014.

Texto de quarenta e quatro páginas produzido a partir de seus textos anteriores e informações trocadas nas entrevistas, além de conteúdo inédito. Apresenta a trajetória pessoal de Ernesto e Georgia Hauner, a experiência de ambos na Artesanal, o surgimento e desenvolvimento da Mobilinea, suas concepções sobre design de interiores, sua experiência na Editora Abril, anedotas e encontros durante o período em que estiveram no Brasil e reflexões atuais sobre os eventos descritos, com um epílogo sobre a vida no Canadá. 

Anexos 

Anexo 01- Lista de propagandas e reportagens da Mobilinea entre 1959 e 1975

\begin{tabular}{|c|c|c|c|c|c|c|c|c|c|c|c|c|c|c|c|c|}
\hline $\begin{array}{l}\text { Lojas e } \\
\text { fábricas* }\end{array}$ & 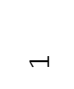 & & $\neg$ & $r$ & $\begin{array}{l}\vec{I} \\
\vec{r}\end{array}$ & $\begin{array}{l}ت \\
\vec{r}\end{array}$ & $\begin{array}{l}\overrightarrow{7} \\
\vec{i}\end{array}$ & $\dashv$ & 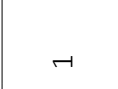 & $\begin{array}{l}ت \\
\vec{H} \\
-1\end{array}$ & - & $\dashv$ & $\begin{array}{l}\overrightarrow{7} \\
\overrightarrow{7}\end{array}$ & $\begin{array}{l}\overrightarrow{7} \\
-i\end{array}$ & 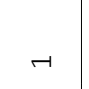 & $\sim$ \\
\hline 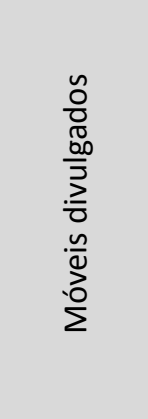 & 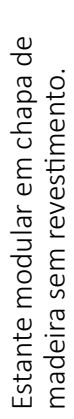 & 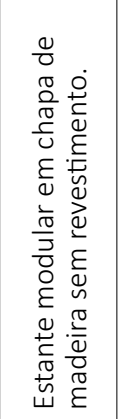 & & 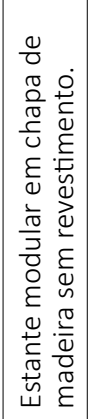 & 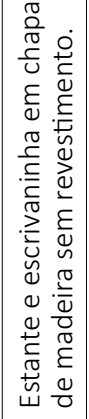 & & 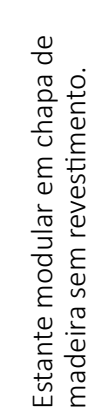 & 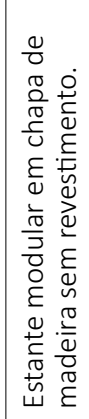 & 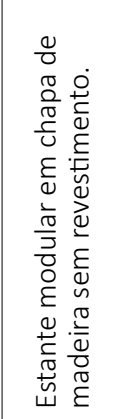 & & & & 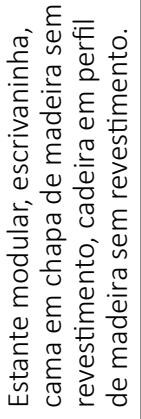 & & & 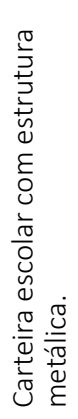 \\
\hline 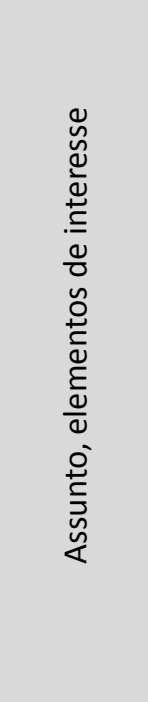 & 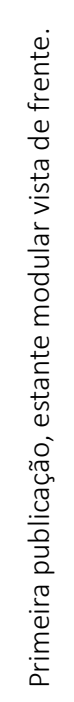 & 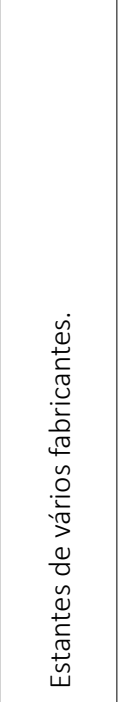 & & 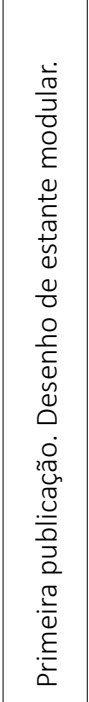 & 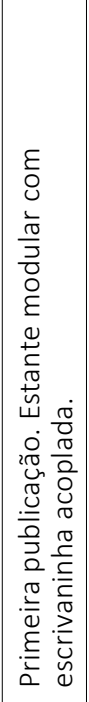 & & 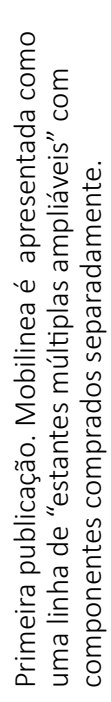 & 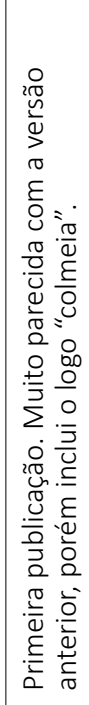 & 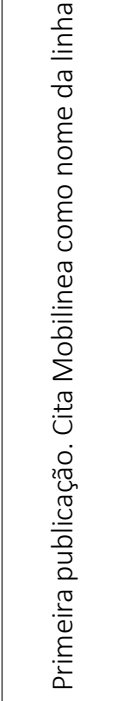 & & & & 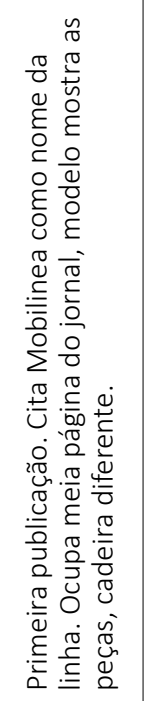 & & & 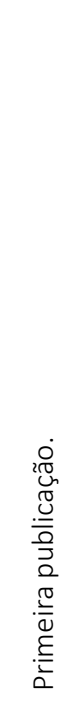 \\
\hline 을 & 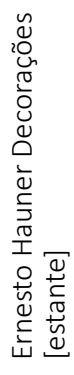 & 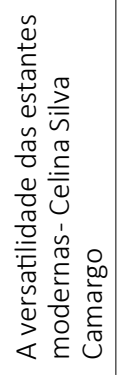 & 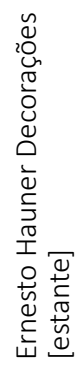 & 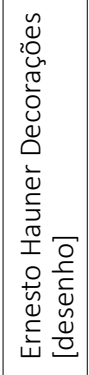 & 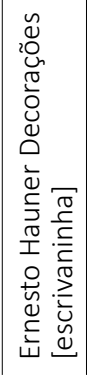 & 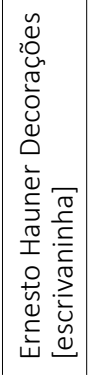 & 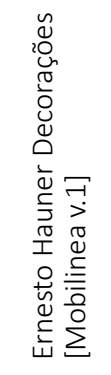 & 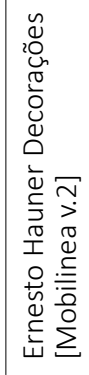 & 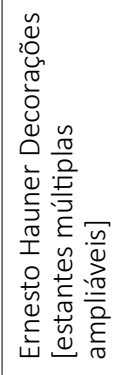 & 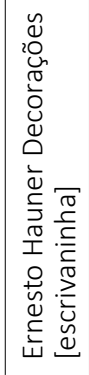 & 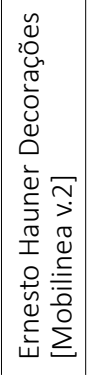 & 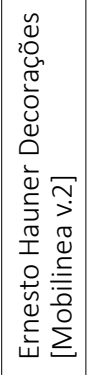 & 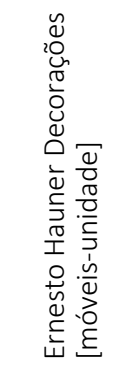 & 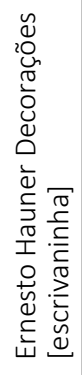 & 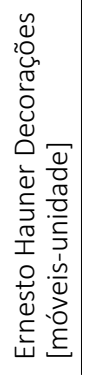 & 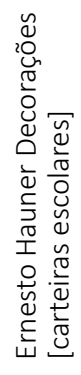 \\
\hline 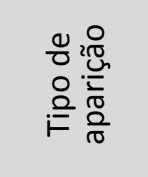 & $\begin{array}{l}\frac{\pi}{0} \\
\frac{0}{0} \\
0 \\
\pi \\
0 \\
0 \\
0 \\
0\end{array}$ & 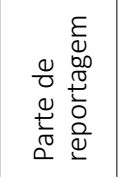 & $\begin{array}{l}\frac{\pi}{0} \\
\frac{0}{0} \\
00 \\
\pi \\
\frac{0}{0} \\
\frac{0}{0}\end{array}$ & $\begin{array}{l}\frac{\pi}{0} \\
\frac{0}{\pi} \\
00 \\
0 \\
0 \\
0 \\
0 \\
0\end{array}$ & $\begin{array}{l}\frac{\pi}{0} \\
0 \\
0 \\
00 \\
0 \\
0 \\
0 \\
0\end{array}$ & $\begin{array}{l}\frac{\pi}{0} \\
0 \\
0 \\
00 \\
00 \\
0 \\
0 \\
0 \\
0\end{array}$ & $\begin{array}{l}\frac{\pi}{0} \\
\frac{0}{\pi} \\
00 \\
\widetilde{0} \\
\frac{0}{0} \\
\frac{0}{2}\end{array}$ & $\begin{array}{l}\frac{\pi}{0} \\
\frac{0}{0} \\
00 \\
\pi \\
\frac{0}{0} \\
0 \\
0\end{array}$ & 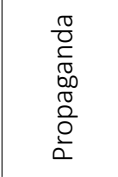 & $\begin{array}{l}\frac{\pi}{0} \\
0 \\
0 \\
00 \\
00 \\
0 \\
0 \\
0\end{array}$ & $\begin{array}{l}\frac{\pi}{0} \\
\frac{0}{0} \\
0 \\
0 \\
0 \\
0 \\
0 \\
0\end{array}$ & \begin{tabular}{|l|l}
$\frac{\pi}{0}$ \\
0 \\
0 \\
00 \\
0 \\
0 \\
0 \\
0 \\
0
\end{tabular} & $\begin{array}{l}\frac{\pi}{0} \\
\frac{0}{0} \\
0 \\
00 \\
0 \\
0 \\
0 \\
0\end{array}$ & $\begin{array}{l}\frac{\pi}{0} \\
\frac{0}{0} \\
00 \\
00 \\
\frac{0}{2} \\
\frac{0}{2}\end{array}$ & $\begin{array}{l}\frac{\pi}{0} \\
\frac{0}{0} \\
00 \\
0 \\
0 \\
0 \\
0 \\
0\end{array}$ & $\begin{array}{l}\frac{\pi}{0} \\
\frac{0}{0} \\
00 \\
00 \\
\frac{0}{2} \\
\frac{2}{2}\end{array}$ \\
\hline $\begin{array}{l}\frac{0}{0} \\
\frac{0}{0} \\
\frac{0}{2} \\
0\end{array}$ & $\begin{array}{l}\text { है } \\
\text { ᄒे } \\
\infty \\
0 \\
0 \\
0 \\
0\end{array}$ & 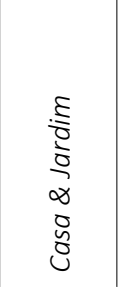 & $\begin{array}{l}\frac{\xi}{0} \\
\overline{0} \\
\vdots \\
\infty \\
0 \\
0 \\
0\end{array}$ & 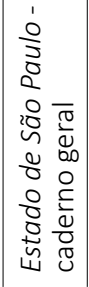 & $\begin{array}{l}\frac{\varepsilon}{0} \\
\text { ᄒे } \\
\vdots \\
\infty \\
0 \\
0 \\
0\end{array}$ & $\begin{array}{l}\frac{5}{\overline{0}} \\
\text { o } \\
\infty \\
0 \\
0 \\
0 \\
0\end{array}$ & 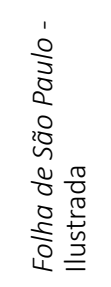 & 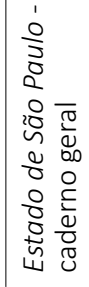 & 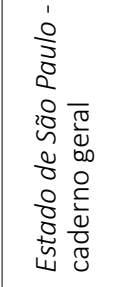 & 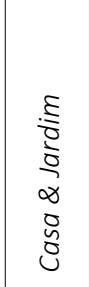 & 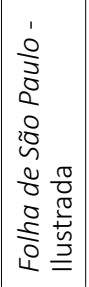 & 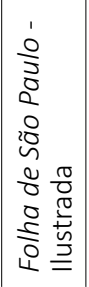 & 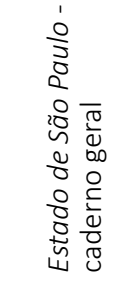 & 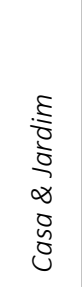 & 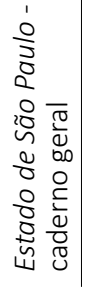 & 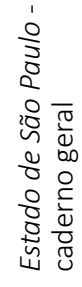 \\
\hline Dia & & & & $\exists$ & & & 0 & $\vec{\sim}$ & $\vec{\sim}$ & & 우 & $\stackrel{\nabla}{\sim}$ & Фి & & $\stackrel{n}{\sim}$ & $\stackrel{\bullet}{\sim}$ \\
\hline Mês & 几n & n & 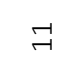 & $\underset{\neg}{\sim}$ & $m$ & $\sigma$ & in & 乞n & in & 0 & 0 & 0 & $\infty$ & $\infty$ & 아 & 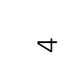 \\
\hline 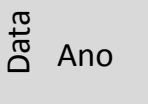 & 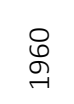 & 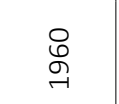 & 吕 & 욤 & $\begin{array}{l}\vec{\sigma} \\
\stackrel{-}{न}\end{array}$ & $\begin{array}{l}\overrightarrow{8} \\
\text { ه్ }\end{array}$ & $\begin{array}{l}\vec{ष} \\
\stackrel{-}{7}\end{array}$ & $\begin{array}{l}\vec{ه} \\
\stackrel{-}{न}\end{array}$ & $\begin{array}{l}\vec{\sigma} \\
\text { ه్ }\end{array}$ & $\begin{array}{l}\overrightarrow{0} \\
\text { gे }\end{array}$ & 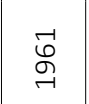 & $\begin{array}{l}\overrightarrow{8} \\
\text { Оे }\end{array}$ & $\begin{array}{l}\overrightarrow{0} \\
\stackrel{\sigma}{\sigma}\end{array}$ & $\begin{array}{l}\overrightarrow{0} \\
\stackrel{\sigma}{\sigma}\end{array}$ & $\begin{array}{l}\vec{ه} \\
\text { هे }\end{array}$ & ণু \\
\hline
\end{tabular}


Anexo 01- Lista de propagandas e reportagens da Mobilinea entre 1959 e 1975

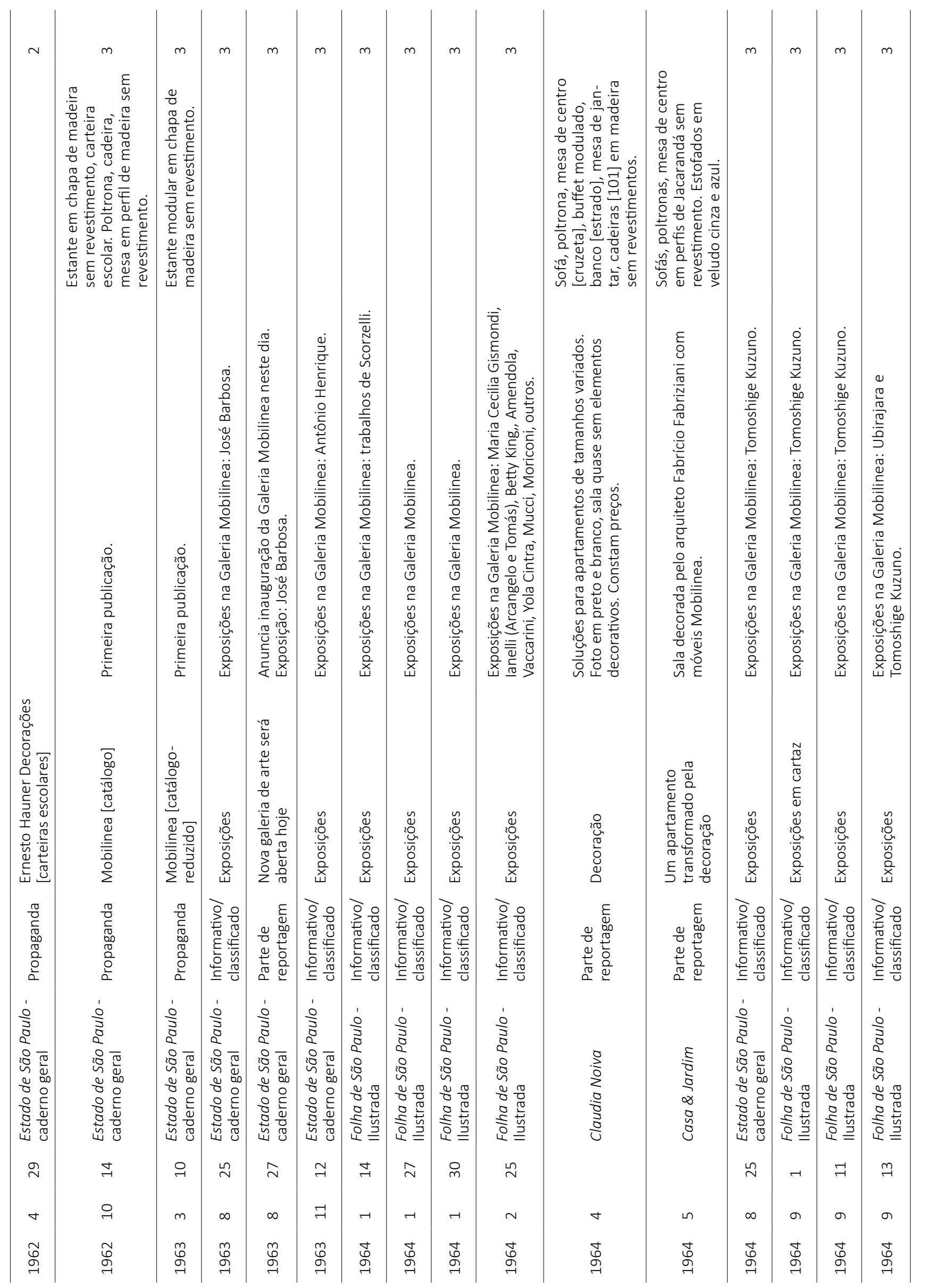


Anexo 01- Lista de propagandas e reportagens da Mobilinea entre 1959 e 1975

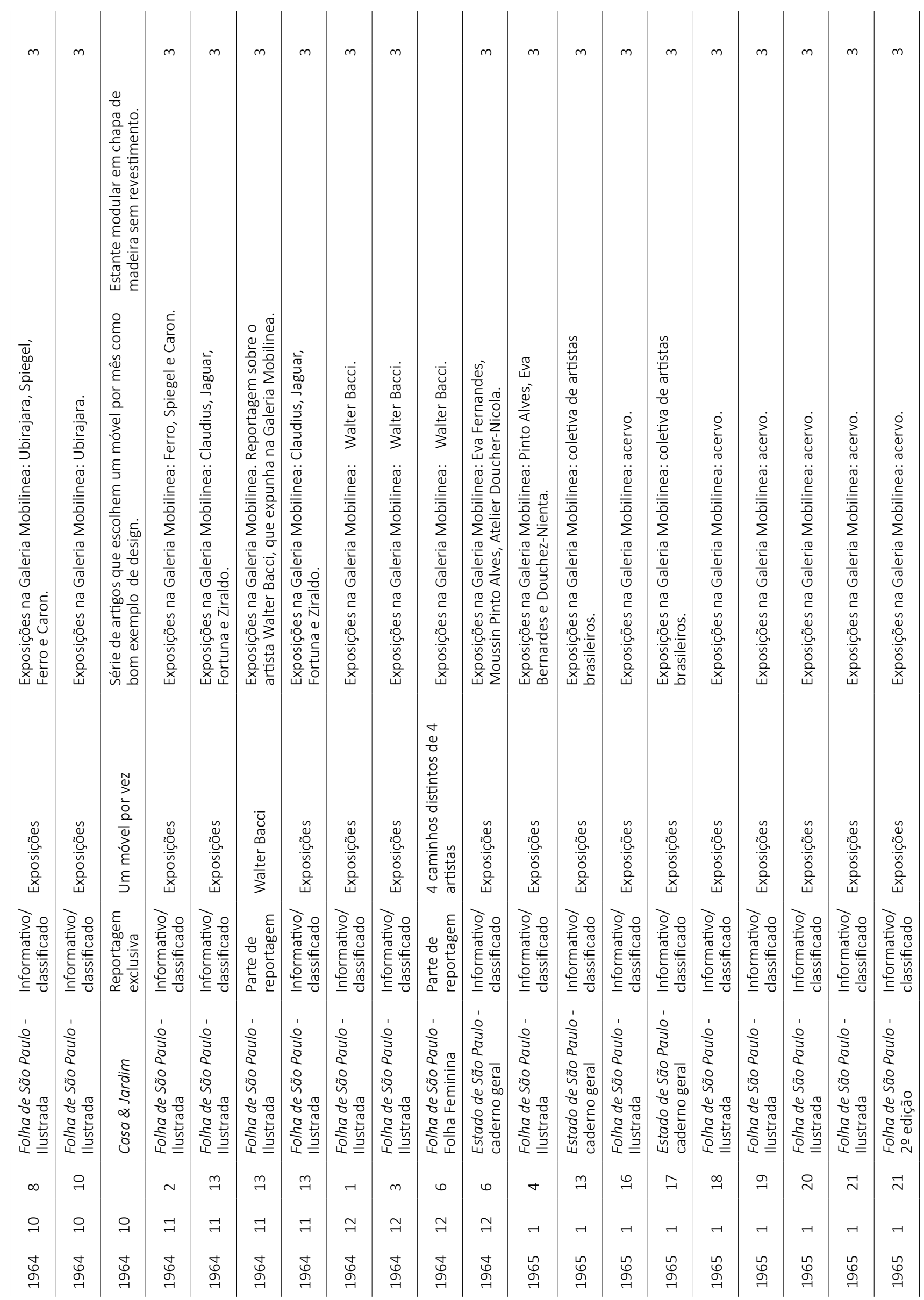


Anexo 01- Lista de propagandas e reportagens da Mobilinea entre 1959 e 1975

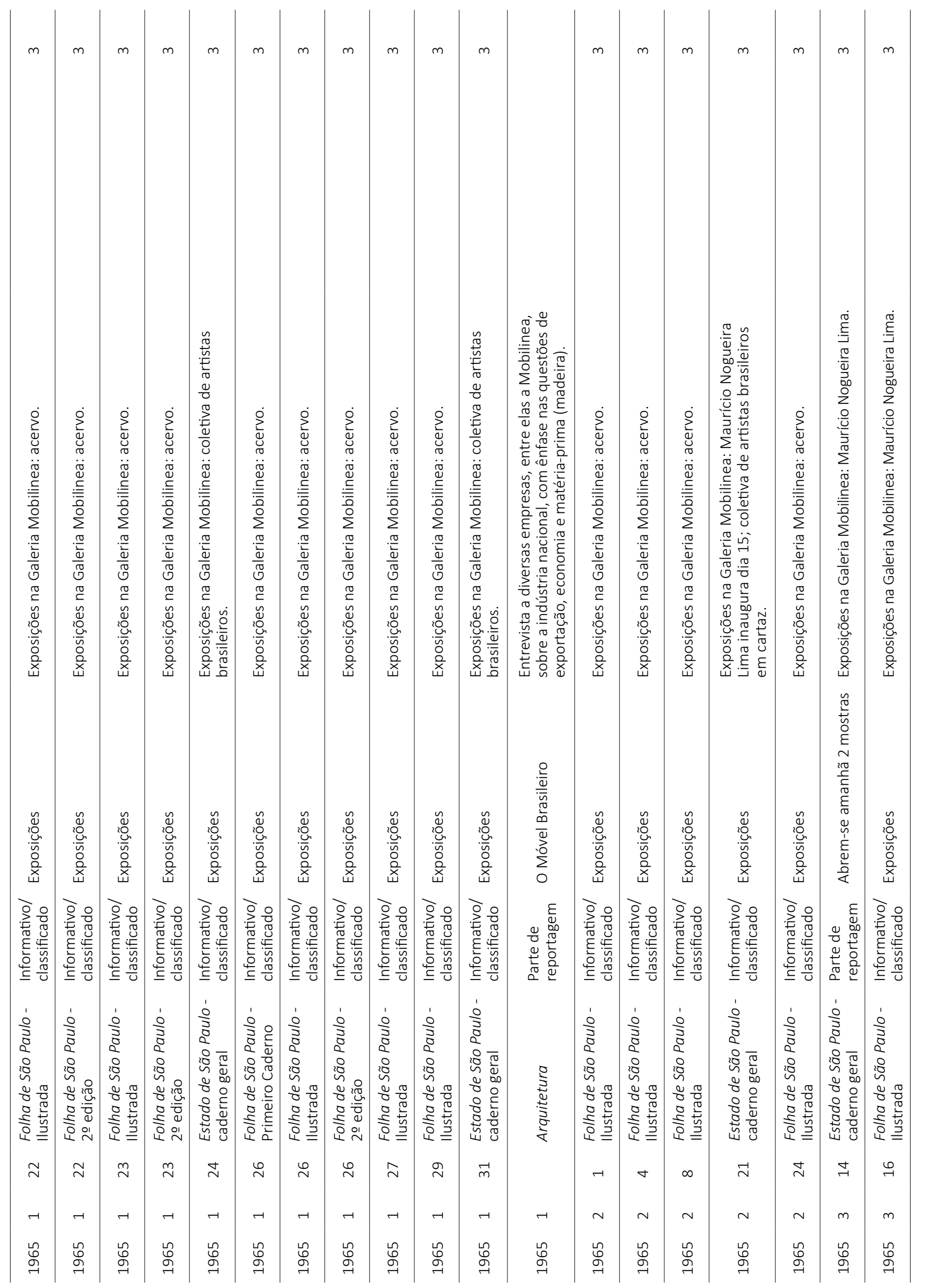


Anexo 01- Lista de propagandas e reportagens da Mobilinea entre 1959 e 1975

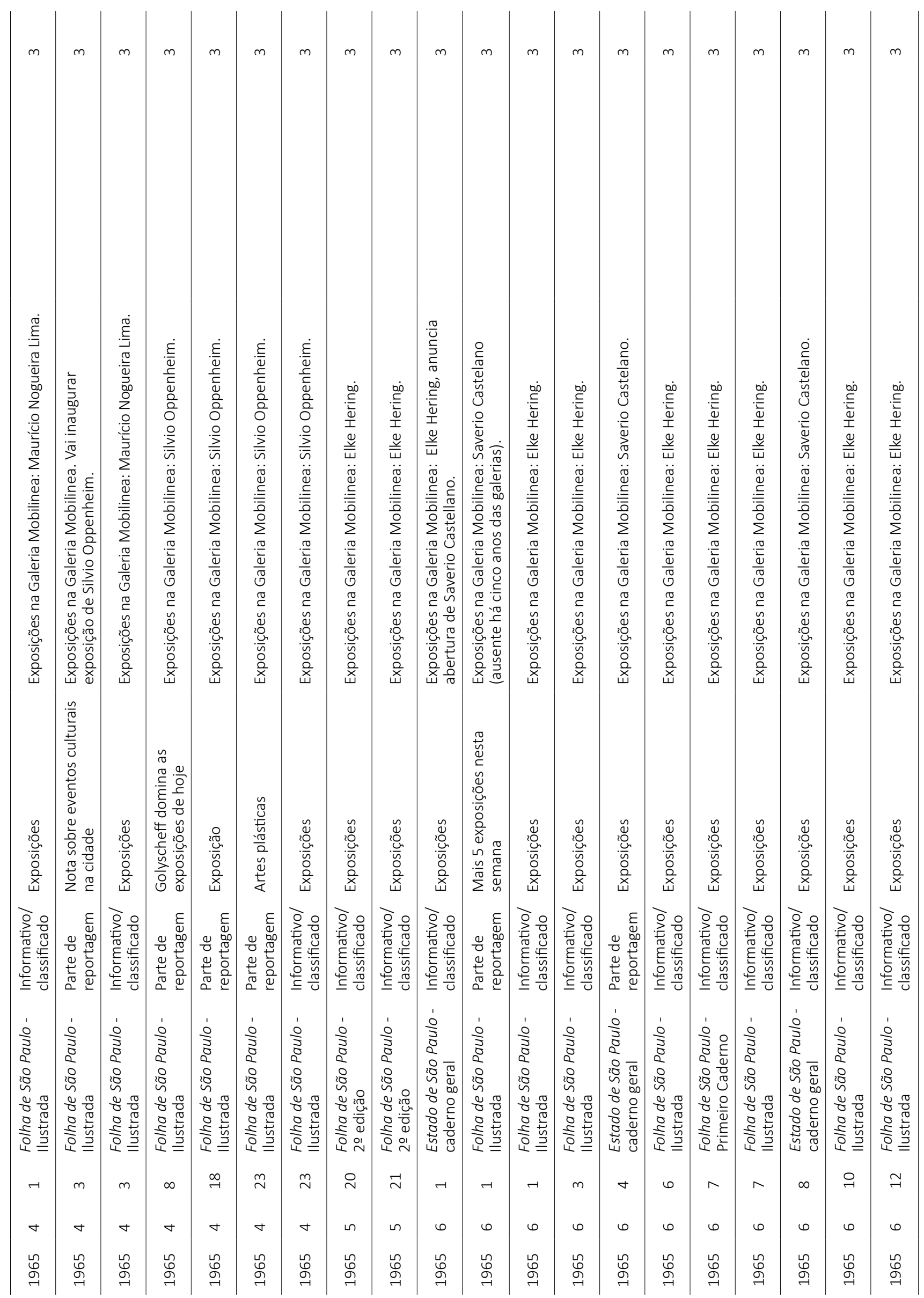


Anexo 01- Lista de propagandas e reportagens da Mobilinea entre 1959 e 1975

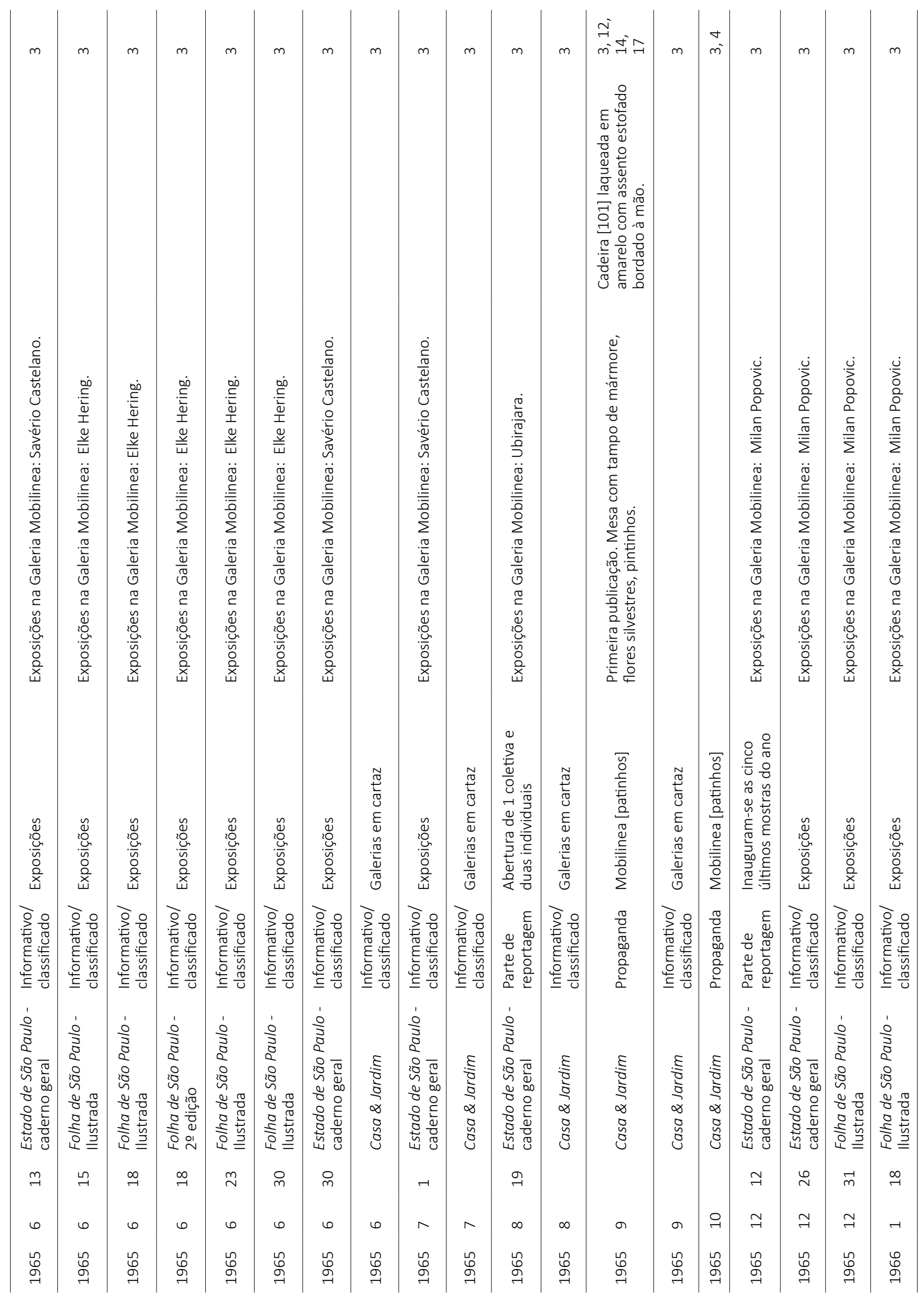


Anexo 01- Lista de propagandas e reportagens da Mobilinea entre 1959 e 1975

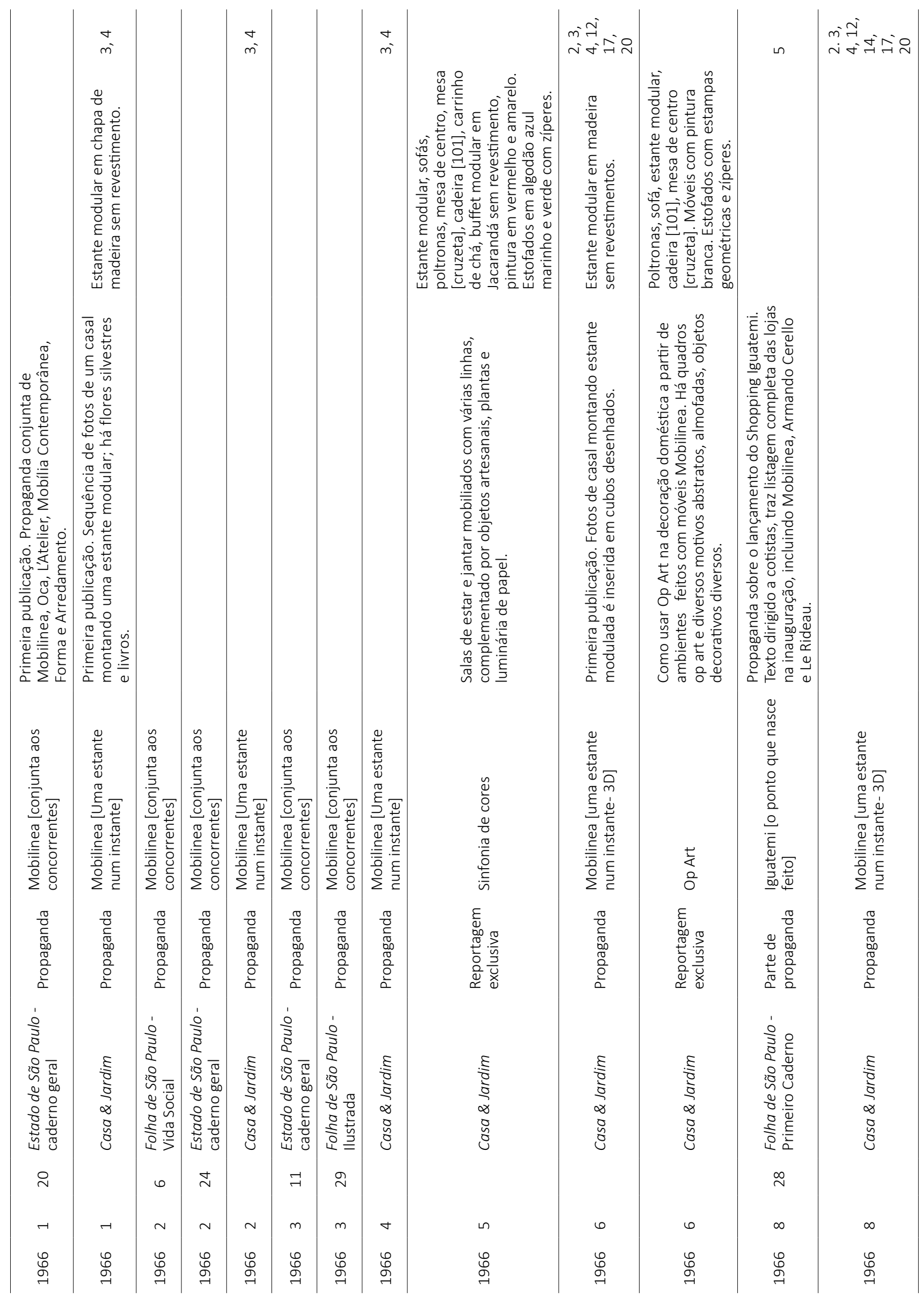


Anexo 01- Lista de propagandas e reportagens da Mobilinea entre 1959 e 1975

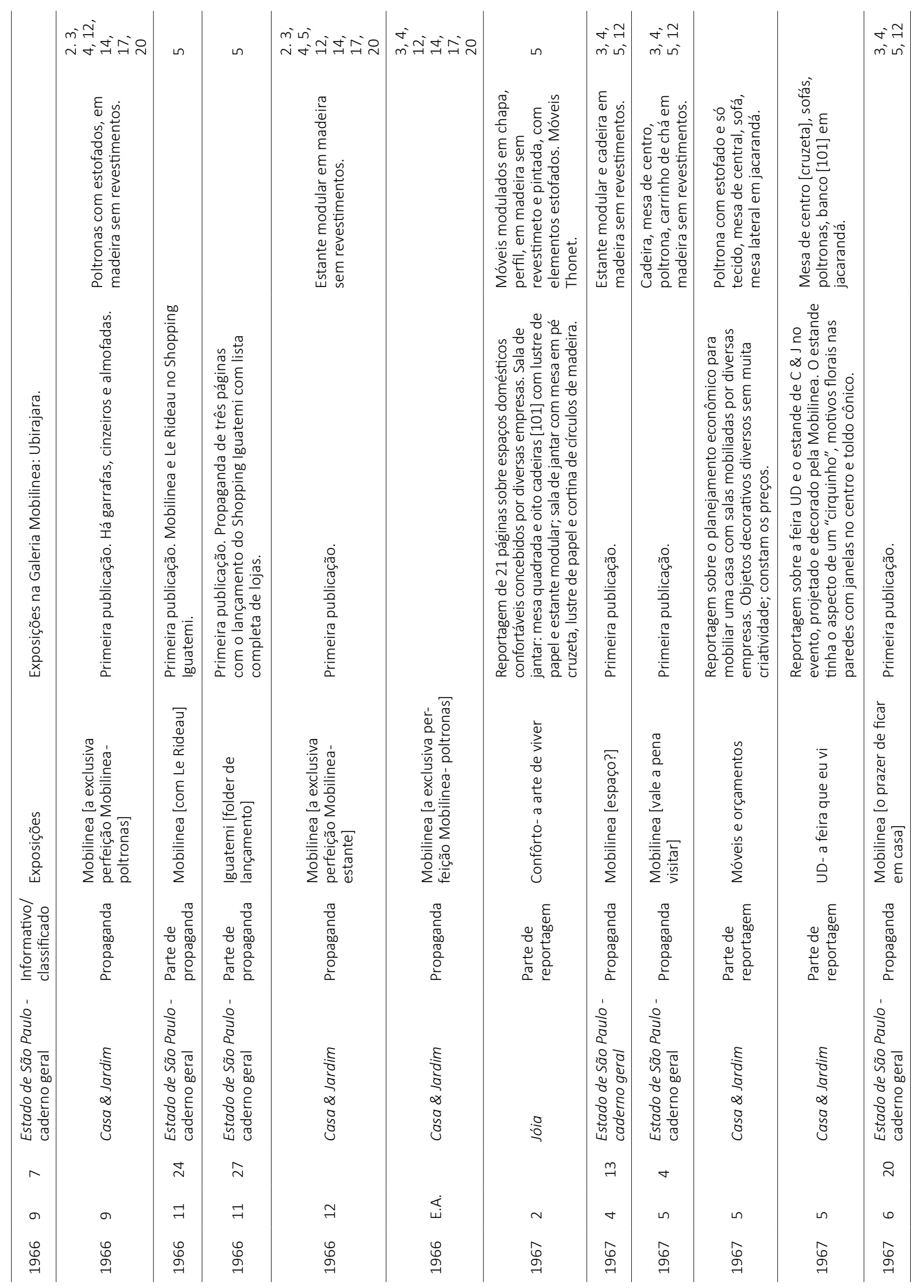




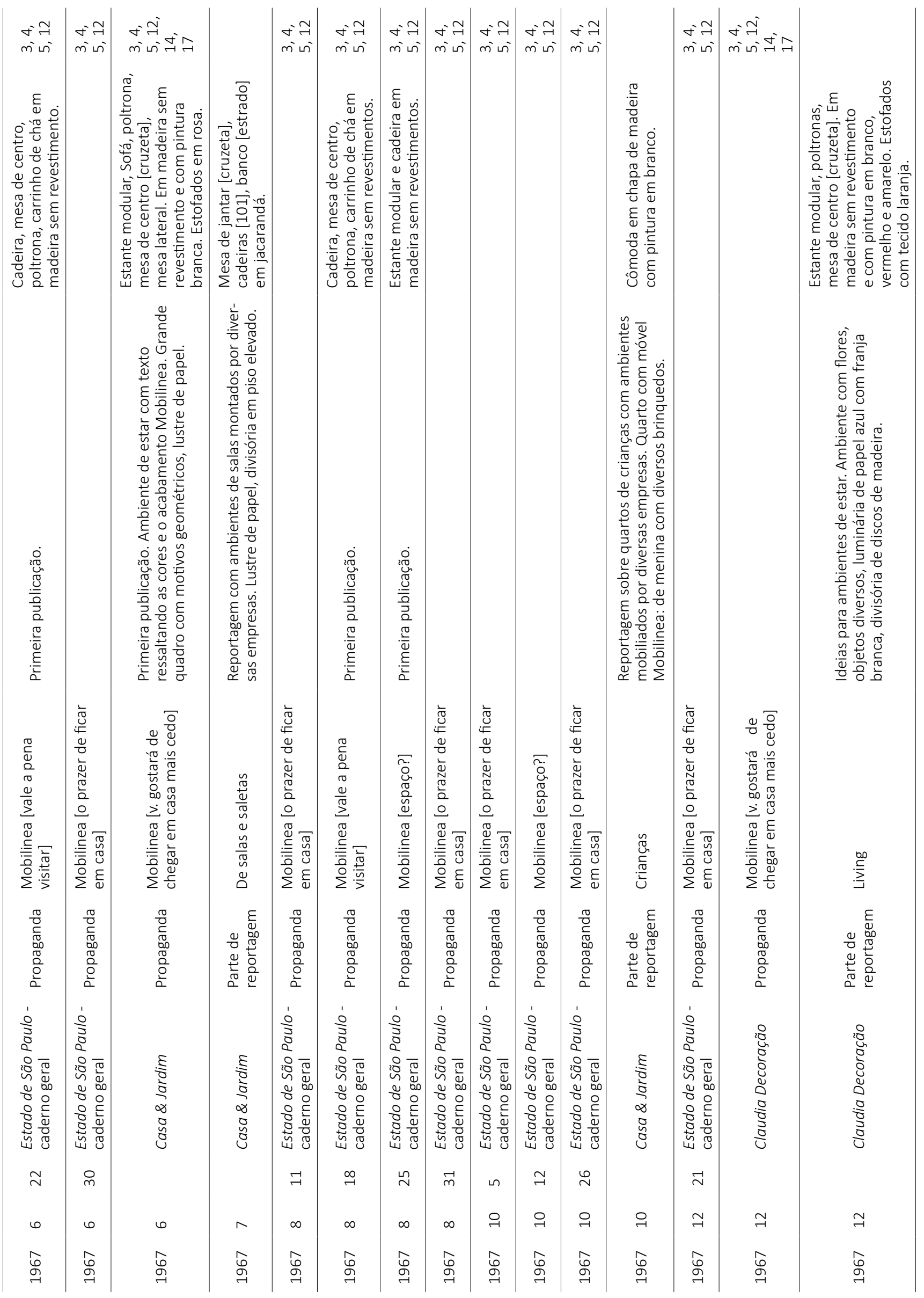


Anexo 01- Lista de propagandas e reportagens da Mobilinea entre 1959 e 1975

\begin{tabular}{|c|c|c|c|c|c|c|c|c|}
\hline & 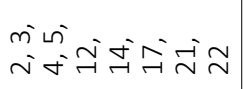 & in & & & & & 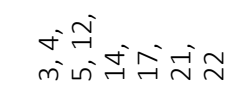 & 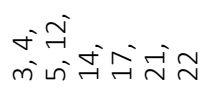 \\
\hline 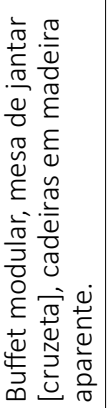 & 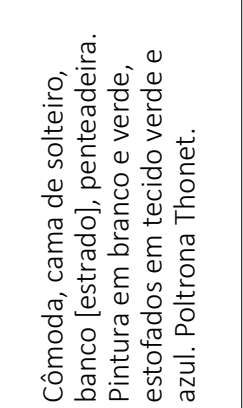 & & & 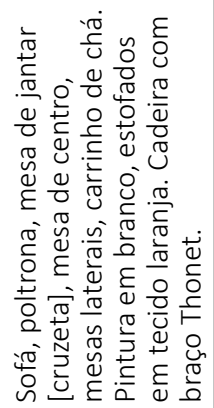 & 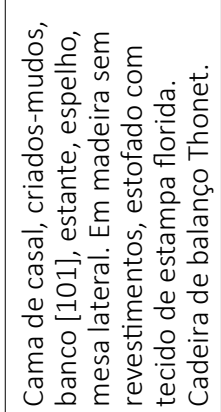 & 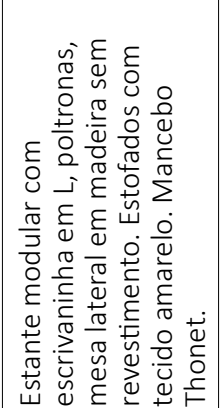 & 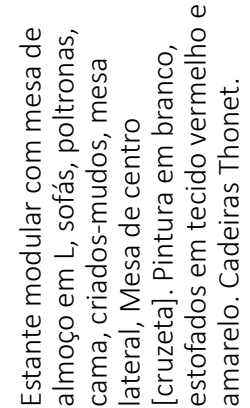 & \\
\hline 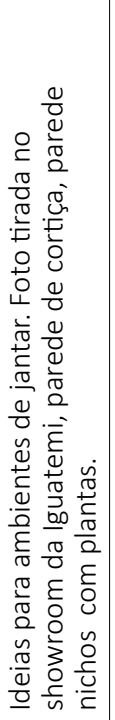 & 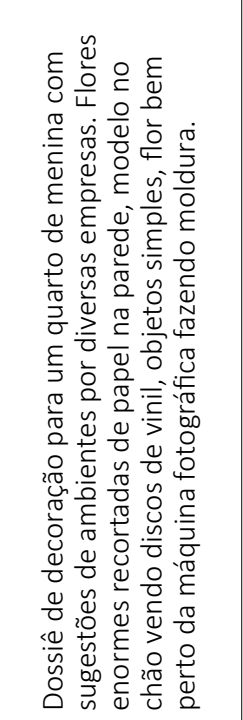 & 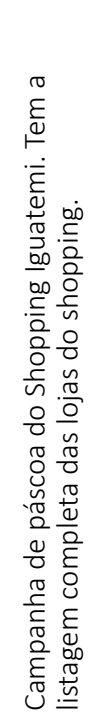 & 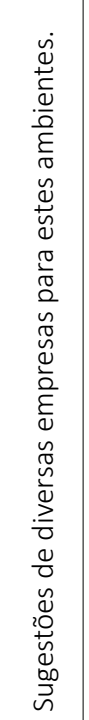 & 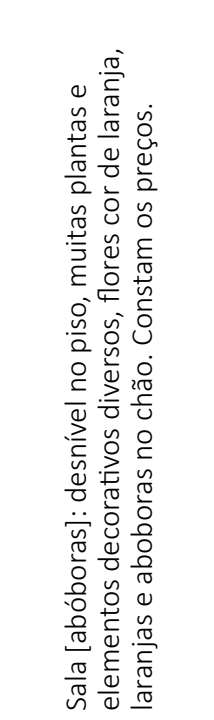 & 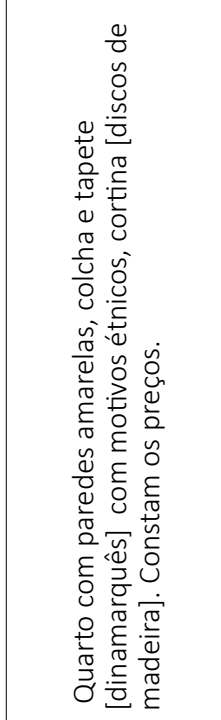 & 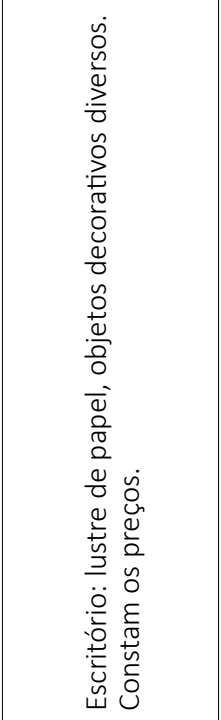 & 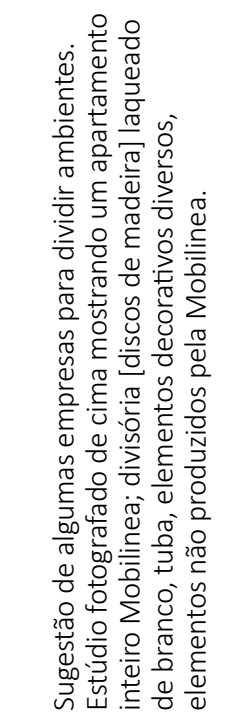 & 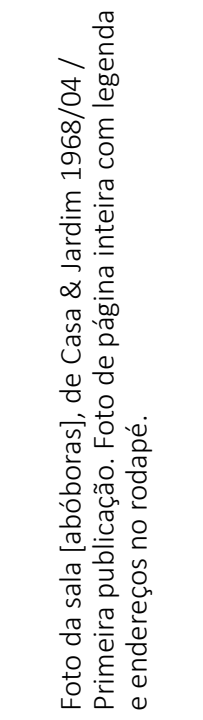 \\
\hline 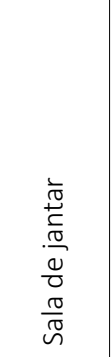 & 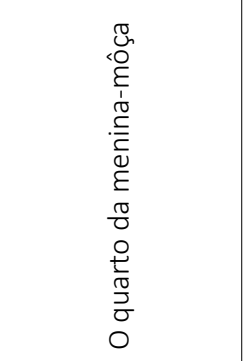 & 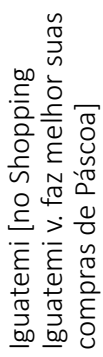 & 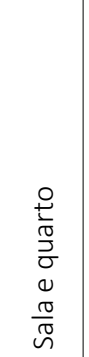 & 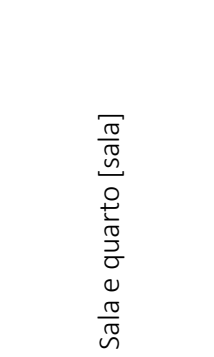 & 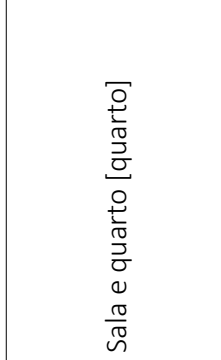 & 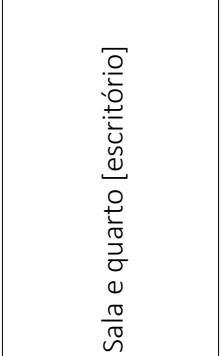 & 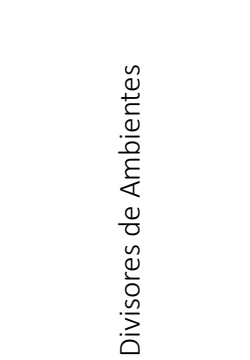 & 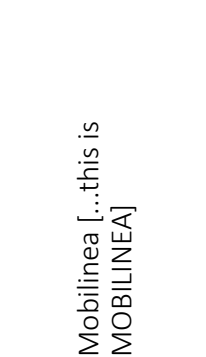 \\
\hline 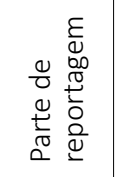 & 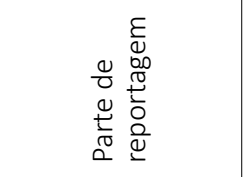 & $\begin{array}{ll} & \frac{\pi}{0} \\
0 & \frac{0}{0} \\
0 & 0 \\
0 & 0 \\
0 & 0 \\
0 & 0 \\
0 & 0 \\
0 & 0 \\
0\end{array}$ & 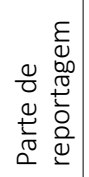 & 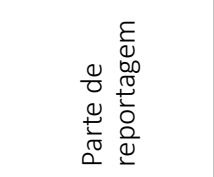 & 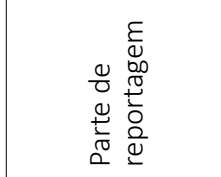 & 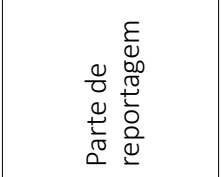 & 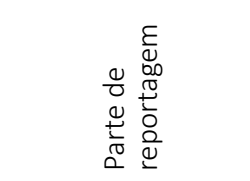 & $\begin{array}{l}\frac{\pi}{0} \\
0 \\
0 \\
00 \\
\pi \\
00 \\
\frac{0}{2} \\
\frac{1}{2}\end{array}$ \\
\hline 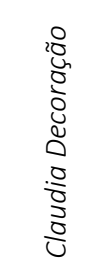 & $\begin{array}{l}\frac{5}{5} \\
\frac{0}{0} \\
\infty \\
0 \\
0 \\
0 \\
0\end{array}$ & 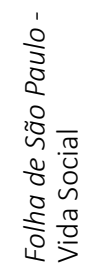 & $\begin{array}{l}\frac{5}{0} \\
\frac{0}{0} \\
\infty \\
0 \\
0 \\
0 \\
u\end{array}$ & $\begin{array}{l}\frac{1}{5} \\
\frac{5}{0} \\
\alpha \\
0 \\
0 \\
0 \\
0\end{array}$ & $\begin{array}{l}\frac{5}{0} \\
\frac{5}{0} \\
\infty \\
0 \\
0 \\
0 \\
0\end{array}$ & $\begin{array}{l}\xi \\
\frac{\xi}{0} \\
o \\
\infty \\
0 \\
0 \\
0 \\
0\end{array}$ & $\begin{array}{l}\varepsilon \\
\frac{\varepsilon}{0} \\
\vdots \\
\infty \\
0 \\
0 \\
0 \\
0\end{array}$ & 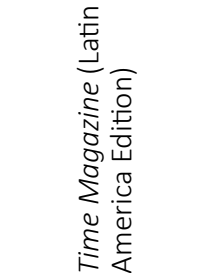 \\
\hline-7 & $m$ & $\nabla$ & 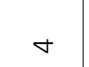 & $\nabla$ & $\nabla$ & ナ & n & 乞 \\
\hline के & $\begin{array}{l}\infty \\
\stackrel{\sigma}{\sigma}\end{array}$ & $\begin{array}{l}\infty \\
\text { ఫे }\end{array}$ & $\begin{array}{l}\infty \\
\stackrel{్}{\sigma}\end{array}$ & $\underset{\wp}{\infty}$ & $\begin{array}{l}\infty \\
\stackrel{\infty}{G}\end{array}$ & 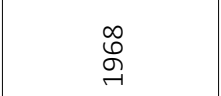 & $\begin{array}{l}\infty \\
\stackrel{\infty}{\sigma}\end{array}$ & $\begin{array}{l}\infty \\
\stackrel{\infty}{\leftrightarrow} \\
\stackrel{\sim}{\sim}\end{array}$ \\
\hline
\end{tabular}




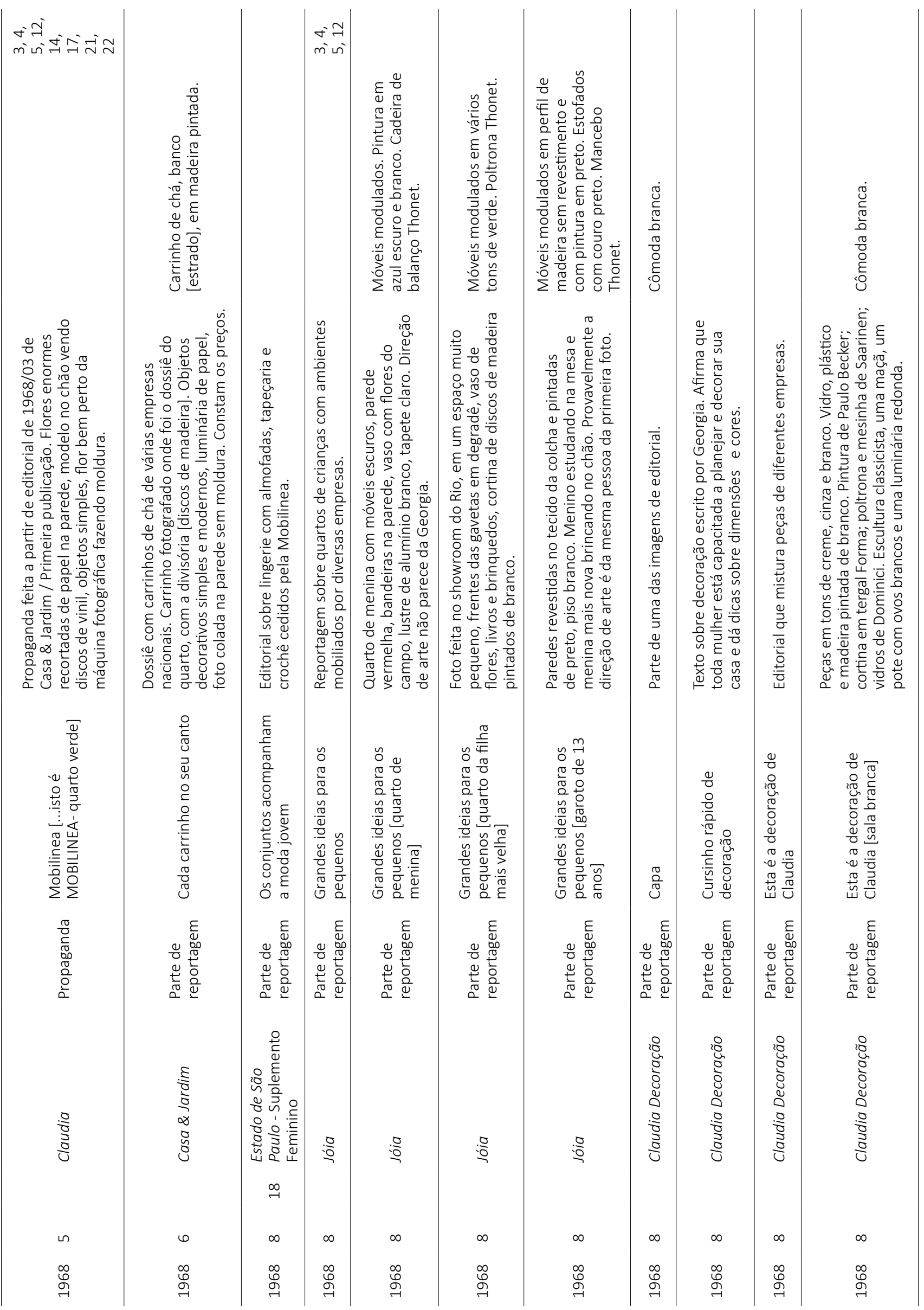


Anexo 01- Lista de propagandas e reportagens da Mobilinea entre 1959 e 1975

\begin{tabular}{|c|c|c|c|c|c|c|c|c|}
\hline & 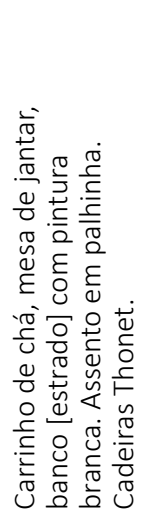 & 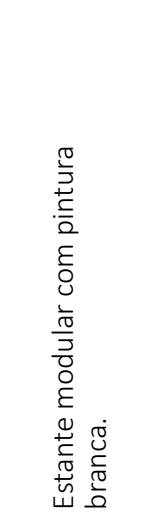 & 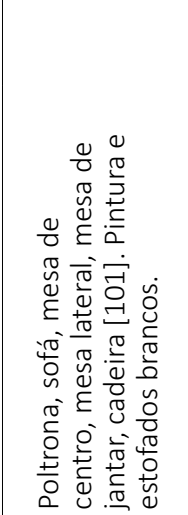 & 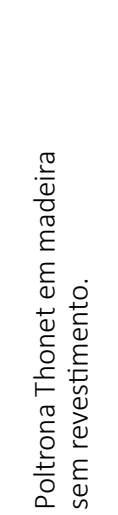 & 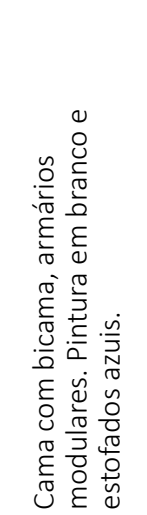 & 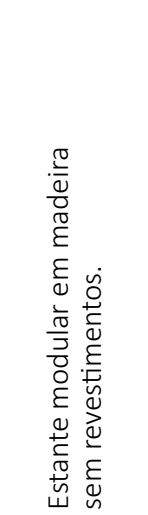 & miّ & 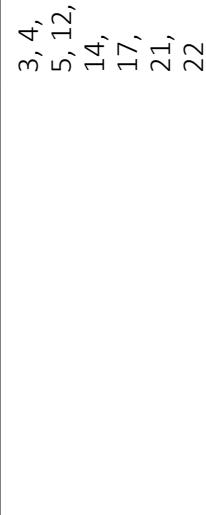 \\
\hline 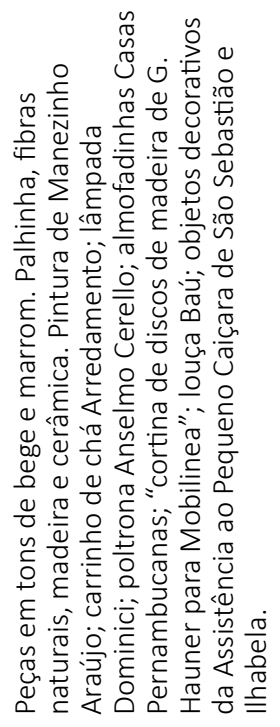 & 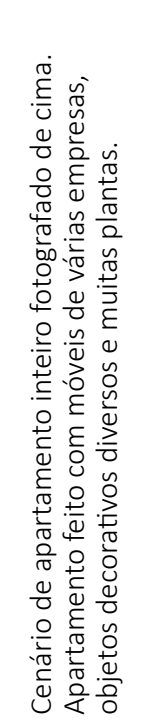 & 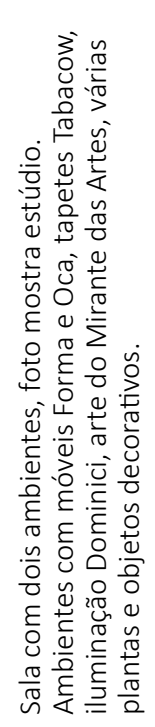 & 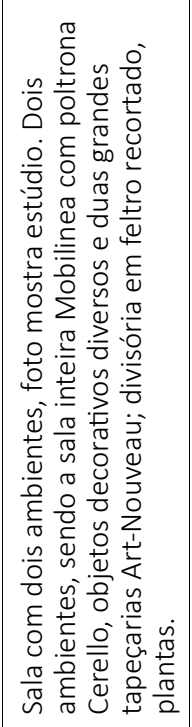 & 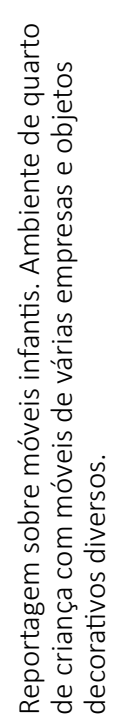 & 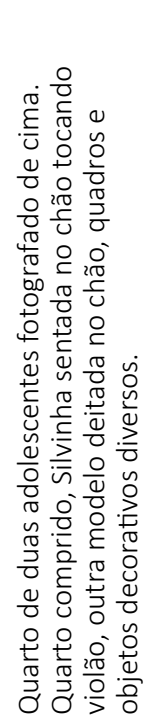 & 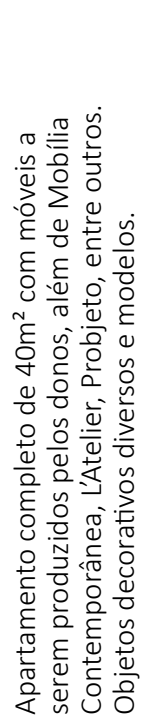 & 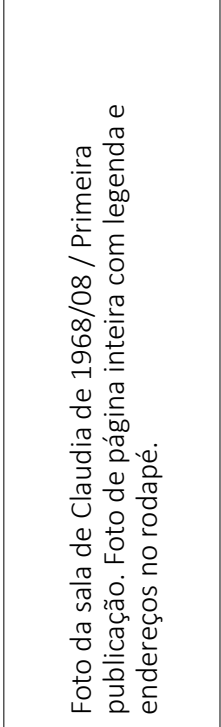 & \\
\hline 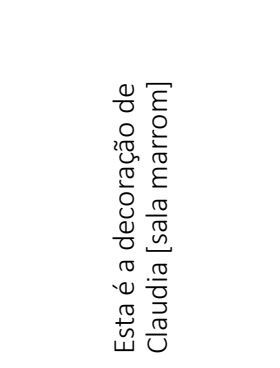 & 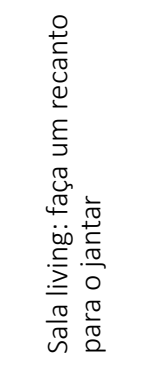 & 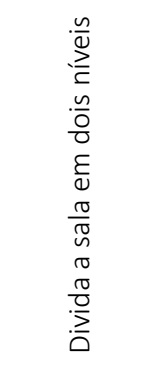 & 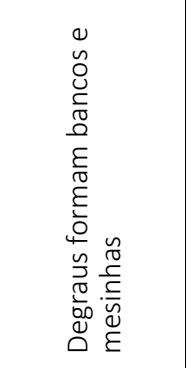 & 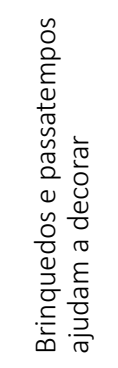 & 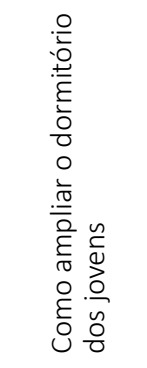 & 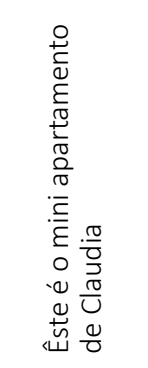 & 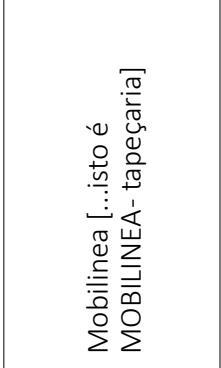 & 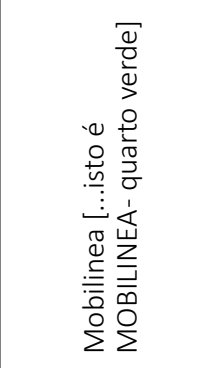 \\
\hline 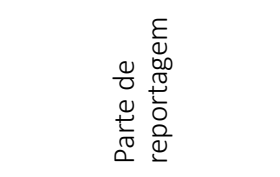 & 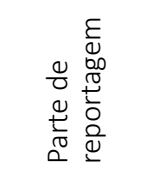 & 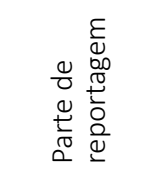 & 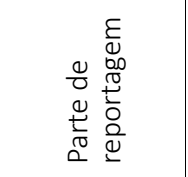 & 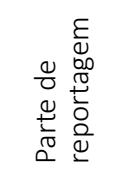 & 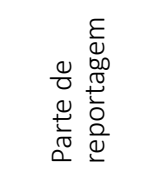 & 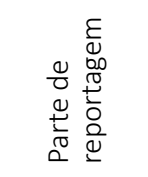 & $\begin{array}{l}\frac{\pi}{0} \\
0 \\
0 \\
00 \\
0 \\
00 \\
0 \\
0 \\
0\end{array}$ & $\begin{array}{l}\frac{\pi}{0} \\
\frac{0}{0} \\
00 \\
\frac{0}{0} \\
0 \\
0 \\
0\end{array}$ \\
\hline 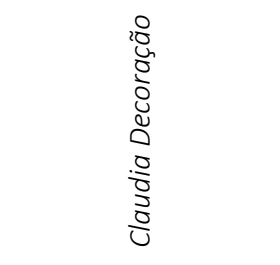 & 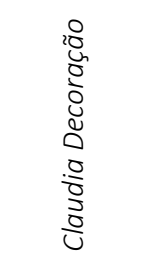 & 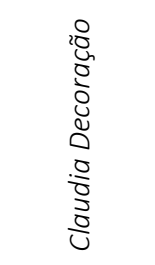 & 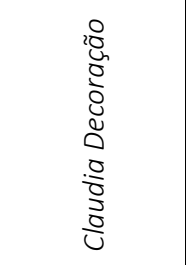 & 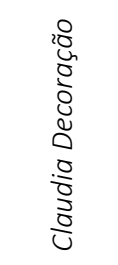 & 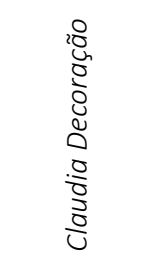 & 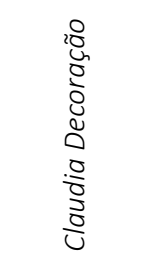 & $\frac{\square}{\bar{s}}$ & $\begin{array}{l}\frac{.0}{9} \\
\frac{0}{U} \\
\frac{0}{U}\end{array}$ \\
\hline$\infty$ & $\infty$ & $\infty$ & $\infty$ & $\infty$ & $\infty$ & $\infty$ & $\sigma$ & $\sigma$ \\
\hline $\begin{array}{l}\infty \\
\stackrel{\sigma}{\sigma}\end{array}$ & 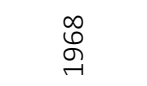 & $\begin{array}{l}\infty \\
\stackrel{\leftrightarrow}{\sigma}\end{array}$ & $\begin{array}{l}\infty \\
\stackrel{\infty}{\sigma} \\
\stackrel{\sigma}{\sigma}\end{array}$ & $\begin{array}{l}\infty \\
\stackrel{\leftrightarrow}{\sigma} \\
\stackrel{\sim}{\sigma}\end{array}$ & $\begin{array}{l}\infty \\
\stackrel{్}{\sigma} \\
\stackrel{7}{7}\end{array}$ & $\begin{array}{l}\infty \\
\stackrel{్}{\sigma}\end{array}$ & $\begin{array}{l}\infty \\
\stackrel{్}{\sigma}\end{array}$ & $\begin{array}{l}\infty \\
\stackrel{్}{\sigma}\end{array}$ \\
\hline
\end{tabular}


Anexo 01- Lista de propagandas e reportagens da Mobilinea entre 1959 e 1975

\begin{tabular}{|c|c|c|c|c|c|c|c|c|}
\hline 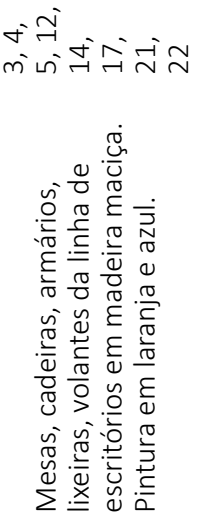 & 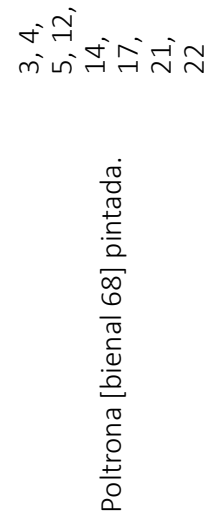 & & 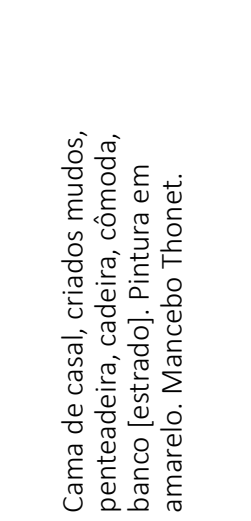 & 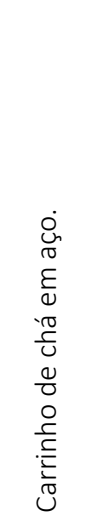 & 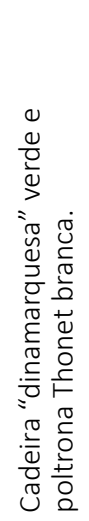 & 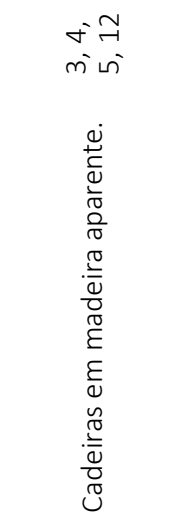 & 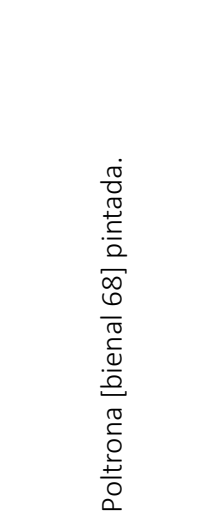 & 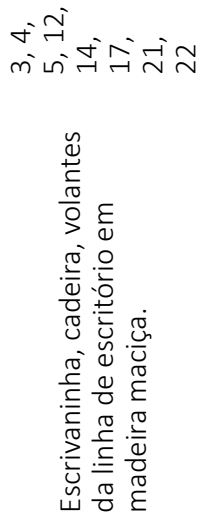 \\
\hline 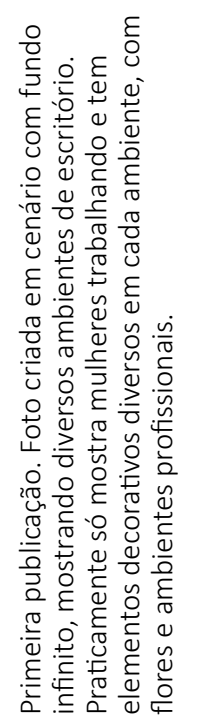 & 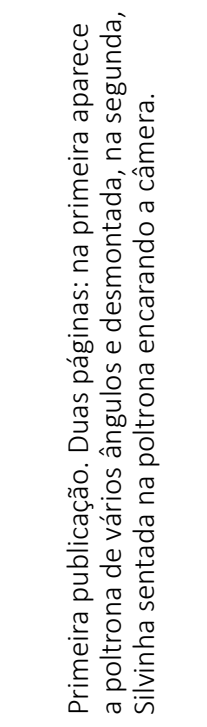 & 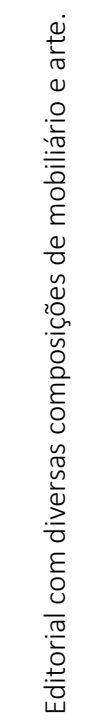 & 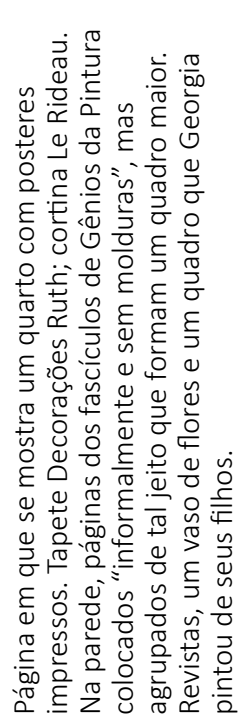 & 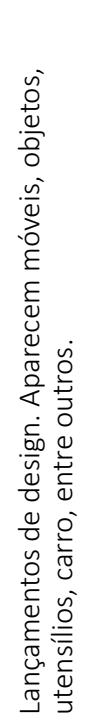 & 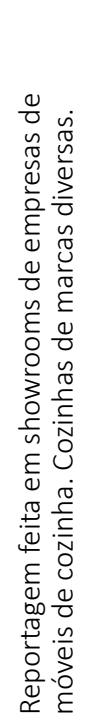 & 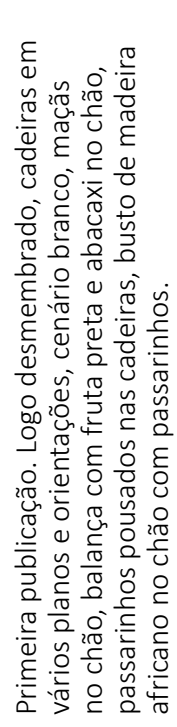 & 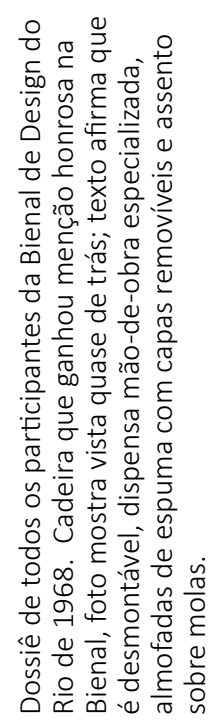 & 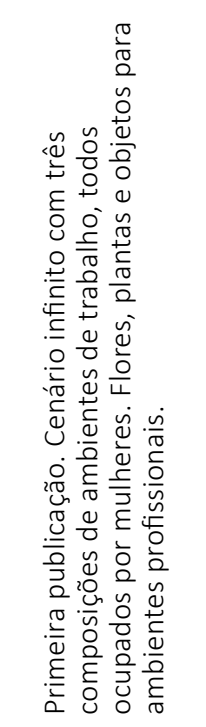 \\
\hline 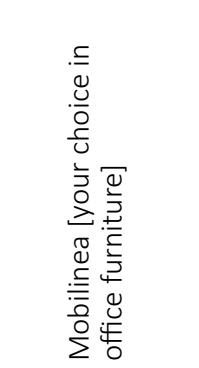 & 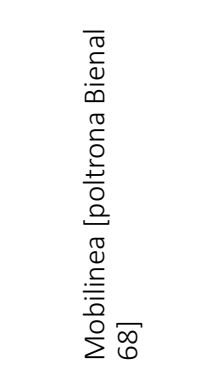 & 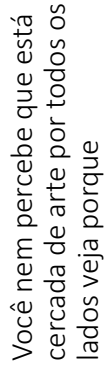 & 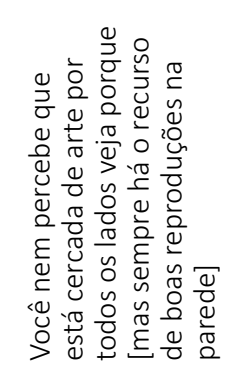 & 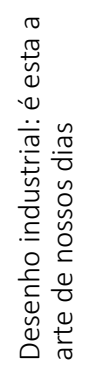 & 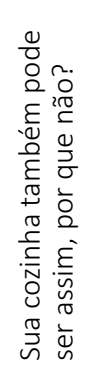 & 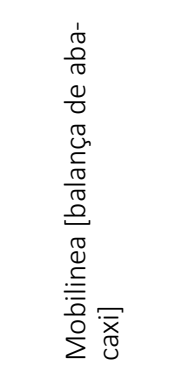 & 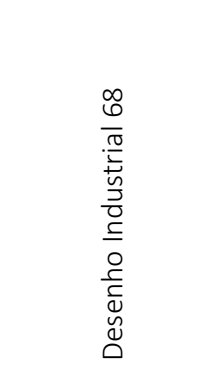 & 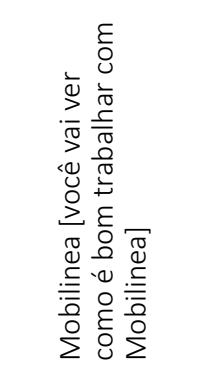 \\
\hline 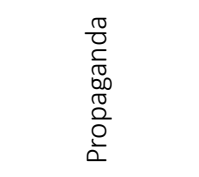 & $\begin{array}{l}\frac{\pi}{0} \\
\frac{0}{0} \\
0 \\
\pi \\
\frac{0}{0} \\
0 \\
\frac{0}{2}\end{array}$ & 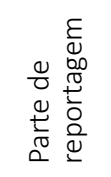 & 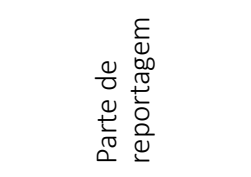 & 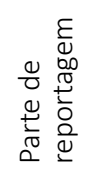 & 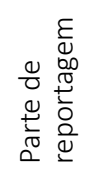 & $\begin{array}{l}\frac{\pi}{0} \\
\frac{0}{0} \\
0 \\
\pi \\
\frac{0}{0} \\
\frac{0}{2} \\
0\end{array}$ & 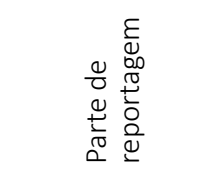 & $\begin{array}{l}\frac{\pi}{0} \\
0 \\
0 \\
00 \\
00 \\
\frac{0}{0} \\
\frac{0}{2}\end{array}$ \\
\hline 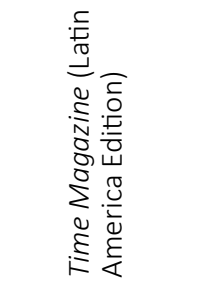 & 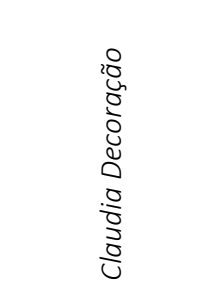 & 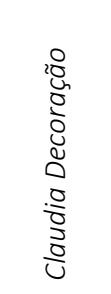 & 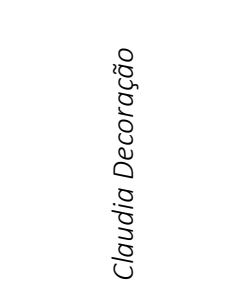 & 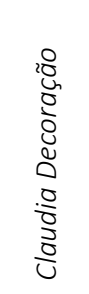 & 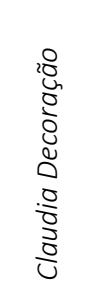 & 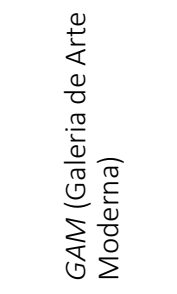 & 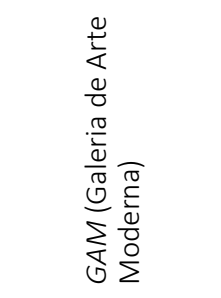 & \begin{tabular}{l}
20 \\
20 \\
\hdashline \\
$j$
\end{tabular} \\
\hline ㄱ & $\underset{\neg}{\sim}$ & ᄀ & $\underset{\sim}{\sim}$ & નૈ & $\approx$ & نُّن & نُّن & $\sim$ \\
\hline $\begin{array}{l}\infty \\
\stackrel{\leftrightarrow}{\circ} \\
\stackrel{-}{2}\end{array}$ & 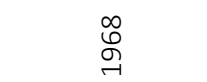 & $\begin{array}{l}\infty \\
\stackrel{0}{\sigma} \\
\stackrel{-}{2}\end{array}$ & 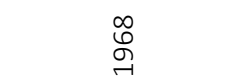 & $\begin{array}{l}\infty \\
\stackrel{్}{\sigma} \\
\stackrel{్}{\sigma}\end{array}$ & $\begin{array}{l}\infty \\
\stackrel{్}{\sigma} \\
\stackrel{7}{7}\end{array}$ & $\begin{array}{l}\infty \\
\stackrel{0}{\circ} \\
\stackrel{-}{2}\end{array}$ & $\begin{array}{l}\infty \\
\stackrel{\infty}{\sigma} \\
\stackrel{\sim}{\sigma}\end{array}$ & $\begin{array}{l}\text { Oे } \\
\text { ه్ }\end{array}$ \\
\hline
\end{tabular}


Anexo 01- Lista de propagandas e reportagens da Mobilinea entre 1959 e 1975

\begin{tabular}{|c|c|c|c|c|c|c|c|}
\hline 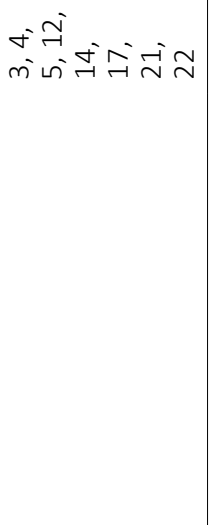 & 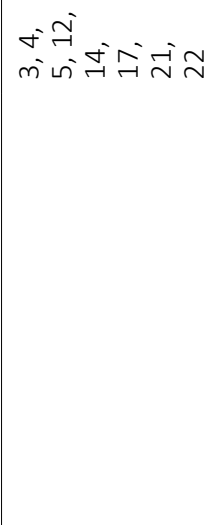 & & 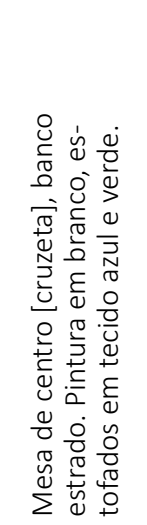 & $m$ & 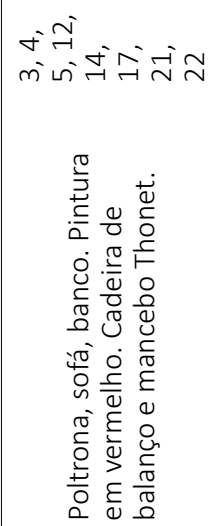 & 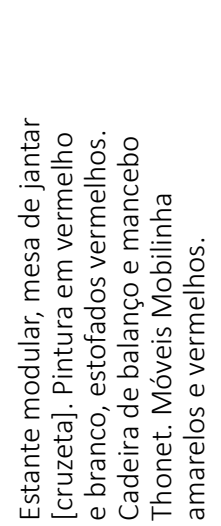 & 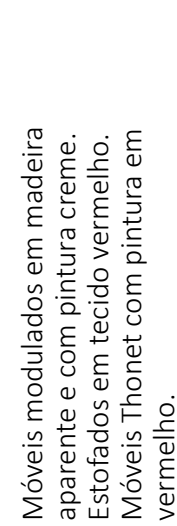 \\
\hline 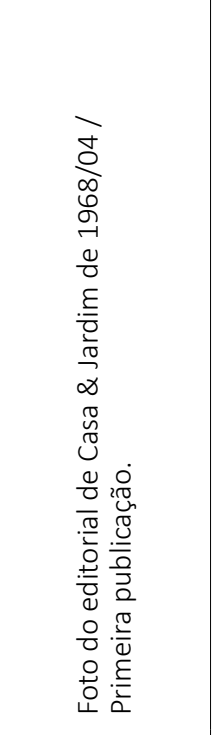 & & 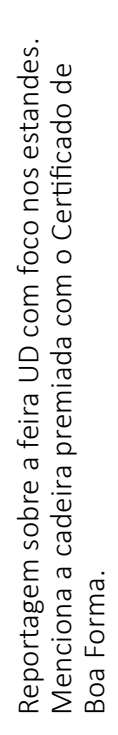 & 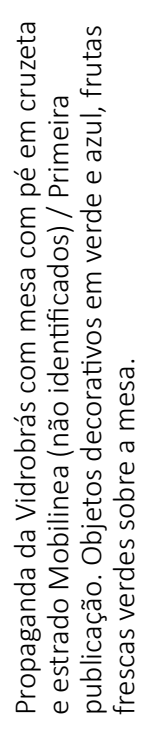 & 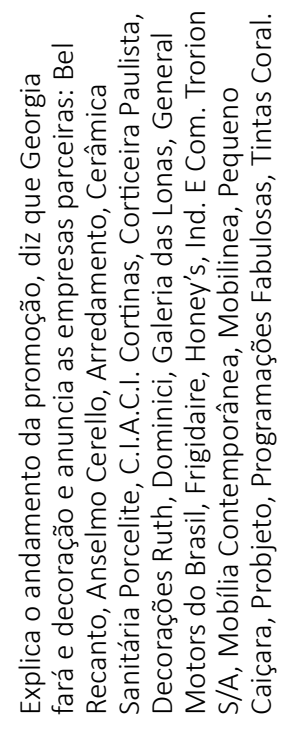 & 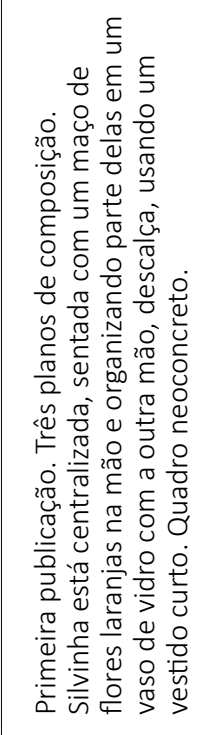 & 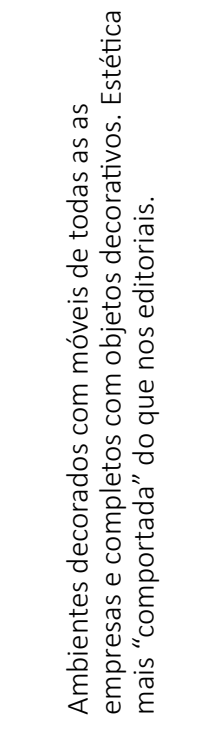 & 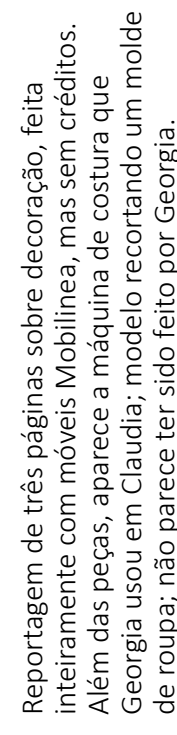 \\
\hline 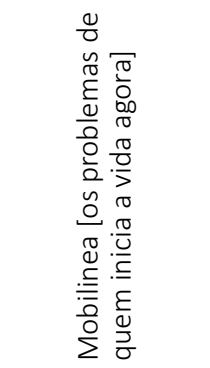 & 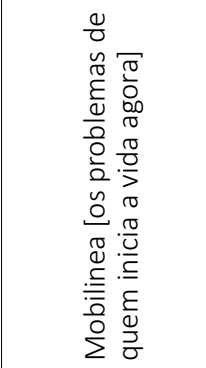 & 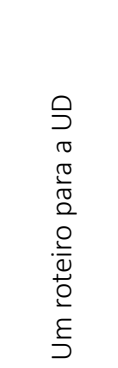 & 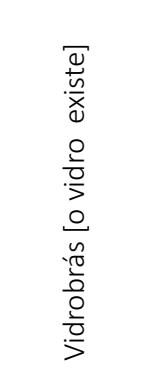 & 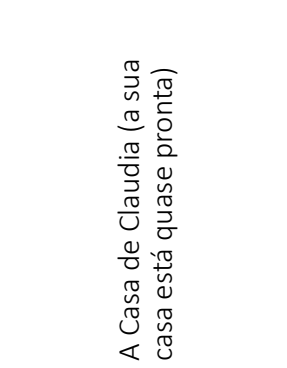 & 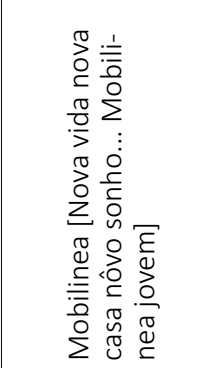 & 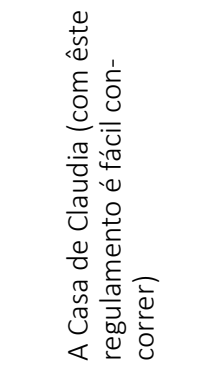 & 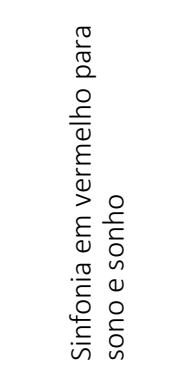 \\
\hline $\begin{array}{l}\frac{\pi}{0} \\
\frac{0}{0} \\
00 \\
0 \\
0 \\
0 \\
0 \\
\frac{0}{2}\end{array}$ & $\begin{array}{l}\frac{\pi}{0} \\
\frac{0}{0} \\
00 \\
\pi \\
\frac{0}{0} \\
\frac{0}{2}\end{array}$ & 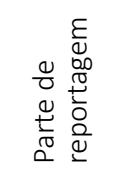 & $\begin{array}{l}\frac{\pi}{0} \\
\frac{0}{0} \\
0 \\
\pi \\
0 \\
0 \\
0 \\
0\end{array}$ & 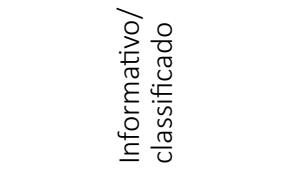 & $\begin{array}{l}\frac{\pi}{0} \\
\frac{0}{0} \\
0 \\
\widetilde{0} \\
\frac{0}{0} \\
\frac{0}{2}\end{array}$ & 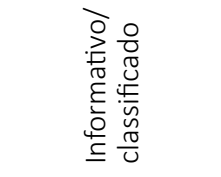 & 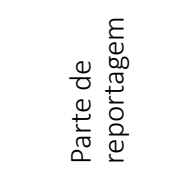 \\
\hline $\begin{array}{l}\frac{0}{0} \\
\frac{0}{0} \\
\frac{0}{U}\end{array}$ & $\begin{array}{l}\frac{0}{2} \\
0 \\
2 \\
0 \\
\frac{0}{9} \\
\frac{0}{0} \\
0\end{array}$ & 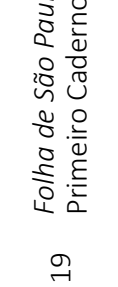 & $\begin{array}{l}\frac{5}{\delta} \\
\overline{0} \\
\infty \\
0 \\
0 \\
0 \\
0\end{array}$ & $\frac{\frac{9}{9}}{\frac{0}{0}}$ & $\begin{array}{l}\frac{.0}{0} \\
\frac{0}{0} \\
\end{array}$ & $\begin{array}{l}\frac{.0}{0} \\
\frac{0}{0} \\
\frac{0}{U}\end{array}$ & $: \frac{0}{0}$ \\
\hline$m$ & $m$ & $\nabla$ & $\nabla$ & $\sigma$ & $\nabla$ & in & $\wedge$ \\
\hline 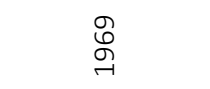 & 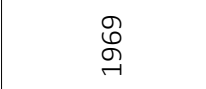 & $\begin{array}{l}\stackrel{9}{\circ} \\
\stackrel{ }{-}\end{array}$ & $\begin{array}{l}\text { के } \\
\text { oे }\end{array}$ & $\begin{array}{l}\stackrel{\circ}{\sigma} \\
\stackrel{్}{\sigma}\end{array}$ & 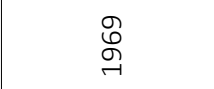 & 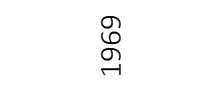 & $\begin{array}{l}\text { O্ } \\
\text { ه্ }\end{array}$ \\
\hline
\end{tabular}




\begin{tabular}{|c|c|c|c|c|c|c|c|}
\hline 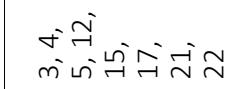 & 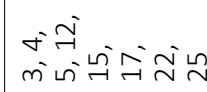 & & & & & & 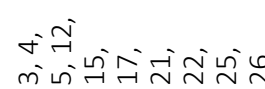 \\
\hline 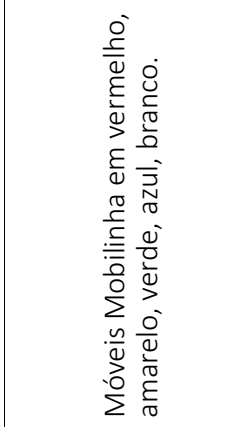 & 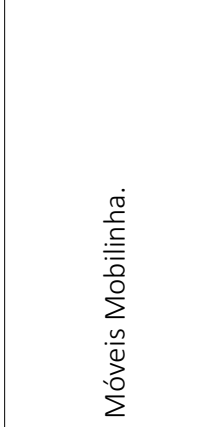 & 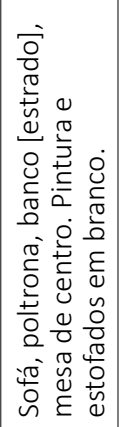 & 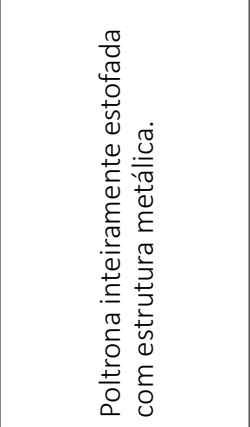 & & 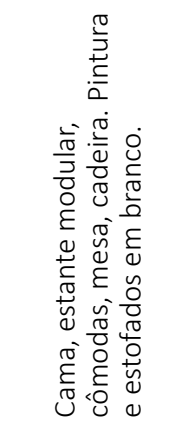 & 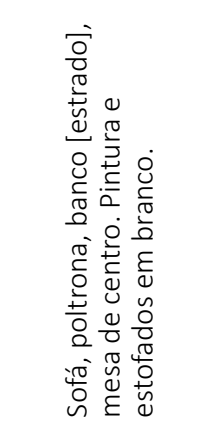 & 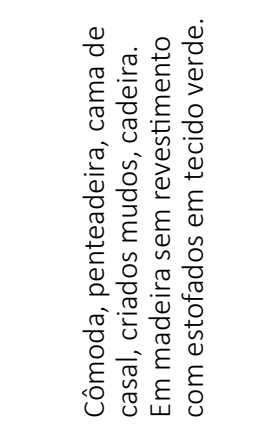 \\
\hline 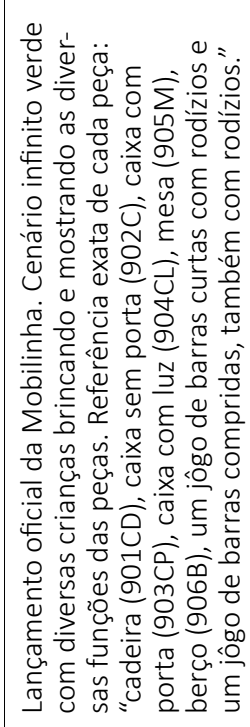 & 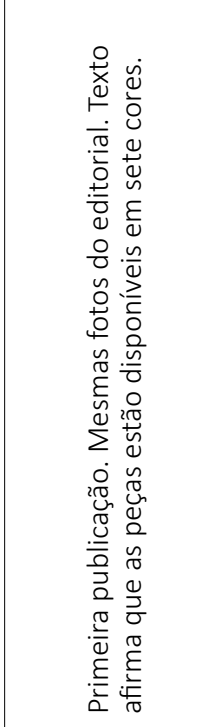 & 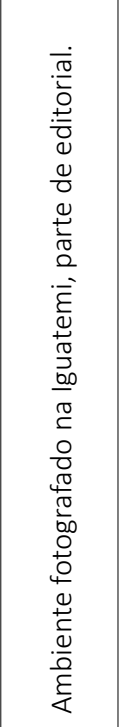 & 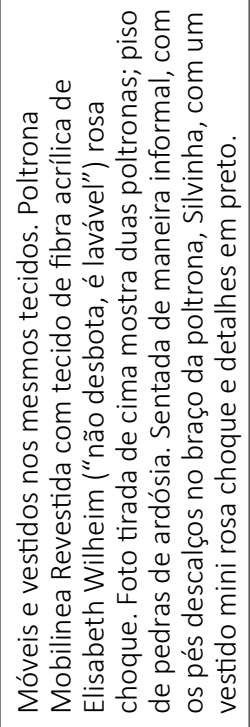 & 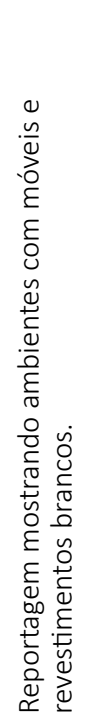 & 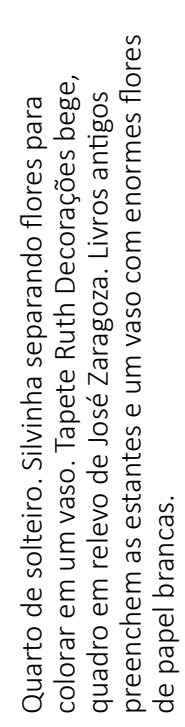 & 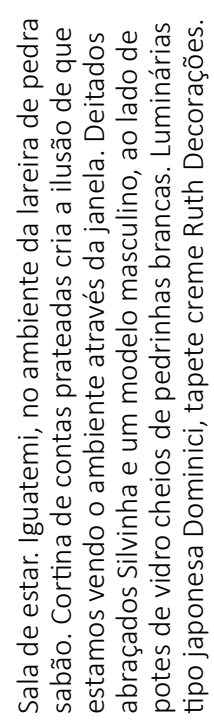 & 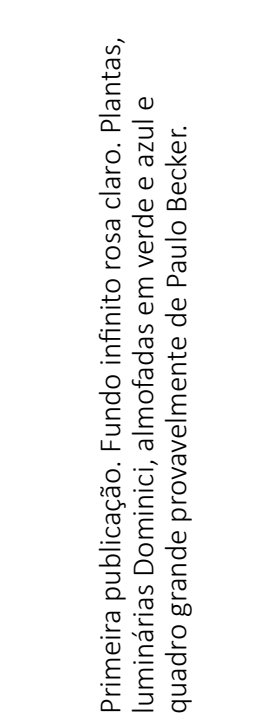 \\
\hline 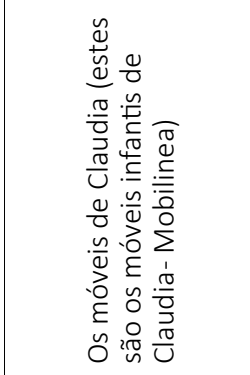 & 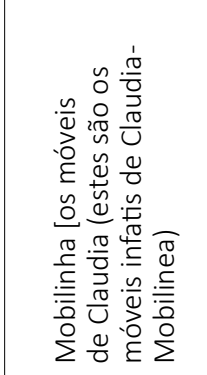 & $\frac{\pi}{0}$ & 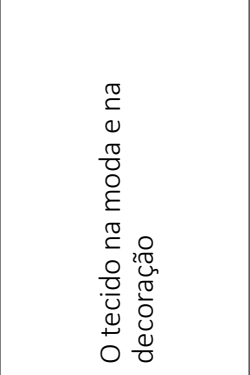 & 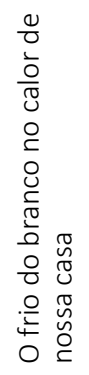 & 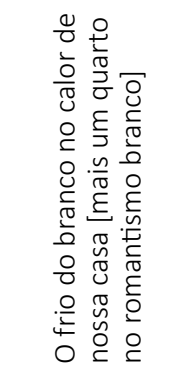 & 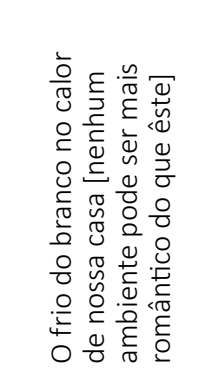 & 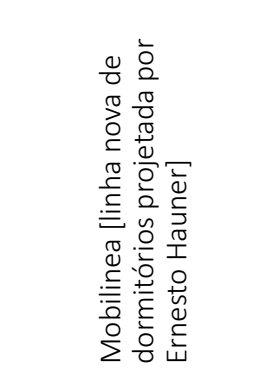 \\
\hline 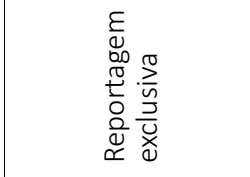 & $\begin{array}{l}\frac{\pi}{0} \\
\frac{0}{0} \\
00 \\
\pi \\
00 \\
0 \\
0 \\
0\end{array}$ & 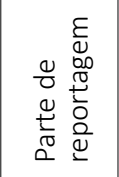 & 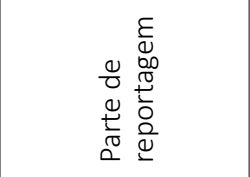 & 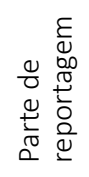 & 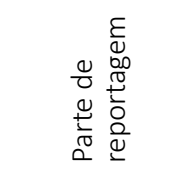 & 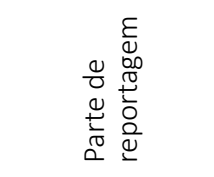 & $\begin{array}{l}\frac{\pi}{0} \\
\frac{0}{0} \\
0 \\
0 \\
0 \\
0 \\
0 \\
0 \\
0\end{array}$ \\
\hline $\begin{array}{l}\frac{D}{0} \\
\frac{0}{U}\end{array}$ & $\begin{array}{l}\frac{0}{\overline{0}} \\
\frac{\overrightarrow{0}}{0}\end{array}$ & 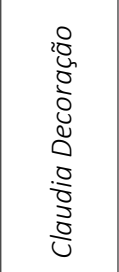 & 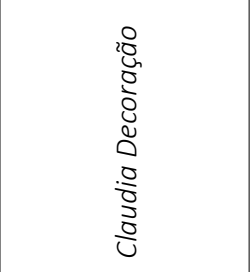 & 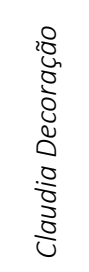 & 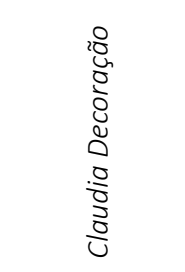 & 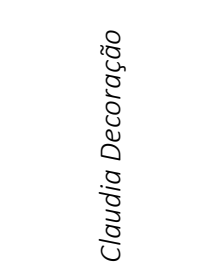 & 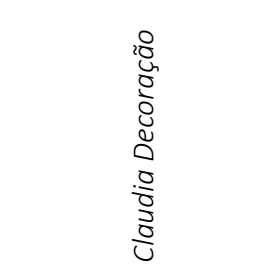 \\
\hline$\sigma$ & 우 & $\underset{\neg}{\sim}$ & $\underset{\sim}{\sim}$ & $\underset{\sim}{\sim}$ & ㄱ & $\underset{\sim}{\sim}$ & $\underset{\sim}{\sim}$ \\
\hline 兽 & 囟 & 兽 & 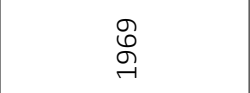 & 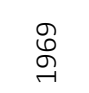 & 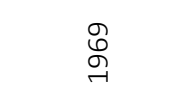 & $\underset{\circ}{\mathscr{O}}$ & ஜ̊ \\
\hline
\end{tabular}


Anexo 01- Lista de propagandas e reportagens da Mobilinea entre 1959 e 1975

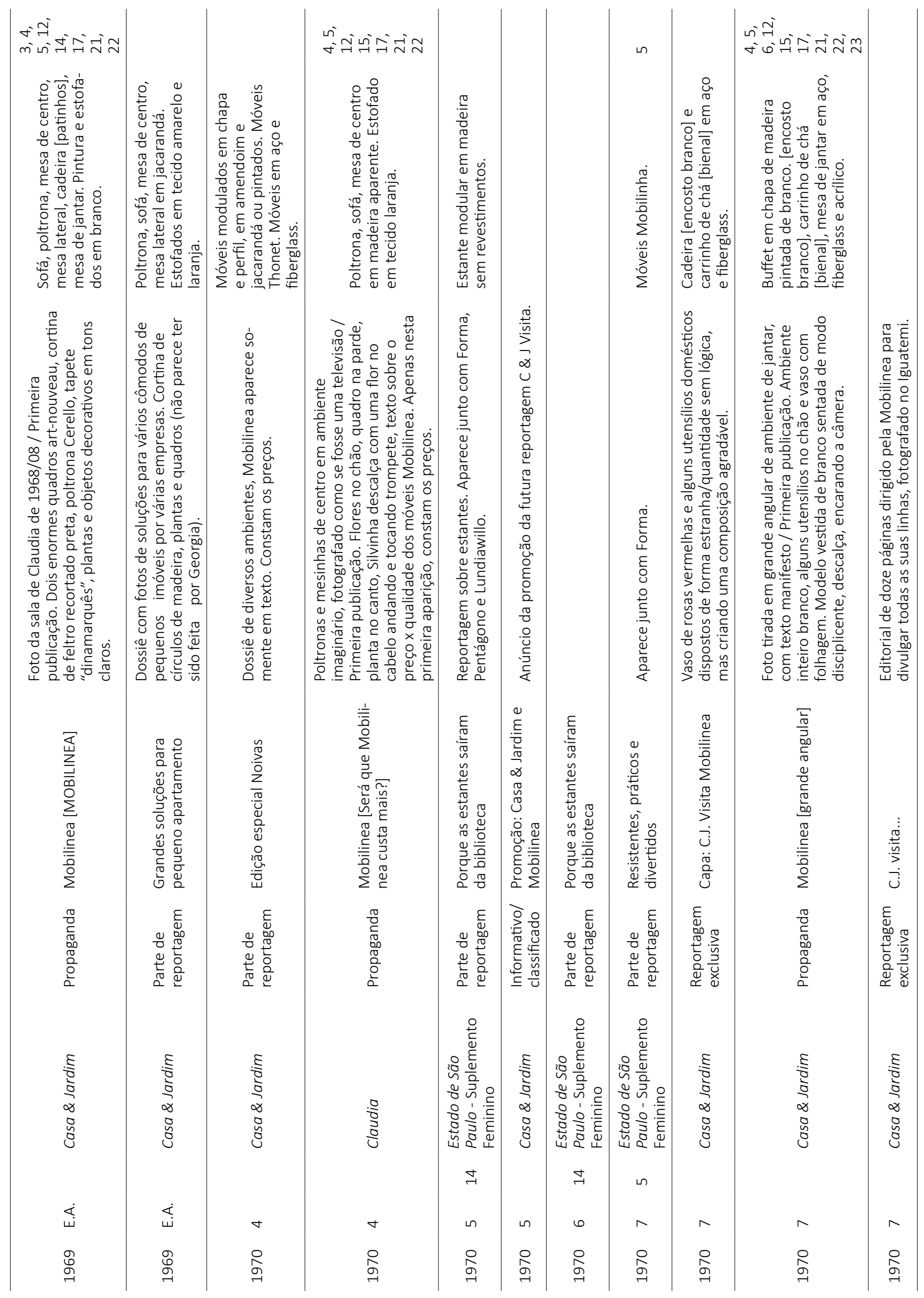


Anexo 01- Lista de propagandas e reportagens da Mobilinea entre 1959 e 1975

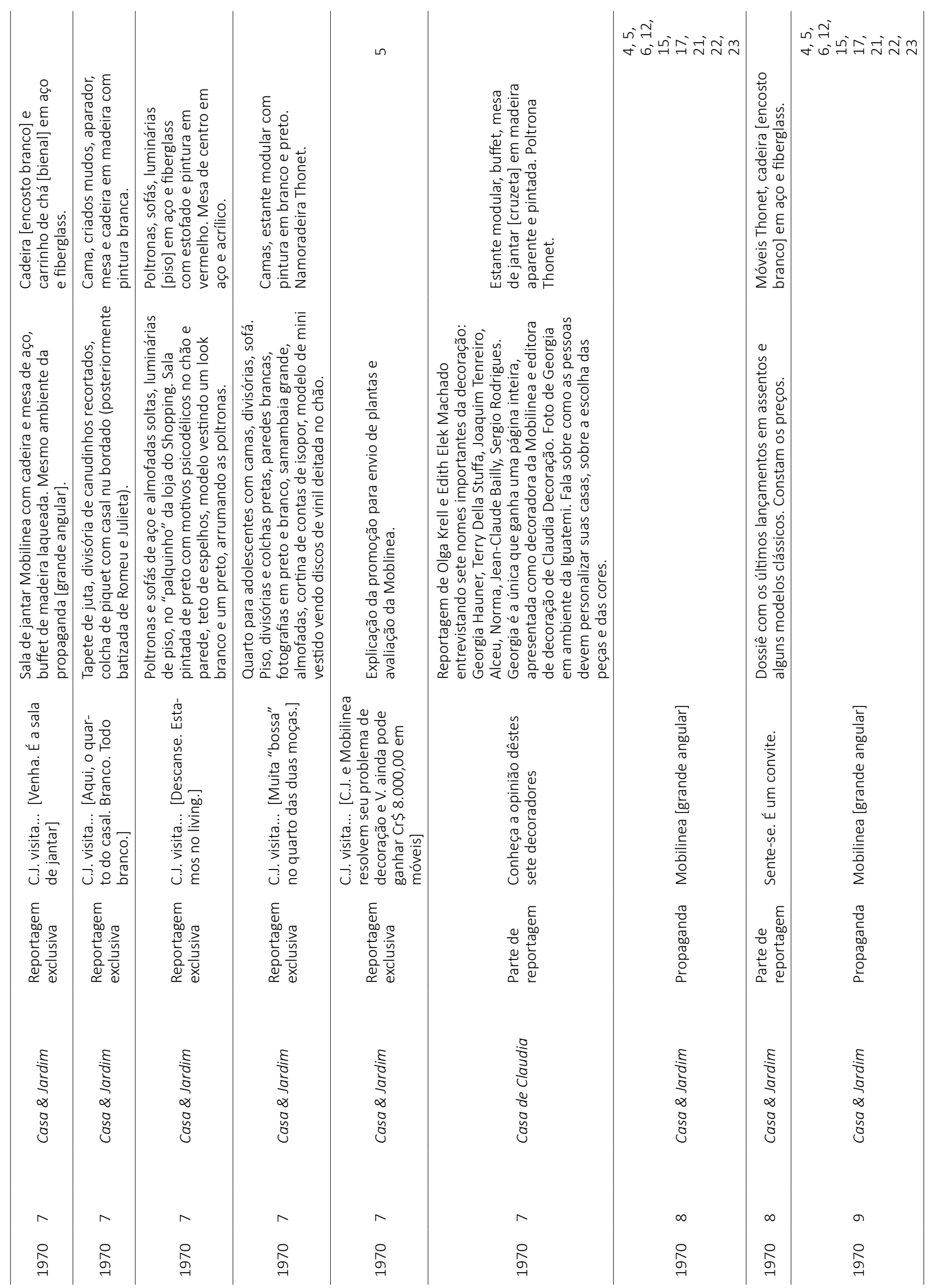


Anexo 01- Lista de propagandas e reportagens da Mobilinea entre 1959 e 1975

\begin{tabular}{|c|c|c|c|c|c|c|c|c|}
\hline 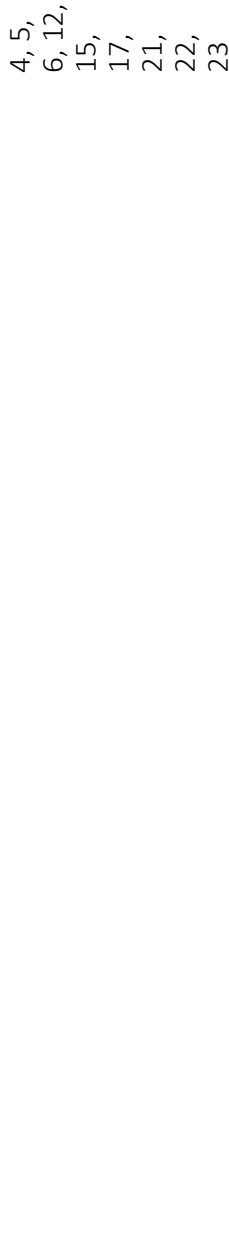 & 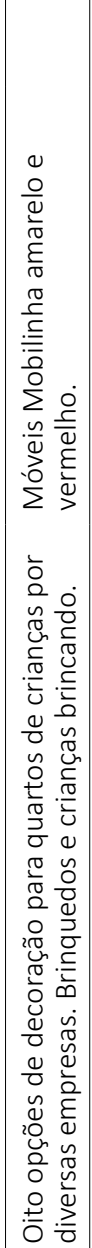 & 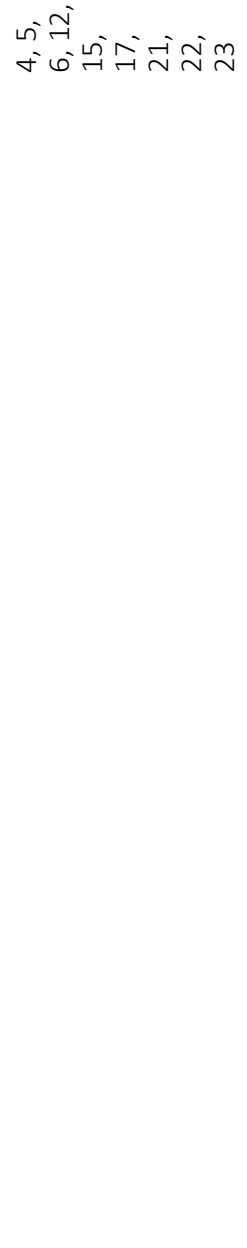 & 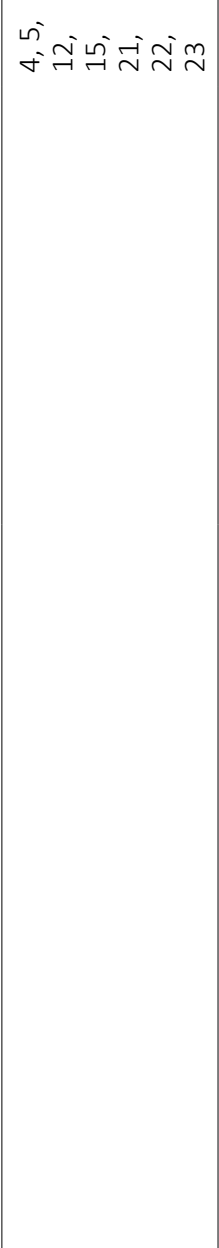 & 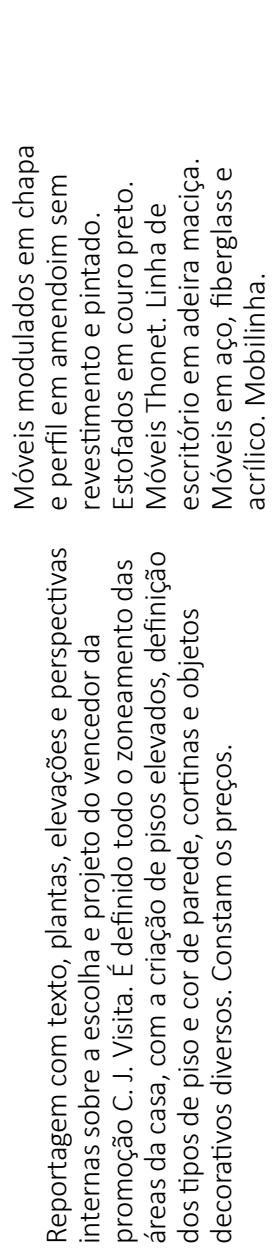 & 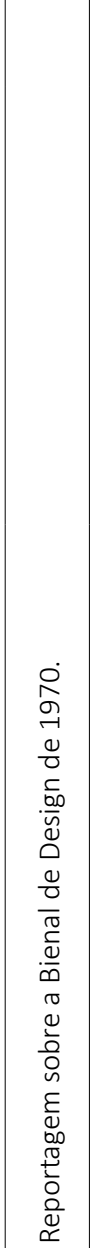 & 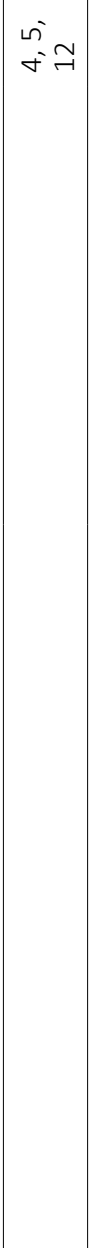 & 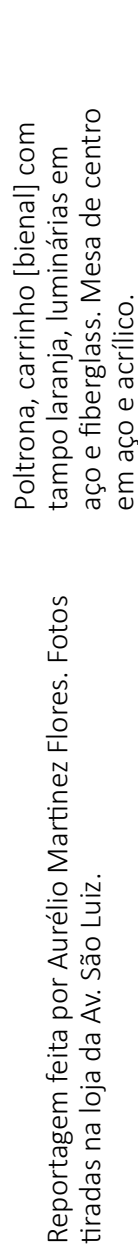 & 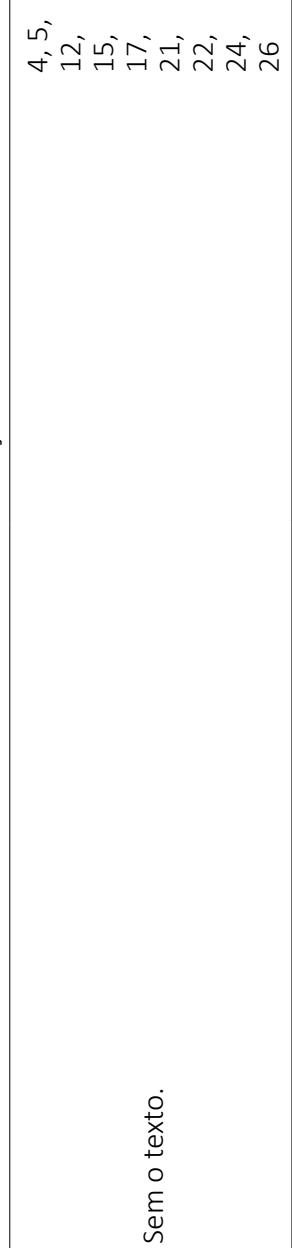 \\
\hline 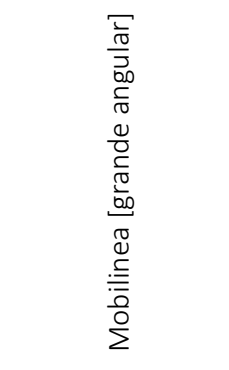 & 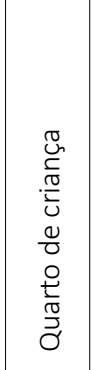 & 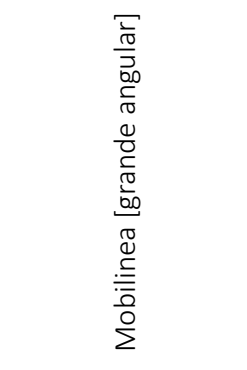 & 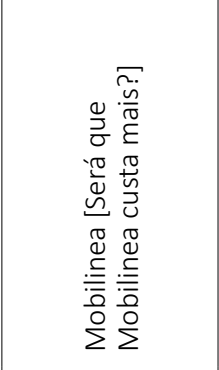 & 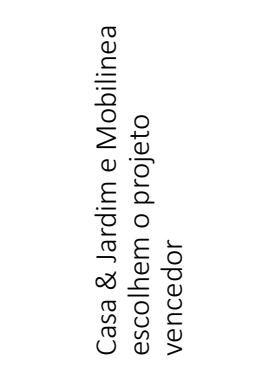 & 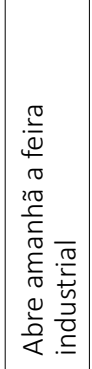 & 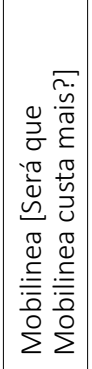 & 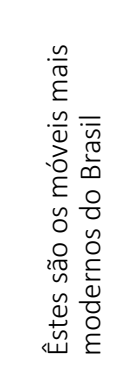 & 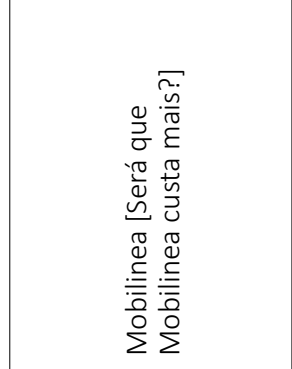 \\
\hline $\begin{array}{l}\frac{\pi}{0} \\
\bar{c} \\
\text { on } \\
\text { on } \\
\text { o }\end{array}$ & 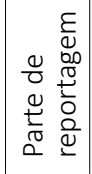 & 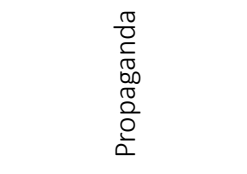 & $\begin{array}{l}\frac{\pi}{c} \\
\text { con } \\
\text { on } \\
\text { on } \\
\frac{0}{2}\end{array}$ & 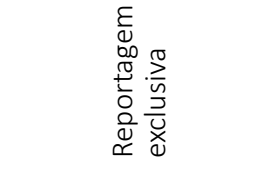 & 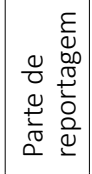 & 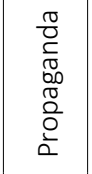 & 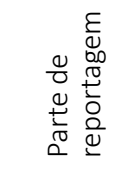 & 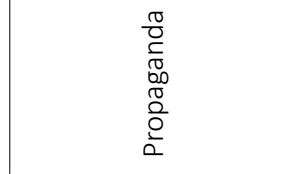 \\
\hline 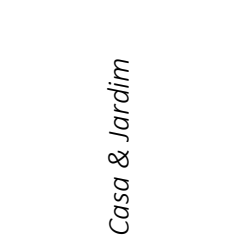 & 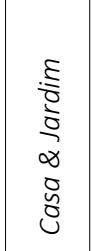 & 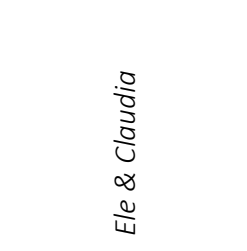 & 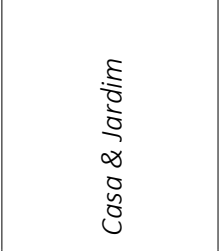 & 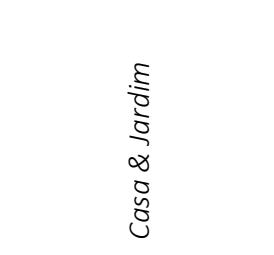 & 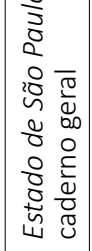 & $\begin{array}{l}\frac{\xi}{\delta} \\
\frac{\delta}{0} \\
\infty \\
0 \\
0 \\
0\end{array}$ & 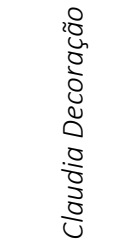 & 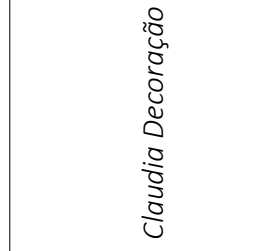 \\
\hline O & ㅇ & of & $\vec{F}$ & $\vec{F}$ & $\approx$ & $\approx$ & $\approx$ & $\approx$ \\
\hline 今ి & 足 & 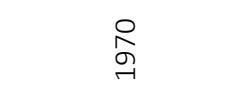 & 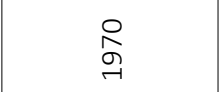 & 今. & 尽 & 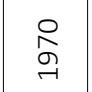 & 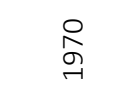 & 只 \\
\hline
\end{tabular}


Anexo 01- Lista de propagandas e reportagens da Mobilinea entre 1959 e 1975

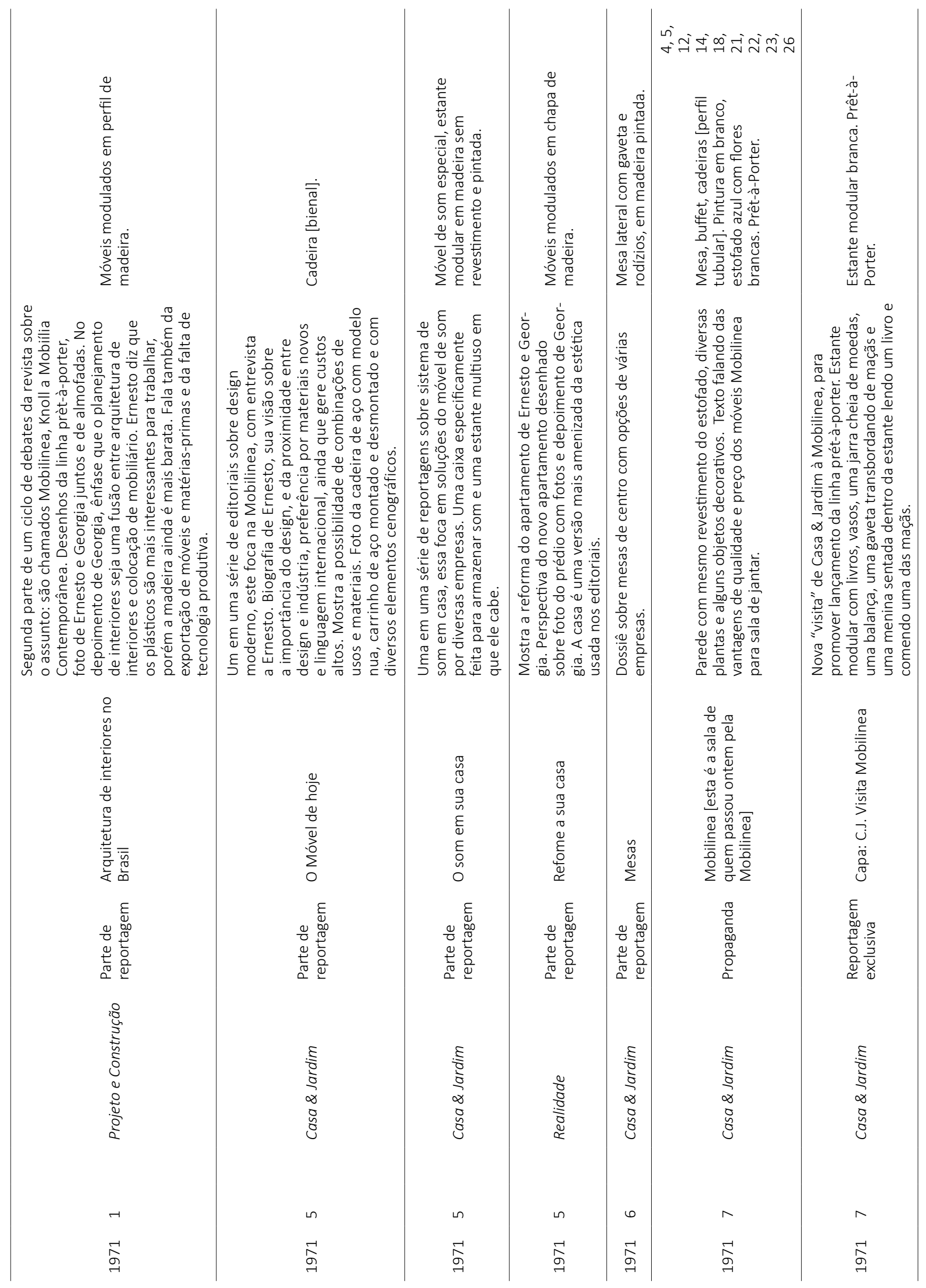


Anexo 01- Lista de propagandas e reportagens da Mobilinea entre 1959 e 1975

\begin{tabular}{|c|c|c|c|c|c|c|c|c|}
\hline & 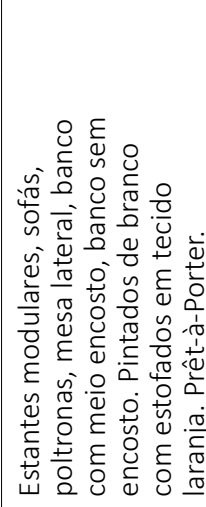 & 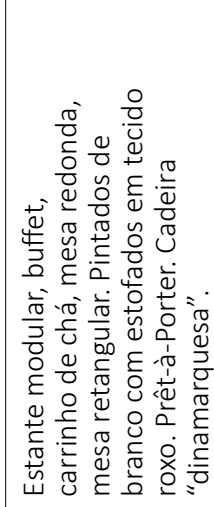 & 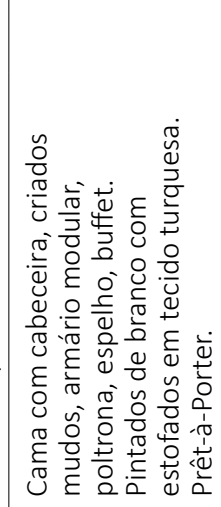 & 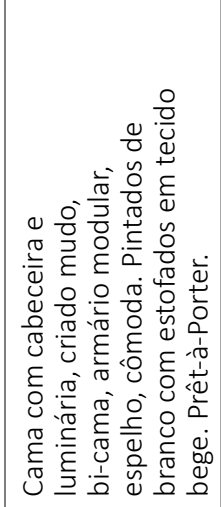 & in & & 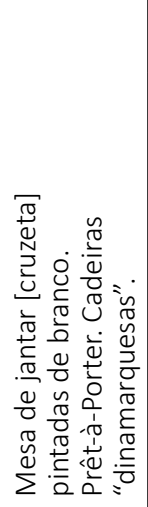 & 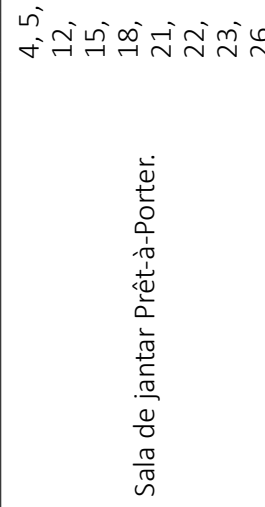 \\
\hline 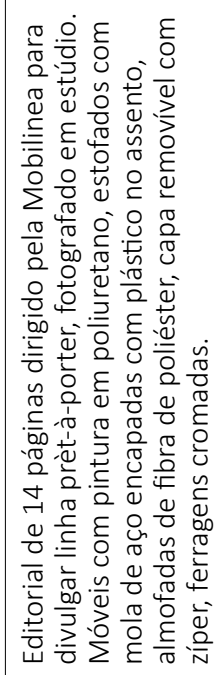 & 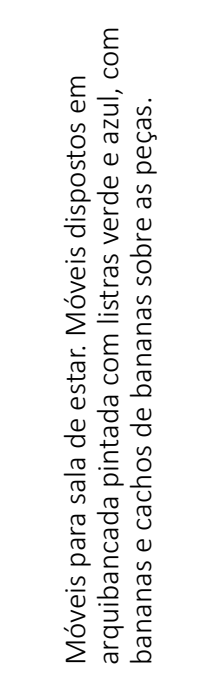 & 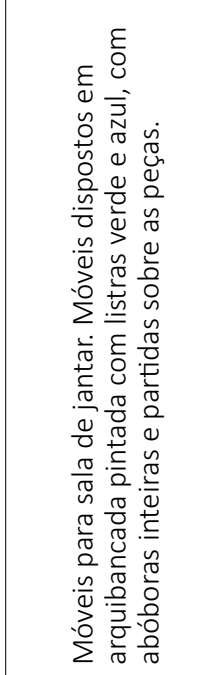 & 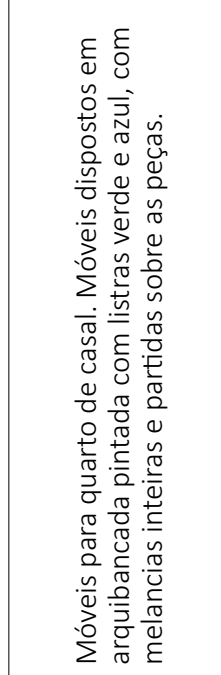 & 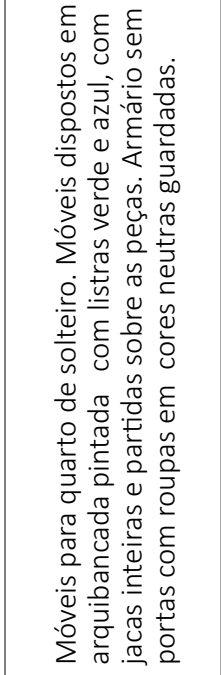 & 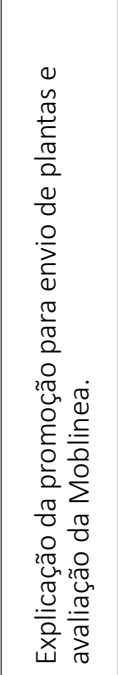 & 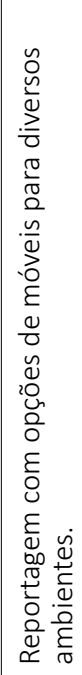 & 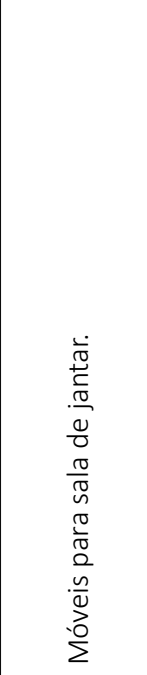 & 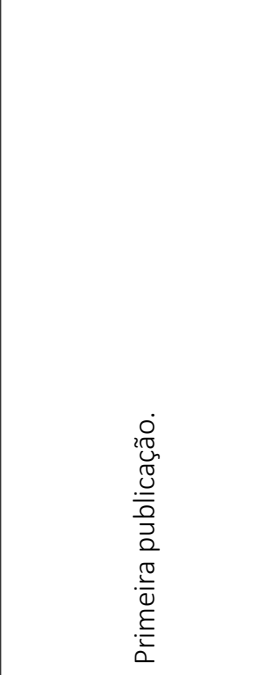 \\
\hline 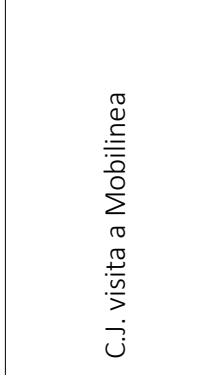 & 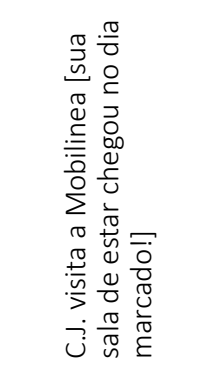 & 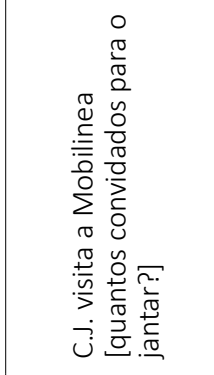 & 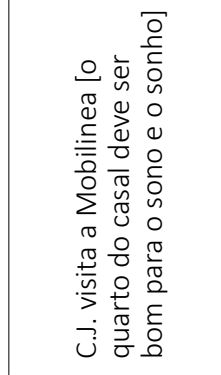 & 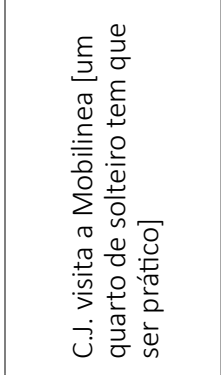 & 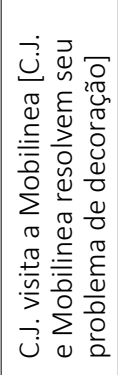 & 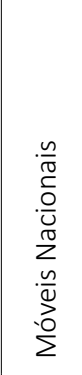 & 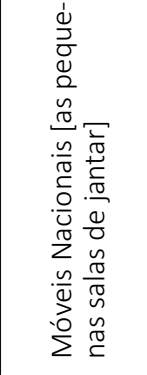 & 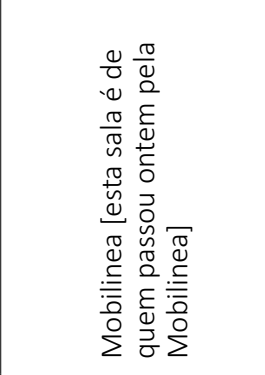 \\
\hline 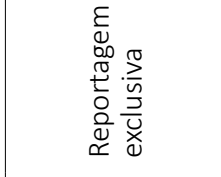 & 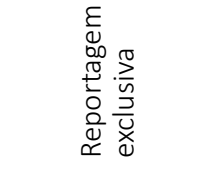 & 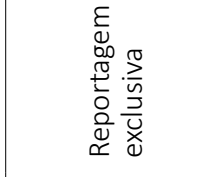 & 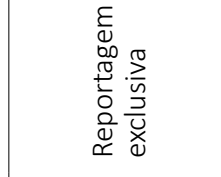 & 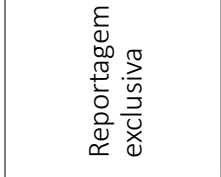 & 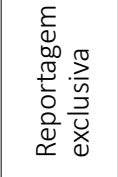 & 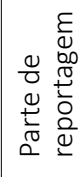 & 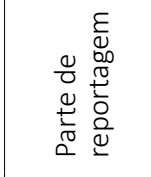 & $\begin{array}{l}\frac{\pi}{0} \\
\frac{0}{0} \\
0 \\
0 \\
0 \\
0 \\
0 \\
0\end{array}$ \\
\hline $\begin{array}{l}\frac{\varepsilon}{y} \\
\text { o } \\
\infty \\
0 \\
0 \\
0\end{array}$ & $\begin{array}{l}\frac{\varepsilon}{y} \\
\text { oे } \\
\infty \\
0 \\
0 \\
0\end{array}$ & 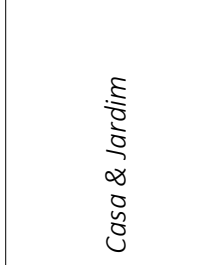 & 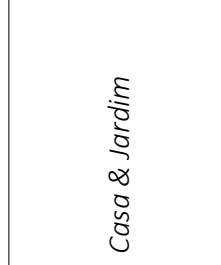 & $\begin{array}{l}\frac{5}{\delta} \\
\text { o } \\
\infty \\
0 \\
0 \\
0 \\
0\end{array}$ & $\begin{array}{l}\frac{5}{0} \\
\overline{0} \\
o \\
0 \\
0 \\
0 \\
0\end{array}$ & 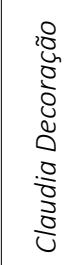 & 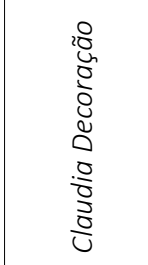 & 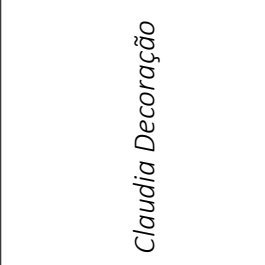 \\
\hline$\wedge$ & $\wedge$ & $\wedge$ & $\wedge$ & $\wedge$ & $\wedge$ & $\wedge$ & $\wedge$ & $\wedge$ \\
\hline 곡 & 点 & 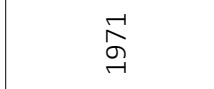 & 索 & 离 & 离 & 点 & $\begin{array}{l}\overrightarrow{\hat{\sigma}} \\
\text { }\end{array}$ & $\stackrel{\vec{\sigma}}{\stackrel{\sigma}{\sigma}}$ \\
\hline
\end{tabular}


Anexo 01- Lista de propagandas e reportagens da Mobilinea entre 1959 e 1975

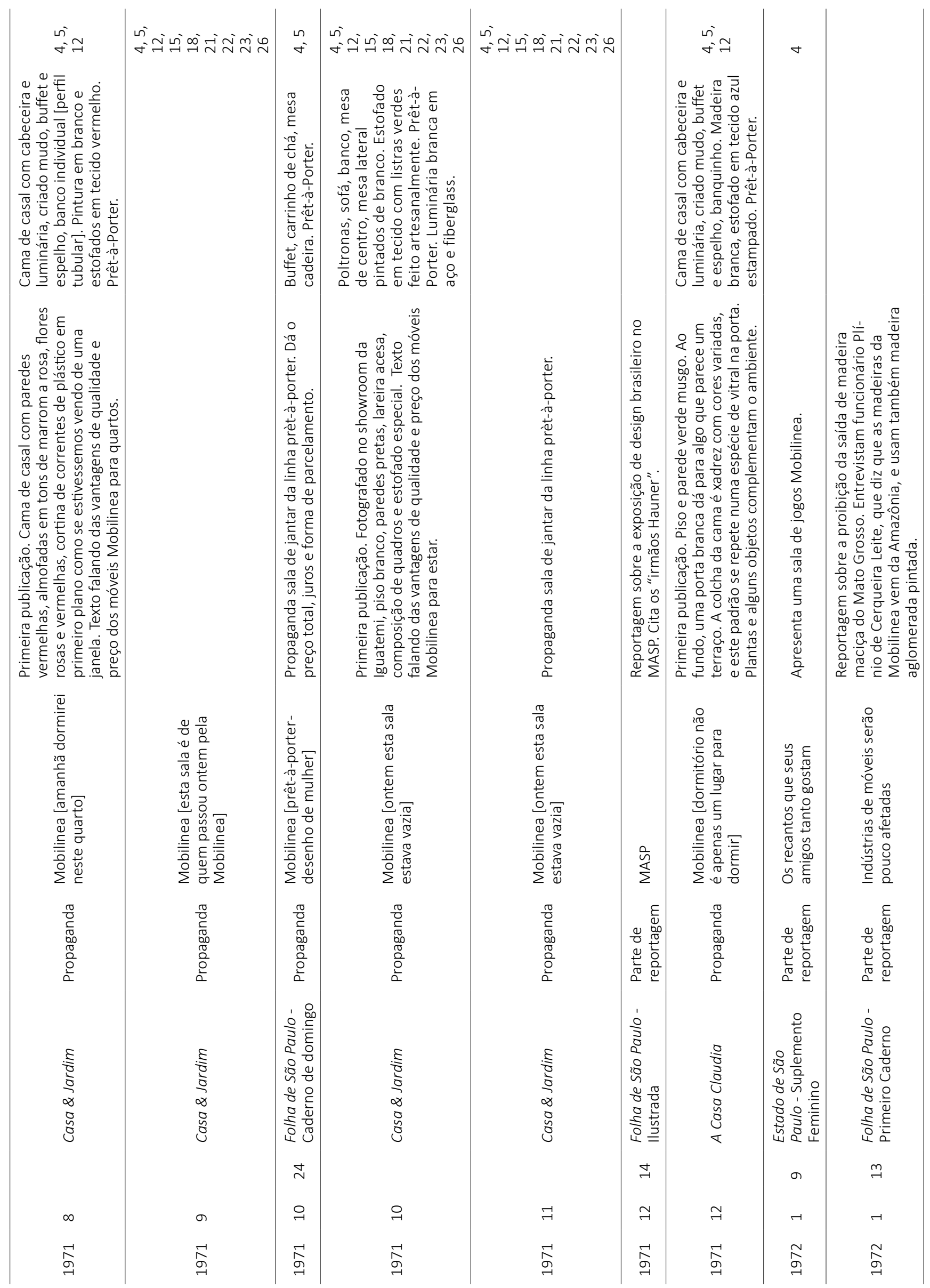




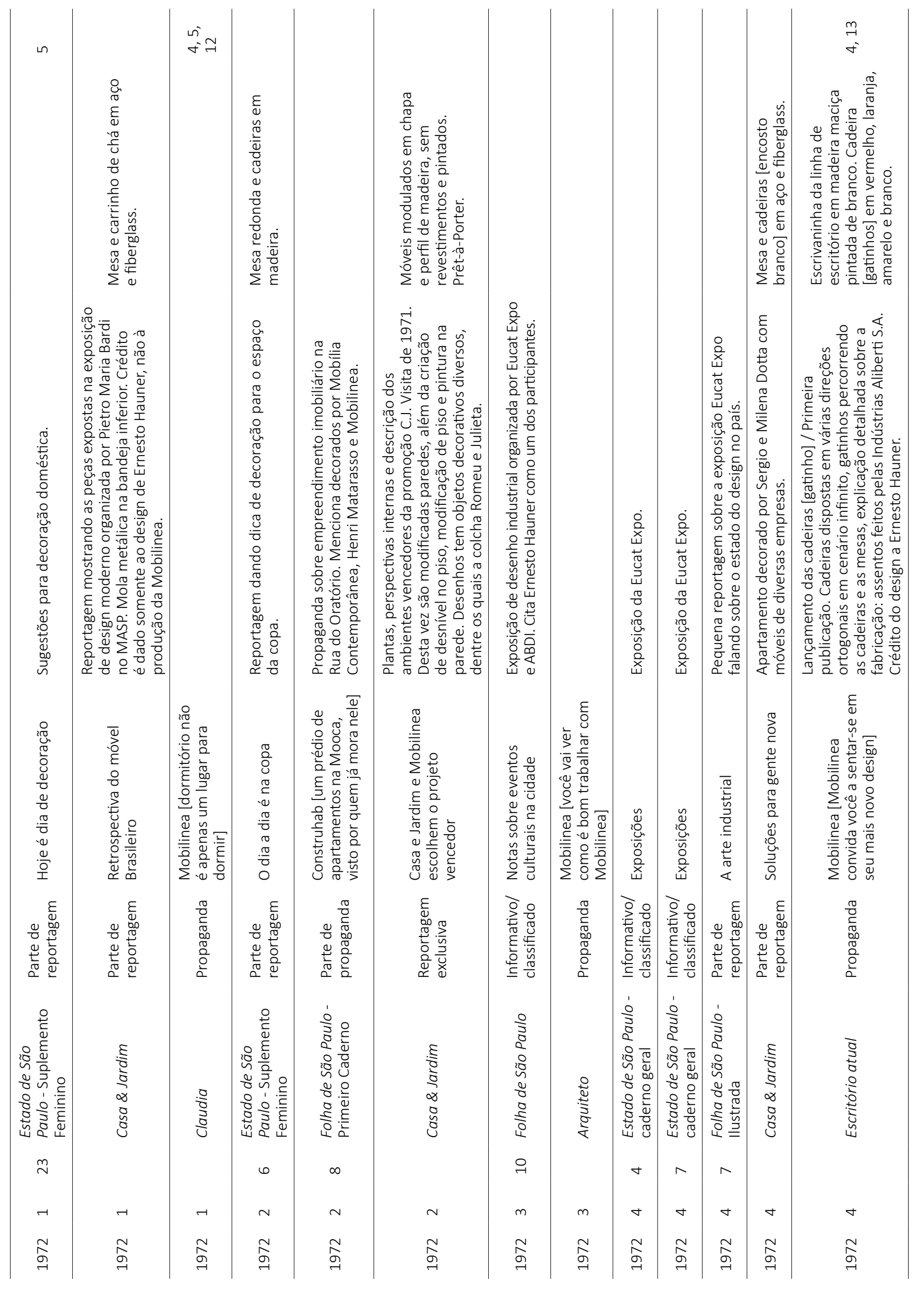


Anexo 01- Lista de propagandas e reportagens da Mobilinea entre 1959 e 1975

\begin{tabular}{|c|c|c|c|c|c|c|c|c|}
\hline 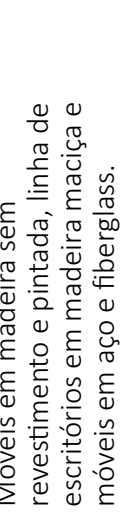 & $\stackrel{m}{\stackrel{m}{\sim}}$ & 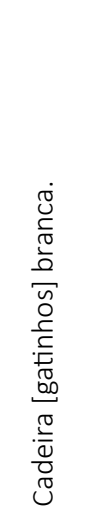 & $\wedge$ & 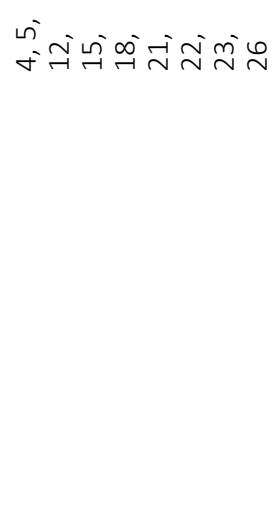 & 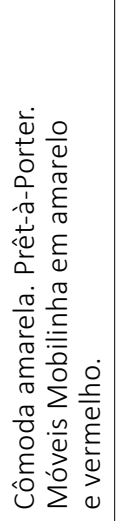 & 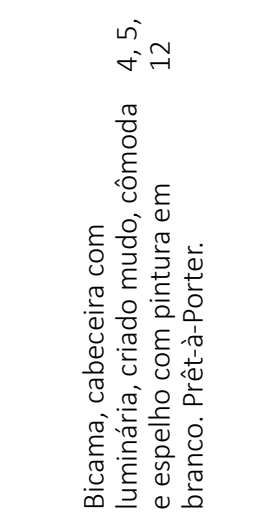 & 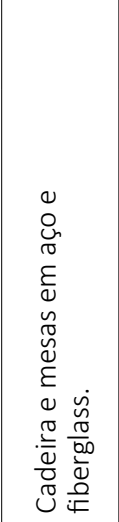 & 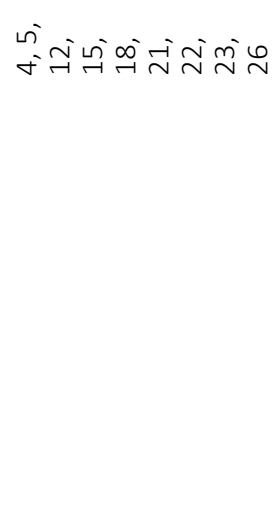 \\
\hline 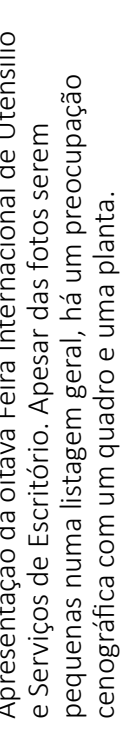 & & 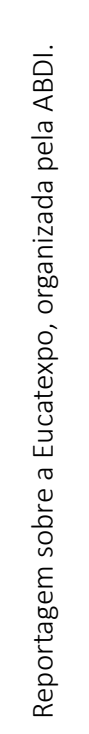 & 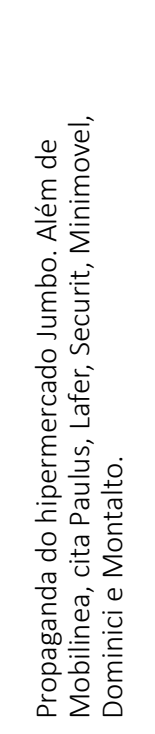 & & 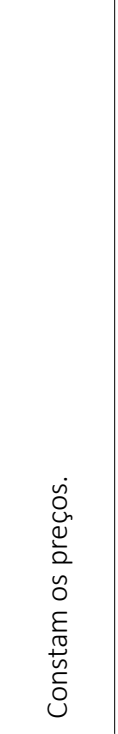 & 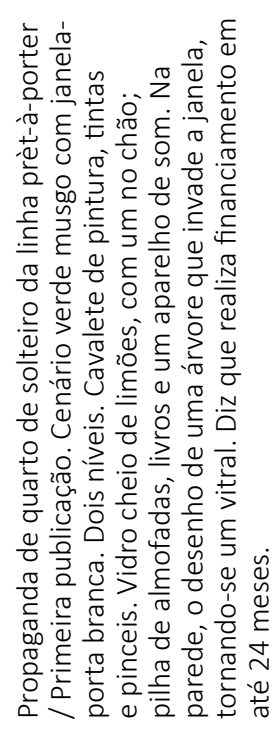 & 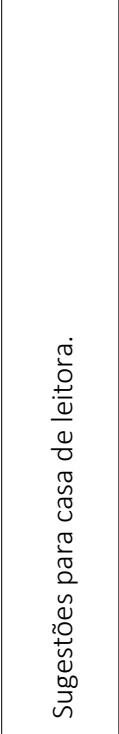 & \\
\hline 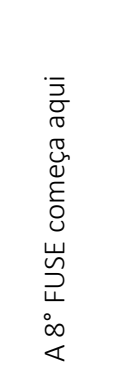 & 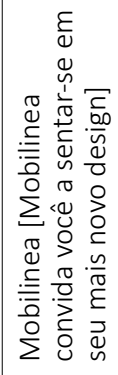 & 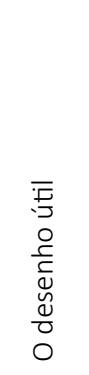 & 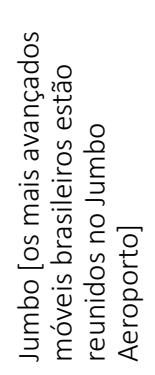 & 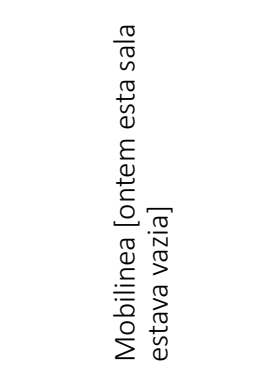 & 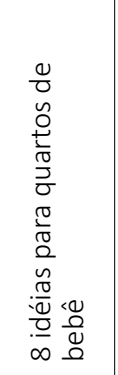 & 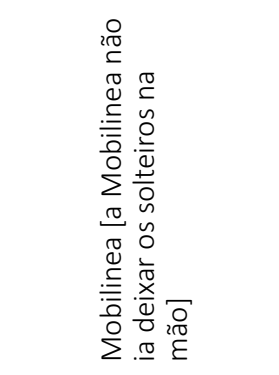 & 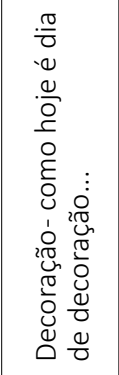 & 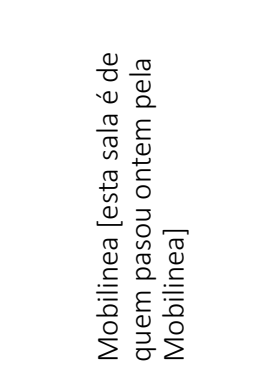 \\
\hline 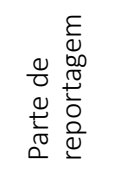 & 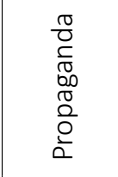 & 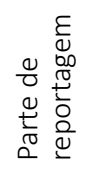 & $\begin{array}{rl} & \frac{\pi}{0} \\
0 & \frac{1}{0} \\
0 & 0 \\
0 & 0 \\
0 & 0 \\
\frac{\pi}{\pi} & 0 \\
0 & 0\end{array}$ & $\begin{array}{l}\frac{\pi}{0} \\
\frac{0}{0} \\
00 \\
0 \\
0 \\
0 \\
0\end{array}$ & 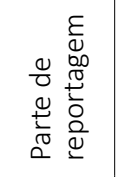 & $\begin{array}{l}\frac{\pi}{0} \\
\frac{0}{0} \\
00 \\
00 \\
0 \\
\frac{0}{2} \\
0\end{array}$ & 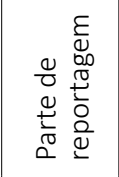 & $\begin{array}{l}\frac{\pi}{0} \\
0 \\
0 \\
00 \\
00 \\
0 \\
0 \\
0 \\
0\end{array}$ \\
\hline 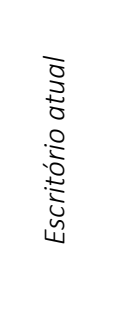 & 密 & $\frac{\bar{a}}{\bar{a}}$ & 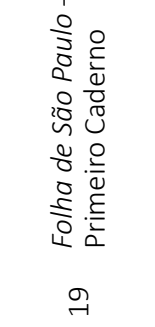 & $\begin{array}{l}\frac{5}{0} \\
\frac{0}{0} \\
\infty \\
0 \\
0 \\
0 \\
0\end{array}$ & $\begin{array}{l}\frac{D}{0} \\
\frac{a}{0}\end{array}$ & $\begin{array}{l}\frac{D}{\bar{s}} \\
\frac{0}{0} \\
\end{array}$ & 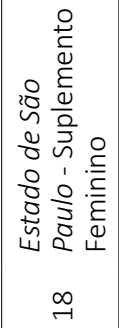 & $\begin{array}{l}\frac{\varepsilon}{0} \\
\text { ᄒे } \\
\infty \\
0 \\
0 \\
0\end{array}$ \\
\hline$\diamond$ & ナ & $\nabla$ & in & เn & in & in & 0 & 0 \\
\hline 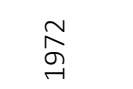 & $\begin{array}{l}\text { N } \\
\text { హิ }\end{array}$ & 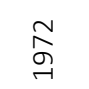 & 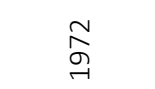 & 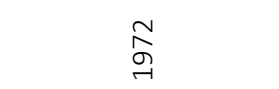 & 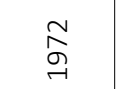 & 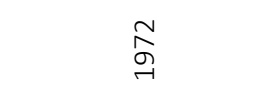 & 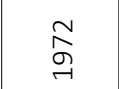 & 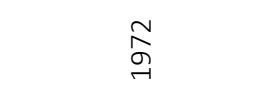 \\
\hline
\end{tabular}


Anexo 01- Lista de propagandas e reportagens da Mobilinea entre 1959 e 1975

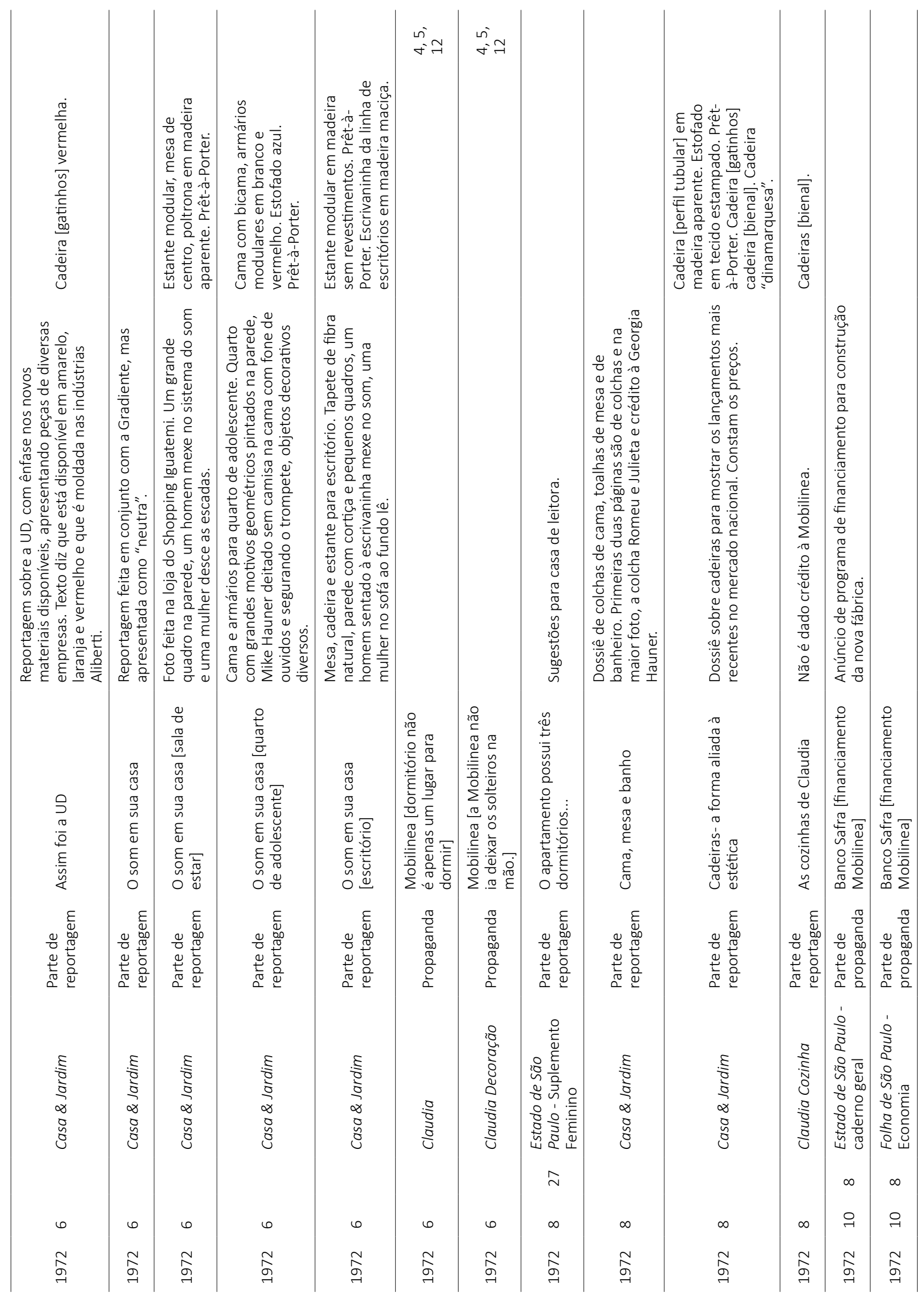


Anexo 01- Lista de propagandas e reportagens da Mobilinea entre 1959 e 1975

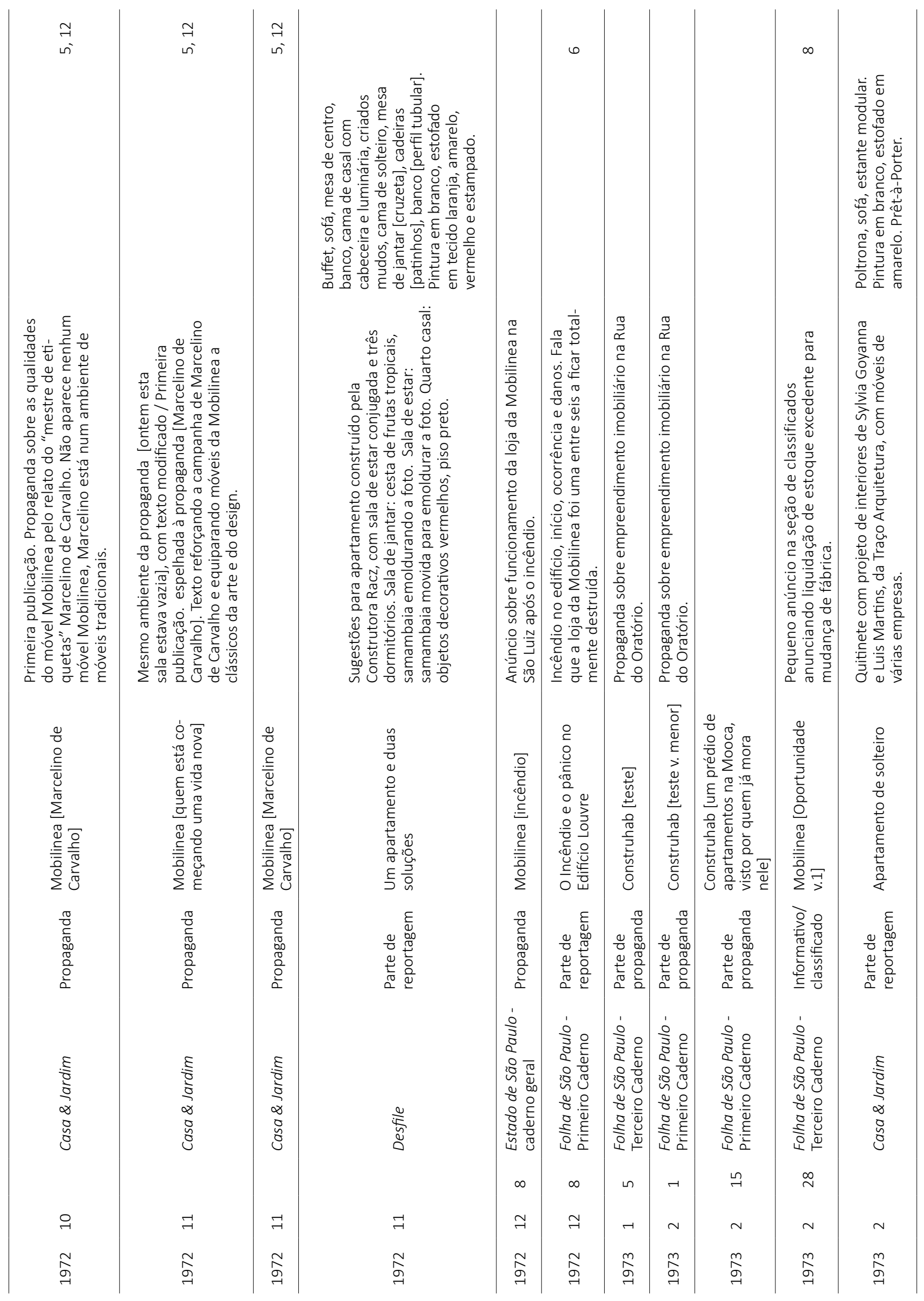


Anexo 01- Lista de propagandas e reportagens da Mobilinea entre 1959 e 1975

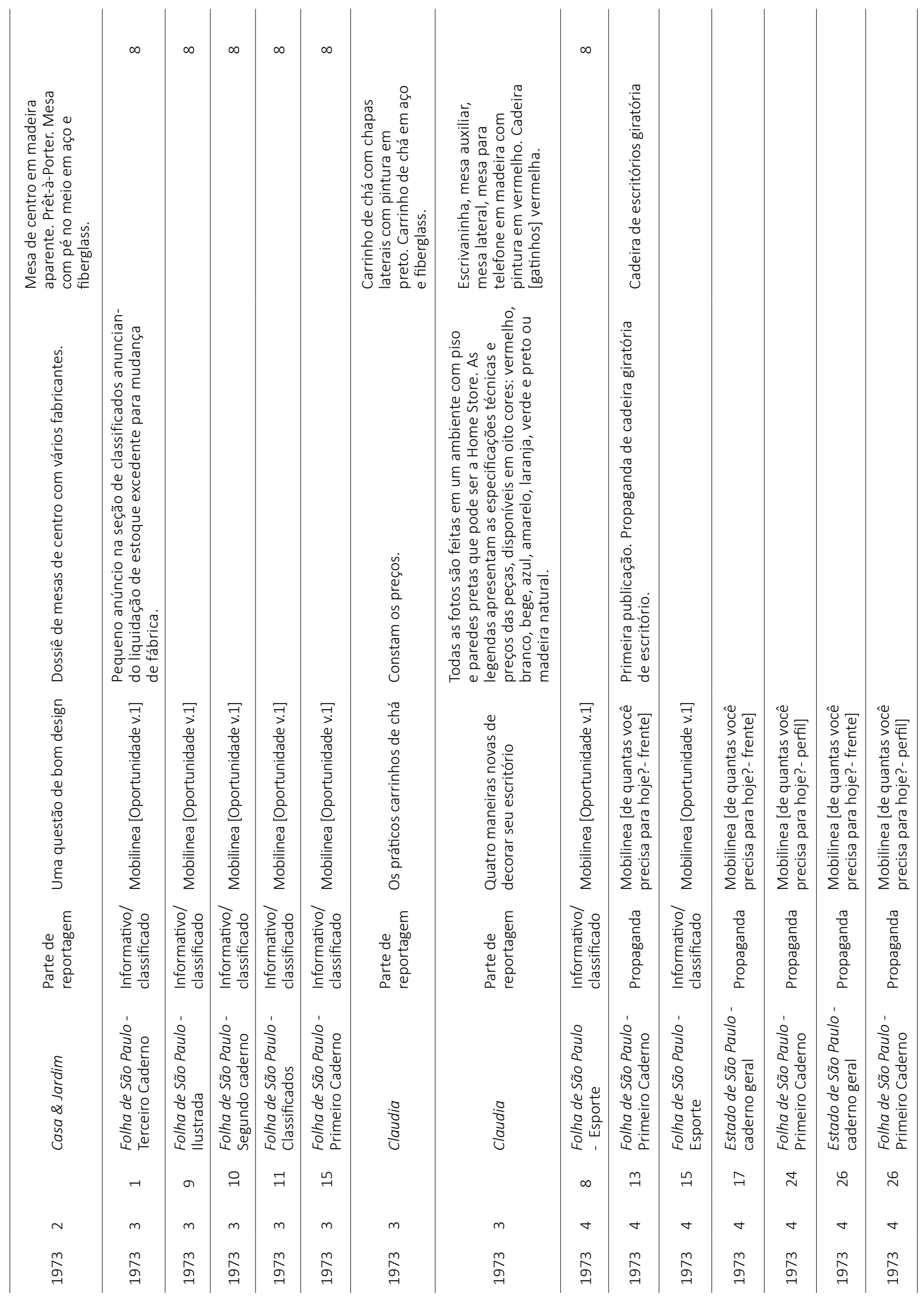


Anexo 01- Lista de propagandas e reportagens da Mobilinea entre 1959 e 1975

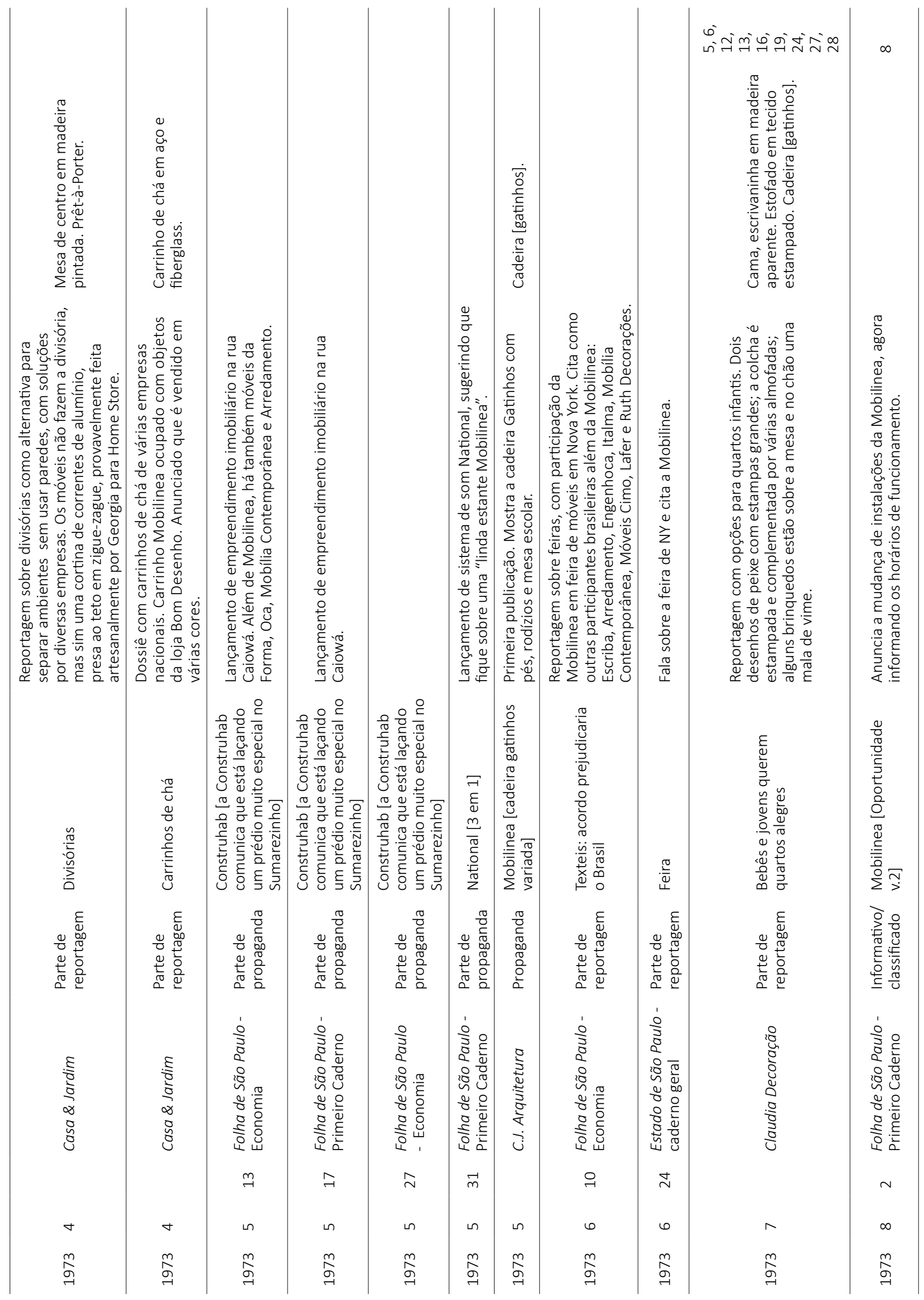


Anexo 01- Lista de propagandas e reportagens da Mobilinea entre 1959 e 1975

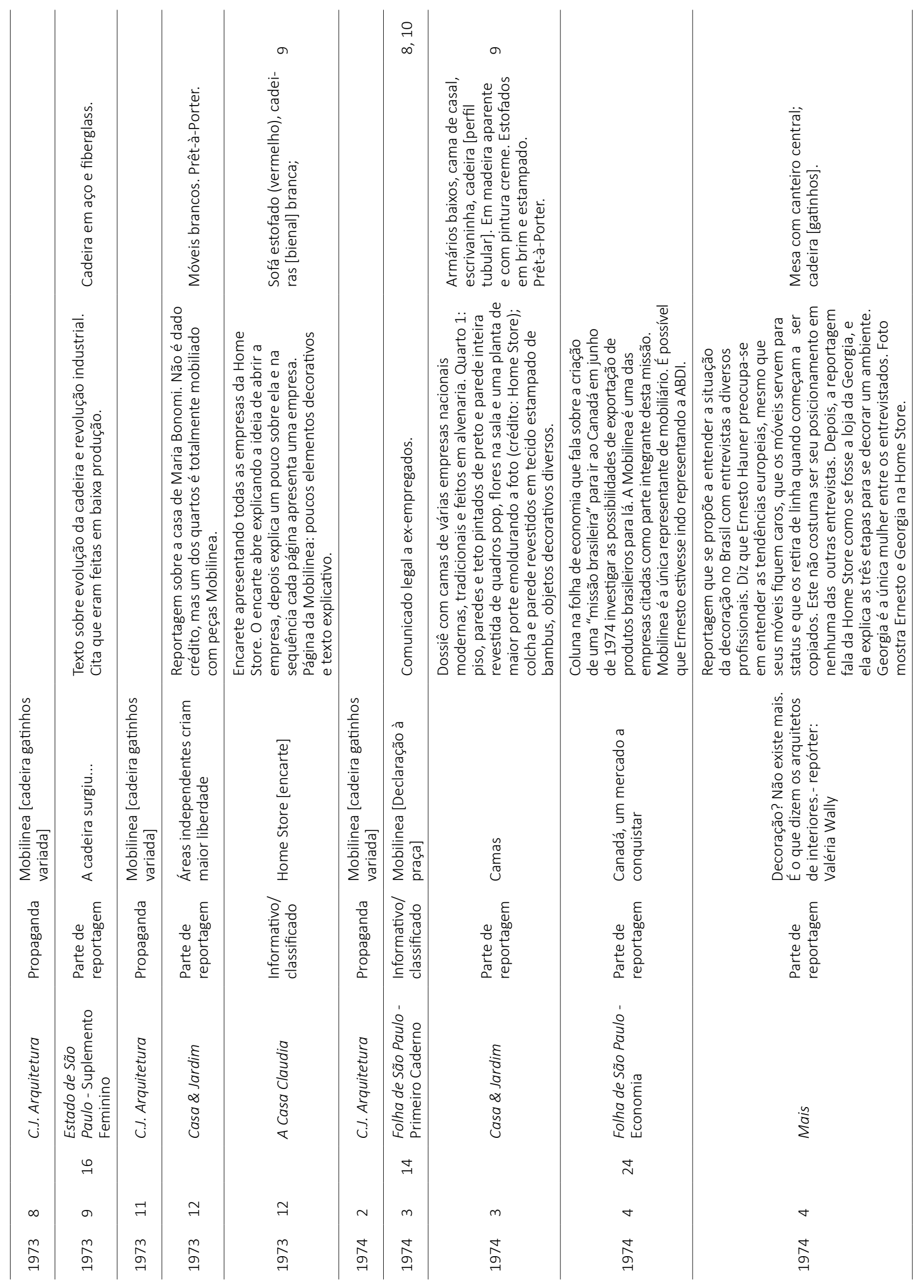




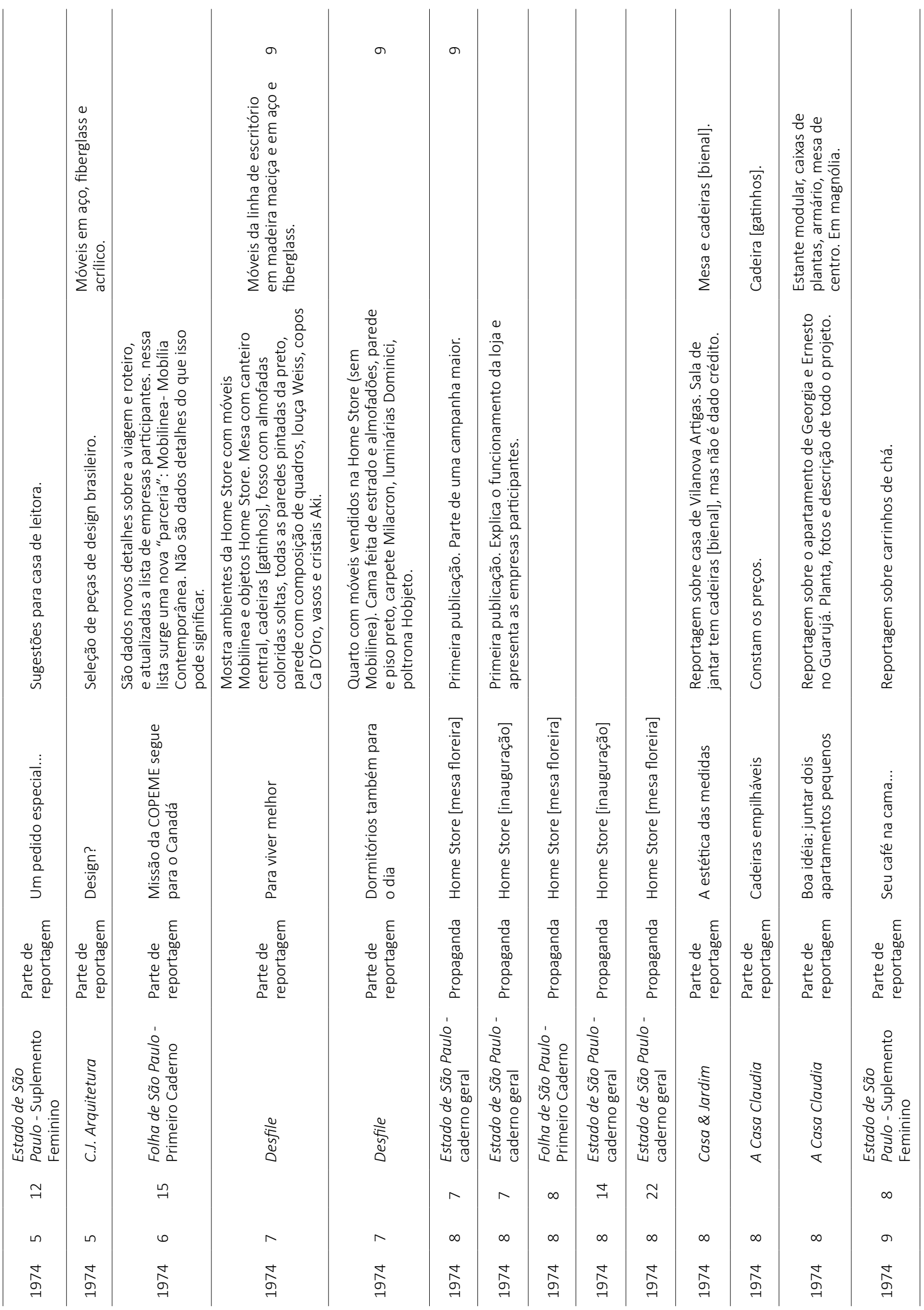


Anexo 01- Lista de propagandas e reportagens da Mobilinea entre 1959 e 1975

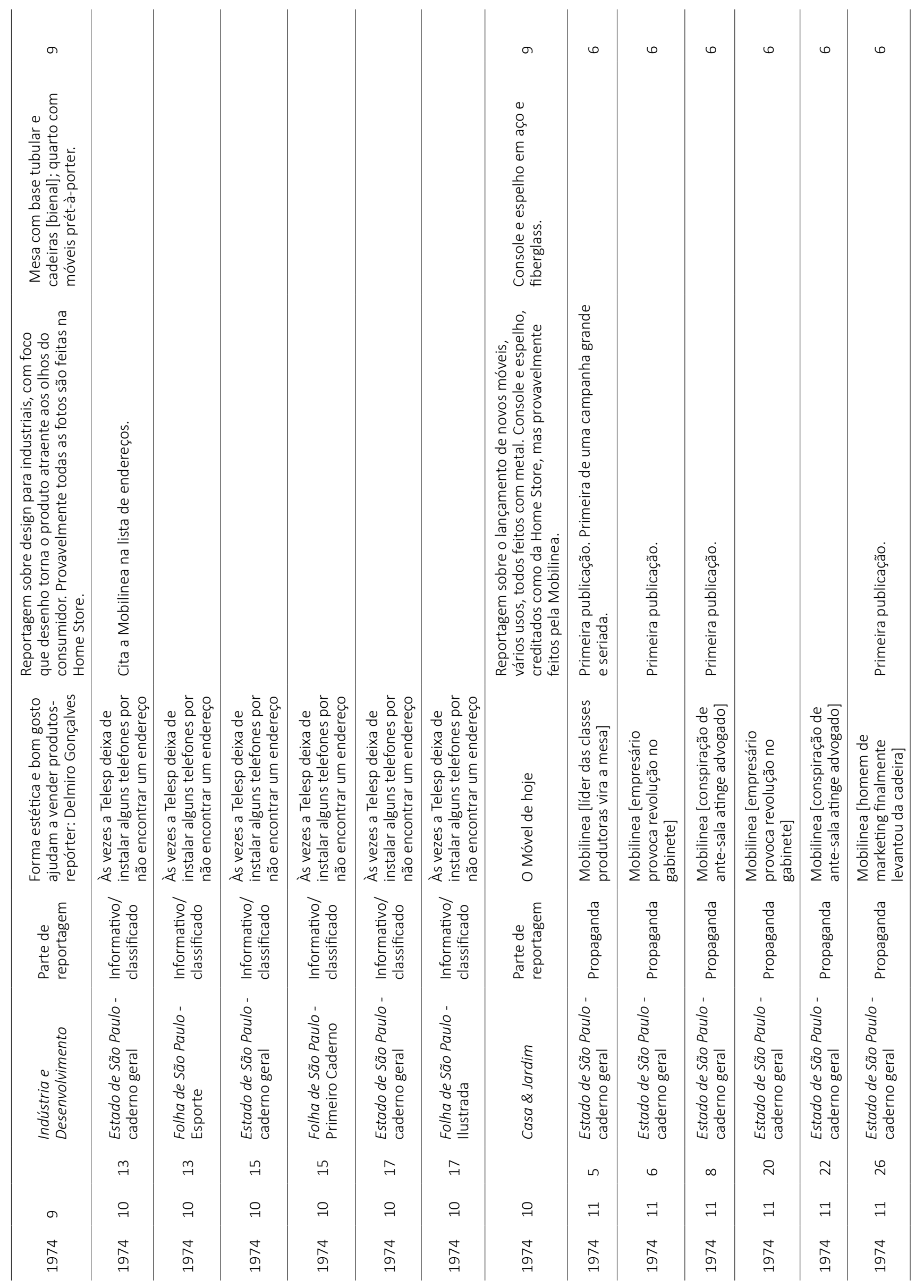


Anexo 01- Lista de propagandas e reportagens da Mobilinea entre 1959 e 1975

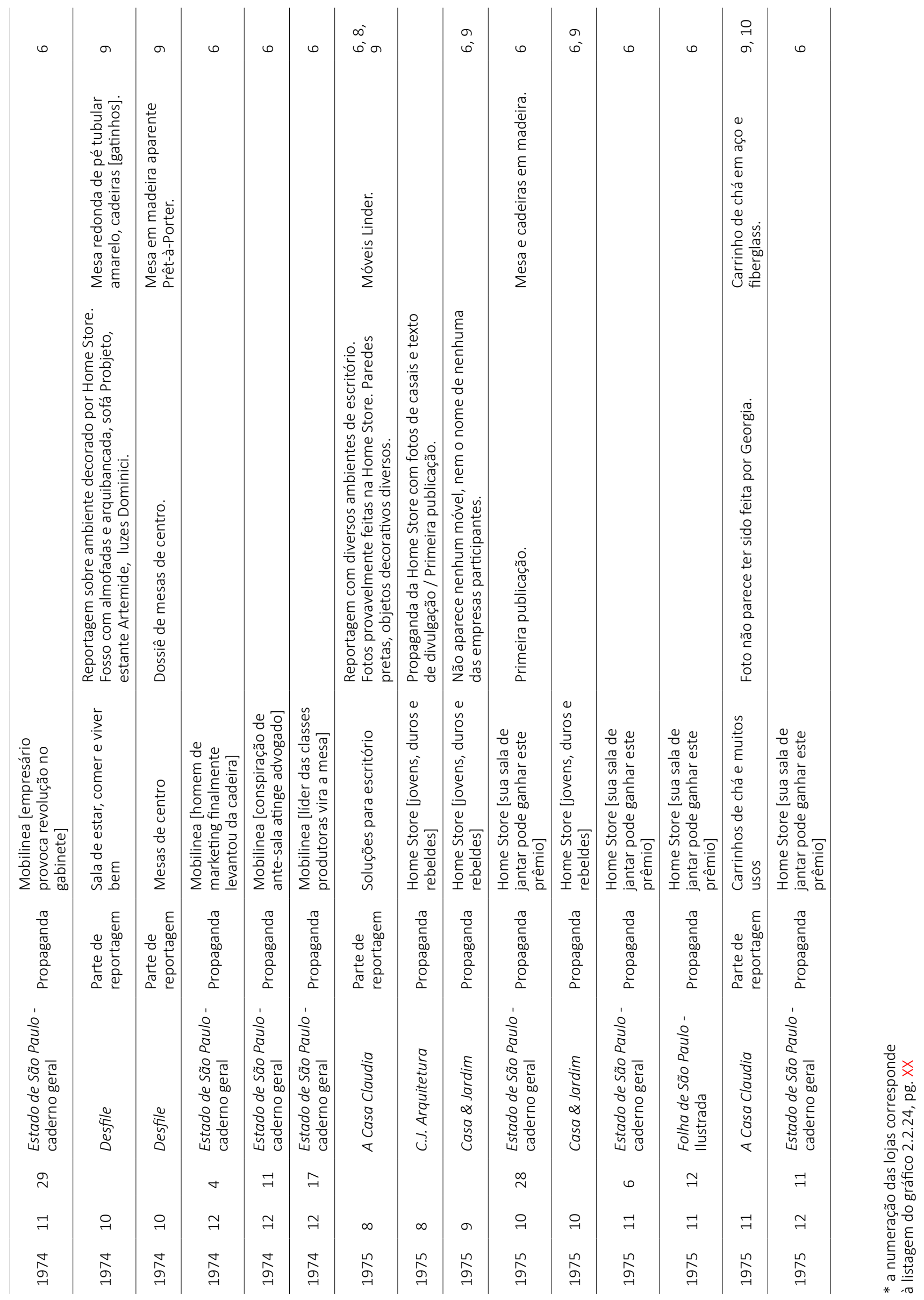


Anexo 02- Relação de documentos catalogados no acervo pessoal de Georgia Hauner

\begin{tabular}{|c|c|c|c|c|c|}
\hline \multicolumn{2}{|c|}{ Tema } & \multirow{2}{*}{$\begin{array}{l}\text { Título } \\
\text { Ernesto e Carlo Hauner }\end{array}$} & \multirow{2}{*}{$\begin{array}{l}\text { Natureza } \\
\text { A4, } 01 \text { foto PB } \\
\text { impressa }\end{array}$} & \multirow{2}{*}{$\begin{array}{l}\text { Data } \\
1953\end{array}$} & \multirow{2}{*}{$\begin{array}{l}\text { Descrição } \\
\text { Foto de Ernesto e Carlo Hauner. }\end{array}$} \\
\hline \multirow{3}{*}{$\stackrel{\substack{0 \\
\xi}}{\dot{0}}$} & \multirow{3}{*}{ 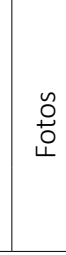 } & & & & \\
\hline & & Foto Georgia e Ernesto & $\begin{array}{l}\text { A4, } 01 \text { foto PB } \\
\text { impressa }\end{array}$ & 1955 & Foto de Georgia e Ernesto abraçados no ano de seu casamento. \\
\hline & & $\begin{array}{l}\text { Ernesto Huner e } \\
\text { Martin Eisler }\end{array}$ & $\begin{array}{l}\text { A4, } 01 \text { foto PB } \\
\text { impressa }\end{array}$ & 1956 & Foto de Ernesto e Martin Eisler em uma espécie de sítio. \\
\hline \multicolumn{2}{|c|}{ 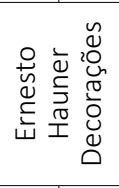 } & $\begin{array}{l}\text { Fotos e descritivo de } \\
\text { peças a venda }\end{array}$ & $\begin{array}{l}\text { Envelope com } \\
\text { quatro fotos } \\
\text { PB e um A4 } \\
\text { datilografado }\end{array}$ & $\begin{array}{l}1904 \\
1961\end{array}$ & $\begin{array}{l}\text { Três fotos de estantes de piso a teto e uma foto de estante em } \\
\text { caixas com mesa e cadeira. Todas montadas em ambientes } \\
\text { reais, com objetos decorativos. Lista com todos os modelos e } \\
\text { componentes para estante e buffet, com descrição de material } \\
\text { e medidas. }\end{array}$ \\
\hline \multirow{19}{*}{ 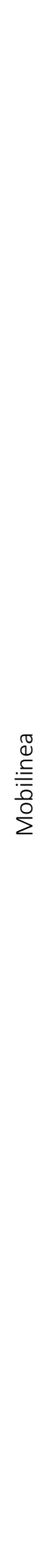 } & \multirow{19}{*}{$\begin{array}{l}\text { O } \\
\stackrel{0}{0} \\
\text { ㄴ }\end{array}$} & $\begin{array}{l}\text { Fotos do ambiente } \\
\text { [abóboras] }\end{array}$ & 09 fotos PB & 1968 & $\begin{array}{l}\text { Fotos de ângulos diferentes, em duas há uma pessoa (não sei se } \\
\text { é Georgia ou uma modelo). }\end{array}$ \\
\hline & & Funcionários & 33 fotos PB 10x15 & c. 1968 & $\begin{array}{l}\text { Fotos de funcionários, provavelmente da inauguração da fábrica } \\
\text { em Osasco. }\end{array}$ \\
\hline & & Berço [Mobilinha] & 03 fotos PB & c. 1969 & $\begin{array}{l}\text { Berço Mobilinha laqueado em branco: foto dele armado com } \\
\text { um bebê, foto dele como sofazinho com uma menina brincando, } \\
\text { foto dele como sofazinho com uma adolescente lendo. Fundo } \\
\text { infinito. Acho que não foram publicadas. }\end{array}$ \\
\hline & & Ernesto Hauner & $\begin{array}{l}\text { A4, } 04 \text { fotos PB } \\
\text { impressas }\end{array}$ & 1970 & $\begin{array}{l}\text { Fotos } 1 \text { e 4: cadeira em aço e fibra de vidro; fotos } 2 \text { e } 3 \text { : Ernesto } \\
\text { segurando e posando com a cadeira. }\end{array}$ \\
\hline & & Ernesto Hauner & $\begin{array}{l}\text { A4, } 02 \text { fotos PB } \\
\text { impressas }\end{array}$ & 1970 & Fotos de Ernesto no - provável - escritório da Mobilinea. \\
\hline & & $\begin{array}{l}\text { Fotos dos ambientes } \\
\text { editorial C.J. Visita } \\
1970\end{array}$ & $\begin{array}{l}05 \text { fotos pequenas } \\
\text { coloridas }\end{array}$ & 1970 & $\begin{array}{l}\text { Três fotos do quarto de casal em ângulos diversos e duas fotos } \\
\text { da sala de jantar em ângulos diversos. Em três fotos aparece } \\
\text { a iluminação cenográfica, sugerindo que foram tiradas como } \\
\text { making of. }\end{array}$ \\
\hline & & Georgia Hauner & Foto PB impressa & $\mathrm{jul} / 70$ & Foto de Georgia na revista A Casa de Claudia de 07/1970. \\
\hline & & $\begin{array}{l}\text { Carrinho de chá de aço } \\
\text { e fibra de vidro }\end{array}$ & 15 fotos PB & c. 1970 & $\begin{array}{l}\text { Ensaio com fotos de Silvinha levando o carrinho em diversos } \\
\text { ângulos e brincando. Alguns objetos sobre o carrinho. Fundo } \\
\text { infinito. Acho que não foram publicadas. }\end{array}$ \\
\hline & & $\begin{array}{l}\text { Mesa de aço e fibra de } \\
\text { vidro }\end{array}$ & 02 fotos PB & c. 1970 & $\begin{array}{l}\text { Mesa vista em ângulos diversos. Fundo infinito. Acho que não } \\
\text { foram publicadas. }\end{array}$ \\
\hline & & Sala de jantar & 01 foto PB & 1971 & $\begin{array}{l}\text { Foto da sala de jantar usada na propaganda [esta sala é de quem } \\
\text { passou ontem pela Mobilinea] divulgada três vezes em Casa \& } \\
\text { Jardim entre } 1971 \text { e } 1972 .\end{array}$ \\
\hline & & Quarto & 01 foto PB & 1971 & $\begin{array}{l}\text { Foto do quarto usado na propaganda [amanhã dormirei neste } \\
\text { quarto] divulgada em Casa \& Jardim 08/1971. }\end{array}$ \\
\hline & & $\begin{array}{l}\text { Estande Mobilinea na } \\
8^{\circ} \text { FUSE }\end{array}$ & 02 fotos coloridas & mai/72 & $\begin{array}{l}\text { Foto de dois ângulos bem diferente do estande da Mobilinea, } \\
\text { mostrando cenografia e os móveis divulgados. Ao lado das fotos, } \\
\text { título da feira, símbolo da Kodak e a legenda "cortesia da Kodak". }\end{array}$ \\
\hline & & Georgia Hauner & $\begin{array}{l}\text { A4, } 01 \text { foto cor } \\
\text { impressa }\end{array}$ & 1973 & Foto de Georgia no - provável - escritório da Mobilinea. \\
\hline & & Foto Georgia e Ernesto & $\begin{array}{l}\text { A4, } 01 \text { foto cor } \\
\text { impressa }\end{array}$ & $\mathrm{abr} / 74$ & Foto de Georgia e Ernesto tirada da revista Mais de 04/1974. \\
\hline & & Vaso de madeira & 01 foto $P B$ & $\begin{array}{l}\text { Sem } \\
\text { data }\end{array}$ & $\begin{array}{l}\text { Três vasos de madeira, dois sem revestimento e um pintado de } \\
\text { branco. Um vazio, dois com plantas. Fundo infinito. Acho que } \\
\text { não foram publicadas. }\end{array}$ \\
\hline & & $\begin{array}{l}\text { Estante de som e } \\
\text { jovens }\end{array}$ & 09 fotos PB & $\begin{array}{l}\text { Sem } \\
\text { data }\end{array}$ & $\begin{array}{l}\text { Estante de som modular laqueada, repleta de equipamentos } \\
\text { de som. Â frente, dois jovens no chão com discos, almofadas e } \\
\text { guitarra. Acho que não foram publicadas. }\end{array}$ \\
\hline & & Funcionários & $\begin{array}{l}17 \text { fotos PB } \\
\text { pequenas }\end{array}$ & $\begin{array}{l}\text { Sem } \\
\text { data }\end{array}$ & $\begin{array}{l}\text { Fotos de um jogo de futebol, provavelmente funcionários da } \\
\text { Mobilinea. }\end{array}$ \\
\hline & & $\begin{array}{l}\text { Mesa de escritório em } \\
\text { madeira e aço }\end{array}$ & 01 foto $P B$ & $\begin{array}{l}\text { Sem } \\
\text { data }\end{array}$ & $\begin{array}{l}\text { Mesa com estrutura em aço e superfícies em madeira. Cadeira } \\
\text { giratória em aço e estofado. É a primeira vez que vejo o uso de } \\
\text { aço e madeira juntos. Acho que não foi publicada. }\end{array}$ \\
\hline & & Mesa [cruzeta] & 01 foto PB & $\begin{array}{l}\text { Sem } \\
\text { data }\end{array}$ & $\begin{array}{l}\text { Foto de mesa [cruzeta] em madeira maciça com plantas sem } \\
\text { vaso sobre ela. Fundo infinito. }\end{array}$ \\
\hline
\end{tabular}


Anexo 02- Relação de documentos catalogados no acervo pessoal de Georgia Hauner

\begin{tabular}{|c|c|c|c|c|c|}
\hline & & Sala de jantar & 01 foto $P B$ & $\begin{array}{l}\text { Sem } \\
\text { data }\end{array}$ & $\begin{array}{l}\text { Foto de ambiente de jantar tirado em um cômodo de verdade, } \\
\text { móveis prèt-à-porter laqueados em banco e elementos } \\
\text { decorativos. Foto redonda. Não acho que foi publicada. }\end{array}$ \\
\hline & & $\begin{array}{l}\text { Mesa de centro } \\
\text { [bandeja] }\end{array}$ & 01 foto $P B$ & $\begin{array}{l}\text { Sem } \\
\text { data }\end{array}$ & $\begin{array}{l}\text { Mesa de centro quadrada com dois tampos, sendo que o de } \\
\text { cima parece ser de plástico e removível. Laqueada. Acho que } \\
\text { não foi publicada. }\end{array}$ \\
\hline & 足 & $\begin{array}{l}\text { Fotos de ambiente } \\
\text { mobiliado com móveis } \\
\text { de escritório }\end{array}$ & 05 fotos PB & $\begin{array}{l}\text { Sem } \\
\text { data }\end{array}$ & $\begin{array}{l}\text { Fotos de um ambiente de escritórios mobiliado com mesas de } \\
\text { madeira maciça e cadeiras de fibra de vidro. Forro do ambiente } \\
\text { é de concreto sem revestimento e estrutura aparente. }\end{array}$ \\
\hline & & $\begin{array}{l}\text { Foto de duas cadeiras } \\
\text { e mesa lateral }\end{array}$ & 01 foto $P B$ & $\begin{array}{l}\text { Sem } \\
\text { data }\end{array}$ & $\begin{array}{l}\text { Foto em fundo infinito de cadeiras e mesa lateral, com poucos } \\
\text { objetos decorativos. }\end{array}$ \\
\hline & & Buffet & 01 foto PB & $\begin{array}{l}\text { Sem } \\
\text { data }\end{array}$ & $\begin{array}{l}\text { Foto de buffet modular laqueado de branco com dois vasos de } \\
\text { flores. Entreaberto, vê-se utensílios dentro. Relógio antigo na } \\
\text { parede. Fundo infinito. }\end{array}$ \\
\hline & & $\begin{array}{l}\text { Parte de planta de } \\
\text { layout Shopping } \\
\text { Iguatemi }\end{array}$ & $\begin{array}{l}\text { A4, } 2 \text { pg } \\
\text { fotocopiadas de } \\
\text { desenho à mão }\end{array}$ & $\begin{array}{l}\text { Sem } \\
\text { data }\end{array}$ & $\begin{array}{l}\text { Indicado por Georgia como uma planta da Iguatemi, mas é difícil } \\
\text { entender a configuração em relação à outra planta. }\end{array}$ \\
\hline & & $\begin{array}{l}\text { Convite para } \\
\text { inauguração da loja no } \\
\text { Shopping Iguatemi }\end{array}$ & $\begin{array}{l}\text { A4 dobrado em } \\
\text { três com impres- } \\
\text { são PB }\end{array}$ & $\begin{array}{l}0712 \\
1966\end{array}$ & $\begin{array}{l}\text { Fora: em branco. Dentro: logo no cabeçalho; foto do relógio } \\
\text { antigo usado nas propagandas Mobilinea. Dentro dele, texto } \\
\text { datilografado do convite para inauguração. }\end{array}$ \\
\hline & & $\begin{array}{l}\text { Projeto de loja em } \\
\text { Brasília }\end{array}$ & $\begin{array}{l}\text { A2, } 4 \text { pg, helio- } \\
\text { grafia }\end{array}$ & c. 1973 & $\begin{array}{l}\text { Projeto completo com fachada, planta e cortes. Não é executivo, } \\
\text { mas especifica revestimentos, bem como os móveis e os objetos } \\
\text { decorativos e complementares. }\end{array}$ \\
\hline & $\frac{0}{9}$ & $\begin{array}{l}\text { Parte de planta de } \\
\text { layout Shopping } \\
\text { Iguatemi }\end{array}$ & $\begin{array}{l}\text { A4, fotocópia de } \\
\text { desenho à mão }\end{array}$ & $\begin{array}{l}\text { Sem } \\
\text { data }\end{array}$ & $\begin{array}{l}\text { Mostra ambiente de entrada e da vitrine, com layout de móveis } \\
\text { e especificação do piso. }\end{array}$ \\
\hline 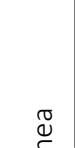 & & $\begin{array}{l}\text { Planta de layout } \\
\text { Shopping Iguatemi }\end{array}$ & $\begin{array}{l}\text { A3, manteiga com } \\
\text { desenho à mão }\end{array}$ & $\begin{array}{l}\text { Sem } \\
\text { data }\end{array}$ & $\begin{array}{l}\text { Planta para layout de loja, parece que para uma mudança } \\
\text { numa configuração existente, tem indicações do que já tem e } \\
\text { o que deve ser encomendado. Inclui vitrine interna e externa } \\
\text { planejamento interno. }\end{array}$ \\
\hline 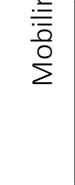 & 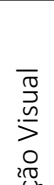 & $\begin{array}{l}\text { Estudo para vitrine } \\
\text { Mobilinea }\end{array}$ & $\begin{array}{l}02 \text { folhas grandes, } \\
\text { desenho à mão }\end{array}$ & $\begin{array}{l}\text { Sem } \\
\text { data }\end{array}$ & $\begin{array}{l}\text { Desenhos para a construção de uma estrutura de quatro } \\
\text { módulos de cerca de } 1,20 \text { m de altura, em caixas de igual largura, } \\
\text { cerca de } 15 \text { caixas de largura. Em cada uma ou duas está um } \\
\text { móvel Mobilinea, uma cor, um grafismo ou um fechamento com } \\
\text { uma das letras do nome da empresa. }\end{array}$ \\
\hline & 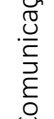 & Estudos para logo & $\begin{array}{l}\mathrm{A} 4,4 \mathrm{pg},+1 \mathrm{pg} \\
\text { cortada, desenho } \\
\text { à mão }\end{array}$ & $\begin{array}{l}\text { Sem } \\
\text { data }\end{array}$ & $\begin{array}{l}\text { Estudos com a fonte do logotipo Mobilinea formando diferentes } \\
\text { composições a partir do uso e sobreposição das letras em } \\
\text { tamanhos e cores diferentes. Feito com canetas e canetinhas. }\end{array}$ \\
\hline & & Estudo para pasta & $\begin{array}{l}\mathrm{A} 3,1 \mathrm{pg} \text {, desenho } \\
\text { à mão }\end{array}$ & $\begin{array}{l}\text { Sem } \\
\text { data }\end{array}$ & $\begin{array}{l}\text { Estudo para pasta com aba com o logo da Mobilinea } \\
\text { desconstruído. Feito com tinta. }\end{array}$ \\
\hline & & $\begin{array}{l}\text { Catálogo do Shopping } \\
\text { Iguatemi }\end{array}$ & $\begin{array}{l}\text { A5, } 62 \text { pg com } \\
\text { fotos PB e colorida } \\
\text { coladas em feltro } \\
\text { colorido }\end{array}$ & c. 1967 & $\begin{array}{l}\text { Capa e contracapa feitas madeira revestida; capa com uma } \\
\text { chapa de metal em que talvez houvesse algo gravado. Interior } \\
\text { feito com "páginas" de feltro em cores diversas com fotografias } \\
\text { coladas. Fotos com fundo infinito, em ambientações e lojas } \\
\text { (Iguatemi); maior parte das peças em madeira aparente. Há } \\
\text { indicação em algumas fotos das peças fora de linha. Algumas } \\
\text { fotos foram usadas também em propagandas. }\end{array}$ \\
\hline & $\begin{array}{l}\tilde{D} \\
\text { 品 }\end{array}$ & $\begin{array}{l}\text { Páginas de divulgação } \\
\text { da linha de escritórios }\end{array}$ & $\begin{array}{l}\text { A4, } 4 \text { pg com } \\
\text { texto, foto e } \\
\text { desenhos }\end{array}$ & c. 1970 & $\begin{array}{l}\text { Páginas avulsas apresentam fotos de peças da linha em madeira } \\
\text { maciça, algumas com descritivo e endereços. Última página } \\
\text { traz perspectiva simples de todas as peças, com numeração, } \\
\text { descritivo e dimensões. }\end{array}$ \\
\hline & $\frac{\frac{0}{\pi}}{\frac{\pi}{0}}$ & $\begin{array}{l}\text { Catálogo de móveis da } \\
\text { linha de escritórios }\end{array}$ & $\begin{array}{l}\text { A4, } 46 \mathrm{pg} \text {, papel } \\
\text { kraft e branco, } \\
\text { foto e texto. } \\
\text { Canaleta de } \\
\text { plástico }\end{array}$ & c. 1972 & $\begin{array}{l}\text { Páginas brancas tem foto de móveis Mobilinea. Alguns com } \\
\text { cadeiras Giroflex, alguns fundo infinito, alguns em ambientes } \\
\text { verdadeiros, cores, tipos e cenografia variados. Diagramação } \\
\text { e arranjo dos textos muito interessante. Endereço SP: Av. São } \\
\text { Luiz, 192; GB: Av. Nilo Peçanha. Papeis kraft: Perspectivas, vistas } \\
\text { e descritivo dos móveis, com espaço para anotação. Mesma } \\
\text { diagramação interessante das páginas de foto. }\end{array}$ \\
\hline & & $\begin{array}{l}\text { Catálogo de móveis da } \\
\text { linha de escritórios }\end{array}$ & $\begin{array}{l}\text { A4, } 48 \mathrm{pg} \text {, papel } \\
\text { kraft e branco, } \\
\text { foto e texto } \\
\text {. Canaleta de } \\
\text { plástico }\end{array}$ & c. 1972 & $\begin{array}{l}\text { Apresenta muitas páginas em comum ao outro catálogo, } \\
\text { somando páginas que foram encontradas soltas e uma bem } \\
\text { diferente de uma poltrona em madeira moldada. }\end{array}$ \\
\hline
\end{tabular}




\begin{tabular}{|c|c|c|c|c|c|}
\hline & & $\begin{array}{l}\text { Ficha para compor } \\
\text { estante } 1600\end{array}$ & $\begin{array}{l}\text { A5, } 7 \text { pg com im- } \\
\text { pressão em azul }\end{array}$ & $\begin{array}{l}\text { Sem } \\
\text { data }\end{array}$ & $\begin{array}{l}\text { Páginas grampeadas. Na primeira, linhas com indicações } \\
\text { de medidas para desenhar uma estante em escala com os } \\
\text { elementos escolhidos. Nas seguintes, todos os elementos } \\
\text { possíveis de usar (montantes, fechamentos, gavetas, prateleiras, } \\
\text { etc), com espaço para anotações. }\end{array}$ \\
\hline & 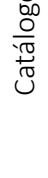 & $\begin{array}{l}\text { Catálogo da linha de } \\
\text { escritórios }\end{array}$ & $\begin{array}{l}1 / 3 \text { de } A 4,14 \mathrm{pg}, \\
\text { PB }\end{array}$ & $\begin{array}{l}\text { Sem } \\
\text { data }\end{array}$ & $\begin{array}{l}\text { Capa tem desenho abstrato e marca. Dentro: pequenas } \\
\text { fichas de todas as peças de escritório em madeira maciça } \\
\text { com perspectiva, Modelo, descrição, material, dimensões. Há } \\
\text { Modelos que só aparecem como de escritório e outros que são } \\
\text { também da linha residencial. Endereço citado: Galeria Zarvos. }\end{array}$ \\
\hline & & $\begin{array}{l}\text { Catálogo de móveis da } \\
\text { linha de escritórios }\end{array}$ & $\begin{array}{l}1 / 3 \text { de } A 4,12 \mathrm{pg} \\
\text { PB }\end{array}$ & $\begin{array}{l}\text { Sem } \\
\text { data }\end{array}$ & $\begin{array}{l}\text { Sem capa, apenas grandes fotos dos móveis de escritórios em } \\
\text { madeira maciça, isolados ou em grupos, em fundo infinito. }\end{array}$ \\
\hline & & $\begin{array}{l}\text { Catálogo Alex Linder } \\
\text { linha L.CD em alemão }\end{array}$ & $\begin{array}{l}\text { A4, } 14 \text { pg foto e } \\
\text { texto coloridos }\end{array}$ & $\begin{array}{l}\text { Sem } \\
\text { data }\end{array}$ & $\begin{array}{l}\text { Catálogo apresenta diversas peças inseridas em ambiente } \\
\text { corporativo. Sem elementos decorativos ou pessoas. Depois } \\
\text { apresenta peça a peça com medidas e descritivo. }\end{array}$ \\
\hline & .0. & $\begin{array}{l}\text { Flyer Mobilinea de } \\
\text { móveis Linder linha } \\
\text { L.CD }\end{array}$ & $\begin{array}{l}\text { A4, texto e ima- } \\
\text { gem PB }\end{array}$ & c. 1975 & $\begin{array}{l}\text { Anuncia o lançamento da linha Linder pela Mobilinea, com breve } \\
\text { explicativo sobre os componentes e uma foto de ambiente. }\end{array}$ \\
\hline & 㞭 & $\begin{array}{l}\text { Catálogo Mobilinea + } \\
\text { L.CD Alex Linder }\end{array}$ & $\begin{array}{l}\text { A4, } 6 \mathrm{pg} \text {, foto e } \\
\text { texto coloridos }\end{array}$ & c. 1975 & $\begin{array}{l}\text { Catálogo apresenta as diversas peças, com imagens similares ao } \\
\text { catálogo alemão, porém com cadeiras da Mobilinea. Não tem } \\
\text { texto de abertura. Na contracapa, há um texto promocional. }\end{array}$ \\
\hline & & $\begin{array}{l}\text { Catálogo Alex Linder } \\
\text { linha L.CD em inglês }\end{array}$ & $\begin{array}{l}\text { A4, } 18 \mathrm{pg} \text { foto e } \\
\text { texto coloridos }\end{array}$ & $\begin{array}{l}\text { Sem } \\
\text { data }\end{array}$ & $\begin{array}{l}\text { Catálogo apresenta as diversas peças, com imagens similares ao } \\
\text { catálogo alemão. }\end{array}$ \\
\hline & $\tilde{0}$ & $\begin{array}{l}\text { Texto de apresentação } \\
\text { da linha prèt-à-porter }\end{array}$ & $\begin{array}{l}\text { A4, } 1 \mathrm{pg} \text {, datilo- } \\
\text { grafado }\end{array}$ & c. 1971 & $\begin{array}{l}\text { Texto para lançamento da linha prèt-à-porter, explicando suas } \\
\text { qualidades. Não sei onde/se foi publicado. }\end{array}$ \\
\hline & $\stackrel{\widetilde{\Perp}}{\Perp}$ & $\begin{array}{l}\text { Ernesto Hauner } \\
\text { falando sobre a } \\
\text { indústria de móveis }\end{array}$ & $\begin{array}{l}\text { A4, } 3 \mathrm{pg} \text {, datilo- } \\
\text { grafado }\end{array}$ & $\begin{array}{l}\text { Sem } \\
\text { data }\end{array}$ & $\begin{array}{l}\text { Fala sobre a situação de industrialização, importação de } \\
\text { maquinário, exportação de matéria-prima e design. }\end{array}$ \\
\hline 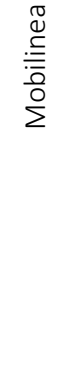 & & $\begin{array}{l}\text { Panfleto de divulgação } \\
\text { dos móveis }\end{array}$ & $\begin{array}{l}\text { A4, } 1 \text { pg dobrada } \\
\text { em 3, texto e foto } \\
\text { PB, frente e verso. }\end{array}$ & c. 1965 & $\begin{array}{l}\text { Frente: página dividida em seis, mostra estante modular, sofás, } \\
\text { mesa oval com cadeiras, cama de casal com criados mudos, } \\
\text { mesa expansível com cadeiras, poltrona com sofás. Móveis são } \\
\text { identificados por modelo e número, com descrição dos materiais } \\
\text { e dimensões. Fotografias em fundo infinito com adereços. Dois } \\
\text { logos pequenos. Verso: fotografia grande de estante modular } \\
\text { com cadeira. Móveis são identificados por Modelo e número, } \\
\text { com descrição dos materiais e dimensões. Fotografias em fundo } \\
\text { infinito com adereços. Um logo grande. Endereços de revenda: } \\
\text { Rua Augusta (SP), Rua Montenegro (RJ), Móveis Ralf (BA), Taba } \\
\text { (GO), Morada (MG). }\end{array}$ \\
\hline & & $\begin{array}{l}\text { Mobilinea [poltrona } \\
\text { Bienal 68] }\end{array}$ & Página de revista & c. 1968 & $\begin{array}{l}\text { Metade da propaganda de duas páginas da poltrona que faz } \\
\text { parte da Bienal de } 1968 \text { e que aparece em Claudia Decoração } \\
\text { 12/1968. }\end{array}$ \\
\hline & 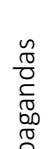 & $\begin{array}{l}\text { Mobilinea [nova } \\
\text { vida nova casa nôvo } \\
\text { sonho... Mobilinea } \\
\text { jovem] }\end{array}$ & Página de revista & c. 1969 & $\begin{array}{l}\text { Página de revista com propaganda que aparece em Claudia } \\
\text { 04/1969. }\end{array}$ \\
\hline & 음 & Fotos Jô Soares & 15 fotos PB & $\begin{array}{l}\text { Sem } \\
\text { data }\end{array}$ & $\begin{array}{l}\text { Campanha publicitária em que Jô Soares, vestido de ladrão, ia } \\
\text { assaltar uma casa, mas acha o sofá tão confortável que desiste } \\
\text { e dorme nele. Sofá de três lugares e mesa de centro [cruzeta] } \\
\text { e objetos roubados e ferramentas para arrombar a casa } \\
\text { completam a foto, em fundo infinito. Nunca foram publicadas. }\end{array}$ \\
\hline & & Mobilinea, filme $30^{\prime \prime}$ & $\begin{array}{l}\text { A4, } 2 \mathrm{pg} \text {, datilo- } \\
\text { grafado }\end{array}$ & $\begin{array}{l}\text { Sem } \\
\text { data }\end{array}$ & $\begin{array}{l}\text { Roteiro para propaganda com duração de } 30 \text { segundos, } \\
\text { mostrando quatro ambientes de uma casa construídos em } \\
\text { estúdio no cotidiano de uma família com casal e dois filhos. Não } \\
\text { há muita descrição das peças apresentadas, mas sim do estilo de } \\
\text { vida retratado. }\end{array}$ \\
\hline & & $\begin{array}{l}\text { Mobilinea [sofás de } \\
\text { tecido] }\end{array}$ & $\begin{array}{l}\text { Prova de impres- } \\
\text { são }\end{array}$ & $\begin{array}{l}\text { Sem } \\
\text { data }\end{array}$ & $\begin{array}{l}\text { Propaganda com modelo de sofá e poltrona que não aparece } \\
\text { em nenhum outro catálogo ou propaganda. Não foi publicada } \\
\text { nas revistas examinadas. }\end{array}$ \\
\hline & & $\begin{array}{l}\text { Mock-up: Mobilinea [if } \\
\text { you would never part } \\
\text { with these] }\end{array}$ & $\begin{array}{l}\text { A4 com fotos e } \\
\text { desenhos à mão }\end{array}$ & $\begin{array}{l}\text { Sem } \\
\text { data }\end{array}$ & $\begin{array}{l}\text { Montagem de propaganda. Texto em inglês e alemão com } \\
\text { fotos e desenhos, de ambientes clássicos, não foi publicada nas } \\
\text { revistas examinadas. }\end{array}$ \\
\hline
\end{tabular}




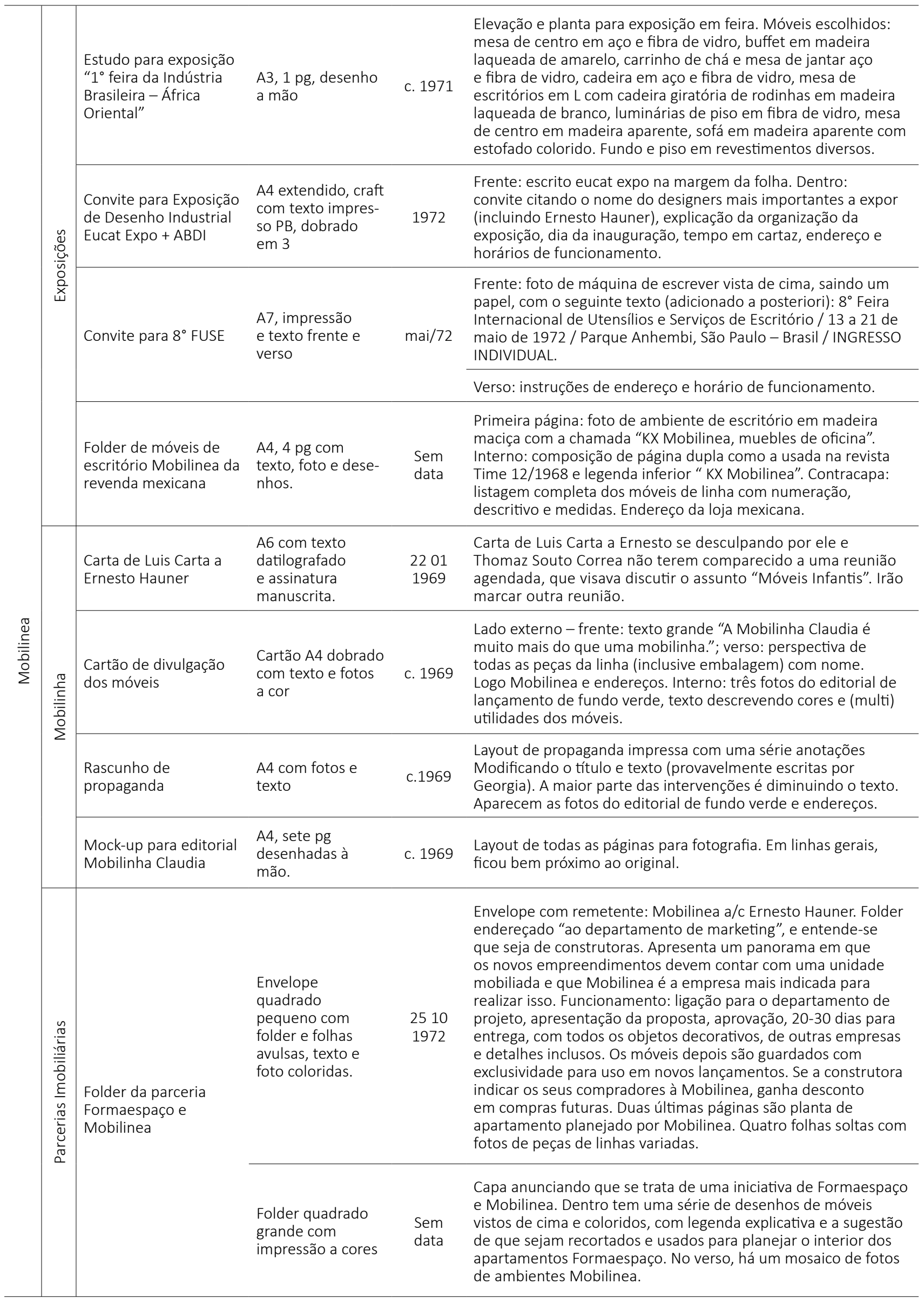


Anexo 02- Relação de documentos catalogados no acervo pessoal de Georgia Hauner

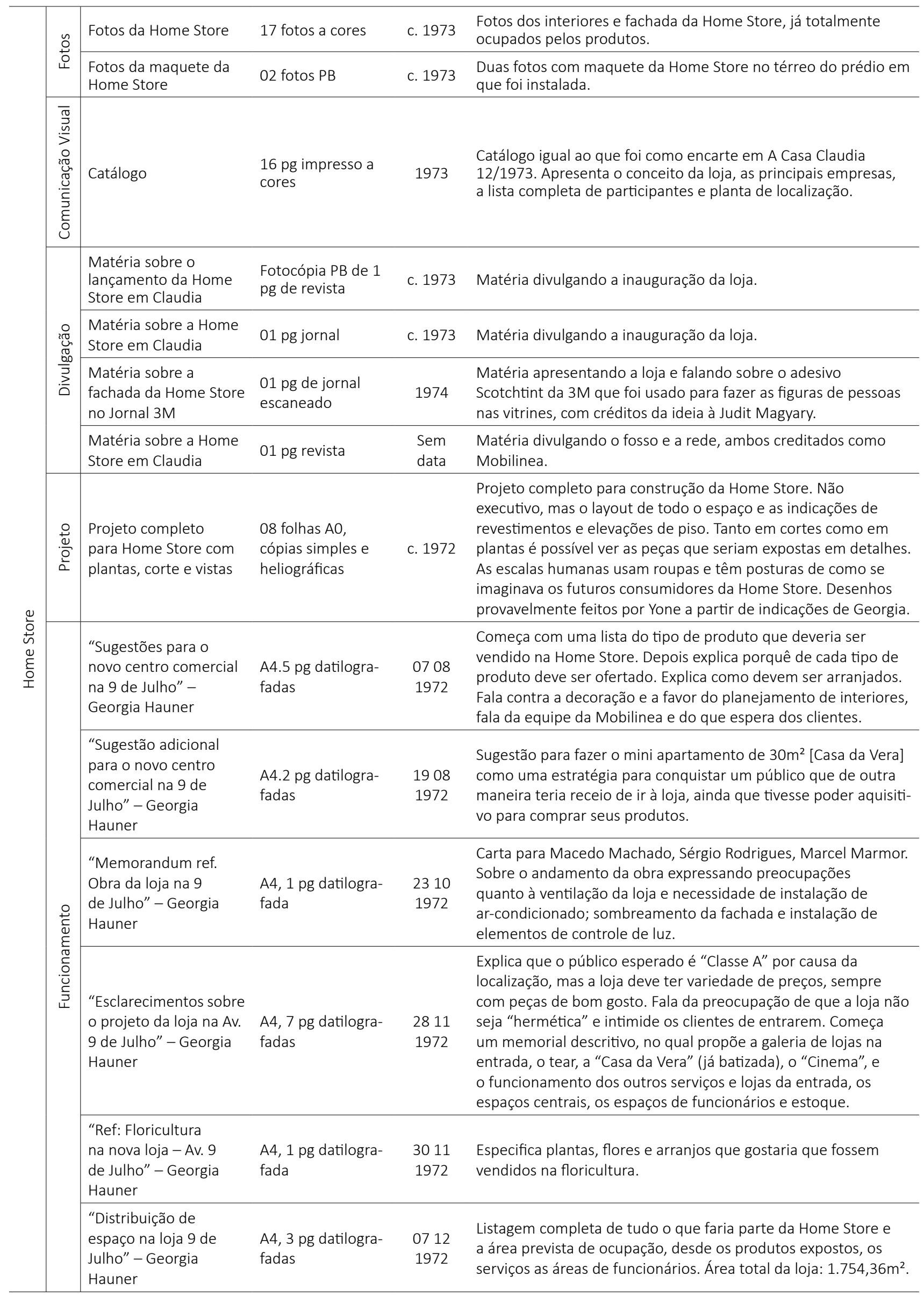




\begin{tabular}{|c|c|c|c|c|c|}
\hline \multirow{3}{*}{ 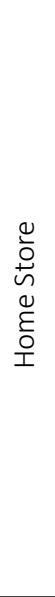 } & \multirow{3}{*}{ 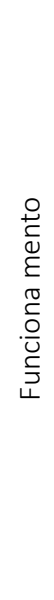 } & $\begin{array}{l}\text { "Nova firma de } \\
\text { comercialização } \\
\text { de móveis e } \\
\text { complementos para o } \\
\text { lar" - John de Souza }\end{array}$ & $\begin{array}{l}\text { A4.4 pg datilogra- } \\
\text { fadas }\end{array}$ & c. 1972 & $\begin{array}{l}\text { Texto anterior à criação da loja. Começa explicando os motivos, } \\
\text { que são problemas com revendas, há um interesse e demanda } \\
\text { dos clientes. Depois apresenta as vantagens aos fabricantes e } \\
\text { clientes. Na sequência, explica a estruturação econômica para as } \\
\text { empresas participantes. Havia um desejo de ser pioneiro em SP } \\
\text { e logo abrir uma filial no RJ e outras cidades. }\end{array}$ \\
\hline & & $\begin{array}{l}\text { "Loja Nove de Julho" - } \\
\text { John de Souza }\end{array}$ & $\begin{array}{l}\text { A4, } 8 \mathrm{pg}, \\
\text { datilografadas }\end{array}$ & c. 1972 & $\begin{array}{l}\text { Apresenta os modelos comerciais da nova loja: terceirização, } \\
\text { revenda e representação. Na sequência, apresenta os } \\
\text { principais setores a ser organizados com sugestões de pessoas } \\
\text { a serem contatadas e/ou os responsáveis pelo andamento } \\
\text { destes contatos. }\end{array}$ \\
\hline & & $\begin{array}{l}\text { Cartela de adesivos } \\
\text { dos móveis à venda }\end{array}$ & $\begin{array}{l}\text { A3, uma folha de } \\
\text { adesivo }\end{array}$ & c. 1973 & $\begin{array}{l}\text { Folha de adesivo com marca d'água escrito "home store" por } \\
\text { toda a folha. Sobre ela, uma série de desenhos de móveis } \\
\text { originalmente desenhados à mão, destacados para uso no } \\
\text { planejamento da casa de clientes. }\end{array}$ \\
\hline \multirow{4}{*}{ 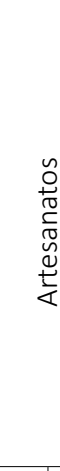 } & & $\begin{array}{l}\text { Rascunho do desenho } \\
\text { para almofadas }\end{array}$ & $\begin{array}{l}\text { A4, PB, } 1 \mathrm{pg}, \\
\text { fotocópia de } \\
\text { desenho }\end{array}$ & 1968 & $\begin{array}{l}\text { Desenho da mulher deitada a ser bordada em três almofadas, } \\
\text { com assinatura de Georgia. }\end{array}$ \\
\hline & & Colcha Romeu e Julieta & $\begin{array}{l}04 \text { fotos da colcha } \\
\text { Original }\end{array}$ & $\begin{array}{l}1970- \\
2013\end{array}$ & $\begin{array}{l}\text { Fotos da colcha Original bordada em piquet feita por Georgia } \\
\text { para editorial de Casa \& Jardim de } 1970 \text { e posteriormente } \\
\text { reproduzida em silk-screen. }\end{array}$ \\
\hline & & Luminárias de papel & 12 fotos PB & $\begin{array}{l}\text { Sem } \\
\text { data }\end{array}$ & $\begin{array}{l}\text { Fotos de vários Modelos de luminárias feitos por Georgia, } \\
\text { provavelmente para divulgação. }\end{array}$ \\
\hline & & Luminárias de papel & $\begin{array}{l}19 \text { filipetas de pa- } \\
\text { pel datilografadas }\end{array}$ & $\begin{array}{l}\text { Sem } \\
\text { data }\end{array}$ & $\begin{array}{l}\text { Fichas com todos os modelos (romântico, oval, pião, pera, } \\
\text { lanterna, bola, São Luiz, achatado, coluna), tamanhos (pequena, } \\
\text { média, grande), acabamentos (sem e com tecido, sem e com } \\
\text { passamanaria) e valores das luminárias. }\end{array}$ \\
\hline \multirow{5}{*}{ 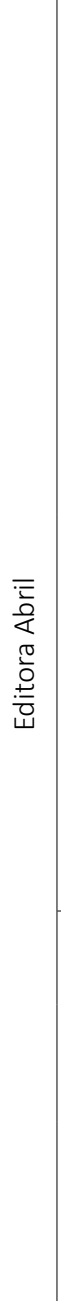 } & \multirow[t]{2}{*}{ 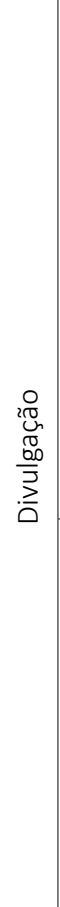 } & $\begin{array}{l}\text { Folder de divulgação } \\
\text { institucional: "Abril - } \\
\text { uma história brasileira" }\end{array}$ & $\begin{array}{l}\text { A4, } 64 \mathrm{pg} \text { com } \\
\text { fotos coloridas e } \\
\text { texto }\end{array}$ & $\operatorname{mar} / 71$ & $\begin{array}{l}\text { Folder que visa contar ao leitor "o que somos, como somos e o } \\
\text { que fazemos". São apresentados os títulos periódicos da editora } \\
\text { com informações sobre público, ano de lançamento e tiragem, } \\
\text { situando dentro da trajetória da Abril. Também é descrita a } \\
\text { estrutura das redações com fotos. A página de Claudia tem a } \\
\text { foto de um cenário feito por Georgia (sala branca Mobilinea + } \\
\text { quarto amarelo Arredamento, mostrando o estúdio). A legenda } \\
\text { diz que a foto foi tirada na Abril e planejada por uma equipe } \\
\text { da casa. São apresentados também os fascículos, incluindo a } \\
\text { coleção "Gênios da Pintura", organizada por Bardi em } 1967 \text { e } \\
\text { usada por Georgia em Claudia. É feita uma apresentação dos } \\
\text { departamentos e divisões da empresa, a gráfica e a distribuição. } \\
\text { Os volumes são vendidos em bancas e por representantes. } \\
\text { Finalmente, aparecem dados socioeconômicos do país e } \\
\text { atividades educativas promovidas pela editora. }\end{array}$ \\
\hline & & $\begin{array}{l}\text { Folder para empresas } \\
\text { anunciarem em revis- } \\
\text { tas: "Por que revistas?' }\end{array}$ & $\begin{array}{l}\text { A4, } 64 \text { pg com } \\
\text { fotos coloridas e } \\
\text { texto }\end{array}$ & & $\begin{array}{l}\text { Folder que visa explicar os benefícios de anunciar em revistas } \\
\text { da editora. As características apresentadas em revistas } \\
\text { são: seletividade, qualidade, flexibilidade, envolvimento, } \\
\text { permanência, utilidade, portabilidade, intimidade, versatilidade } \\
\text { e credibilidade. Apresenta novidades em diversos campos e } \\
\text { como foram as revistas quem divulgaram este conhecimento. } \\
\text { Na página de decoração é apresentado o ambiente que Georgia } \\
\text { criou e fotografou de cima no Estúdio Giró e o texto fala sobre } \\
\text { como as revistas trouxeram as novidades do design e ensinaram } \\
\text { como deixar a casa personalizada e moderna. Ao final, apresenta } \\
\text { todos os títulos com um breve descritivo. }\end{array}$ \\
\hline & \multirow{3}{*}{$\frac{\frac{\pi}{0}}{\frac{\pi}{\partial}}$} & $\begin{array}{l}\text { "Cursinho Rápido de } \\
\text { Decoração" }\end{array}$ & $\begin{array}{l}\text { A4, } 3 \mathrm{pg}, \\
\text { datilografado }\end{array}$ & 1968 & $\begin{array}{l}\text { Texto produzido para Claudia Decoração agosto/1968 escrito por } \\
\text { Georgia Hauner. }\end{array}$ \\
\hline & & $\begin{array}{l}\text { Roteiro Claudia Noiva } \\
\text { - Março/1968 }\end{array}$ & $\begin{array}{l}\text { A4, } 3 \mathrm{pg}, \\
\text { datilografado }\end{array}$ & $\begin{array}{l}\text { c. } 03 / \\
1968\end{array}$ & $\begin{array}{l}\text { Roteiro indicando fotos a ser feitas e texto para editorial do } \\
\text { jovem casal. O texto não foi aproveitado na revista, mas direção } \\
\text { de arte é precisa. }\end{array}$ \\
\hline & & $\begin{array}{l}\text { Mock-up Claudia } \\
\text { Decoração- } \\
\text { Agosto/1968 }\end{array}$ & $\begin{array}{l}\text { A4, } 33 \mathrm{pg}, \\
\text { fotografia PB } \\
\text { colada em papel }\end{array}$ & $\begin{array}{l}\text { c. } 08 / \\
1968\end{array}$ & $\begin{array}{l}\text { Mock-up de todas as páginas feitas por Georgia para esta edi- } \\
\text { ção, com as fotografias usadas recortadas e coladas da maneira } \\
\text { que deveriam ser diagramadas. O espaço dos textos é deixado } \\
\text { vazio. Há alguma mudança entre o mock-up e a versão final, } \\
\text { mas nada significativo. }\end{array}$ \\
\hline
\end{tabular}




\begin{tabular}{|c|c|c|c|c|c|}
\hline \multirow{4}{*}{ 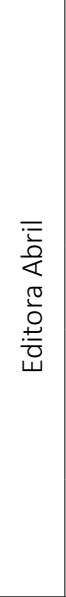 } & \multirow{4}{*}{$\frac{\frac{\pi}{0}}{\frac{\pi}{0}}$} & $\begin{array}{l}\text { "Era uma vez uma } \\
\text { garagem..." }\end{array}$ & $\begin{array}{l}\text { A4, } 11 \mathrm{pg}, \\
\text { datilografado }\end{array}$ & 1969 & $\begin{array}{l}\text { Conto de ficção escrito por Georgia Hauner para revista Claudia } \\
\text { (não publicado). Conta a história de duas irmãs que renovaram } \\
\text { a garagem sem uso da casa da família. Elas têm a ideia em uma } \\
\text { revista, aprendem a desenhar a planta e resolvem o espaço } \\
\text { basicamente com soluções artesanais e ajuda de amigos. O pai } \\
\text { é conservador, mas elas mostram com o resultado final como o } \\
\text { estilo de vida Moderno é bonito e confortável. }\end{array}$ \\
\hline & & $\begin{array}{l}\text { Planta - Casa de } \\
\text { Claudia }\end{array}$ & $\begin{array}{l}\text { A4, } 1 \mathrm{pg} \text {, desenho } \\
\text { a mão }\end{array}$ & 1969 & $\begin{array}{l}\text { Planta da Casa de Claudia, não foi aproveitada na revista (que } \\
\text { mostra a mesma planta, porém perspectivada, em 06/1969). }\end{array}$ \\
\hline & & $\begin{array}{l}\text { Mock-up Claudia } \\
\text { Decoração-Gradiente }\end{array}$ & $\begin{array}{l}\text { A4, } 4 \text { pg, desenho } \\
\text { a mão }\end{array}$ & $\begin{array}{l}\text { c. } 09 / \\
1969\end{array}$ & $\begin{array}{l}\text { Mock-up do editorial sobre a sala feita para ouvir música de } \\
\text { Claudia Decoração de dezembro/1969. Feito em canetinhas } \\
\text { coloridas. O estudo tem duas páginas a mais do que a matéria } \\
\text { publicada, mas no geral é bastante semelhante. }\end{array}$ \\
\hline & & $\begin{array}{l}\text { Dados - reforma } \\
\text { apartamento em } \\
\text { Guarujá }\end{array}$ & $\begin{array}{l}\text { A4, } 1 \mathrm{pg}, \\
\text { datilografado }\end{array}$ & $\begin{array}{l}\text { c. } 08 / \\
1974\end{array}$ & $\begin{array}{l}\text { Um parágrafo com descritivo sobre a reforma no apartamento } \\
\text { dos Hauner no Guarujá, seguido de listagem dos fornecedores } \\
\text { da decoração (todos da Home Store). }\end{array}$ \\
\hline \multirow{4}{*}{ 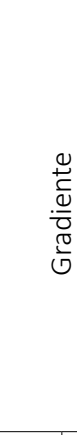 } & & $\begin{array}{l}\text { Estudo para } \\
\text { reportagem Gradiente- } \\
\text { Mobilinea }\end{array}$ & $\begin{array}{l}03 \text { desenhos à } \\
\text { mão }\end{array}$ & $\begin{array}{l}2403 \\
1972\end{array}$ & $\begin{array}{l}\text { Desenhos detalhados de como seriam as fotos para Casa \& } \\
\text { Jardim 06/1972. }\end{array}$ \\
\hline & & Catálogo Gradiente & Catálogo 08 pg & c. 1972 & $\begin{array}{l}\text { Catálogo Gradiente feito com as fotos que Georgia produziu } \\
\text { para Casa \& Jardim 06/1972. }\end{array}$ \\
\hline & & Propaganda Gradiente & Página de revista & $\begin{array}{l}\text { Sem } \\
\text { data }\end{array}$ & $\begin{array}{l}\text { Foto provavelmente feita na Iguatemi, com sala inteiramente } \\
\text { laqueada em vermelho e equipamentos de som Gradiente. Não } \\
\text { foi possível se a imagem foi publicada. }\end{array}$ \\
\hline & & $\begin{array}{l}\text { Estudo para } \\
\text { propaganda Gradiente }\end{array}$ & $\begin{array}{l}\text { Papel manteiga } \\
\text { desenhados à mão }\end{array}$ & $\begin{array}{l}\text { Sem } \\
\text { data }\end{array}$ & $\begin{array}{l}\text { Desenho detalhado de como seria a foto deste anúncio. Atenção } \\
\text { à indicação sobre o desenho: "com humor". Assinado por } \\
\text { Georgia. }\end{array}$ \\
\hline \multirow{3}{*}{ 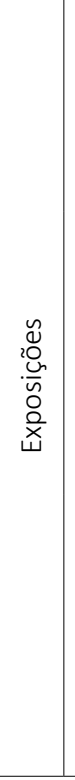 } & \multirow{3}{*}{ 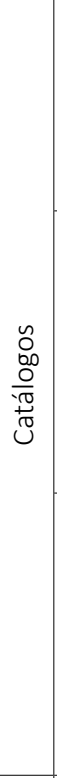 } & $\begin{array}{l}\text { Rascunho para } \\
\text { fotografias a ser } \\
\text { integradas no catálogo } \\
\text { da exposição do } \\
\text { MASP "Premissas e } \\
\text { Realidade" }\end{array}$ & $\begin{array}{l}03 \mathrm{pg} \text {, tamanhos } \\
\text { diversos, desenho } \\
\text { à mão }\end{array}$ & 1971 & $\begin{array}{l}\text { Folha 1: } 8 \text { desenhos em papel branco e caneta de todas as } \\
\text { fotos a ser feitas e integradas no catálogo. } 4 \text { da cadeira, } 4 \text { do } \\
\text { carrinho de chá. Folhas } 2 \text { e } 3 \text { : mesmos desenhos em outra } \\
\text { ordem, coloridos com caneta cinza e colados em fundo preto. } \\
\text { No catálogo, foram aproveitadas duas fotos de cada móvel e } \\
\text { acrescentada uma foto da mesa de centro. }\end{array}$ \\
\hline & & $\begin{array}{l}\text { Catálogo da Bienal } \\
\text { de Desenho Industrial } \\
\text { de } 1972\end{array}$ & $\begin{array}{l} \pm 15 \times 15 \mathrm{~cm} \\
\text { embalagem com } \\
\text { texto e } 39 \text { fichas } \\
\text { dos vencedores, } \\
\text { PB texto e foto }\end{array}$ & $\begin{array}{l}1972 / \\
1973\end{array}$ & $\begin{array}{l}\text { Na parte externa da embalagem estão os nomes dos países } \\
\text { participantes em português e alemão. Nas abas abertas está } \\
\text { uma explicação sobre a Bienal e sua ficha técnica. As fichas só } \\
\text { apresentam os projetos brasileiros, de produto e comunicação } \\
\text { visual. Têm a indicação da Bienal, título, data, fabricante e } \\
\text { projeto. Um dos projetos é a cadeira [gatinhos] da Mobilinea, } \\
\text { creditada como projetada por Ernesto em } 1972 \text { e fabricada pela } \\
\text { empresa. O nome é apenas "cadeira de fiber glass". }\end{array}$ \\
\hline & & Catálogo IDI & $\begin{array}{l}\text { A4, } P B+\text { verde. } 16 \\
\text { pg, fotos e texto }\end{array}$ & 1978 & $\begin{array}{l}\text { Catálogo bilíngue. Apresenta o MAM; o Instituto de Desenho } \\
\text { Industrial; a Bienal de Desenho Industrial de } 1968 \text { (e seus } \\
\text { participantes em uma composição geral de fotos das peças e da } \\
\text { exposição sem legendas, onde está a foto de Silvinha sentada } \\
\text { na poltrona desmontável); a Bienal de Desenho Industrial de } \\
\text { 1970; a Bienal de Desenho Industrial de 1972; a exposição } \\
\text { "Imagem Empresarial"; a exposição "O Talher Contemporâneo"; } \\
\text { o desenvolvimento no campo. }\end{array}$ \\
\hline \multirow{2}{*}{\multicolumn{2}{|c|}{ 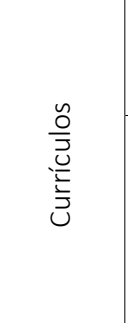 }} & $\begin{array}{l}\text { Currículo Georgia } \\
\text { Hauner }\end{array}$ & $\begin{array}{l}\text { A4, } 2 \mathrm{pg} \text {, datilo- } \\
\text { grafado }\end{array}$ & ago/71 & $\begin{array}{l}\text { Currículo de Georgia Hauner com informações sobre sua } \\
\text { formação, início da carreira, até colaboração com revista } \\
\text { Claudia. }\end{array}$ \\
\hline & & $\begin{array}{l}\text { Currículo Ernesto } \\
\text { Hauner }\end{array}$ & $\begin{array}{l}\text { A4, } 6 \mathrm{pg} \text {, datilo- } \\
\text { grafado }\end{array}$ & c. 1976 & $\begin{array}{l}\text { Currículo de Ernesto Hauner escrito já em Vancouver. Primeiras } \\
\text { três páginas apresentam contato, objetivos, informações } \\
\text { pessoais, experiência profissional, prêmios e referências (do } \\
\text { Brasil, coloca Pietro Maria Bardi e João Carlos Cauduro). Nas três } \\
\text { páginas seguintes, reproduções de fotos de seus trabalhos na } \\
\text { Mobilinea. }\end{array}$ \\
\hline
\end{tabular}


Anexo 03- Relação de slides digitalizados do acervo pessoal de Georgia Hauner

\begin{tabular}{|c|c|c|c|}
\hline Pasta & Subpasta & Qtde. & Conteúdo \\
\hline Original & Roll 26: & 1 & Fundo infinito - banquinho em madeira maciça \\
\hline Data & “ & “ & “ \\
\hline Modified & “ & “ & “ \\
\hline Original & Roll 31: & 1 & Fundo infinito - cadeiras com estofado estrutural \\
\hline Data & “ & “ & “" \\
\hline Modified & “ & “ & " \\
\hline Original & Roll 33: & 1 & Fundo infinito - poltronas em chapa de madeira maciça \\
\hline Data & " & “ & " \\
\hline Modified & “ & “ & “ \\
\hline Original & Roll 34: & 1 & Fundo infinito - poltronas em perfil de madeira maciça \\
\hline Data & " & " & “ \\
\hline Modified & “ & “ & “ \\
\hline Original & Roll 36: & 1 & Fundo infinito - sofá $2 \mathrm{~L}$ em chapa de madeira maciça \\
\hline Data & $"$ & “ & “ \\
\hline Modified & “ & “ & “ \\
\hline Original & Roll 37: & 1 & Fundo infinito - sofá $2 \mathrm{~L}$ em perfil de madeira maciça \\
\hline Data & “ & “ & “ \\
\hline Modified & “ & " & “ \\
\hline Original & Roll 38: & 1 & Fundo infinito - sofá $3 \mathrm{~L}$ em perfil de madeira maciça \\
\hline Data & " & " & “ \\
\hline Modified & “ & “ & “ \\
\hline Original & Roll 40: & 1 & Fundo infinito - sofá 3L em chapa de madeira maciça \\
\hline Data & “ & “ & “ \\
\hline Modified & “ & “ & “ \\
\hline Original & Roll 41: & 1 & Fundo infinito - mesa retangular $6 \mathrm{~L}$ com seis cadeiras em madeira maciça \\
\hline Data & “ & “ & “ \\
\hline Modified & “ & “ & “ \\
\hline Original & Roll 43: & 1 & Fundo infinito - mesa lateral em madeira maciça \\
\hline Data & “ & “ & “ \\
\hline Modified & “ & “ & “ \\
\hline Original & Roll 44: & 1 & Fundo infinito - mesa lateral com estrutura em madeira maciça e tampo em material branco \\
\hline Data & “ & “ & “ \\
\hline Modified & “ & “ & " \\
\hline Original & Roll 45: & 1 & Fundo infinito - mesa de centro em madeira maciça \\
\hline Data & " & “ & “ \\
\hline Modified & “ & “ & “ \\
\hline Original & Roll 47: & 1 & Fundo infinito - mesa 4L com tampo removível em madeira maciça \\
\hline Data & “ & “ & “ \\
\hline Modified & “ & “ & " \\
\hline Original & Roll 48: & 1 & Fundo infinito - mesa com duas cadeiras em madeira maciça \\
\hline Data & “ & “ & “ \\
\hline Modified & " & " & " \\
\hline Original & Roll 49: & 1 & Fundo infinito - mesa/banco com dois volumes que encaixam em madeira maciça \\
\hline Data & " & “ & " - n \\
\hline
\end{tabular}


Anexo 03- Relação de slides digitalizados do acervo pessoal de Georgia Hauner

\begin{tabular}{|c|c|c|c|}
\hline Modified & “ & “ & “ \\
\hline Data & Roll 51: & 1 & Fundo infinito - mesa de centro quadrada com pé cruzeta em madeira maciça \\
\hline Original & “ & “ & “ \\
\hline Modified & “ & “ & “ \\
\hline Original & Roll 52: & 1 & Fundo infinito - mesa de centro redonda com pé cruzeta em madeira maciça \\
\hline Data & “ & “ & “ \\
\hline Modified & “ & “ & “ \\
\hline Original & Roll 54: & 1 & Fundo infinito - mesa de centro redonda com pé cruzeta em madeira maciça, tampo de pedra \\
\hline Data & “ & “ & “ \\
\hline Modified & “ & “ & “ \\
\hline Original & Roll 55: & 1 & Fundo infinito - mesa de centro quadrada com pé cruzeta em madeira maciça, tampo de pedra \\
\hline Data & “ & “ & “ \\
\hline Modified & “ & “ & “ \\
\hline Original & Roll 59: & 1 & $\begin{array}{l}\text { Fundo infinito - mesa de jantar com pé cruzeta em madeira maciça e tampo de pedra, cadeiras em } \\
\text { madeira maciça }\end{array}$ \\
\hline Data & “ & “ & “ \\
\hline Modified & “ & “ & “ \\
\hline Original & Roll 60: & 1 & Fundo infinito - mesa de jantar com pé em cruzeta em madeira maciça, cadeiras em madeira maciça \\
\hline Data & “ & “ & “ \\
\hline Modified & “ & “ & “ \\
\hline Original & Roll 57: & 1 & Fundo infinito - estrutura para mesa de centro com pé cruzeta em madeira maciça \\
\hline Data & “ & “ & “ \\
\hline Modified & “ & “ & “ \\
\hline Original & Roll 62: & 1 & $\begin{array}{l}\text { Fundo infinito - mesa de jantar oval com pé cruzeta duplo em madeira maciça, cadeiras em } \\
\text { madeira maciça }\end{array}$ \\
\hline Data & “ & “ & “ \\
\hline Modified & “ & “ & “ \\
\hline Original & Roll 64: & 1 & $\begin{array}{l}\text { Fundo infinito - mesa de jantar oval com pé cruzeta duplo com tampo em pedra, cadeiras em ma- } \\
\text { deira maciça }\end{array}$ \\
\hline Data & “ & “ & “ \\
\hline Modified & “ & “ & “ \\
\hline Original & Roll 65: & 1 & Fundo infinito - cama de casal com dois criados em madeira maciça \\
\hline Data & “ & " & “ \\
\hline Modified & “ & “ & “ \\
\hline Original & Roll 67: & 1 & Fundo infinito - cômoda em madeira maciça \\
\hline Data & “ & “ & “ \\
\hline Modified & “ & “ & “ \\
\hline Original & Roll 68: & 1 & $\begin{array}{l}\text { Fundo infinito - estante Modular baixa com dois módulos com escrivaninha e cadeira em } \\
\text { madeira maciça }\end{array}$ \\
\hline Data & “ & “ & $"$ \\
\hline Modified & " & " & $"$ \\
\hline Original & Roll 70: & 1 & $\begin{array}{l}\text { Fundo infinito - estante Modular baixa com quatro módulos com escrivaninha e cadeira em } \\
\text { madeira maciça }\end{array}$ \\
\hline Data & $"$ & " & $"$ \\
\hline Modified & $" “$ & " & $"$ \\
\hline Original & Roll 71: & 1 & Fundo infinito - estante Modular média com dois módulos com escrivaninha e cadeira em madeira maciça \\
\hline Data & “ & “ & “ \\
\hline Modified & “ & “ & “ \\
\hline
\end{tabular}


Anexo 03-Relação de slides digitalizados do acervo pessoal de Georgia Hauner

\begin{tabular}{|c|c|c|c|}
\hline Original & Roll 72: & 1 & Fundo infinito - estante Modular média com três módulos com escrivaninha e cadeira em madeira maciça \\
\hline Data & " & " & " \\
\hline Modified & " & " & " \\
\hline Original & Roll 74: & 1 & Fundo infinito - estante Modular alta com quatro módulos com escrivaninha e cadeira em madeira maciça \\
\hline Data & “ & “ & “ \\
\hline Modified & " & " & " \\
\hline Original & Roll 75: & 1 & Fundo infinito - estante Modular baixa com dois módulos \\
\hline Data & " & " & “ \\
\hline Modified & " & " & " \\
\hline Original & Roll 76: & 1 & Fundo infinito - estante Modular baixa com três módulos \\
\hline Data & " & " & “ \\
\hline Modified & “ & “ & " \\
\hline Original & Roll 78: & 1 & Fundo infinito - estante Modular baixa com quatro módulos \\
\hline Data & " & " & " \\
\hline Modified & “ & " & " \\
\hline Original & Roll 79: & 1 & Fundo infinito - estante Modular média com dois módulos \\
\hline Data & " & " & “ \\
\hline Modified & “ & " & “ \\
\hline Original & Roll 80: & 1 & Fundo infinito - prateleira de parede e espelho \\
\hline Data & " & “ & " \\
\hline Modified & " & " & “ \\
\hline Original & Roll 82: & 1 & Fundo infinito - banco ripado em madeira maciça \\
\hline Data & " & " & “ \\
\hline Modified & “ & “ & “ \\
\hline Original & Roll 83: & 1 & Fundo infinito - carrinho de chá com bandejas removíveis em madeira maciça \\
\hline Data & " & " & “ \\
\hline Modified & " & " & “ \\
\hline Original & Roll 84: & 1 & $\begin{array}{l}\text { Fundo infinito - carrinho de chá com bandejas removíveis em madeira maciça e revestimento } \\
\text { superior em fórmica }\end{array}$ \\
\hline Data & “ & " & “ \\
\hline Modified & " & “ & “ \\
\hline Original & Roll 86: & 1 & Fundo infinito - cadeiras em madeira maciça \\
\hline Data & “ & “" & “ \\
\hline Modified & “ & “ & “ \\
\hline Original & Roll 91: & 1 & Fundo infinito - cadeiras em madeira maciça usado em propagandas \\
\hline Data & “ & " & “ \\
\hline Modified & " & “ & “ \\
\hline Original & Roll 32: & 1 & $\begin{array}{l}\text { Shopping Iguatemi - mesa e cadeira laqueados de branco, estofado vermelho, estante modular } \\
\text { preta, luminária, cortina }\end{array}$ \\
\hline Data & " & “ & " \\
\hline Modified & “ & “ & “ \\
\hline Original & Roll 35: & 1 & Shopping Iguatemi - sala de estar, poltronas e mesa em madeira maciça, divisória em discos de madeira \\
\hline Data & " & “ & " \\
\hline Modified & “ & " & " \\
\hline Original & Roll 39: & 1 & Shopping Iguatemi - sala de estar branca \\
\hline Data & “ & “ & “ \\
\hline
\end{tabular}


Anexo 03- Relação de slides digitalizados do acervo pessoal de Georgia Hauner

\begin{tabular}{|c|c|c|c|}
\hline Modified & “ & " & " \\
\hline Original & Roll 42: & 1 & Shopping Iguatemi - mesa de jantar anexa a estante modular, branco \\
\hline Data & " & " & " \\
\hline Modified & " & " & " \\
\hline Original & Roll 46: & 1 & Shopping Iguatemi - sala de jantar, atrás da sala branca; em madeira maciça com estofado verde \\
\hline Data & “ & “ & “ \\
\hline Modified & “ & “ & " \\
\hline Original & Roll 50: & 1 & $\begin{array}{l}\text { Shopping Iguatemi - sala da lareira e parede nichos, conjunto de sofás, mesa de centro e estante } \\
\text { em madeira maciça }\end{array}$ \\
\hline Data & “ & “ & " \\
\hline Modified & “ & " & " \\
\hline Data & Roll 53: & 1 & Shopping Iguatemi - ambiente com vários desníveis, salas e quartos, cadeiras Probjeto \\
\hline Original & “ & “ & “ \\
\hline Modified & " & “ & " \\
\hline Original & Roll 56: & 1 & Shopping Iguatemi - sala de almoço e estar, madeira maciça e cadeiras Thonet \\
\hline Data & “ & “ & “ \\
\hline Modified & " & " & " \\
\hline Original & Roll 61: & 1 & Shopping Iguatemi - ambiente atrás da lareira, escada de acesso ao mezanino, ambientes diversos \\
\hline Data & " & “ & " \\
\hline Modified & “ & " & “ \\
\hline Original & Roll 63: & 1 & Shopping Iguatemi - ambiente de vitrine, quarto branco e móveis em vime Cerello \\
\hline Data & “ & “ & “ \\
\hline Modified & " & " & “ \\
\hline Original & Roll 66: & 1 & Shopping Iguatemi - ambiente atrás da lareira, vista mais aproximada \\
\hline Data & " & " & " \\
\hline Modified & “ & " & " \\
\hline Original & Roll 69: & 1 & Shopping Iguatemi - quarto branco com gavetas coloridas, cortina de disco de madeira colorida \\
\hline Data & " & “ & “ \\
\hline Modified & " & “ & " \\
\hline Original & Roll 73: & 1 & Shopping Iguatemi - vista da loja através da vitrine interna \\
\hline Data & “ & “ & “ \\
\hline Modified & “ & " & “ \\
\hline Original & Roll 77: & 1 & Shopping Iguatemi - vista geral, mostra parcialmente ambiente das Thonets, divisória de nichos \\
\hline Data & “ & “ & “ \\
\hline Modified & “ & “ & “ \\
\hline Original & Roll 81: & 1 & Shopping Iguatemi - ambiente que dá para a vitrine, com dormitório em madeira maciça \\
\hline Data & “ & “ & “ \\
\hline Modified & “ & “ & “ \\
\hline Original & Roll 85: & 1 & Shopping Iguatemi - ambiente de escritório em Madeira maciça \\
\hline Data & “ & “ & “ \\
\hline Modified & " & “ & " \\
\hline Original & Roll 16: & 1 & Home Store - terraço \\
\hline Data & “ & “ & “ \\
\hline Modified & “ & “ & “ \\
\hline Original & Roll 19: & 1 & Home Store - vista da galeria de arte \\
\hline Data & “ & " & " \\
\hline
\end{tabular}


Anexo 03-Relação de slides digitalizados do acervo pessoal de Georgia Hauner

\begin{tabular}{|c|c|c|c|}
\hline Original & Roll 20: & 35 & $\begin{array}{l}\text { Home Store - terraço, fachada, detalhes de objetos, Mobilinha, jornaleiro, ambientes, detalhes, } \\
\text { cozinha, vista geral da rua e galeria, loja de discos, joias, luminárias de área externa }\end{array}$ \\
\hline Data & " & " & " \\
\hline Modified & “ & 8 & Home Store -terraço, Mobilinha, ambientes, estante de toalhas \\
\hline Original & Roll 22: & 14 & Home Store - ambientes, detalhes \\
\hline Data & “ & “ & “ \\
\hline Modified & “ & 3 & Home Store - cadeira de palha, tapete, ambiente de jantar \\
\hline Original & Roll 94: & 9 & Home Store - tapetes, quarto infantil, estante, detalhes de sala, vista sala e terraço \\
\hline Data & $"$ & $"$ & " \\
\hline Modified & " & 3 & Home Store - estante, detalhe de sala e terraço \\
\hline Original & Roll 95: & 14 & Home Store - vista da rua, fosso com Ernesto, vistas da área externa da fachada, tecidos, tapete \\
\hline Data & $"$ & $"$ & " \\
\hline Modified & “ & 4 & Home Store - vista da rua, fosso, tecidos \\
\hline Original & Roll 102: & 1 & Home Store - vista interna \\
\hline Data & " & " & “" \\
\hline Original & Roll 103: & 1 & Home Store - vista de sala com divisória em metal \\
\hline Data & " & " & " \\
\hline Original & Roll 110: & 2 & Home Store - ambientes \\
\hline Data & $"$ & $"$ & " \\
\hline Original & Roll 104: & 2 & São Luiz - cadeiras em aço e fibra de vidro \\
\hline Data & “" & " & " \\
\hline Original & Roll 105: & 3 & São Luiz - sala, mesa de acrílico, poltronas [LC] \\
\hline Data & " & " & " \\
\hline Original & Roll 107: & 1 & São Luiz - cadeiras [gatinhos] empilhadas \\
\hline Data & " & “" & “ \\
\hline Original & Roll 58: & 1 & Cenário - ambiente de estar com móveis brancos e estofado rosa, utilizado em propagandas \\
\hline Data & " & " & “ \\
\hline Modified & " & “ & “" \\
\hline Original & Roll 88: & 1 & Cenário - foto da mesa e cadeira amarela com fundo vermelho usado em propagandas \\
\hline Data & " & " & “ \\
\hline Modified & " & " & " \\
\hline Original & Roll 106: & 1 & $\begin{array}{l}\text { Cenário - poltronas e sofás inteiramente estofados com modelos brincando, deve ter sido pensado } \\
\text { para propaganda }\end{array}$ \\
\hline Data & " & " & " \\
\hline Modified & " & " & " \\
\hline Original & Roll 108: & 27 & $\begin{array}{l}\text { Diversos - } 3 \text { fotos dos estofados com modelos, várias fotos da Home Store e da São Luiz, foto da } \\
\text { capa do } 2^{\circ} \text { CJ-Visita, foto de divulgação da linha prèt-à-porter e fotos internas mostrando cenário, } \\
\text { foto de estofados [LC] de propaganda, foto invertida da mas e cadeira amarelas, foto de ambiente } \\
\text { de escritórios }\end{array}$ \\
\hline Data & " & " & " \\
\hline Modified & “ & 11 & $\begin{array}{l}\text { Diversos - } 3 \text { fotos dos estofados com modelos, } 3 \text { fotos da Home Store, foto da capa do } 2^{\circ} \mathrm{CJ} \text {-Visita, } \\
\text { foto de divulgação da linha prèt-à-porter, foto de estofados [LC] de propaganda, foto invertida da } \\
\text { mas e cadeira amarelas, foto de ambiente de escritórios }\end{array}$ \\
\hline Original & Roll 109: & 5 & Diversos - fotos do $2^{\circ} \mathrm{CJ}$-Visita mostrando cenário, fotos da Home Store, fotos da São Luiz \\
\hline Data & " & "“ & " \\
\hline
\end{tabular}





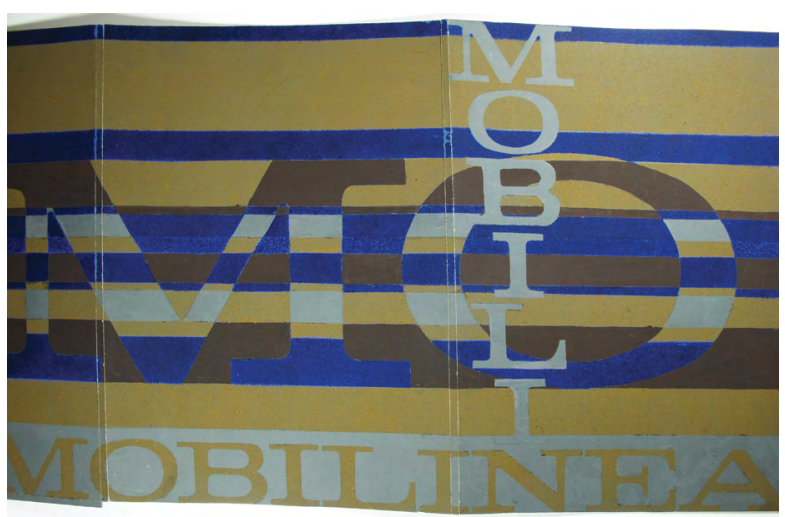

Sobre a capa

Desenho inspirado em pasta feita à mão localizada no acervo pessoal de Georgia Hauner. Sem data. 